WSRC-RP-95-360, Rev. 1, Final

\title{
RCRA Facility Investigation/Remedial Investigation Report for Gunsite 720 Rubble Pit Unit (631-16G) - March 1996
}

by

E. Palmer

Westinghouse Savannah River Company

Savannah River Site

Aiken, South Carolina 29808

This paper was prepared in connection with work done under the above contract number with the U.S.

Department of Energy. By acceptance of this paper, the publisher and/or recipient acknowledges the U.S. Government's right to retain a nonexclusive, royalty-free license in and to any copyright covering this paper, along with the right to reproduce and to authorize others to reproduce all or part of the copyrighted paper.

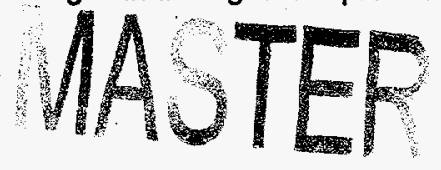




\section{DISCLAIMER}

This report was prepared as an account of work sponsored by an agency of the United States Government. Neither the United States Government nor any agency thereof, nor any of their employees, makes any warranty, express or implied, or assumes any legal liability or responsibility for the accuracy, completeness, or usefulness of any information, apparatus, product, or process disclosed, or represents that its use would not infringe privately owned rights. Reference herein to any specific commercial product, process, or service by trade name, trademark, manufacturer, or otherwise does not necessarily constitute or imply its endorsement, recommendation, or favoring by the United States Government or any agency thereof. The views and opinions of authors expressed herein do not necessarily state or reflect those of the United States Government or any agency thereof.

This report has been reproduced directly from the best available copy.

Available to DOE and DOE contractors from the Office of Scientific and Technical Information, P. O. Box 62, Oak Ridge, TN 37831; prices available from (423) 576-8401.

Available to the public from the National Technical Information Service, U. S. Department of Commerce, 5285 Port Royal Road, Springfield, VA 22161. 


\section{DISCLAIMER}

Portions of this document may be illegible electronic image products. Images are produced from the best available original document. 
Gunsite 720 Rubble Pit Unit

RFI/RI Report
WSRC-RP-95-360, Rev. 1

March 1996

\section{RCRA FACILITY INVESTIGATION/ REMEDIAL INVESTIGATION REPORT}

FOR THE

GUNSITE 720 RUBBLE PIT UNIT (631-16G) (U)

PREPARED BY:

WESTINGHOUSE SAVANNAH RIVERCOMPANY

SAVANNAH RIVER SITE

AIKEN, SOUTH CAROLINA 


\section{DISCLAIMER}

This report was prepared for the United States Department of Energy under Contract No. DE-AC09-89SR18035 and is an account of work performed under that contract. Reference herein to any specific commercial product, process, or service by trademark, name, manufacturer or otherwise does not necessarily constitute or imply endorsement, recommendation, or favoring of same by Westinghouse Savannah River Company or by the United States Government or any agency thereof.

Printed in the United States of America

Prepared for

U. S. Department of Energy

by

Westinghouse Savannah River Company 
RFI/RI Report for the GUNSITE 720 Rubble Pit Unit (631-16G)
WSCRC -RP-95-360, Rev. 1 April 8, 1996

\title{
CERTIFICATION PAGE
}

\author{
Revision 1 \\ RFI/RI Report for the \\ GUNSITE 720 (631-16G) RUBBLE PIT UNIT
}

"I certify under the penalty of law that this document and all attachments were prepared under my direction or supervision in accordance with a system designed to assure that qualified personnel properly gather and evaluate the information submitted. Based on my inquiry of the person or persons who manage the system, the information submitted is, to the best of my kmowledge and belief, true, accurate, and complete. I am aware that there are significant penalties for submitting false information, including the possibility of fines and imprisonment for knowing violations."

Date:

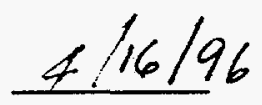

Date:

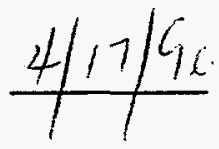

Signature: Title:

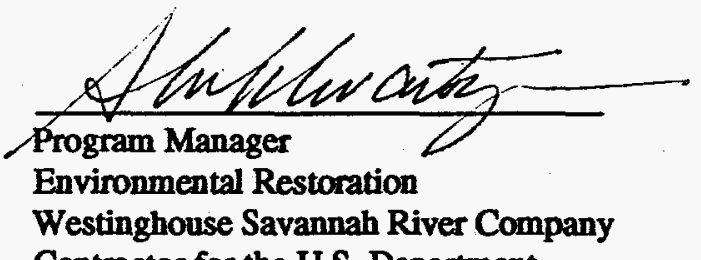

Contractor for the U.S. Department

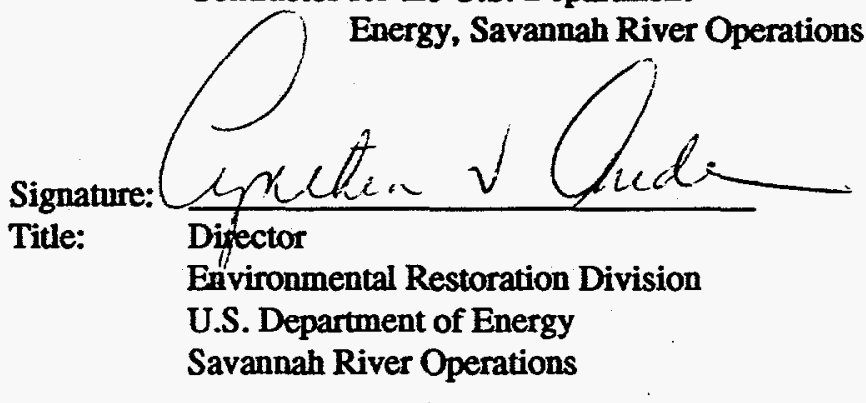




\section{TABLE OF CONTENTS}

EXECUTTVE SUMMARY ES-1

1.0 INTRODUCTION $1-1$

1.1 Purpose. 1-1

1.1.1 SRS RCRA 3004(u)/CERCLA Program Description 1-1

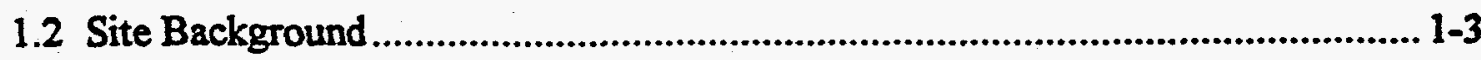

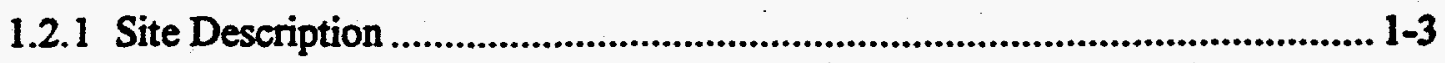

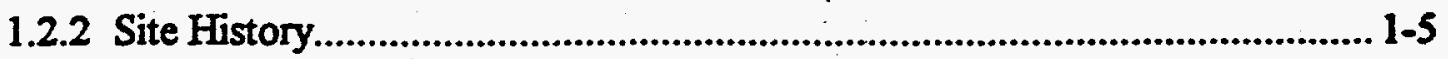

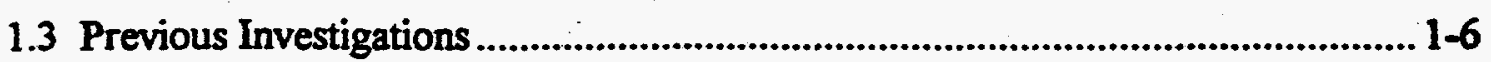

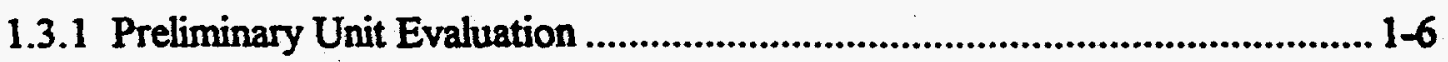

1.3.1.1 Existing Literature and Information................................................. 1-8

1.3.1.2 RFI/RI Literature Review Checklist ..............................................1-8

1.3.1.3 RFI/RI Site Reconnaissance ......................................................... 1-8

1.3.1.4 Preliminary Unit Evaluation Results ................................................. 1-8

1.3.1.4.1 Waste Characteristics ................................................................. 1-9

1.3.1.4.2 Unit/Disposal Area Characteristics .............................................. 1-9

1.3.2 Unit Screening .......................................................................................... 1-10

1.3.2.1 Evaluation of Unit Screening Options............................................... 1-10

1.3.2.2 Unit Screening Geophysical Survey ............................................... 1-11

1.3.2.3 Unit Screening/Confirmation Soil Analysis Sampling .......................... 1-11

1.3.2.3.1 Soil Sampling .........................................................................1-11

1.3.2.3.2 Soil Analytical Results.......................................................... 1-12

1.3.2.3.3 Trenching Observations......................................................1-17

1.3.2.4 Unit Screening Conclusions.........................................................1-18

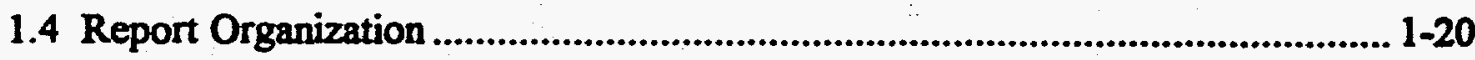

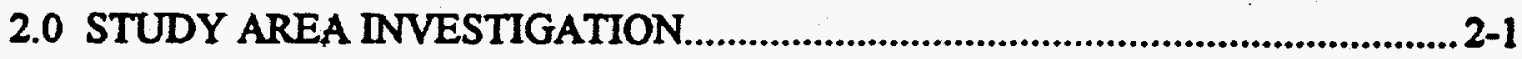

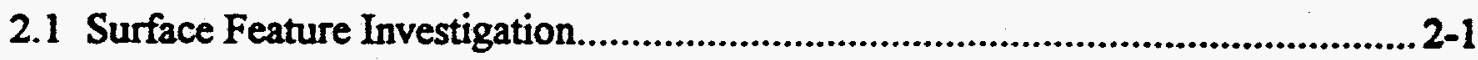


2.2 Contaminant Source Investigation.

2.3 Meteorological Investigation.

2.4 Surface Water and Sediment Investigation $2-2$

2.5 Soil/Vadose Zone Investigations ...................................................................... 2-3

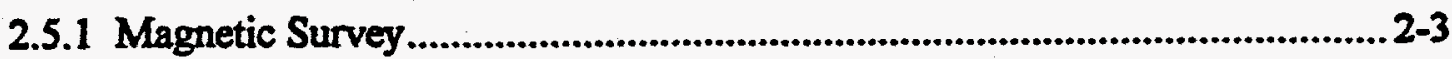

2.5.2 Ground Penetrating Radar Survey.............................................................. 2-6

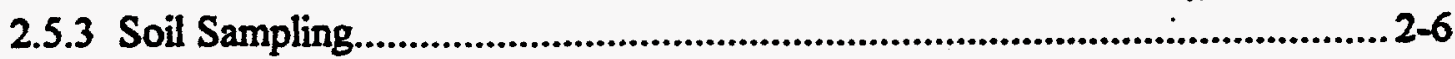

2.5.4 Conclusions from the Magnetic, GPR and Soil Surveys................................ 2-9

2.5.5 Identification of Human Health Chemicals of Potential Concern (COPCs)

2.5.5.1 Chemicals of Potential Concern

2.6 Groundwater Investigation

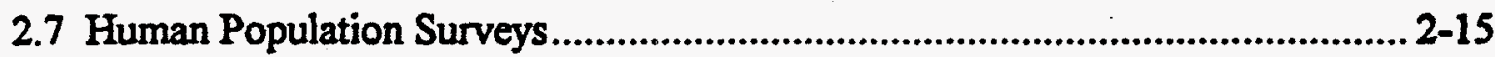

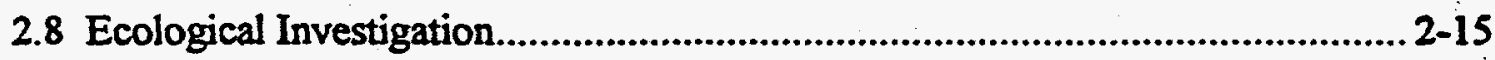

3.0 PHYSICAL CHARACTERISTICS OF THE STUDY AREA

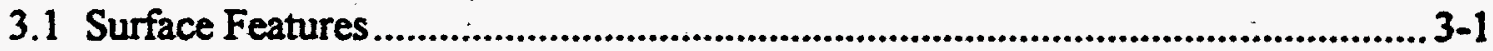

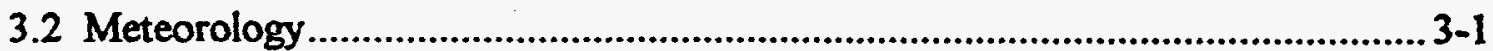

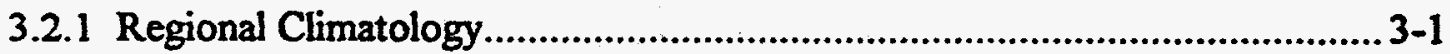

3.2.2 Temperature and Humidity..................................................................... 3-1

3.2.3 Precipitation and Evapotranspiration ......................................................... 3-2

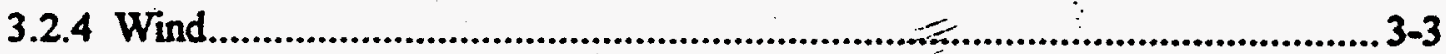

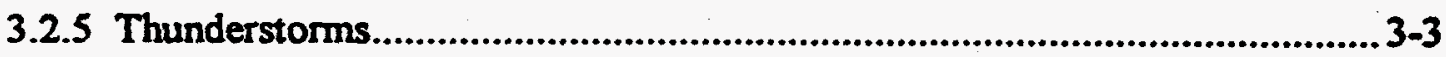

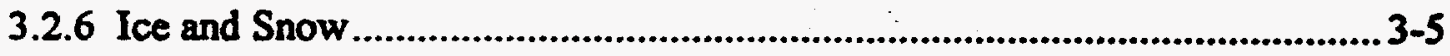

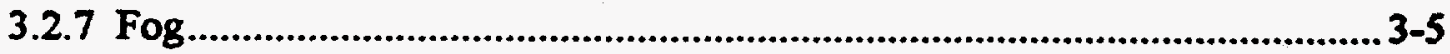

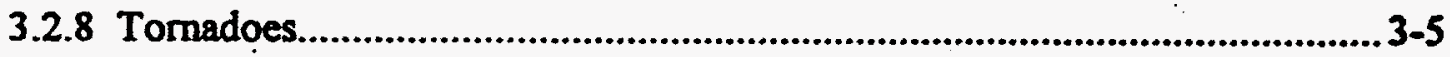

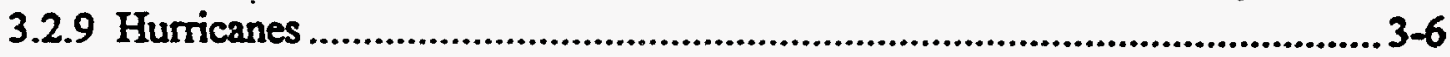

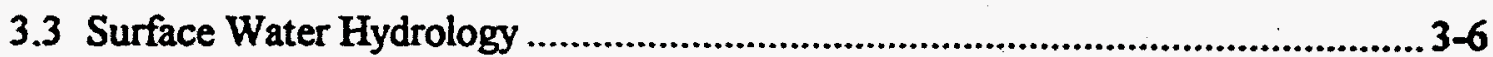




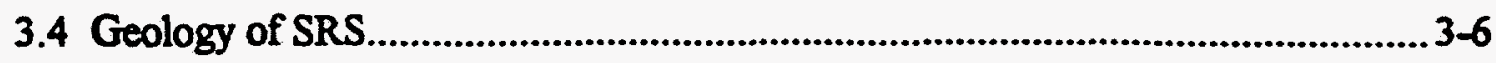

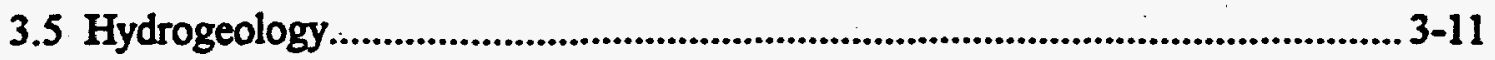

3.6 Geology and Hydrology of the Gunsite 720 Rubble Pit Unit.............................3-13

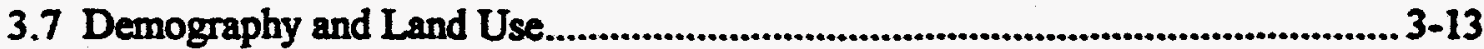

3.7.1 Demographics............................................................................................... 3-13

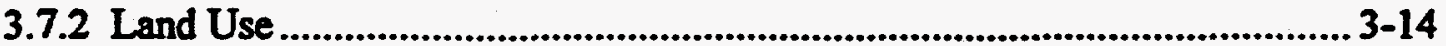

4.0 NATURE AND EXTENT OF CONTAMINATION ........................................... 4-1

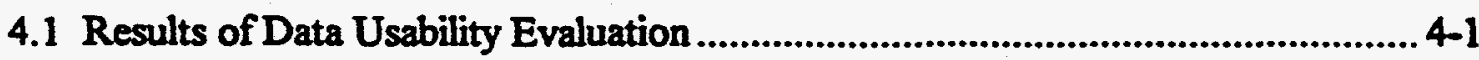

4.2 Results of Site Characterization .................................................................. 4-1

5.0 CONTAMINANT FATE AND TRANSPORT ….............................................. 5-1

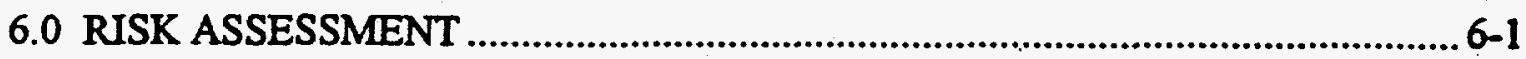

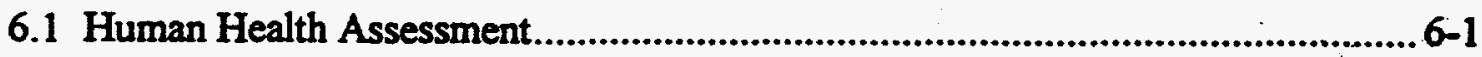

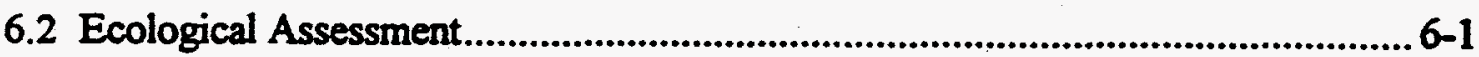

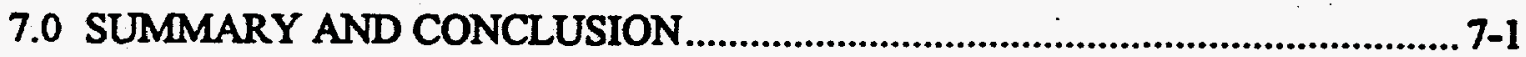

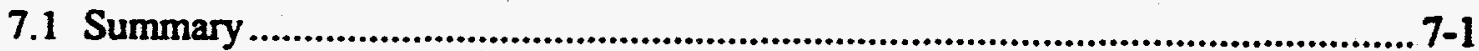

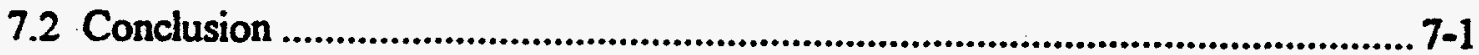

8.0 REFERENCES REF-1

APPENDIX A - Technical Memoranda on Field Activities APPENDIX B - Analytical Data and QA/QC Evaluation Results APPENDIX C - Risk Assessment Methods 


\section{UIST OF FIGURES}

Number

Title

Page

1-1 Location of Gunsite 720 in Relation to Major SRS Facilities. $1-4$

1-2 Soil Gas Sample Locations. $1-7$

1-3 Unit Screening Soil Sample Locations $1-13$

2-1 Topographic Map of Gunsite 720 Rubble Pit Unit $2-2$

2-2 Station Location for the 1986 Magnetic Survey ....................................... 2-4

2-3 Station Location for the 1993 Magnetic Survey......................................... 2-5

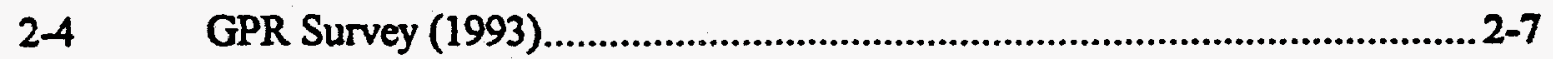

2-5 Sample Locations for the 1993 Soil Survey .......................................... 2-8

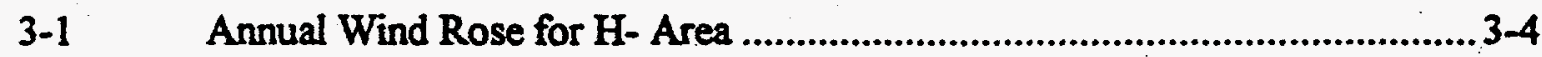

3-2 Comparison of Chronostratigraphic, Lithostratigraphic and Hydrostratigraphic Units

3-3 Hydrogeologic Nomenclature for the SRS Region. 3-12

4-1 Map Showing the Location and Concentration of Metals Which Exceed the Unit-Specific Background Level. 


\section{LIST OF TABLES}

Number

Title

1-1 Soil Sampling Intervals and Constituents Analyzed

1-2 Gunsite 720 Rubble Pit Soil Sample Data Summary

1-3 Laboratory Quality Control Results $1-16$

1-4 Comparison of Maximum Soil Concentrations with Background Levels for Gunsite 720 Rubble Pit Unit

2-1 1993 Soil Sample Results: UST Area

2-2 1993 Soil Sample Results: Drum Area

2-3 Comparison of Maximum Soil Concentrations with Unit-Specific and SRS Background Levels and EPA Region III RBCs. 1990 and 1993 Data

4-1 Comparison of Maximum Soil Concentrations with Background Levels for Gunsite 720 Rubble Pit Unit 


\section{LIST OF ACRONYMS}

ARAR

BRA

BTEX

CERCLA

CEC

CLP

COPCs

CRQL

DOE

EIS

EM

EPA

FFA

FS

GPR

NEPA

NPL

NWS

OVA

PIP

PQL

QA

QC

RBC

RCRA

RFA

RFI

RI

SCDHEC

SRS

SWMU
Applicable or Relevant and Appropriate Requirements

Baseline Risk Assessment

benzene, toluene, ethylbenzene, xylene

Comprehensive Environmental Response, Compensation, and

Liability Act

Cation Exchange Capacity

Contract Laboratory Program

Chemicals of Potential Concern

Contract Required Quantitation Limit

Department of Energy

Environmental Impact Statement

Electromagnetics

Environmental Protection Agency

Federal Facility Agreement

Feasibility Study

Ground Penetrating Radar

National Environmental Policy Act

National Priority List

National Weather Service

Organic Vapor Analyzer

Public Involvement Plan

Practical Quantitation Limit

Quality Assurance

Quality Control

Risk-Based Concentration

Resource Conservation and Recovery Act

RCRA Facility Assessment

RCRA Facility Investigation

Remedial Investigation

South Carolina Department of Health and Environmental Control Savannah River Site

Solid Waste Management Unit 
TAL

TCL

TIC

TOC

TPH

UST

VOC

WSRC
Target Analyte List

Target Compound List

Tentatively Identified Compounds

Total Organic Carbon

Total Petroleum Hydrocarbons

Underground Storage Tank.

Volatile Organic Compound

Westinghouse Savannah River Company 


\section{EXECUTTVE SUMMMARY}

Gunsite 720 Rubble Pit Unit is located on the west side of SRS. This RCRAVCERCLA unit is approximately 304.9 meters (1000 feet) west of South Carolina Highway 125 , 167.7 meters (550 feet) north of SRS Road A-2 and 2.4 kilometers (1.5 miles) from the nearest site boundary. The unit, which consists of an open area covered with natural shrub growth and surrounded by native pine trees and shrubs, encompasses an area of approximately 2,250 square meters $(25,000$ square feet). Two concrete slabs are located on the east side of the open area.

In the early to mid 1980s, while work was being performed in the area, nine empty, partially buried drums, labeled "du Pont Freon 11", were found. As a result, Gunsite 720 became one of the original waste units specified in the SRS RCRA Facility Assessment (RFA). The drums were excavated on July 30, 1987 and placed on a pallet at the unit. Both the drums and pallet were removed and disposed of in October 1989. The area around the drums was screened during the excavation and the liquid (rainwater) that collected in the excavated drums was sampled prior to disposal. No evidence of hazardous materials was found.

There is no documentation or record of any hazardous substance management, disposal, or any other type of waste disposal at this unit. There is no evidence of any burning, excavation or recent disposal activities having occurred in this area or that disposal activities were more widespread. Facility documents indicate that an underground fuel tank was located in the area; however, magnetic surveys, ground penetrating radar (GPR), and trenching failed to detect any storage tanks.

Unit Screening data indicate that hazardous substance concentrations appear to be "at or below background" although statistical background concentrations have not been calculated. The only hazardous substances exceeding their respective unit-specific background concentrations are acetone (laboratory artifact), bis(2-ethylhexyl) phthalate (laboratory artifact), barium, chromium, lead, and total mercury. 
For the four hazardous substance metals which exceeded unit-specific background levels (barium, chromium, lead, and total mercury), a comparison with SRS and southeastern U. S. mean background values was made. Lead and chromium maximum field concentrations are less than both the maximum SRS background level and southeastern U. S. mean background levels. The maximum field value for barium is significantly less than mean southeastern U. S. background level. The maximum field value for total mercury is less than the SRS mean background level.

Based on comparison with unit-specific, SRS, and southeastern U. S. background concentrations, it appears that there has been no environmental impact due to hazardous substance disposal at the Gunsite 720 Rubble Pit Unit. There is also no evidence of any hazardous substance release from this unit.

Trenching operations at the unit uncovered common household garbage and a small amount of construction debris, but no buried tanks. Analytical results of soil samples taken from the trenches and debris identified in the trenches suggest that hazardous waste handling activity at the unit is unlikely.

A magnetic survey was conducted in 1986 to locate underground storage tanks (UST) believed to be buried on the unit. Three distinct anomalies were noted near the concrete pads, but the results of the survey were essentially inconclusive. Because of this and concerns regarding the existence of the UST and potential releases from those tanks, it was decided to run additional magnetic and ground penetrating radar (GPR) surveys and obtain additional soil samples from the area of concern. These samples would be analyzed for VOCs, TPH, benzene, toluene, ethylbenzene, xylene (BTEX) and metals.

Trenching, GPR, and magnetic surveys of Gunsite 720 found no evidence of burial pits or a UST. The soil sampling results indicate there are no substances at Gunsite 720 that trigger any regulatory action levels. In most cases, the substances detected are below unit-specific background levels. The results of the investigation indicate that no hazardous substances have been managed or are present at Gunsite 720.

Data collected during Preliminary Unit Evaluation, Unit Screening, and field investigations found no evidence of contamination at Gunsite 720 Rubble Pit Unit. Magnetic and GPR 
surveys showed no signs of any buried hazardous materials including the UST that was previously located at the unit. An analysis of soil samples collected in 1990 and 1993 show that all materials detected in the soil are at or below background levels. No chemicals of concern were identified as a result of the investigations at this unit.

A review of the unit sampling plan and the resulting soil and soil vapor analytical data for the Gunsite 720 indicate the data are sufficient for use in an unit risk assessment evaluation. This evaluation was conducted to estimate the health or environmental problems that could result from the no further action alternative. The results indicate that the concentrations of all hazardous materials analyzed were near or below naturally occurring background levels and/or below any risk-based concentration action levels. Therefore, they pose no risk to human health and the environment.

Based upon screening available evidence, there are no potential chemicals of concern available for evaluation by a CERCLA baseline risk assessment and, therefore, there is no determinable risk associated with Gunsite 720 .

An analysis of data collected as a result of the studies performed at Gunsite 720 Rubble Pit Unit indicates there is no contamination at that unit that will endanger human health or the environment. Survey data indicate that the substances found in the soils at the unit are within the levels normally associated with SRS background levels. In addition, it is also reasonable to conclude that, since there is no contamination, the unit presents no significant ecological risk.

Based on the review of the analytical data and screening techniques used to evaluate all the chemicals of potential concern at Gunsite 720 Rubble Pit Unit, it is recommended that no further remedial action be performed at this unit. 


\subsection{INTRODUCTION}

\subsection{Purpose}

This report summarizes the activities and documents the results of a Resource Conservation and Recovery Act (RCRA) Facility Investigation/Remedial Investigation (RFI/R) conducted at Gunsite 720 Rubble Pit Unit on the Savannah River Site (SRS) near Aiken, South Carolina. The RFI/RI was conducted in stages, beginning with a preliminary unit evaluation in October 1988, followed by a screening phase, and culminating in a field assessment stage in 1993.

The primary objective of the Remedial Investigation/Feasibility Study (RI/FS) is "to gather data sufficient to support an informed risk management decision regarding which remedy appears to be most appropriate for a given site" (EPA, 1988). In order to accomplish this, it is necessary to define the nature and extent of the contamination, determine the fate and transport of the contaminants, complete a baseline risk assessment (BRA), and identify remedial action objectives. In the event that a FS is required, this information is then used to identify potential remedial action alternatives and potential applicable or relevant and appropriate requirements (ARARs). To achieve the goals of this RI, both historical data and data collected during the 1993 characterization were used.

This introductory section presents background information about the unit, outlines the regulatory requirements guiding the investigation, the unit's history, and previous investigations at the unit.

\subsubsection{SRS RCRA 3004(u)/CERCLA Program Description}

The United States Department of Energy (DOE) Savannah River Field Office manages waste materiais regulated under the Resource Conservation and Recovery Act (RCRA). In particular, certain activities require RCRA operating or post closure permits. Savannah River Site (SRS) has received a RCRA permit from the South Carolina Department of Health and Environmental Control (SCDHEC). Part V of the permit mandates that SRS establish and implement a RCRA Facility Investigation (RFI) Program to fulfill 
requirements of RCRA Section 3004(u). Section V.A.1 of the permit lists solid waste management units (SWMUs) that were identified by the United States Environmental Protection Agency (EPA) Region IV through the RCRA Facility Assessment (RFA) process and therefore subject to the RFI process.

On December 21, 1989, SRS was included on the National Priority List (NPL). A unit included on the NPL falls under the jurisdiction of the Comprehensive Environmental Response, Compensation, and Liability Act (CERCLA). This inclusion created the need to integrate the established RFI Program with CERCLA RI requirements. In accordance with Section 120 of CERCLA, DOE has negotiated a Federal Facility Agreement (FFA) with EPA and SCDHEC to integrate remedial activities at SRS into one comprehensive strategy which fulfills these dual regulatory requirements

SWMUs listed in the RCRA permit and the FFA Appendix are required to be further investigated to determine their actual or potential impact on the environment. Those listed units are called RCRA/ CERCLA Remedial Investigation Units in this document. Gunsite 720 Rubble Pit Unit is one of the RCRA/CERCLA units mandated for further investigation.

In order to conduct the RUFS, SRS developed the RFI/RI Program Plan (WSRC [Westinghouse Savannah River Company], 1993) (originally titled the RFI Program Plan) to provide guidance and delineate standard procedures. It also provides a reasonable and cost effective approach while allowing SRS flexibility in the investigation of each RCRA/CERCLA unit. The plan specifies generic methods and procedures to be used for each unit investigation. Because of continuing change in the status of facilities at SRS, the program plan is periodically reviewed and modified to keep it current.

The RFI/RI Program Plan (WSRC, 1993), in conjunction with Guidance for Conducting Remedial Imvestigations and Feasibility Studies (FS) Under CERCLA, Interim Final (EPA, 1988), were used as the primary sources of guidance for work plan preparation. These references are jointly referred to as RFI/RI guidance documents. The work plan for Gunsite 720 Rubble Pit Unit conformed to the requirements specified in the RFIRI guidance documents. 
Sections 113 and 117 of CERCLA lists the requirements for public participation in the restoration process. These requirements include the establishment of an Administrative Record File that documents the selection of cleanup alternatives and provides for public review and comment on those altematives. The DOE document, Public Imwolvement, $A$ Plan for the Savannah River Site (DOE, 1994), is designed to facilitate public involvement in the decision-making processes for permitting, closure, and selection of remedial alternatives. The Public Involvement Plan (PIP) addresses the requirements of CERCLA, RCRA, and the National Environmental Policy Act (NEPA).

Unit-specific documentation, such as work plans and RIs, are a part of the Administrative Record File and are available to the public. Information repositories have been established at the DOE Public Reading Room located at the Gregg-Graniteville Library of the University of South Carolina in Aiken, South Carolina and the Thomas Cooper Library located at the University of South Carolina in Columbia, South Carolina. A notice will be published in local newspapers when information is compiled regarding the investigation of Gunsite 720 Rubble Pit Unit . Additional repositories may be added and/or locations changed to better meet the needs of the public.

\subsection{Site Background}

\subsubsection{Site Description .}

Gunsite 720 Rubble Pit Unit is located on the west side of SRS. Figure 1-1 shows the location of the Gunsite 720 Rubble Pit Unit in relation to major SRS facilities. This RCRA/CERCLA unit is approximately 304.9 meters (1000 feet) west of South Carolina Highway 125, 167.7 meters (550 feet) north of SRS Road A-2 and 2.4 kilometers (1.5 miles) from the nearest site boundary. SRS coordinates for the unit are N80000/E27350.

Gunsite 720 Rubble Pit Unit consists of an open area covered with natural shrub growth and surrounded by native pine trees and shrubs which encompasses approximately 2,250 square meters (25,000 square feet). Two concrete slabs are located on the east side of the open area. Surface drainage in the area is to Upper Three Runs Creek. There are also swamps located to the west and northwest of the unit. 
Gunsite 720 Rubble Pit Unit

WSRC-RP-95-360, Rev. 1

RFI/RI Report

March 1996

$\because:$

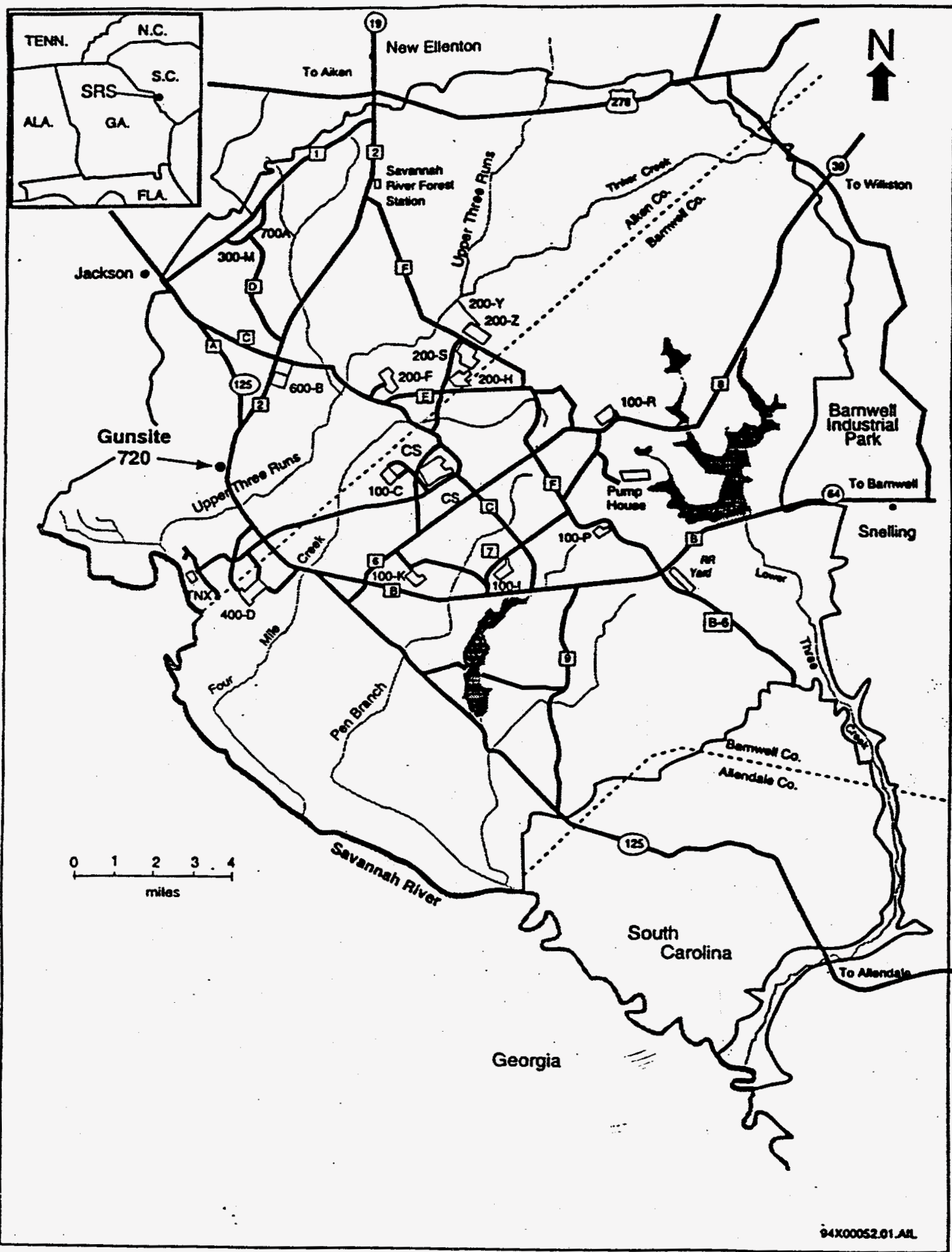

Figure 1-1 Location of Gunsite 720 in Relation to Major SRS Facilities 


\subsubsection{Site History}

During the period from 1955 to 1960 , the U. S. Army established anti-aircraft artillery gun emplacements onsite to defend SRS in the event of an air attack. A total of 19 gun emplacements with both $75 \mathrm{~mm}$ and $90 \mathrm{~mm}$ guns were set up. Gunsite 720 is one of those emplacements.

In the early to mid 1980 s, while work was being performed in the area, nine empty, partially buried drums, labeled "du Pont Freon 11" were found at Gunsite 720 . As a result, Gunsite 720 became one of the original waste units specified in the SRS RCRA Facility Assessment (RFA). When SRS was listed on the NPL, those waste units became RCRA/CERCLA waste units and were placed in Appendix C (RCRA/CERCLA units) of the FFA.

The drums were excavated on July 30, 1987 and placed on a pallet at the unit. The drums and pallet were removed and disposed of in October 1989. The area around the drums was screened during the excavation and the liquid (rainwater) that collected in the excavated drums was sampled prior to disposal. Information about the screening/sampling is vague, but it was reported that no evidence of hazardous materiais was found.

Older SRS maps and plans indicate that an underground fuel storage tank (UST) was at the unit. An above ground tank was also noted on the maps. There is no physical evidence that the tanks currently exist at Gunsite 720. The unit presently consists of two concrete slabs and an abandoned well.

There is no documentation or record of any hazardous substance management, disposal, or any other type of waste disposal at this unit. There is no evidence of any burning, excavation or recent disposal activities having occurred in this area or that disposal activities were more widespread. Facility documents indicate that an underground fuel tank was located in the area; however, magnetic surveys, ground penetrating radar (GPR), and trenching failed to detect any storage tanks or buried debris. 


\subsection{Previous Investigations}

The first step towards determining if a hazardous substance has been released from a RCRACERCLA unit consists of a Preliminary Unit Evaluation. The primary goal of the preliminary evaluation is to determine what hazardous substances, if any, were disposed of or released from the unit.

Previous sampling data for Gunsite 720 Rubble Pit Unit consists of four soil gas samples taken in March 1988 as part of a survey of selected potential waste sites at SRS (Looney et al, 1988). Those soil gas sampling locations are indicated in Figure 1-2. All four soil gas samples were taken from $0.5 \mathrm{~m}$ (1.5 feet) depths around the palletized drums. Analytical results of these samples found only trace levels of volatile organic compounds (VOCs). No analyses for light or fuel-related hydrocarbons were performed at this time.

Based on the preliminary evaluation results, a Unit Screening Plan for Gunsite 720 Rubble Pit Unit was formulated. The following sections describe the Preliminary Unit Evaluation and Unit Screening procedures and results. Chapter 2 describes the activities conducted to complete the Unit Assessment.

\subsubsection{Preliminary Unit Evaluation}

A review of existing literature and information from Gunsite 720 Rubble Pit Unit, conducted in accordance with the RFI/RI Program Plan (WSRC, 1993), included:

- Physical and chemical characteristics of the waste (hazardous and non-hazardous) known to be managed at the unit;

- Unit/disposal area characteristics;

- General hydrogeologic conditions of the unit and the current environmental setting;

- Any previous sampling and/or monitoring data for the unit. 


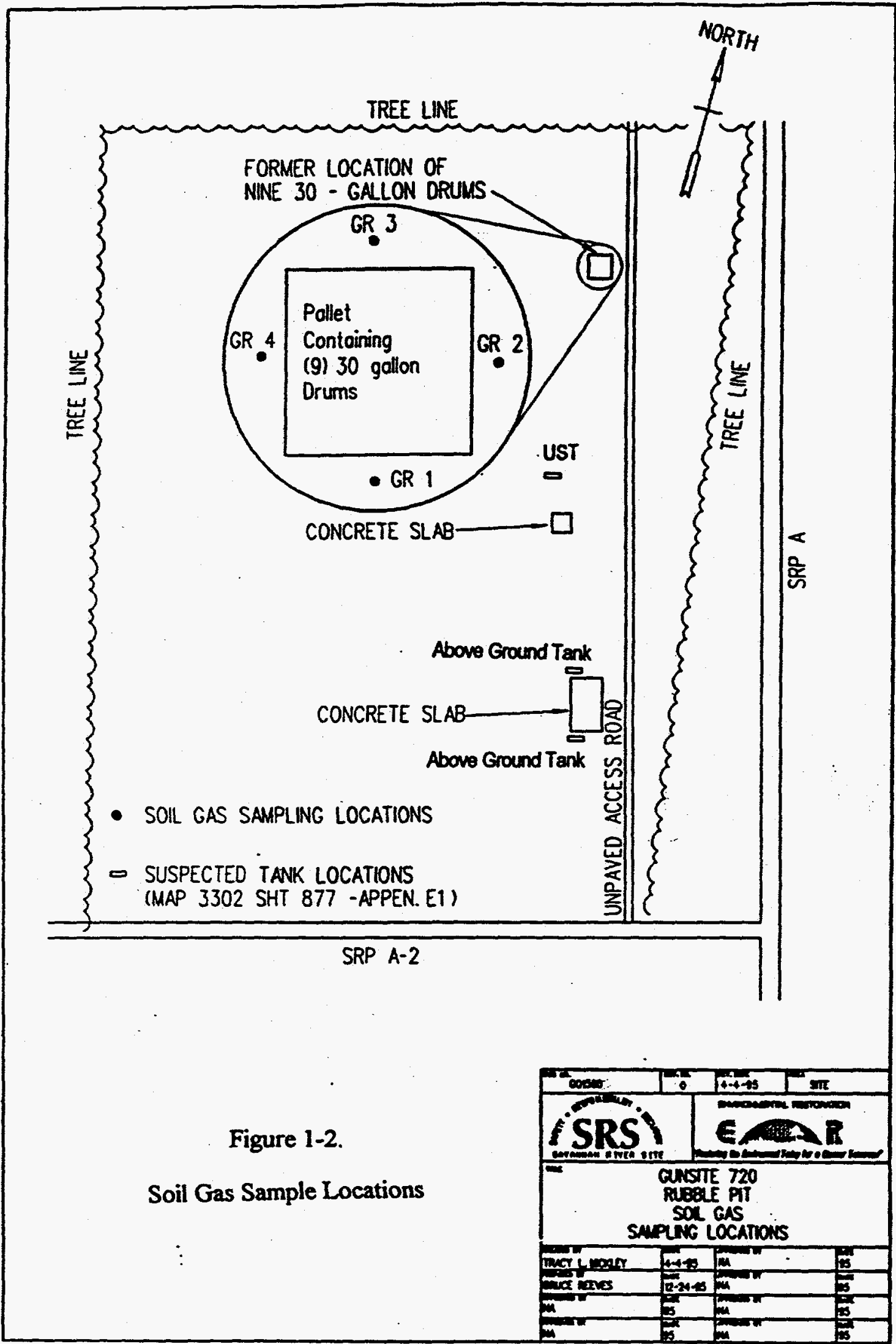




\subsubsection{Existing Literature and Information}

Existing information specifically pertaining to the Gunsite 720 Rubble Pit Unit was reviewed: A complete list of the documents reviewed is included in Section 5.2.1 of the RFIRI Plan for the Gunsite 720 Rubble Pit, WSRC-RP-90-1049 (WSRC, 1990)

\subsubsection{RFIRI Literature Review Checklist}

This checklist presents RFI data and information that are specific to each individual environmental medium. Copies of the completed checklist appear in Appendix D.1 of the RFI/RI Plan for the Gunsite 720 Rubble Pit, IVSRC-RP-90-1049 (WSRC, 1990).

\subsubsection{RFI/RI Site Reconnaissance}

Following a review of all existing data and information, a unit reconnaissance was performed to further assess the following field conditions:

- environmental setting;

- source characterization (RCRAICERCLA unit conditions and waste characteristics);

- waste release potential (for each environmental medium).

The completed "Site Reconnaissance Field Data Sheet" lists unit-specific factors considered during the actual reconnaissance. This data sheet was completed in full to provide appropriate written documentation of field observations. Following the unit reconnaissance; the Literature Review Checklist was updated to include information and data collected from the field visit.

\subsubsection{Preliminary Unit Evaluation Results}

Information regarding current unit conditions is listed on the Literature Review Checklist and the Unit Reconinaissance Field Data Sheet which can be found in Appendix D.2 of the RFI/RI Plan for the Gunsite 720 Rubble Pit, WSRC-RP-90-1049 (WSRC, 1990). That information is summarized in Sections 1.3.1.4.1 through 1.3.1.4.2. 


\subsection{Waste Characteristics}

Little is known about any waste disposal activities at this unit. The unit was originally used by the military for air defense of the Savannah River reservation. Several antiaircraft guns were located at the unit, hence the name "Gunsite". Additionally, barracks and other support facilities were located at or near the unit to house and support military personnel working at the Gunsite. Presently, Gunsite 720 Rubble Pit Unit is an inactive receptor of waste; however, no documentation describing past waste disposal activities at the unit is known to exist. No known hazardous waste disposal activities have occurred at the unit.

Nine empty 30-gallon drums were excavated and palletized on 31 July, 1987. The drums, located in an 2.5 meter by 2.5 meter ( 8 feet by 8 feet) area, were found partially exposed among piled refuse and some shrubs. Six of the drums had their tops cut out, their sides folded inward and were found bottom side up. The other three drums were found intact but not sealed. "du Pont Freon 11" was painted on the drums. A survey of the drums and two soil samples using a photoionization detector produced readings of less than $2 \mathrm{ppm}$. These drums were removed from the unit in October 1989.

A review of the 1952 SRS Map 3302 Sheet 877 indicated that an underground tank and one or more fuel tanks. were located near each of the concrete slabs. In 1986, a magnetic survey was conducted to locate underground tank(s) believed to be buried at the unit. The results of the survey were inconclusive although high readings were recorded near one of the concrete pads. It was not known, however, whether these readings were caused by a buried tank, concrete reinforcement rods, or other construction debris buried near the pad.

\subsection{Unit/Disposal Area Characteristics}

The palletized drums and rubble pit area encompass approximately 2250 square meters (25,000 square feet). There is no evidence of excavation, but construction debris and soil appear to have been disposed of in a random manner throughout the unit. Ground penetrating radar, conducted in March 1989, revealed small objects scattered throughout 
the unit. No underground tanks were identified during this survey, although large objects were detected near both concrete pads.

\subsubsection{Unit Screening}

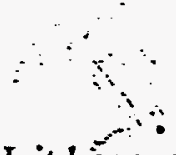

A Unit Screening program was performed at Gunsite 720 Rubble Pit Unit because the Preliminary Unit Evaluation indicated a possible receipt of hazardous-substances. The primary goal of the Unit Screening phase is to identify if a release of hazardous substances did occur and areas potentially impacted by a hazardous substance release. The $R \dot{F I} / R I$ Program Plan (WSRC, 1993) specifies that Unit Screening investigative activities include one or more of the following geophysical and/or geochemical techniques:

- Geophysical investigations such as ground penetrating radar (GPR) or electromagnetics (EM);

- Soil gas analysis; and/or

- Confirmation soils analysis.

The three options listed above were first evaluated regarding their applicability at Gunsite 720 Rubble Pit Unit and a program was then designed and implemented.

\subsubsection{Evaluation of Unit Screening Options}

A geophysical investigation using ground penetrating radar (GPR) was selected because the unit consists of several mounds of dirt and appears to have been used as a surface disposal area for construction rubble and/or spoil dirt. This technology would allow for a search of buried drums, other containers, and subsurface features.

Soil gas data (Looney et al, 1988) collected during a survey of selected potential waste sites at SRS (see Section 1.3) show trace levels of volatile organic compounds (VOCs) that suggests the possible past disposal of chlorinated solvents at this unit. Because of this, confirmation soil analysis was selected to screen for semi-volatile and volatile organic compounds, metals and radioactivity. 


\subsubsection{Unit Screening Geophysical Survey}

A ground penetrating radar (GPR) survey was conducted by Site personnel in March 1989. Reports based on that survey indicate that there is no evidence of buried or underground objects in the area. Additional documentation on that survey is not available.

\subsubsection{Unit Screening/Confirmation Soil Analysis Sampling}

The goal of the unit screening effort was to evaluate whether a hazardous substance release had occurred and to identify any chemical constituents involved. Chemical parameters which indicate the presence and magnitude of a hazardous waste or hazardous substance release were selected for analysis. For screening at Gunsite 720 Rubble Pit Unit, the following chemical parameters were analyzed at selected locations:

- Full EPA Appendix IX (40 CFR, Part 264) scan;

- Radionuclide indicators (gross alpha, gross beta);

- Total metals (eight RCRA metals: $\mathrm{As}, \mathrm{Ba}, \mathrm{Cd}, \mathrm{Cr}, \mathrm{Pb}, \mathrm{Hg}, \mathrm{Se}, \mathrm{Ag}$ );

- Volatile organics (EPA Method 8240);

- Semi-Volatile Organics (EPA Method 8270); and

- Physical parameters (soil pH, TOC);

- Total petroleum hydrocarbons.

Chemical parameters were selected to obtain information on waste disposal history (waste oils, volatile organics, semi-volatile organics, and metals), waste characterization (Appendix IX, radionuclide indicators), constituents in excess of background, or to provide sufficient information to indicate constituent absence (Appendix $\mathrm{DX}$, radionuclide indicators).

\subsection{Soil Sampling}

Soil samples were collected in 1990 by two different methods at Gunsite 720 Rubble Pit Unit. A stainless steel hand auger was used to obtain soil samples from seven boreholes within the unit as well as one background soil sample outside the unit. Subsurface soil samples were taken from depths of 0-0.9 meters (0-3 foot) and 1.8-2.4 meters (6-8 feet) 
below the ground surface. Two additional soil grab samples were taken from Trench 01 at a depth of 1.8-2.4 meters (6-8 feet). Borehole and trench sample locations are shown on Figure 1-3.

Soil samples were analyzed at the intervals and for the constituents indicated in Table 1-1. Sample identification nomenclature and quality control field samples are also indicated in this table.

\subsection{Soil Analytical Results}

All substances detected at concentrations greater than analytical method detection limits have been summarized and are reported in Table 1-2. The constituent concentrations listed are those which the contract laboratory has reported "above detection limits". Reporting of these values does not imply that these levels are above background because statistical background levels have not been quantified. Similarly, reported levels are not "remediation trigger levels" or "clean-up levels".

Three organics species, acetone, bis(2-ethylhexyl) phthalate, and methylene chloride, were detected in soil samples collected from the target areas. Concentrations ranged from 12$24 \mu \mathrm{g} / \mathrm{kg}$ (acetone), 39-660 $\mu \mathrm{g} / \mathrm{kg}$ bis (2-ethylhexyl) phthalate, and 8-14 $\mu \mathrm{g} / \mathrm{kg}$ (methylene chloride). Acetone, bis(2-ethylhexyl) phthalate and methylene chloride are documented laboratory artifacts. The concentration of acetone and methylene chloride found in laboratory blanks ranged from $<13$ to $16 \mu \mathrm{g} / \mathrm{kg}$ and $<8$ to $11 \mu \mathrm{g} / \mathrm{kg}$ respectively (Table 1-3). The concentrations of these common laboratory contaminants, in their respective samples, do not exceed 10 times the maximum concentration of like compounds detected in any blank. Consequently, the concentrations of acetone, and methylene chloride detected in unit samples are not considered to be positive detections.

The Practical Quantitation Limit (PQL) for bis(2-ethylhexyl) phthalate is $660 \mu \mathrm{g} / \mathrm{kg}$ for soils and sediments. The PQL is the lowest level that can be reliably achieved within specified limits of precision and accuracy during routine laboratory operating conditions. Since the highest concentration of bis(2-ethylhexyl) phthalate detected in any sample is $660 \mu \mathrm{g} / \mathrm{kg}$, or the PQL, and bis(2-ethylhexyl) phthalate is known laboratory artifact, the significance of its detection in unit samples is believed to be minimal. 


\section{RFI/RI Report}

March 1996

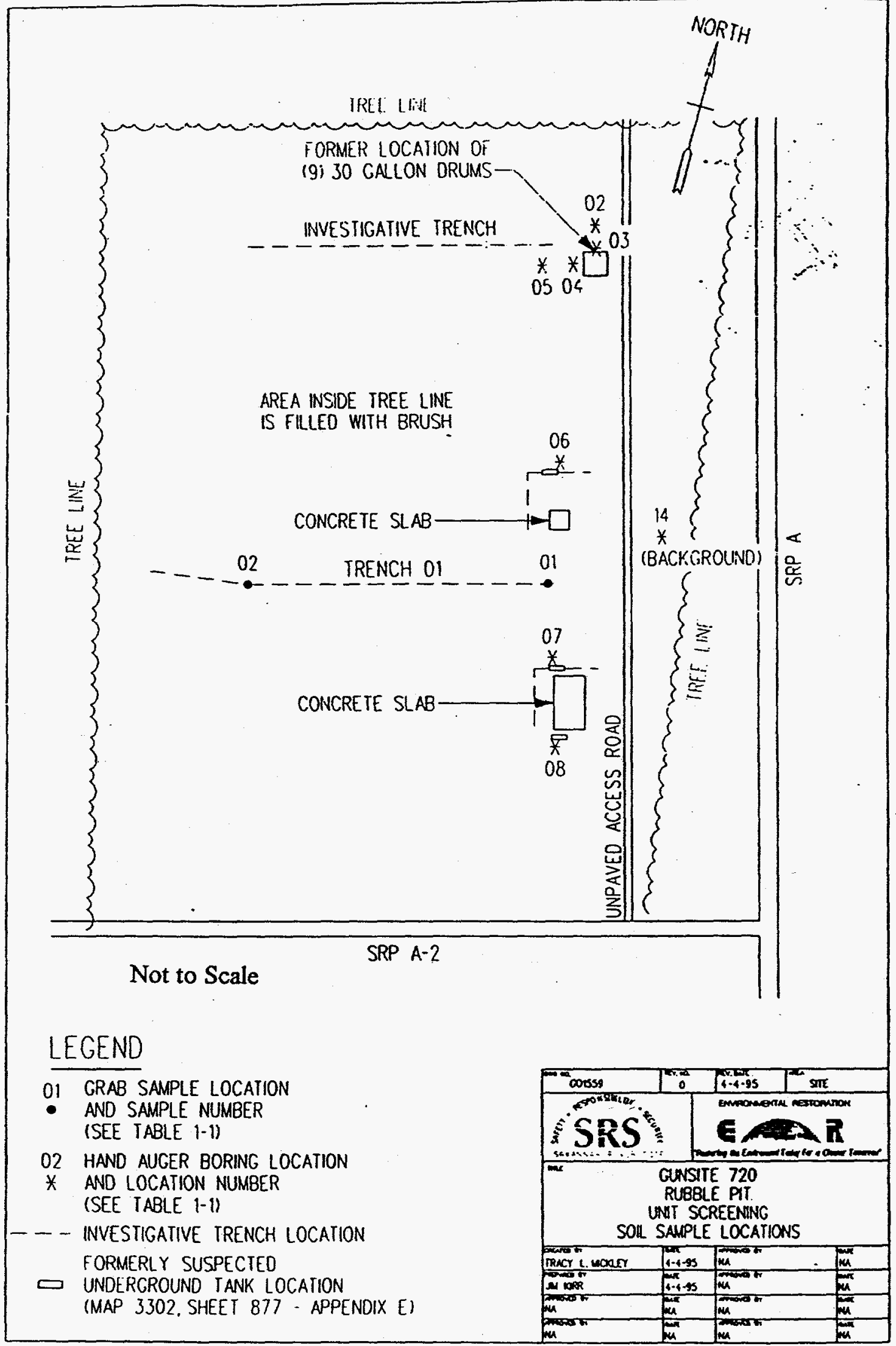

Figure 1-3 Unit Screening Soil Sample Locations 
TABLE 1-1

Soil Sampling Intervals and Constituents Analyzed (1990)

\begin{tabular}{|l|c|c|l|ll|l|}
\hline $\begin{array}{l}\text { GS720 } \\
\text { Location }\end{array}$ & $\begin{array}{l}\text { Location } \\
\text { Number }\end{array}$ & $\begin{array}{l}\text { Sample } \\
\text { Number }\end{array}$ & $\begin{array}{l}\text { Sampling } \\
\text { Method }\end{array}$ & $\begin{array}{l}\text { Sample Depth } \\
\text { meters } \\
\text { (feet) }\end{array}$ & $\begin{array}{l}\text { Required } \\
\text { Analyses }\end{array}$ \\
\hline Trench & 01 & 01 & Grab & $1.8-2.4$ & $(6-8)$ & $1,2,4,5,7$ \\
& 01 & 02 & Grab & $1.8-2.4$ & $(6-8)$ & $1,3,4,5$ \\
\hline Borehole & 02 & 01 & Hand Auger & $0-0.9$ & $(0-3)$ & $1,4,5$ \\
& 02 & $01 \mathrm{~A}$ & Duplicate & $0-0.9$ & $(0-3)$ & 1,5 \\
\hline Borehole & 03 & 01 & Hand Auger & $0-0.9$ & $(0-3)$ & $1,2,4$ \\
\hline Borehole & 04 & 01 & Hand Auger & $0-0.9$ & $(0-3)$ & $1,4,7$ \\
\hline Borehole & 05 & 01 & Hand Auger & $0-0.9$ & $(0-3)$ & 1,5 \\
& 05 & $01 \mathrm{D}$ & Split Sample & $0-0.9$ & $(0-3)$ & 1,5 \\
\hline Borehole & 06 & 01 & Hand Auger & $1.8-2.4$ & $(6-8)$ & $1,5,6$ \\
\hline Borehole & 07 & 01 & Hand Auger & $1.8-2.4$ & $(6-8)$ & $1,5,6$ \\
\hline Borehole & 08 & 01 & Hand Auger & $1.8-2.4$ & $(6-8)$ & $1,5,6$ \\
\hline GS 720 & 10 & $01 \mathrm{E}$ & Auger Rinsate & \multicolumn{2}{|c|}{ N/A } & 1,4 \\
\hline GS 720 & 11 & $01 \mathrm{E}$ & Backhoe Rinsate & \multicolumn{2}{|c|}{ N/A } & 1 \\
\hline GS 720 & 12 & $01 \mathrm{~B}$ & Trip Blank & \multicolumn{2}{|c|}{ N/A } & 1 \\
\hline Background & 14 & 01 & Hand Auger & $0-0.9$ & $(0-3)$ & $1,2,4,5,7$ \\
\hline
\end{tabular}

Analyses are coded as follows:

1. Volatile Organics

2. Radionuclide indicators (gross alpha and gross beta using a gas proportional counter)

3. Appendix IX' Compounds

4. Total metals (eight RCRA metals: $\mathrm{As}, \mathrm{Ba}, \mathrm{Cd}, \mathrm{Cr}, \mathrm{Pb}, \mathrm{Hg}, \mathrm{Se}, \mathrm{Ag}$ )

5. Semi-Volatile Organics

6. Total Petroleum Hydrocarbons (TPH)

7. Indicator Parameters: $\mathrm{pH}$, specific conductance, Total Organic Carbon (TOC)

Note: Headspace Screening for volatile organics was performed on all samples in the field using an OVA. 


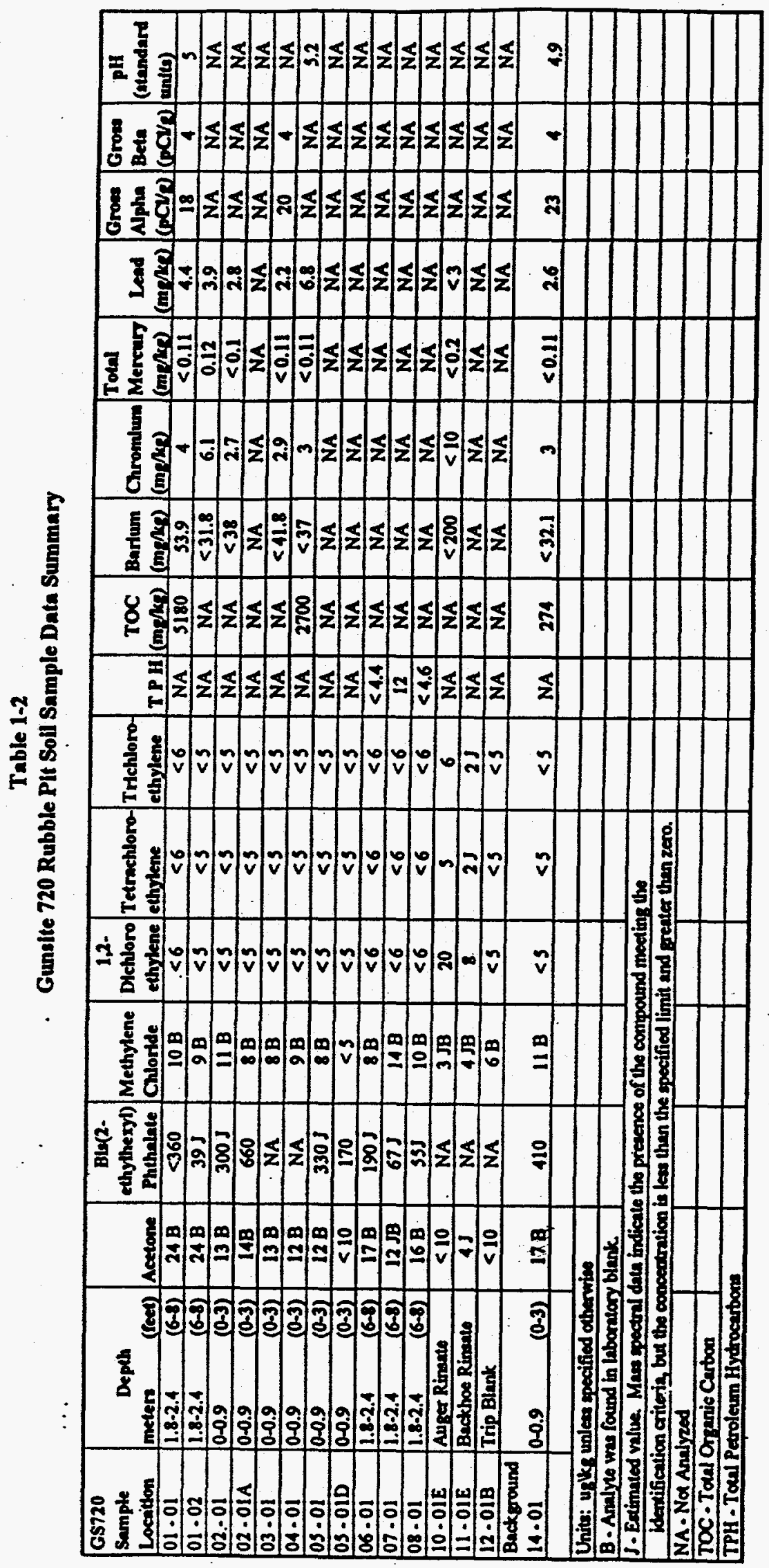




\section{TABLE 1-3}

\section{LABORATORY QUALTYY CONTROL RESULTS}

\section{A. Laboratory Method Blanks (for all values exceeding method detection limits)}

\begin{tabular}{llc} 
& $\begin{array}{l}\text { Lab Blank } \\
\text { Concentration }\end{array}$ & $\begin{array}{c}\text { Field Sampling } \\
\text { Concentration }\end{array}$ \\
Range $(\mu \mathrm{g} / \mathrm{kg})$ & Range $(\mu \mathrm{g} / \mathrm{kg})$ \\
\hline Constituent & $<13$ to $16^{*}$ & 12 to 24 \\
acetone & $<8$ to $11^{* *}$ & 8 to 14 \\
methylene chloride & &
\end{tabular}

* The Contract Required Quantitation Limit (CRQL) for acetone is $10 \mu \mathrm{g} / \mathrm{kg}$. CLP protocol allows blank concentrations of up to 5 times the CRQL for this constituent. If the blank contains detectable levels of acetone, then a sample result should be considered a "positive" result only if the acetone concentration in the sample exceeds 10 times the maximum amount detected in any blank.

** The CRQL for methylene chloride is $5 \mu \mathrm{g} / \mathrm{kg}$. Contract Laboratory Program (CLP) protocol allows blank concentrations of up to 5 times the CRQL for this constituent. If the blank contains detectable levels of methylene chloride, then a sample result should be considered a "positive" result only if the methylene chloride concentration in the sample exceed 10 times the maximum amount detected in any blank.

The CRQL is a chemical specific level that a CLP laboratory must be able to routinely and reliably detect and quantitate in specific matrices. The CRQL may or may not be equal to the reported quantitation limit of a given chemical in a given sample trace levels of gross alpha and gross beta detected in the unit samples were no greater than unit background. Low concentrations of barium, chromium, total mercury, and lead were also detected, but these concentrations are less than SRS and Southeastern U. S. background soil concentrations. These results as well as total organic carbon (TOC) and $\mathrm{pH}$ are also included in Table 1-2. 
Results of the Appendix IX analysis indicate that no herbicides, pesticides, PCBs, dioxins/furans, or other organic substances were detected. No chlorinated solvents other than trace levels of methylene chloride were detected in any sample.

\subsection{Trenching Observations}

Four trenches (see Figure 1-3) were excavated at the unit for the purpose of visually characterizing buried waste and to positively locate and identify buried tanks, if any, at the unit. A backhoe was used to dig all trenches to an approximate depth of 2.4 meters (8 feet) and a width of 1 meter ( 3.3 feet). The local water table was encountered at a depth of about 2.1 meters ( 6.9 feet) in all trenches. All trenches were backfilled with the excavated materials and leveled after all observations had been made.

Trench 01 was approximately 61 meters (200 feet) long and transected the unit where the majority of debris was believed to be buried (Figure 1-3). The purpose of this trench was to characterize any debris found buried at the unit. Only localized areas of household garbage, including cans, bottles, bottlecaps, wire, hose, and a tire, were found in the trench. Two soil composite grab samples were taken from depths between 1.8 - 2.4 meters (6-8 feet). Analysis of these samples is discussed in Section 1.3.2.3.1.

An additional investigative trench, approximately 55 meters (180 feet) long, transects the unit north of Trench 01 (Figure 1-3). The purpose of this trench was to characterize the debris buried at the unit and to visually compare with Trench 01 for vertical and horizontal consistencies. Like Trench 01 , only localized areas of household refuse were found. The lithology of the investigative trench was identical to that of Trench 01 . Consequently, the test pit report for Trench 01 was used to describe the investigative trench lithology. The investigative trench was identified as Trench " 02 " on the test pit report. No soil samples were taken from this trench.

The purpose of the trench excavated around the large concrete slab in the southeastern part of the unit was to confirm or deny the existence of two fuel storage tanks (Figure 1-3). No tanks were found; however, wires, two buried pipes, and a possible sewerline originating from the concrete slab were uncovered. Two composite soil samples were 
taken from a depth of 1.8-2.4 meters (6-8 feet) using a band auger. Analytical results from those samples are provided in Table 1-2.

The trench excavated around the small concrete slab (Figure 1-3) was to locate an underground storage tank listed on Savannah River Plant Topographic Map 3302, Sheet 877. Although a large concrete foundation was discovered, no buried tank was found. One composite soil sample was taken from a depth of 1.8-2.4 meters (6-8 feet) using a hand auger. Analytical results for this sample are provided in Table 1-2.

All the trenches were lithologically characterized by a field geologist. Geologic characterization results are discussed in detail in the RFIRI Plan for the Gunsite 720 Rubble Pit, WSRC-RP-90-1049 (WSRC, 1990).

\subsubsection{Unit Screening Conclusions}

Based on the Unit Screening data, hazardous substance concentrations appear to be "at or below background" although statistical background concentrations have not been calculated. A comparison of field data with unit-specific background data is shown in Table 1-4. The only hazardous substances exceeding their respective unit-specific . background concentrations are acetone (laboratory artifact), bis(2-ethylhexyl) phthalate (laboratory artifact), barium, chromium, lead, and total mercury.

For the four hazardous substance metals which exceeded unit-specific background levels (barium, chromium, lead, and total mercury), a comparison with SRS and southeastern U. S. mean background values was made (Table 1-4). Lead and chromium maximum field concentrations are less than both the maximum SRS background level and southeastern U. S. mean background levels. The maximum field value for barium is significantly less than mean southeastern U. S. background level. The maximum field value for total mercury is less than the SRS mean background level. When compared to two times background levels, lead and chromium exceed the levels but only by a small margin (Table 1-4). Based on comparison with unit-specific, SRS, and southeastern U. S. background concentrations, it appears that there has been no environmental impact due to hazardous substance disposal at the Gunsite 720 Rubble Pit Unit. There is also no evidence of any hazardous substance release from this unit. 
TABLE $1-4$

\section{COMPARISON OF MAXTMUM SOL CONCENTRATIONS}

WITH BACKGROUND LEVELS FOR

GUNSITE 720 RUBBLE PIT UNTT

\begin{tabular}{|c|c|c|c|c|c|}
\hline $\begin{array}{l}\text { Hazardous } \\
\text { Substance*(units) }\end{array}$ & $\begin{array}{l}\text { Maximum Soil } \\
\text { Concentration - } \\
\text { Unit Screening }\end{array}$ & $\begin{array}{l}\text { Unit-Specific } \\
\text { Background } \\
\text { Level }\end{array}$ & $\begin{array}{l}\text { Two times } \\
\text { Unit-Specifie } \\
\text { Background } \\
\text { Level }\end{array}$ & $\begin{array}{l}\text { SRS Medin } \\
\text { Background } \\
\text { Level** }\end{array}$ & $\begin{array}{l}\text { Southenstern } \\
\text { U.S.Level** }\end{array}$ \\
\hline Acetone $(\mu \mathrm{g} / \mathrm{kg})$ & $24 B$ & 17B & 34 & - & - \\
\hline $\begin{array}{l}\text { Bis(2-ethylhexyl) } \\
\text { phthalate }(\mu g / \mathrm{kg})\end{array}$ & 660 & 410 & 820 & - & - \\
\hline $\begin{array}{l}\text { Methylene Chloride } \\
(\mu \mathrm{g} / \mathrm{kg})\end{array}$ & $14 \mathrm{~B}$ & $11 B$ & 22 & - & - \\
\hline $\begin{array}{l}\text { Total Petroleum } \\
\text { Hydrocarbons }(\mu \mathrm{g} / \mathrm{kg})\end{array}$ & 12 & NA & NA & - & - \\
\hline Gross alpha (pCi/g) & 20 & 23 & 46 & - & - \\
\hline Gross beta (pCi/g) & 4 & 4 & 8 & - & - \\
\hline Barium (mg/kg) & 53.9 & $<32.1$ & $<64.2$ & $50.4-65.13$ & 225 \\
\hline Chromium (mg/kg) & 16.32 & 3 & 6 & $1.31-105.1$ & - \\
\hline $\begin{array}{l}\text { Total mercury } \\
\text { (mg/kg) }\end{array}$ & 0.12 & $<0.11$ & $<0.22$ & $<0.01-0.1$ & 0.1 \\
\hline Lead (mg/kg) & 6.8 & 2.6 & 5.2 & $<1.0-16.67$ & $13 \vdots$ \\
\hline
\end{tabular}

- For substances detected in excess of method detection limit

** data from Looney et, 1990

*** For substances which exceeded the unit-specific background area results; data from Conner and Shacklette, 1975

B Analyte was found in Laboratory Blank.

NA Not Analyzed 
Trenching operations at the unit uncovered common household garbage and little construction debris, but no buried tanks. Analytical results of soil samples taken from the trenches and debris identified in the trenches suggest that hazardous waste handling activity at the unit is unlikely as is the existence of buried tanks. No other buried materials were located by the GPR, magnetic or soil gas surveys.

\subsection{Report Organization}

This RFI/RI Report, following EPA Guidance (EPA, 1988), consists of seven chapters for describing the rationale for the investigation, unit characterization activities conducted, data evaluation, risk assessment, and data assessment. Chapter 1 provides background information summarizing the history of the unit, and the purpose and objectives of this investigation. Chapter 2 describes the objectives of the EPA-approved work plan.

Chapter 3 describes the physical characteristics of the unit including surface topography, hydrogeology, soil types, demography and land use, and ecology. Chapter 4 presents an evaluation of the contamination present at Gunsite 720 Rubble Pit Unit. Chapter 5 evaluates the fate and transport mechanisms applicable to the contaminants detected, and Chapter 6 presents a summary of the human health and ecological baseline risk assessment. Chapter 7 summarizes the results of the RCRA/CERCLA Unit Assessment along with conclusions derived from data analysis. 


\subsection{STUDY AREA INVESTIGATION}

\subsection{Surface Feature Investigation}

The general topography of Gunsite 720 Rubble Pit Unit has been mapped and the surface drainage delineated. Figure 2-1 is a topographic map of the unit and Chapter 3.0 provides additional information on area physiography.

\subsection{Contaminant Source Investigation}

The general history of this area does not provide any information about its use as a waste unit. However, a unit screening program was required since the preliminary unit evaluation indicated the possible disposal of hazardous substances. The unit screening is discussed in Section 1.3.2.

\subsection{Meteorological Investigation}

As a nuclear facility, SRS maintains a system of seven meteorological towers located adjacent to each production area and at the WJBG-TV tower about 15 kilometers ( 9 miles) north of the unit. In addition, the National Weather Service (NWS) maintains a station at Augusta's Bush Field airport approximately 26 kilometers (16 miles) northwest of this area.

Data from these sources have been compiled and published in numerous documents including the environmental impact statement (EIS) for continued operation of $K_{-}, \mathrm{L}$, and P- Reactors (DOE, 1990), and the Draft EIS for the Siting Construction, and Operation of New Production Reactor Capacity (DOE, 1991). Meteorological data are summarized in Section 3.2 No ambient air sampling was performed because Gunsite 720 Rubble Pit Unit is inactive with no potential for impact to the air. 


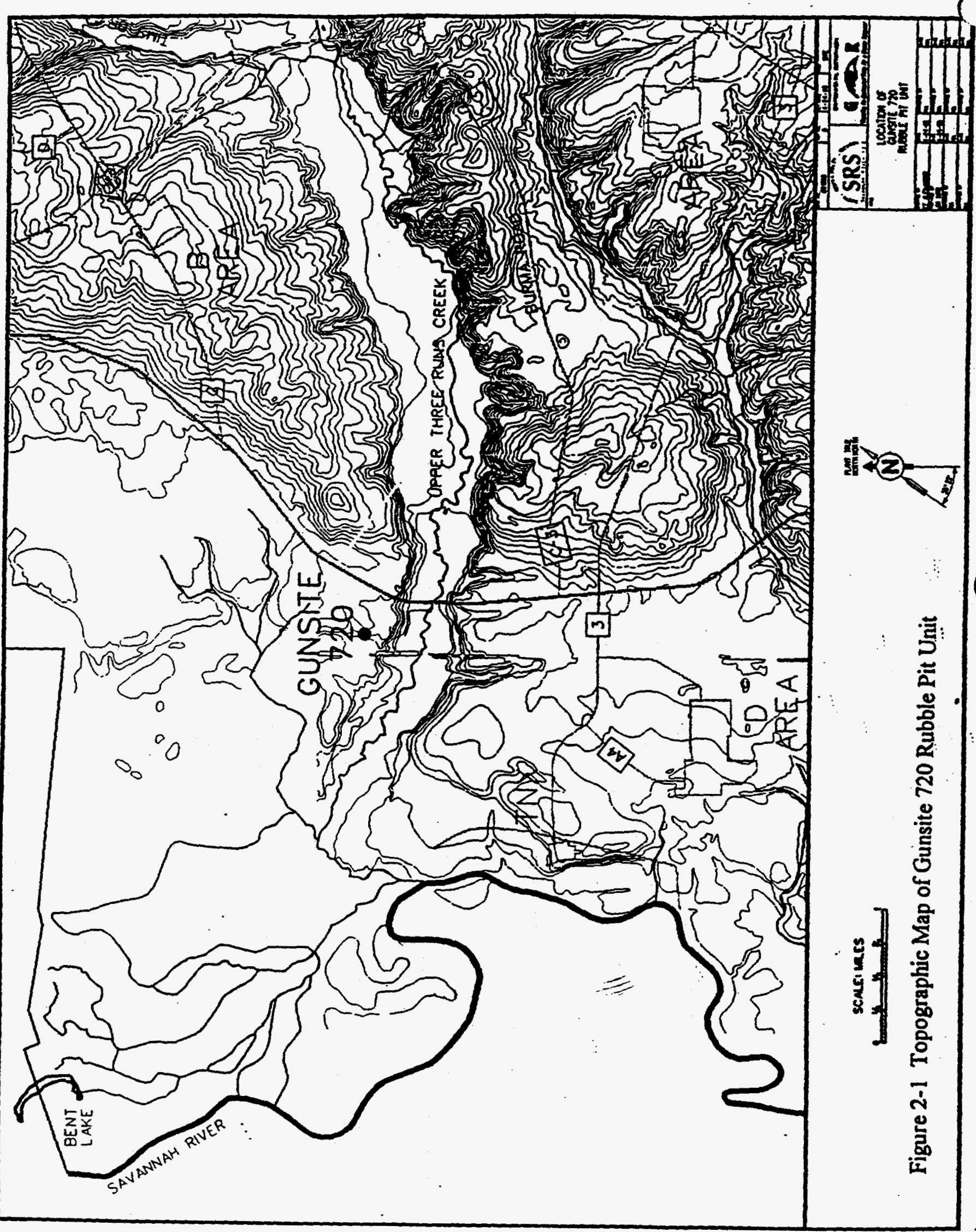




\subsection{Surface Water and Sediment Investigation}

Surface water/sediment sampling was not conducted because the nearest surface water is Upper Three Runs Creek located about 1.3 kilometers (0.8 miles) southeast of the unit.

\subsection{Soil/ Vadose Zone Investigations}

As noted in Section 1.3.1.4.1, a magnetic survey was conducted in 1986 to locate underground storage tanks (UST) believed to be buried on the unit. The location of that survey is shown in Figure 2-2. Three distinct anomalies were noted near the concrete pads, but the results of the survey were essentially inconclusive. Because of this and concerns regarding the existence of the UST and potential releases from those tanks, it was decided to run additional magnetic and ground penetrating radar (GPR) surveys and obtain additional soil samples from the area of concern. These samples would be analyzed for VOCs, TPH, benzene, toluene, ethylbenzene, xylene (BTEX) and metals.

\subsubsection{Magnetic Survey}

A magnetic survey of Gunsite 720 was conducted in 1993 by the Environmental Monitoring Section Groundwater Group. Figure 2-3 shows the location of that survey. Data were collected with an EG\&G Geometrics G-856 Gradiometer.

The most prominent feature noted in this survey was an anomaly in the vicinity of the small concrete pad. This anomaly has the same shape as that noted in the 1986 survey except that the anomaly appears to be rotated 90 degrees. The 1993 anomaly is what would be expected from a flat slab at this latitude. The difference in orientation between the 1986 and 1993 reading has no reasonable explanation. However; the shape and magnitude of the anomaly is consistent with an anomaly produced by a concrete slab reinforced with steel bars.

An anomaly noticed on the surface in the 1986 survey was interpreted as being caused by a truck parked on the highway. A metal cable anchor is also located in that area and is the most probable cause of that anomaly. The third anomaly detected in 1986 was not noted 


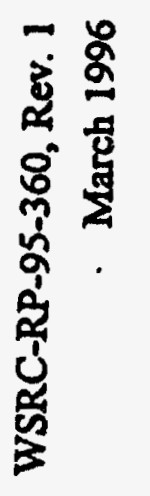

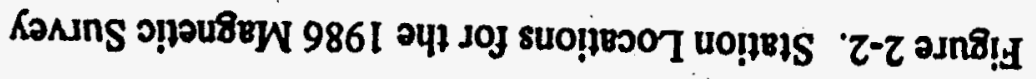

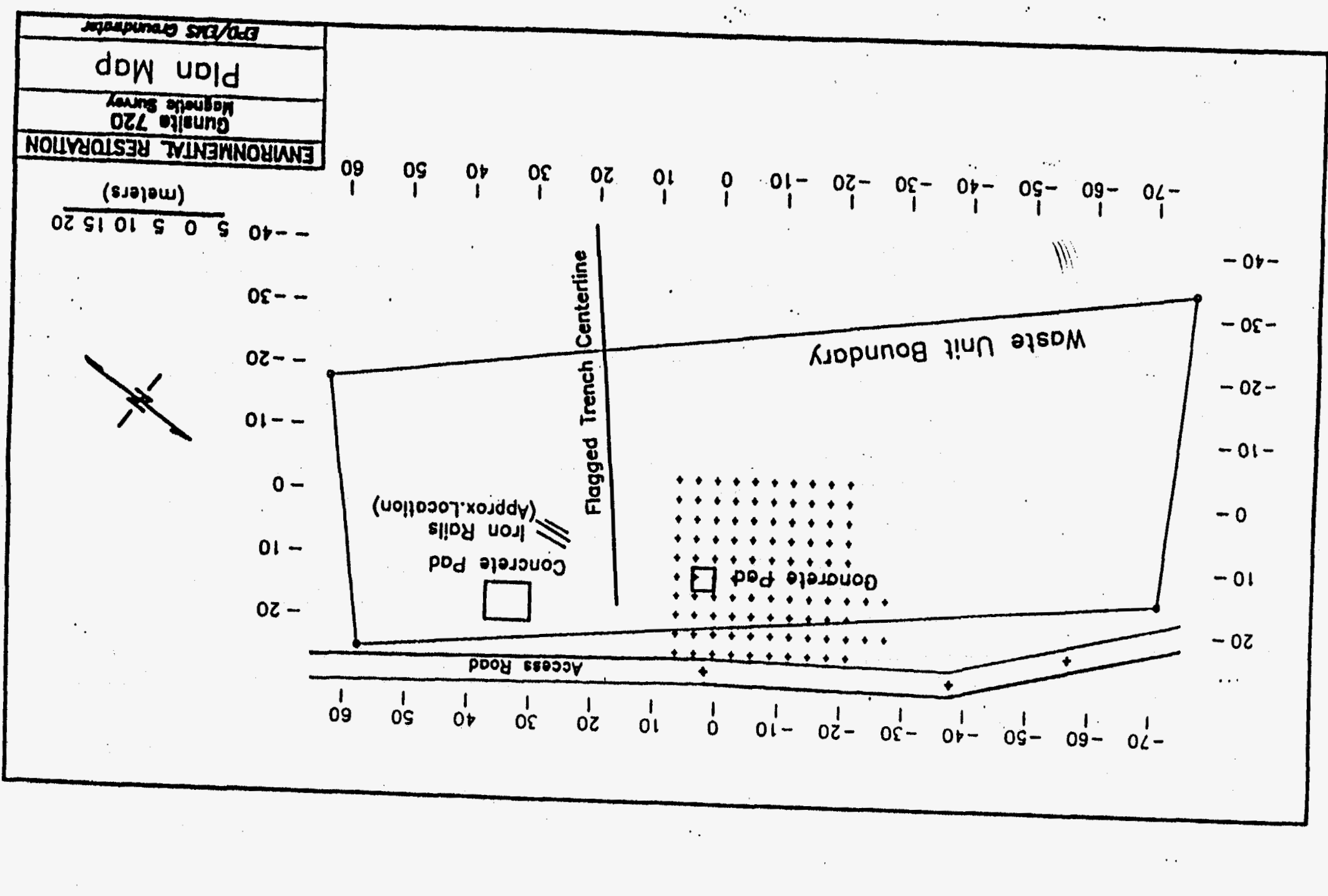


Gunsite 720 Rubble Pit Unit

RFI/RI Report

WSRC-RP-95-360, Rev. 1

March 1996

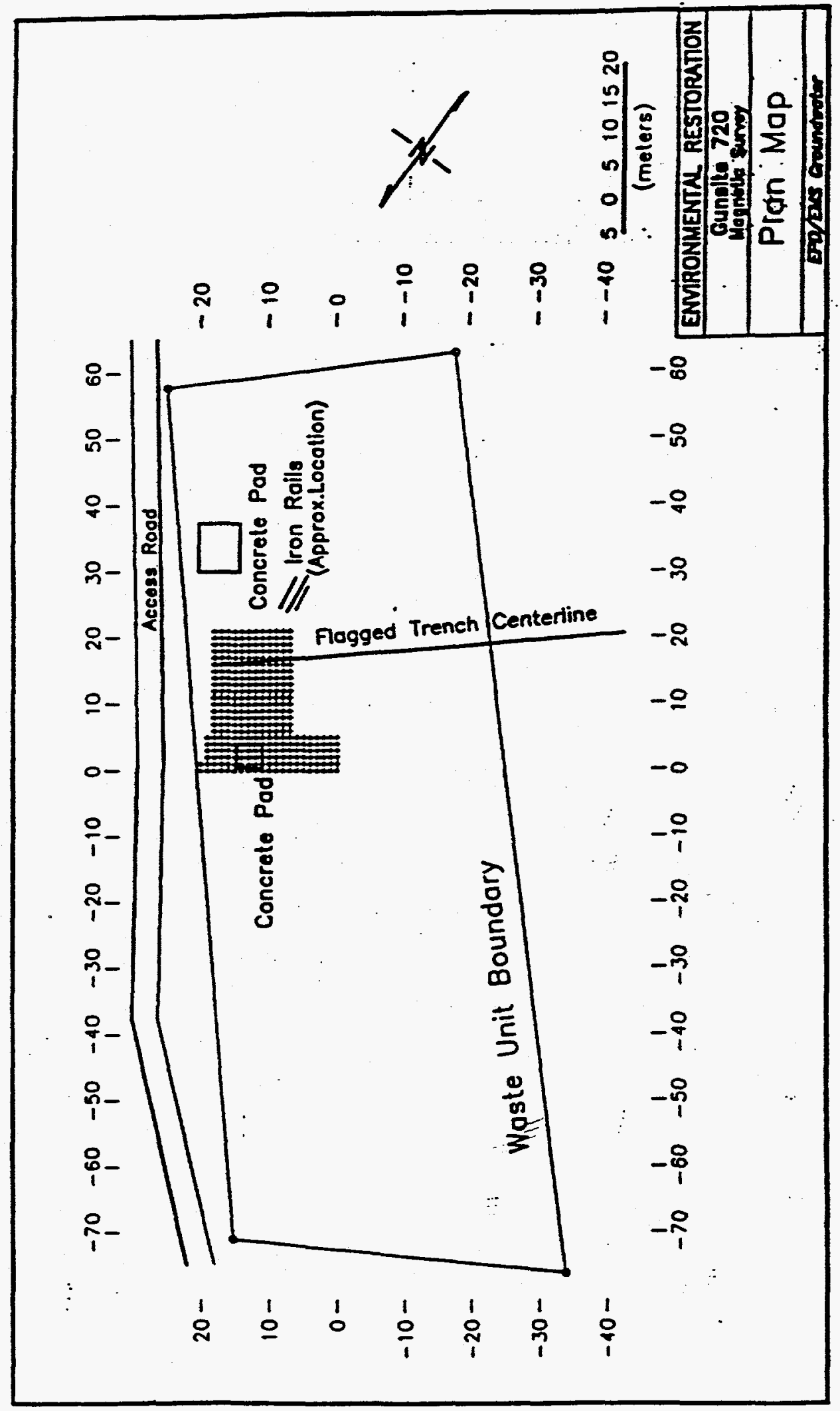

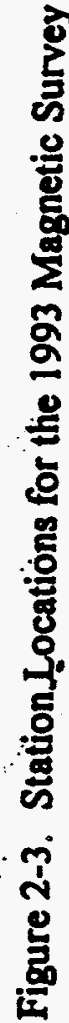


in this recent survey. This is apparently caused by the excavation and removal from this location of a large concrete object with metal pipes in the time interval between the two surveys.

The 1993 survey has produced a much better resolution of the magnetic anomaly associated with the pad. That anomaly is produced only by the pad. The possible presence of a buried metal tank around the pad is unsupported based on the magnetic data. All other anomalies identified in the 1986 and 1993 surveys can be attributed to metal objects that were either excavated between the two surveys, or that can be identified on the ground surface. Specific data for the magnetic survey are provided in Appendix A.2.

\subsubsection{Ground Penetrating Radar Survey}

Ground Penetrating Radar (GPR) surveys were run at Gunsite 720 in January and March 1993 for the purpose of locating trenched areas, pipelines and subsurface targets of interest. GPR data were acquired on 22 lines totaling 3437 feet. Figure 2-4 is a map of the location of the lines that were investigated during this survey.

Data collected at Gunsite 720 was of good quality. Lines 1 - 22 (see Figure 2-4) contain prominent diffractions possibly indicating pipes or buried metallic objects along the GPR transect. Areas within the red ball markers are distinguished by chaotic returns indicating disturbed soils where trenching or back-filling has occurred. A high amplitude event occurring almost continuously on each line may indicate the water table. Copies of the GPR records for each line are provided in Appendix A.1.

\subsubsection{Soil Sampling}

Additional soils samples were collected from the areas where the drums had been found and the UST was believed to be located to make a final determination if there has been any release of hazardous substances into the environment. Figure 2-5 shows the location of the samples collected in the 1993 survey. Samples were collected from $1.2-1.8$ meters (4 - 6 feet), 2.4 - 3.1 meters ( 8 - 10 feet), 3.1 - 3.7 meters ( 10 - 12 feet), 3.7 - 4.3 meters (12 - 14) feet at both sites. Additional samples from $4.3-4.9$ meters (14- 16 feet) and 4.9 - 5.5 meters (16-18 feet) were collected in the vicinity of the UST. All samples 
Gunsite 720 Rubble Pit Unit

WSRC-RP-95-360, Rev. 1

RFI/RI Report

March 1996

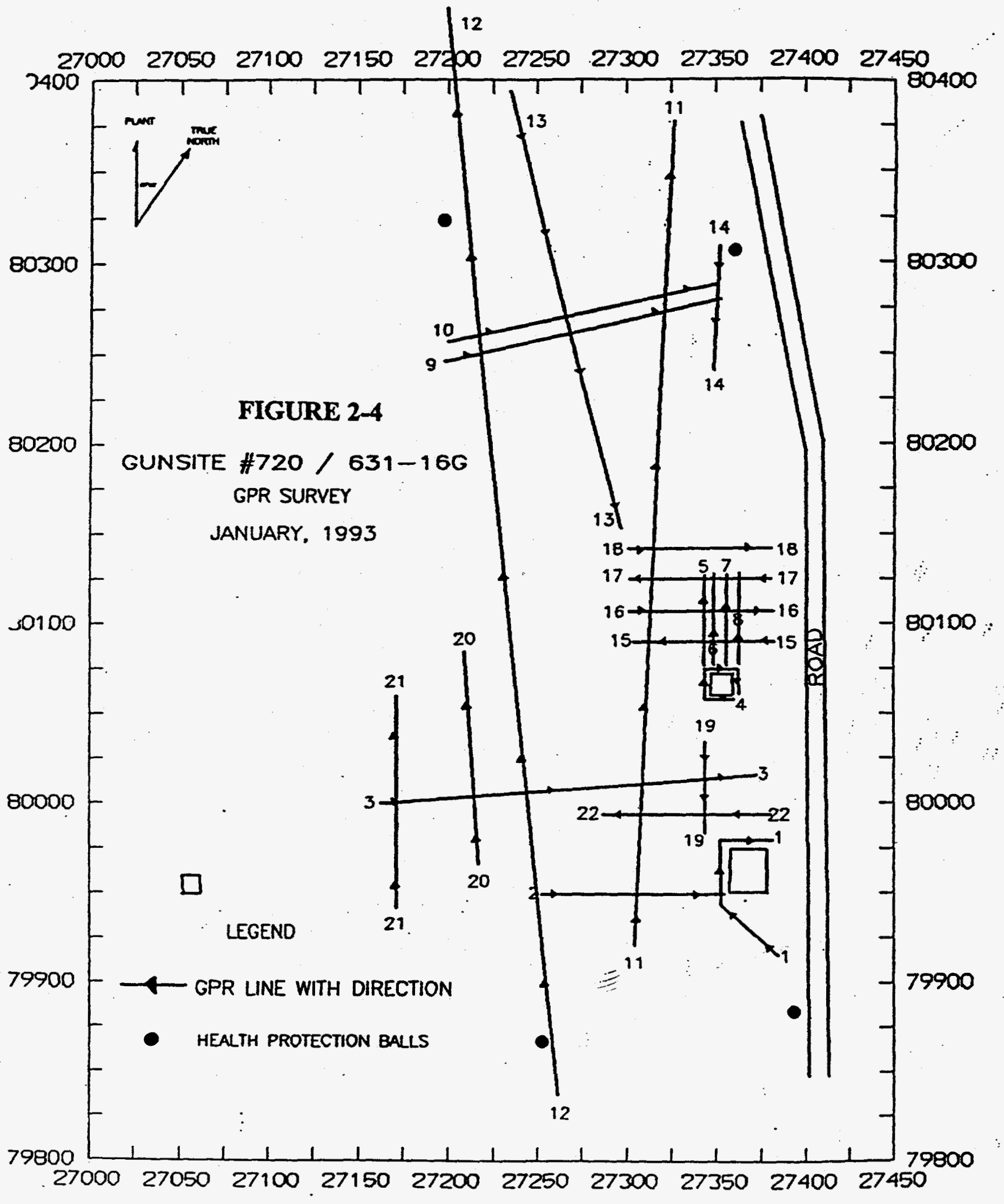




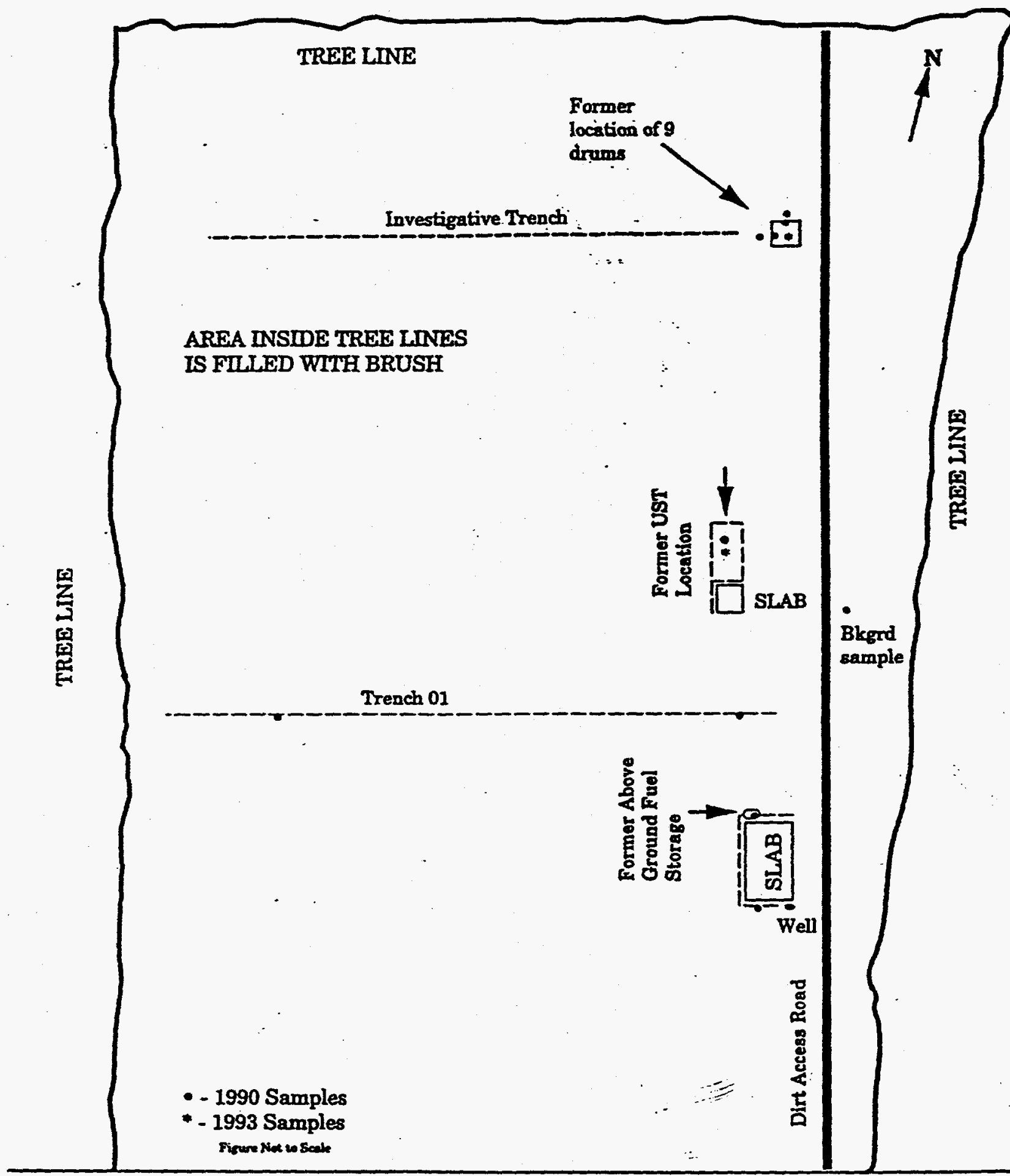

SRP A-2

Well

Figure 2-5. Sample Locations for the 1993 Soil Survey 
Gunsite 720 Rubble Pit Unit

WSRC-RP-95-360, Rev. 1

RFI/RI Report

March 1996

were analyzed for VOCs, TPH, BTEX, and metals.

Table 2-1 and 2-2 summarize the 1993 soil sampling results. Barium, chromium and lead were detected in the samples, but were below background levels. Petroleum hydrocarbons were not detected in the soil samples. Trace levels of 1,1,1-trichloroethane were detected in some samples. All substances were well below any proposed EPA action level.

\subsubsection{Conclusions from the Magnetic, GPR and Soil Surveys}

Trenching, GPR, and magnetic surveys of Gunsite 720 found no evidence of burial pits or a UST. The soil sampling results indicate there are no substances at Gunsite 720 that trigger any regulatory action levels. In most cases, the substances detected are below background levels. In addition, the nine empty, 30-gallon drums found at the unit were excavated, screened and removed. The results of the investigation indicate that no hazardous substances have been managed or are present at Gunsite 720.

\subsubsection{Identification of Human Health Chemicals of Potential Concern (COPCs)}

Soil samples were collected in four primary areas at the unit: around a large concrete slab, around a small concrete slab, within trench 01 , and around the empty 30-gallon drums. No samples from the investigative trench were obtained because no evidence of any disturbance was found. In addition a background soil sample was collected across a gravel road in a wooded area upgradient from the site.

All analyses were performed in accordance with standard EPA Contract Laboratory Program (CLP) protocols. An evaluation of the laboratory QAVC documentation proved that adequate controls were applied and that the resulting analytical data are of sufficient quality for use in a CERCLA risk assessment. All laboratory control samples responded within instrument and method limits. 
TABLE 2-1

1993 Soil Sample Results: UST Area

(Units in ppm unless otherwise specified)

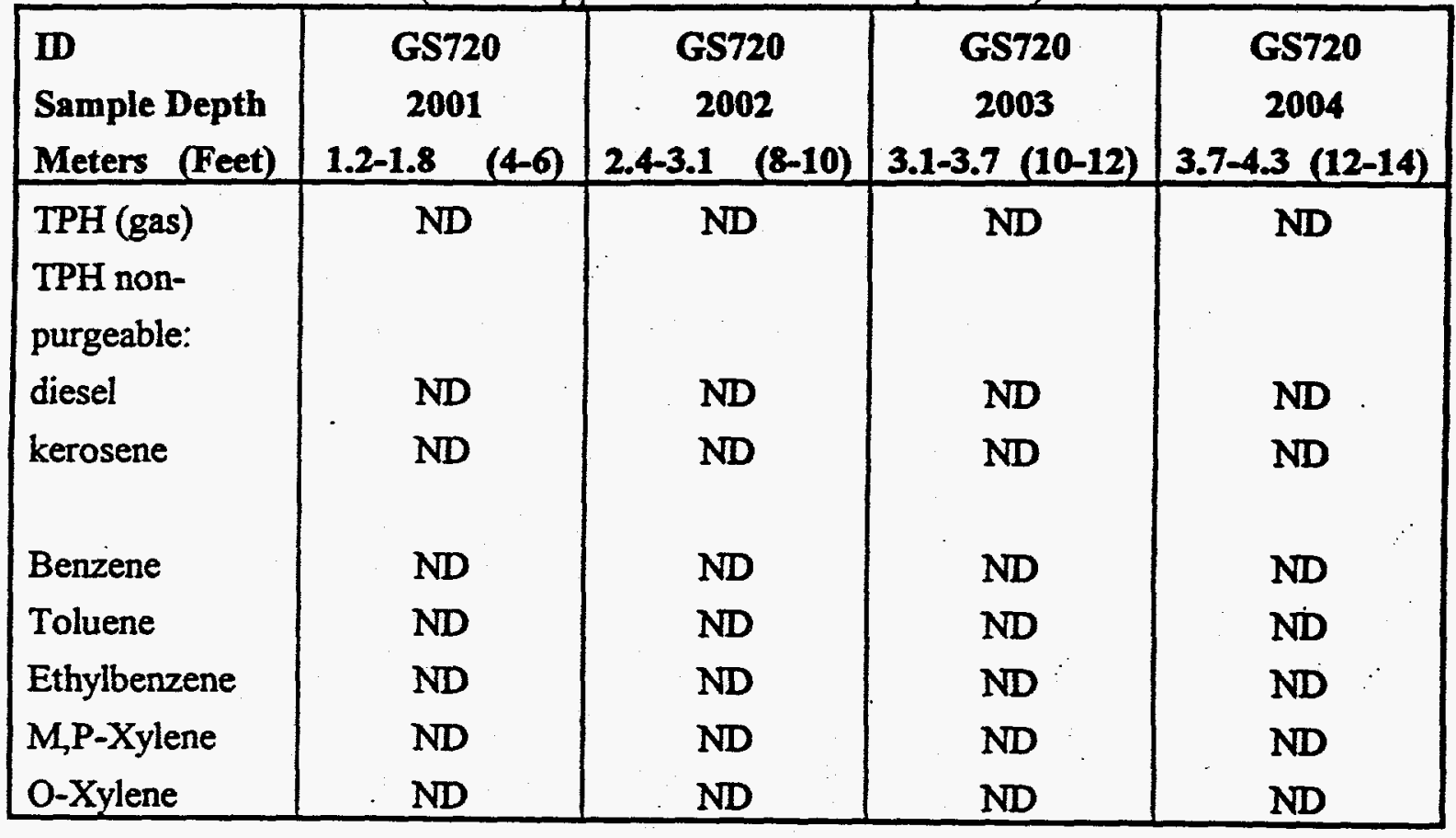

$\mathrm{ND}=$ not detected 
TABLE 2-2

1993 Soil Sample Results: Drum Area

(Units in ppm unless otherwise specified)

\begin{tabular}{|l|c|c|c|c|c|c|}
\hline ID & GS720 & GS720 & GS720 & GS720 & GS720 & GS720 \\
Depth & 3001 & 3002 & 3003 & 3004 & 3005 & 3006 \\
Meters & $1.2-1.8$ & $2.4-3.1$ & $3.1-3.7$ & $3.7-4.3$ & $4.3-4.9$ & $4.9-5.5$ \\
Feet) & $(4-6)$ & $(8-10)$ & $(10-12)$ & $(12-14)$ & $(14-16$ & $(16-18)$ \\
\hline Silver & ND & ND & ND & ND & ND & ND \\
Arsenic & ND & 2.31 & 1.37 & 1.04 & ND & ND \\
Barium & 26.4 & 30.7 & 10.9 & 11.9 & 6.59 & 8.55 \\
Cadmium & ND & ND & ND & ND & ND & ND \\
Chromium & 2.99 & 14.4 & 16.32 & 12.3 & 4.04 & 4.21 \\
Mercury & ND & ND & ND & ND & ND & ND \\
Lead & 4.65 & 5.81 & 4.17 & 3.24 & ND & ND \\
Selenium & ND & ND & ND & ND & ND & ND \\
& & & & & & \\
1,1,1 TCE & 0.028 & 0.02 & 0.02 & 0.015 & ND & 0.016 \\
\hline
\end{tabular}

$\mathrm{ND}=$ not detected 


\subsubsection{Chemicals of Potential Concern}

Four metals (barium, chromium, mercury, and lead) were detected above unit-specific background levels (Table 2-3). Two of the metals, barium and mercury, did not exceed twice the unit-specific background levels. Barium was detected at $53.9 \mathrm{mg} / \mathrm{kg}$ and twice the unit-specific background level is $64.2 \mathrm{mg} / \mathrm{kg}$. A comparison of the barium concentration to SRS background levels, detected by Looney et al (1990), in samples taken within $\mathbf{3 0 0 0}$ feet of the Gunsite shows that the level of barium detected is within the naturally occurring range for barium in upland sandy soils.

Mercury was detected at $0.12 \mathrm{mg} / \mathrm{kg}$ and twice the unit-specific background level is 0.22 $\mathrm{mg} / \mathrm{kg}$. The background level for mercury is reported as the detection limit of $0.11 \mathrm{mg} / \mathrm{kg}$. While the background sample did not detect mercury above the detection limit of 0.11 $\mathrm{mg} / \mathrm{kg}$, the detected level in one sample of $0.12 \mathrm{mg} / \mathrm{kg}$ is the lowest quantifiable level that can be detected. Additionally, the SRS background range for mercury is from $0.01 \mathrm{mg} / \mathrm{kg}$ to $0.89 \mathrm{mg} / \mathrm{kg}$ in upland sandy soils (Looney, 1990) and the mercury detected at the Gunsite falls within the lowest quartile of the SRS range. Furthermore, the quality control report for this sample states that the laboratory control standards were within the control limits of $80 \%$ to $120 \%$ for mercury. The $80 \%$ to $120 \%$ control limit is a measure of the analytical method's accuracy. The control limit range for the method detection limit of $0.11 \mathrm{mg} / \mathrm{kg}$ is $0.088 \mathrm{mg} / \mathrm{kg}$ to $0.132 \mathrm{mg} / \mathrm{kg}$. The control limit range of the $11 \mathrm{mg} / \mathrm{kg}$ method detection limit and the $0.12 \mathrm{mg} / \mathrm{kg}$ sample result overlap by a significant amount, supporting the probability that the $0.12 \mathrm{mg} / \mathrm{kg}$ sample result is an artifact of the analytical method and does not represent an actual environmental concentration. This probability coupled with the fact that this is the only one of four environmental (and one background) samples to yield a result above the method detection limit is convincing evidence that the mercury detected is a spurious result.

Lead was detected at $6.8 \mathrm{mg} / \mathrm{kg}$, with a unit-specific background level of $2.6 \mathrm{mg} / \mathrm{kg}$, and the EPA soil cleanup guideline for lead in soil is $400 \mathrm{mg} / \mathrm{kg}$ (EPA, 1994).

Chromium was detected at $16.3 \mathrm{mg} / \mathrm{kg}$, with a unit-specific background level of 3.0 $\mathrm{mg} / \mathrm{kg}$. The EPA Region III Risk-Based Concentration (RBC) for ingestion of chromium 
TABLE 2-3

Comparison of Maximum Soil Concentrations with Unit-Specific and SRS Background Levels and EPA Region III RBCs. 1990 and 1993 data.

\begin{tabular}{|c|c|c|c|c|}
\hline \multirow[b]{2}{*}{ Constituent } & \multicolumn{2}{|c|}{$\begin{array}{c}\text { Gunsite } 720 \text { Soil } \\
\text { Sample Concentration }\end{array}$} & \multirow{2}{*}{$\begin{array}{c}\text { EPA } \\
\text { Region III } \\
\text { RBC * } \\
\end{array}$} & \multirow{2}{*}{$\begin{array}{c}\text { SRS Soil Background } \\
\text { Levels** }\end{array}$} \\
\hline & Marimum & Background & & \\
\hline \multirow{2}{*}{$\begin{array}{l}\text { ORGANICS (mg/kg) } \\
\text { TPH } \quad(1990)\end{array}$} & \multirow[b]{2}{*}{12} & \multirow[b]{2}{*}{ ND } & \multirow[b]{2}{*}{ - } & \multirow[b]{2}{*}{ NA } \\
\hline & & & & \\
\hline $\begin{array}{l}\text { 1,1,1-Trichloroethane } \\
\text { (1993) }\end{array}$ & 0.028 & NA & 7,000 & NA \\
\hline METALS (mg/kg) & \multirow[b]{2}{*}{53.9} & \multirow[b]{2}{*}{32.1} & \multirow[b]{2}{*}{5500} & \multirow[b]{2}{*}{$50.4-65.13$} \\
\hline Barium (1990) & & & & \\
\hline $\begin{array}{l}\text { Chromium (total) } \\
\text { (1993) }\end{array}$ & 16.32 & 3.0 & $390^{* * *}$ & $1.31-105.1$ \\
\hline Mercury (1990) & 0.12 & 0.11 & 23 & $<0.01-0.1$ \\
\hline Lead $\quad(1990)$ & 6.8 & 2.6 & 400 & $<1.0-16.67$ \\
\hline
\end{tabular}

* EPA Region III Risk-Based Concentration Table (soil ingestion-residential scenario), March, 1995

** Looney et al, 1990

*** Published action level for $(\mathrm{Cr})$ is for the $\mathrm{Cr}^{+6}, \mathrm{Cr}^{+3}$ is $78000 \mathrm{ppm}$

NA Not Available/Not Analyzed

ND Not Detected (below analytical limits) 
in soil by residents is $78,000 \mathrm{mg} / \mathrm{kg}$ for $\mathrm{Cr}^{+3}$ and $390 \mathrm{mg} / \mathrm{kg}$ for $\mathrm{Cr}^{+6}$ (EPA, 1995). The Soil Screening Levels for transfers from soil to groundwater from the EPA Region III $\mathrm{RBC}$ list is $19 \mathrm{mg} / \mathrm{kg}$ for $\mathrm{Cr}^{+6}$ in soil (there is no listing for $\mathrm{Cr}^{+3}$ and the +6 form of chromium is the most toxic). The level of chromium detected in the Gunsite soils falls below all of the risk-based concentrations, therefore, chromium would not be considered for analysis in a risk assessment.

Table 2-3 contains data for the samples in which substances were detected, the corresponding background values, and the EPA Region III Risk-Based Concentrations (considering the soil ingestion-residential scenario). This table illustrates the screening of the results.

A review of the unit sampling plan and the resulting soil and soil vapor analytical data for the Gunsite 720 indicate the data are sufficient for use in a unit risk assessment evaluation. This evaluation was conducted to estimate the health or environmental problems that could result from the no further action alternative. The results indicate that the concentrations of all hazardous materials analyzed were near or below natural occurring background levels and/or below any risk-based action levels. Therefore, they pose no risk to human health and the environment.

Based upon screening available evidence, there are no chemicals of potential concern available for evaluation by a CERCLA baseline risk assessment.

\subsection{Groundwater Investigation}

No groundwater monitoring wells have been installed at this unit, so there is no unit groundwater quality nor water level data available. Based on the topographic location of the unit, the depth to the groundwater table is estimated to be 3 meters ( 9.8 feet). Natural ground water discharge is to Upper Three Runs Creek. However, since there is no evidence of hazardous disposal at this unit, there was no need to collect water samples. 
Gunsite 720 Rubble Pit Unit

WSRC-RP-95-360, Rev. 1

RFIRI Report

March 1996

\subsection{Human Population Surveys}

There is no resident population on or in close proximity to Gunsite 720 Rubble Pit. The closest worker population to the unit is located in TNX, 4 lilometers ( 2.5 miles) southeast of the unit (see Figure 1-2). Gunsite 720 Rubble Pit is accessible from SRS Road A-2 to SRS workers and other authorized visitors. At present, the unit is outside the controlled access secured zone, but within the SRS security area and requires authorization for access. In addition, the area has been marked and labeled by the Environmental Restoration Department.

\subsection{Ecological Investigation}

No ecological investigation was conducted at this unit because there is no evidence that any hazardous material was disposed of at this location. 
Gunsite 720 Rubble Pit Unit

RFI/RI Report
WSRC-RP-95-360, Rev. 1

March 1996

THIS PAGE INTENTIONALLY LEFT BLANK

$\equiv$ 


\subsection{PHYSICAL CHARACTERISTICS OF THE STUDY AREA}

\subsection{Surface Features}

There are no structures other than the concrete slabs located at or near the Gunsite $\mathbf{7 2 0}$ Rubble Pit Unit. The only nearby man-made features are South Carolina Highway 125 about 304.9 meters (1000 feet) east of the unit, and SRS Road A-2 about 30.5 meters (100 feet) to the south. The topography is relatively flat at an elevation of about 45.7 meters (150 feet) above mean sea level (msl).

\subsection{Meteorology}

Climatology and meteorology of SRS are based on data collected on the unit; at Bush Field in Augusta, Georgia (DOE, 1990), and from the H-Area tower and A-Area shelter (DOE, 1991).

\subsubsection{Regional Climatology}

The SRS region has a temperate climate with short, mild winters and long, humid summers. The region is subject to continental influences, but is protected from the more severe winters in the Tennessee Valley by the Appalachian Mountains to the north and northwest, and is often influenced by warm and moist maritime air masses throughout the year. Gently rolling hills with no unusual topographic features that would significantly influence the general climate characterize the unit and the surrounding area.

\subsubsection{Temperature and Humidity}

The annual average temperature at $\mathrm{SRS}$ is $18^{\circ} \mathrm{C}\left(66.2^{\circ} \mathrm{F}\right)$ : Monthly averages range from $7^{\circ} \mathrm{C}\left(45.3^{\circ} \mathrm{F}\right)$ in January to $27^{\circ} \mathrm{C}\left(83.3^{\circ} \mathrm{F}\right)$ in July. The annual average relative humidity is 66 percent. The lowest monthly average daily minimum (36 percent) occurs in April, and the highest monthly average daily maximum (98 percent) occurs in August. 
Gunsite 720 Rubble Pit Unit

WSRC-RP-95-360, Rev. 1

RFI/RI Report

March 1996

\subsubsection{Precipitation and Evapotranspiration}

The average annual precipitation at SRS is 122 centimeters (48 inches). Precipitation is distributed fairly evenly throughout the year, with the highest precipitation in summer $(36.1 \mathrm{~cm} ; 14.2 \mathrm{in})$. Average precipitation totals for the fall months are less than the average totals for the other seasons, accounting for about 18 percent of the average annual total. For Augusta, precipitation totals greater than 0.025 centimeters $(0.01$ inches) occur, on average, about 107 days per year.

The average number of days per month with measurable precipitation range from about six in October to about 12 in July. Monthly precipitation extremes in Augusta range from a maximum of about 30 centimeters ( 11.8 inches), recorded in March 1980, to a trace, observed in October 1959.

The greatest observed rainfall for a 24-hour period was about 15 centimeters ( 5.9 Inches) in August 1964. Hourly observations from Augusta indicate that the rainfall rate is usually less than the 1.3 centimeters ( 0.5 inches) per hour, although rates greater than 1.3 centimeters per hour can be expected during spring and summer thunderstorms. The calculated 24-hour/100 year rainfall at SRS is 20.8 centimeters ( 8.2 inches; DOE, 1990)

Although snow can fall from October through March, the average annual snowfall is only 3.0 centimeters ( 1.2 inches). Large snowfalls are rare. The National Weather Service (NWS) station in Augusta, Georgia, observes maximum total snowfalls for 24-hour and monthly periods. From 1951 to 1987, the maximum snowfall in the SRS area was 36 centimeters (14.2 inches), recorded in February 1973 (DOE, 1990).

Evapotranspiration in the southeastern Coastal Plain physiographic province is approximately $88.9 \mathrm{~cm} / \mathrm{yr}$ ( 35 inches/yr), which is 73 percent of the reported average annual precipitation (DOE, 1990). The remaining precipitation represents the amount available to surface streams for overland flow and to groundwater for recharge. 


\subsubsection{Wind}

Wind data measured at the 6 meter ( 20 feet) level at the H-Area tower for the period 1982-1986 indicate that there is no predominant wind direction at SRS. The maximum directional frequency is from the northeast (about 9 percent of the time). Figure 3-1 shows an annual wind rose for H-Area, which is near the center of SRS. These data indicate that the observed wind directions tend to favor the southwest and northeast quadrants ( 28 and 30 percent of the time respectively) in relation to the northwest (20 percent) and the southeast ( 22 percent) quadrants. For all data, winds from the northeast sector occurred most frequently (nearly 10 percent of the time). Winds from direction sectors in the southwest quadrant also occurred with a relatively high frequency ( 7 to 8 percent of the time).

The average wind speed, from onsite data, from 1982 to 1986 was $3.25 \mathrm{~m} / \mathrm{s}$ ( $7.3 \mathrm{mph}$ ). Hourly wind speeds less than 2 meters per second occurred about 9 percent of the hours. For about half of the hours, wind speeds were less than $4 \mathrm{~m} / \mathrm{s}$ ( $9 \mathrm{mph})$. From 1975 to 1979 onsite data, the average speed was greatest during the winter $(3.35 \mathrm{~m} / \mathrm{s} ; 7.5 \mathrm{mph})$ and least during the summer $(2.48 \mathrm{~m} / \mathrm{s} ; 5.5 \mathrm{mph})$.

Winter storms in the SRS area occasionally bring strong and gusty winds with speeds as high as $32 \mathrm{~m} / \mathrm{s}$ (72 mph). On occasion, SRS instruments have recorded winds as high as $39 \mathrm{~m} / \mathrm{s}$ ( $87 \mathrm{mph}$ ) during winter storms. Thunderstorms can generate winds as high as 18 $\mathrm{m} / \mathrm{s}$ ( $40 \mathrm{mph}$ ) and even stronger gusts. During the history of the Site, only Hurricane Gracie, in September 1959, had onsite winds stronger than $34 \mathrm{~m} / \mathrm{s}$ (76 mph; DOE, 1990).

\subsubsection{Thunderstorms}

On average, 56 thunderstorm days occur per year on the site. Summer thunderstorms occur primarily during the late afternoon and evening; they can be accompanied by strong winds, heavy precipitation, or, less frequently, hail (DOE, 1990). On average, based on observations in a one-degree square of latitude and longitude, hail occurred once every two years. 
Gunsite 720 Rubble Pit Unit

WSRC-RP-95-360, Rev. 1

\section{RFURI Report}

March 1996

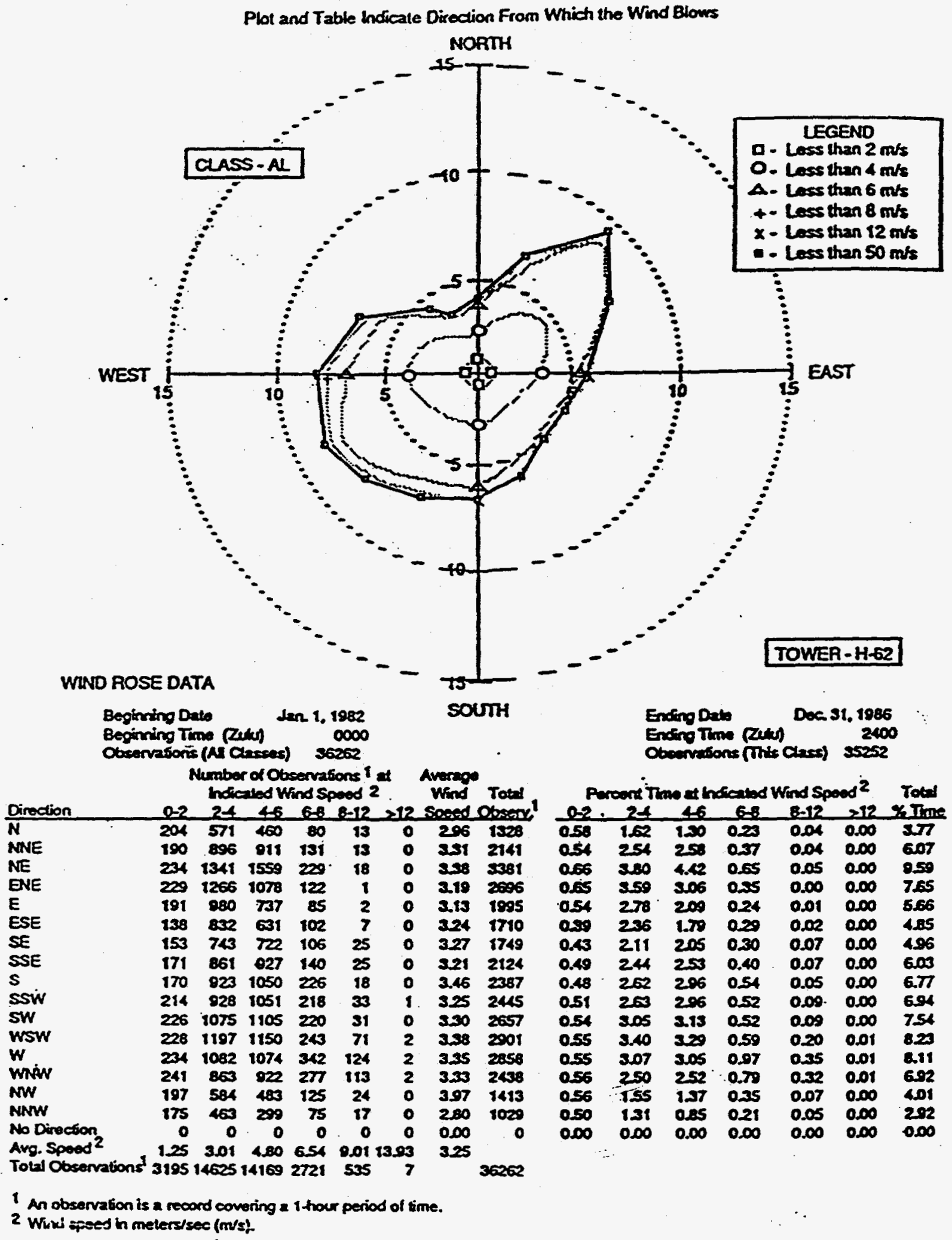

Aninual Wind Rose of Hourly Averaged Winds from H-Area Tower, 1982-86.

(Directions Are Sectors from Which Wind Blows.)

Source: . DOE, 1990

Figure 3-1. Annual Wind Rose for H Area 


\subsubsection{Ice and Snow}

Winter storms that produce more than 2.5 centimeters ( 1 inch) of ice or snow are rare. Snowfalls of 2.5 centimeters or greater occur once every five years on the average. Any accumulation of snow rarely lasts longer than three days.

For a nine year period of record, storms resulting in an accumulation of ice on exposed surfaces occurred in the SRS vicinity an average of about once every two years. Based on a 50-year period of record (1920 to 1969), a 1.3 centimeter ( 0.5 inches) accumulation of ice would occur once every 25 years (DOE, 1990).

\subsubsection{Fog}

Heavy fog, reducing visibility to less than 0.4 kilometer, occurred at Augusta on a average of about 28 days per year (1951 to 1969). Occurrences averaged about three days per month during the fall and winter and slightly more that one day per month during spring and summer. Most of the heavy fog observed at Augusta is caused by its proximity to the Savannah River.

\subsubsection{Tornadoes}

The estimated probability of a tornado striking a point at SRS is 7.0E-5/yr. (DOE, 1991). About half the total number of observed tomadoes, and most of the tomadoes resulting in severe or devastating damage, occurred in March, April, and May. However, tornadoes have been observed in the SRS area in every month of the year. Investigations of tornadoes occurring near the Site in 1975 and 1976 indicated wind speeds between about $45 \mathrm{~m} / \mathrm{s}$ (100 mph) and $78 \mathrm{~m} / \mathrm{s}$ (174 mph; DOE, 1990)

Since operations began at SRS in 1953, six tomadoes have been confirmed on or near SRS. Nothing more than light damage was reported from any of these storms, with the sole exception of a tomado in October 1989. That tomado caused considerable damage to timber resources in an unpopulated wooded area of SRS (DOE, 1991). 


\subsubsection{Hurricanes}

Thirty-six hurricanes caused damage in South Carolina from 1700 to 1987 . From 1899 to 1980, 13 hurricanes were experienced in South Carolina and Georgia, for an average frequency of about one hurricane every six years; however, the observed interval between hurricane occurrence has ranged from two months to 27 years. Three of these hurricanes were classified as major. Instruments at SRS measured winds associated with Hurricane Gracie, which passed to the north of the Site on September 29, 1959, as high as $34 \mathrm{~m} / \mathrm{s}$ (76 mph). No other hurricane-force wind has been measured on the Site. On September 22, 1989, Hurricane Hugo struck the coast of South Carolina near Charleston; sustained winds recorded at SRS were $17 \mathrm{~m} / \mathrm{s}$ (38 mph).

Because the Site is approximately 161 kilometers (100 miles) inland, winds associated with tropical weather systems usually have diminished below hurricane force (sustained speeds of 121 kilometers per hour (75 mph) or greater). Extreme rainfall and tomadoes, which frequently accompany tropical weather systems, usually have the most significant impact on facility operations (DOE, 1990)

\subsection{Surface Water Hydrology}

Gunsite 720 Rubble Pit Unit is situated on soil mapped as part of the Wagram Series. The Wagram Series consists of well- drained; moderately permeable soils that formed in beds of loamy marine sediment. These soils are on relatively broad ridgetops and side slopes of the Coastal Plain. Based on the soil description and the absence of perennial or intermittent streams in close proximity to the unit, it is unlikely that hazardous constituents would be carried from the unit by surface water runoff. The local terrain is flat, with drainage to Upper Three Runs Creek to the southeast of theunit.

\subsection{Geology of SRS}

The subsurface geology underlying SRS includes crystalline basement rock and Triassic sediments which are overlain by Cretaceous and younger Coastal Plain sediments (Price, 1988). The crystalline basement rock is composed of chlorite-homblende schist, 
homblende gneiss, and lesser amounts of other types of crystalline rock. This bedrock is buried beneath approximately 274.4 meters ( 900 feet) of sediments. The Triassic sediments occur in the southern portion of SRS. Sediments of the Triassic bedrock are composed of poorly sorted conglomerate, sandstone and mud-rock, and are generally dark red in color. The stratigraphic units of the Coastal Plain, from oldest to youngest, are the Cape Fear Formation, the Lumbee Group, the Black Mingo Group, the Orangeburg Group, the Barnwell Group, and the Upland Unit (Figure 3-2).

The Cape Fear Formation is composed of Upper Cretaceous, poorly sorted, silty to clayey quartz sands and interbedded clays. The Cape Fear thickens across SRS, ranging from 9.2 meters (30 feet) at the northwest SRS site boundary to more than 54.9 meters (180 feet) at the southeast SRS site boundary.

The Lumbee Group (Upper Cretaceous) is subdivided into the Middendorf and the Black Creek Formations, and the Steel Creek Member of the Peedee Formation. The lower contact between the Middendorf and the Cape Fear Formations is a sharp erosional unconformity. The Middendorf Formation is dominantly made up of medium to coarse sand with some thin kaolinitic clay lenses. The Black Creek Formation is generally comprised of interbedded sands, silts and clays. The Peedee Formation (Steel Creek Member) contains poorly to well-sorted, silty-to-clayey sands in the lower section and interbedded clayey-sands in the upper section. The thickness of the Lumbee Group is from 115.9 meters ( 380 feet) to more than 213.4 meters ( 700 feet) from the northwestern SRS boundary to the southeastern SRS boundary, respectively.

The Lumbee Group formations are overlain unconformably by the Paleocene to Eocene aged Black Mingo Group. Locally, the Black Mingo Group Formations dip to the southeast, and range in thickness from 21.3 meters ( 70 feet) at the northwestem boundary of the SRS to approximately 45.7 meters (150 feet) near the southeastern boundary. The Black Mingo Group at the SRS is comprised of, from older to younger, the Ellenton Formation (Early Paleocene), the Snapp Member of the Williamsburg Formation (Late Paleocene), and the Fourmile Member of the Fishburne Formation (Early Eocene).

The Ellenton Formation consists mostly of gray, poorty sorted, micaceous, lignitic, silty and clayey quartz sand interbedded with gray clays. The Ellenton is approximately 12.2 


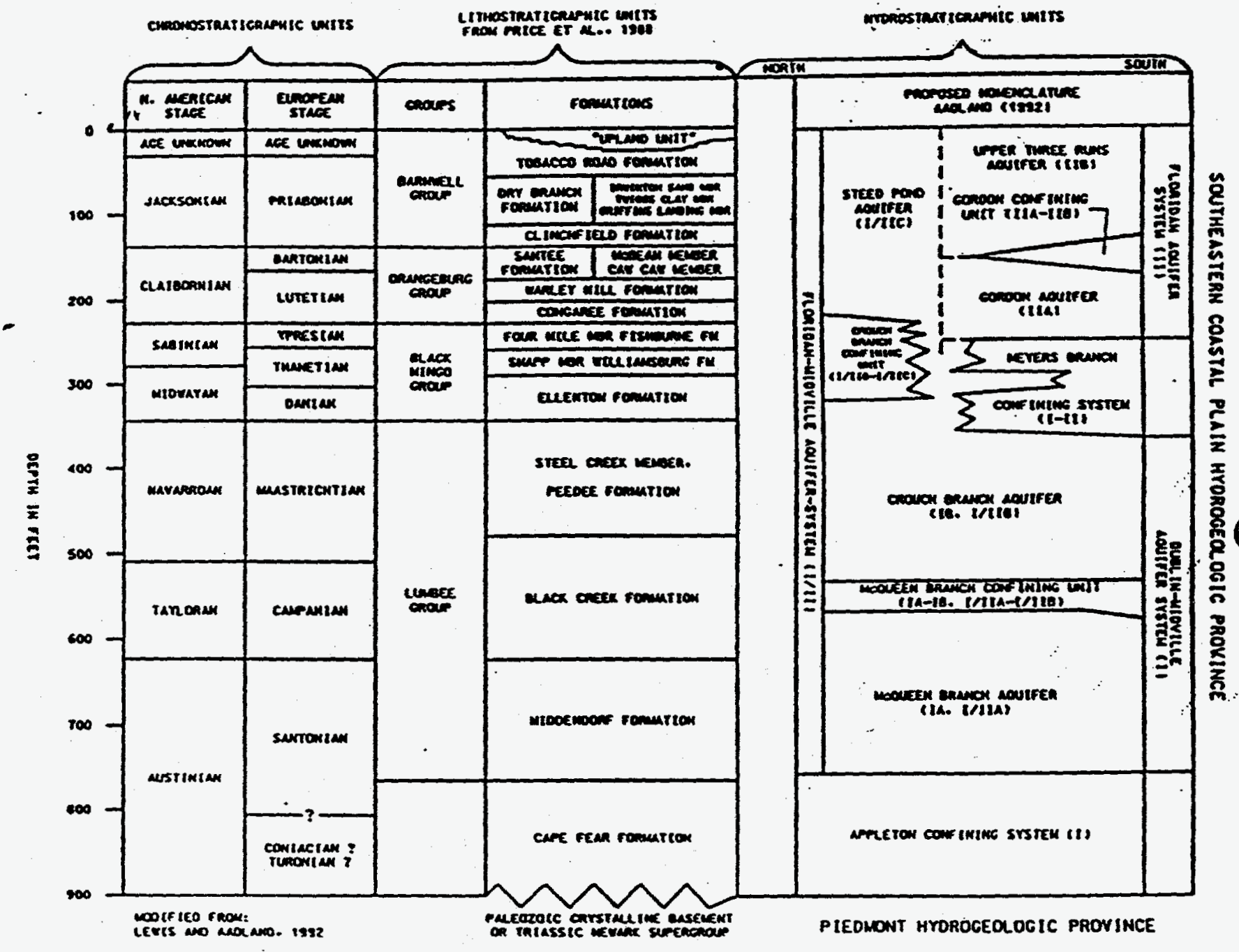

Figure 3-2 Comparison of Chronostratigraphic, Lithostratigraphic, and Hydrostratigraphic Units at SRS 
meters ( 40 feet) thick at the northwestern SRS boundary and thickens to approximately 30.5 meter (100 feet) at the southeastem SRS boundary.

The Snapp Member of the Williamsburg Formation is typically comprised of silty, medium to coarse grained quartz sand interbedded with clay. The Williamsburg thickens from 9.2 meters ( 30 feet) at the northwestern SRS boundary to 15.2 meters ( 50 feet) at the southeastern SRS boundary. The Fourmile Member of the Fishburne Formation consists of tan, orange, yellow, brown, and white clayey and micaceous sand (Fallaw, 1991). The Fishburne has been traced from well PBF-3 into the AM area, the only locale of known distribution at SRS. The Fourmile section is 4.6 meters (15 feet) to 22.9 meters ( 75 feet) thick in this area.

The Black Mingo Group is overlain by the Middle Eocene age Orangeburg Group. The Orangeburg Group outcrops at many areas of low elevation around the SRS. The thickness of the Group ranges from approximately 30.5 meters (100 feet) at the northwestern SRS boundary to 48.8 meters (160 feet) at the southeastern boundary. The Orangeburg Group is made up of the lower Middle Eocene Congaree Formation and the upper Middle Eocene Santee Limestone Formation.

The Congaree Formation consists of yellow, orange, tan, gray and greenish gray, well sorted, quartz sands with thin clay laminae. The top section of the Congaree Formation is cemented with silica in may areas of the SRS and is slightly calcareous in other areas. The Congaree Formation is approximately 18.3 meters (60 feet) thick at the northwestern SRS boundary and thickens to approximately 25.9 meters ( 85 feet) near the southeastem SRS boundary.

The Warley Fill Formation is a fine-grained, often glauconitic sandstone occurring at or near the base of the Santee Formation at SRS (Aadland et al, 1992). The Warley Fill Formation and the Caw Caw Member of the overlying Santee Formation make up what has been informally referred to in many SRS reports as the "green clay". The "green clay" is composed of glauconitic, silty and clayey quartz sands and silty clays. Clay beds in this interval are laterally discontinuous in the northernmost SRS areas (Lewis and Aadland, 1992). The overlying Santee Formation is subdivided into the Caw Caw and the McBean Members, and varies in lithology from carbonates and calcareous quartz sands to quartz 
and glauconitic sands and clays. The uppermost member, McBean, consists of limestone overlain by quartz sand. The thickness of the formation ranges from 12.2 meters ( 40 feet) to more than 24.4 meters ( 80 feet) from the northwestern SRS boundary to the southeastem SRS boundary, respectively.

The Orangeburg Group is overlain by the Late Eociene deposits of the Barnwell Group. The Barnwell Group at the SRS is subdivided into the Clinchfield, Dry Branch, and Tobacco Road Formations. The Clinchfield Formation is present at some SRS locations, but it is not continuous enough to be correlated across the site. The quartz sand of the Clinchfield Formation has been identified at the SRS only when the contrasting carbonates of both the Griffins Landing Member of the Dry Branch Formation (stratigraphically above) and the McBean Member of the Santee Formation (stratigraphically below) are present, with the sand between them. The Dry Branch Formation is divided into (from oldest to youngest) the Griffins Landing, Twiggs Clay, and Irwinton Sand Member. This formation outcrops in several places across the SRS and ranges in thickness from $\mathbf{1 5 . 2}$ meters ( 50 feet) from the northwest boundary to 24.4 meters ( 80 feet) near the southeastern SRS boundary.

The Griffins Landing Member of the Dry Branch Formation is composed of carbonates that occur sporadically at the SRS. The Irwinton Sand Member contains tan, yellow, and orange, moderately sorted quartz sand with interlaminated clays. The Twiggs Clay Member of the Dry Branch Formation is informally called the "tan clay." This clay lithofacies, which is tan, light gray, and brown, varies in thickness up to 3.7 meters (12 feet) at the SRS, but is not laterally continuous.

The Tobacco Road Formation, which overlies the Dry Branch Formation, consists of red, fine to coarse, moderately to poorly sorted, clayey quartz sand with minor clay laminae. The Tobacco Road outcrops at the surface at many locations throughout the site and ranges in thickness from 6.1 to 9.1 meters ( 20 to 30 feet).

The Upland Unit (previously mapped at SRS as the Hawthorn Formation) is composed of poorly sorted, clay-to-silty sands, with lenses and layers of pebbly and cobbly quartz sands with extreme lateral and vertical variation. (Price, 1988). The presence of the Upland Unit in this area is inconsistent, occurring predominantly at higher elevations around SRS. 


\subsection{Hydrogeology}

A multilayer hydrologic system exists in the Coastal Plain sediments at the SRS. Confining units within the system are interspersed with more transmissive units. Aadland and Bledsoe (1990) developed an alpha mumeric hydrostratigraphic nomenclature system for SRS and Aadland et al (1992) introduced proposed names for the systems, units and zones (Figure 3-2). Within this nomenclature, the basement complex underlying the Coastal Plain deposits is referred to as the Piedmont Hydrogeologic System. This system is overlain by three aquifer systems of Coastal Plain deposits, the Midville, the Dublin, and the Floridan Aquifer Systems, separated by the Allendale and Meyers Branch Confining Systems. These Aquifer systems are separated from the lower Piedmont Hydrogeologic System by the Appleton Confining System. The Appleton Confining System is composed of poorly sorted, clayey sediments of the Cape Fear Formation. Confining clay sediments of the middle Black Creek Formation make up the Allendale Confining Unit which separates the Midville and Dublin Aquifers. The Midville Aquifer is composed of sands of the Middendorf Formation and the lower sands of the Black Creek and lower Peedee Formations. As the confining systems and units thin and become discontinuous in a northeriy direction at the SRS, the Midville and Dublin Aquifer Systems are combined to form a single Dublin-Midville Aquifer System. Figure 3-3 is a graphic illustration of the hydrogeologic nomenclature for the SRS region. The reader is referred to Aadland et al (1992) for the most recent description of SRS hydrogeology.

The Floridan Aquifer System is divided into the Gordon Aquifer and the Upper Three Runs Aquifer by the Gordon Confining Unit. Congaree/Fourmile sands comprise the Gordon Aquifer, and sands of the Santee Limestone and Tobacco Road Formation comprise the Upper Three Runs Aquifer. Warley Hill and Caw Caw clays (including the "green clay") comprise the Gordon Confining Unit. Northwest of Upper Three Runs Creek (UTRC), the individual confining beds separating the two Aquifer Systems become thin and discontinuous. 
Gunsite 720 Rubble Pit Unit

WSRC-RP-95-360, Rev. 1

RFIRI Report

March 1996

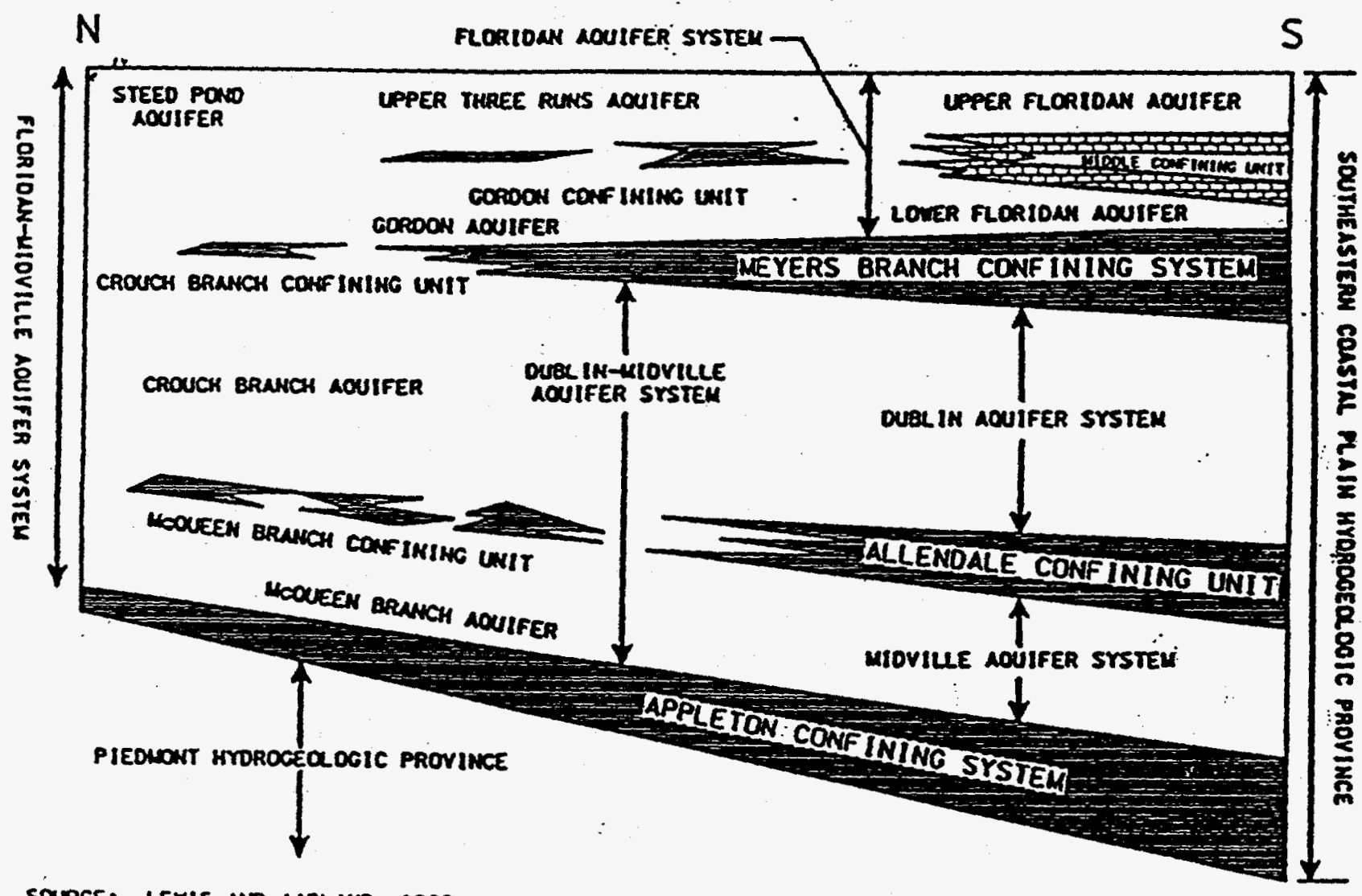

SOURCE: LEWIS ANO MALLANO. 1992

Figure 3-3 Hydrogeologic Nomenclature for the SRS Region 


\subsection{Geology and Hydrology of the Gunsite 720 Rubble Pit Unit}

The amount of detailed geologic and hydrogeologic information on the Gunsite $\mathbf{7 2 0}$ Rubble Pit Unit is limited. There has been no need to make a detailed investigation of the geology and hydrology of this area mainly because of its location on the western edge of the site, its distance from the more heavily industrialized site locations, and its lack of history as a waste area.

\subsection{Demography and Land Use}

\subsubsection{Demographics}

SRS is located approximately 40 kilometers (25 miles) southeast of Augusta, Georgia, and 32 kilometers (20 miles) south of Aiken, South Carolina. According to 1990 census data (Rand McNalley, 1992) the average population densities (in people per square mile) for the surrounding South Carolina counties are 111 for Aiken County, 36 for Barnwell County, and 28 for Allendale County. For the surrounding Georgia counties the densities are 228 for Columbia County, 524 for Richmond County, 25 for Burke County and 21 for Screven County. The population within an 80.5 kilometer ( 50 mile) radius of SRS is 634,784 people.

The estimated population for the area in the year 2000 is projected to be 852,000 (Rand McNalley, 1992). This estimate was calculated utilizing the 1970 to 1980 growth rate of each county in an 80.5 kilometer ( 50 miles) radius, assuming that the same rate of growth would continue into the future. The calculation assumed that the population would remain constant for counties that experienced a negative population growth between 1970 and 1980.

Calibrated demographic data is available for the six-county area that provides 90 percent of the SRS work force (DOE, 1994). These are Aiken, Allendale, Bamberg and Barnwell Counties in South Carolina and Richmond and Columbia Counties in Georgia. The population in those six counties increased 13 percent between 1980 and 1990, from 376,000 to 425,607 and is expected to increase to 474,820 by the year 2000 (DOE, 
1992). A disproportionate share of the six county population increase was concentrated in Columbia County where the population increased more that 55 percent to 66,031 between 1980 and 1991.

\subsubsection{Land Use}

Less than 5 percent of the existing land in the area surrounding SRS is devoted to urban and developed uses (DOE, 1990). Most of the urbanized development in the area has occurred in and around the cities of Augusta, Georgia and Aiken, South Carolina. Agriculture accounts for 24 percent of total land use; forests, wetlands, water bodies, and unclassified land that is predominantly rural accounts for about 70 percent of the total land use. A projected 2 percent increase in the development of urban land surrounding SRS is expected by the year 2000 .

Less than 5 percent of the total SRS land area is used by facilities engaged in the production of special nuclear materials. Reservoirs and ponds comprise approximately 13 square kilometers (5 square miles) of SRS. The remainder of the 780+ square kilometers. $(300+$ square miles) area is undeveloped. 


\subsection{NATURE AND EXTENT OF CONTAMINATION}

\subsection{Results of Data Usability Evaluation}

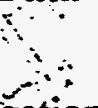

The field investigation for Gunsite 720 Rubble Pit Unit was conducted prior to the establishment of a formal data validation program at SRS. Data collected were subjected to the QA/QC standards in use at that time and considered to be acceptable by EPA Level 3 criteria. Information on the QA/QC methods employed during the investigation are provided in the RFI/RI Plan for the Gunsite 720 Rubble Pit Unit, WSRC-RP-90-1049 (WSRC, 1990). Additional information on the QAVQ procedures used for this unit are provided in Appendix B.

\subsection{Results of Site Characterization}

Data collected during Preliminary Unit Evaluation, Unit Screening, and field investigations found no evidence of contamination at Gunsite 720 Rubble Pit Unit. The magnetic survey: showed no signs of any buried materials including the UST that was previously located at the unit. The GPR survey showed some signs of prominent diffractions possibly indicating buried pipes or metallic objects. However, trenching operation in the area of the GPR survey found only localized areas of household garbage. No tanks were found but wires, two buried pipes and a possible sewerline were uncovered.

An analysis of soil samples collected in 1990 and 1993 show that all materials detected in the soil are at or below background levels. The only hazardous substances exceeding their respective unit-specific background concentrations are acetone (laboratory artifact), bis(2ethylhexyl) phthalate (laboratory artifact), methylene chloride-(laboratory artifact), barium, chromium, lead, and total mercury. Figure 4-1 shows the location and concentration of the metals which exceed the unit-specific background level. When compared to two times background levels, lead and chromium exceed the levels but only by a small margin (Table 4-1). 


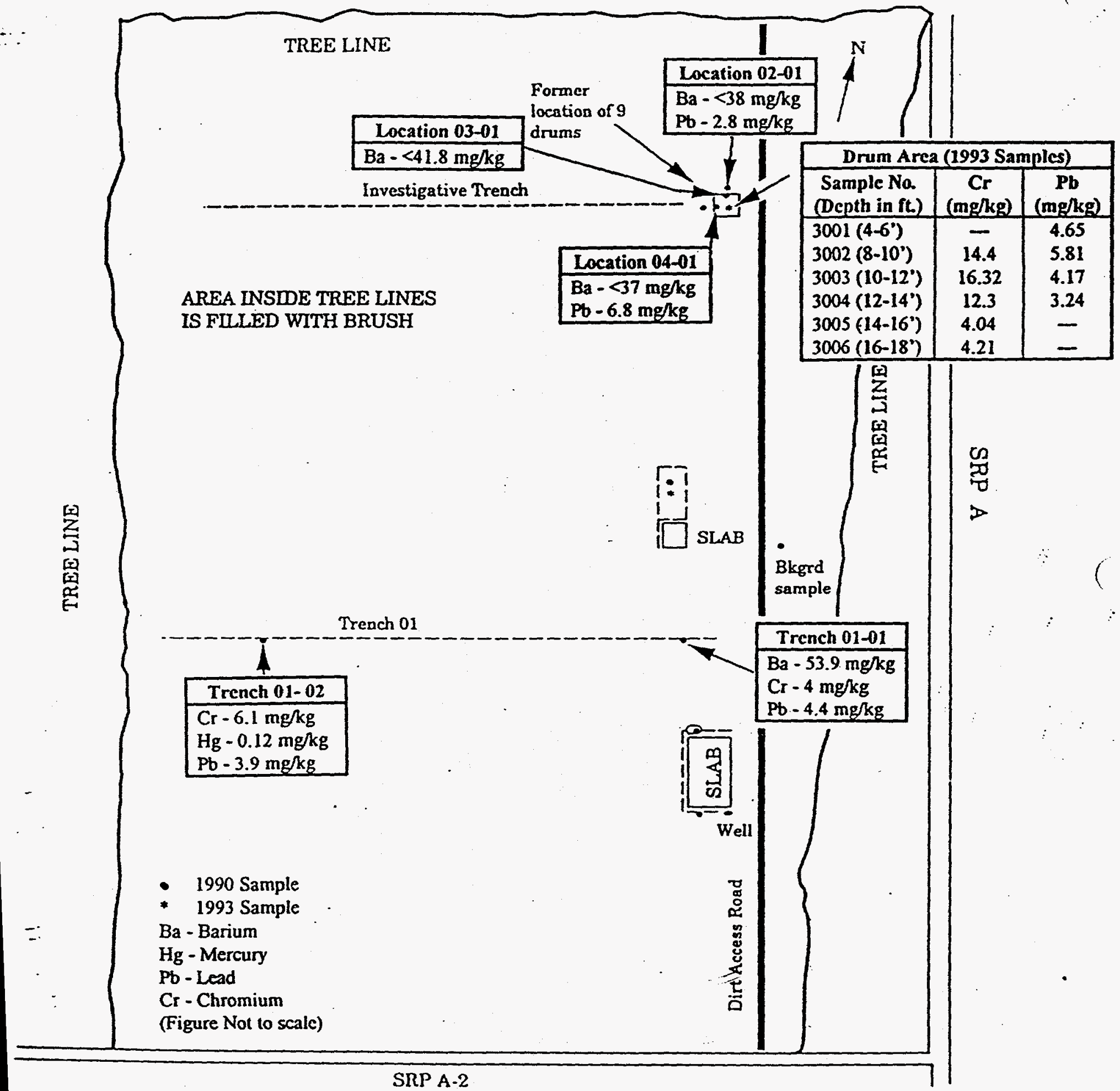

Figure 4-1 Map Showing the Location and Concentration of Metals Which Exceed the Unit-Specific Background Level. 
TABLE 4-1

COMPARISON OF MAXIMUM SOIL CONCENTRATIONS WTTH BACKGROUND LEVELS FOR

GUNSITE 720 RUBBLE PIT UNIT

\begin{tabular}{|l|c|c|c|c|c|}
\hline $\begin{array}{l}\text { Hazardous } \\
\text { Substance*(units) }\end{array}$ & $\begin{array}{l}\text { Maximum Soil } \\
\text { Concentration - } \\
\text { Unit Screening }\end{array}$ & $\begin{array}{l}\text { Unit-Specific } \\
\text { Background } \\
\text { Level }\end{array}$ & $\begin{array}{l}\text { Two times } \\
\text { Unit-Specific } \\
\text { Background } \\
\text { Level }\end{array}$ & $\begin{array}{l}\text { SRS Media } \\
\text { Background } \\
\text { Level** }\end{array}$ & $\begin{array}{l}\text { Southeastern } \\
\text { U.S.Level** } \\
*\end{array}$ \\
\hline Acetone $(\mu \mathrm{g} / \mathrm{kg})$ & $24 \mathrm{~B}$ & $17 \mathrm{~B}$ & 34 & - & - \\
\hline $\begin{array}{l}\text { Bis(2-ethylhexyl) } \\
\text { phthalate }(\mu \mathrm{g} / \mathrm{kg})\end{array}$ & 660 & 410 & 820 & - & - \\
\hline $\begin{array}{l}\text { Methylene Chloride } \\
(\mu \mathrm{g} / \mathrm{kg})\end{array}$ & $14 \mathrm{~B}$ & $11 \mathrm{~B}$ & 22 & - & - \\
\hline $\begin{array}{l}\text { Total Petroleum } \\
\text { Hydrocarbons }(\mu \mathrm{g} / \mathrm{kg})\end{array}$ & 12 & $\mathrm{NA}$ & $\mathrm{NA}$ & - & - \\
\hline Gross alpha (pCi/g) & 20 & 23 & 46 & - & - \\
\hline Gross beta (pCi/g) & 4 & 4 & 8 & - & - \\
\hline Barium (mg/kg) & 53.9 & $<32.1$ & $<64.2$ & $50.4-65.13$ & 225 \\
\hline Chromium (mg/kg) & 16.32 & 3 & 6 & $1.31-105.1$ & - \\
\hline $\begin{array}{l}\text { Total mercury } \\
\text { (mg/kg) }\end{array}$ & 0.12 & $<0.11$ & $<0.22$ & $<0.01-0.1$ & 0.1 \\
\hline Lead (mg/kg) & 6.8 & 2.6 & 5.2 & $<1.0-16.67$ & 13 \\
\hline
\end{tabular}

* For substances detected in excess of method detection limit

** data from Looney et, 1990

*** For substances which exceeded the unit-specific background area results; data from Conner and Shacklette, 1975

B Analyte was found in Laboratory Blank.

NA Not Analyzed 
As shown in Table 4-1, both acetone and methylene chloride were detected in the laboratory blanks. Bis(2-ethylhexyl)phthalate was detected at $660 \mu \mathrm{g} / \mathrm{kg}$. The Practical Quantitation Limit (PQL) for bis(2-ethylhexyl) phthalate is $660 \mu \mathrm{g} / \mathrm{kg}$ for soils and sediments. The PQL is the lowest level that can be reliably achieved within specified limits of precision and accuracy during routine laboratory operating conditions. Since the highest concentration of bis(2-ethylhexyl) phthalate detected in any sample is $660 \mu \mathrm{g} / \mathrm{kg}$, or the $\mathrm{PQL}$, and bis(2-ethylhexyl) phthalate is known laboratory artifact, the significance of its detection in unit samples is believed to be minimal.

For the four hazardous substance metals which exceeded unit-specific background levels (barium, chromium, lead, and total mercury), a comparison with SRS and southeastern U. S. mean background values was made (Table 4-1). Lead and chromium maximum field concentrations are less than both the maximum SRS background level and southeastern U. S. mean background levels. The maximum field value for barium is significantly less than mean southeastern U. S. background level. The maximum field value for total mercury is less than the SRS mean background level.

Trenching operations at the unit uncovered common household garbage and little construction debris, but no buried tanks. Analytical results of soil samples taken from the trenches and debris identified in the trenches suggest that hazardous waste handling activity at the unit is unlikely as is the existence of buried tanks.

No constituents of concern were identified as a result of the investigations at this unit. The general conclusion reached is that this unit has no contamination. 


\subsection{CONTAMUNANT FATE AND TRANSPORT}

Contaminants may migrate in environmental media following release from secondary sources by any of several release or transport mechanisms, including:

- suspension and dispersal by the wind of particulate contaminants or contaminants adsorbed to surface soil particles (fugitive dust generation);

- direct volatilization of volatile organic compounds from surface soil to air

- uptake of soil contaminants by vegetation;

- transport of soil contaminants by storm water runoff to surface water and sediments;

- leaching of deep soil contaminants into groundwater.

In addition to the exposure pathways which result from the above secondary release and transport mechanisms, potential receptors also may be exposed directly to contaminants present in surface soils.

Data collected during Preliminary Unit Evaluation, Unit Screening, and field investigations indicate that materials found in the soils at Gunsite 720 Rubble Pit Unit are within normal background levels found at SRS. Since there is no contamination at this unit there is no need for a model on contaminant fate and transport. 
Gunsite 720 Rubble Pit Unit

RFI/RI Report
WSRC-RP-95-360, Rev. 1

March 1996

THIS PAGE INTENTIONALLY LEFT BLANK

$\equiv$ 


\subsection{RISK ASSESSMENT}

\subsection{Human Health Assessment}

A review of the unit sampling plan and the resulting soil and soil vapor analytical data for the Gunsite 720 (see Table 2-3) indicate the data are sufficient for use in an unit risk assessment evaluation. This evaluation was conducted to estimate the health or environmental problems that could result from the no further action alternative. The results indicate that the concentrations of all hazardous materials analyzed were near or below naturally occurring background levels and/or below any proposed health-based action levels. Therefore, they pose no risk to human health and the environment.

Based upon screening available evidence, there are no potential contaminants of concern available for evaluation by a CERCLA baseline risk assessment and, therefore, there is no determinable risk associated with Gunsite 720.

\subsection{Ecological Assessment}

Information utilized included recorded existing unit history, preliminary unit evaluation, and unit characterization data. These informational sources form the basis for this ecological characterization. That information can be summarized as follows:

- There is no evidence of contaminant associated vegetation stress or ecological impact related to the unit;

- Review of the unit characterization data indicates that there are no constituents in the physical media analyzed at Gunsite $\mathbf{7 2 0}$ that are different from the unit-specific background condition.

Based on the physical and analytical data obtained for this unit, there appears to be no compelling evidence that waste materials were managed or disposed at Gunsite 720. Therefore, it is reasonable to conclude that the unit, as it is currently characterized, 
presents no significant ecological risk. A further detailed ecological risk assessment and characterization would not be warranted. 


\subsection{SUMMARY AND CONCLUSION}

\subsection{Summary}

An analysis of data collected as a result of the studies performed at Gunsite 720 Rubble Pit Unit indicates that there is no contamination at that unit. Survey data indicate that the substances found in the soils at the unit are within the levels normally associated with SRS background levels.

In addition, it is also reasonable to conclude that, since there is no contamination, the unit presents no significant ecological risk.

\subsection{Conclusion}

Based on the review of the analytical data and screening techniques used to evaluate all the chemicals of potential concern at Gunsite 720 Rubble Pit Unit, it is recommended that no further remedial action be performed at this unit. 
Gunsite 720 Rubble Pit Unit

RFI/RI Report
WSRC-RP-95-360, Rev. 1 March 1996

$\because:$

THIS PAGE INTENTIONALLY LEFT BLANK 


\section{REFERENCES}

Aadland, R. K., and H. W. Bledsoe, Classification of Hydrostratigrophic Units at Savamnah River Site, South Carolina, WSRC-RP-90-987, Westinghouse Savannah River Company, Savannah River Laboratory, Aiken, SC. (1990).

Aadland, R. K., A. D. Smits, and P. A. Thayer, Geology and Hydrostratigraphy of the A/M-Area, Savannah River Site (SRS), South Carolina (U). WSRC-RP-92-440, Westinghouse Savannah River Company, Savannah River Site, Aiken, SC. (1992).

Conner and Shacklette, Background Geochemistry of Some Rocks, Soils, Plants, and Vegetables in the Conterminous United States., U. S. Geological Survey Professional Paper 574-F, Government Printing Office, Washington, DC (1975).

DOE, Contimued Operation of $K-, L$, and P-Reactors Savamah River Site: Final Environmental Impact Statement, DOE/EIS-0147, U. S. Department of Energy, (1990).

DOE, Environmental Impact Statement for the Siting, Construction, and Operations of New Production Reactor Capacity Draft, Volume 2: Sections 1-6. DOE/EIS0144D, U. S. Department of Energy, Office of New Production Reactors, (1991).

DOE, Public Involvement, A Plan for the Savamah River Site U. S. Department of Energy, Savannah River Site, Aiken, SC (1994).

EPA, Guidance for Conducting Remedial Imvestigations and Feasibility Studies Under CERCLA, Interim Final. EPA540/G-89-004, U. S. Environmental Protection Agency, Washington, DC. (1988).

EPA, Revised Interim Soil Lead Guidance for CERCLA Sites and RCRA Corrective Action Facilities, Office of Solid Waste and Emergency Response, OSWER Directive 9355.4-12, (1994).

EPA, Risk-Based Concentration Table, Jamuary - June 1995, EPA Region III, Technical Support Section, (1995). 
Looney, B. B., V. Price, .D. J. Master, and C. A. Bledsoe, Soil Gas Survey at Selected Potential Waste Sites at the Savamah River Plant, DPST-88-619, E. I. du Pont de Nemours and Company, Savannah River Laboratory, Aiken, SC, (1988).

Looney, B. B., C. A. Eddy, M. Ramdeen, J. Pickett, V. Rogers, M. T. Scott, and P. A. Shirley, Geochemical and Physical Properties of Soils and Shallow Sediments at the Savamah River Site (U), WSRC-RP-90-1031, Westinghouse Savannah River Co., Aiken, SC (1990)

Pickett, J. B., Technical Data Summary, Extended Characterization of the M-Area Settling Basin and Vicinity, DPSTD-85-121, E. I. du Pont de Nemours and Company, Savannah River Laboratory, Aiken, SC. (1985).

Price, V., Subsurface Hydrogeology; in Stephenson, A., 2 ed., Final Safety Analysis Report for DWPF (Draft). DPSTSA-200-10, E. I. du Pont de Nemours and Company, Savannah River Plant, Aiken, SC. (1988).

Rand McNalley, Commercial Atlas and Marketing Guide, 123 rd edition, Skokie, II, (1992).

WSRC (Westinghouse Savannah River Company), RCRA Facility Investigation' Remedial Investigation Plan for the Gunsite 720 Rubble Pit Unit $(C)$ ), WSRCRP-90-1049, Westinghouse Savannah River Company, Aiken, SC, (1990).

WSRC (Westinghouse Savannah River Company), RCRA Facility Investigation/Remedial Investigation Program Plan, WSRC-RP-89-994, Rev. 1, Westinghouse Savannah River Company, Aiken, SC. (1993). 
Gunsite 720 Rubble Pit Unit

WSRC-RP-95-360, Rev. 1

RFI/RI Report

March 1996

APPENDIX A

TECHNICAL MEMORANDA ON FIELD ACTTVTTIES

Appendix A.1 Ground Penetrating Radar Survey

Appendix A.2 Magnetic Survey 
Gunsite 720 Rubble Pit Unit

WSRC-RP-95-360, Rev. 1

RFI/RI Report

March 1996

THIS PAGE DNTENTIONALLY LEFT BLANK 
Gunsite 720 Rubble Pit Unit

RFURI Report
WSRC-RP-95-360, Rev. 1

March 1996

THIS PAGE INTENTIONALLY LEFT BLANK

$\equiv$

A. 1-2 
Final Report

GROUND PENETRATING RADAR INVESTIGATIONS

at

GUNSITE 720

(631-16G)

SAVANNAH RIVER SITE

June, 1993

: G.Boyd Sexton

Robert J. Pirkle

Task 21, 29

Subcontract \#AA38232N

A. 1-3 
$\ldots$

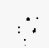

A. 1-4 


\section{EXECUTIVE SUMMARY}

Ground penetrating radar surveys were executed at Gunsite \#720 for the purpose of locating disturbed soil, trenches, pipelines and other targets of interest. The survey was conducted on January 27, 1993 with a return visit on March 25, 1993.

Numerous areas of disturbed soil were observed, several of which contain prominent diffractions thought to represent pipelines or other targets of interest. A $300 \mathrm{Mhz}$ transmitter and antenna were used in the acquisition of the data. 


\section{TABLE OF CONTENTS}

Executive Summary

i

List of Figures

iii

Iist of Tables

I. Introduction

iv

II. Background

1

1

III. Acquisition and Processing Parameters

2

IV. Results

2

v. Conclusions 


\section{LIST OF FIGURES}

Figure 1. GPR Line Location Map

Figure 2. Sample GPR Section With Illustrated Computerized Interpretation

Figure 3. GPR Line \#I

Figure 4. GPR Line \#2

Figure 5. GPR Line \#3

Figure 6. GPR Line \#4

Figure 7. GPR Line \#5

Figure 8. GPR Line \#6

Figure 9. GPR Line \#7

Figure 10. GPR Line \#8

Figure 11. GPR Line \#9

Figure 12. GPR Iine \#10

Figure 13. GPR Line \#11

Figure 14. GPR Line \#12

Figure 15. GPR Line \#13

Figure 16. GPR Line \#14

Figure 17. GPR Line \#15

Figure 18. GPR Line \#16

Figure 19. GPR Iine \#17

Figure 20. GPR Line \#18

Figure 21. GPR Line \#19

Figure 22. GPR Line \#20

Figure 23. GPR Line \#21

Figure 24. GPR Line \#22 


\section{LIST OE TABLES}

Table 1. Coordinates, Bearings, and Distances of GPR Iines

Table 2. Acquisition and Processing Parameters 


\section{INTRODUCTION}

Ground Penetrating Radar (GRR) surveys were run at Gunsite \#720 for the purpose of locating trenches, pipelines and subsurface targets of interest. GPR data were acquired on a total of 22 lines totaling 3437 feet as shown on Figure 1 and listed on Table 1. Lines 1-22 contain data recorded inside and around the red ball markers at the gunsite. All lines were recorded with the $300 \mathrm{Mhz}$ antenna, 100 ns range.

\section{BACKGROUND AND OBSERVATIONS}

At Gunsite \#720, anti-aircraft guns were mounted and used for protection against a possible invasion or attack. The guns have been removed and the area is overgrown with brush and trees. There: is little or no visual indication that would characterize this as a gunsite.

The weather during field acquisition was cool, windy and ! cloudy. Personnel on-site during data acquisition were Ken Grace, Clark Sharlock and Art Carion. 
III. ACQUISITION AND PROCESSING PARAMETERS

The equipment and software used in the acquisition and processing of the GRR data are listed on Table 2.

IV. RESULTS

The results of the GPR surveys at Gunsite 113 are shown on Figures 3 - 24. A sample GPR section with labeled interpretive information is shown on Figure 2. A typical signature of an area of disturbed soil is labeled so that similar anomalous areas on the actual lines presented on Figures 3 - 24 can be easily recognized. The horizontal scale, vertical time scale, and maximum depth of penetration are also shown on each line. The radar velocity in this area is $6-7$ ns per foot.

The gunsite was generally a good data area. Iines 1-22, shown on Figures 3 - 24, contain prominent diffractions possibly indicating pipes or buried metallic objects along the GPR transect. Areas within the red ball markers are distinguished by chaotic returns indicating disturbed soil where trenching or back filling has occurred.

The high amplitude event (red, blue, red, etc.) at 25-30 ns, which occurs almost continuously on each line, may indicate the water table. If this event does represent the water table, it is doubtful that any of the data below this event is valid. 
V. CONCLUSIONS

The quality of the data recorded at Gunsite 720 was good. It contains numerous prominent diffractions which represent shallow subsurface targets. Areas of disturbed soil are present indicating previous trenching or excavation. The high amplitude event seen relatively continuous on all lines at about 25-30 ns could possibly be the water table at this location. 
MaBts 1

GuxsID $720 / 631-160$

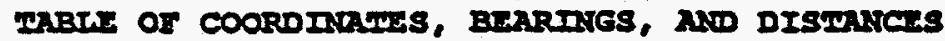

\begin{tabular}{|c|c|c|c|c|c|c|c|c|c|}
\hline EI & Sandes & & $\begin{array}{c}x \\
\text { syIne }\end{array}$ & $\frac{I}{\text { SORutare }}$ & & UARTIO & & xes. & Inte \\
\hline 3 & $\frac{1}{1}$ & $\begin{array}{l}\text { START } \\
\text { END }\end{array}$ & $\begin{array}{l}27385 \\
27383\end{array}$ & $\begin{array}{l}79914 \\
79979\end{array}$ & $\mathbf{N}$ & 1.7624 & ผ & 99 & 1 \\
\hline 4 & $\begin{array}{l}2 \\
2\end{array}$ & $\begin{array}{l}\text { START } \\
\text { END }\end{array}$ & $\begin{array}{l}27251 \\
27356\end{array}$ & $\begin{array}{l}79948 \\
79948\end{array}$ & $\mathbf{s}$ & 90.0000 & $\mathbf{E}$ & 142 & 2 \\
\hline 5 & 3 & $\begin{array}{l}\text { START } \\
\text { END }\end{array}$ & $\begin{array}{l}27162 \\
27372\end{array}$ & $\begin{array}{l}79999 \\
80016\end{array}$ & $\mathbf{y}$ & 85.3719 & $\mathbf{E}$ & 442 & 3 \\
\hline 6 & $\begin{array}{l}4 \\
4\end{array}$ & $\begin{array}{l}\text { START } \\
\text { END }\end{array}$ & $\begin{array}{l}27363 \\
27362\end{array}$ & $\begin{array}{l}80057 \\
80058\end{array}$ & $\mathbf{x}$ & 45.0000 & $n$ & 81 & 4 \\
\hline 7 & $\begin{array}{l}5 \\
5\end{array}$ & $\begin{array}{l}\text { START } \\
\text { END }\end{array}$ & $\begin{array}{l}27343 \\
27344\end{array}$ & $\begin{array}{l}80076 \\
80126\end{array}$ & N & 1.1458 & $\mathbf{E}$ & 88 & 5 \\
\hline 8 & $\begin{array}{l}6 \\
6\end{array}$ & $\begin{array}{l}\text { START } \\
\text { END }\end{array}$ & $\begin{array}{l}27349 \\
27348\end{array}$ & $\begin{array}{l}80076 \\
80127\end{array}$ & N & 1.1233 & 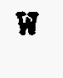 & 68 & 6 \\
\hline 9 & $\begin{array}{l}7 \\
7\end{array}$ & $\begin{array}{l}\text { START } \\
\text { END }\end{array}$ & $\begin{array}{l}27356 \\
27355\end{array}$ & $\begin{array}{l}80075 \\
80127\end{array}$ & N & 1.1017 & 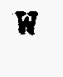 & 69 & 7 \\
\hline 10 & $\begin{array}{l}8 \\
8\end{array}$ & $\begin{array}{l}\text { START } \\
\text { END }\end{array}$ & $\begin{array}{l}27363 \\
27364\end{array}$ & $\begin{array}{l}80076 \\
80127\end{array}$ & $N$ & 1.1233 & $\mathbf{E}$ & 71 & 8 \\
\hline 11 & $\begin{array}{l}9 \\
9\end{array}$ & $\begin{array}{l}\text { START } \\
\text { END }\end{array}$ & $\begin{array}{l}27198 \\
27354\end{array}$ & $\begin{array}{l}80245 \\
80279\end{array}$ & N & 77.7047 & $\mathbf{z}$ & 179 & 9 \\
\hline 12 & $\begin{array}{l}10 \\
10\end{array}$ & $\begin{array}{l}\text { START } \\
\text { END }\end{array}$ & $\begin{array}{l}27200 \\
27351\end{array}$ & $\begin{array}{l}80256 \\
80287\end{array}$ & N & 78.3985 & $\mathbf{E}$ & 176 & 10 \\
\hline 13 & $\begin{array}{l}11 \\
11\end{array}$ & $\begin{array}{l}\text { START } \\
\text { END }\end{array}$ & $\begin{array}{l}27305 \\
27326\end{array}$ & $\begin{array}{l}79919 \\
80375\end{array}$ & N & 2.6368 & $\mathbf{E}$ & 461 & 11 \\
\hline 14 & $\begin{array}{l}12 \\
12\end{array}$ & $\begin{array}{l}\text { START } \\
\text { END }\end{array}$ & $\begin{array}{l}27261 \\
27197\end{array}$ & $\begin{array}{l}79835 \\
80437\end{array}$ & $\mathrm{H}$ & 6.0685 & $n$ & 609 & 12 \\
\hline 15 & $\begin{array}{l}13 \\
13\end{array}$ & $\begin{array}{l}\text { START } \\
\text { END }\end{array}$ & $\begin{array}{l}27233 \\
27296\end{array}$ & $\begin{array}{l}80394 \\
80153\end{array}$ & $s$ & 14.6499 & $\mathbf{E}$ & 248 & 13 \\
\hline 16 & $\begin{array}{l}14 \\
14\end{array}$ & $\begin{array}{l}\text { START } \\
\text { END }\end{array}$ & $\begin{array}{l}27351 \\
27349\end{array}$ & $\begin{array}{l}80307 \\
80241\end{array}$ & $s$ & 1.7357 & $\pi$ & 67 & 14 \\
\hline 17 & $\begin{array}{l}15 \\
15\end{array}$ & $\begin{array}{l}\text { START } \\
\text { END }\end{array}$ & $\begin{array}{l}27381 \\
27301\end{array}$ & $\begin{array}{l}80089 \\
80089\end{array}$ & $\mathbf{s}$ & 90.0000 & $n$ & 74 & 15 \\
\hline 18 & $\begin{array}{l}16 \\
16\end{array}$ & $\begin{array}{l}\text { START } \\
\text { END }\end{array}$ & $\begin{array}{l}27300 \\
27381\end{array}$ & $\begin{array}{l}80106 \\
80106\end{array}$ & $s$ & 90.0000 & $\mathbf{E}$ & 76 & 16 \\
\hline 19 & $\begin{array}{l}17 \\
17\end{array}$ & $\begin{array}{l}\text { START } \\
\text { END }\end{array}$ & $\begin{array}{l}27380 \\
27300\end{array}$ & $\begin{array}{l}80123 \\
80124\end{array}$ & N & 89.2838 & $W$ & 76 & 17 \\
\hline 20 & $\begin{array}{l}18 \\
18\end{array}$ & $\begin{array}{l}\text { START } \\
\text { END }\end{array}$ & $\begin{array}{l}27301 \\
27380\end{array}$ & $\begin{array}{l}80140 \\
80140\end{array}$ & $\mathbf{s}$ & 90.0000 & $\mathbf{E}$ & 76 & 18 \\
\hline 21 & $\begin{array}{l}19 \\
19\end{array}$ & $\begin{array}{l}\text { START } \\
\text { END }\end{array}$ & $\begin{array}{l}27343 \\
27343\end{array}$ & $\begin{array}{l}80034 \\
79982\end{array}$ & $s$ & 0.0000 & ผ & 53 & 19 \\
\hline 22 & $\begin{array}{l}20 \\
20\end{array}$ & $\begin{array}{l}\text { START } \\
\text { END. }\end{array}$ & $\begin{array}{l}27216 \\
27209\end{array}$ & $\begin{array}{l}79964 \\
80082\end{array}$ & $N$ & 3.3949 & $w$ & 103 & 20 \\
\hline 23 & $\begin{array}{l}21 \\
21\end{array}$ & $\begin{array}{l}\text { START } \\
\text { END }\end{array}$ & $\begin{array}{l}27170 \\
27170\end{array}$ & $\begin{array}{l}79940 \\
80058\end{array}$ & $N$ & 0.0000 & $\eta$ & 115 & 21 \\
\hline 24 & $\begin{array}{l}22 \\
22\end{array}$ & $\begin{array}{l}\text { START } \\
\text { END }\end{array}$ & $\begin{array}{l}27381 \\
27288\end{array}$ & $\begin{array}{l}79993 \\
79992\end{array}$ & $s$ & 89.3839 & $w$ & 64 & 22 \\
\hline
\end{tabular}


Table 2

Acquisition and Processing Parameters

at the

Gunsite $720 / 631-16 G$

Date Data Acquired

Instrument Type

Antenna Type

Calibration Numbers
$1 / 27 / 93$ and $3 / 25 / 1993$

GSSI (SIR 10) S/N 1158

$300 \mathrm{Mhz}$

Supplied by GSSI PG-90-177

Version 2.05

Max 141

Min 20

Diff 121

Post Processing Software

GSSI (RADANIII)

Range

$100 \mathrm{~ns}$

Start Position

$-5 \mathrm{~ns}$

End Position

95 ns

Survey Wheel

129.25 ticks/foot

Scans/Foot

4

Samples/Scan .

512

Transmit Pulse Rate

$50 \mathrm{Khz}$

Vertical IIR Low Pass Filter

$N=2 \quad E=60$

Vertical IIR High Pass Filter

Horizontal Low Pass Filter

$N=2 \quad F=7$

$\mathrm{TC}=0 \%$

Scans/Meter

13.1234

Marks/Meter (on plot) 
Created Mar 30,1993 16:24 Modified Apr 1,1993 17:36

$\because$ (i12 samples/scan 31.9922 scans/sec position: -5 ns range: 100 ns Vert. IIR Iow pass $N=1 \quad F=60$

Vert. IIR high pass $N=2 \quad F=7$

SAVANNAB RIVER SITE

F-AREA ACID CAUSTIC PIPELINE

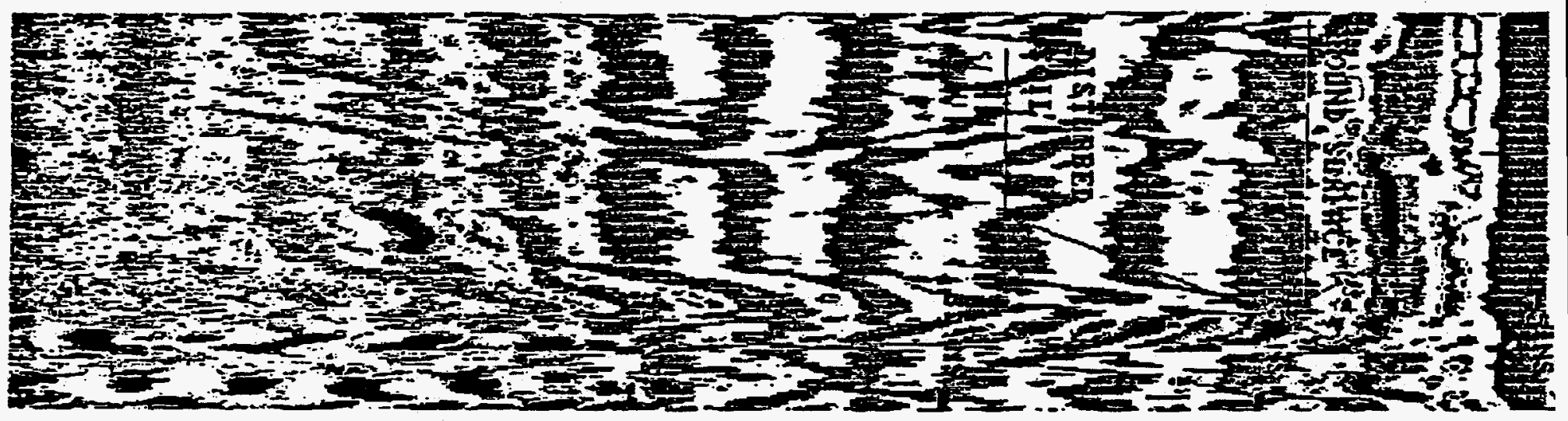

A. $1-15$ 
1 Created Jan 26,1993 11:57 Modified Date Unknown

512 samples/scan 30.0019 scans/sec position: $-5 \mathrm{~ns}$ range: $100 \mathrm{~ns}$ vert. IIR low pass $N=2 \quad F=60$

Vert. IIR high pass $N=2 \quad F=7$

\section{GUNSITE $720 / 631-166$}

SAVANNAH RIVER SITE

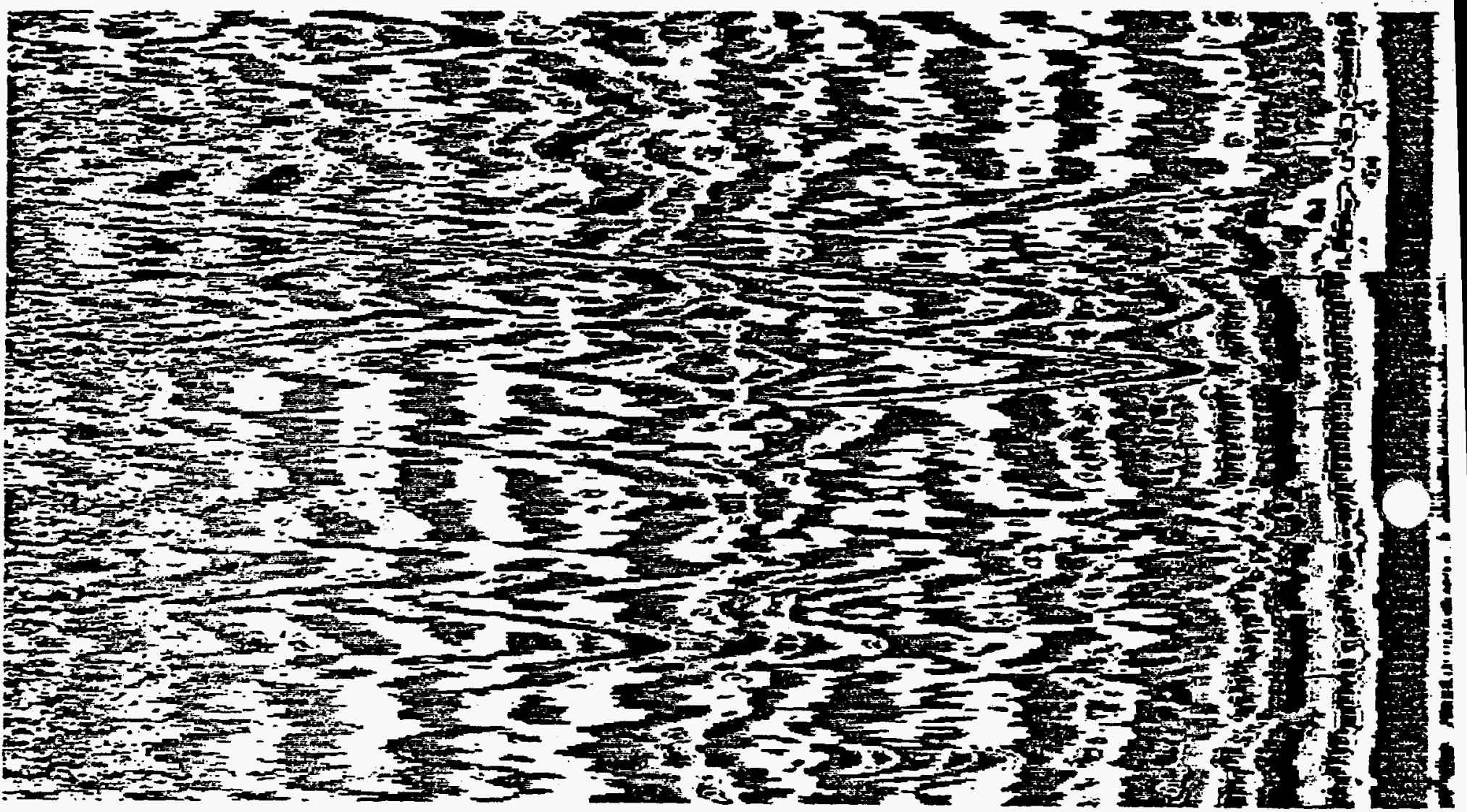


2 Created Jan 26,1993 12:04 Modified Date Unknown

512 samples/scan 30.0019 scans/sec position: -5 ns range: 100 ns Vert. IIR low pass $N=2 \quad F=60$

Vert. IIR high pass $N=2 \quad F=7$

GUNSITE $720 / 631-16 \mathrm{G}$

SAVANIAA RIVER SITE

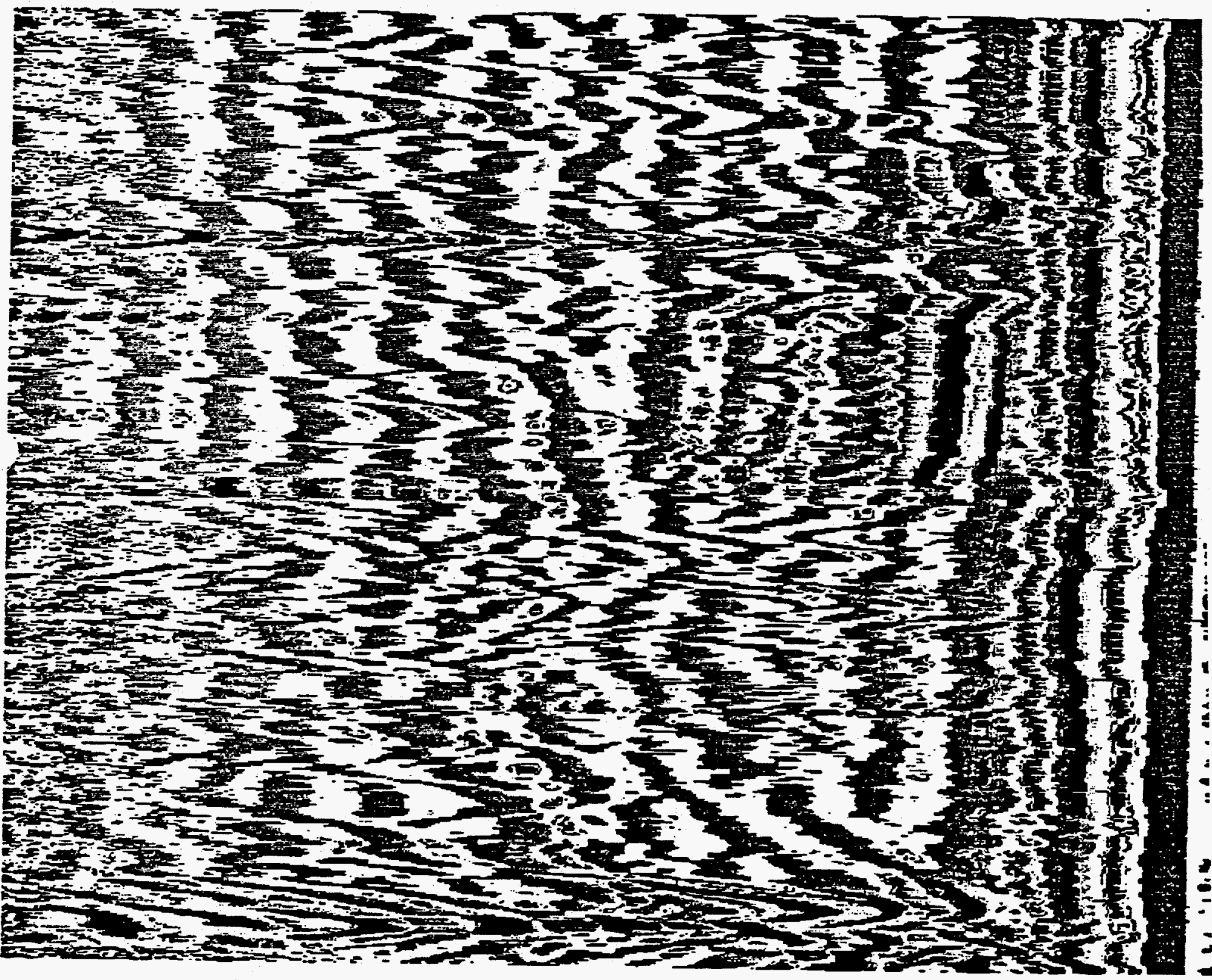


3 Croated Jan 26,1993 $12: 13$ roareled Dete Dothon

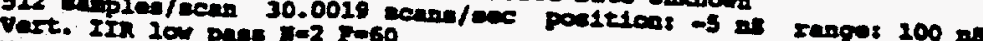

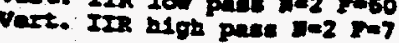

CunsIm $720 / 631-160$

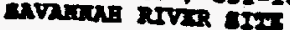

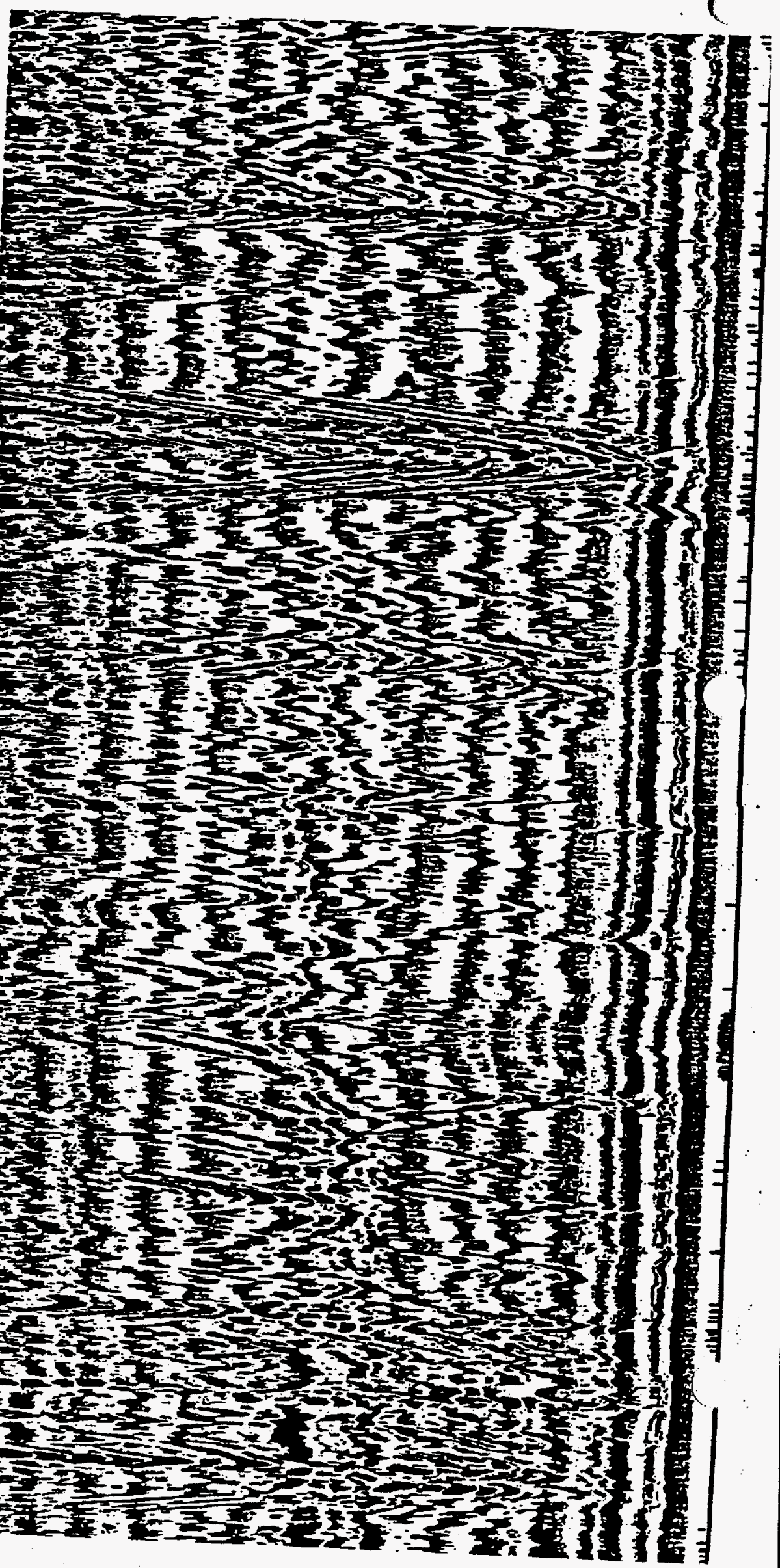


4 Created Jan 26,1993 12:20 Modified Date Unknown 512 samples/scan 30.0019 scans/sec position: -5 ns range: 100 ns Vert. IIR low pass $N=2 \quad F=60$

Vert. IIR high pass $N=2 \quad F=7$

GUNSITE $720 / 631-166$

SAVANTAE RTVER SIIE

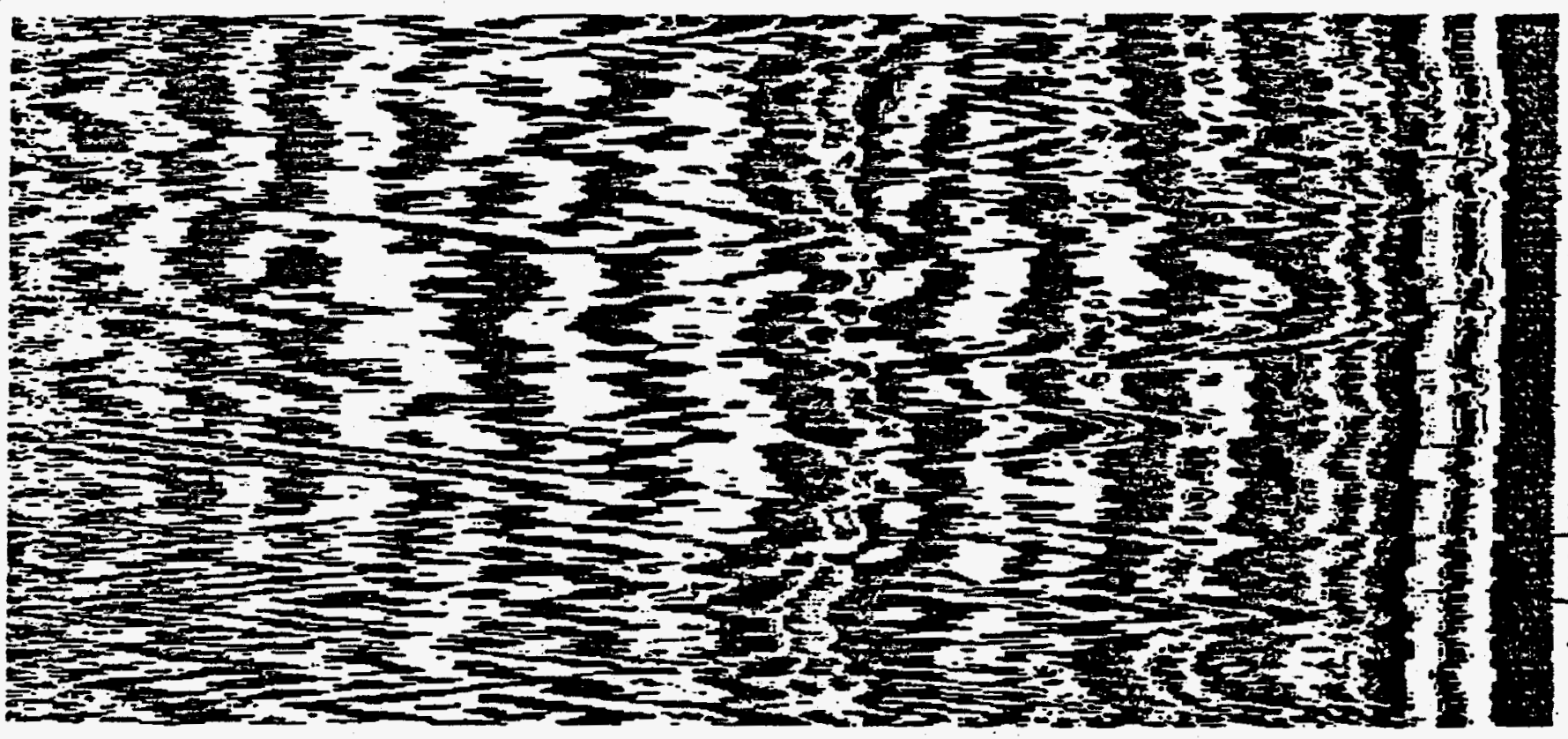


5 Created Jan 26,1993 12:23 Modified Date Unknown 512 samples/8can 30.0019 scans/sec position: -5 ns range: 100 ns Vert. IIR low pass $N=2 \quad F=60$ Vert. IIR high pass $N=2 \quad F=7$

GUNSITE $720 / 631-166$

SAVANRAB RIVER SIME

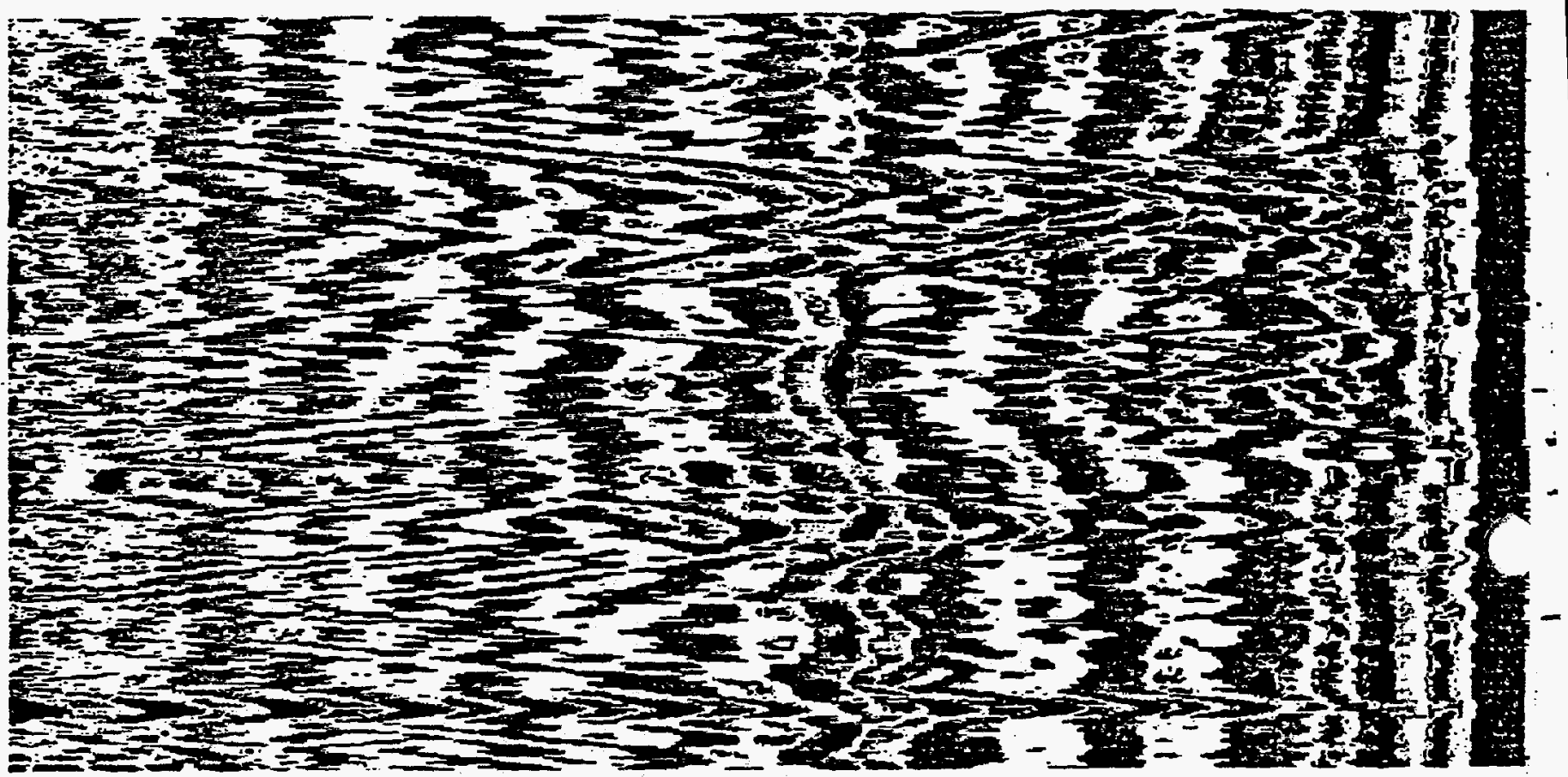




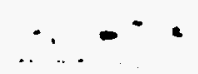

Figure 8

6 Created Jan 26,1993 12:26 Modified Date Unknown

512 samples/scan 30.0019 scans/sec position: -5 ns Iange: $100 \mathrm{~ns}$

Vert. IIR low pass $\quad F=2 \quad F=60$

Vert. IIR high pass $N=2 \quad F=7$

GUNSITE $720 / 631-166$

SAVANNAB RIVER SITE

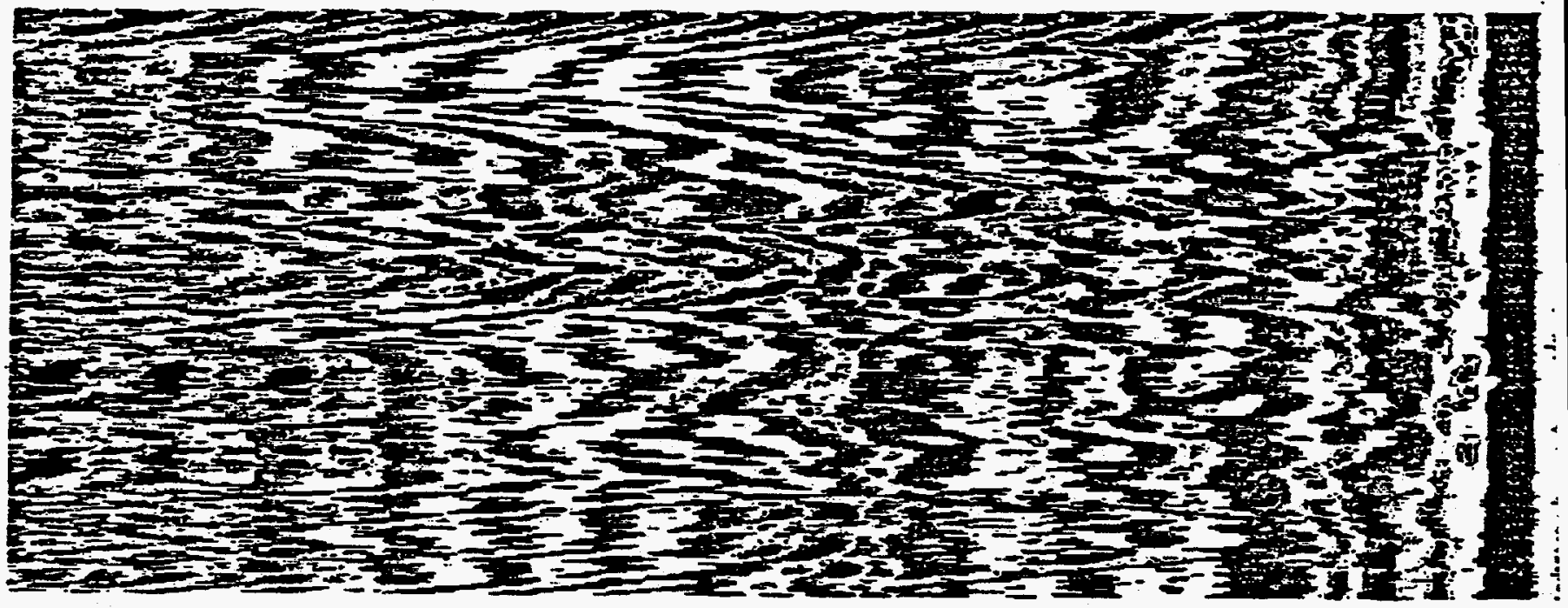


7 Created Jan 26,1993 12:31 Modified Date Unknown 512 samples/scan 30.0019 scans/sec position: $-5 \mathrm{~ns}$ range: $100 \mathrm{~ns}$ vert. IIR low pass $N=2 \quad F=60$

Vert. IIR high pass $N=2 \quad F=7$

GUNSITE $720 / 631-166$

SAVANRAB RIVER SITE

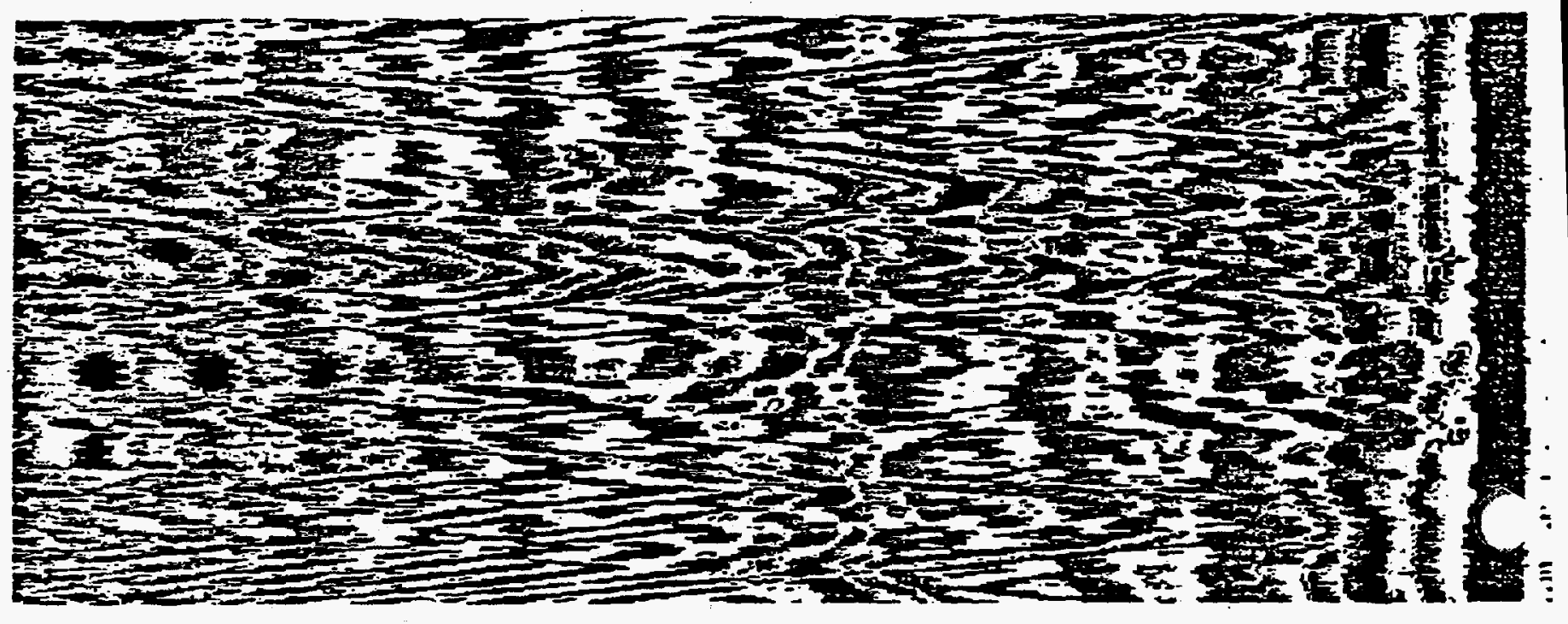


8 Created Jan 26,1993 12:33 Modifled Date Unknown

512 samples/scan 30.0019 scans/sec position: -5 ns range: 100 ns Vert. IIR low pass $N=2 \quad F=60$

Vert. IIR high pass $N=2 \quad F=7$

GUNSITE $720 / 631-166$

SAVANNAE RIVER SITE

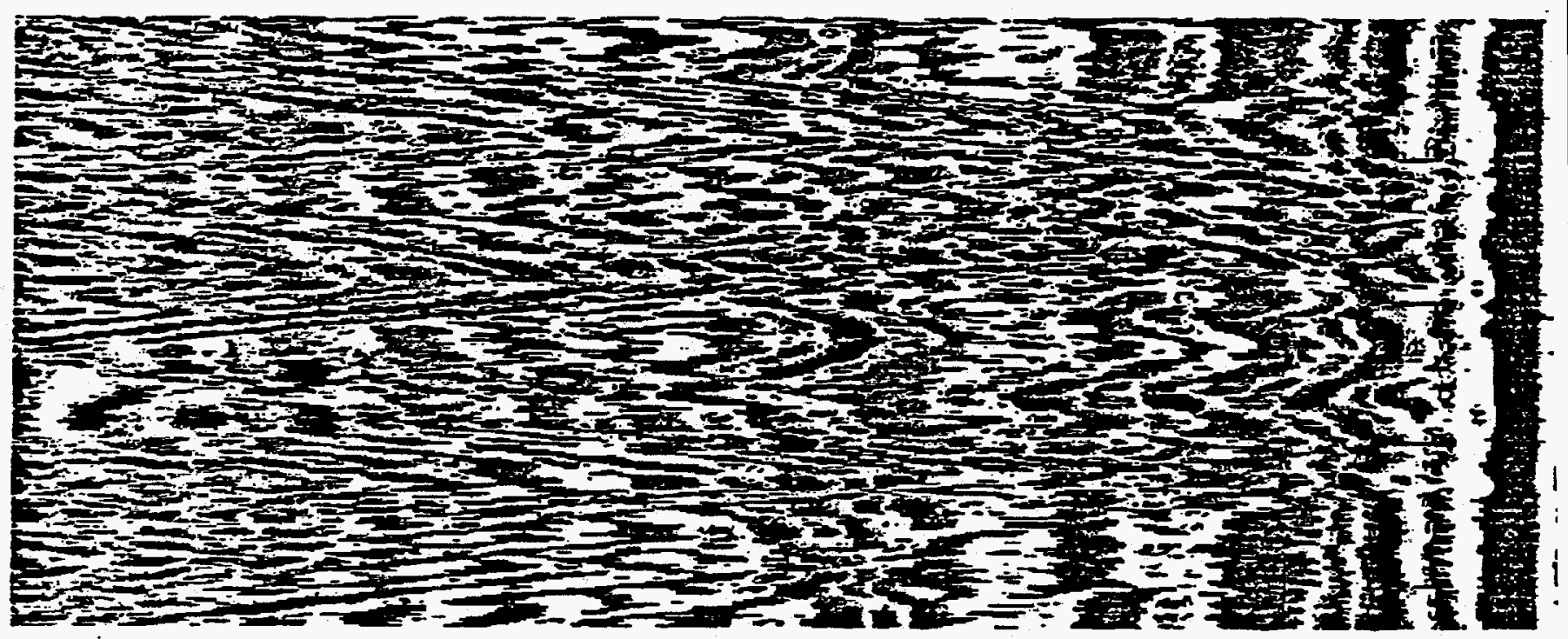


9 Created $\operatorname{Jan} 26,199312: 40$ Modified Date Unknown

512 samples/scan 30.0019 scans/sec position: -5 ns range: 100 ns Vert. IIR Iow pass $N=2 \quad F=60$

Vert. IIR high pass $\quad \mathrm{N}=2 \quad \mathrm{~F}=7$

GUNSITE $720 / 631-16 G$

SAVANNAE RIVER SITE

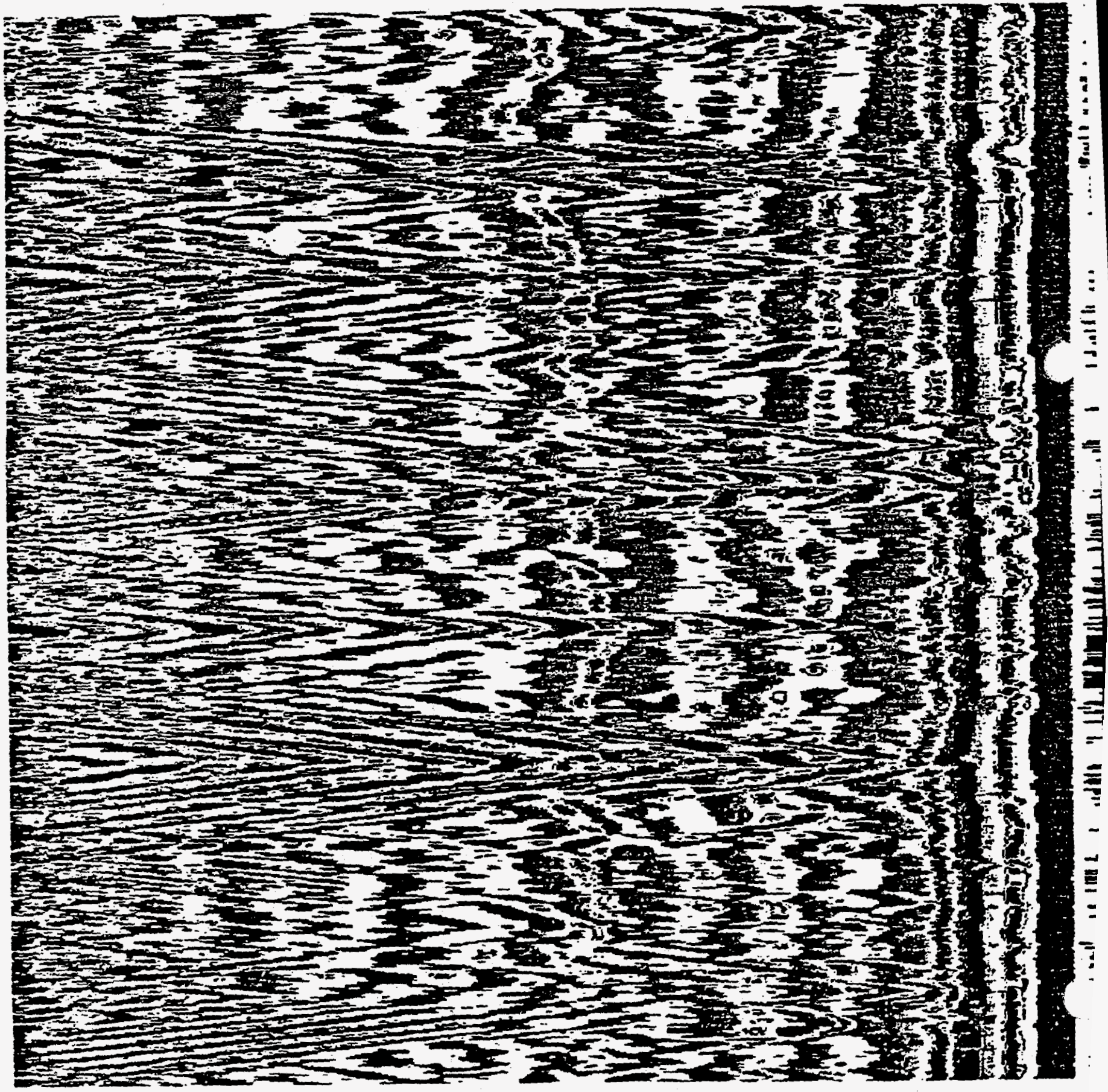


10 Created Jan 26,1993 12:43 Modifled Date Unknown 512 samples/scan 30.0019 scans/sec position: -5 ns range: 100 ns Vert. IIR Iow pass $N=2 \quad F=60$

Vert. IIR high pass $N=2 \quad F=7$

GUNSITE $720 / 631-16 G$

SAVAMNAB RIVER SITE

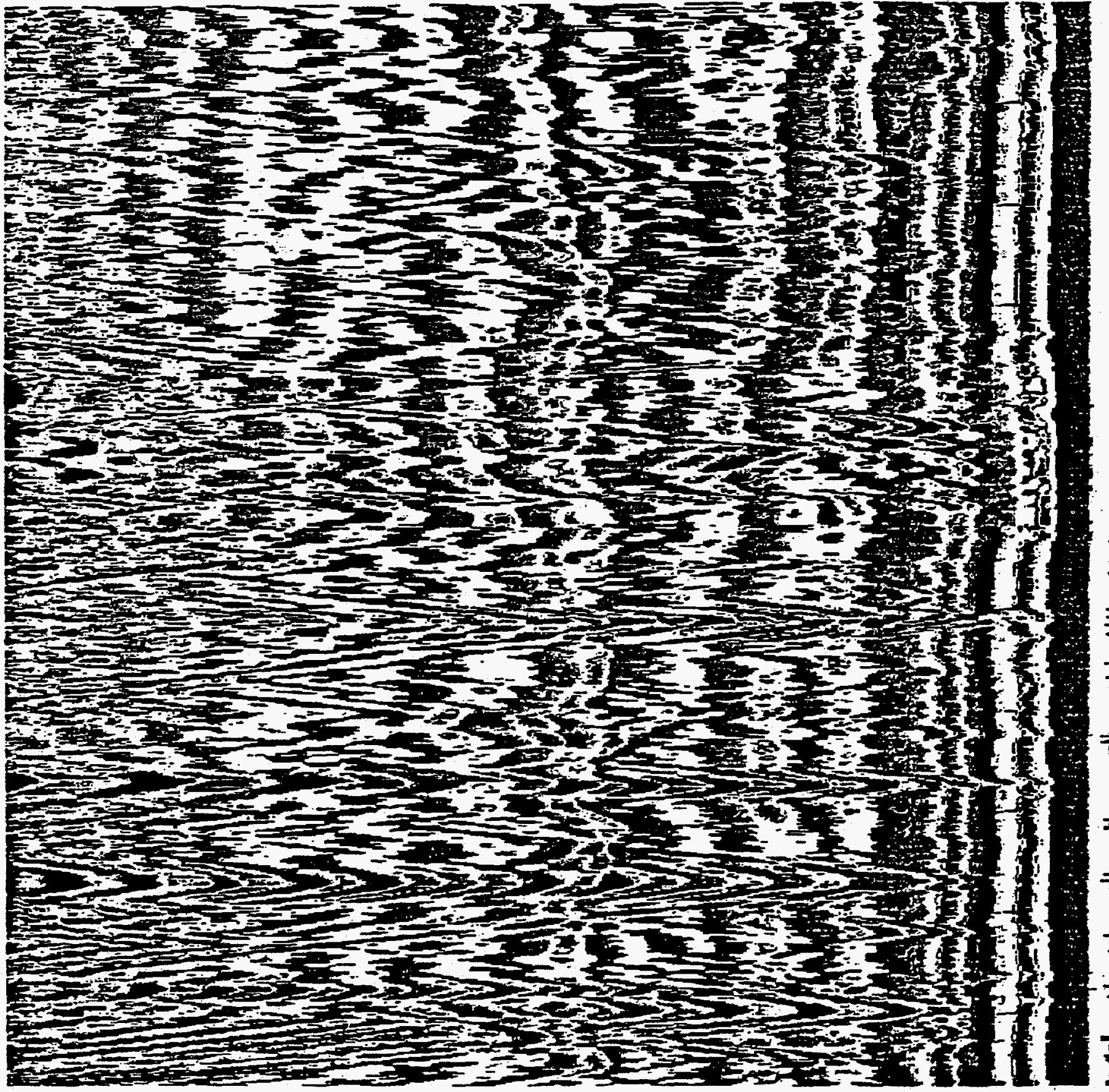




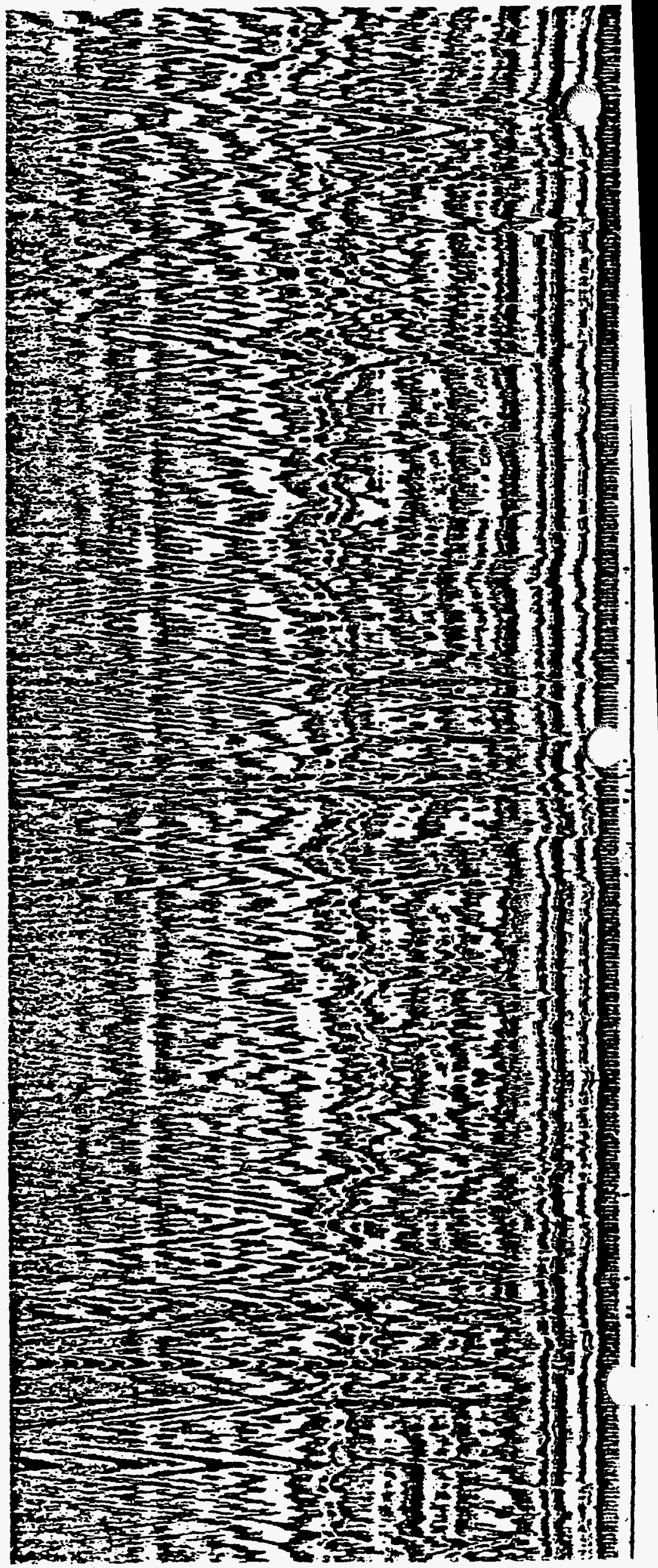




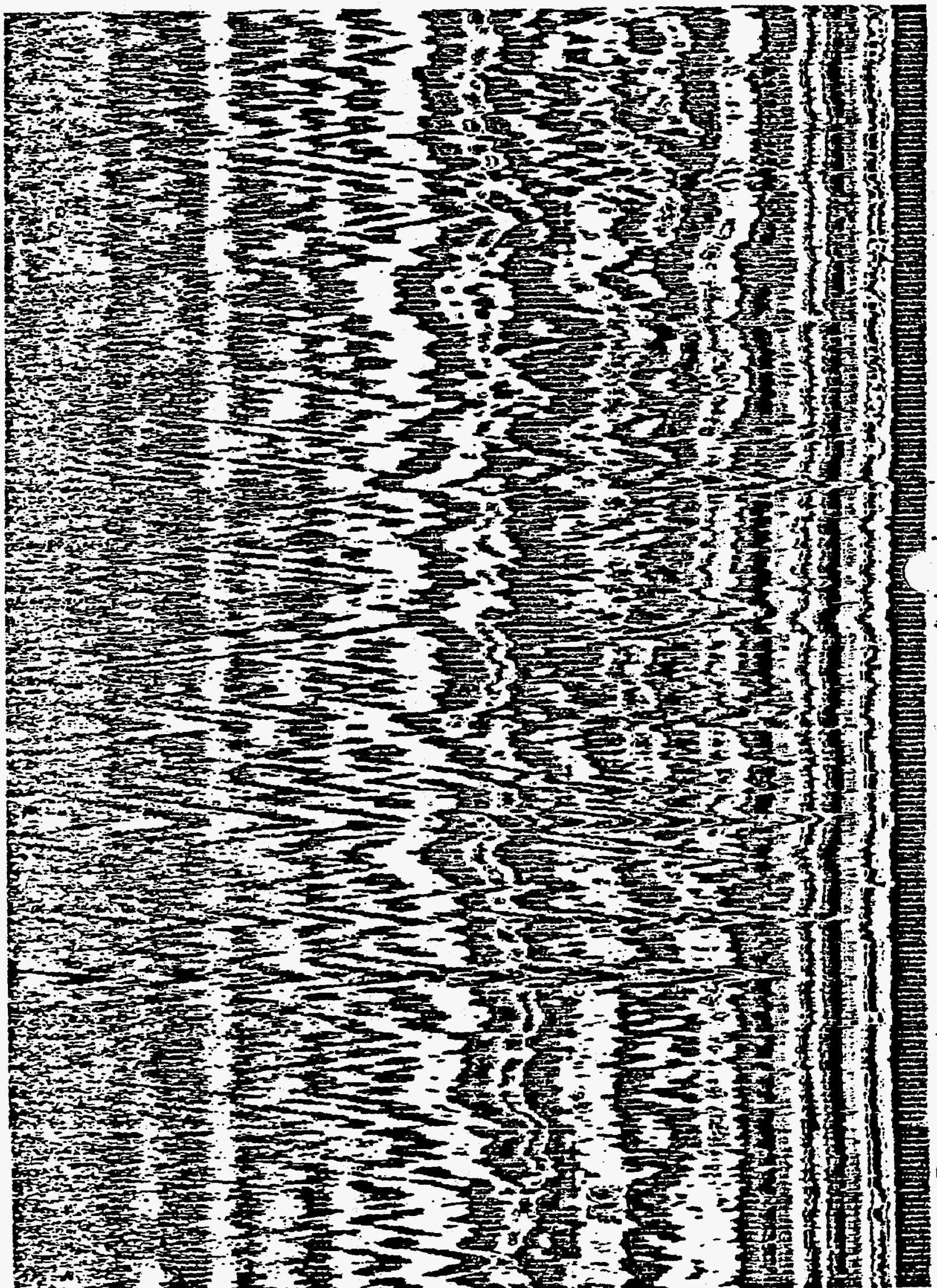


Vert. IIR low pass $\mathrm{N}=1 \quad F=60$

Vert. IIR hIgh pass $N=2 \quad F=7$

rauge: Luv as

rive87:

Figure 16

SAVANNAA RIVER SITE

GUNSITE 720/631-16G

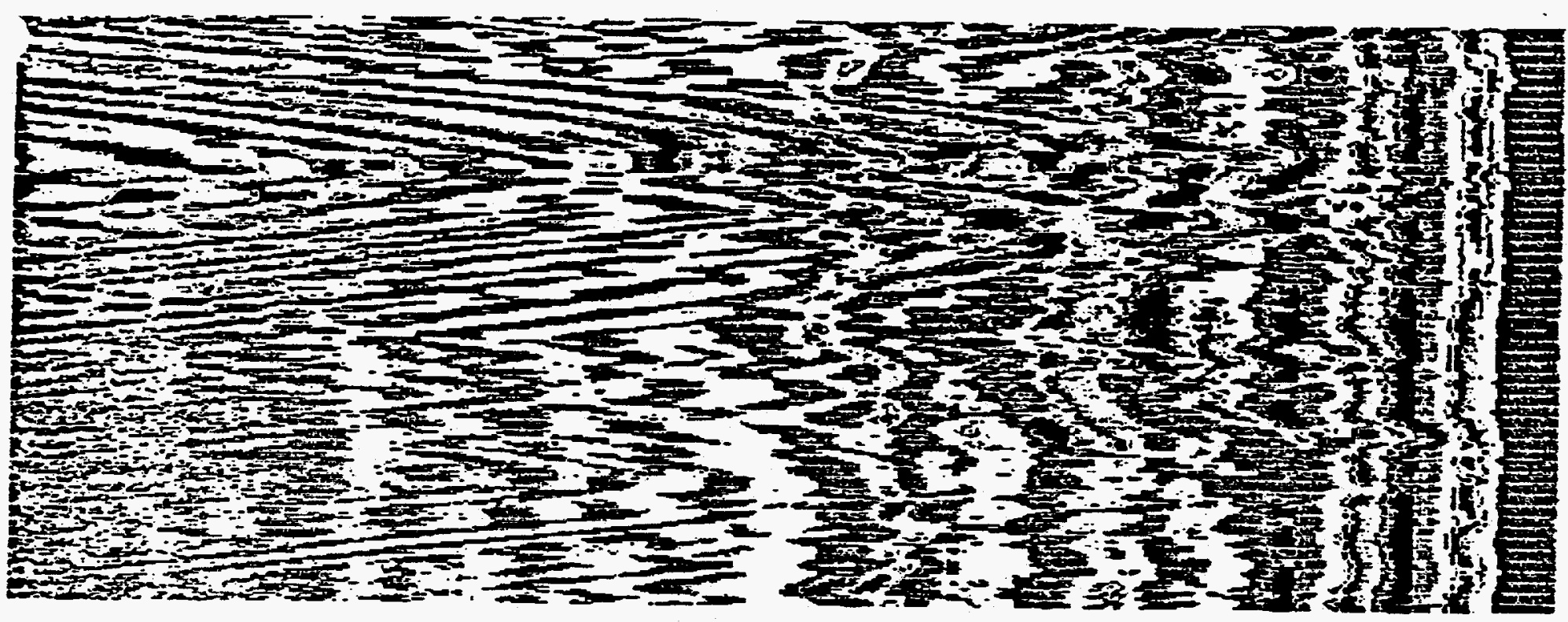

A. $1-29$ 


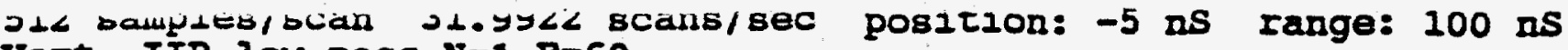

Vert. IIR low pass $N=1 \quad F=60$

Vert. IIR high pass $N=2 \quad F=7$

SAVANNAE RIVER SITE

GUNSITE 720/631-16G

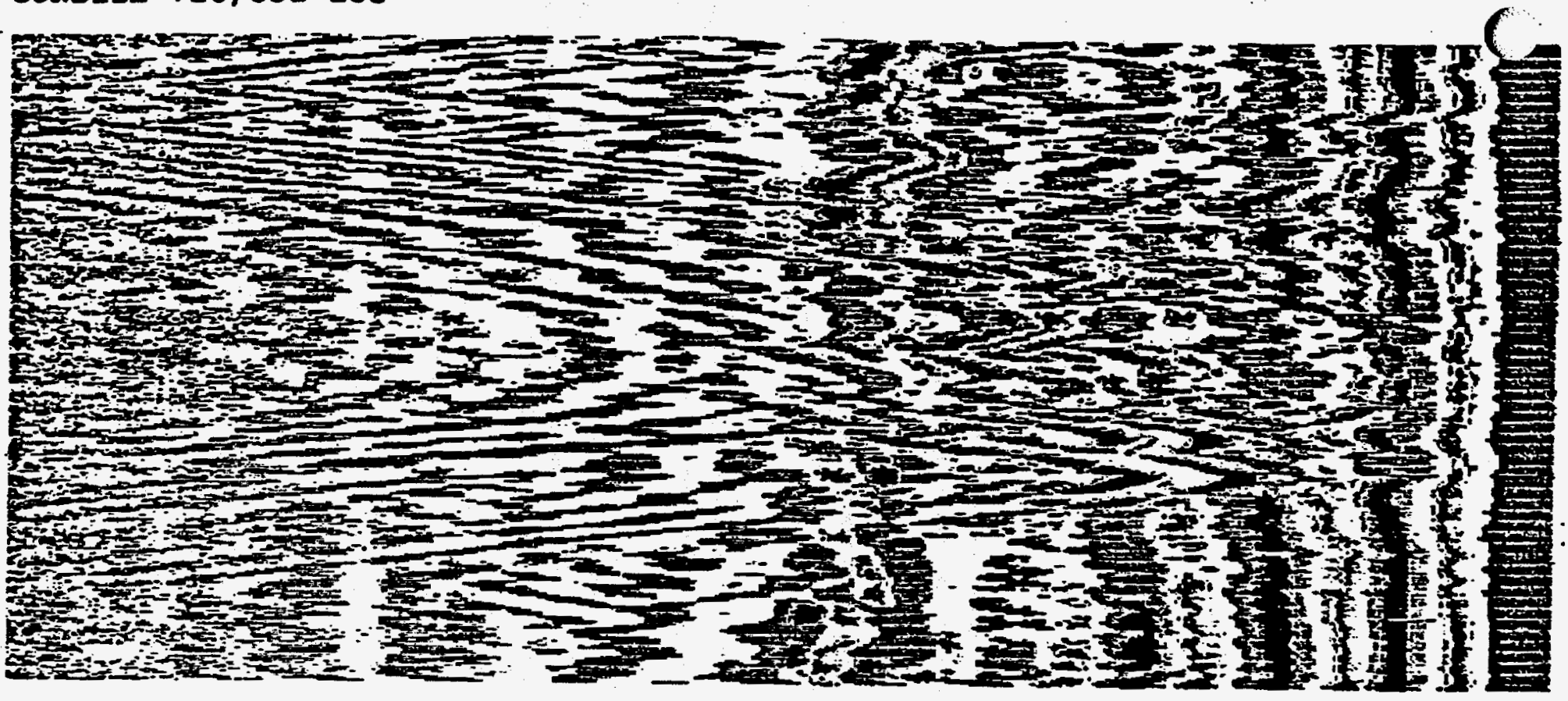


Vert. IIR low pass $N=1 \quad F=60$

postlion: -2 ns range: 100 ns

Vert. IIR high pass $N=2 \quad F=7$

SAVANNAE RIVER SIIE

GUNSITE 720/631-16G

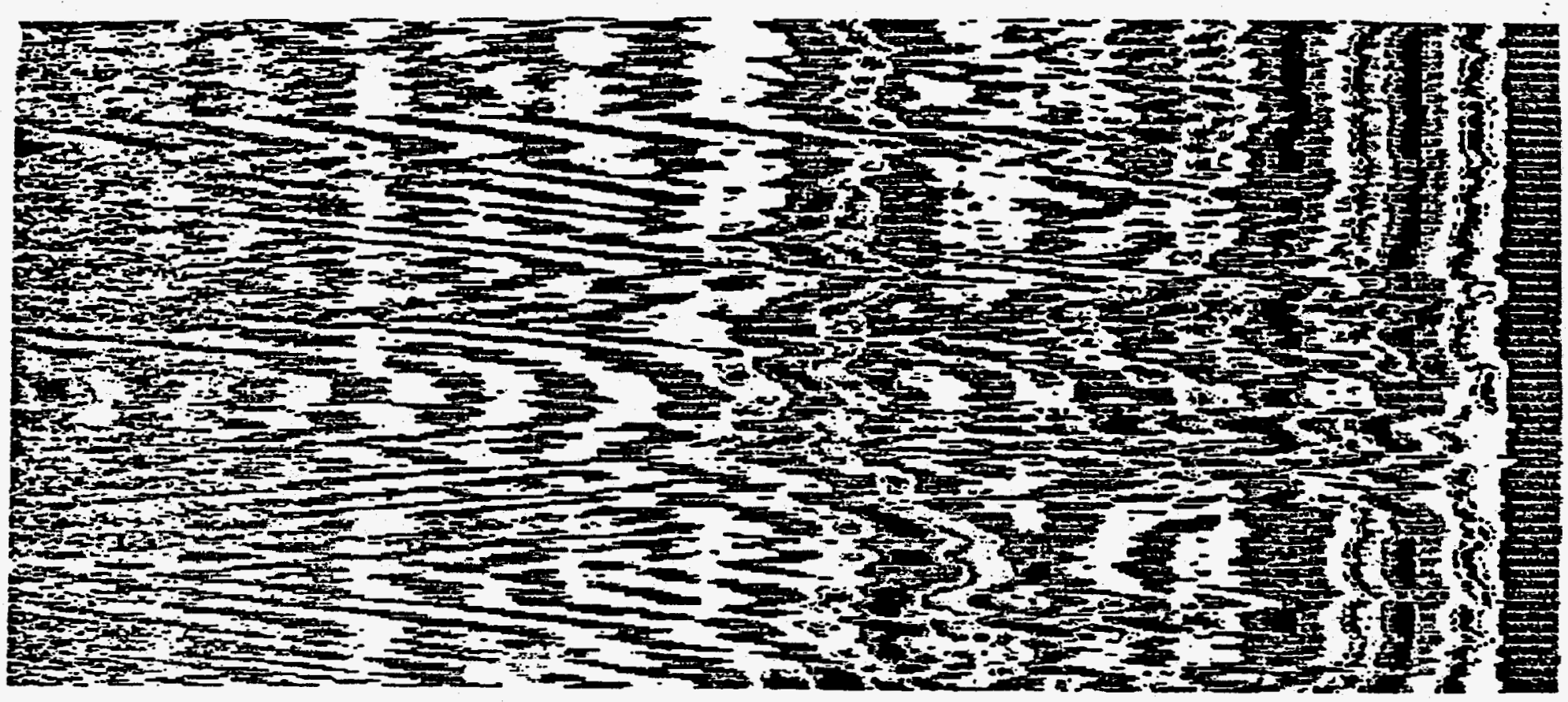




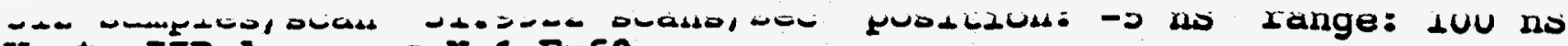

Vert. IIR low pass $N=1 \quad F=60$

Vert. IIR high pass $\mathrm{N}=2 \mathrm{~F}=7$

SAVANNAH RIVER SITE

GUNSITE 720/631-16G

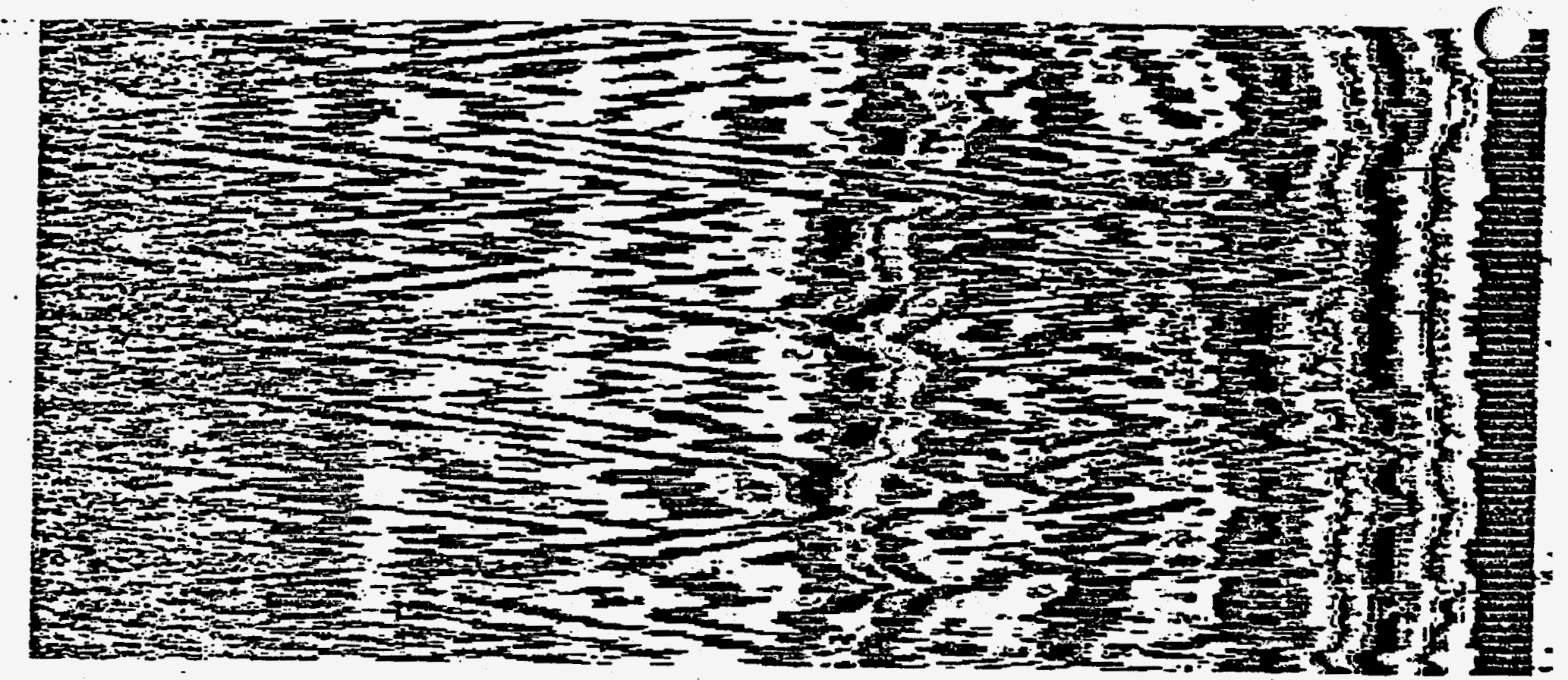


- - -

Vert. IIR low pass $\quad F=1 \quad F=60$

Figure 20

Vert. IIR high pass $N=2 \quad F=7$

SAVANNAB RIVER SITE

GUNSITE 720/631-16G

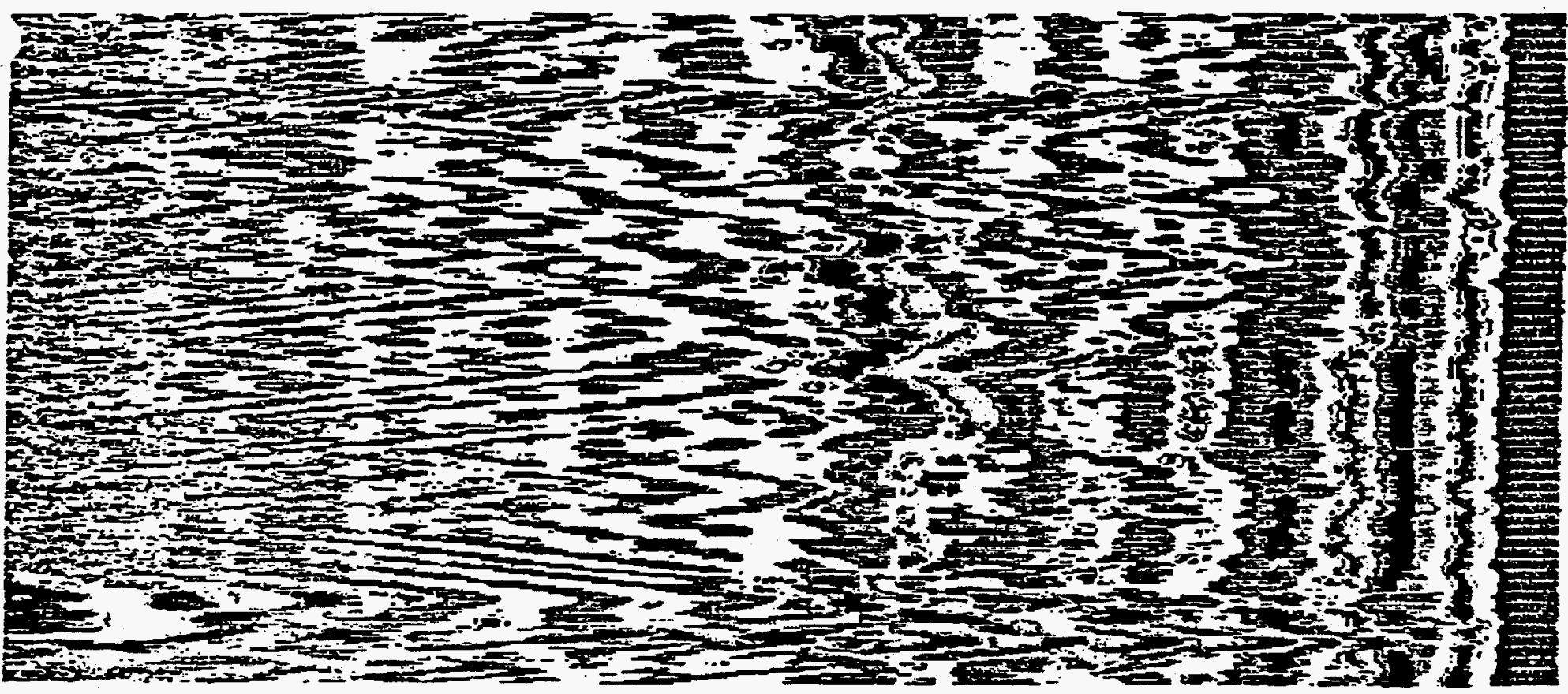

A. 1-33 
2t< sanples/scan 31.9922 scans/sec position: -5 ns Iange: 100 ns

Vert. IIR Iow pass $N=1 \quad F=60$

Vert. IIR high pass $N=2 \quad F=7$

SAVANNAB RIVER SITE

GUNSITE 720/631-166

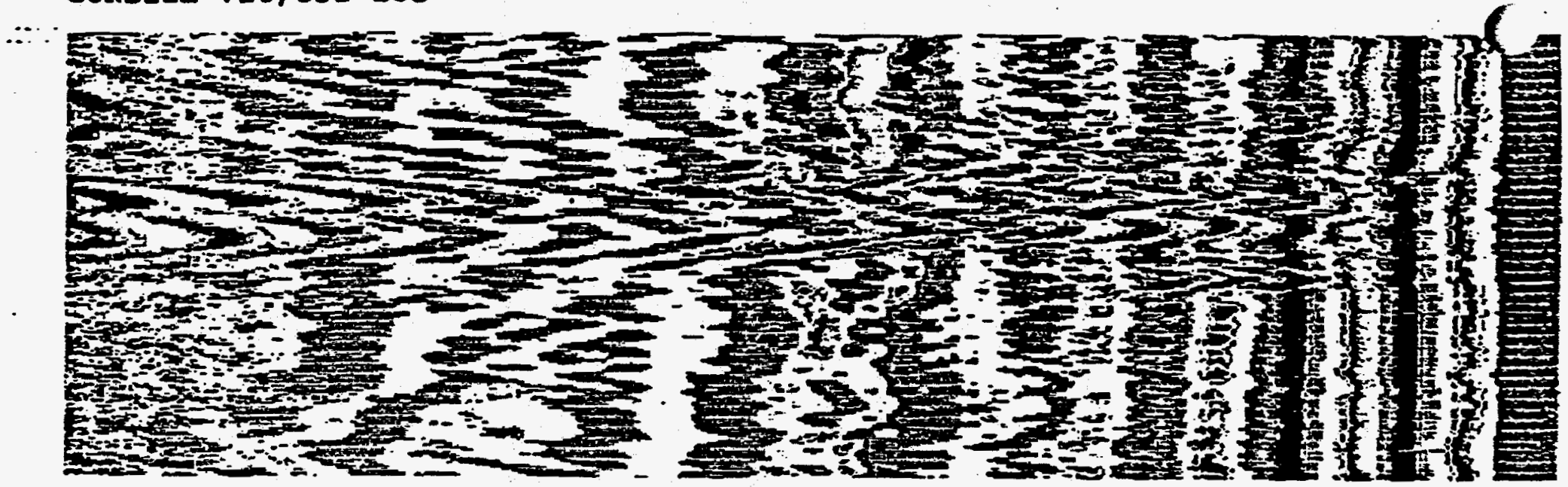


$31<$ samples/8can 32.9922 scans/sec position: -5 ns range: 100 ns

Vert. IIR Iow pass $N=1 \quad F=60$

Figure

Vert. IIR high pass $N=2 \quad F=7$

SAVANAAE RIVER SITE

GUNSITE 720/631-16G

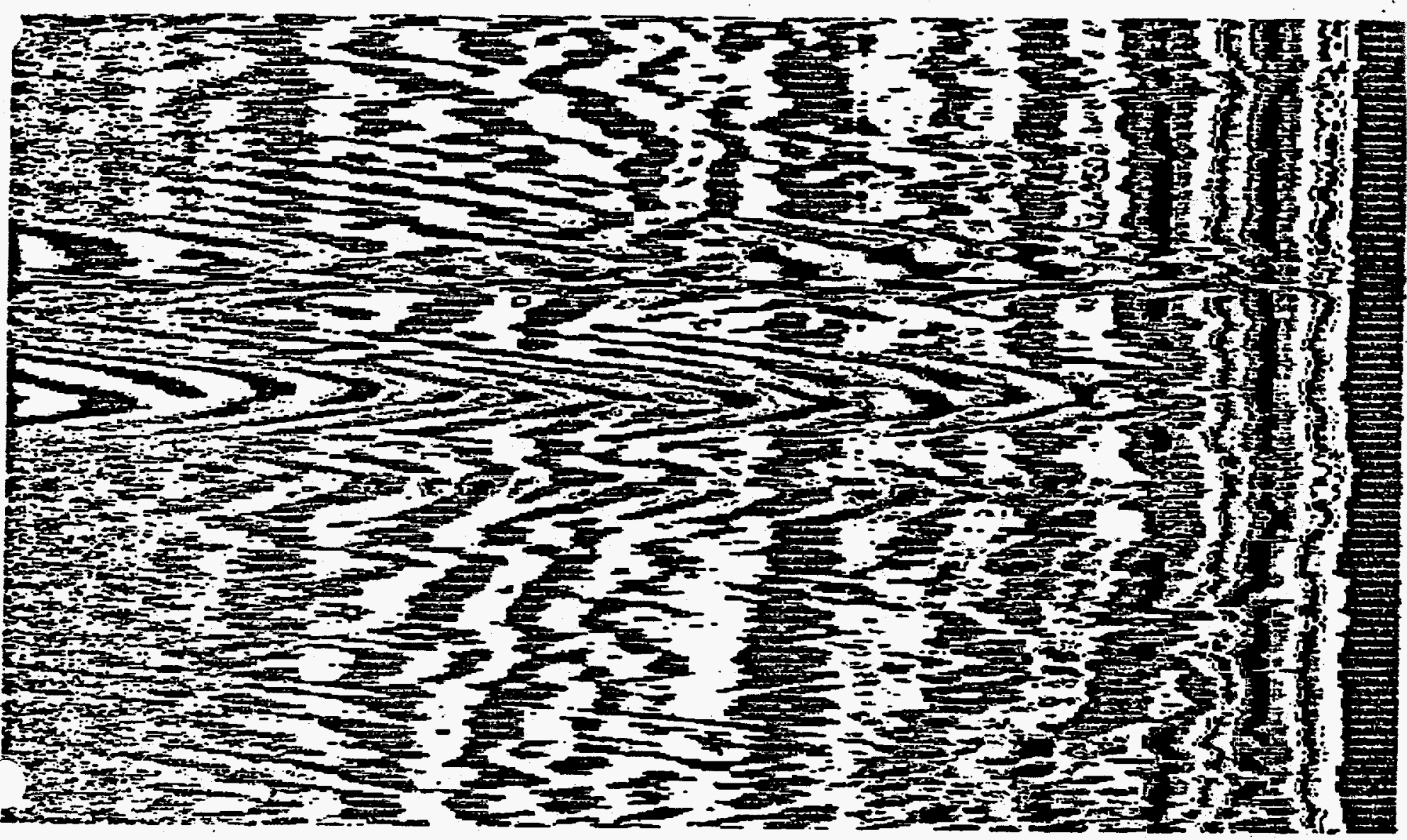


Vert. IIR low pass $N=1 \quad F=60$

posifion: -2 ns range: $100 \mathrm{~ns}$

Vert. IIR high pass $N=2 \quad F=$ ?

SAVANNAE RIVER SITE

GUNSITE 720/631-16G

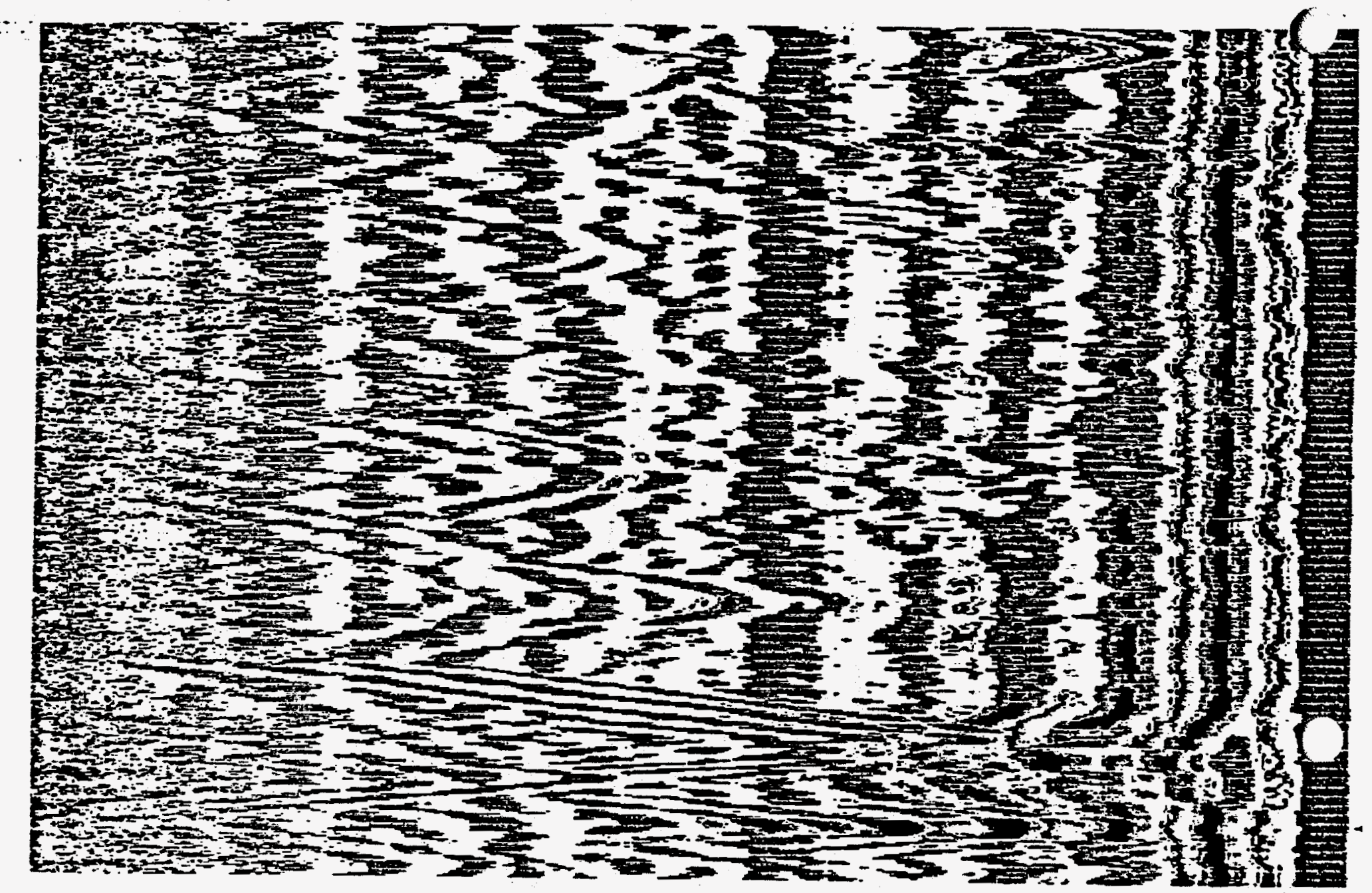


Vert. IIR low pass $N=1 \quad F=60$

Vert. IIR high pass $N=2 \quad F=7$

SAVANNAB RIVER SITE

GUNSITE 720/631-16G

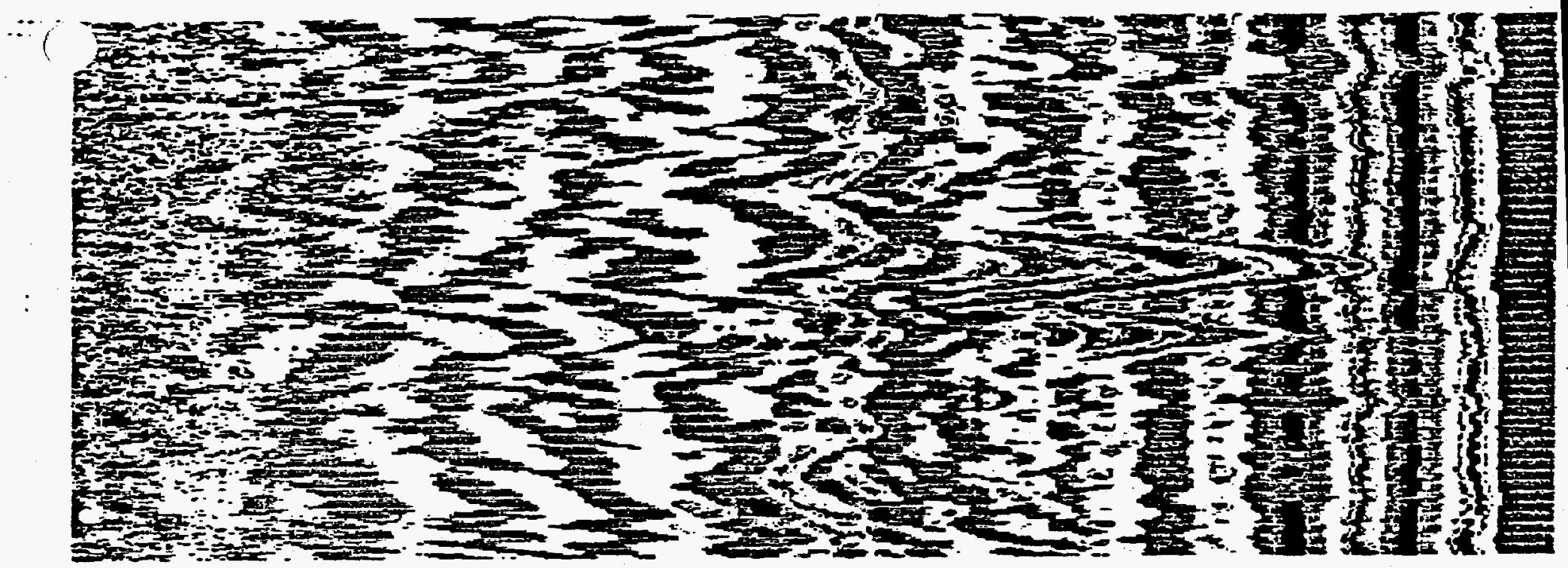


$\because:$ 
Gunsite 720 Rubble Pit Unit

RFI/RI Report
WSRC-RP-95-360, Rev. 1

March 1996

APPENDIX A.2

MAGNETIC SURVEY

$\Xi:$ 
Gunsite 720 Rubble Pit Unit

WSRC-RP-95-360, Rev. 1

RFI/RI Report

March 1996

THIS PAGE INTENTIONALLY LEFT BLANK

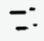




\section{Magnetic Survey of a Portion of Gunsite 720 Waste Site(U)}

\section{R. J. Cumbest, D. Marcy, D. Wells, and R. Hunter}

Westinghouse Savannah River Company

Savannah River Site

Aiken, SC 29808

$=$

Prepared for the U. S. Department of Energy under contract no. DE-AC09-89SR18035 
$\therefore$ :

A. 2-4 


\section{Introduction and Scope}

The Gunsite 720 Resource Conservation and Recovery Act (RCRA) Waste Unit is located on the Savannah River Site (SRS) off Brinkley Road northwest of the intersection of Upper Three Runs Creek and U. S. 125 (see Figure 1). A magnetic survey was conducted at this waste unit on March 21, 1986, by J. A. Smith and K. Mims to search for an underground storage bank. The data and results of this survey are deseribed in a memorandum dated March 26, 1986, to Van Price of the Environmental Monitoring Section. Environmental Protection Department. The March 1986 survey revealed several magnetic anomalies, one of which was closely associated with a concrete pad located on the waste unit. In conjunction with this survey, a rod was used to probe around the northwest side of the pad. No buried object was located and further work was recommended on the south side of the pad.

On March 15, 1993, at the request of the Environmental Restoration Department, the Environmental Monitoring Section Groundwater Group conducted a magnetic survey. This survey consisted of several lines in the vicinity of the concrete pad in Smith's 1986 survey. During the 1993 survey, a reconnaissance line extending southeast of the concrete pad assisted personnal to locate a magnetic anomaly that had not been identified before. On May 17, 1993, the survey grid was expanded to characterize the unknown anomaly. This report describes the 1993 magnetic survey of the Gunsite 720 Waste Unit and integrates the results of Smith's 1986 survey.

\section{Magnetic Survey Concepts}

The magnitude of the magnetic field measured near the Earth's surface is influenced by several factors. The main contribution to the total intensity is the internal magnetic field of the Earth produced near the it's core. However, this field is modified by the solar wind of charged particles produced by electromagnetic activity on the sun. This solar wind distorts the magnetic field produced by the Earth into a tear drop shape with the blunt end pointing toward the sun. More importantly, the effect of the solar wind is to produce time variations in the total field. The Earth's rotation, in effech introduces a diumal variation with a 24-hour period. Also, superposed on this well-defined 24-hour cycle are variations with an undefined period produced by the chaotic aature of the sun's electromagnetic activity. Typically, these variations manifest themselves as micropulsations less than $10 \mathrm{nT}$. but significantly larger variations can be produced by magnetic storms on the sun (i.e.e. sunspots). The net result of these variations are illuserated in Figure 2.

The Earth's magnetic field also is modified by feanures near the surface that produce localized, spatial variations or anomalies in the field intensity. Using magnetic techniques to search for buried metallic objects is a consequence of the ability of iron and iron alloys to cause relatively large amplitude anomalies. These anomalies are produced by two effects. Some materials have properties that allow them to become magnetized in the presence of an external magnetic field. This process is called induction. The external magnetic field is the inducing field, and the field produced by the material is the induced field, so that the total field, $B$ now becomes the sum of the inducing external field $\overline{\mathbf{A}}$ and the field produced by the material $\overline{\mathbf{H}}$. This relationship can be expressed:

$$
\overline{\mathbf{B}}=\overline{\mathbf{A}}+\overline{\mathbf{H}} \mathbf{r}
$$

In addition, some materials possess a magnetic field independent from any external source. This field typically is acquired at some time in the past history of the material and is called remnant magnetization. For most magnetic survey applications, the magniude of the induced field is assumed to be much greater than the remnant magnetization.

In reality, magnetic fields always are manifested as tipoles, that is, north and south magnetic poles occur in pairs to produce dipole fields. A field line representation of a dipole field and a monopole field are illustrated in Figure 3. In this type of representation, the density of the field lines is proportional to the freld magnitude. Initially, the magnetic field produced near the core of the Earth can be considered a single dipole, with the magnetic field lines impinging the Earth's surface at 90 degrees at the narth and south magnetic poles and parallel to the Earth's surface at the magnetic equators. 
The geometric relationship of the magnetic field lines to the geographic poles is expressed by magnetic inclination and declination. Declination describes the angular relationship between a component in the field line parallel to the surface on the Earth and the geographic north. The magnetic inclination expresses the angular relationship between the magnetic field lines and the horizontal (see Figure 4). Although these angular relationships change slowly because of poorly understood, long-term variations, the declination in the vicinity of SRS is about 4 degrees west, and the inclination about 65 degrees north.

Although inducing bodies usually possess highly irregular shapes and sizes, they can be modeled usefully as dipoles or arrays of dipoles. In some instances, if the area of consideration is near one end of a dipole relative to the dipole separation. the local field can be considered to be produced by a single pole and approximates monopole behavior. The anomalous fields produced by a dipole and monopole for a magnetic inclination of 60 degrees in the northern hemisphere (i.e., conditions very similar to SRS) and the resultant effects on the wotal magnetic field measured near the body are illustrated in Figure 3. Notice that the anomalous field lines on the north side of the dipole are opposite of the ambient field, thereby reducing the field strength in this location. In contrast, the anomalous field lines on the south side increase the field strength. The monopole exhibits similar behavior although not as extreme. This phenomena explains the asymmetrical-shaped magnetic highs and lows produced by inducing bodies at mid-latimdes on the Earth. Figure 5 illustrates typical magnetic profiles that would be observed at the latioude of SRS over monopoles and dipoles in addition $10 \mathrm{a}$ generalized contour representation of a dipole, with illustrative profiles across the contours.

Generalized magnetic field intensity profiles for an inclination of 60 degrees are illustrated in Figure 6. These profiles exhibit the typical asymmetrical signatures along the north-south profiles with magnetic highs occurring over southem portions of the bodies. The profiles for the horizontal and verical cylinders would be similar to that exhibited by a buried cylindrical fuel tank. The presence of concrete pads on the waste unit make the profiles for the horizontal slab insuructive because these pads contain steel reinforcement bars and will exhibit significant magnetic anomalies.
The previous discussion was based on the intensity of the total magnetic field. Another measurement that can be useful in interpreting magnetic anomalies is the vertical magnetic gradient, which changes much more rapidly with distance than the total field. Using the vertical magnetic gradient resulas in edge enhancement of anomalies and more effective anomaly separation (see Figure 7). The vertical magnetic gradient can be determined by making measurements of the conal magnetic intensity at two known elevations. The vertical gradient is then determined by the difference between the two measurements divided by their separation. These measurements can be taken by sensors. This is done by moving a sensor between the two measurements of having an instrument with two separated sensors.

In order to conduet a magnetic survey, magnetic data are collected at discrete intervals either along a traverse or over a two-dimensional (2-D) grid. In practice, data for 2-D grids usually are collected as multiple traverses. Traverse data can be displayed conveniently as magnetic intensity profiles, while 2-D gridded data usually are contoured and displayed as contour diagrams. Displayed in this fashion, these data can be interpreted qualitatively by comparing them with profiles or contours that would be predicted from bodies of known shape and size as presented eartier.

\section{Description of Survey Site}

A planimetric map of Gunsite 720 Waste Unit is presented in Figure 8. The reference for this map is the Planimetric Map of Gunsite 720 prepared by Cranston, Robertson, and Whitehurst, P. C., 1990. An unimproved dirt road that runs southeast-northwest along the northeast side of the waste unit is the boundary. The most prominent objects at the waste site are two conerete pads, the smaller of which serves as a foundation fór a amall shed. The vicinity around the smaller pad has been the focus of the magnetic surveys conducted so far. In addition to these pads, several iron rails are located west of the larger concrete pad. These rails are located a

- few meters south of the 1993 survey grid but do not extend into the grid. This planimetric map also shows a flagged trench. This feature is included on Figure 8, but the trench was not recognized during the survey. 


\section{Magnetic Survey}

The magnetic survey data reponed by Smith are tabulated in Appendix I. Based on Smith's diagram of the pad location and size, the locations of the survey stations in Appendix I have been converted into the coordinate system established for the 1993 magnetic survey. The positions of the 1986 survey stations relative to the 1993 survey coordinate system are illustrated in Figure 9.

The 1986 magnetic survey reveals three distinct magnetic anomalies (Figures $10 \mathrm{a}$ and 10b). The largest anomaly occurs in the vicinity of the small pad and exhibits dipole behavior, which is defined by a 700 nT magnetic high, located southwest of the pad's southwestern edge, and a $100 \mathrm{nT}$ magnetic low, located northwest of the pad. A smaller magnetic high of $80 \mathrm{nT}$ that approximates monopole behavior occurs nine meters northwest of the pad at conrdinates $(-10,12)$. In addition to these two features, a $400 \mathrm{nT}$ magnetic high occurs in the northwestern corner of the grid near the road. Smith attributed this feature to a truck parked nearby at the time of his survey.

The results of Smith's survey were inconclusive. The magnetic anomaly associated with the pad exhibited a magnetic high offset to the southwest of the pad instcad of directly over the southwestern edge. This would be expected if the pad were the sole source of the anomaly.

\section{Magnetic Survey}

\section{Survey and Analytical Techniques}

The 1993 magactic survey conducted by the Environmental Monitoring Section Groundwater Group was conducted in two parts. All grids and lines surveyed in 1993 were defined by one meter station intervals. Prior to collecting the magnctic data, the station locations were positioned using a transit to establish 90 degrec angles and straight lines and a cord marked at one meter intervals.

Magnetic data were collected with an EG\&G Geometrics G.856 Gradiometer. The top sensor. was 2.44 meters from ground level and the bottom sensor 1.22 meters from ground level. This instrument has a nominal accuracy of $0.1 \mathrm{nT}$; however, the high magnetic gradients produced near the concretc pad and other metal objects caused the sccuracy to deteriorate to I nT in these areas. As a quality assurance/quality control (QAVC) check, and in order to account for diurnal variation, a single station was occupied severd times during cach survey.

$\therefore .$.

The date were downloaded from the magnetometer through a RS-232 port to an IBM PC Model 80. After downloading, the data were assigned coordinates and diurnally corrected with MAGLOC, a software provided by EG\&G. Further data display and processing, including gridding and contouring, were accomplished with software provided by GEOSOFT Inc. Gridding date was accomplished with RANGRID, which fits a minimal curvature surface to the gridded data. Magnetic gradients were calculated by subtracting the top sensor reading from the bottom sensor reading and dividing by their separation.

Section I was surveyed on March 15, 1993. The station locations for this survey are illustrated in Figure 11. Section 1 consists of a $6 \times 21$ grid approximately centered on the small pad that cxicnds in long dimension to the northeast and southwest of the pad. This survey also included two reconnaissance lines $(710$ and 810$)$ that extend perpendicular to the long axis of the grid (Figure 11). During the survey, station $(5,0)$ was oceupied several times in order 10 establish the diumal variation. The data for this survey are presented in Appendix Ila.

Section II was surveyed en May 17, 1993. The station locations for Section II are illustrated in Figure 12. During the survey, the station coordinate $(4,7)$ was oceupied several times in order to establish the diumal variation. The data for Section II are presented in Appendix Ilb.

In order to make the two surveys compatible, stations coordinates $(4,7)$ through $(4,18)$ and - coordinate $(5,7)$ through $(5,18)$ wetre common to both Section I and Section II. The surveys were combined by taking the average of the diumally corrected values for each survey and assigning the average value to these stations.

$9.412+4.000$ 


\section{Magnetic Data Set}

The magnetic gradients for the two reconnaissance lines $(710$ and 810 ) are plotied as profiles in Figure 13. Line $\mathbf{7 1 0}$ shows a large negative gradient anomaly near the small pad, but exhibits no gradient anomalies over the rest of its length. Note that the $\mathbf{8 0} \mathrm{nT}$ magnetic high seen at coordinate $(-10,12)$ in the 1986 data is not seen on line 710. Line 810 exhibits a large positive gradient anomaly near the small concrete pad and another smaller anomaly approximately 8 meters southeast of the pad. This anomaly was the subject of the survey conducted in Section II.

The station locations for the combined Seetion I and Section II data set are shown in Figure 14 and the data tabulated in Appendix Ile. Several magnetic anomalies are present in the data (see Figures 15-17). A dipole anomaly is defined by a magnetic high that occurs directly over the southern corner of the small pad and a magnetic low associated with the northern corner of the pad, with a monotonically decreasing ficld between these two areas. Note that the zero vertical gradient contour diagonally bisects the concrete pad, and there is no east-west horizontal gradient over the center of the pad.

The anomaly secn on reconnaissance line 810 to the southeast of the pad approximates a circular monopole centered at coordinate $(14,12)$. An elongate magnetic high also occurs in the southern corner of the grid at coordinate $(20,9)$. As shown on the plan maps, this corner is very near the location of scveral iron rails.

\section{Discussion}

The most promincnt feature seen on the 1986 and 1993 magnetic surveys is the dipole anomaly located in the vicinity of the small concrete pad. However, the character of the anomaly shows significant differences in the two surveys. The magnetic high in the 1993 data coincides with the southern corner of the pad, and a corresponding low is present just north of the pad with the field monotonically decreasing between these two areas. This is the expected behavior for a flat slab at this latitudc. The same anomaly in the 1986 data has gencrally the same shape in both surveys, however, it appears to be rotated 90 degrees and the magnetic high is not coincident with the southern comer of the pad. This discrepancy is unexplained; however, the 1993 data were collected at a much smaller grid spacing and is considered to more accurately represent the character of the pad anomaly. Based on the 1993 data, the shape and magnitude of the anomaly is consistent with that which is produced by a concrete slab reinforced with steel bar.

The monopole magnetic high located at coordinate $(-10,12)$ in the 1986 survey is not present on line 710. This is apparently due to the fact that a large concretc object with metal pipes and bars was excavated and removed from this location in the time interval between the two surveys.

The monopole anomaly, which was noticed on the surface of this location during conduct of the survey, is located at coordinate $(14,12)$ in the 1993 survey and is probably duc to a metal cable anchor. Smith attributed this magnetic high, seen in the northeast corner of the 1986 survey, to a truck parked on the road, which was not present in the 1993 survey, thereby indicating that Smith's interpretation for the source of this anomaly is correct. The clongate magnetic high, seen in the southern corner of the 1993 magnetic survey, occurs near the location of several iron rails on the surface near the grid in this area. This anomaly is attributed to the presence of these rails.

\section{Conclusions}

A detailed magnetic survey in the vicinity of a small concrete pad at the Gunsite 720 Waste Unit has allowed much better resolution of the magnetic anomaly associated with the pad. This anomaly is only produced by the pad. The possible presence of a buried metal tank around the pad is unsupported based on the magnetic data. All other anomalies identified in the 1986 and 1993 magnetic surveys can be attributed to

- metal objects that were either excavated between the two surveys, or that can be identified on the ground surface. 


\section{References}

1. Breiner, S. Applications Manual for Potable Magnetometers, Sunnyvale, California 94084 (1973).

2. Telford, W. M., Gcldart, L P. Shcriff, R. E Keys, D. A.. Applied Geophysics. P. 860, Cambridge University Press, Boston, MA (1978). 
Appendix I: 1986 Magnetic Survey Data

\{Coordinates (Coord) relative to 1993 survey grid\}

corde Con

653

$6.53 \quad 18.62$

$6.53 \quad 1557$

$6.53 \quad 1252$

$6.53 \quad 9.47$

$\begin{array}{ll}6.53 & 6.42 \\ 6.53 & 3.37\end{array}$

$6.53 \quad 0.32$

6.53

3.48

3.48

3.48

3.48

3.48

3.48

3.48

3.48

3.48

3.48

0.43

0.43

0.43

0.43

0.43

0.43

0.43

0.43

0.43

0.43

$-262$

$-262$

$-262$

$-262$

$-2.62$

$-262$

$-2.62$

$-262$

$-262$

$-262$

$-5.67$

$-5.67$

$-5.67$

24.72

21.67

18.62

1557

1252

9.47

6.42

\subsection{7}

0.32

$-273$

24.72

21.67

18.62

15.57

1252

9.47

6.42

3.37

0.32

$-273$

24.72

21.67

18.62

1557

1252

9.47
6.42

6.42

3.37

0.32

$-273$

24.72

21.67

18.62

\begin{tabular}{l} 
Fidd \\
(nT7 \\
\hline 51798 \\
52421 \\
52393 \\
52372 \\
52371 \\
52466 \\
52438 \\
52419 \\
52427 \\
52452 \\
52333 \\
52428 \\
52398 \\
52327 \\
52327 \\
53769 \\
52501 \\
52450 \\
52441 \\
52457 \\
52412 \\
52431 \\
52415 \\
52308 \\
53080 \\
53395 \\
52536 \\
52444 \\
52441 \\
52457 \\
52430 \\
52439 \\
52428 \\
52373 \\
52074 \\
52290 \\
52418 \\
52435 \\
52439 \\
52453 \\
52439 \\
52445 \\
52426 \\
\end{tabular}

Y Connd. Y

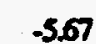

$-567$

-567
-56

$-567$

$-567$

$-5.67$

$-872$

8.72

$-872$

872

872

872

872

872

$-872$

872

$-11.77$

$-11.77$

$-11.77$

$-11.77$

$-11.77$

$-11.77$

$-11.77$

$-11.77$

$-11.77$

$-11.77$

$-14.82$

.1482

$-14.82$

$-14.82$

$-14.82$

.14 .82

$-14.82$

$-14.82$

$-14.82$

$-14.82$

$-17.87$

$-17.87$

$-17.87$

$-17.87$

$-17.87$

$-17.87$
Fied

(aT)

52408

52354

52486

52424

52428

52436

52452

52443

52440

52432

52378

52641

52458

52443

52410

$\mathbf{5 2 4 3 4}$

52449

52437

52441

52423

$\mathbf{5 2 4 0 1}$

$\mathbf{5 2 3 9 3}$

52421

52416

S2421

52433

52444

52442

52417

52410

52421

52418

52423

52371

52420

52429

52451

$\$ 2446$

52440

52491

52433

$\mathbf{5 2 4 3 8}$

52408
$Y$ Fidd

$x$ Coord.

Coond.

(nT)

$-17.87$

$\begin{array}{lll}-1787 & 032 & 52430\end{array}$

$\begin{array}{lll}-1787 & 273 \quad 52452\end{array}$

$\begin{array}{lll}2092 & 24.72 & 52440\end{array}$

$\begin{array}{lll}-2092 & 21.67 & 52471\end{array}$

$\begin{array}{lll}-20.92 & 1862 & 52416\end{array}$

$\begin{array}{lll}-20.92 & 1557 & 52440\end{array}$

$\begin{array}{lll}-20.92 & 1252 & 52438\end{array}$

$\begin{array}{lll}-20.92 & 9.47 & 52429\end{array}$

$\begin{array}{lll}-20.92 & 6.42 & 52430\end{array}$

$\begin{array}{lll}-20.92 & 337 \quad 52421\end{array}$

$\begin{array}{lll}-20.92 & 0.32 & 52431\end{array}$

$\begin{array}{lll}-20.92 & -273 & 52449\end{array}$

$\begin{array}{lll}-23.97 & 21.67 & 52435\end{array}$

$\begin{array}{lll}-23.97 & 1557 & 52415\end{array}$

$\begin{array}{lll}-23.97 & 1252 & 52443\end{array}$

$\begin{array}{lll}-27.02 & 21.67 & 52476\end{array}$

$\begin{array}{lll}-27.02 & 1557 & 52417\end{array}$ 
Appendix IIA: 1993 Magnetic Survey Data

Section I Uncorrected (Uncorr) and Diurnally Corrected (Corr) Magnetic Data for Top and Bottom (Bott), collected March 15, 1993.

Values preceded by "?" accurate to $1 \mathrm{nT}$.

\begin{tabular}{|c|c|c|c|c|c|c|c|}
\hline $\begin{array}{c}Y \\
\text { Coord. } \\
\end{array}$ & $\begin{array}{c}Y \\
\text { Comend. } \\
\end{array}$ & $\begin{array}{c}\text { Bute. } \\
\text { Uncorr. }\end{array}$ & $\begin{array}{l}\text { Bork } \\
\text { Corr. }\end{array}$ & $\begin{array}{l}\text { Both. } \\
\text { Diri. }\end{array}$ & $\begin{array}{c}\text { Top } \\
\text { Unsopt. }\end{array}$ & $\begin{array}{l}\text { Top } \\
\text { Corr. }\end{array}$ & $\begin{array}{l}\text { Top } \\
\text { Dif. }\end{array}$ \\
\hline 5 & 0 & 51822.1 & 518221 & 0 & 51818. & 51818.1 & 0 \\
\hline $\begin{array}{l}5 \\
5\end{array}$ & $\begin{array}{l}1 \\
2\end{array}$ & $\begin{array}{l}51819.6 \\
51820\end{array}$ & $\begin{array}{l}51819.5 \\
518198\end{array}$ & $\begin{array}{l}0.1 \\
02\end{array}$ & $\begin{array}{l}51818 \\
518186\end{array}$ & $\begin{array}{l}51817.9 \\
\text { S1818.5 }\end{array}$ & a) \\
\hline $\begin{array}{l}3 \\
5\end{array}$ & 3 & S1819.1 & 518188 & 03 & $\begin{array}{l}\text { S1820.1. } \\
\text { S1810.0 }\end{array}$ & 51819.9 & $\begin{array}{l}01 \\
02\end{array}$ \\
\hline 5 & 4 & 51821.5 & 51821.1 & $a_{4}$ & 51823 & 518227 & 03 \\
\hline 5 & 5 & 518228 & 518223 & os & 51828.8 & 51828.4 & 0.4 \\
\hline 5 & 6 & 51829.6 & S1829.1 & as & 51840.1 & 51839.6 & as \\
\hline 5 & 7 & 51844.1 & 51843.5 & 06 & 518598 & 518592 & 06 \\
\hline 5 & 8 & 51875.7 & 51874.9 & 08 & 519015 & 51960.8 & 0.7 \\
\hline 5 & 9 & 51967.4 & 519665 & 0.9 & 51987.4 & 51986.6 & 08 \\
\hline 5 & 10 & ?52199.2 & 52198.2 & 1 & 52123.3 & 521224 & 0.9 \\
\hline 5 & 11 & .52309 .4 & 523083 & 1.1 & 352160.8 & 52159.8 & 1 \\
\hline 5 & 12 & 3519120 & 51910.8 & 12 & 52032 & 52030.9 & 1.1 \\
\hline 5 & 13 & 251659.6 & 51658.3 & 13 & 51860.9 & 51859.8 & I.1 \\
\hline 5 & 14 & 351579.4 & 51578 & 14 & 51749 & 51747.8 & 12 \\
\hline 5 & 15 & 51626.6 & 51625.2 & 1.4 & 51720.7 & 51719.4 & 13 \\
\hline 5 & 16 & 51707.9 & 51706.4 & 15 & 51737.5 & 51736.1 & 1.4 \\
\hline 5 & 17 & 51759.8 & 51758.2 & 16 & 517625 & 51761 & 15 \\
\hline 5 & 18 & 51777.7 & 51776 & 1.7 & 517782 & 51776.7 & 15 \\
\hline 5 & 19 & 51794.4 & 51792.6 & 18 & 51790.4 & 51788.8 & 16 \\
\hline 4 & 19 & 51783.3 & 51781 & 23 & 51786.2 & 51784.1 & 21 \\
\hline 4 & 18 & 51754.6 & 517522 & 24 & 51765.1 & 517629 & 22 \\
\hline 4 & 17 & 51687.5 & 51684.9 & 26 & 517282 & 51725.9 & 23 \\
\hline 4 & 16 & 251556.9 & 51554.2 & 27 & 51689 & 51686.6 & 24 \\
\hline 4 & 15 & 251487.9 & 51485.1 & 28 & 51720.2 & 51717.7 & 25 \\
\hline 4 & 14 & 752092.1 & 520892 & 29 & 51914.5 & 51911.9 & 26 \\
\hline 4 & 13 & ?52459.4 & 524563 & 3.1 & 352131.0 & 52128.2 & 28 \\
\hline 4 & 12. & 253470.7 & 53467.5 & 32 & 252408.4 & 52405.5 & 29 \\
\hline 4 & 11 & 253618.0 & 53614.7 & 33 & 352469.8 & 52466.8 & 3 \\
\hline 4 & in & 252243.1 & 52239.6 & 35 & 52179.2 & 52176.1 & 3.1 \\
\hline 4 & 9 & 51914.1 & 51910.5 & 36 & 519633 & 51960 & 33 \\
\hline 4 & 8 & 518585 & 51854.8 & 3.7 & 518868 & 51883.4 & 3.4 \\
\hline 4 & 7 & 51826.2 & 51822.4 & 38 & 51848 & 51844.5 & 35 \\
\hline 4 & 6 & 51814.7 & 51810.8 & 3.9 & 51834.9 & 51831.4 & 35 \\
\hline 4 & 5 & 51814 & 51810 & 4 & 51827.8 & 518242 & 36 \\
\hline 4 & 4 & 51813.4 & 518093 & 4.1 & 518242 & 518205 & 3.7 \\
\hline 4 & 3 & 51813 & 51808.8 & 42 & 518227 & 51818.9 & 38 \\
\hline 4 & 2 & 51810.3 & 51806 & 43 & 51821.9 & 51818 & 3.9 \\
\hline 4 & 1 & 51814.9 & 51810.5 & 4.4 & 51821.8 & 51817.9 & 3.9 \\
\hline 4 & 0 & 51813.7 & 51809.2 & 45 & 51821.9 & 51817.9 & 4 \\
\hline 3 & 0 & 51828.1 & 51822.9 & 52 & 518227 & 51817.7 & 5 \\
\hline 3 & 1 & 51829.7 & 51824 & 5.7 & 51823.5 & 51817.9 & 56 \\
\hline 3 & 2 & 51829.5 & 51823.7 & 58 & -51823.5 & 518178 & 5.7 \\
\hline 3 & 3 & 51827.1 & 518213 & 58 & 518252 & 51819.4 & 58 \\
\hline 3 & 4 & 51824.2 & 51818.3 & 5.9 & 518282 & 518222 & 6 \\
\hline
\end{tabular}

$0.3 \times 12+4.000$ 
Appendix IIA: 1993 Magniclic Survcy Data (Coned)

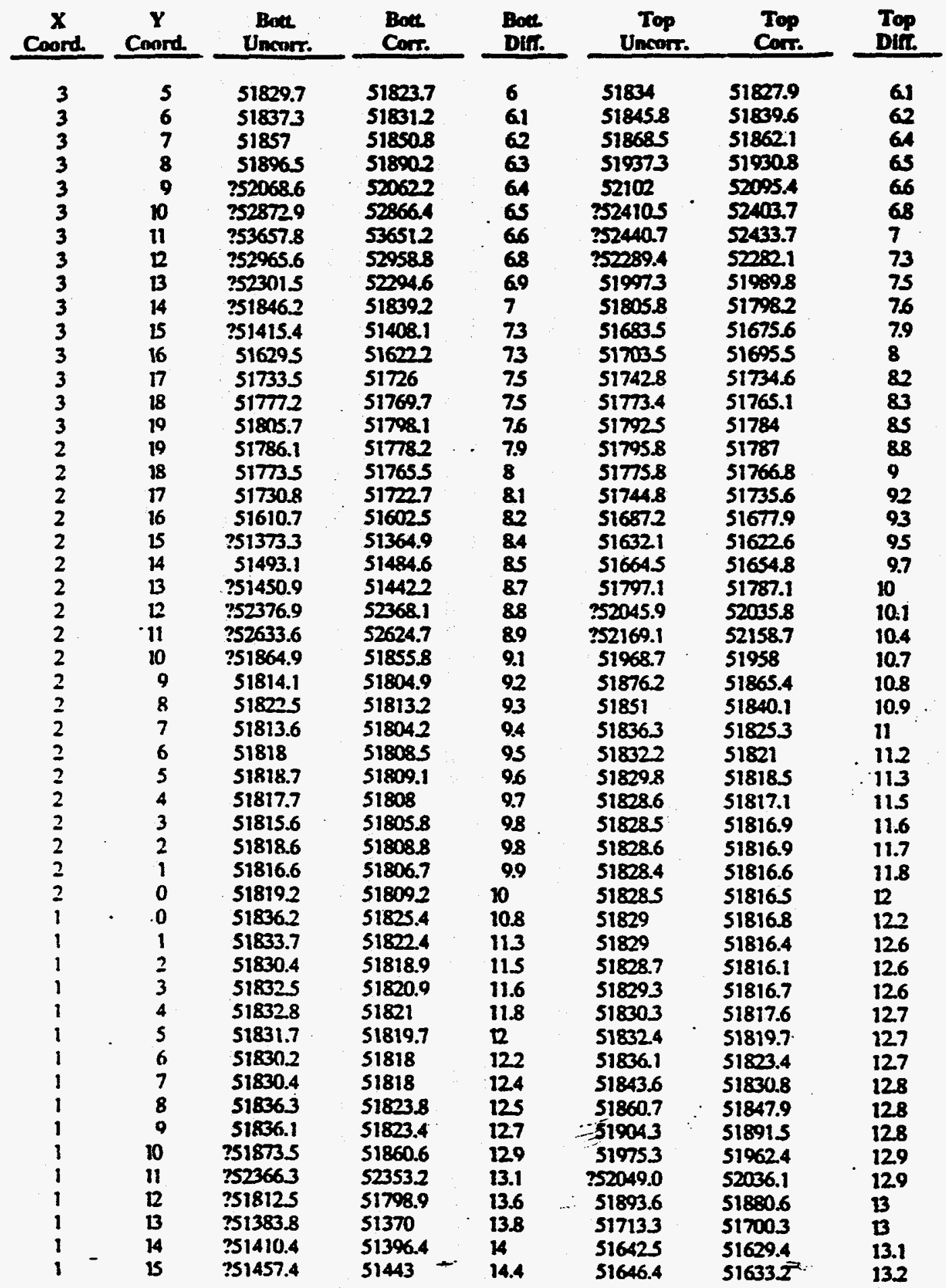


Appendix IIA: 1993 Magnctic Survcy Data (Contd)

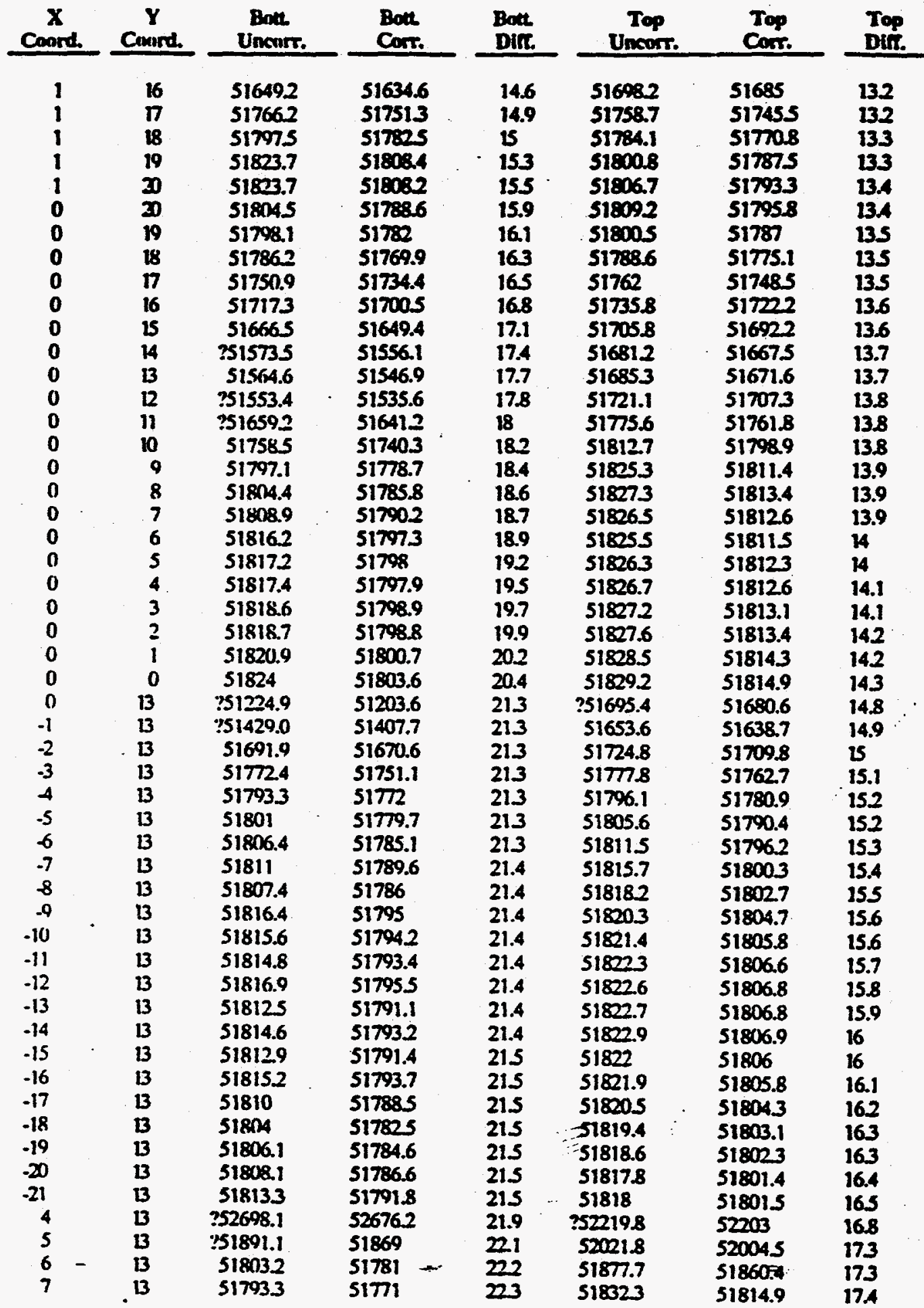

$0.0 \times 12+4$. 
Appendix IIA: 1993 Magnctic Survcy Data (Contd)

\begin{tabular}{|c|c|c|c|c|c|c|c|}
\hline $\begin{array}{c}\mathrm{X} \\
\text { Coord. }\end{array}$ & $\begin{array}{c}\mathbf{Y} \\
\text { Conrd. }\end{array}$ & $\begin{array}{l}\text { Bath } \\
\text { Uncort. }\end{array}$ & $\begin{array}{l}\text { Bot. } \\
\text { Corr. }\end{array}$ & $\begin{array}{l}\text { Bot } \\
\text { Dit. }\end{array}$ & $\begin{array}{l}\text { Top } \\
\text { Uncorr. }\end{array}$ & $\begin{array}{l}\text { Top } \\
\text { Cor. }\end{array}$ & $\begin{array}{l}\text { Top } \\
\text { Dtit. }\end{array}$ \\
\hline $\begin{array}{l}8 \\
9 \\
20 \\
11 \\
12 \\
13 \\
14 \\
15 \\
16 \\
17 \\
18 \\
19 \\
20 \\
21 \\
22 \\
23\end{array}$ & $\begin{array}{l}\mathbf{1 3} \\
\mathbf{1 3} \\
\mathbf{1 3} \\
\mathbf{1 3} \\
\mathbf{1 3} \\
\mathbf{1 3} \\
\mathbf{1 3} \\
\mathbf{1 3} \\
\mathbf{1 3} \\
\mathbf{1 3} \\
\mathbf{1 3} \\
\mathbf{1 3} \\
\mathbf{1 3} \\
\mathbf{1 3} \\
\mathbf{1 3} \\
\mathbf{1 3}\end{array}$ & $\begin{array}{r}51777.1 \\
51771.3 \\
251780.9 \\
252023.6 \\
52059.5 \\
51891.8 \\
51837.6 \\
51815.5 \\
51809.3 \\
51794.1 \\
51780.9 \\
51740.8 \\
51669.4 \\
251695.0 \\
? 52011.7 \\
? 51812.2\end{array}$ & $\begin{array}{l}51754.7 \\
51748.8 \\
51758.3 \\
52000.9 \\
52036.7 \\
51868.9 \\
51814.6 \\
517924 \\
51786.1 \\
51770.8 \\
51757.5 \\
517173 \\
51645.8 \\
51671.3 \\
51987.9 \\
51788.3\end{array}$ & $\begin{array}{l}22.4 \\
22.5 \\
226 \\
227 \\
228 \\
22.9 \\
23 \\
23.1 \\
232 \\
23.3 \\
23.4 \\
23.5 \\
23.6 \\
23.7 \\
23.8 \\
23.9\end{array}$ & $\begin{array}{l}51814.9 \\
51818.3 \\
51853.1 \\
51937.3 \\
51948 \\
518904 \\
51850.8 \\
51808.1 \\
51815 \\
518029 \\
517861 \\
51761.8 \\
51744.5 \\
51754.9 \\
51812.8 \\
51814.5\end{array}$ & $\begin{array}{l}51797.5 \\
51800.9 \\
51835.6 \\
51919.7 \\
51930.4 \\
518727 \\
51833.1 \\
51810.3 \\
51797.2 \\
51785 \\
51768.2 \\
51743.8 \\
5176.5 \\
51736.8 \\
51794.7 \\
517963\end{array}$ & $\begin{array}{l}17.4 \\
17.4 \\
17.5 \\
17.6 \\
17.6 \\
17.7 \\
17.7 \\
17.8 \\
17.8 \\
17.9 \\
17.9 \\
18 \\
18 \\
18.1 \\
18.1 \\
18.2\end{array}$ \\
\hline
\end{tabular}




\section{Section I Diurnal Variation}

\begin{tabular}{|c|c|c|c|c|c|c|c|}
\hline \multicolumn{4}{|c|}{ Bottom } & \multicolumn{4}{|c|}{ Top } \\
\hline Day & Trme & Station & $\begin{array}{l}\text { Fuedd } \\
\text { (nT) }\end{array}$ & Day & Ine & Stuntone & $\begin{array}{l}\text { Fed } \\
\text { (nI) }\end{array}$ \\
\hline $\begin{array}{l}35 \\
35 \\
35 \\
35 \\
35 \\
35\end{array}$ & $\begin{array}{l}13: 13: 59 \\
13: 26: 48 \\
13: 41: 29 \\
13: 56: 08 \\
14: 04: 20 \\
14: 11: 02\end{array}$ & $\begin{array}{c}0 \\
80 \\
162 \\
248 \\
294 \\
336\end{array}$ & $\begin{array}{l}518221 \\
51826.9 \\
518324 \\
51843.3 \\
51843.7 \\
518465\end{array}$ & $\begin{array}{l}35 \\
35 \\
35 \\
35 \\
35 \\
35\end{array}$ & $\begin{array}{l}13: 14: 00 \\
13: 26: 51 \\
13: 41: 33 \\
13: 56: 11 \\
14: 04: 23 \\
14: 11: 05\end{array}$ & $\begin{array}{c}1 \\
81 \\
163 \\
249 \\
295 \\
337\end{array}$ & $\begin{array}{l}51818.1 \\
518224 \\
51830.5 \\
518325 \\
51835.1 \\
51836.5\end{array}$ \\
\hline
\end{tabular}

\section{Section I Divrnal Variation 9}

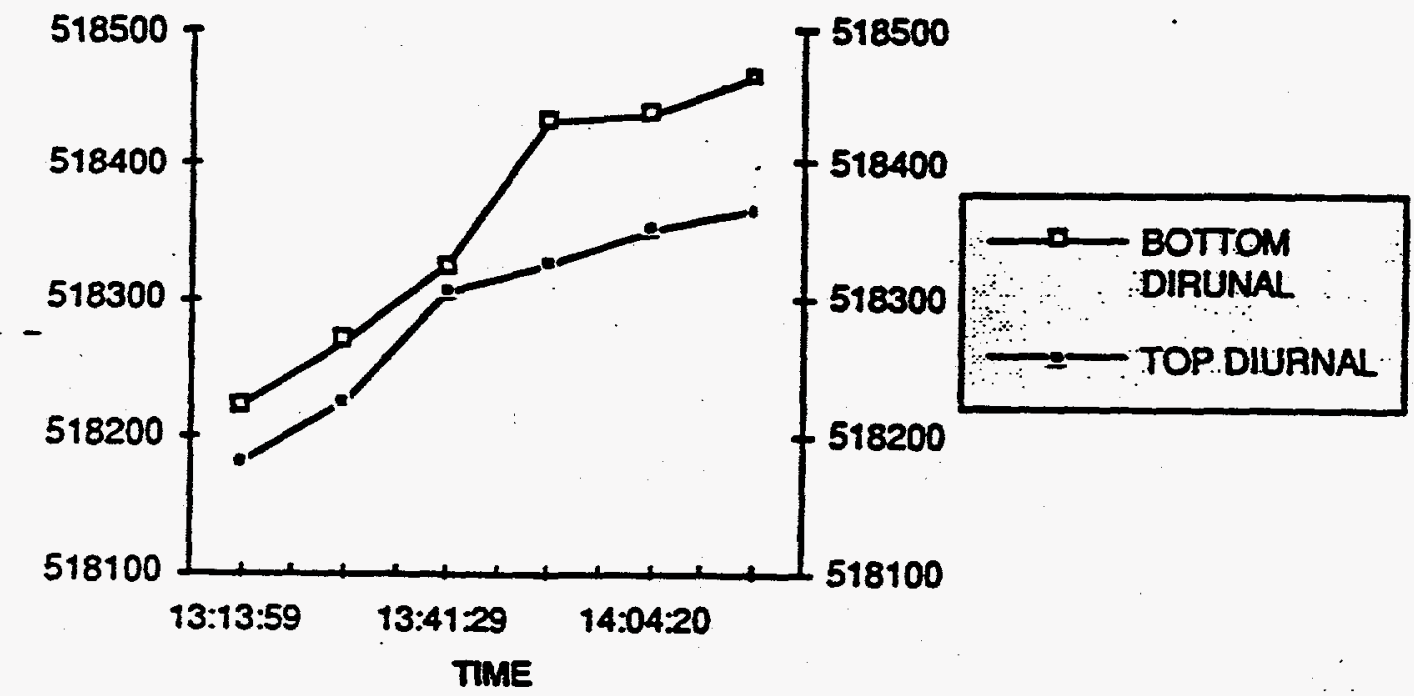


Appendix ItB: 1993 Magnetic Survcy Data

Scetion II Uncorrected (Uncorr) and Diumally Corrected (Corr) Magnetic Data (collected May 17, 1993)

Values preceded by "?" accurate to $1 \mathrm{nT}$.

\begin{tabular}{|c|c|c|c|c|c|c|c|}
\hline $\begin{array}{c}X \\
\text { Coord }\end{array}$ & $\begin{array}{c}\mathbf{Y} \\
\text { Coord }\end{array}$ & $\begin{array}{l}\text { Bott } \\
\text { Uncorr. }\end{array}$ & $\begin{array}{l}\text { Dow } \\
\text { Corr. }\end{array}$ & $\begin{array}{l}\text { Bote } \\
\text { Defr. }\end{array}$ & $\begin{array}{l}\text { Top } \\
\text { Uncars. }\end{array}$ & $\begin{array}{l}\text { Top } \\
\text { Corr. }\end{array}$ & $\begin{array}{l}\text { Top } \\
\text { Deff. }\end{array}$ \\
\hline 4 & 7 & 251945.3 & 51945.3 & 0 & 519492 & 519492 & 0 \\
\hline 5 & 7 & 51927.4 & 51927.6 & .02 & 51938 & 51937.9 & a.1 \\
\hline 6 & 7 & 51905.6 & 51906 & 0.4 & 51914.4 & 519143 & 01 \\
\hline 7 & 7 & 51881.8 & 518824 & .06 & 51889.1 & 51888.9 & 02 \\
\hline 8 & 7 & 51864.4 & 518652 & -08 & 51868.9 & 51868.6 & 03 \\
\hline 9 & 7 & 51850.1 & S1851.1 & -1 & 51855s & 51855.2 & $\mathbf{0 3}$ \\
\hline 10 & 7 & 51842.4 & 51843.6 & -12 & 51846.6 & 51846.2 & 04 \\
\hline 11 & 7 & 51844.6 & 51846 & -14 & 51841.6 & 51841.1 & os \\
\hline 12 & 7 & $? 51840.6$ & 518422 & -16 & 51840 & 51839.5 & 0.5 \\
\hline 13 & 7 & 51837.7 & 51839.5 & -18 & s1841S & 51840.9 & 06 \\
\hline 14 & 7 & 51837.2 & 518392 & -2 & 51843.9 & 518432 & 07 \\
\hline 15 & 7 & 51840.2 & 518424 & .22 & 51845.3 & 51844.6 & 07 \\
\hline 16 & $?$ & 51840.1 & 51842.4 & .23 & 51845.6 & 51844.8 & 08 \\
\hline 17 & 7 & 51846.4 & 51848.9 & -25 & 51850.2 & 51849.4 & OB \\
\hline 18 & 7 & 518595 & 518622 & -27 & s1866.1 & 518652 & 09 \\
\hline 19 & 7 & 519032 & 51906. & -28 & 518926 & 51891.6 & 1 \\
\hline 20 & 7 & $? 51945.2$ & 519482 & -3 & 51910.8 & 51909.8 & 1 \\
\hline 21 & 7 & 51923.4 & 51926.6 & .32 & 51897.4 & 518963 & 1.1 \\
\hline 21 & 8 & 52026 & 52030.1 & -4.1 & 51951.5 & 51950.1 & $1 A$ \\
\hline 20 & 8 & ?521025 & 52106.8 & 43 & 51977.3 & 51975.9 & $1 A$ \\
\hline 19 & 8 & 51974.6 & 51979.1 & 45 & 51935.3 & 51933.8 & 15 \\
\hline 18 & $\mathrm{~g}$ & 51859.7 & 51864.4 & -4.7 & 51887.4 & 51885.8 & 16 \\
\hline 17 & 8 & 518227 & 51827.6 & -4.9 & 51862.4 & 51860.8 & 16. \\
\hline 16 & 8 & 51828.8 & 51833.9 & -5.1 & 51857.6 & 51855.9 & 1.7 \\
\hline 15 & 8 & 51832.4 & 51837.6 & -52 & 51861 & 51859.3 & 1.7 \\
\hline 14 & 8 & 51829 & 51834.4 & -5.4 & 51857.9 & 51856.1 & 18 \\
\hline 13 & 8 & 51819.2 & 51824.8 & -5.6 & 51849.6 & 51847.7 & 1.9 \\
\hline 12 & 8 & 51813.2 & 51819 & -58 & 51841.8 & 51839.9 & 1.9 \\
\hline 11 & 8 & 51814.7 & 51820.6 & -5.9 & 51840.5 & 51838.5 & 2 \\
\hline 10 & 8 & 51822.4 & 518285 & -6.1 & 51845.8 & 51843.8 & 2 \\
\hline 9 & 8 & 51833 & 518392 & -62 & 51857.3 & 51855.2 & 21 \\
\hline 8 & 8 & 51849.2 & 51855.6 & -6.4 & 518772 & 51875.1 & 21 \\
\hline 7 & 8 & 51880.6 & 518872 & -6.6 & 51910.6 & 51908.4 & 22 \\
\hline 6 & 8 & 51920.2 & 51926.9 & -6.7 & 51959.1 & 51956.9 & 22 \\
\hline 5 & 8 & 519725 & 51979.4 & -6.9 & 52018 & 52015.7 & 23 \\
\hline 4 & 8 & 3520125 & 52019.6 & -7.1 & 52057 & 52054.6 & 24 \\
\hline 4 & 9 & $: 52037.2$ & 52245.4 & 82 & .52242 .8 & 52240.7 & 21 \\
\hline 5 & 9 & ?52133.3 & 521425 & -92 & 52143.5 & 52141.3 & 22 \\
\hline 6 & 4 & 52004.4 & 52013.9 & -95 & 52032 & 52029.9 & 21 \\
\hline 7 & 9 & 51920 & 51929.8 & -98 & 51938.9 & 51936.9 & 2 \\
\hline 8 & 9 & 51877.2 & 518873 & -10.1 & $\$ 18863$ & 51884.3 & 2 \\
\hline 9 & 4 & 518463 & 51856.8 & -105 & 51857.6 & 51855.7 & 1.9 \\
\hline
\end{tabular}


Appendix IIB: 1993 Magnetic Survey Data (Contd)

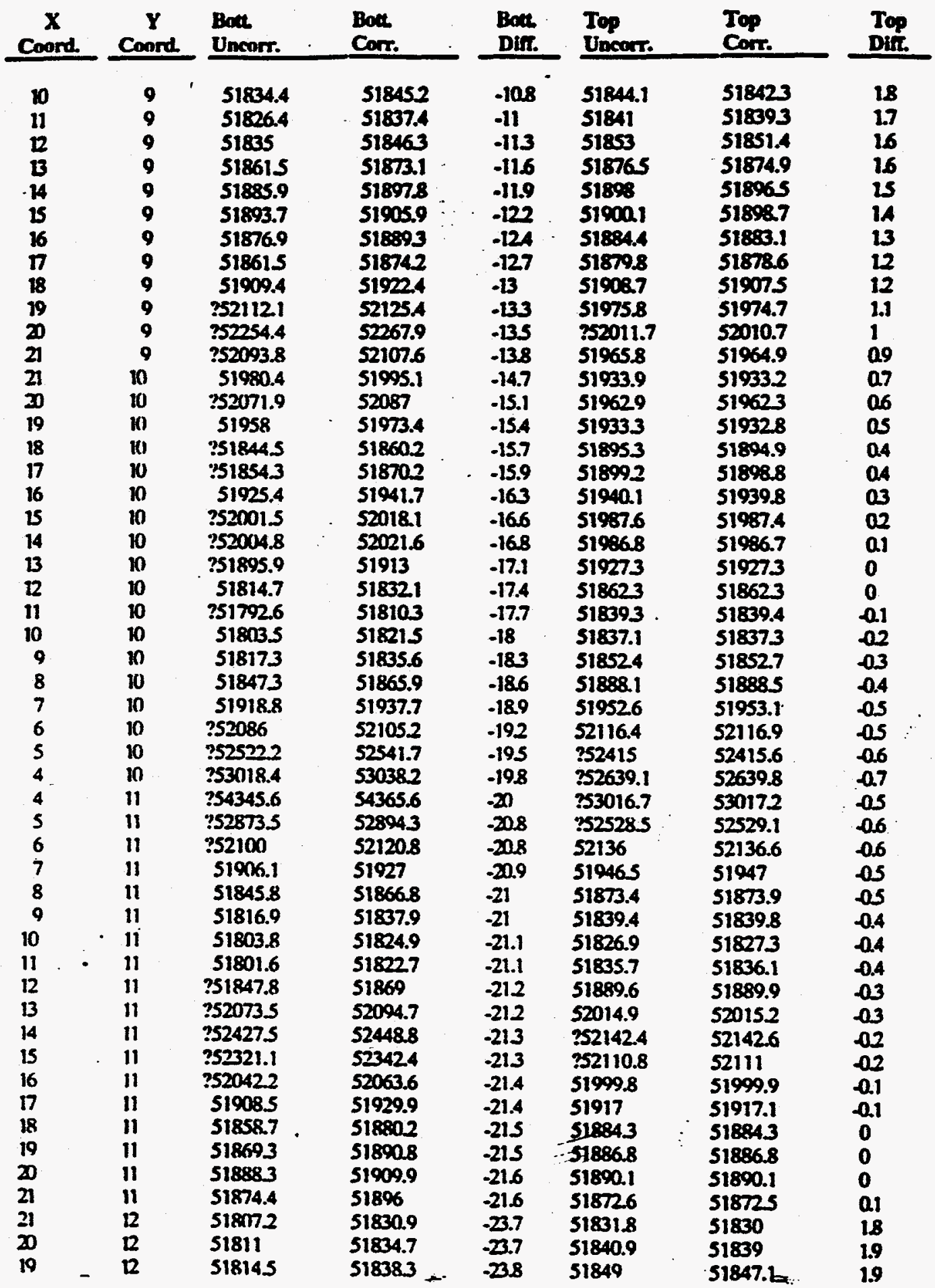

$0.3 \times 12+4=0$ 
Appendix IIB: 1993 Magnetic Survey Data (Contd)

\begin{tabular}{|c|c|c|c|c|c|c|c|}
\hline$\underset{\text { coond. }}{X}$ & $\begin{array}{c}Y \\
\text { Coond. }\end{array}$ & $\begin{array}{l}\text { Bate } \\
\text { Unmin. }\end{array}$ & $\begin{array}{l}\text { Bart } \\
\text { Corr. }\end{array}$ & $\begin{array}{l}\text { Bent } \\
\text { Dif. }\end{array}$ & $\begin{array}{l}\text { Top } \\
\text { Unmr. }\end{array}$ & $\begin{array}{l}\text { Top } \\
\text { Con. }\end{array}$ & $\begin{array}{l}\text { Top } \\
\text { Dir. }\end{array}$ \\
\hline 18 & 12 & 51832 & 51855.8 & .238 & 51865.6 & 51863.6 & 2 \\
\hline$\pi$ & 12 & 518915 & 51915.4 & -23.9 & 51913.1 & S1911.] & 2 \\
\hline 16 & $\overline{12}$ & 52058.9 & 520829 & -24 & 520152 & 52013.1 & 21 \\
\hline 25 & $\overline{12}$ & ?52513.7 & 52537.7 & -24 & 32171 & 521689 & 21 \\
\hline 4 & 12 & 257575 & 57599.1 & -241 & 322118 & 52209.6 & 22 \\
\hline $\mathbb{1} \mathbf{B}$ & 12 & 252154.8 & 52178.9 & -24.1 & 3520302 & 52028 & 22 \\
\hline 2 & 12 & 351808.6 & 518328 & -242 & 51881.2 & 51878.9 & 23 \\
\hline$\pi$ & D & 51761.4 & 51785.6 & .212 & 51821.9 & 51819.6 & 23 \\
\hline$\ddot{10}$ & $\bar{D}$ & 51767.3 & 51791.6 & -243 & 518127 & 51810.4 & 23 \\
\hline 9 & 12 & 51781.4 & 51805.7 & -243 & 518213 & 51818.9 & 24 \\
\hline 8 & $\bar{D}$ & 51805.4 & 51829.8 & $.24 A$ & 51847 & 51844.6 & 24 \\
\hline 7 & 12 & 51829.9 & 518543 & -24.4 & 518995 & 51897 & 25 \\
\hline 6 & 12 & 351919.4 & 51943.9 & -245 & 52031.6 & 52029.1 & 25 \\
\hline 5 & 12 & 252330.9 & 52355.4 & .245 & 3523113 & 52308.7 & 26 \\
\hline 4 & 12 & :53232.1 & 53256.7 & -246 & 352605 & 526024 & 26 \\
\hline 4 & $\bar{B}$ & ?52485.2 & 525093 & .24 .1 & 352266.9 & 52264 & 29 \\
\hline 5 & 13 & $\div 51863.2$ & 518872 & -24 & 520722 & 52069 & 32 \\
\hline 6 & 13 & ?517*0.6 & 51804.4 & -238 & 51890 & 51886.7 & 33 \\
\hline 7 & 13 & 51786.5 & 518102 & .23 .7 & 51838.2 & 518348 & 3.4 \\
\hline 8 & 13 & 51789.8 & 51813.4 & $-\overline{23.6}$ & 518163 & 518129 & 3.4 \\
\hline 9 & 13 & 51781.9 & 51805.4 & -235 & 51803.2 & 51799.7 & 35 \\
\hline 10 & 13 & 51773.7 & 51797 & .233 & 517995 & 51795.9 & 36 \\
\hline u1 & 13 & 251762.4 & 51785.6 & -232 & 518072 & 51803.6 & 36 \\
\hline 12 & 13 & $? 51782.8$ & 51805.8 & -23 & 51854.7 & 51851 & 3.7 \\
\hline$\overline{13}$ & i3 & ?52005.8 & 52028.7 & .20 & 51971.7 & 51967.9 & 38 \\
\hline 14 & 13 & ?S2323.6 & 52346.3 & .27 & ?52086 & 52082.1 & 3.9 \\
\hline 15 & 13 & :52213.8 & 52236.4 & .226 & ?52066.6 & 520627 & 3.9 \\
\hline 16 & 13 & 51979.3 & 52001.7 & .224 & 51959.2 & 59955.2 & 4 \\
\hline 17 & 13 & 51879.4 & 51901.7 & -223 & 51883.1 & 51879 & 4.1 \\
\hline 18 & 13 & 51835.5 & 51857.6 & .221 & 51847.2 & 51843 & 42 \\
\hline 19 & 13 & 51821.4 & 51843.4 & -22 & 51833.7 & 518295 & 42 \\
\hline 20 & 13 & 51818.6 & 51840.5 & -21.9 & 51823.7 & 51819.4 & 43 \\
\hline 21 & 13 & 51816.5 & 518382 & -21.7 & 51814.9 & 51810.5 & 44 \\
\hline 21 & 14 & 51786.4 & 518073 & -20.9 & 51806.8 & 51802 & 48 \\
\hline 20 & 14 & 51794 & 51814.8 & -208 & 51815.8 & 51810.9 & 4.9 \\
\hline 19 & 14 & 51800.3 & 51820.9 & -2066 & 51824.8 & 518198 & 5 \\
\hline 18 & 14 & 51809.1 & 51829.6 & -205 & 51837.2 & 518322. & 5 \\
\hline 17 & 14 & 51829.3 & 51849.7 & -20.4 & 51858.1 & 51853 & 5.1 \\
\hline 16 & 14 & 51866.2 & 51886.4 & .202 & 51895.6 & 51890.4 & 52 \\
\hline is & 14 & $? 51911.1$ & 51931.2 & -20.1 & 51934 & 51928.8 & 52 \\
\hline 14 & 14 & $? 51894.3$ & 519143 & -20 & 51924.8 & S1919S & 53 \\
\hline 13 & 14 & ?51781.4 & 518012 & -198 & 51859.6 & 518542 & $5 A$ \\
\hline 12 & 14 & ?51727.1 & 51746.8 & -19.7 & 51807.8 & 51802.4 & 5.4 \\
\hline 11 & 14 & 51736.9 & 517565 & -19.6 & 51791.4 & 51785.9 & 55 \\
\hline 10 & 14 & 517452 & 51764.6 & -19.4 & 51788.9 & 51783.3 & 56 \\
\hline 9 & 14 & 51755.3 & 51774.6 & -193 & 51789.5 & 51783.9 & 56 \\
\hline 8 & 14 & 51748.6 & 51767.7 & -19.1 & 51789.6 & 51783.9 & 5.7 \\
\hline 7 & 14 & 51722 & 51741 & -19 & 517902 & 51784.4 & 58 \\
\hline
\end{tabular}


Appendix IIB: 1993 Magnetic Survey Data (Contd)

\begin{tabular}{|c|c|c|c|c|c|c|c|}
\hline $\begin{array}{c}x \\
\text { Conord. }\end{array}$ & $\begin{array}{c}Y \\
\text { Coond }\end{array}$ & $\begin{array}{l}\text { Bont: } \\
\text { Uncorr. }\end{array}$ & $\begin{array}{l}\text { Bare } \\
\text { Corr. }\end{array}$ & $\begin{array}{l}\text { Bout } \\
\text { Dif. }\end{array}$ & $\begin{array}{l}\text { Top } \\
\text { Unomr. }\end{array}$ & $\begin{array}{l}\text { Top } \\
\text { Corr. }\end{array}$ & $\begin{array}{l}\text { Top } \\
\text { Dif. }\end{array}$ \\
\hline 6 & 14 & 251656.8 & 51675.7 & -18.9 & 518028 & 51797 & 58 \\
\hline 5 & 14 & $\begin{array}{l}251679 \\
252228.4\end{array}$ & $\begin{array}{l}51697.7 \\
52247\end{array}$ & $\begin{array}{l}-187 \\
-186\end{array}$ & $\begin{array}{l}51893.5 \\
2500125\end{array}$ & $\begin{array}{l}51887.6 \\
520065\end{array}$ & 59 \\
\hline $\begin{array}{l}4 \\
4\end{array}$ & $\begin{array}{l}14 \\
15\end{array}$ & 351668.9 & 51687.4 & $\begin{array}{l}-1000 \\
-185\end{array}$ & S17742 & 51768.1 & $\begin{array}{r}6 \\
61\end{array}$ \\
\hline 5 & 15 & 2515733 & S1591A & -181 & 51747.9 & 51741.6 & 63 \\
\hline 6 & 25 & 3516672 & 516853 & -181 & s17uss & 517372 & 63 \\
\hline 7 & 15 & 351724.9 & 51743 & -181 & 517606 & 517543 & 63 \\
\hline 8 & 15 & 517623 & 517703 & -18 & 51776.6 & 51770.3 & 63 \\
\hline 9 & 15 & 51778 & 51796 & -18 & 51785.1 & 517788 & 63 \\
\hline 10 & is & 351769.5 & 51787.5 & .18 & 51785.9 & 51779.6 & 63 \\
\hline 11 & 15 & 51769.9 & 51787.9 & -18 & 51788 & 51781.7 & 63 \\
\hline D & 25 & 51762.1 & 51780.1 & .18 & 51795.7 & 517893 & 64 \\
\hline 13 & 15 & 51774.6 & 51792.6 & -18 & 51811.6 & 518052 & 64 \\
\hline 14 & 15 & 351799.6 & 51817.5 & 17.9 & 51833 & 51826.6 & 6.4 \\
\hline 15 & is & 51816.1 & 51834 & - 17.9 & 51838.2 & 51831.8 & 64 \\
\hline 16 & 15 & 518212 & 51839.1 & . 17.9 & 51835.7 & 518293 & 64 \\
\hline$n$ & 15 & 51819.8 & 51837.7 & - 17.9 & 51829.1 & 51822.7 & 64 \\
\hline 18 & is & 51818.7 & 51836.6 & -17.9 & 518224 & 51816 & 64 \\
\hline 19 & 15 & 518122 & 51830 & -178 & 51816.3 & 51809.9 & 64 \\
\hline 20 & 15 & 51813.1 & 51830.9 & -178 & 51810 & 51803.6 & 64 \\
\hline 21 & is & 518024 & 518202 & .178 & 51801.4 & 51794.9 & 65 \\
\hline 21 & 16 & 51791.4 & 51809.1 & -17.7 & 518021 & 51795.6 & 65 \\
\hline 20 & 16 & 51796.9 & 51814.6 & -17.7 & 51809.1 & 518025 & 66 \\
\hline 19 & 16 & 51801 & 51818.6 & -17.6 & 51814.1 & 518075 & 66 \\
\hline 18 & 16 & 51802 & 51819.6 & .17 .6 & 51817.6 & 51811 & 66 \\
\hline 17 & 16 & 51795.7 & 51813.3 & -17.6 & 51819.2 & 518126 & 66 \\
\hline 16 & 16 & 51794.1 & 51811.7 & .17 .6 & 51816.9 & 51810.3 & 66 \\
\hline 15 & 16 & 51786.1 & 51803.7 & -17.6 & 51816.1 & 51809.5 & 66 \\
\hline 14 & 16 & 51776.6 & 51794.2 & -17.6 & 51809.2 & 51802.6 & 66 \\
\hline 13 & 16 & 51767.1 & 51784.6 & -175 & 518021 & 51795.5 & 66 \\
\hline 12 & 16 & 51761.9 & 51779.4 & -175 & 51794.7 & 51788 & 6.7 \\
\hline$n$ & 16 & 51768.7 & 51786.2 & -175 & 51791.7 & 51785 & 67 \\
\hline 10 & 16 & 51766 & 51783.5 & -175 & 51788.4 & 51781.7 & 6.7 \\
\hline 9 & 16 & 51766.8 & 517843 & -175 & 51784.2 & $517 m .5$ & 67 \\
\hline 8 & 16 & 51751.5 & 51768.9 & -17.4 & 51773.4 & 51766.7 & 67 \\
\hline 7 & 16 & 51718.1 & 517355 & -17.4 & 51755.8 & 51749.1 & 6.7 \\
\hline 6 & 16 & 51668.9 & 51686.3 & .17 .4 & 517283 & 51721.6 & 67 \\
\hline 5 & 16 & ?51579s & 51596.9 & -17.4 & 51696.4 & 51689.6 & 68 \\
\hline 4 & 16 & 951461.6 & 51479 & -17.4 & 351660.2 & 51653.4 & 68 \\
\hline 4 & 17 & $? 51594.5$ & 51611.7 & .172 & $\$ 1680.6$ & 51673.8 & 68 \\
\hline 5 & 17 & 51676.5 & 51693.6 & -17.1 & 51715.1 & 517083 & 68 \\
\hline 6 & 17 & 51722.8 & 51739.9 & -17.1 & 517427 & 51735.9 & 68 \\
\hline 7 & 17 & 51748 & 51765.1 & -17.1 & 51763 & 51756.2 & 68 \\
\hline 8 & 17 & 51780.6 & 51797.7 & -17.1 & 51779.8 & 51773 & 68 \\
\hline 9 & 17 & 51792.6 & 51809.7 & -17.1 & 51789.1 & 51782.3 & 68 \\
\hline 20 & 17 & 517983 & 518153 & -17 & 51795.4 & 51788.6 & 68 \\
\hline 11 & 17 & 51798.5 & S1815s & -17 & 51797.8 & 51791 & 68 \\
\hline 12 & 17 & 51795.3 & 518123 & .17 & 51800.5 & 51793.7 & 68 \\
\hline
\end{tabular}

$0.1 \times 12+1+100$ 
Appendix IIB: 1993 Magnetic Survey Data (Contd)

\begin{tabular}{|c|c|c|c|c|c|c|c|}
\hline $\begin{array}{c}x \\
\text { Croond }\end{array}$ & $\begin{array}{c}Y \\
\text { Conde } \\
\end{array}$ & $\begin{array}{l}\text { Botat } \\
\text { Uncorr. }\end{array}$ & $\begin{array}{l}\text { Bout. } \\
\text { Corr. }\end{array}$ & $\begin{array}{l}\text { Batt } \\
\text { Dirt. }\end{array}$ & $\begin{array}{l}\text { Top } \\
\text { Uncorr. } \\
\end{array}$ & $\begin{array}{l}\text { Top } \\
\text { Corr. }\end{array}$ & $\begin{array}{l}\text { Top } \\
\text { Dufl }\end{array}$ \\
\hline 13 & 17 & $\operatorname{sism.3}$ & 518173 & -17 & s18045 & 51797.7 & 68 \\
\hline 14 & 17 & 51805.4 & 518223 & -16.9 & 51808.1 & 518013 & 68 \\
\hline 15 & 17 & 518042 & 51821.1 & -16.9 & 51810.6 & 51803.8 & 68 \\
\hline 16 & 17 & 51815 & 51831.9 & .169 & 518128 & 51806 & 68 \\
\hline 17 & 17 & 51816.1 & 51833 & -16.9 & 51815.8 & 51809 & 68 \\
\hline 18 & 17 & 51819.7 & 518366 & -169 & S1817.1 & 51810.3 & 68 \\
\hline 19 & 17 & 51820.6 & 51837.4 & -168 & S1815.7 & 51808.9 & 68 \\
\hline 20 & 17 & 51816.4 & 51833.2 & -168 & S1811.7 & 51804.9 & 68 \\
\hline 21 & 17 & 518153 & 518321 & -168 & 51805.9 & 51799.1 & 68 \\
\hline $2 \pi$ & 18 & 51803 & 51819.7 & -16.7 & 518072 & 51800s & 67 \\
\hline 20 & 18 & 51806.6 & 51823.2 & -166 & 518127 & 51806 & 67 \\
\hline 19 & 18 & 51807.7 & 518243 & -166 & 51816.7 & S1810 & 67 \\
\hline 18 & 18 & 51800.5 & 51817.1 & -366 & 51818.6 & 51811.9 & 67 \\
\hline 17 & 18 & 51802.9 & 51819.5 & -166 & 51817 & 518103 & 67 \\
\hline 16 & 18 & s17825 & 51799 & -165 & 518135 & 518068 & 67 \\
\hline 15 & 18 & 51791.5 & 51808 & -165 & 518121 & 51805.4 & 67 \\
\hline 14 & 18 & 51795.5 & 51812 & -165 & 51811.4 & 51804.7 & 67 \\
\hline 13 & 18 & 51791.8 & 518083 & -165 & 51809.4 & 518027 & 67 \\
\hline 12 & 18 & 517852 & 51801.6 & -16.4 & 518065 & 51799.8 & 67 \\
\hline 11 & 18 & 51788 & 51804.4 & -16.4 & 51804.5 & 51797.8 & 67 \\
\hline 10 & 18 & 51787.1 & 51803.5 & -164 & 518013 & 51794.6 & 67 \\
\hline 9 & 18 & 51785.7 & 518021 & -16.4 & 51796.4 & 51789.7 & 6.7 \\
\hline 8 & 18 & 51776.1 & 517925 & -164 & 51787.8 & 51781.1 & 67 \\
\hline 7 & 18 & 51756.3 & 517726 & -163 & 5i775.7 & 51769 & 67 \\
\hline 6 & 18 & 51743.4 & 51759.7 & -163 & 51762 & 517553 & 67 \\
\hline 5 & 18 & 51720 & 51736.3 & -163 & 51745.5 & 51738.8 & 67 \\
\hline 4 & 18 & 51695.6 & 51711.9 & -163 & 517222 & 51715.5 & 67 \\
\hline
\end{tabular}


Section II Diurnal Variation

\begin{tabular}{|c|c|c|c|c|c|c|c|}
\hline \multicolumn{4}{|c|}{ Battom } & \multicolumn{4}{|c|}{ Top } \\
\hline Dar & The & Station & $\begin{array}{l}\text { Feld } \\
\text { (nT) }\end{array}$ & Dar & The & Stantion & $\begin{array}{l}\text { Fudd } \\
\text { (II) }\end{array}$ \\
\hline 153 & $13: 26: 57$ & 0 & 519453 & 153 & $13: 27: 01$ & 1 & 519492 \\
\hline 153 & $13: 36: 19$ & 72 & 519375 & 153 & $13: 36: 22$ & $\overline{3}$ & 51951.8 \\
\hline 153 & $13: 45: 30$ & 146 & 519248 & 153 & $13: 45: 33$ & 147 & 519483 \\
\hline 153 & 14:02:25 & 2200 & 519205 & 153 & $14: 00 \cdot 28$ & 221 & 519520 \\
\hline 153 & $14: 12: 46$ & 294 & 51927.1 & 153 & $14: 12=50$ & 295 & 519554 \\
\hline 153 & $14: 22: 40$ & 368 & 519280 & 153 & $14: 22 \times 43$ & 369 & 51956.0 \\
\hline 153 & $14: 32: 30$ & 442 & 51929.1 & 153 & $14: 32: 33$ & 413 & 519559 \\
\hline
\end{tabular}

Section II Diurnal Variation

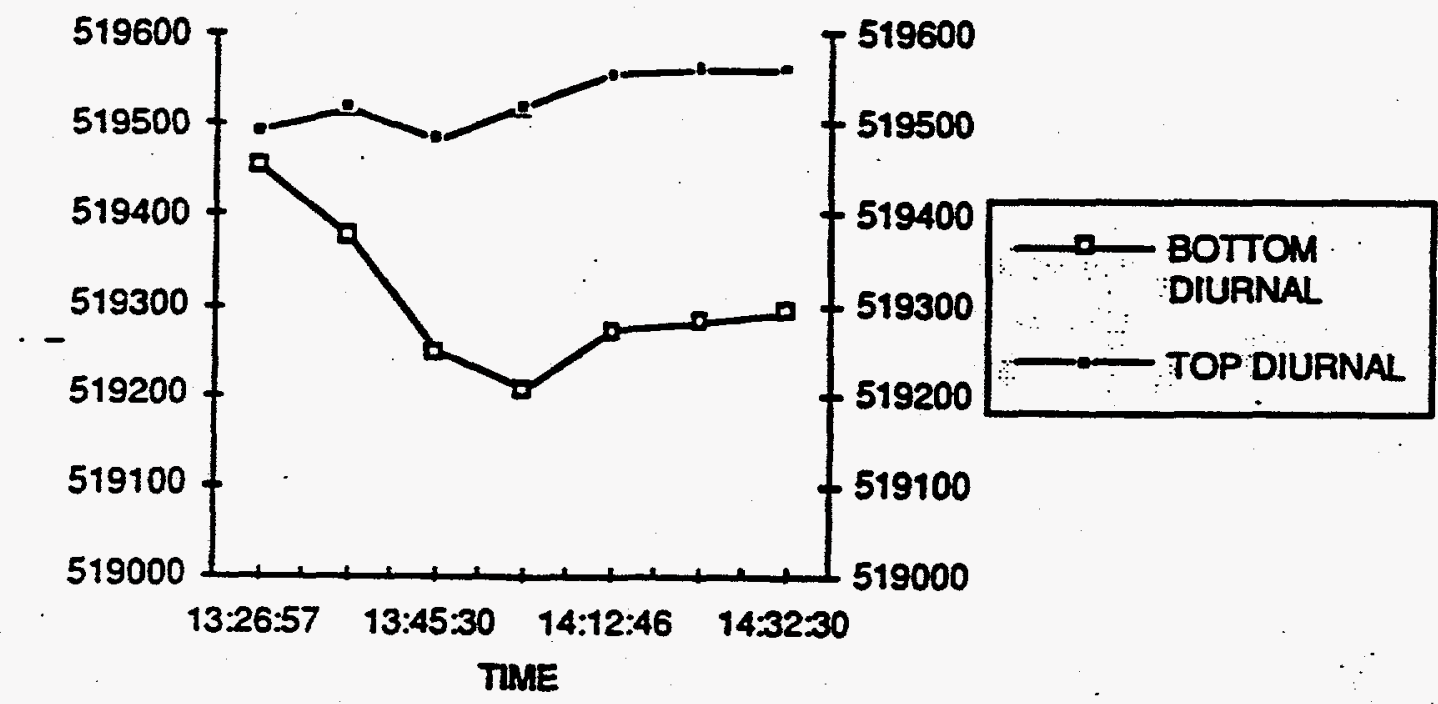

$93 \times 1244$ man 
Appendix IIC: Magnetic Survey Data

Section I and Section II Combined Duts Set (Diurnally Corrected)

\begin{tabular}{|c|c|c|c|c|c|c|c|c|}
\hline $\begin{array}{l}\mathbf{X} \\
\text { Cound. }\end{array}$ & $\begin{array}{l}\mathbf{Y} \\
\text { Coord }\end{array}$ & $\begin{array}{l}\text { Butean } \\
\text { Srasor } \\
\text { (nT) }\end{array}$ & $\begin{array}{l}\text { Tap } \\
\text { Senuer } \\
\text { (ni) }\end{array}$ & $\begin{array}{l}\text { Verticel } \\
\text { Gradient } \\
\text { (nT/m) }\end{array}$ & Line & Der & Inve & $\underline{s}$ \\
\hline 5 & 0 & 518221 & 51818.1 & 33 & $\boldsymbol{0}$ & 35 & 131359 & 0 \\
\hline 5 & 1 & 518195 & 51817.9 & 13 & $\boldsymbol{n}$ & 3 & 131412 & 2 \\
\hline 5 & 2 & 51819.8 & 518185 & 1.1 & $\boldsymbol{D}$ & 35 & 131425 & 4 \\
\hline 5 & 3 & 51818.8 & 51819.9 & 9 & 0 & 35 & 131440 & 6 \\
\hline 5 & 4 & 51821.1 & 518227 & -13 & $\boldsymbol{D}$ & 35 & 131458 & 8 \\
\hline 5 & 5 & 518223 & 51828.4 & -50 & 10 & 35 & 131512 & $\boldsymbol{n}$ \\
\hline 5 & 6 & 51829.1 & 51839.6 & -86 & 0 & 35 & 131527 & D \\
\hline 5 & 19 & 517926 & 51788.8 & 31 & $\mathbf{n}$ & 35 & 131850 & 38 \\
\hline 4 & 19 & 51781 & 51784.1 & -25 & 110 & 35 & 132014 & 0 \\
\hline 4 & 6 & 51810.8 & 51831.4 & -169 & 110 & 35 & 132429 & 66 \\
\hline 4 & 5 & 51810 & 518242 & -116 & 110 & 35 & 132444 & $\bar{B}$ \\
\hline 4 & 4 & $5180 \times 3$ & sine0s & -92 & 110 & 35 & 132458 & $\pi$ \\
\hline 4 & 3 & 51808.8 & 51818.9 & -83 & .110 & 35 & 132512 & $\boldsymbol{R}$ \\
\hline 4 & 2 & 51806 & 51818 & -9.8 & 110 & 35 & 132529 & 74 \\
\hline 4 & 1 & 51810.5 & 51817.9 & -6.1 & 110 & 35 & 132541 & $x$ \\
\hline 4 & 0 & 51809.2 & 51817.9 & -7.1 & 110 & 35 & 132557 & 78 \\
\hline 3 & 0 & 518229 & 51817.7 & 43 & 310 & 35 & 132833 & 8 \\
\hline 3 & 1 & 51824 & 51817.9 & 50 & 310 & 35 & 132908 & 84 \\
\hline 3 & 2 & 51823.7 & 51817.8 & 48 & 310 & 35 & 132921 & 86 \\
\hline 3 & 3 & 518213 & 51819.4 & 16 & 310 & 35 & 132935 & 8 \\
\hline 3 & 4 & 51818.3 & 51822.2 & -32 & 310 & 35 & 132950 & 90 \\
\hline 3 & 5 & 51823.7 & 51827.9 & -3.4 & 310 & 35 & 133006 & $\tilde{\boldsymbol{2}}$ \\
\hline 3 & 6 & 518312 & 51839.6 & -6.9 & 310 & 35 & 133019 & 9 \\
\hline 3 & 7 & 518S0.8 & 51862.1 & -93 & 310 & 35 & 133033 & 96 \\
\hline 3 & 8 & 51890.2 & 51930.8 & .333 & 310 & 35 & 133048 & 9 \\
\hline 3 & 9 & 520622 & 52095.4 & -272 & 310 & 35 & 133101 & 100 \\
\hline 3 & 10 & 52866.4 & 52403.7 & 3793 & 310 & 35 & 133116 & 102 \\
\hline 3 & 11 & 53651.2 & 52433.7 & 9980 & 310 & 35 & 133140 & 104 \\
\hline 3 & 12 & 52958.8 & 52382.1 & 554.7 & 310 & 35 & 133216 & 106 \\
\hline 3 & 13 & 52294.6 & 51989.8 & 2498 & 310 & 35 & 133231 & 108 \\
\hline 3 & 14 & 51839.2 & 51798.2 & 33.6 & 310 & 35 & 133247 & 110 \\
\hline 3 & 15 & 51408.1 & 51675.6 & -2193 & 310 & 35 & 133321 & 112 \\
\hline 3 & 16 & 516222 & 516955 & -60.1 & 310 & 35 & 133335 & 114 \\
\hline 3 & 17 & 51726 & 51734.6 & -7.0 & 310 & 35 & 133353 & 116 \\
\hline 3 & 18 & 51769.7 & 51765.1 & 38 & 310 & 35 & 133407 & 118 \\
\hline 3 & 19 & 51798.1 & 51784 & 11.6 & 310 & 35 & 133422 & 120 \\
\hline 2 & 19 & 51778.2 & 51787 & -72 & 410 & 35 & 133501 & 122 \\
\hline 2 & 18 & 51765.5 & 51766.8 & -1.1 & 410 & 35 & 133522 & 124 \\
\hline 2 & 17 & 51722.7 & 51735.6 & -106 & 410 & 35 & 133541 & 126 \\
\hline 2 & 16 & 516025 & 51677.9 & -61.8 & 410 & 35 & 133556 & 128 \\
\hline 2 & 15 & $513 \times 4.9$ & 51622.6 & -2112 & 410 & 35 & 133618 & 130 \\
\hline 2 & 14 & 51484.6 & 51654.8 & -1395 & 410 & 35 & 133635 & 132 \\
\hline 2 & 13 & 51442.2 & 51787.1 & -2827 & 410 & 35 & 133709 & 134 \\
\hline 2 & 12 & $523 \times R .1$ & 52035.8 & 272.4 & $410^{\circ}$ & 35 & 133723 & 136 \\
\hline
\end{tabular}


Appendix 1IC: Magnetic Survey Data (Contd)

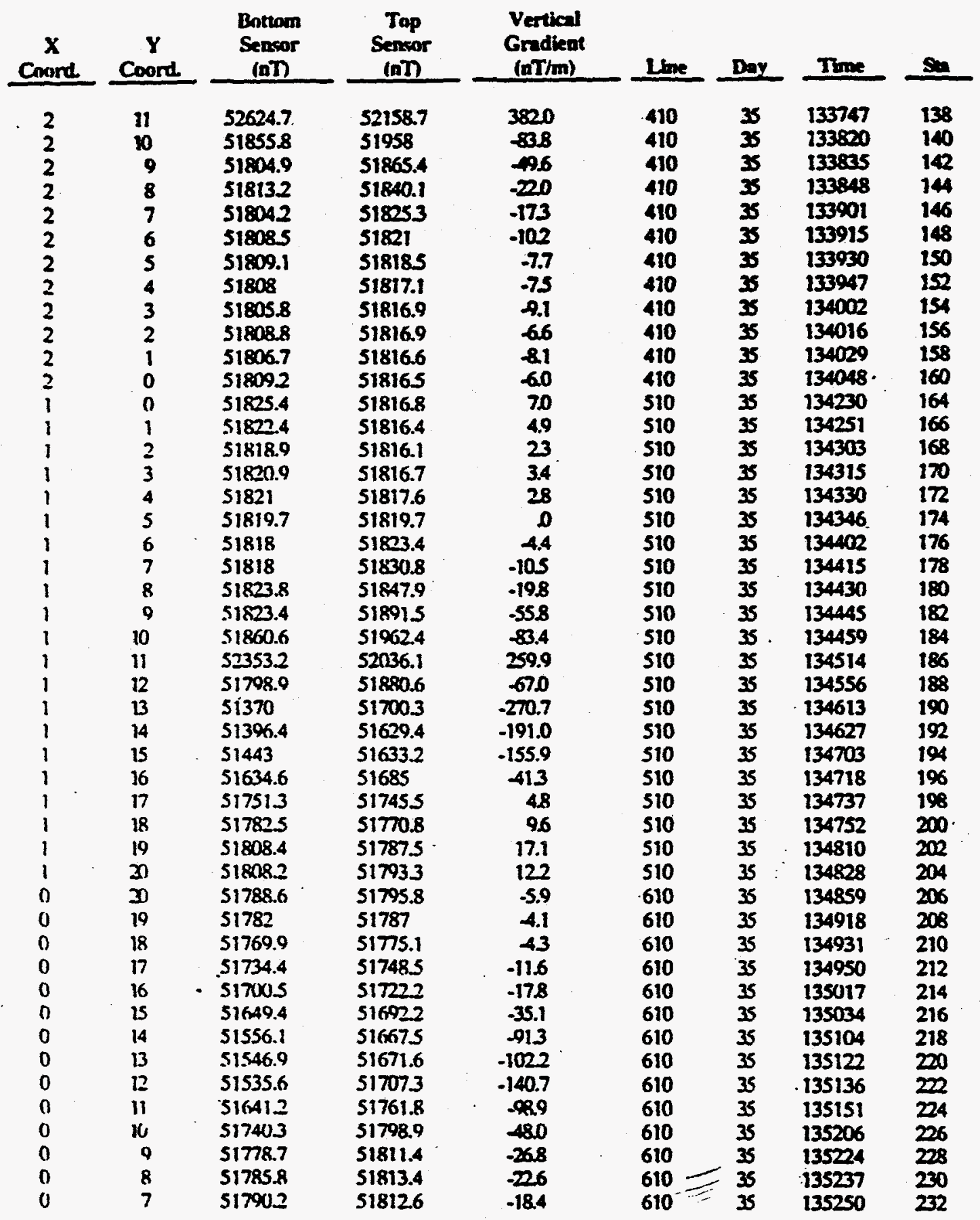

$0.2 \times 12+4$ 
Appendix IIC: Magnctic Survcy Data (Contd)

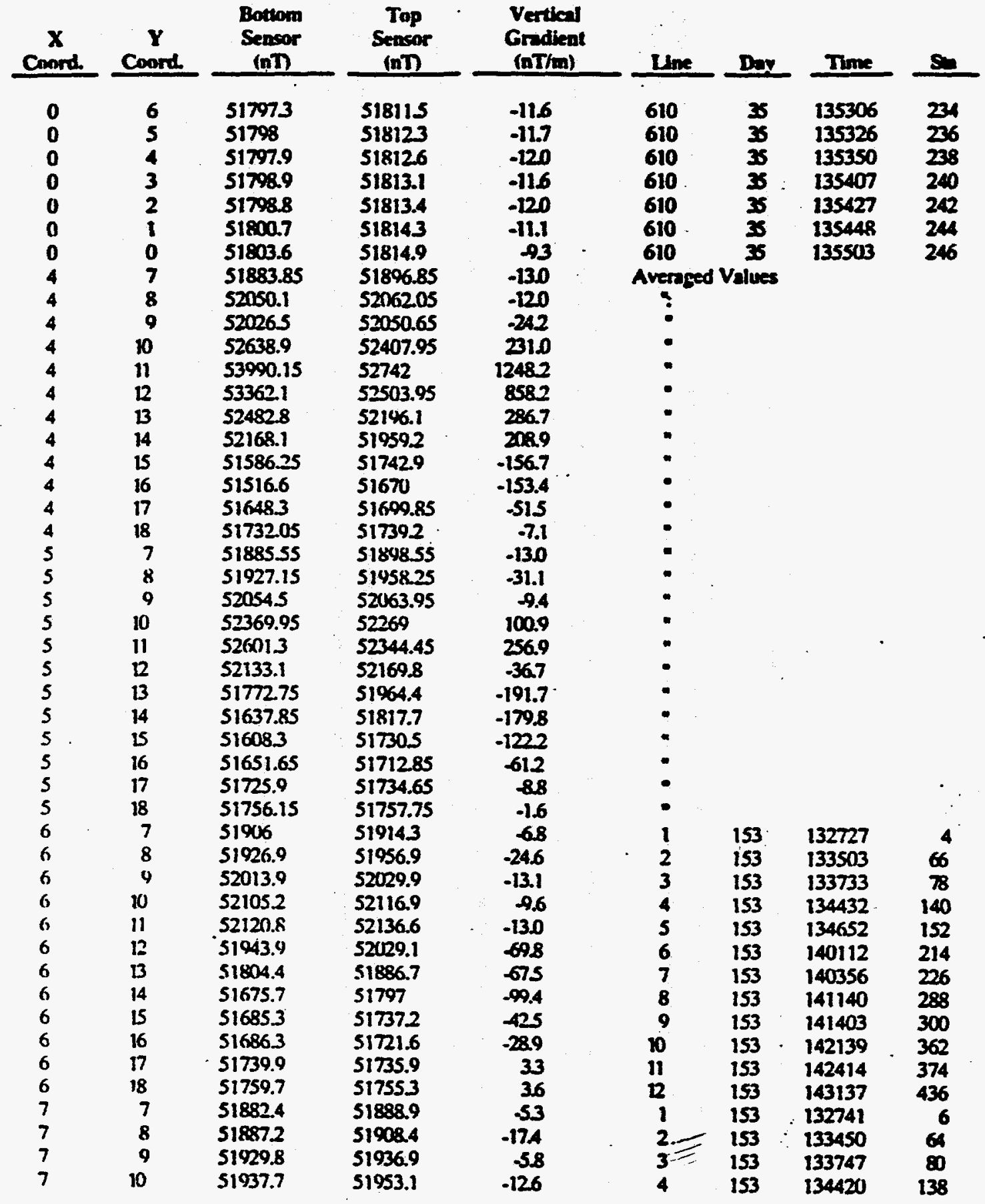


Appendix IIC: Magnctic Survcy Data (Contd)

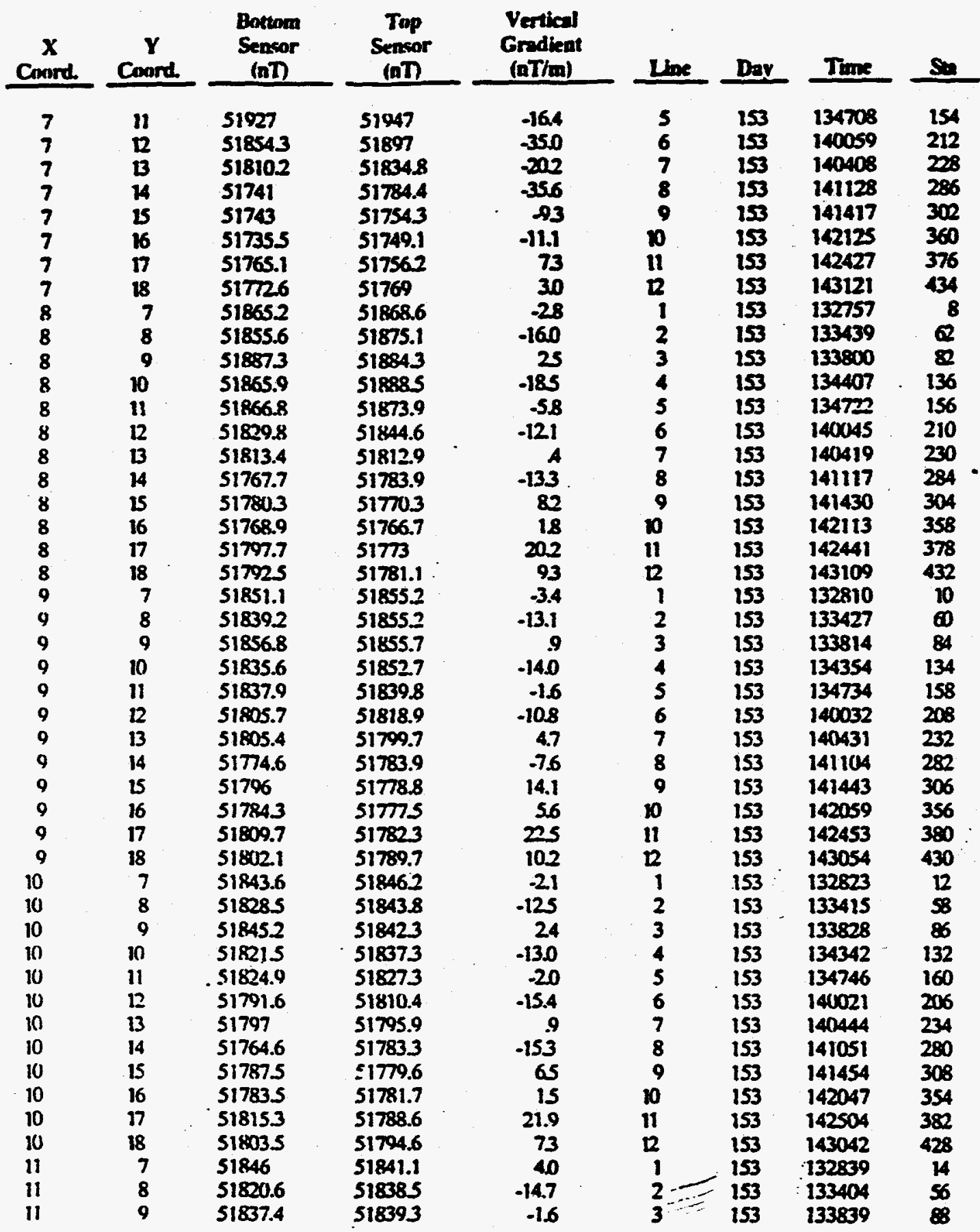

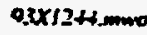

\author{
A. 2-25
}


Appendix IIC: Magnetic Survey" Data (Contd)

\begin{tabular}{|c|c|c|c|c|c|c|c|c|}
\hline $\begin{array}{c}\mathbf{x} \\
\text { Conord. }\end{array}$ & $\begin{array}{c}Y \\
\text { Coord. }\end{array}$ & $\begin{array}{l}\text { Bottom } \\
\text { Sensor } \\
\text { (nT) }\end{array}$ & $\begin{array}{c}\text { Top } \\
\text { Semwor } \\
\text { (nT) }\end{array}$ & $\begin{array}{l}\text { Vertical } \\
\text { Gradieat } \\
\text { (nT/ma) }\end{array}$ & Lne & Dor & Nine & so \\
\hline 11 & 10 & 51810.3 & 51839.4 & -23.9 & 4 & 153 & 134329 & 130 \\
\hline$\ddot{u}$ & n & 518227 & 51836.1 & -110 & 5 & 153 & 134758 & 162 \\
\hline$\ddot{11}$ & 12 & 517856 & 51819.6 & -27.9 & 6 & 153 & 140009 & 204 \\
\hline 11 & 13 & 51785.6 & 51803.6 & -148 & 7 & 153 & 140456 & 236 \\
\hline it & 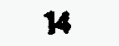 & 517565 & Si785.9 & -24.1 & 8 & 153 & 141037 & 278 \\
\hline 11 & 15 & 51787.9 & 51781.7 & 51 & 9 & 153 & 141507 & 310 \\
\hline 11 & 16 & 517862 & 51785 & 10 & 10 & 153 & 142033 & 352 \\
\hline 11 & 17 & 518155 & 51791 & 20.1 & 11 & 153 & 142518 & 384 \\
\hline 11 & 18 & 51804.4 & 51797.8 & SA & 12 & 153 & 143030 & 426 \\
\hline 12 & 7 & 518422 & 518395 & 22 & 1 & 153 & 132853 & 16 \\
\hline 12 & 8 & 51819 & 51839.9 & -17.1 & 2 & 153 & 133352 & 54 \\
\hline 12 & 9 & 518463 & 51851.4 & -42 & 3 & 153 & 133851 & $\boldsymbol{\Phi}$ \\
\hline 12 & 10 & 518321 & 518623 & -248 & 4 & 153 & 134315 & 128 \\
\hline 12 & $n$ & 51869 & 51689.9 & -17.1 & 5 & 153 & 134811 & 164 \\
\hline 12 & 12 & 51832.8 & 51878.9 & -37.8 & 6 & 153 & 135957 & 202 \\
\hline 12 & 13 & 51805.8 & S1851 & -370 & 7 & 153 & 140511 & 238 \\
\hline 12 & 14 & 51746.8 & 518024 & -45.6 & 8 & 153 & 141025 & 276 \\
\hline 12 & 15 & s1780.1 & 517893 & -75 & 9 & 153 & 141519 & 312 \\
\hline 12 & 16 & 51779.4 & 51788 & -7.0 & 0 & 153 & 142018 & 350 \\
\hline 12 & 17 & 518123 & 51793.7 & 15.2 & 11 & 153 & 142529 & 386 \\
\hline 12 & 18 & 51801.6 & 51799.8 & 15 & 12 & 153 & 143019 & 424 \\
\hline 13 & 7 & 518395 & 51840.9 & -1.1 & 1 & 153 & 132908 & 18 \\
\hline 13 & 8 & 51824.8 & 51847.7 & -188 & 2 & 153 & 133340 & 2 \\
\hline 13 & 9 & 51873.1 & 51874.9 & -15 & 3 & 153 & 133904 & $\boldsymbol{2}$ \\
\hline 13 & 10 & 51913 & 519273 & -11.7 & 4 & 153 & 134304 & 126 \\
\hline $\mathfrak{B}$ & 11 & 52094.7 & 52015.2 & 652 & 5 & 153 & 1345824 & 166 \\
\hline 13 & 12 & 52178.9 & 52028 & 123.7 & 6 & 153 & 135945 & 200 \\
\hline 13 & 13 & 52028.7 & 51967.9 & 49.8 & 7 & 153 & 140524 & 240 \\
\hline 13 & 14 & 51801.2 & 518542 & -43.4 & 8 & 153 & 141013 & 274 \\
\hline 13 & 15 & 517926 & 518052 & -103 & 9 & 153 & $14 i 530$ & 314 \\
\hline 13 & 16 & 51784.6 & 517955 & 8.9 & 10 & 153 & 142007 & 348 \\
\hline 13 & 17 & 51817.3 & 51797.7 & 16.1 & 11 & 153 & 142542 & 388 \\
\hline 13 & 18 & 518083 & 518027 & 46 & D & 153 & 143007 & 422 \\
\hline 14 & 7 & 51839.2 & 51843.2 & -3.3 & 1 & 153 & 132921 & 20 \\
\hline 14 & 8 & 51834.4 & 51856.1 & .178 & 2 & 153 & 133328 & 50 \\
\hline 14 & 9 & 51897.8 & 51896.5 & 1.1 & 3 & 153 & 133917 & 94 \\
\hline 14 & 10 & 52021.6 & 51986.7 & 28.6 & 4 & 153 & 134251 & 124 \\
\hline 14 & 11 & 52448.8 & 52142.6 & 251.0 & 5 & 153 & 134836 & 168 \\
\hline 14 & 12 & 57599.1 & 52209.6 & 4417.6 & 6 & 153 & 135931 & 198 \\
\hline 14 & 13 & 52346.3 & 5200211 & 216.6 & 7 & 153 & 140539 & 242 \\
\hline 14 & 14 & 51914.3 & 51919.5 & -43 & 8 & 153 & 140959 & 272 \\
\hline 14 & 15 & 51817.5 & 51826.6 & .75 & 9 & 153 & 141543 & 316 \\
\hline 14 & 16 & 51794.2 & S180126 & 6.9 & $\mathbf{n}$ & 153 & 141954 & 346 \\
\hline 14 & 17 & 518223 & 518013 & 17.2 & 11 & 153 & 142553 & 390 \\
\hline 14 & 18 & 51812 & 51804.7 & 60 & 2 & 153 & 142956 & 420 \\
\hline 15 & 7 & 51842.4 & 51844.6 & -18 & 1 & 153 & 132933 & 2 \\
\hline 15 & 8 & 51837.6 & 518593 & -178 & 2 & 153 & 133315 & 48 \\
\hline
\end{tabular}


Appendix IIC: Magnetic Survey Data (Contd)

\begin{tabular}{|c|c|c|c|c|c|c|c|c|}
\hline Connd. & $\begin{array}{c}\mathbf{Y} \\
\text { Conord. }\end{array}$ & $\begin{array}{c}\text { Bottom } \\
\text { Sensar (nT) } \\
\end{array}$ & $\begin{array}{c}\text { Top } \\
\text { Sensar }(n n) \\
\end{array}$ & $\begin{array}{l}\text { Vertical } \\
\text { Grodient } \\
\text { (nTha) }\end{array}$ & Line & Dar & Irime & $s$ \\
\hline 15 & 9 & 51905.9 & 51898.7 & 5.9 & 3 & 153 & 133929 & 9 \\
\hline is & 10 & 52018.1 & 51987.4 & 252 & 4 & 153 & 134239 & 122 \\
\hline 15 & $\|$ & 523424 & 52111 & 189.7 & 5 & 153 & 134848 & 170 \\
\hline is & D & S2537.7 & 52168.9 & 3023 & 6 & 153 & 135918 & 196 \\
\hline is & B & 52236.4 & 52062.7 & 1424 & 7 & 153 & 140553 & 244 \\
\hline 25 & 14 & 519312 & 51928.8 & 20 & 8 & 153 & 140948 & 270 \\
\hline 15 & 15 & 51834 & 51831.8 & 18 & 9 & 153 & 141555 & 318 \\
\hline 15 & 16 & 51803.7 & 518095 & 48 & 10 & 153 & 141940 & 34 \\
\hline 15 & 17 & 51821.1 & 51803.8 & 142 & $\mathfrak{n}$ & 153 & 142604 & 392 \\
\hline 15 & 18 & 51808 & 51905.4 & 21 & 12 & 153 & 142943 & 418 \\
\hline 16 & 7 & 518424 & 51844.8 & -20 & 1 & 153 & 132946 . & 24 \\
\hline 16 & 8 & 51833.9 & 51855.9 & -180 & 2 & 153 & 133301 & 46 \\
\hline 16 & 9 & 51889.3 & S1RR3.1 & S.1 & 3 & 153 & 133940 & 9 \\
\hline 16 & 10 & 51941.7 & 51939.8 & 16 & 4 & 153 & 134227 & 120 \\
\hline 16 & 11 & 52063.6 & 51999.9 & 523 & 5 & 153 & 134901 & 172 \\
\hline 16 & 12 & 520029 & 52013.1 & 572 & 6 & 153 & 135905 & 194 \\
\hline 16 & 13 & 52001.7 & 51455.2 & 38.1 & 7 & 153 & 140608 & 246 \\
\hline 16 & 14 & 51886.4 & 51890.4 & -33 & 8 & 153 & 140936 & 268 \\
\hline 16 & 15 & 51839.1 & 51829.3 & 80 & 9 & 153 & 141606 & 320 \\
\hline 16 & 16 & 51811.7 & 51810.3 & 1.1 & 10 & 153 & 141928 & 342 \\
\hline 16 & 17 & 51831.9 & $51 k R 6$ & 212 & II & 153 & 142615 & 394 \\
\hline 16 & 18 & 51799 & $518 \times 6.8$ & -6.4 & R & 153 & 142931 & 416 \\
\hline 17 & 7 & 51848.9 & 51849.4 & $A$ & 1 & 153 & 132958 & 20 \\
\hline 17 & 8 & $51 R 27.6$ & 51860.8 & .272 & 2 & 153 & 133248 & 44 \\
\hline 17 & 9 & 518742 & 51878.6 & -36 & 3 & 153 & 133953 & 100 \\
\hline 17 & 10 & 518702 & 51898.8 & -22.4 & 4 & 153 & 134212 & 118 \\
\hline 17 & 11 & 51929.9 & 51917.1 & 105 & 5 & 153 & 134914 & 174 \\
\hline 17 & 12 & S1915.4 & s1911.1 & 35 & 6 & 153 & 135848 & 192 \\
\hline 17 & 13 & 51901.7 & 51879 & 18.6 & 7 & 153 & 140622 & 248 \\
\hline 17 & 14 & 51849.7 & 51853 & .27 & 8 & 153 & 140922 & 266 \\
\hline 17 & 15 & 51837.7 & 51822.7 & 123 & 9 & 153 & 141620 & 322 \\
\hline 17 & 16 & 51813.3 & 518126 & 6 & 10 & 153 & 141916 & 340 \\
\hline 17 & 17 & 51833 & 51809 & 19.7 & $n$ & 153 & 142628 & 396 \\
\hline 17 & 18 & 51819.5 & 518103 & 75 & 12 & 153 & 142920 & 414 \\
\hline 18 & 7 & 51862.2 & .51865 .2 & -25 & 1 & 153 & 133010 & 28 \\
\hline 18 & 8 & 51864.4 & 51885.8 & .175 & 2 & 153 & 133235 & 42 \\
\hline 18 & 9 & 51922.4 & 51907.5 & 12.2 & 3 & 153 & 134004 & 102 \\
\hline 18 & 10 & 51860.2 & 51894.9 & -28.4 & 4 & 153 & 134201 & 116 \\
\hline 18 & 11 & $518 R 22$ & 518843 & -3.4 & 5 & 153 & 134926 & 176 \\
\hline 18 & 12 & 51855.8 & 51863.6 & -6.4 & 6 & 153 & 135834 & 190 \\
\hline 18 & 13 & 51857.6 & 51843 & 120 & 7 & 153 & 140637 & 250 \\
\hline 18 & H & 51829.6 & 518322 & -21 & 8 & 153 & 140910 & 264 \\
\hline 18 & 15 & 51836.6 & 51816 & 16.9 & 9 & 153 & 141631 & 324 \\
\hline 18 & 16 & 51819.6 & 51811 & 70 & 10 & 153 & 141905 & 338 \\
\hline 18 & 17 & 51836.6 & 51810.3 & 21.6 & 11 & 153 & 142640 & 398 \\
\hline 18 & 18 & 5IRIT.1 & 51811.9 & 43 & 12 & 153 & 142908 & 412 \\
\hline 19 & 7 & 51906 & 51891.6 & 118 & 1 & 153 & 133022 & 30 \\
\hline
\end{tabular}

$0.0 \times 13+4.000$ 
Appendix IIC: Magnetic Survey Data (Contd)

\begin{tabular}{|c|c|c|c|c|c|c|c|c|}
\hline $\begin{array}{c}\mathbf{x} \\
\text { Conord }\end{array}$ & $\begin{array}{c}\mathbf{Y} \\
\text { Coond. }\end{array}$ & $\begin{array}{c}\text { Bottom } \\
\text { Sensor } \\
\text { III } \\
\end{array}$ & $\begin{array}{c}\text { Top } \\
\text { Seasor } \\
\text { (nDD }\end{array}$ & $\begin{array}{l}\text { Vertical } \\
\text { Gradient } \\
\text { (nT/m) }\end{array}$ & Lme & Dax & Trme & se \\
\hline 19 & 8 & 51979.1 & 51933.8 & 37.1 & 2 & 153 & 133223 & 0 \\
\hline 19 & 9 & 52125.4 & 51974.7 & 1235 & 3 & 153 & 134016 & 104 \\
\hline 19 & 10 & 51973.4 & 519328 & 33.3 & 4 & 153 & 134149 & 114 \\
\hline 19 & 11 & 51890.8 & 518868 & 33 & 5 & 153 & 134937 & 178 \\
\hline 19 & 2 & 518383 & 51847.1 & .72 & 6 & 153 & 135819 & 188 \\
\hline 19 & $\overline{\mathbf{B}}$ & 51843.4 & 51829.5 & 114 & 7 & 153 & 140649 & 252 \\
\hline 19 & 14 & 51820.9 & 51819.8 & .9 & 8 & 153 & 140858 & 262 \\
\hline 19 & is & 51830 & 51809.9 & 16.5 & 9 & 153 & 141642 & 326 \\
\hline 19 & 16 & 51818.6 & 518075 & 9.1 & $\boldsymbol{D}$ & 153 & 141852 & 336 \\
\hline 19 & 17 & 51837.4 & 51808.9 & 23.4 & 11 & 153 & 142651 & 400 \\
\hline 19 & 18 & 51824.3 & 51810 & 11.7 & D2 & 153 & 142854 & 410 \\
\hline n & 7 & 519482 & 51909.8 & 315 & 1 & 153 & 133035 & 32 \\
\hline 20 & 8 & 52106.8 & 51975.9 & 1073 & 2 & 153 & 133208 & 38 \\
\hline 20 & 9 & 52267.9 & 52010.7 & 210.8 & 3 & 153 & 134028 & 106 \\
\hline 20 & 10 & 52087 & 519623 & 1022 & 4 & 153 & 134134 & 112 \\
\hline $\mathbf{3 0}$ & 11 & 51909.9 & 51890.1 & 162 & 5 & 153 & 134950 & 180 \\
\hline 20 & 12 & 51834.7 & 51839 & -35 & 6 & 153 & 135807 & 186 \\
\hline $\mathbf{3 0}$ & 13 & siRAnS & 51819.4 & 173 & 7 & 153 & 140700 & 254 \\
\hline 3 & 14 & 51814.8 & 51810.9 & 32 & 8 & 153 & 140845 & 260 \\
\hline $\boldsymbol{x}$ & 15 & 51830.9 & 51803.6 & 224 & 9 & 153 & 141654 & 328 \\
\hline $\bar{n}$ & 16 & 51814.6 & 518025 & 9.9 & 10 & 153 & 141840 & 334 \\
\hline 20 & 17 & 51833.2 & 51804.9 & 232 & 11 & 153 & 142703 & 402 \\
\hline $\boldsymbol{x}$ & 18 & 51823.2 & 51806 & 14.1 & 12 & 153 & 142840 & 408 \\
\hline 21 & 7 & 51926.6 & 518963 & 24.8 & 1 & 153 & 133049 & 34 \\
\hline 21 & 8 & 52030.1 & 51950.1 & 65.6 & 2 & 153 & 133153 & 36 \\
\hline 21 & 9 & 52107.6 & 51964.9 & 117.0 & 3 & 153 & 134041 & 108 \\
\hline 21 & 10 & 51995.1 & 51933.2 & 50.7 & 4 & 153 & 134117 & 110 \\
\hline 21 & 11 & 51896 & 518725 & 19.3 & 5 & 153 & 135001 & 182 \\
\hline 21 & 12 & 51830.9 & 51830 & .7 & 6 & 153 & 135756 & 184 \\
\hline 21 & 13 & 51838.2 & 51810.5 & 227 & 7 & 153 & 140712 & 256 \\
\hline 21 & 14 & 51807.3 & 51802 & 43 & 8 & 153 & 140833 & 258 \\
\hline 21 & 15 & 51820.2 & 51794.9 & 20.7 & 9 & 153 & 141731 & 330 \\
\hline 21 & 16 & 51809.1 & 51795.6 & 11.1 & 10 & 153 & 141827 & 332 \\
\hline 21 & 17 & 518321 & 51799.1 & 27.0 & 11 & 153 & 142715 & 404 \\
\hline 21 & 18 & 51819.7 & 51800.5 & 15.7 & 12 & 153 & 142824 & 406 \\
\hline
\end{tabular}



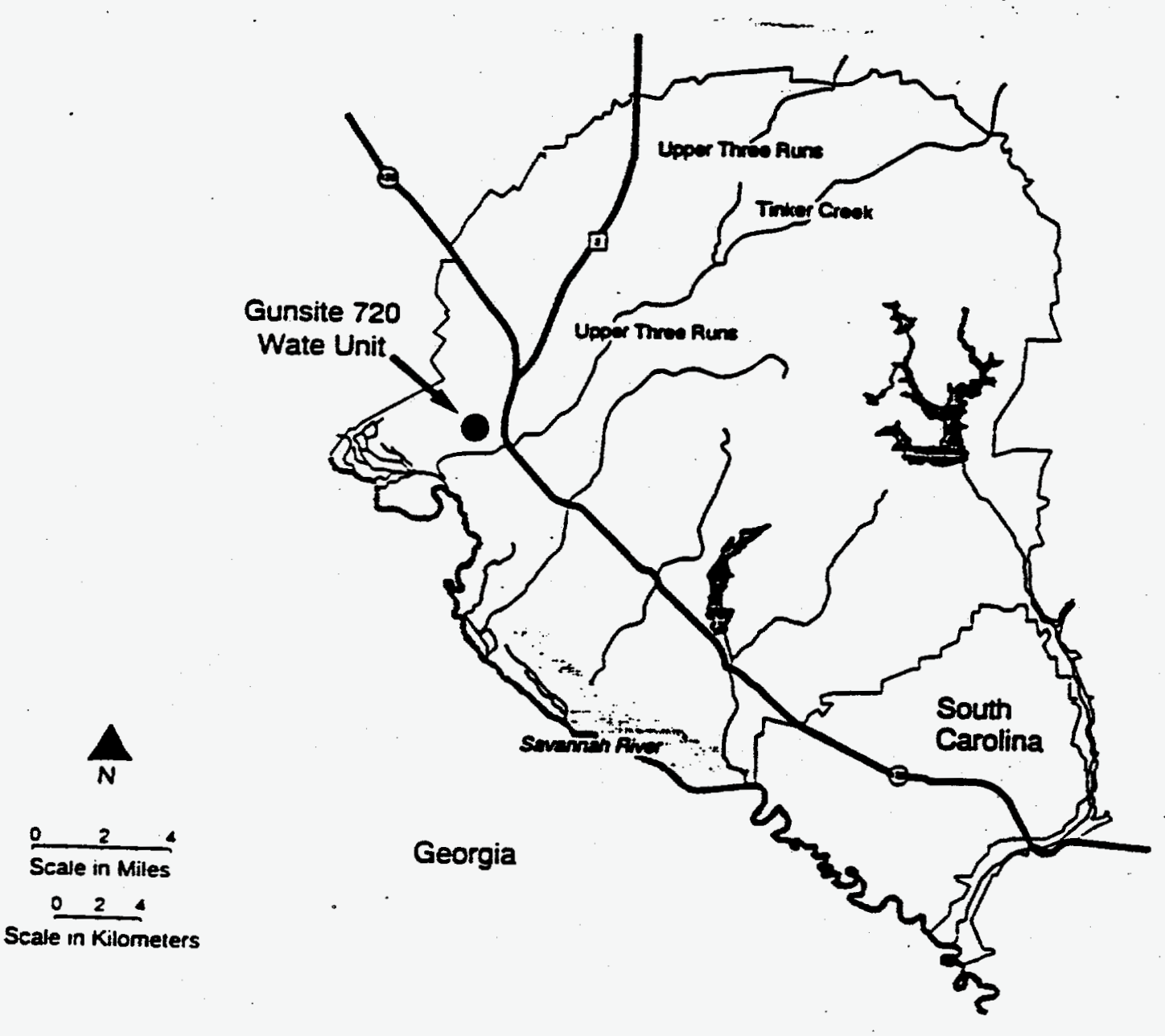

$=$

Figure 1. Lucation of Gunsite Tan Waste Unit 


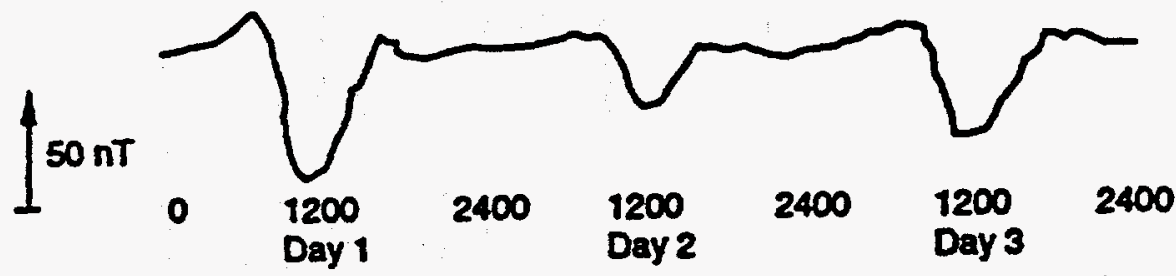

\section{DIURNAL VARIATION}

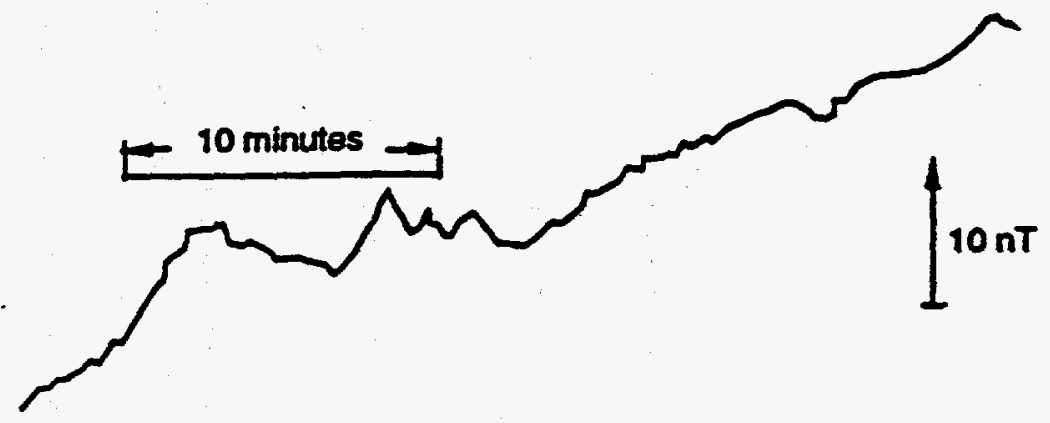

MICROPULSATIONS

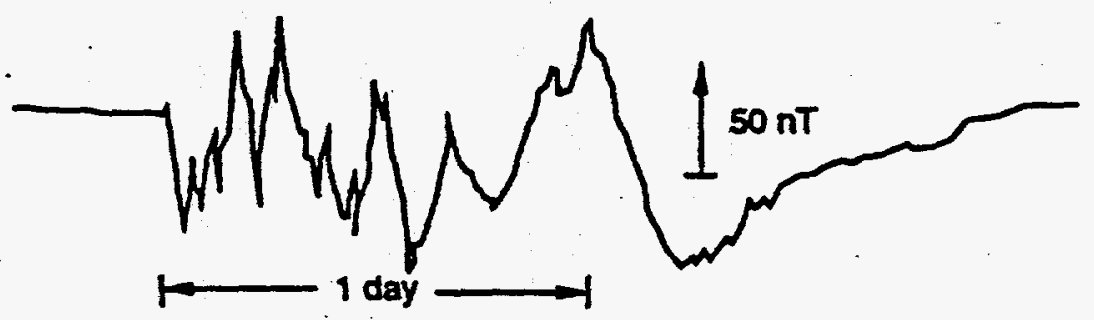

\section{MAGNETIC STORM}

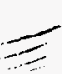

Figure 2. Typical temporal variations exhibited by the total magnetic field due to diurnal variation, micropulsations, and magnetic storms on the sun' 

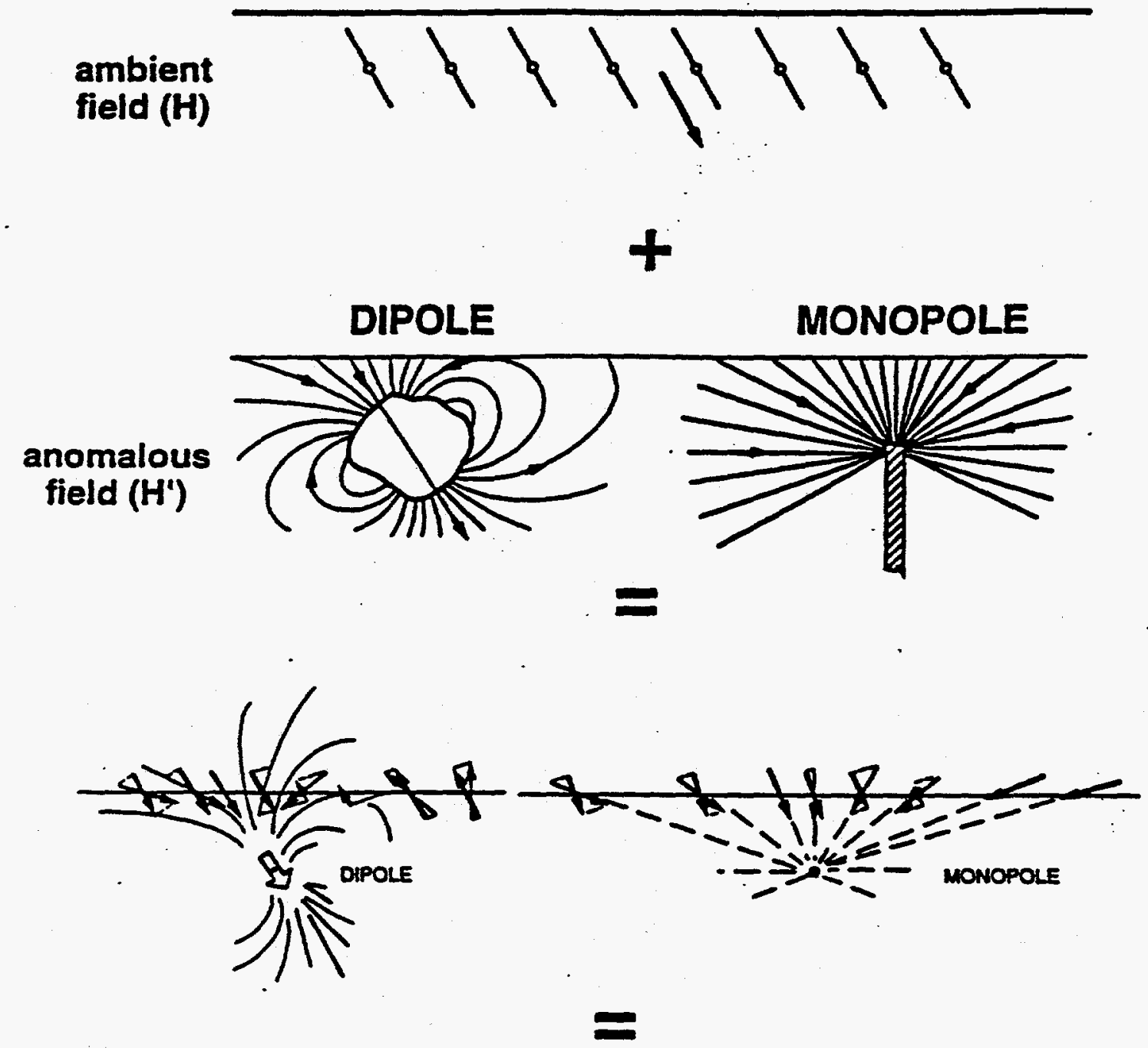

\section{total observed field (B)}

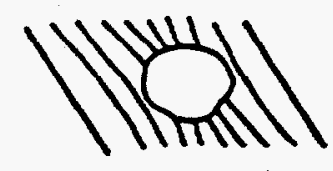

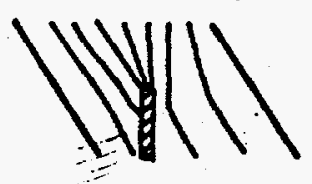

Figure 3. Supcrposition of the Earth's ambient magnetic field and anomalous fields produced by induced monopoles and dipoles to produce anomalies in the total field' 


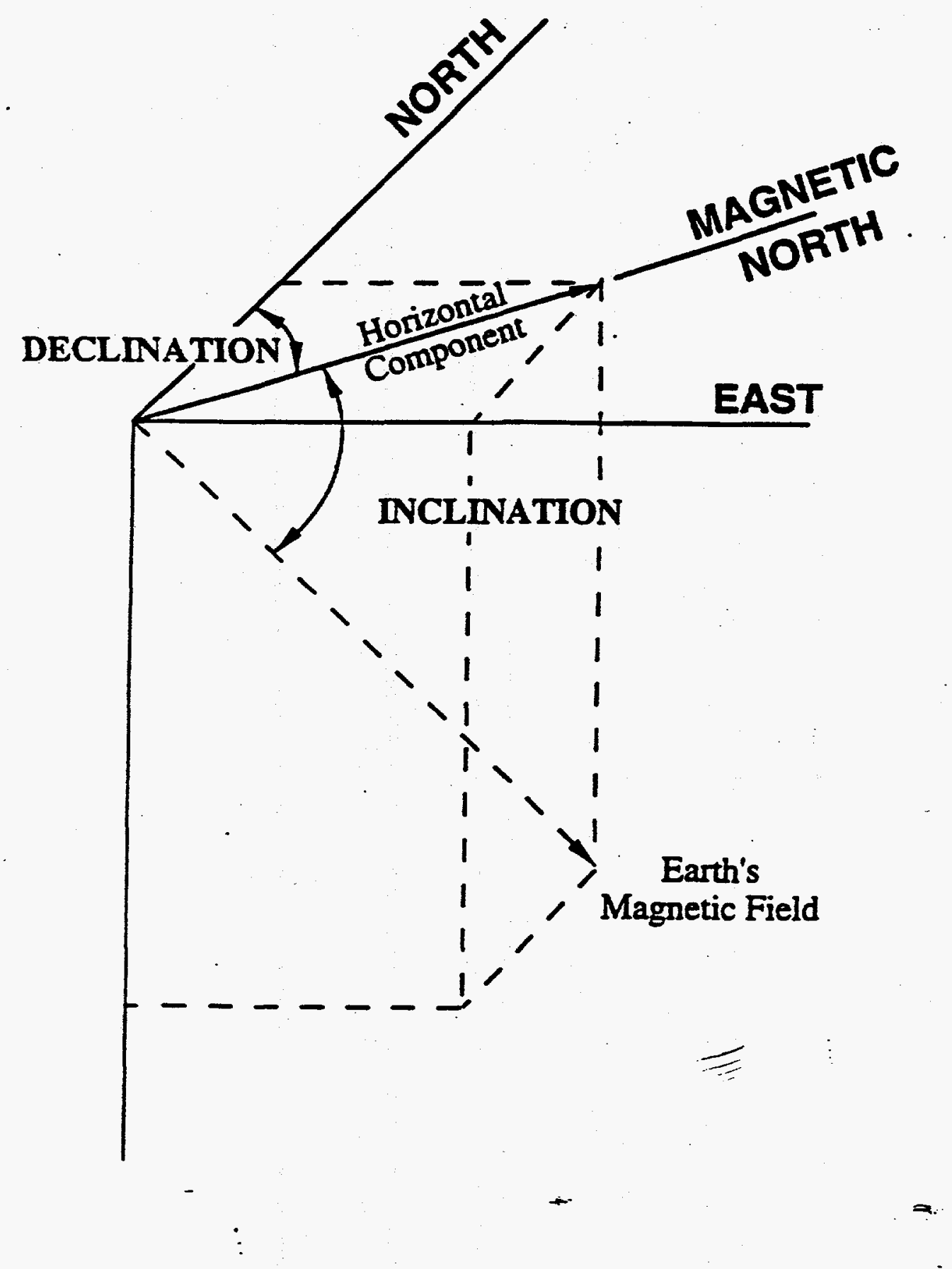

Figure 4. The relationship of magnetic inclination and declination to geographic directions on the
Earh? 

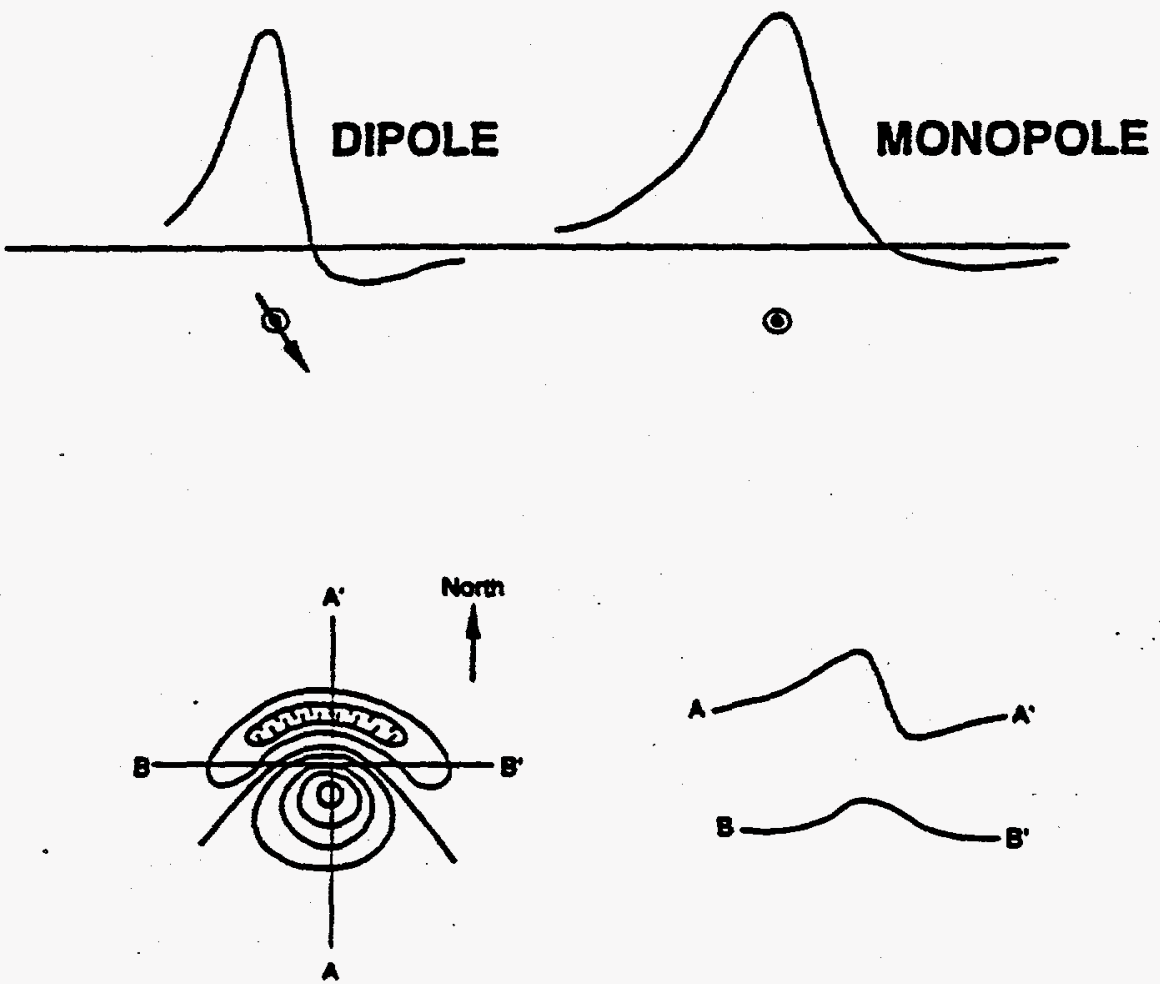

๑

Figure 5. Typical profiles of magnetic field intensity actoss monopales and dipoles, for conditions similar to SRS. Also shown is a contour representation of magnetic field intensity over a dipole with aconmpanying representative profiles. 

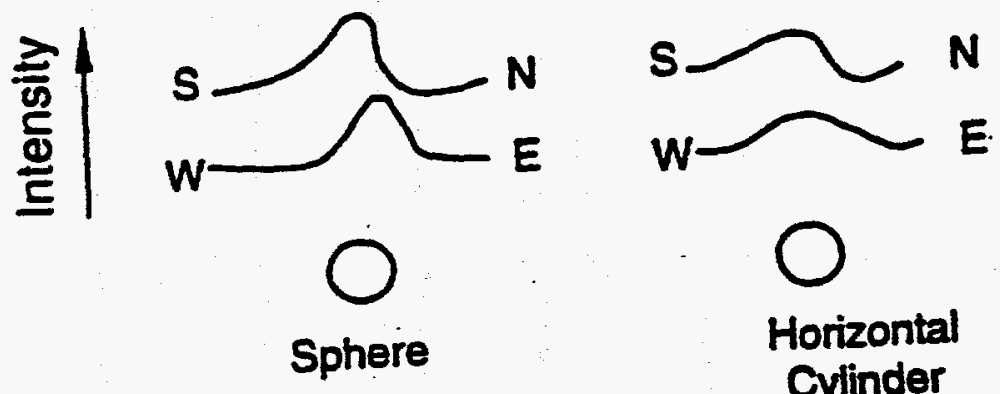

\section{Horizontal \\ Cylinder}

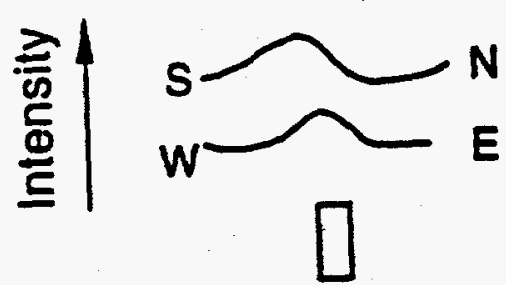

Vertical Cylinder

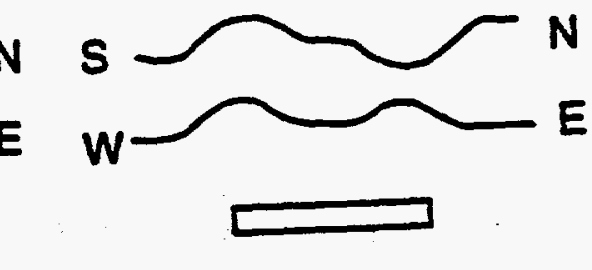

Horizontal

Slab

Figure 6. Magnetic intensity profiles acruss several geometric shapes of interest for magnetic field inclination similar to that of SRS (i.e., 60 degrees)' 

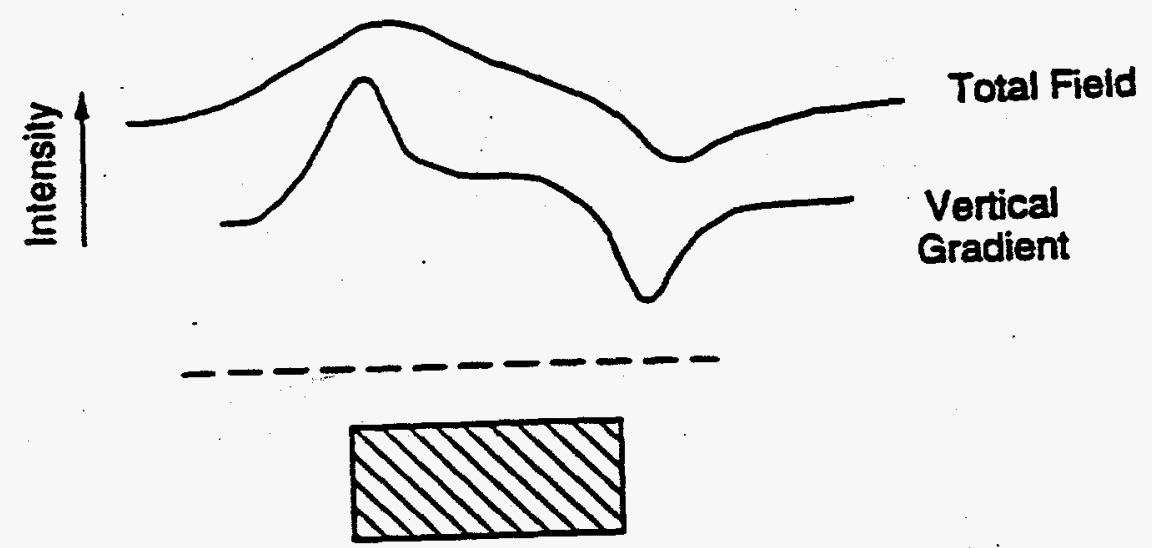

$\bar{Z}$

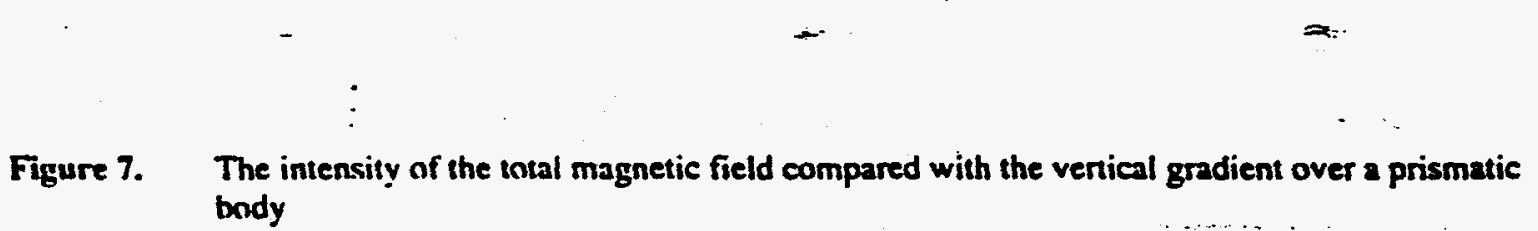
body 
$\therefore$.

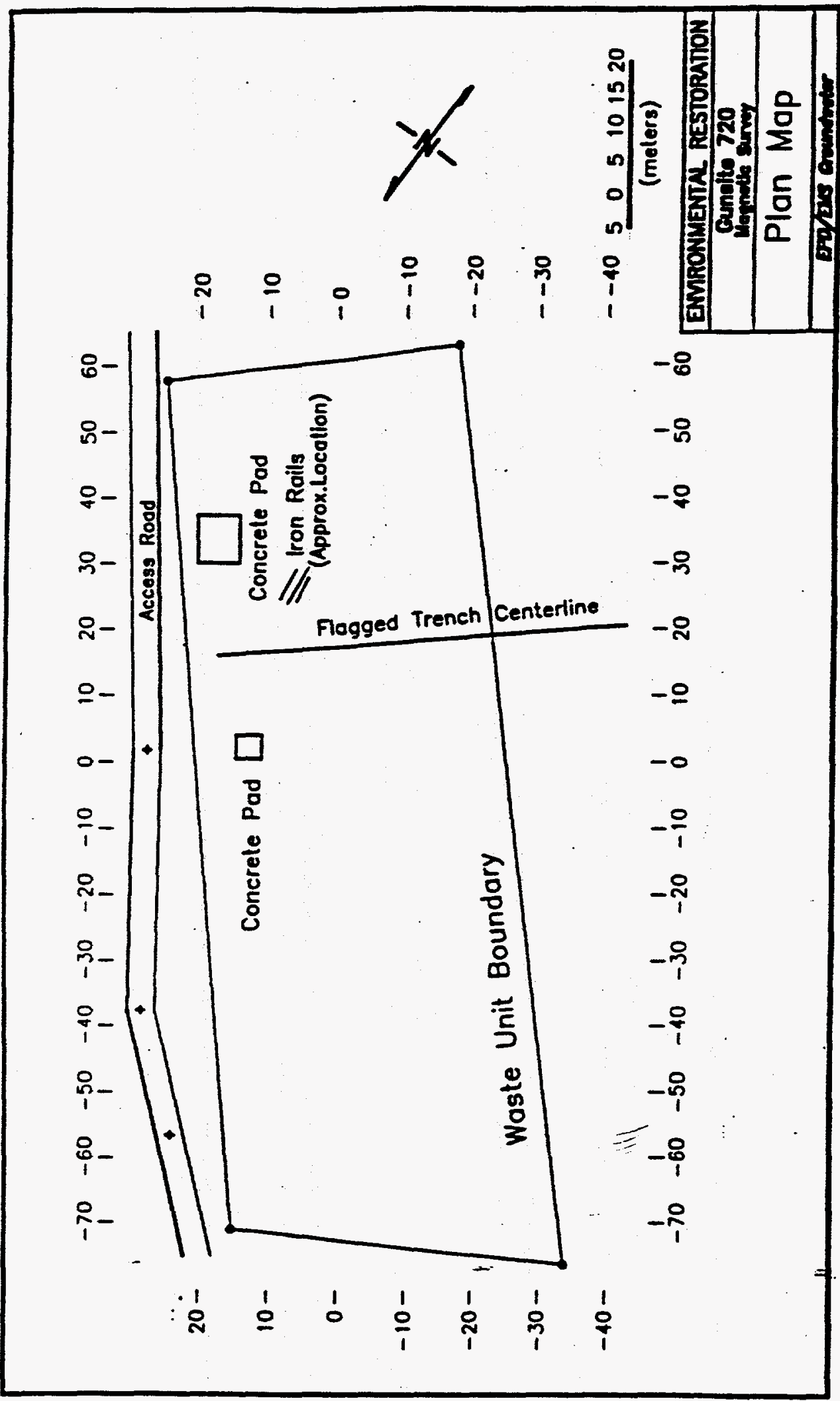

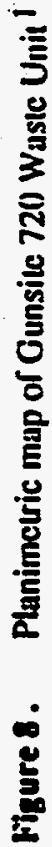




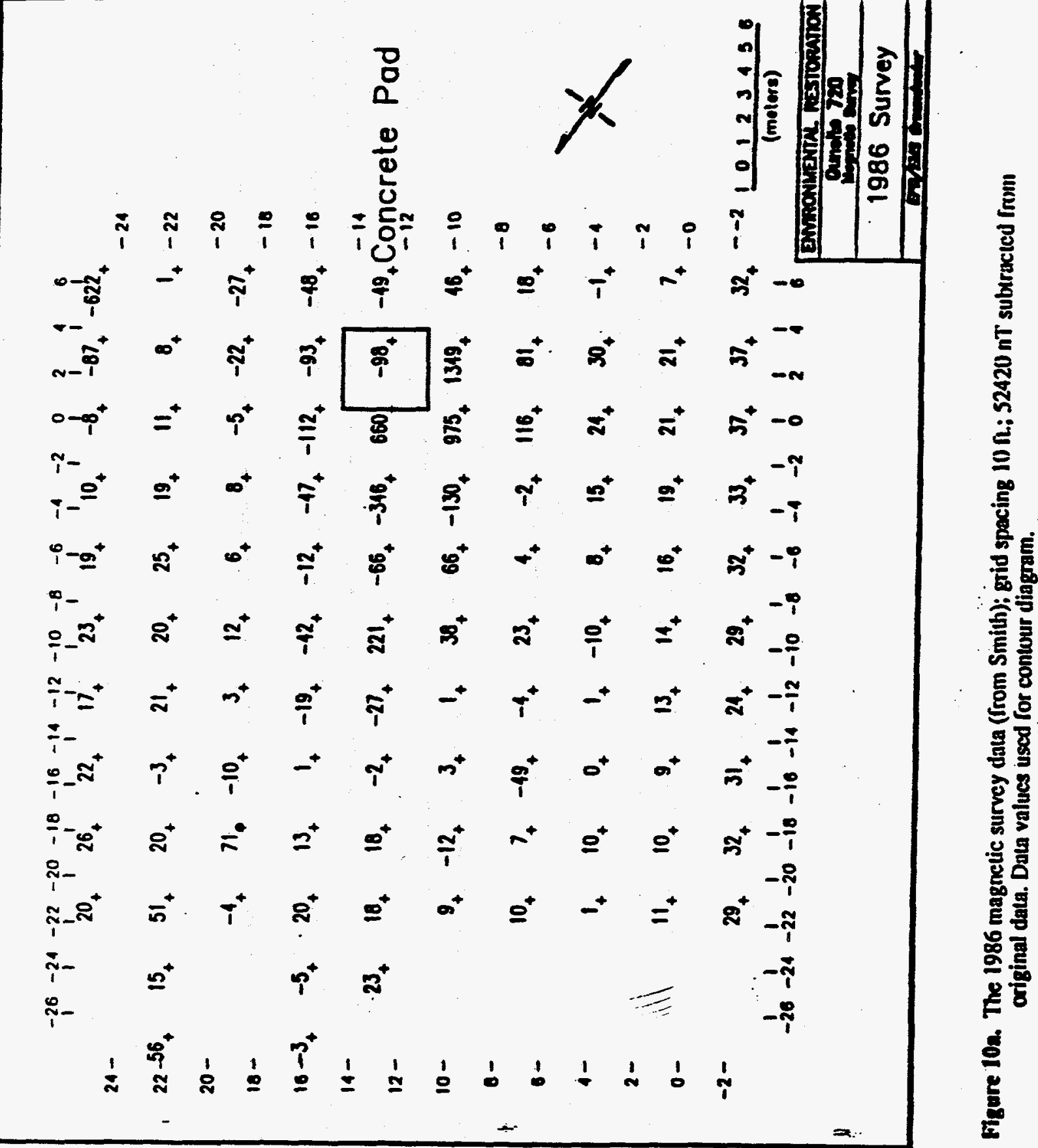




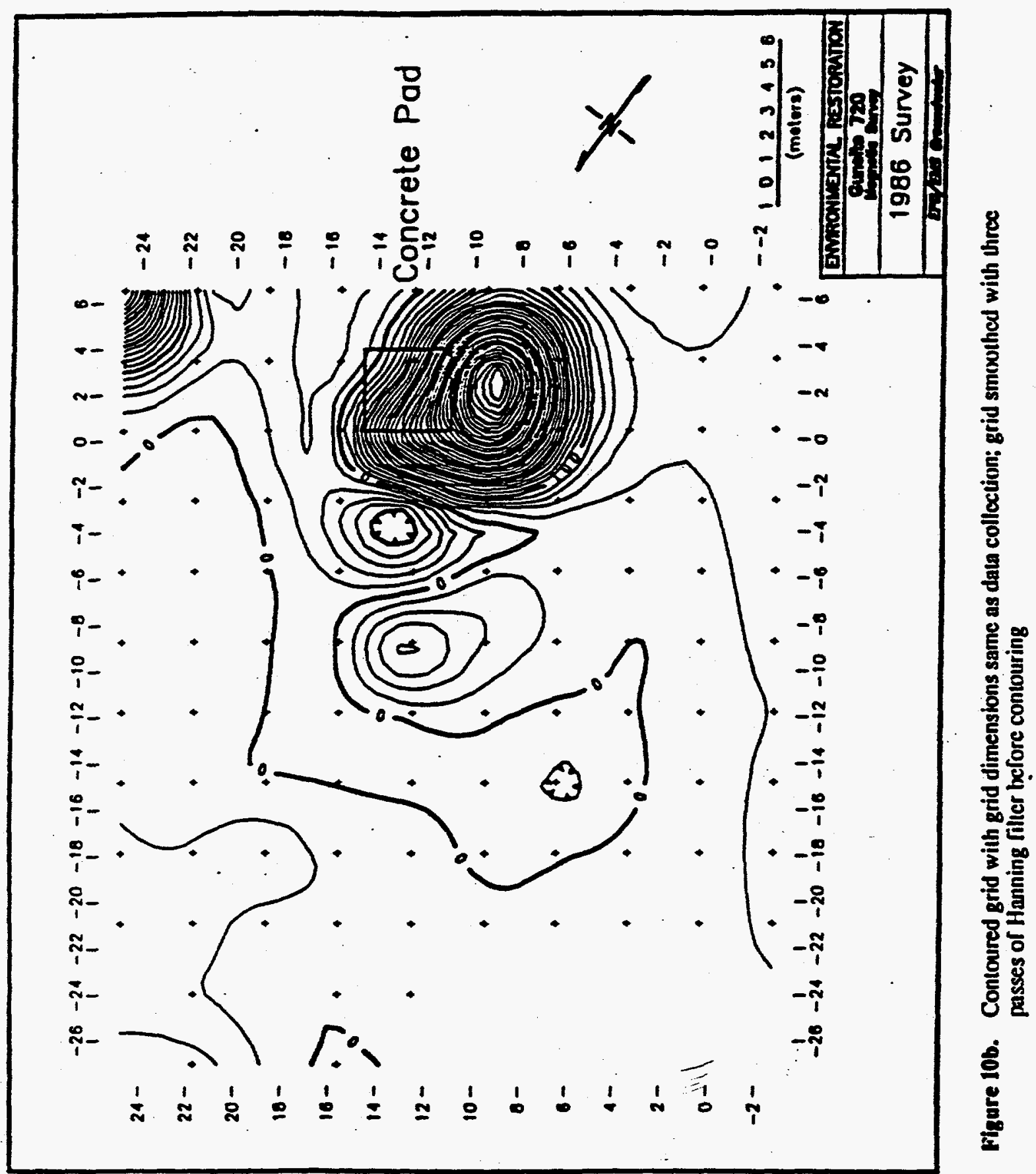




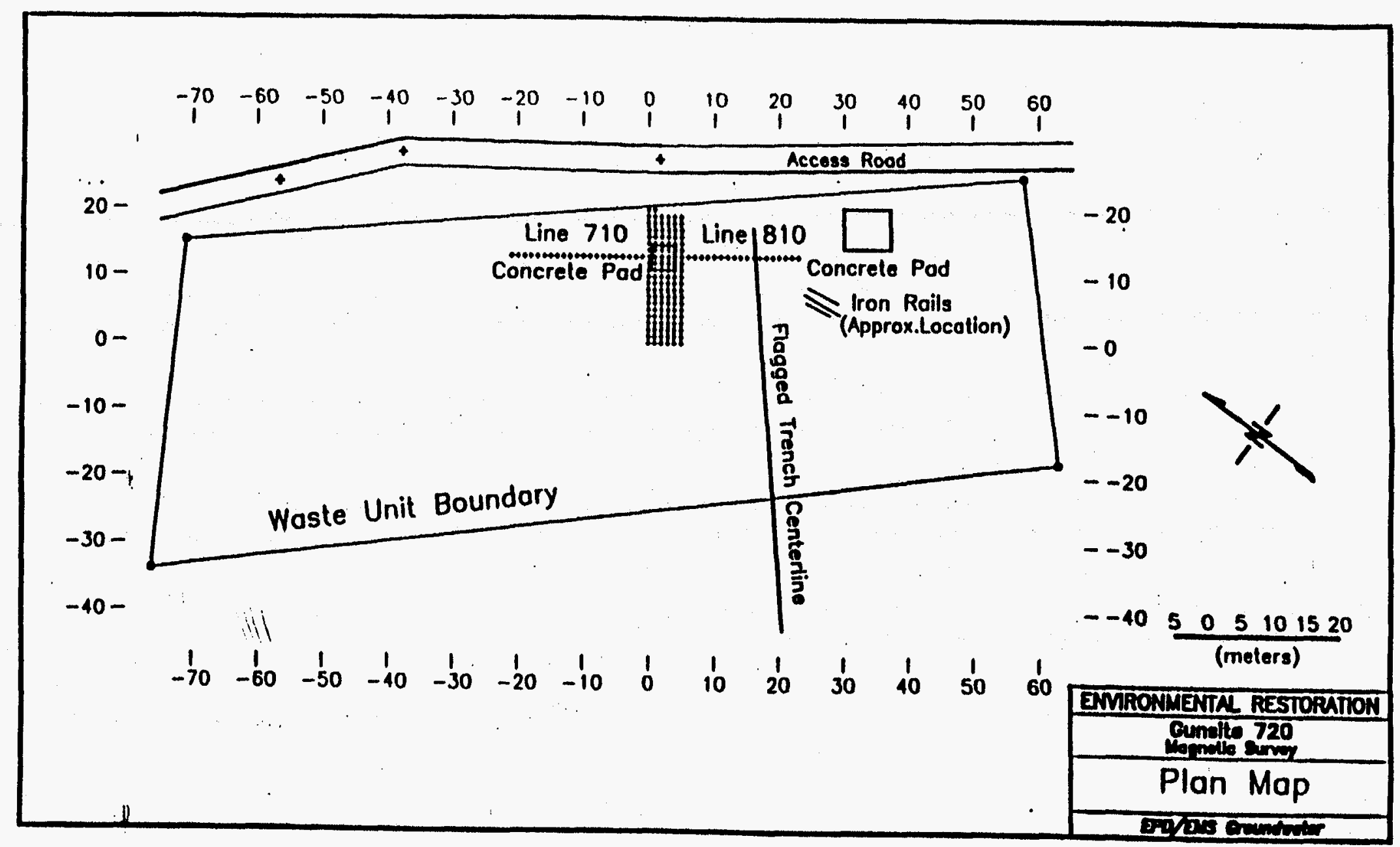

pigure 11. Station locations for Section I of the 1993 magnetic survey. Survey station locations marked by " + ". 


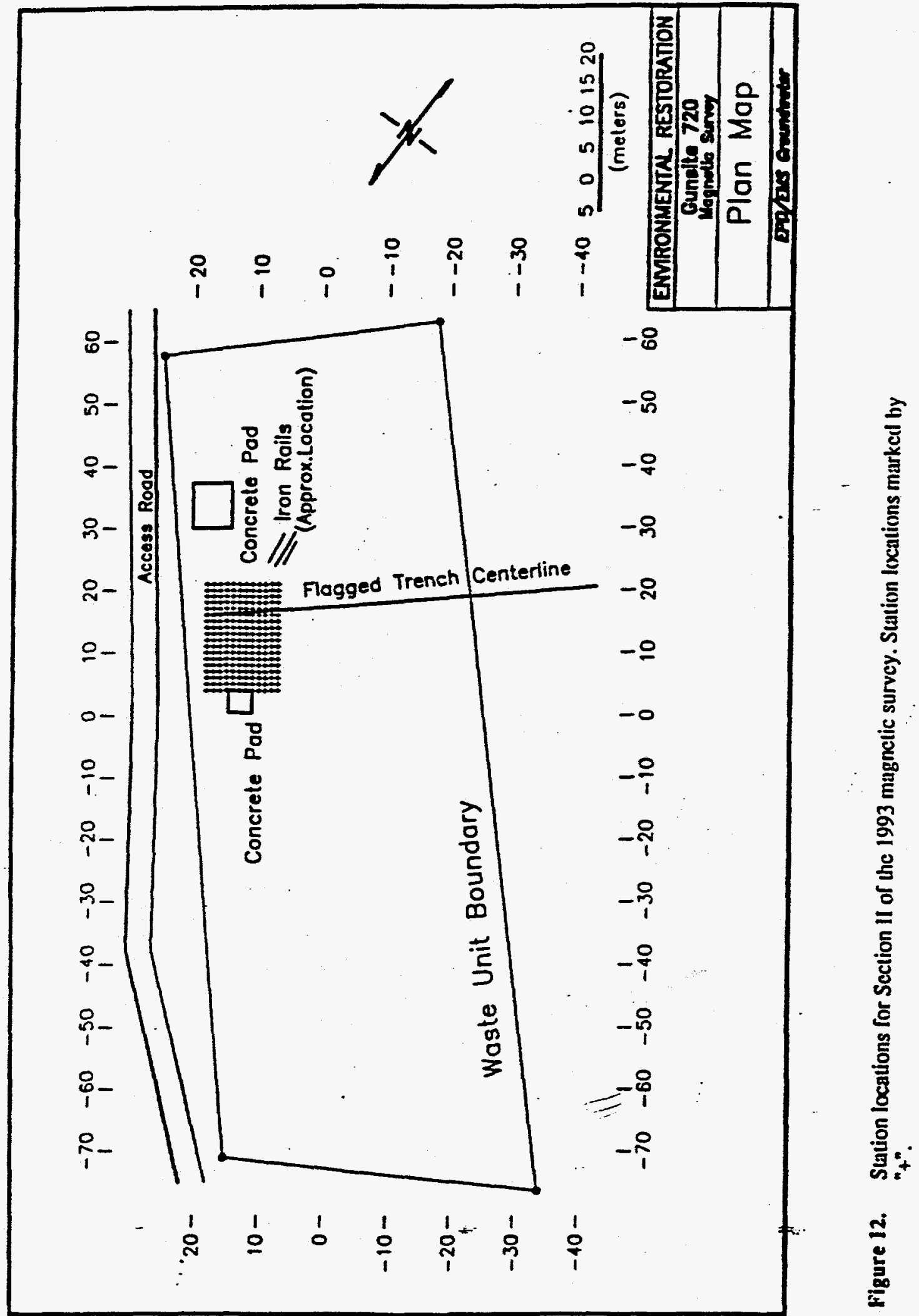

$0.0 \times 12+1 . m 0$ 


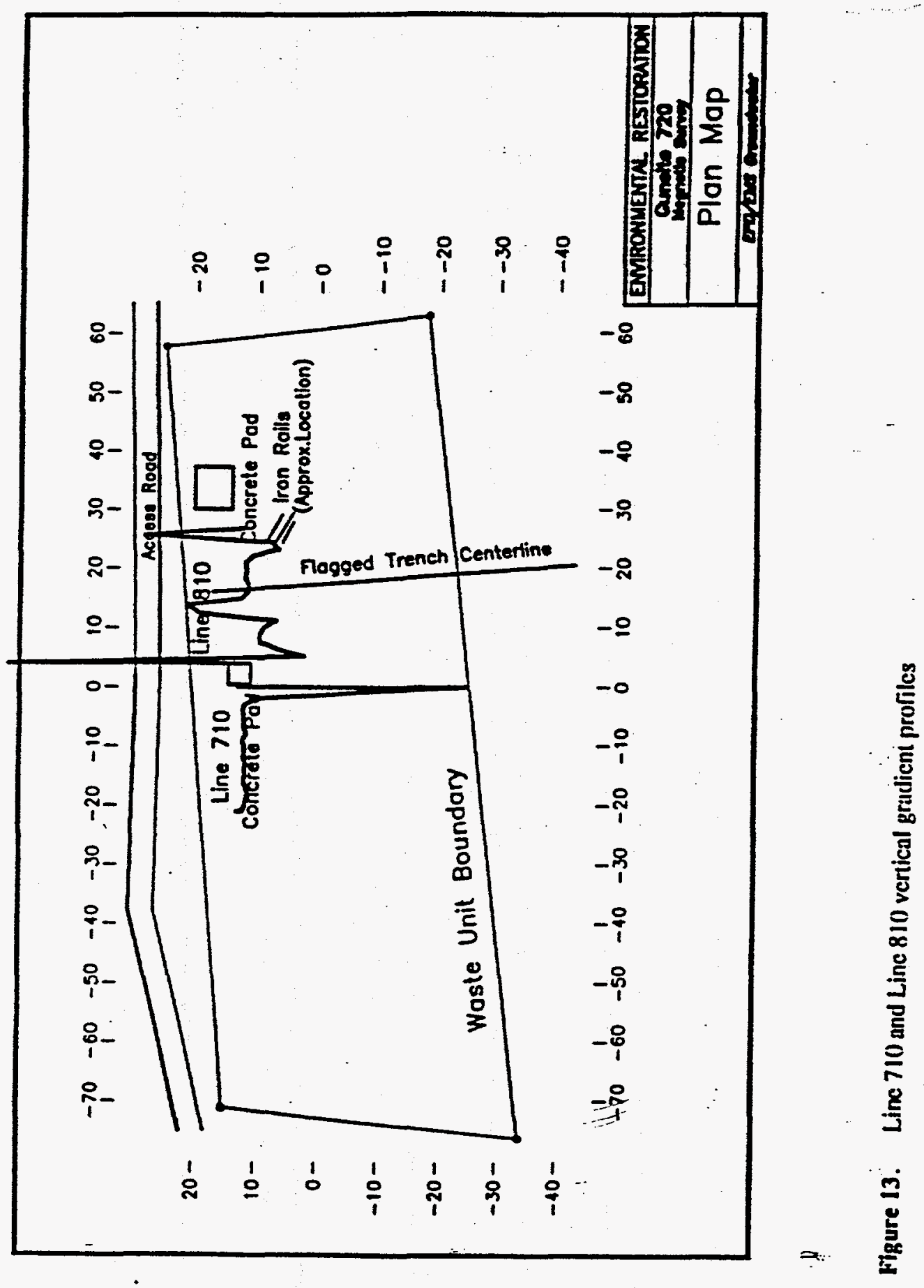

A. 2-42 
$\therefore$.

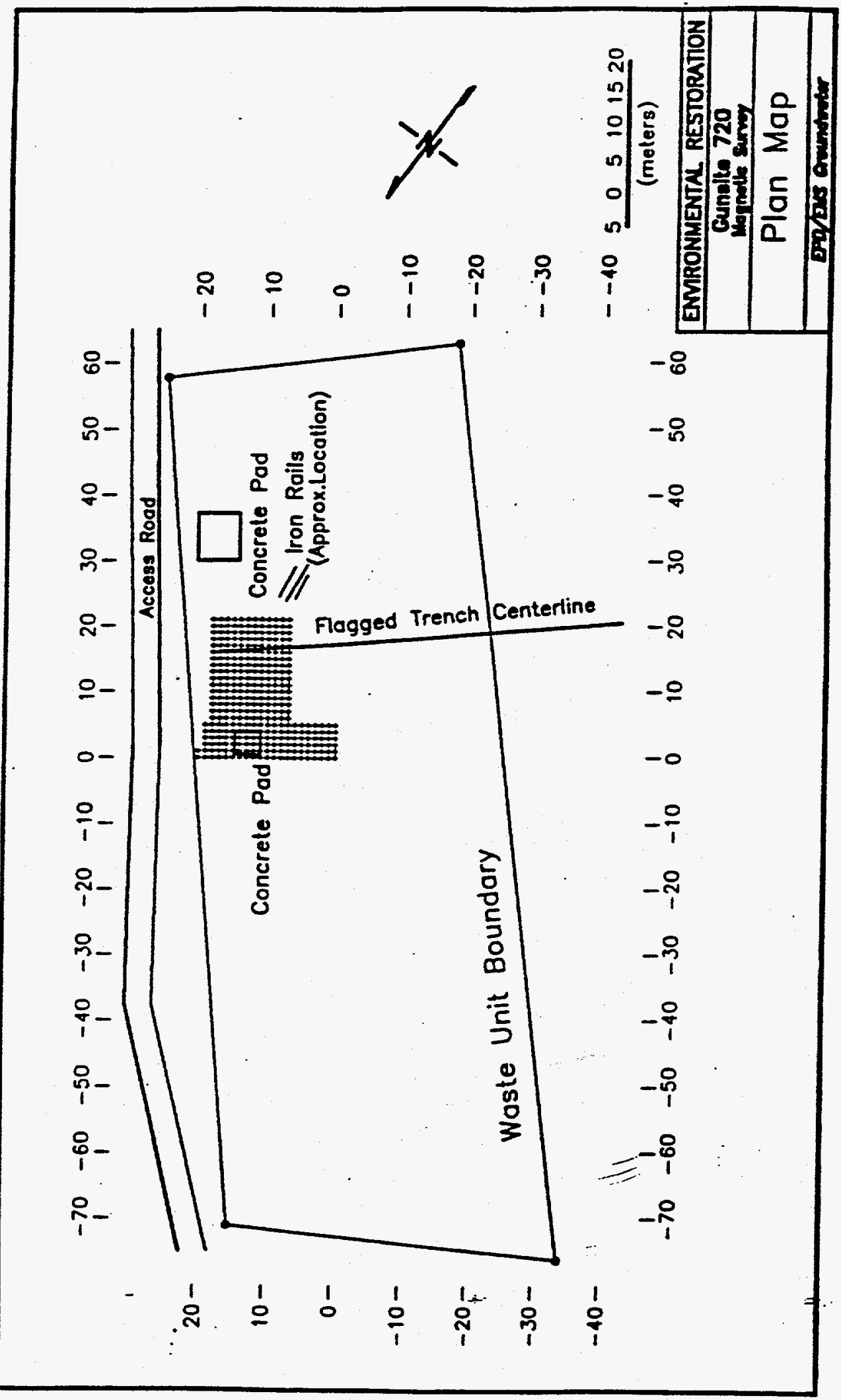

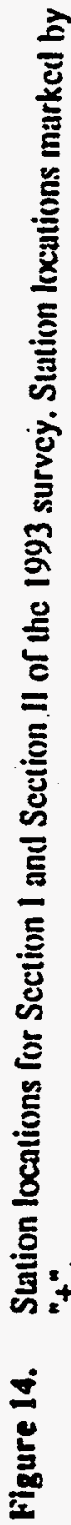




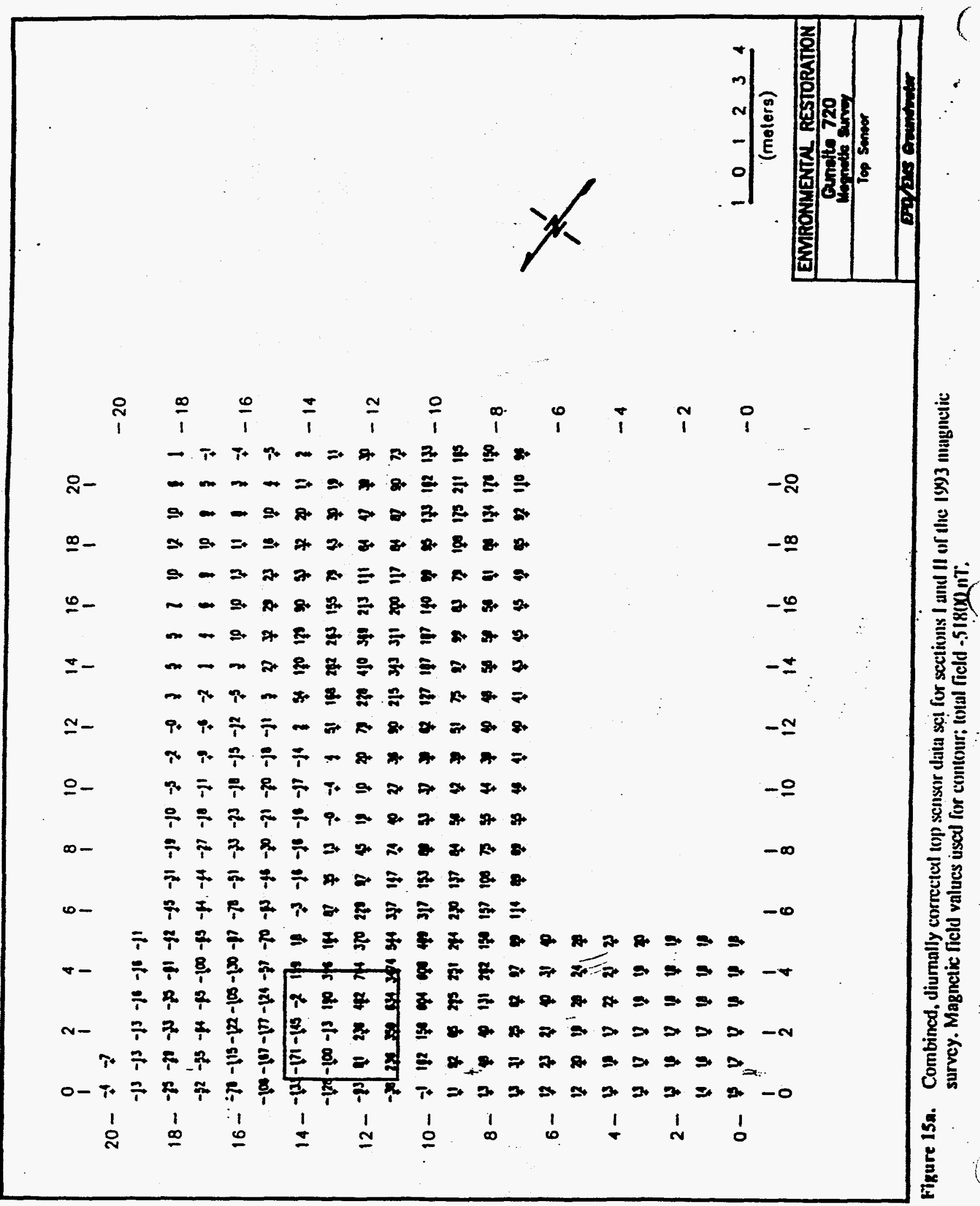




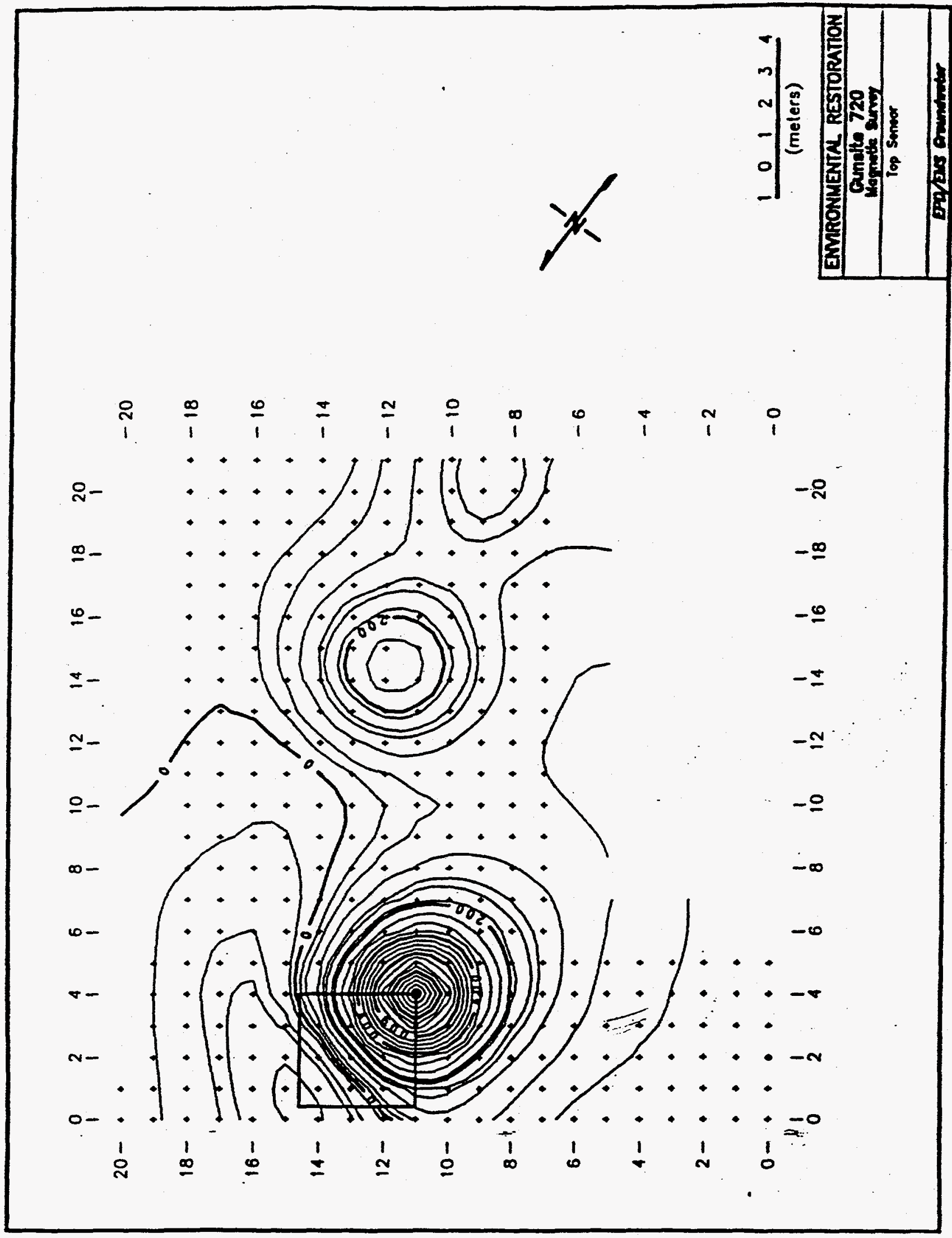

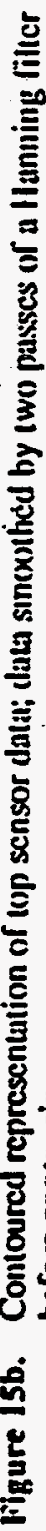

0.1XI:2+ 


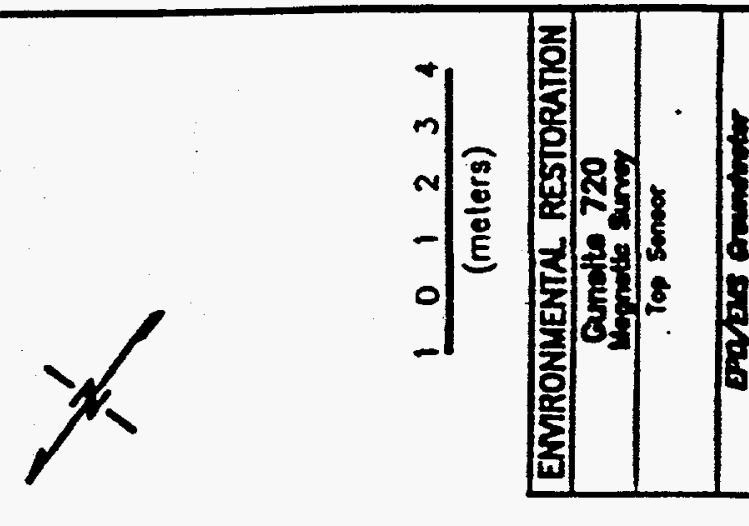

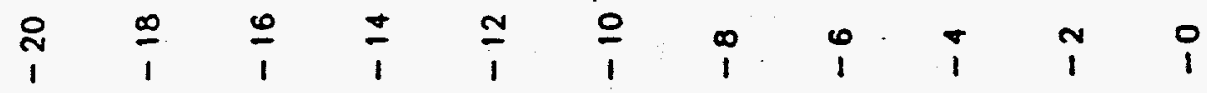

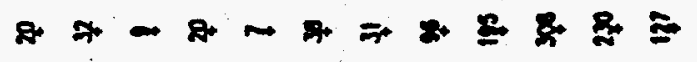

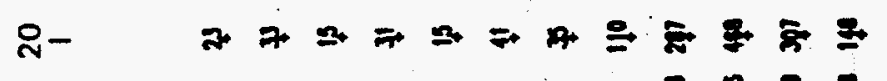

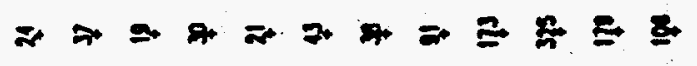

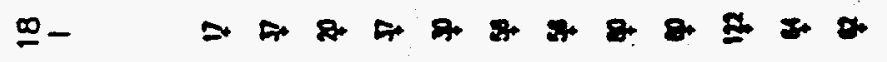

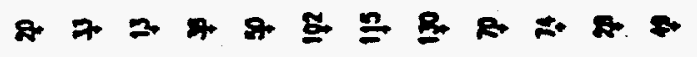

$$
\begin{aligned}
& \text { ㅇ- T+ } \\
& \text { - }
\end{aligned}
$$

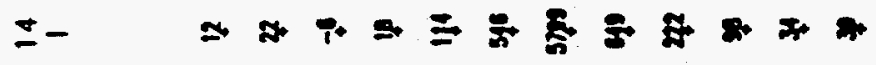

$$
\begin{aligned}
& ->\div \text { - } \rightarrow \text { \& }
\end{aligned}
$$

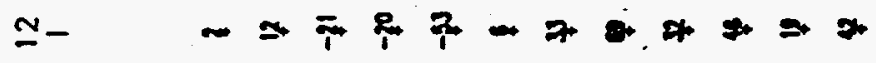

$$
\begin{aligned}
& \text { - }
\end{aligned}
$$

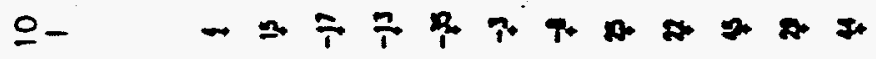

$$
\begin{aligned}
& \text { - } \\
& \text { - } \\
& \text { ำ }
\end{aligned}
$$

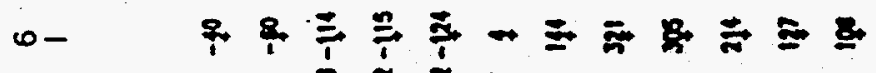

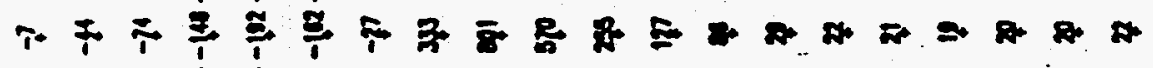

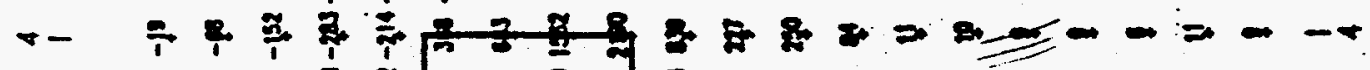

$$
\begin{aligned}
& \text { ศ } \\
& \text { N- } \\
& \text { - }
\end{aligned}
$$

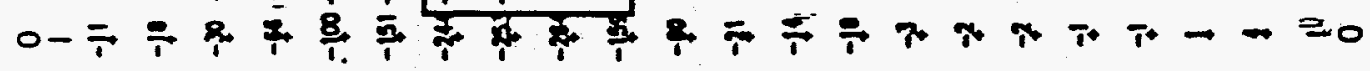

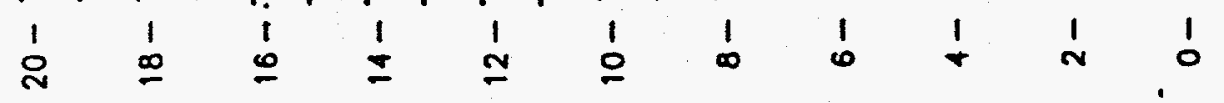



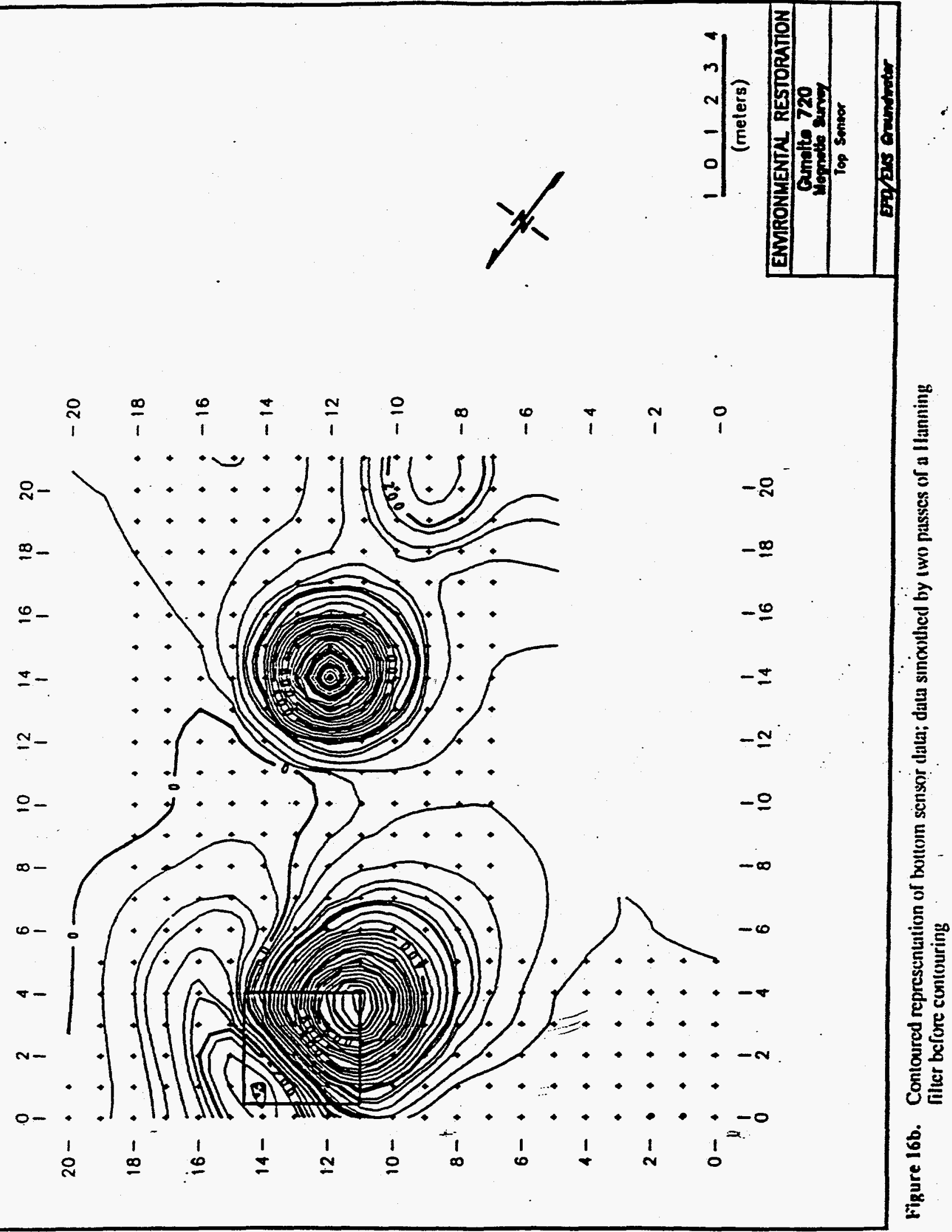

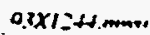




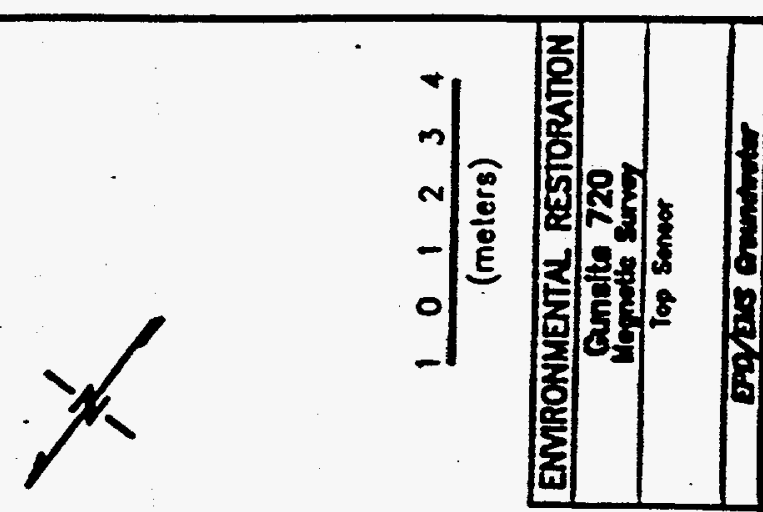

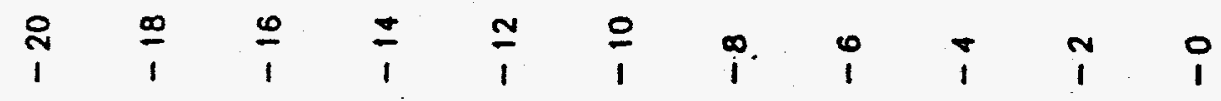

$$
\begin{aligned}
& \therefore=\pi-a-\pi \equiv+\infty
\end{aligned}
$$

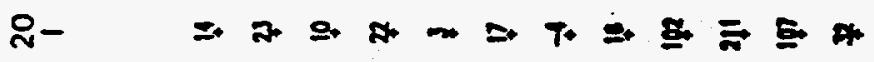

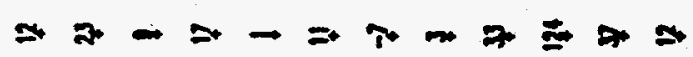

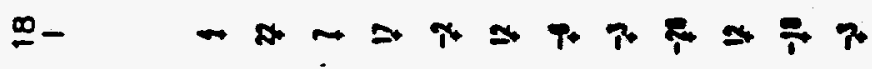

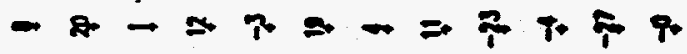

$$
\begin{aligned}
& \text { ㄴ-1 T }
\end{aligned}
$$

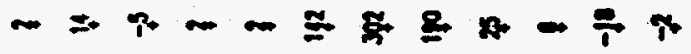

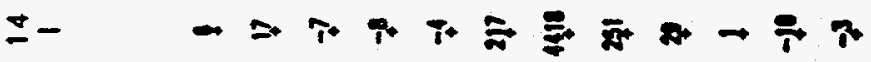

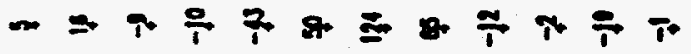

$$
\begin{aligned}
& \text { - } \quad \text { - }
\end{aligned}
$$

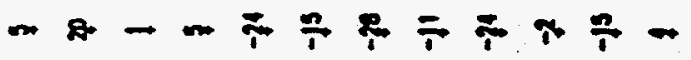

$$
\begin{aligned}
& \text { 으 } \quad-\infty-\infty \frac{2}{1}-\frac{2}{1}+\frac{2}{1} \gamma \\
& \text { ․ } 2- \pm 9 \div \div \div-\frac{1}{1}
\end{aligned}
$$

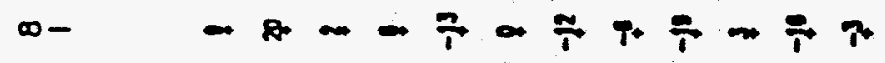

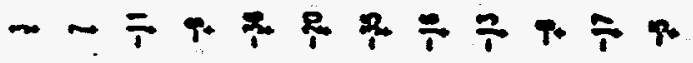

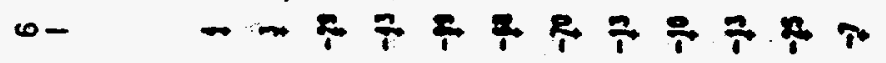

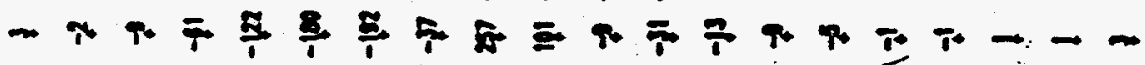

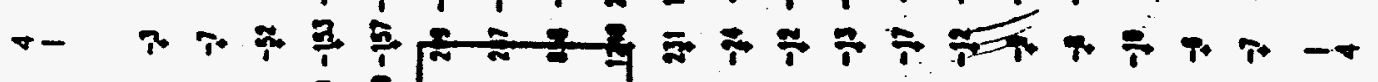

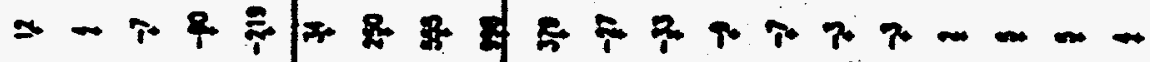

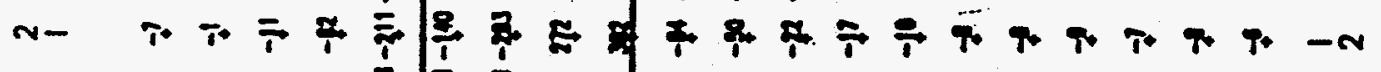

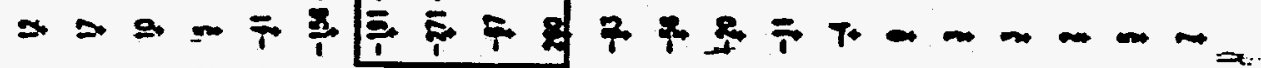

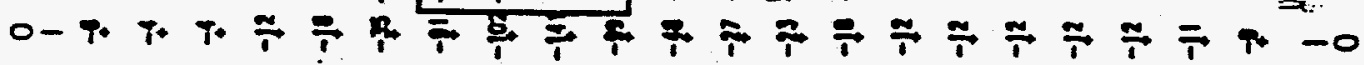

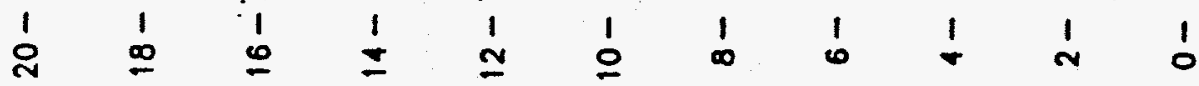

$$
\begin{aligned}
& -2 \\
& -ㅇ \\
& -\infty \\
& -\infty
\end{aligned}
$$




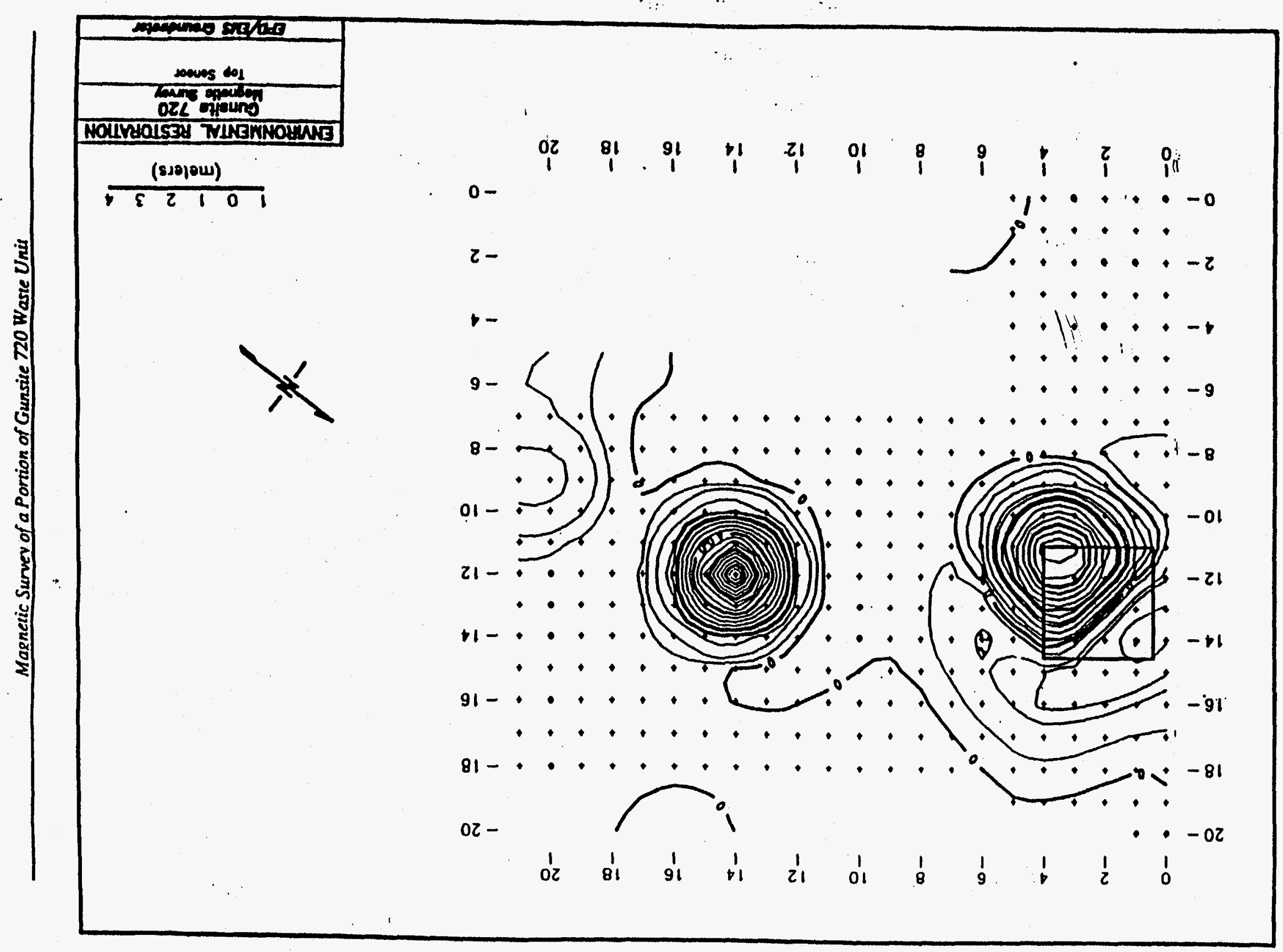


Gunsite 720 Rubble Pit Unit

RFI/RI Report
WSRC-RP-95-360, Rev. 1 ili287 2

March 1996

\section{APPENDLX B}

ANALYTICAL DATA AND QAVC EVALUATION RESULTS

B-1 
Gunsite 720 Rubble Pit Unit

WSRC-RP-95-360, Rev. 1

RFI/RI Report

March 1996

THIS PAGE INTENTIONALLY LEFT BLANK

B-2 


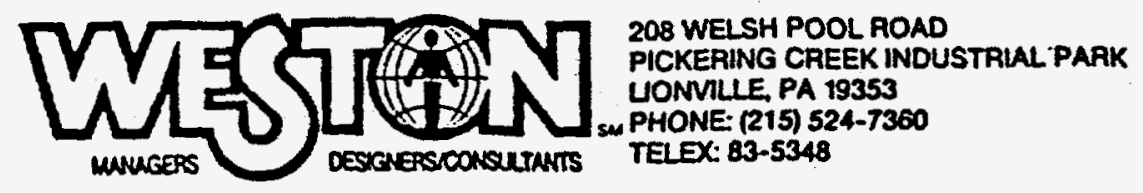

14 May 1990

Mr. Howard Hickey

Westinghouse Savannah River Company

Building 740-3A

Aiken, SC 29808

Re: Analytical results for samples collected at Gunsite 720 (RFW batches 90024603 and 604 )

Dear Mr. Hickey:

Enclosed are the analytical results for WSRC release order 13 , Gunsite 720 . These results consist of an electronic data: deliverable, and a standard comercial report which includes a case narrative sumarizing QA/QC results.

If we can provide any further information, please feel free to contact myself or Ben Shapiro.

very truly yours,

ROY F . WESTON, INC.

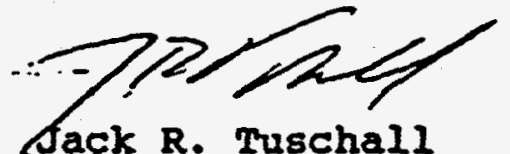

Laboratory Manager

Analytics Division

JRT/CIK

Enclosure:

cc: Michelle Wilson

David Oliphant

Ben Shapizo 
WESTON ANALYTICS

IIONVIITE, PA

DATA TRANSFER RECORD
SHEET 1 OF 1

DISK 1 OF 1

IIMS
WAIIS
INITIAI
CORRECTED
OTHER -

ELECTRONIC $\mathbf{X}$

HARD COPY -

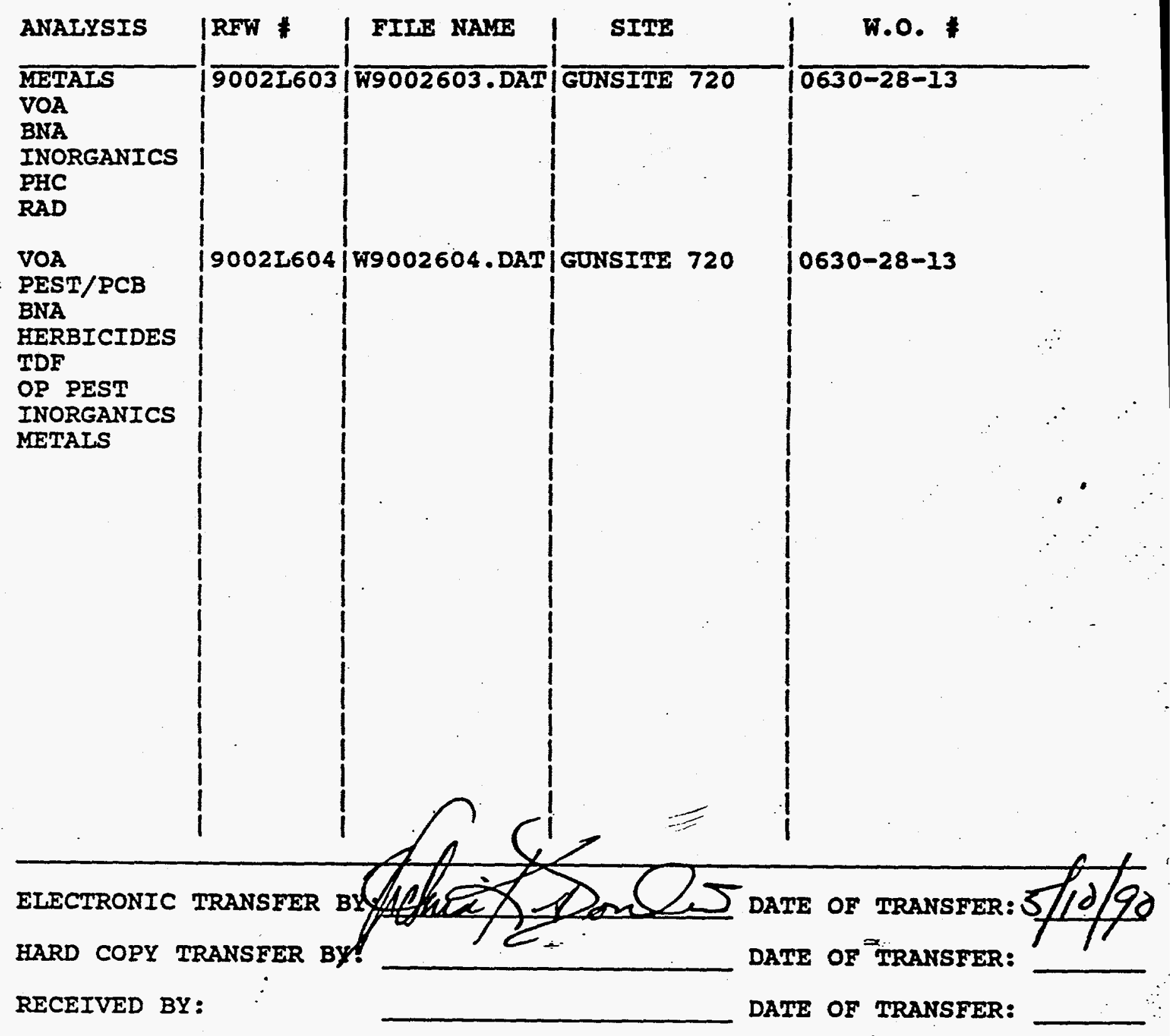


Roy F. Weston, Inc. - Llonville Laboratory

voA anALYTICal Data pactags gor WSRC CUNSITE 720

DATE RECEIVED: 02/16/90

REW IOT * :9002L604

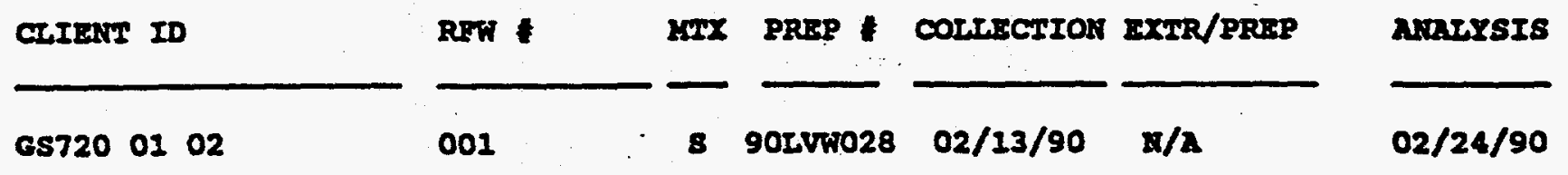

IAB QC:

VBLR

YCBI

s 90LVพ028

N/A

$\mathbf{n} / \mathbf{A}$

$02 / 24 / 90$ 


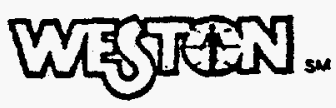

ROY I. NESTOR, IXC.

Ifonville Laboratory

CLIENT: WSRC GUNSITE 720

RFW : $9002 L 604$, GC/MS VOIATIIE

BAMPLEB RBCEIVED: 02-16-90

7.0. : : 0630-28-13

\section{MARRATIYE}

The set of samples consisted of one soil sample collected on $02-13-90$.

The sample was analyzed according to criteria set forth in SW 846 Method 8240 for Appendix IX Volatile target compounds on 02-24-90.

The following is a summary of the QC results accompanying these sample results and a description of any problems encountered during their analysis:

1. Non-target compounds were not detected in this sample.

2. All surrogate recoveries are within EPA QC limits.

3. The blank contains Met: he chioride and Acetone at levels less tha: " the CRQL.

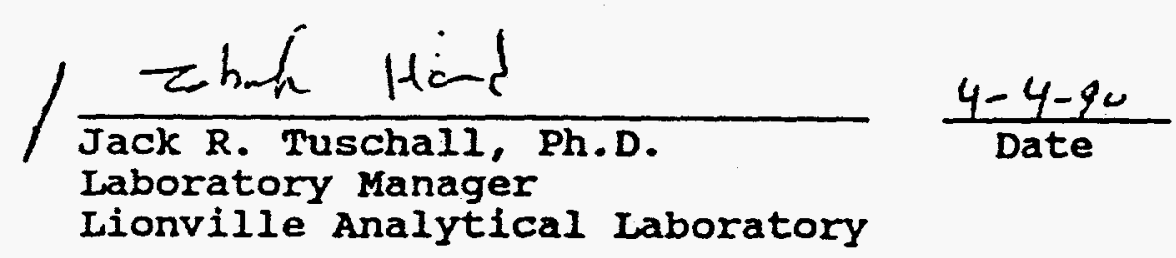


Roy I. Wenton, Ino. - onville Laboratory

Volatiles by $\mathrm{CC} / \mathrm{K}$, Appendix IX Liet

Cust ID\& G8720 0102 VBLK

\begin{tabular}{|c|c|c|c|}
\hline $\begin{array}{l}\text { Bample } \\
\text { Information }\end{array}$ & $\begin{array}{r}\text { RHW: } \\
\text { Matrix: } \\
\text { D.P.: } \\
\text { Unites }\end{array}$ & $\begin{array}{l}001 \\
\text { soIL } \\
0.986 \\
\text { UG/KG }\end{array}$ & $\begin{array}{c}\text { 90LVWO28-KB1 } \\
\text { sOIL } \\
1.00 \\
\text { UG/KG }\end{array}$ \\
\hline
\end{tabular}

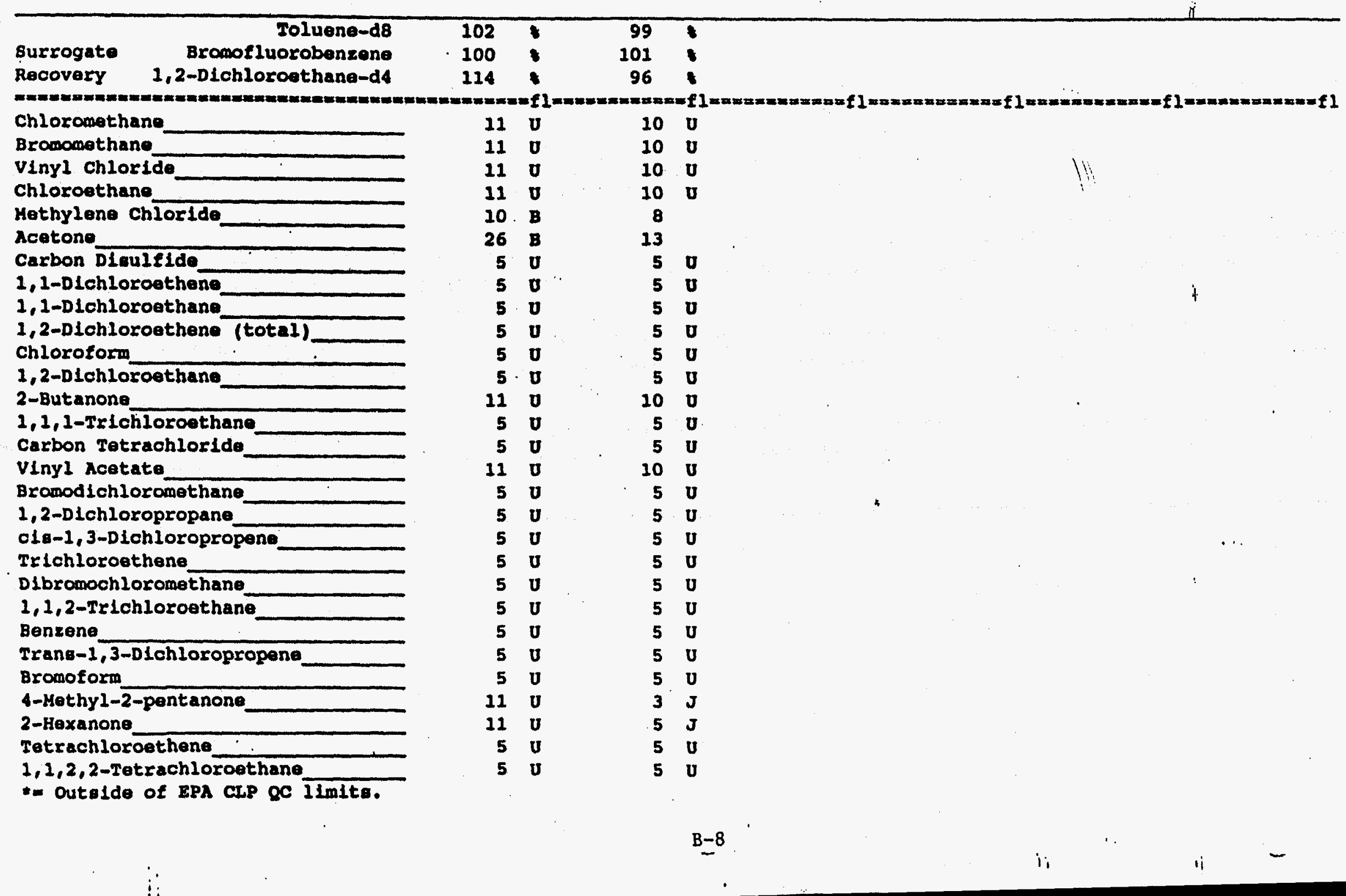


RกN"

001 90LVพ028-24B1.

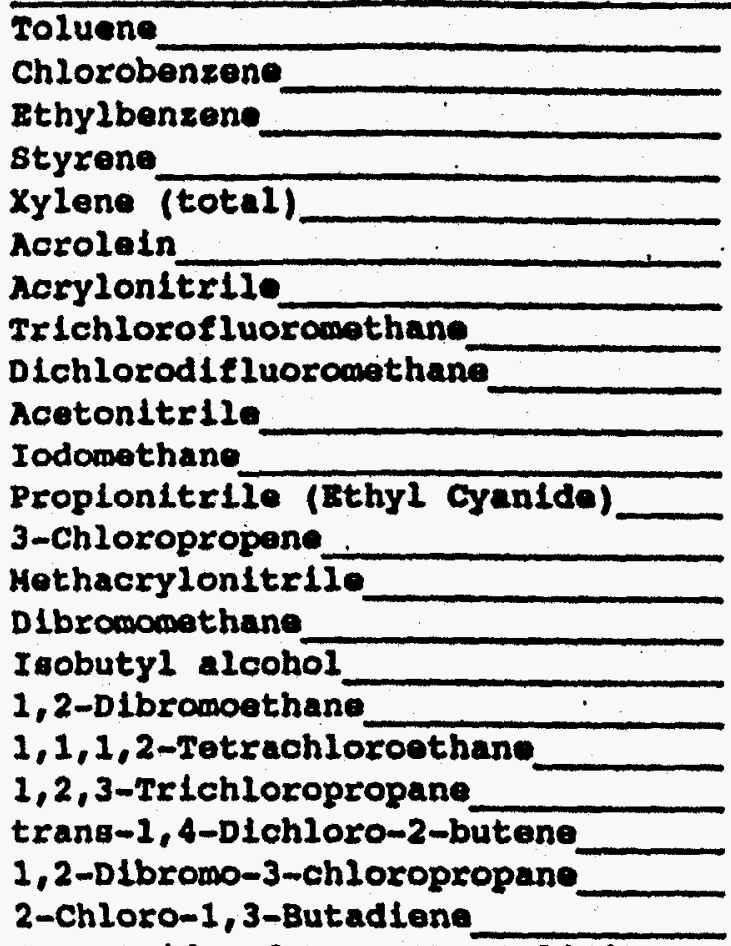

*= Outside of EPA CLP OC IImite.

\begin{tabular}{|c|c|c|c|}
\hline 5 & $\mathbf{0}$ & 5 & $\mathbf{0}$ \\
\hline 5 & $\mathbf{0}$ & 5 & $\mathbf{0}$ \\
\hline 5 & $\mathbf{v}$ & 5 & $\mathbf{v}$ \\
\hline 5 & $\mathbf{U}$ & 5 & $\mathbf{U}$ \\
\hline 5 & $\mathbf{u}$ & 5 & $\mathbf{U}$ \\
\hline 11 & $\mathbf{v}$ & 10 & $\mathbf{U}$ \\
\hline 11 & $\mathbf{0}$ & 10 & $\mathbf{v}$ \\
\hline 2 & $\boldsymbol{J}$ & 5 & $\mathbf{U}$ \\
\hline 11 & $\mathbf{u}$ & 10 & $\mathbf{U}$ \\
\hline 21 & $\mathbf{u}$ & 20 & $\mathbf{U}$ \\
\hline 11 & $\mathbf{0}$ & 10 & $\mathbf{v}$ \\
\hline 54 & $\mathbf{v}$ & 50 & $\mathbf{U}$ \\
\hline 21 & $\mathbf{U}$ & 20 & $\mathbf{U}$ \\
\hline 21 & $\mathbf{v}$ & 20 & $\mathbf{u}$ \\
\hline 11 & $\mathbf{U}$ & 10 & $\mathbf{U}$ \\
\hline 21 & $\mathbf{u}$ & 20 & $\mathbf{u}$ \\
\hline 21 & $\mathbf{v}$ & 20 & $\mathbf{v}$ \\
\hline 11 & $\mathbf{U}$ & 10 & $\mathbf{0}$ \\
\hline 21 & $\mathbf{0}$ & 10 & $\boldsymbol{v}$ \\
\hline 54 & $\mathbf{U}$ & 50 & $\mathbf{U}$ \\
\hline 21 & $\mathbf{v}$ & 20 & $\mathbf{v}$ \\
\hline 110 & $\mathbf{v}$ & 100 & $\mathbf{v}$ \\
\hline
\end{tabular}




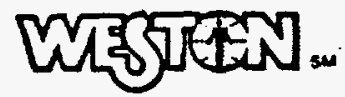

ROY $F$. MESTON, INC.

Lionville Laboratory

CLIENT: WSRC - GUNSITE 720

RFW : : 9002L604, GC/MS SEMIVOLATILE

ข.0. : $0630-28-13$

BAMPLES RECEIVED: $02-16-90$

MARRATIVE

The set of samples consisted of one soil sample collected on 0213-90.

The sample wa extracted on $02-26-90$ and analyzed according to criteria set forth in Method 8270 for Appendix IX Semivolatile target compounds on 03-07-90.

The following is a summary of the QC results accompanying these sample results and a description of any problems encountered. during their analysis:

1. Non-target compounds were detected in these samples.

2. All surrogate, matrix and blank spike recoveries are within EPA QC limits.

$\frac{c h-k \leqslant f}{\text { Jack R. Tuschall, Ph.D. }}-\frac{4-16-90}{\text { Date }}$

$=$

Laboratory Manager

Iionville Analytical Laboratory

ema/erva2-604b.cn 


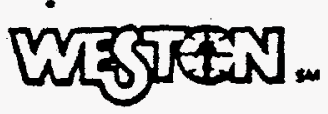

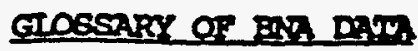

\begin{abstract}
DATA OUATIFIERS
$U=$ compound was analyzed for but not detected. The associated numerical value is the estimated sample quantitation limit which is included and corrected for dilution and percent moisture.

$\mathrm{J}=$ Indicates an estimated value. This $\log$ is used either when estimating a concentration for tentatively identified campounds where a 1:1 respanse is assemed or when the mass spectral data indicate the presence of a compound that meets the identification criteria but the result is less than the specified detection limit but greater than zero; for example, if the limit of detection is $10 \mathrm{ug} / \mathrm{L}$ and a concentration of 3 $u g / L$ is calculated, it is reported as $3 \mathrm{~J}$.

$B=$ This flag is used when the analyte is found in the associated blank as well as in the sample. It- indicates possible/probable blank contamination. This flag is also used for a IIC as well as for a positively identified TCL compound.

$E$ - Indicates that the compound was detected beyond the calibration range and was subsequently analyzed at a dilution.

$I=$ Interference.

A = Aldol condensation Product.

$x=$ Additional qualifiers used as required are explained in the case, narrative.

NQ = Result qualitatively confinmed but not able to quantify.
\end{abstract}

\section{ABEREVIATIONS}

BS = Indicates blank spike in which reagent grade water is spiked with the CIP matrix splking solutions and carried through all the steps in the method. Spike reooveries are reported.

BSD = Indicates blank spike duplicate.

wS = Indicates atrix spike.

MSD = Indicates matrix spike duplicate.

DL = Indicates that surrogate reooveries were not obtained because the extract had to be dilitited for analysis.

NA = Not applicable.

DF = Dilution factor.

$N R=$ Not required. 
Cust ID: G8720 $0102 \quad 687200102 \cdot 687200102 \quad$ SBLK . SBLX Bs

sample

Information

\begin{tabular}{|c|c|c|c|c|c|}
\hline $\begin{array}{r}\text { Ret:8 } \\
\text { Uatrlx: } \\
\text { D.F.8 } \\
\text { Unltes }\end{array}$ & $\begin{array}{c}001 \\
8011 \\
1.11 \\
u g / k g\end{array}$ & $\begin{array}{c}001 \text { REP } \\
\text { SOIL } \\
1.11 \\
\text { ug/Kg }\end{array}$ & $\begin{array}{c}001 \mathrm{Ks} \\
\text { soIL } \\
1.11 \\
u g / \mathrm{Kg}\end{array}$ & $\begin{array}{c}\text { 90LiB0272-KBI } \\
\text { sOIL } \\
1.11 \\
\mathrm{ug} / \mathrm{Kg}\end{array}$ & 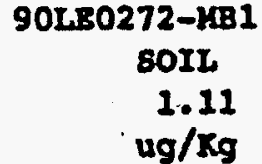 \\
\hline
\end{tabular}

\begin{tabular}{|c|c|}
\hline $\begin{array}{l}\text { 8urrogate } \\
\text { Recovery }\end{array}$ & $\begin{array}{r}\text { N1trobenzene-d5 } \\
\text { 2-Fluoroblphenyl } \\
\text { p-Terphenyl-d14 } \\
\text { Phenol-d5 } \\
\text { 2-Fluorophenol } \\
\text { 6-Tribromophenol }\end{array}$ \\
\hline
\end{tabular}

56
63
73
68
60
57

$\begin{array}{l:l}47 & \\ 57 & \\ 71 & \\ 56 & \end{array}$

Phonol

bis (2-Chloroothy1)athar

$390 \mathrm{v}$

2-Chlorophenol

1,3-Dichlorobenzene

$390 \mathrm{v}$

1,4-Dichlorobenzene

$390 \mathrm{U}$

390 U

Benzyl alcohol

390 v

1,2-Dichlorobenzene

2-Hethylpheriol

bis(2-Chlorol sopropyl)ether

4-Methylphenol

N-Nitroso-DI-n-propylamine

Hexachloroethane

Nitrobenzene

Isophorone

2-Nitrophenol

2,4-Dimethylphenol

Benzolc acld

b18(2-Chloroethoxy) wethane

2, 4-Dichlorophenol

1,2,4-Trichlorobenzene

Naphthalene

4-Chloroaniline

Hexachlorobutadiene

4-Chloro-3-methylphenol

2-Methylnaphthalene

Hexachlorocyclopentadiene

390 ०

390 U

$390 \mathrm{U}$

3900

390 v

$390 \mathrm{~V}$

$390 \mathrm{~V}$

390 v

$390 \mathrm{v}$

$390 \mathrm{U}$

$390 \mathrm{v}$

$2000 \mathrm{~V}$

390 U

3900

$390 \mathrm{U}$

3900

$390 \mathrm{U}$

$390 \mathrm{U}$

$390 \mathrm{U}$

$390 \mathrm{U}$

$390 \mathrm{U}$

48
57
70
61
51
56

$\begin{array}{lll:}68 & 68 \\ 76 & & 75 \\ 91 & & 87 \\ 71 & 78 \\ 55 & 6 & 68 \\ 42 & 59 \\ 370 \quad 0 & 61\end{array}$

" = Outgide of EPA CLP QC IImita.

$\begin{array}{rl}400 & U \\ 400 & U \\ 400 & U \\ 400 & U \\ 400 & U \\ 400 & U \\ 400 & U \\ 400 & U \\ 400 & U \\ 400 & U \\ 400 & U \\ 400 & U \\ 400 & U \\ 400 & U \\ 400 & U \\ 400 & U \\ 2000 & U \\ 400 & U \\ 400 & U \\ 400 & U \\ 400 & U \\ 400 & U \\ 400 & U \\ 400 & U \\ 400 & U \\ 400 & U\end{array}$

63
380

$380 \mathrm{u}$

57

3800

50

$380 \mathrm{U}$

$380 \mathrm{U}$

380 v

380 v

$380 \quad 0$

46

$380 \quad \mathrm{U}$

380 . U

$380 \mathrm{U}$

$380 . v$

$380 \mathrm{U}$

$1900 \mathrm{U}$

$380 \mathrm{U}$

$380 \mathrm{U}$

60 .

$380 \mathrm{U}$

$380 \quad \mathrm{U}$

$380 \mathrm{v}$

61

$380 \mathrm{U}$

$380 \quad \mathrm{~V}$

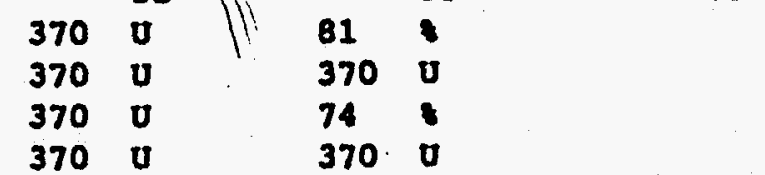

$370 \mathrm{v}$

370 v

3700

370.0

74

370 vi:

$\begin{array}{llll}370 & \mathrm{u} & 370 & 0\end{array}$

3700

$370 \mathrm{U}$

$370 \mathrm{v} \quad 370 \mathrm{U}$

$\begin{array}{llll}370 & \mathrm{U} & 370 & \mathrm{U}\end{array}$

$\begin{array}{lll}370 & 0 & 63\end{array}$

$370 \mathrm{v} \quad 3700$

$370 \mathrm{v}-370 \mathrm{v}$

$\begin{array}{llll}370 & 0 & 370 & 0\end{array}$

$\begin{array}{llll}370 & 0 & 370 & 0\end{array}$

$\begin{array}{llll}370 & \mathrm{U} & \mathbf{3 7 0} & \mathrm{U}\end{array}$

$370 v \quad 370 v$

$370 \mathrm{v}$

$1800 \mathrm{~V}$

$370 \cdot \mathbf{U}$

$370 \mathrm{U}$

$370 \mathrm{v}$

$370 \mathrm{v}$

$370 \mathrm{v}$

370 v

$370 \mathrm{v}$

$370 \mathrm{U}$

$370 \mathrm{U}$

$1800 \mathrm{U}$

3700

370 U

88 \&

$370 \mathrm{U}$

$370 \mathrm{U}$

$370 \mathrm{U}$

76

370 U

$370 \mathrm{~V}$

$-$ 
thunc wSKC GUNSITE 720

Work Order: 0630-28-13-0000

Pagas 1b Cust ID\& $687200102 \quad 687200102$ 68720 0102 BBLK BBLK BS

RFW18 $001 \quad 001$ REP 001 MS 90LE0272-KB1 90L50272-KB1

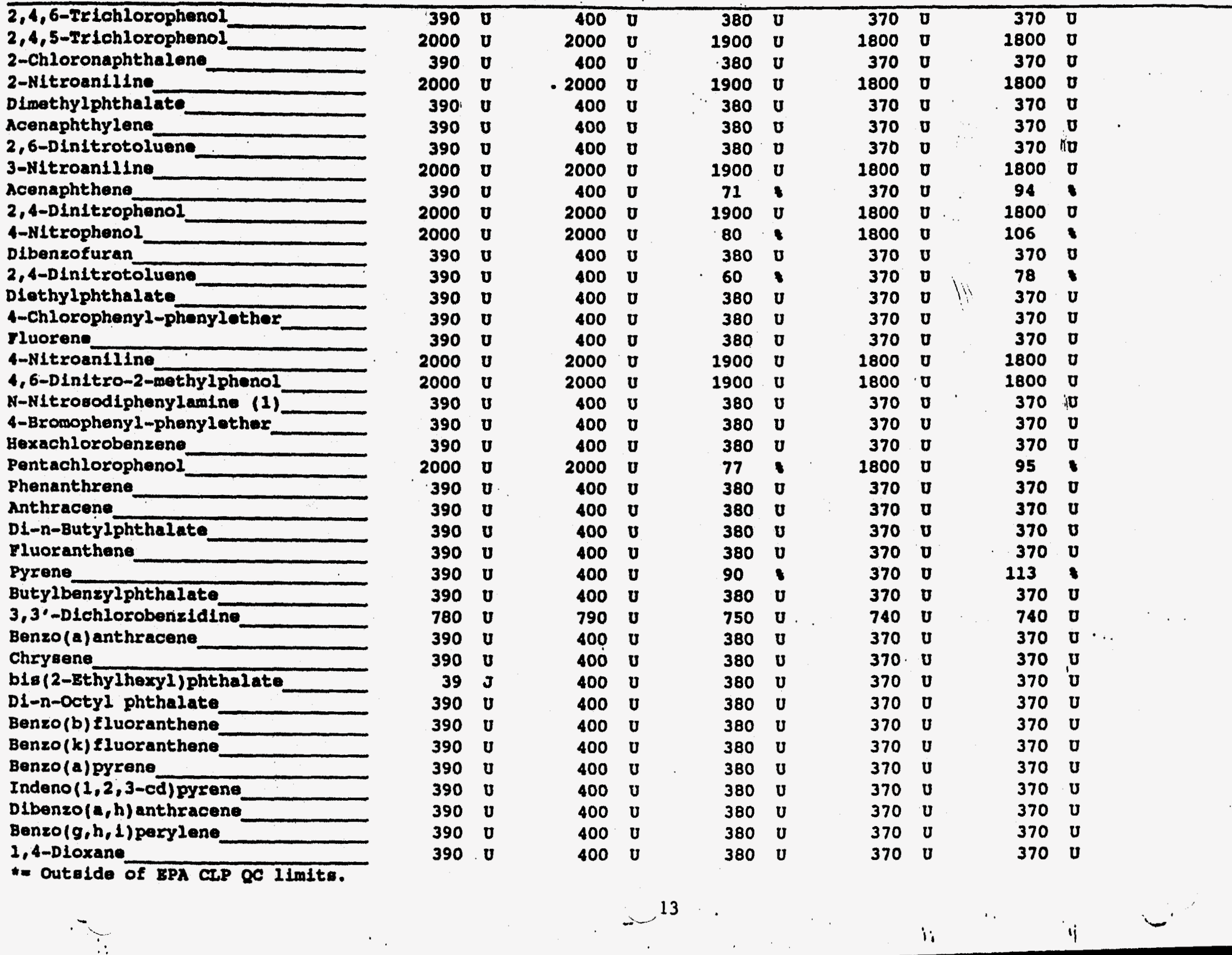



Po $687200102 \quad$ SBLK SBLK BS Cuet ID: G8720 $0102 \quad 6872001$

90T50272-18B1

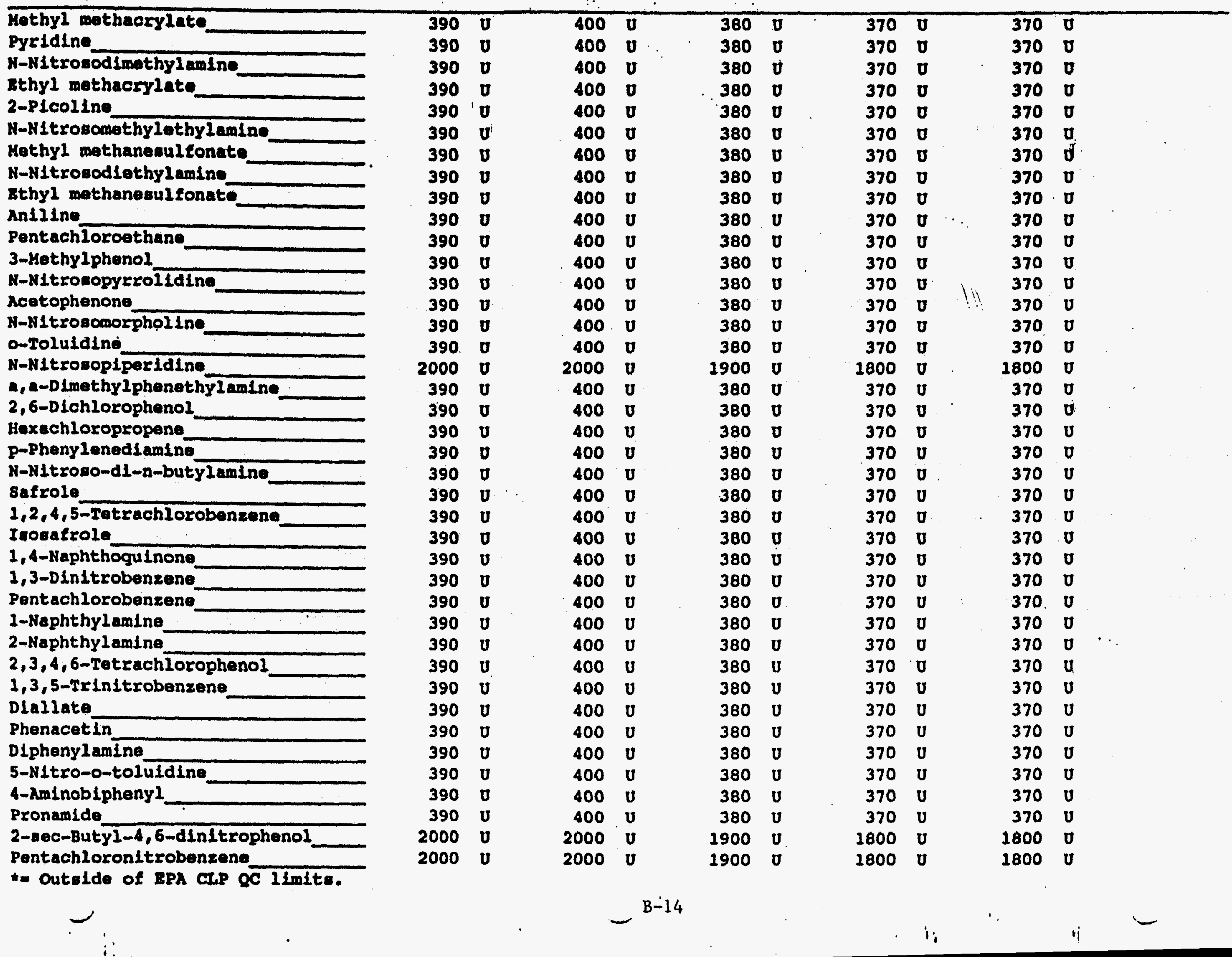




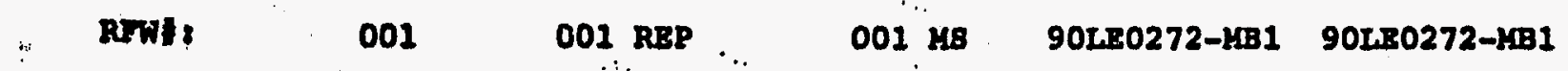

\begin{tabular}{|c|c|c|c|c|c|c|c|c|c|c|}
\hline 4-N1troquinoline-1-oxide & 780 & $\mathbf{0}$ & 790 & $\mathbf{0}$ & 750 & $\mathbf{0}$ & 740 & $\mathbf{v}$ & 740 & $\mathbf{0}$ \\
\hline Mothapyrileno & 390 & $\mathbf{v}$ & 400 & $\mathbf{u}$ & 380 & $\mathbf{v}$ & 370 & $\mathbf{v}$ & 370 & $\mathbf{0}$ \\
\hline Aranlta & 780 & $\mathbf{0}$ & 790 & $\mathbf{v}$ & 750 & $\mathbf{0}$ & 740 & $\mathbf{0}$ & 740 & $\mathbf{0}$ \\
\hline Chlorobenzllate & 390 & $\mathbf{u}$ & 400 & $\mathbf{0}$ & 380 & $\mathbf{v}$ & 370 & $\mathbf{v}$ & 370 & $\mathbf{0}$ \\
\hline P-DLmethy laminoszobenzene & $390^{\prime}$ & $\boldsymbol{0}$ & 400 & $\mathbf{0}$ & 380 & $\mathbf{0}$ & 370 & $\mathbf{0}$ & 370 & $\mathbf{0}$ \\
\hline 3,3'-DlmothylbansLldne & 390 & $\mathbf{U}$ & 400 & $\mathbf{v}$ & 380 & $\mathbf{0}$ & 370 & $\mathbf{0}$ & 370 & 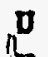 \\
\hline 2-ncotylaminolluorene & 390 & $\mathbf{0}$ & 400 & $\mathbf{v}$ & 380 & $\mathbf{0}$ & 370 & $\mathbf{0}$ & 370 & b \\
\hline 7,12-D lnothylbens (a) anthracene & 390 & $\mathbf{v}$ & 400 & $\mathbf{v}$ & 380 & $\mathbf{0}$ & 370 & $\mathbf{0}$ & 370 & $\mathbf{0}$ \\
\hline Hexachlorophene & 3500 & $\mathbf{0}$ & 3600 & $\mathbf{0}$ & 3400 & $\mathbf{0}$ & 3300 & $\mathbf{0}$ & 3300 & $\mathbf{0}$ \\
\hline 3-Kethy Loholanthrono & 390 & $\mathbf{0}$ & 400 & $\mathbf{0}$ & 380 & $\mathbf{0}$ & 370 & $\mathbf{0}$ & 370 & $\mathbf{0}$ \\
\hline
\end{tabular}

(1) - Cannot be epparated Exom Diphenylamine. t- Outalde of EPA CLP QC IImita. 
Iab vames Roy F. Weston. Inc. Work Order: 0630-28-13-0000

Client: WSRC GUNSITE 720

Matrixs

SOII.

Sample wt/vols $30.8(g / \mathrm{mt}) \mathrm{G}$

Level: (Low/med) IOP

- Moletures not dee. 8 dec.

sxtractions (Sepr/Cont/sonc) sore

GPC Cleanups (Y/N) $Y$ pH: +7.0
Lab Sample ID: 9002L604-001

Lab File ID: M030707

Date Recelved: 02/16/90

Date Extractedz $\underline{02 / 26 / 90}$

Date Analyzed: 03/07/90

Dilution Factor: 1.11

Number TICs found: 5

CONCENIRATIOR ONITS:

(ug/L or ug/ $\mathrm{kg}$ ) ua $/ \mathrm{Kg}$

\begin{tabular}{|c|c|c|c|c|}
\hline CAS NUMBER & 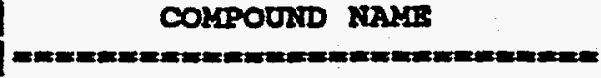 & $\begin{array}{c}R T \\
=m=m=m=0\end{array}$ & IST. CONC. & Q \\
\hline 1. & AIDOL CONDENSATE & 5.37 & 300 & $\boldsymbol{N}$ \\
\hline 2. & ALDOL CORDENSATE & 5.85 & 12000 & JAB \\
\hline 3. & ALDOL CONDENSATE & 6.55 & 1900 & JAB \\
\hline 4. & |ALDOL CONDENSATE & 7.57 & 1500 & $\boldsymbol{\pi}$ \\
\hline 5 . & onrrarown & 19.17 & 1200 & $\boldsymbol{J}$ \\
\hline
\end{tabular}


27

SEMIVOLATILE ORGANICS ANALYSIS SERAT TENTATIVELY IDENTIFIHD COMPOULDS

Lab Name: Roy $F$, Weston, Inc, Work Order: 0630-28-13-0000

GS720 01 02REP

Cllent: WSRC GUNSITE 720

Matrix:

Sample wt/vol:

soIr

$30,2(g / m$ r $)$

$\boldsymbol{E}$

Level: (low/med) LON 8 dec.

roletures not dec.

Extraction:

(Sepr/cont/sonc)

sone

GPC Cleanup: $(\Psi / N) I$ pas $\quad 7.0$
Lab sample IDs 20021604-001 REP

Iab FL10 ID2 Y030709

Date Recelved: 02/16/90

Date Ixtracted: 02/26/90

Date Analyzed: 03/07/90

Dilution Factor: 1.11

Number TICs found: 5

CONCENIRATIOA UNITS:

(ug/L or ug/ $\mathrm{kg}$ ) $\mathrm{ug} / \mathrm{Kg}$

\begin{tabular}{|c|c|c|c|c|}
\hline CAS NUABER & COMPOUND KANR & RT & EST. Covic. & $\mathbf{Q}$ \\
\hline 1. I & Jaknowa & 5.32 & 1200 & $\mathbf{J}$ \\
\hline 2 . & ATDOC CONDEMSATE & 5.82 & 12000 & JAB \\
\hline 3. & AIDOL CONDENSATE & 6.52 & 600 & $\operatorname{JAB}$ \\
\hline 4. & |ALDOL CONDENSATE & 7.55 & 300 & JA \\
\hline 5 . & | OMRaNOWN & 19.17 & 200 & $\boldsymbol{J}$ \\
\hline
\end{tabular}


Lab Names Boy $F$. Weston, Inc, Work Orders 0630-28-13-0000

Cllent: , WSRC GUNSITE 720

\section{Matrix:}

SOIL

Sample wt/rols $30.0(\mathrm{~g} / \mathrm{mr}) \mathrm{G}$

Level:

(Low/med) Lon 0 dec.

- Molaturer not dec.

Extractions (Sepz/Cont/sonc) sokc

GPC Cleanup: $\quad(Y / N) I$ p8: 7.0
Lab sample ID: g0LE0272-MBI

Lab rile IDs

Date Recelveds 02/26/90

Date Ixtracted: 02/26/90

Date Analyzedz 03/07/90

Dllution Factor: 1.11

Number TICB found: 5

CONCENTRATIOA UNITS:

(ug/L or ug/ $\mathrm{Kg}$ ) ug/ $\mathrm{Kq}$

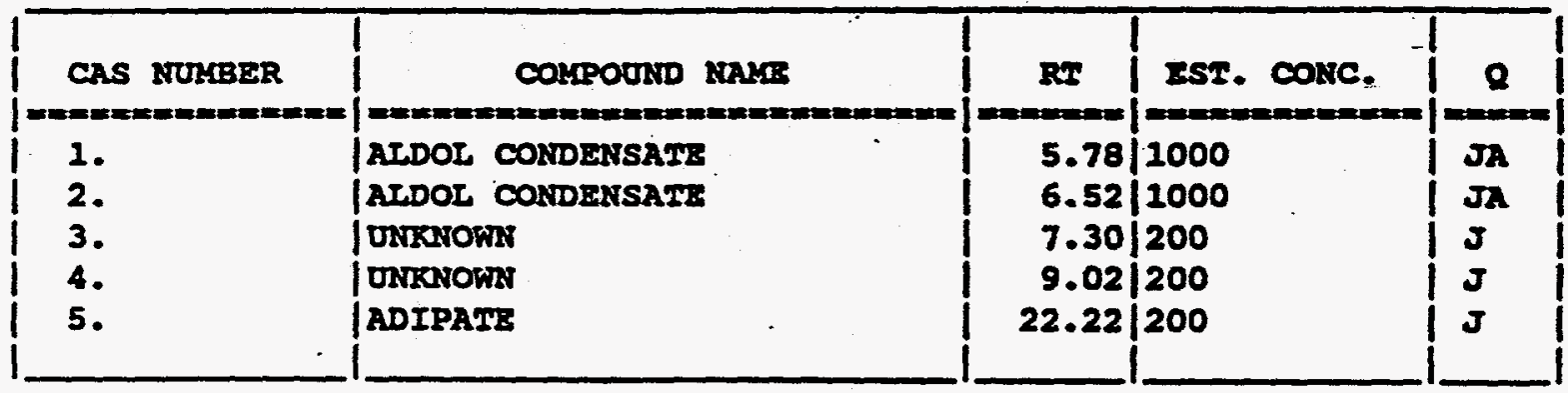


WISTEN.

\author{
GLOSBARY OF PEST LPCB DATA
}

\title{
DATÁ OUALTFERS
}

- - Indicates that the compounds was analyzed for but not detected. The minimum detection limit for the sample (not the method detection 1imit) is reported with the $U$ (e.g., 100).

$\mathrm{J}$ - Indicates an estimated value. This flag is used in cases where a target analyte is detected at a level less than the lower quantification level. If the limit of quantification is $10 \mathrm{ug} / \mathrm{L}$ and a concentration of 3 $u g / L$ is calculated, it is reported as $3 \mathrm{~J}$.

B - This flag is used when the analyte is found in the associated blank as well as in the-sample. It indicates possible/probable blank contamination. This flag is also used for a TIC as well as for a positively identified TCL compound.

8 - Indicates that the compound was detected beyond the calibration range and was subsequently analyzed at a dilution.

I - Interference.

\section{ABBREVIATIONB}

88 - Indicates blank spike in which reagent grade water is spiked with the CLP matrix spiking solutions and carried through all the steps in the method. Spike recoveries are reported.

B8D - Indicates blank spike duplicate.

M8 - Indicates matrix spike.

YSD - Indicates matrix spike duplicate.

DI - Indicates that recoveries were not obtained because the extract had to be diluted for analysis.

NA - Not applicable.

DF - Dilution factor.

NR - Not required. 
koy r. reston, Inc. - Lionv111e Laboratory

Pestlclde/PCBa GC, Appendlx IX Ilst

Report Dates $04 / 2,012,00$

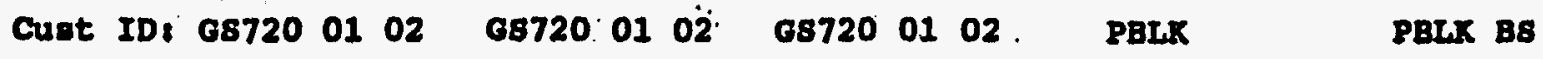

\begin{tabular}{|c|c|c|c|c|c|c|}
\hline $\begin{array}{l}8 \text { amplo } \\
\text { Information }\end{array}$ & $\begin{array}{r}\text { RPA: } \\
\text { Matrix: } \\
\text { D. B.: } \\
\text { Onits: }\end{array}$ & $\begin{array}{c}001 \\
8011 \\
1.00 \\
u g / \mathrm{Rg}\end{array}$ & $\begin{array}{c}001 \text { REP } \\
\text { SOIL } \\
1.00 \\
u g / \mathrm{Kg}\end{array}$ & $\begin{array}{c}001 \mathrm{MS} \\
\text { 80IL } \\
1.00 \\
\mathrm{ug} / \mathrm{Kg}\end{array}$ & $\begin{array}{c}\text { 90LE0272-HB2 } \\
\text { SOIL } \\
1.00 \\
\mathrm{ug} / \mathrm{Kg}\end{array}$ & $\begin{array}{c}90 \mathrm{LB} 0272-\mathrm{KB2} \\
80 \mathrm{IL} \\
1.00 \\
\mathrm{ug} / \mathrm{kg}\end{array}$ \\
\hline
\end{tabular}

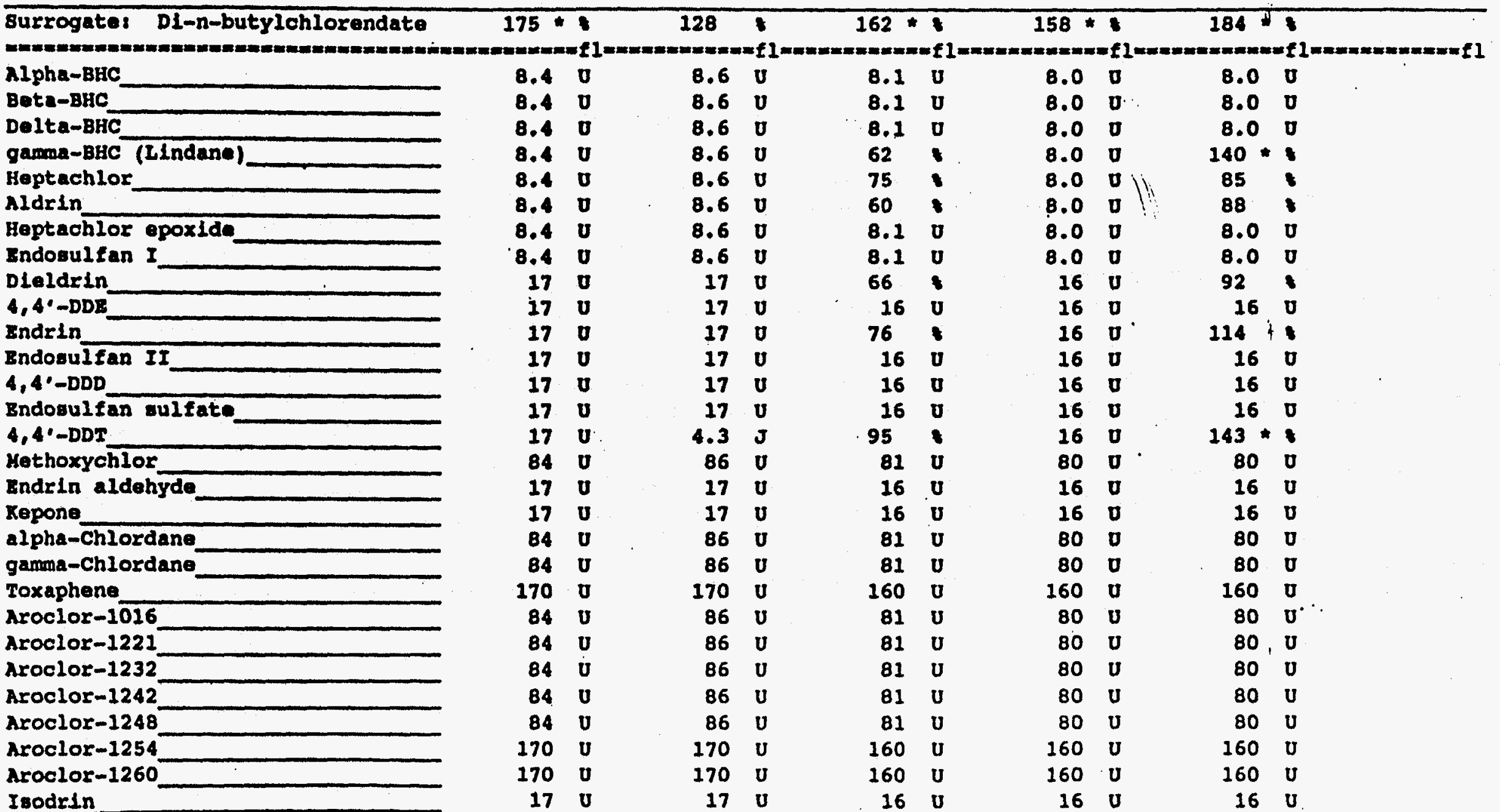

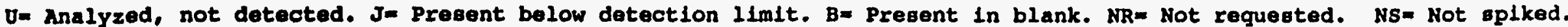
s- Percent recovery. De Diluted out. Im Interference. NA= Not Applicable. 
WESTON Andytics Uae Only $9002 L 604$ uspeloun 120 client wSPC Gunsitz 20 work order ole $30-28-1360$ Dain Roc'd. 2llla lad Dato Dux $3 / 2890$ RFW Contuct

Client ContectPhono

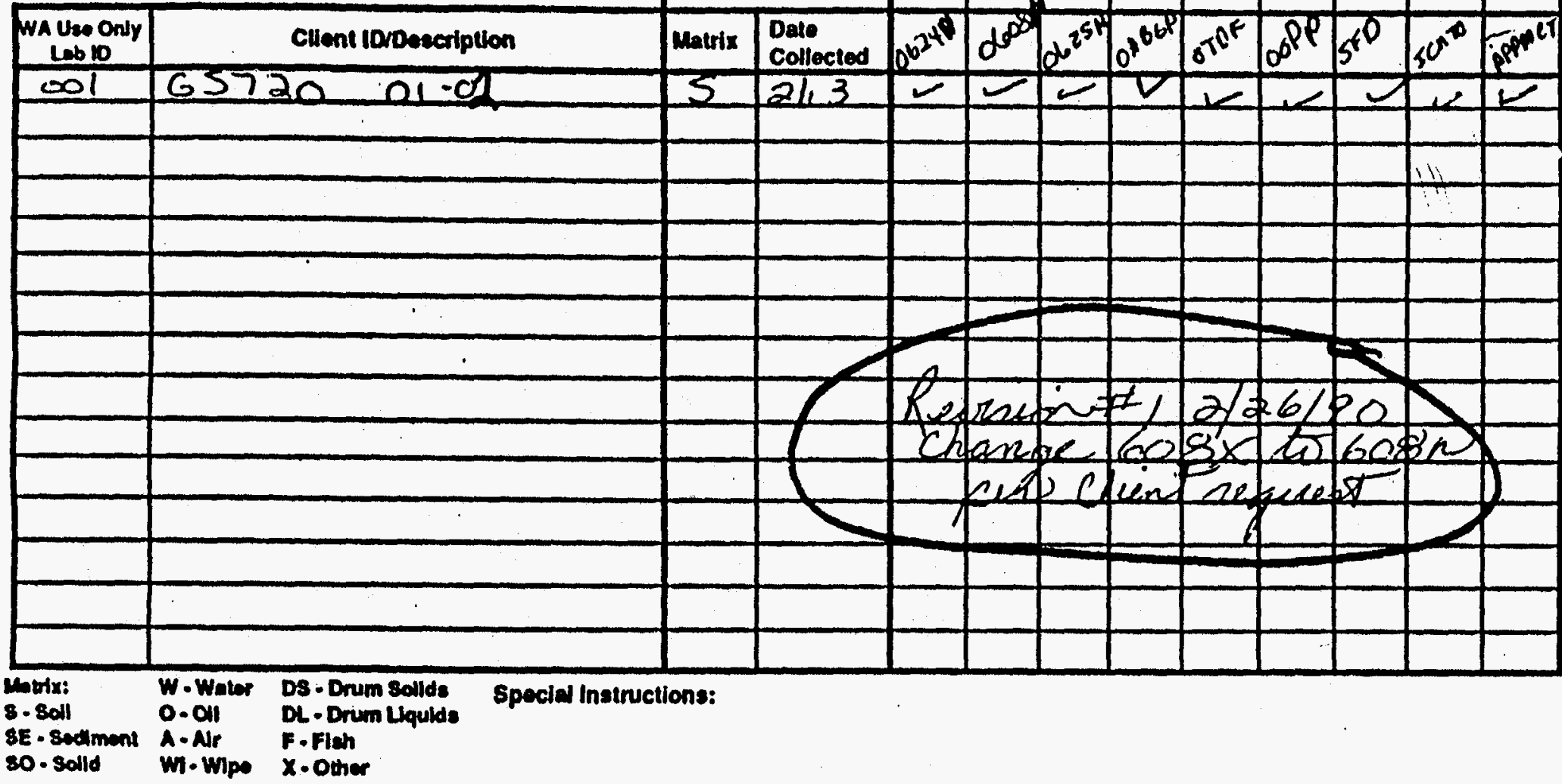

\begin{tabular}{|c|c|c|c|c|c|c|c|c|c|}
\hline Hem/Resson & Aginguilahed by & Recelved by & Dale & $\operatorname{Im}$ & Lem/Benesen & Bellinoulahed by & Beceived by & Dete & Time \\
\hline ald & & & 264 & 936 & & & & & \\
\hline 001 & & & & 0930 & & & & & \\
\hline & $\operatorname{seg} B$ & & $26>6$ & $3=$ & & & & & \\
\hline wet lab & & Dérson. & $3 / 2 /$ & 8140 & & & & & \\
\hline folos) & & TEferdich & 31210 & 1020 & & & & & \\
\hline Hestim & & Wuystuat & 5120 & 1800 & & & & & \\
\hline
\end{tabular}
RFW 21-21-001/A.7/88

Wistren

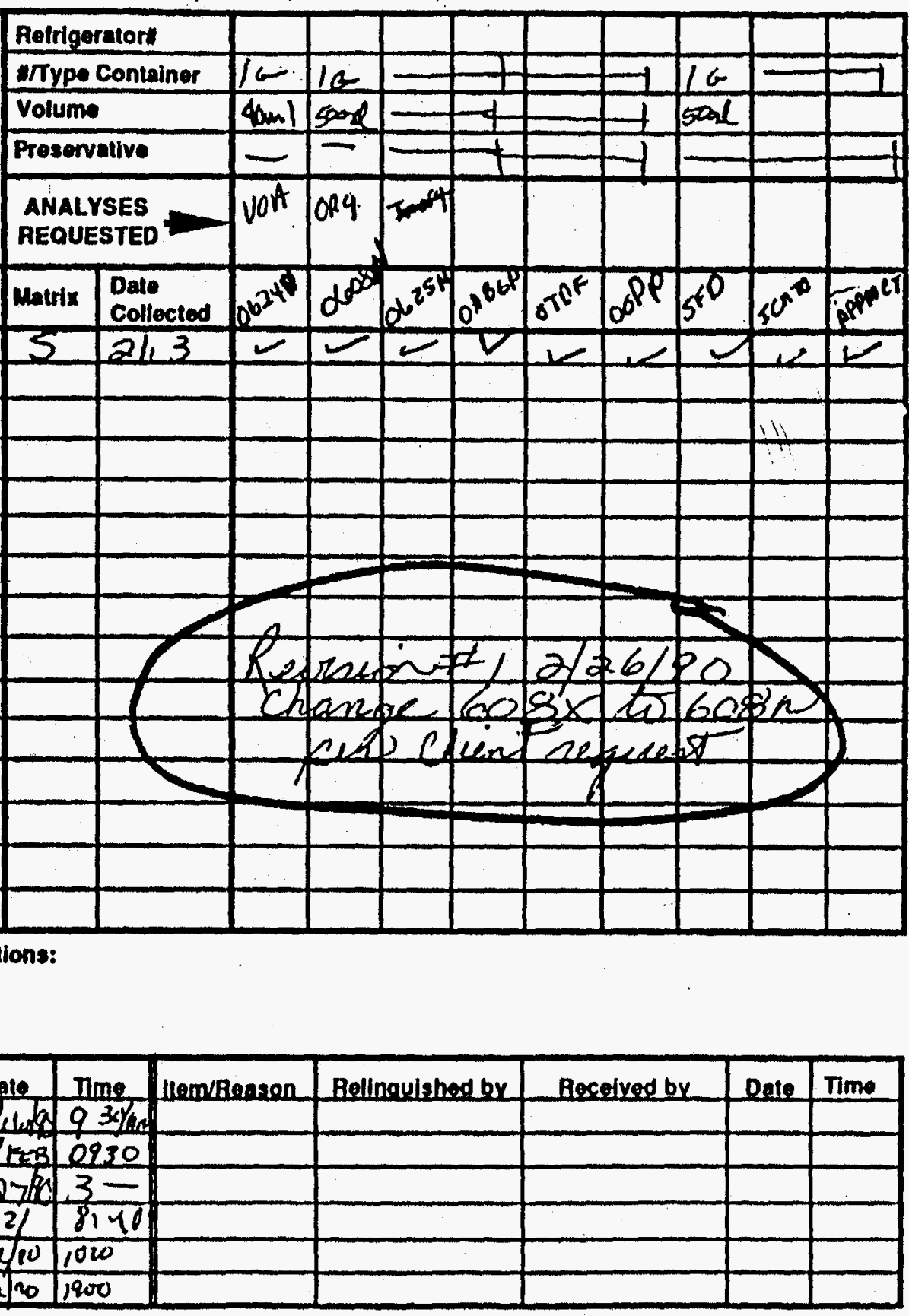

Rolrigerator:

\section{Volume}

-

Whartics

Use galy

Aamplas Wore:

1 Shipped octiand.

Delivand

NOTES:

2 Ambler for Chiled

NOTES:

3 Recoived Broken

Leaking (Improperty

Sealeol

$Y$

NOTES:

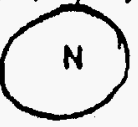

AProgerly Proserved

Nortes:

5 Recoived Within

Trading Times

wares:

COC Tapo Was:

1 Present on Quter

Packago $Y$ N

2 Unbroken on oulu

Packago ' $Y$. N

3 Present on Samo

4 Unbroken on Sampor

NOTES: $\quad Y(N)$

COC Racord Was:

1 Present yporif taceipt of Sambles $Y$

Discrepancies ofiween Sample Labels ard COC

Record?

NOTES:

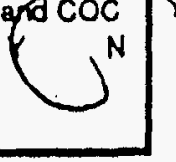

.115 
Roy F. Weston, Inc. - Llonville Laboratory PEST/PCB ANALYTICAL DATA PACARGE FOR

WSRC GUISITE 720

DATE RECEIVED: $02 / 16 / 90$

\section{CLIERT ID}

$G 57200102$

GS720 0102

GS720 0102
RFW *

001

001 REP

001 us
RFT LOT : 80021604

UTX PREP - COLLECTIOU EXTR/PREP

MarysIs

$02 / 26 / 90$

$02 / 26 / 90$

$02 / 26 / 90$

$04 / 08 / 90$

$04 / 08 / 90$

$04 / 08 / 90$

LAB QC:

PBLK

PaLK
MB2

MB2 BS $\begin{array}{ll}\text { s } & 902 \mathrm{LO272} \\ \text { s } & 90 \mathrm{LE0272}\end{array}$ $\boldsymbol{x} / \mathbf{a}$

$x / a$
$02 / 26 / 90$

$02 / 26 / 90$
- 04/08/90 04/08/90 
ROY F. WEBTOX, IXC.

Lionville Laboratory

CLIENT: WSRC GUNSITE

RFT : 9002L604, PESTICIDE/PCB

BAMPLEB RECEIVED: 02-16-90

T.0. : $0630-28-13$

\section{MARRATIVS}

The set of samples consisted of one soil sample collected on $02-13-90$.

The sample was extracted on 02-26-90 and analyzed according to criteria set forth in the contract Lab Program for Pesticide and PCB target compounds on 04-08-90.

The following is a summary of the QC results accompanying these sample results and a description of any problems encountered during their analysis:

1. The following $D B C$ surrogate recoveries are outside EPA QC Iimits:

SAMPLE ID

GS720-01-02

GS720-01-02 MS

PBLKLE0272-MB2

PBLKLE0272-MB2
\&RECOVERY

175

162

158

BS 184
UPPER IIMIT

150

150

150

150

The presence of bis(2-Ethylhexyl) phthalate interferes with the quantitation of DBC recovery.

2. The blank spike recoveries for the following compounds are outside the EPA QC limits:

COMPOUND

lindane

$4,4^{\prime}-D D T$
\&RECOVERY

140

143

\section{UPPER/LOWER IIMIT}

127

134.

3. The matrix spike recoveries are within EPA QC Iimits.

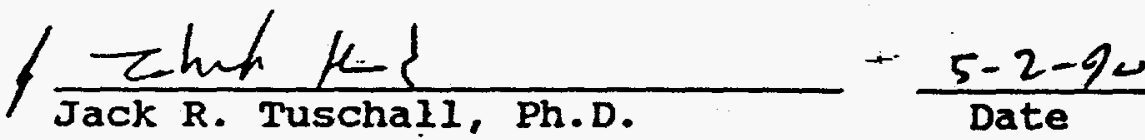

Laboratory Manager

Lionville Analytical Laboratory

in j/upmemo/02-604p.cn 
Roy F. Weston, Inc. - Ilonville Laboratory iB alALYTICAL DATA PACKAGE FOR FSRC GUNSITE 720

DATE RECEIVED: 02/16/90

RFW LOT $\$ 90022604$

CLIENT ID.

RFW * MHX PREP * COLLECTION EXTR/PREP

ARALYSIS

$65720 \quad 01 \quad 02$

001

8 90150282

$02 / 13 / 90$

$02 / 27 / 90$

$03 / 14 / 90$

IAB QC:

Park

PBIX

LBB1

MBI BS
S 90LE0282
s 90 LE0282

$\mathrm{N} / \mathrm{A}$

$02 / 27 / 90$

$n / A \cdots 02 / 27 / 90$

$03 / 14 / 90$

$03 / 14 / 90$ 


\section{WISEREN}

Roy F. Weston, Inc.

Lionville Laboratory

Client: WSRC Gunsite 720

RFW\#: 9002L604, Herbicides

พ.0.\#: $0630-28-13$

Date Received: $02 / 16 / 90$

The set of samples consisted of 1 soil sample collected on 02/13/90.

The sample was extracted on $02 / 27 / 90$ and analyzed according to criteria set forth in Method 8150 for Chlorinated Phenoxy Acid Herbicide target compounds on $03 / 14 / 90$.

The following is a summary of the QC results accompanying these sample results and a description of any problem encountered during their analysis.

1. The blank spike recoveries are within laboratory control chart warning limits.

2. No problems were encountered during these analyses.

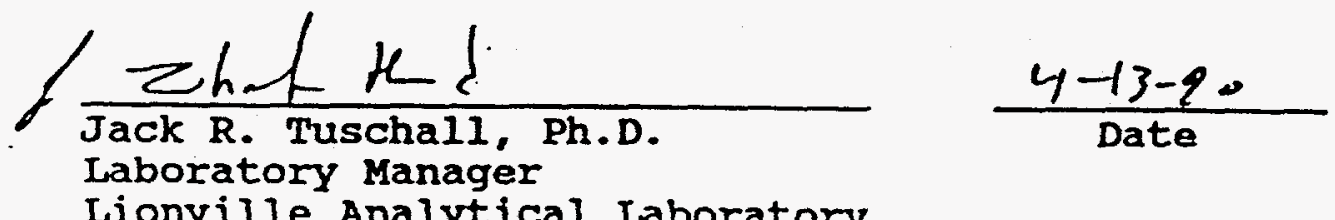


Cuat ID: $687200102 \quad$ PBux $: \cdot \cdot \cdot \quad$ PBLK B8

\section{Bample}

Information

\section{Rrit:}

Metelxs

001

D.2.8

Ondter

001
$80 I L$
1.00
$00 / 1 \times$

90LE0282-KBI $\cdot 902 B 0282-M B 1$

80IL.

vo/xo

SOIL

1.00

ve/ko

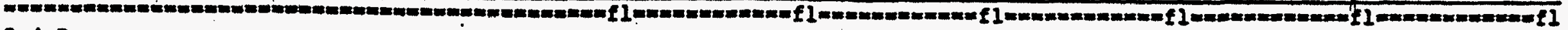

2, 4-D

$2,4,5-9 P$ (811vex)

$2,4,5-5$

220

110

110

$20 \mathrm{v}$

100

63

100

111

$!$

-

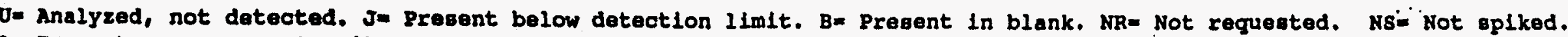

se Percent recovery. Da Dlluted out. I= Interference. NA= Not Applicable, " = Outside of BPA CLP OC 
WTESIEA

ROY P. WESTON, IXC.

Ifonvi110 Iaboratory

CIIENH: WSRC

RFW : 9002L604, PCDD/PCDF

BAMPLES RECEIVED: $02 / 16 / 90$

II.O. : 0630-28-13

MARRATIVE

The set of samples consisted of 1 soll sample. collected on $02 / 13 / 90$.

The samples were extrcted on $03 / 01 / 90$ and analyzed according to criteria set forth in Method 8280 for Tetra through Hexa PCDD/PCDF target compound on $03 / 12 / 90$.

All surrogate and blank spike recoveries are within EPA QC Iimits.

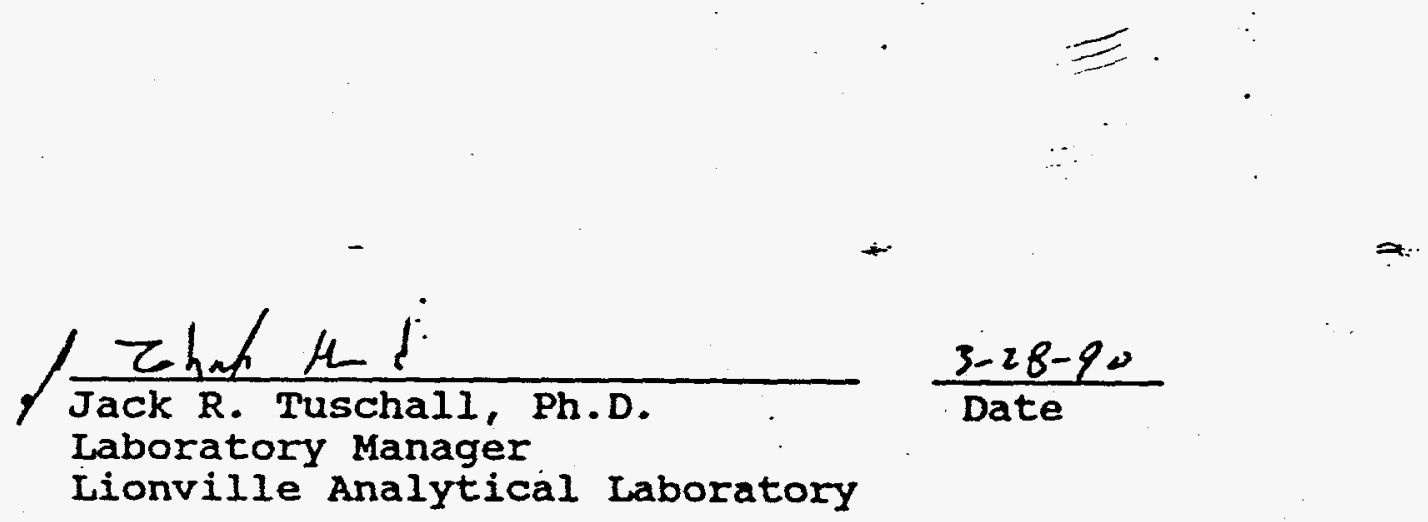


CLIENT: WSRC

BS GC/MS FILE NAME: 20312008

BSD GC/HS PILE NAME: NA

EXTRACTION BATCH NO: 90SP249

SAMPLE ID

: BS
CONTRACTOR: WESTON

DATE EXTRACTED: 03/01/90

DATE ANALYZED: 03/12/90

CLIENT ID:

BS

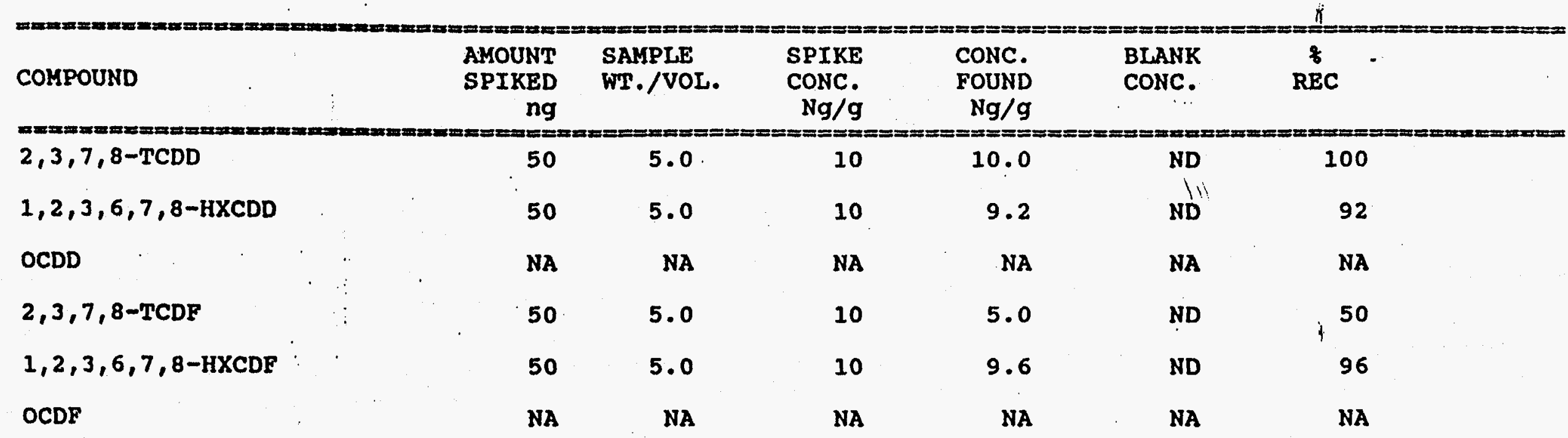




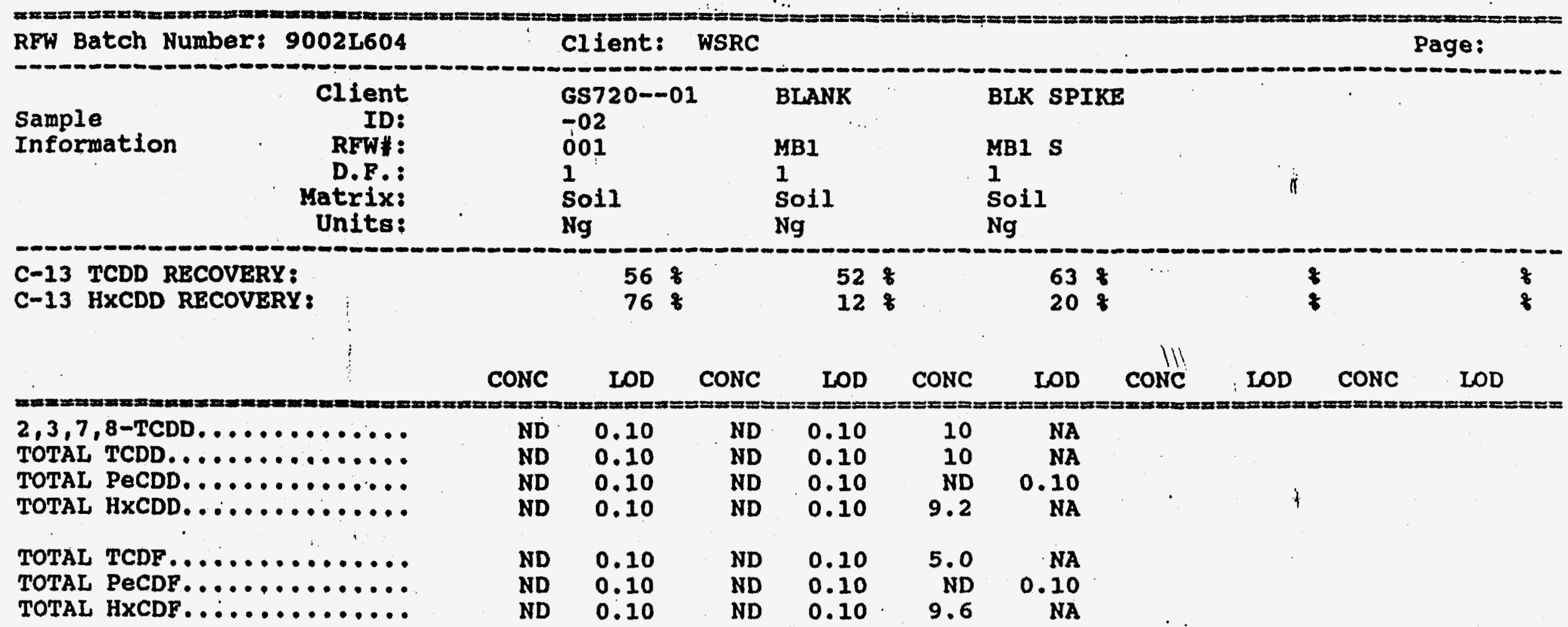

CONC CONCENTRATION

ND NONE DETECTED

NA NOT APPLICABLE

LOD LIMIT OF DETECTION 
Roy F. Weston, Inc. - Ilonville Iaboratory

OPP ANALYTICAL DATA PACKAGE JOR

WSRC GUNSITI 720

DATE RECEIVRD: $02 / 16 / 90$

CIIEAT ID

G5720 0102
RFW

001

RTH LOT +890022604

IIIX PREP * COTLECTIOA EXIR/PREP ARAYSIS

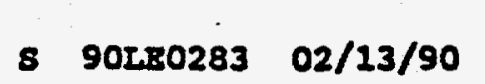

$02 / 27 / 90$

$03 / 23 / 90$

LAB QC:

PBLK

PBLR

MBI

LBI BS

5 90LE0283

8 90LE0283

\section{$x / 2$}

$x / \lambda$

$02 / 27 / 90$

$02 / 27 / 90$

$03 / 23 / 90$

$03 / 23 / 90$ 
Wistritan.

CLIENT: WSRC GUNSITE 720

RFI : $9002 L 604$

W.0. : $0630-28-13$
ROY F. TESTON, INC.

Ifonville Laboratory

SAMPLES RECEIVED: 02/16/90

\section{MARRATIVE}

The set of samples consisted of one soil sample collected on $02 / 13 / 90$.

The samples were extracted on $02 / 27 / 90$ and analyzed according to criteria set forth in Method 8140 for Appendix IX organophosphorus Pesticide target compounds on 03/23/90.

All surrogate and blank spike recoveries are within QC limits. No problems were encounterd during sample analysis.

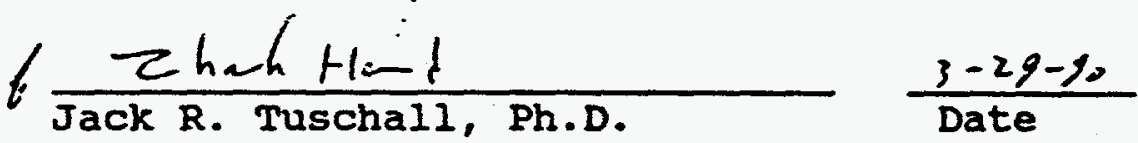

Laboratory Manager

Lionville Analytical Laboratory 


\section{WTSERT.}

\section{GLO8BARY OF DEBTEPGB DATA}

\section{DATA OUATIFIERE}

D - Indicates that the compounds was analyzed for but not detected. The minimum detection 1 imit for the sample (not the method detection 1 imit) 18 reported with the $U$ (e.g., 100).

$J$ - Indicates an estimated value. This flag is used in cases where a target analyte is detected at a level less than the lower quantification level. If the limit of quantification $i s$ $10 \mathrm{ug} / \mathrm{L}$ and a concentration of 3 $\mathrm{ug} / \mathrm{I}$ is calculated, It is reported as $3 \mathrm{~J}$.

B - This flag is used when the analyte is found in the associated blank as well as in the sample. It indicates possible/probable blank contamination. This flag is also used for a TIC as well as for a positiveIy identified TCL compound.

E - Indicates that the compound was detected beyond the calibration range and was subsequently analyzed at a dilution.

I - Interference.

\section{ABBREVIRTIONB}

88 - Indicates blank spike in which reagent grade water is spiked with the CLP matrix spiking solutions and carried through all the steps in the method. spike recoveries are reported.

B8D - Indicates blank spike duplicate.

Ms - Indicates matrix splke.

MBD - Indicates matrix spike dupilcate.

DI - Indicates that recoveries wer not obtained because the extract had to be diluted for analysis.

$2 a$ - Not applicable.

DF - Dilution factor.

IR - Not required. 
Cust ID 687200102 . PBtK $\because \quad$ PBLX B8

\begin{tabular}{|c|c|c|c|c|}
\hline $\begin{array}{l}\text { Bample } \\
\text { Informat } 100\end{array}$ & $\begin{array}{r}\text { Rrits: } \\
\text { Matelxs } \\
\text { D.F. } \\
\text { undtes }\end{array}$ & $\begin{array}{l}001 \\
8012 \\
0.500 \\
u g / \pi g\end{array}$ & $\begin{array}{c}\text { 90LE0283-38B1 } \\
80 \mathrm{IL} \\
0.500 \\
\mathrm{ug} / \mathrm{Kg}\end{array}$ & 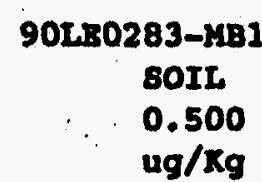 \\
\hline
\end{tabular}

\begin{tabular}{|c|c|c|c|c|c|c|c|}
\hline Burrogatei $\quad$ Ethion & 69 & 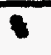 & 62 & 8 & 64 & 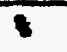 & \\
\hline 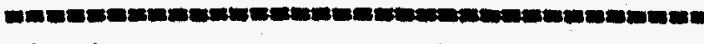 & & & & & & & \\
\hline DLazlnon & 7.3 & $\mathbf{v}$ & 6.7 & $\mathbf{v}$ & 69 & $\$$ & \\
\hline Mothyl Paxathlon & 7.3 & $\mathbf{0}$ & 6.7 & $\mathbf{v}$ & 60 & s & \\
\hline 0,0,0-IrLethyl phosphorothloat & 36 & $\mathbf{0}$ & 33 & $\mathbf{0}$ & 33 & $\mathbf{v}$ & \\
\hline Thionazin (Einophos) & 36 & $\mathbf{0}$ & 33 & $\mathbf{v}$ & 33 & $\mathbf{v}$ & \\
\hline Phorate & 7.3 & $\mathbf{0}$ & 6.7 & $\mathbf{u}$ & 6.7 & $\mathbf{u}$ & \\
\hline 8ultotopg & 36 & $\mathbf{v}$ & 33 & $\mathbf{v}$ & 33 & 0 & !l! \\
\hline Dleulfoton & 7.3 & 0 & 6.7 & $\mathbf{u}$ & 6.7 & $\mathbf{0}$ & \\
\hline Dimethoate & 36 & $\mathbf{v}$ & 33 & $\mathbf{u}$ & 33 & $\mathbf{u}$ & \\
\hline sthyl Parathlon & 7.3 & $\mathbf{0}$ & 6.7 & $\mathbf{u}$ & 6.7 & $\mathbf{0}$ & \\
\hline Famphux (ramophor) & 73 & $\mathbf{0}$ & 67 & $\mathbf{v}$ & 67 & $\mathbf{0}$ & \\
\hline
\end{tabular}

$U=$ Analysed, not doteoted. J= Present below detection 1 imlt. B= Present In blank. wR= Not requested. Ms= Not eplked. I= Percent recovery, Dw DLluted out, In Interference, NA= Not Applicable. " outalue of aPA CLP QC 
Wrster.

CLIENT: WSRC GUNSITE 720

RFW : $9002 L 604$

W.0. : $0630-28-13$
ROY F. WESTON, INC.

Ilonville Laboratory

SAMPLES RECEIVED: $02-16-90$

\section{IMORGANIC MARRATIVE}

The following is a summary of the quality control results and a description of any problems encountered during the analysis of this batch of samples:

1. All preparation blanks were analyzed below the required detection limit.

2. All calibration verification checks were within the required control limits of 90-100\%. Calibration verification is performed using independent standards.

3. All laboratory control standards (blank spikes) were within the control limits of 80-120\%.

4. The analytical methods applied by the laboratory, unless otherwise requested, for all inorganic analyses are derived from the USEPA Method for Chemical Analysis of Water and wastes (USEPA 600/4-79-020), and standard Methods for the Examination of Water and Wastewater 16 ed. Methods for the analysis of solid samples are derived from Test Methods for Evaluating Solid Waste (USEPA SW846).

5. USEPA-CIP SOW 787 was followed for the analysis of cyanide.

NOTE: For solid samples, all results are reported on a dry weight basis. 
ROY F. HESTON, INC.

GLOSSARY OF TERMS - INORGANIC REPORTS

DATA QUALIETERS

U - Indicates that the parameter was not detected at or above the reported limit. The associated numerical value is the sample detection limit.

* - Indicates that the original sample result is greater than $4 x$ the spike amount added. The USEPA-CLP has determined that spike results on samples where this occurs may be unreliable and, therefore, the control limits are not applicable.

\section{ABBREVIATIONS}

MB - Method or preparation blank.

MS - Matrix Spike.

MSD - Matrix spike Duplicate.

REP - Sample Replicate.

LC - Indicates a method LCS or Blank Spike.

NC - Not calculable, result below the detection 1 imit.

\section{LABORATORY CHRONOLOGY AND HOLDTIME REPORT}

The test code Iisted indicates the specific analysis or preparation procedure employed. The codes may be interpreted as follows:

\footnotetext{
MAAW - Metals prep test for AA digestion, water matrix. MAAS - Metals prep test for AA digestion, soil matrix. MICW - Metals prep test for ICP digestion, water matrix. MICS - Metals prep test for ICP digestion, soil matrix.

M**TO- This type of code indicates a total metal analysis (eg. MAGTO indicates an analysis for total silver).

M**SO- This type of code indicates a soluble metal analysis. (eg. MAGSO indicates an analysis for soluble silver).

M**EP- This type of code indicates an EPTJXICITY metals analysis (eg. MAGEP Indicates an analysis for eptox silver).

$I * \star T O-$ This type of code indicates a non-metallic total analysis. There is also a complimentary soluble analysis for each of these codes (eg. ICNTO - indicates an analysis for total cyanide):

A suffix of $-R$ or $-S$ following these codes indicates a replicate or spike analysis respectively.
} 
ROY ?. WESTOT IRe.

INORCANICS DATA SUMARR RAPORE 03/14/90

CLIENT: WSRC CUISIIS 720

MORT ORDIR: 0630-28-13-0000

\section{SAMPIS:}

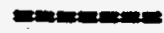

$-001$
SIX: I0

$08720 \quad 0102$

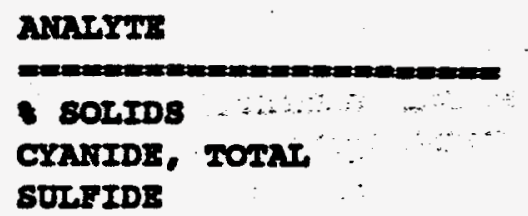

SOLFTDE
TESION BATCa है 90022604

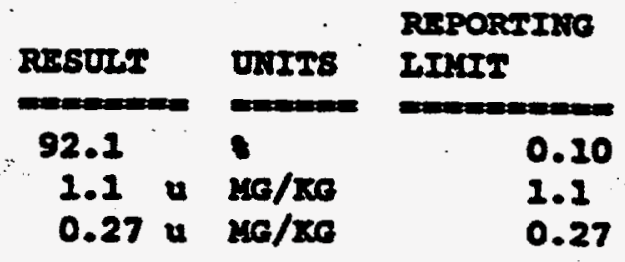


ROY F. WRSTOR InC.

INOREANICS LETHOD BHAMR DATA SURRARY PAGS 03/14/90

CLIEATI: WSRC GUVISITE 720

HORX ORDER: 0630-28-13-0000

SALPL:
BITS ID
BLART2

BLALRIO 90LSD019-KB1

BLANR2O 90LSDO19-KB2

BLANR30 90LSD019-MB3

BLANK40 90LSD019-LB4

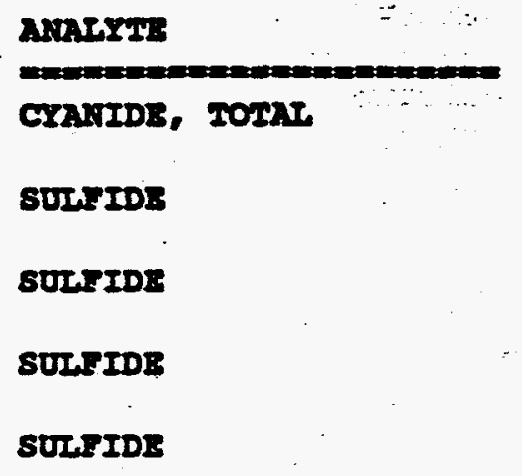

WESTOA BATCH is 90025604

\begin{tabular}{|c|c|c|c|}
\hline RRSULT & & DxxTs & IINST \\
\hline 1.0 & $\mathbf{u}$ & $20 / 20$ & 1.0 \\
\hline 0.25 & $\mathbf{u}$ & $\mathrm{Le} / \mathrm{kO}$ & 0.25 \\
\hline 0.25 & $\mathbf{u}$ & $20 / \mathrm{K} \sigma$ & 0.25 \\
\hline 0.25 & $\mathbf{u}$ & $150 / 120$ & 0.25 \\
\hline 0.25 & & $M E / x G$ & 0.25 \\
\hline
\end{tabular}


ROY P. mestor Iuc.

IMORGANICS ACCURACY REPORT 03/14/90

CLIENT: WSRC GUNSITE 720

WORK ORDER: 0630-28-13-0000

\begin{tabular}{|c|c|}
\hline BAYPL & SIIS ID \\
\hline BLARR20 & 90ISD019-MB1 \\
\hline BLANR20 & 90L5D019-2BB2 \\
\hline BLANK30 & 90LSD019-KB3 \\
\hline BTnurk 40 & 90TSD019-MB4 \\
\hline
\end{tabular}

Ritarieg:

8010.001

SUtrID:

8ULTIDE

SULTD:
Raston Bated to 90022604

\begin{tabular}{|c|c|c|c|}
\hline 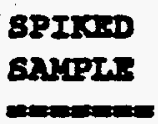 & $\begin{array}{l}\text { IRITIRT } \\
\text { RasuLE }\end{array}$ & 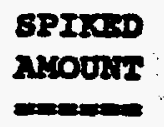 & $8 R \mathrm{coor}:$ \\
\hline $\begin{array}{l}1.0 \\
0.96\end{array}$ & $\begin{array}{l}0.25 \mathrm{u} \\
0.25 \mathrm{u}\end{array}$ & $\begin{array}{l}1.0 \\
1.0\end{array}$ & $\begin{array}{l}102 \\
95.9\end{array}$ \\
\hline $\begin{array}{l}1.0 \\
1.0\end{array}$ & $\begin{array}{l}0.25 u \\
0.25 u\end{array}$ & $\begin{array}{l}1.0 \\
1.0\end{array}$ & $\begin{array}{l}101 \\
102\end{array}$ \\
\hline
\end{tabular}


ROY I. WESTON INC.

INORGANICS IAABORATORY CONTROT STANDARDS RRPORT 03/14/90

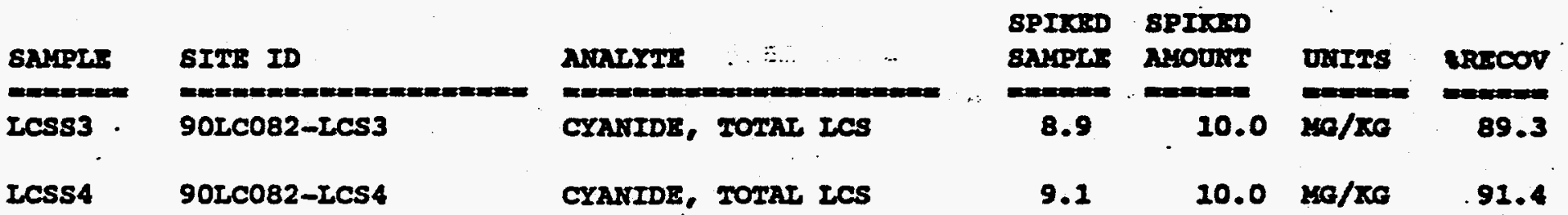


Roy F. Neaton, Inc. - ILonville Laboratory INORGANIC ANAIYTICAL DATA PACKAGE FOR WSRC CUNSITI 720

DATI RECRIVED: 02/16/90 CLIENT ID /ANALYSIS RFA * IEX PREP * COTIECTIOR EXYR/PREP
RFW IOT 890021604

Aratysis

G5720 0202

* SOLIDS TOTAL CYANIDE SULFIDE
001

001

001

$\begin{array}{ll}\text { s } & 90 \text { Ls } 039 \\ \text { s } & 90 \text { LC082 } \\ \text { s } & \text { 90LSD019 }\end{array}$

$02 / 13 / 90$

$02 / 13 / 90$

$02 / 13 / 90$
$03 / 07 / 90$

$02 / 25 / 90$

$03 / 12 / 90$
$03 / 08 / 90$

$02 / 26 / 90$

$03 / 12 / 90$

LAB QC:

TOTAL CYANIDE

TOTAL CYANIDE

TOTAL CYANIDE

TOTAL CYANIDE

TOTAI CYANIDE

TOTAL CYANIDE

TOTAL CYANIDE

TOTAI CYANIDE

TOTAL CYANIDE

SULFIDE

SULPIDE

SULFIDE

SULFIDE

SULFIDE

SULFIDE

SULFIDE

SULFIDE

\begin{tabular}{|c|c|c|c|}
\hline $\mathrm{CCB}$ & & W & 902C082 \\
\hline CCB & & 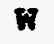 & 90LCO82 \\
\hline $\mathrm{ccv}$ & 工 & ต & 90LCO82 \\
\hline $\mathrm{CV}$ & L & $\boldsymbol{n}$ & 90LCO82 \\
\hline ICB & & ต & 90LC082 \\
\hline ICV & I & $\omega$ & $902 c 082$ \\
\hline LCs & I & $\boldsymbol{n}$ & 90LC082 \\
\hline cs & L & $\dot{\boldsymbol{\varphi}}$ & $902 \mathrm{COB2}$ \\
\hline MB2 & & $\boldsymbol{w}$ & 90LCOB2 \\
\hline LEBI & & ह & 90LSD019 \\
\hline MB1 & BS & $\boldsymbol{W}$ & 90LSD019 \\
\hline MCB2 & & $\boldsymbol{n}$ & 90LSDO1S \\
\hline MB2 & BS & 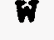 & 90LSD019 \\
\hline LB3 & & $\boldsymbol{w}$ & 90LSD019 \\
\hline ICB3 & BS & $\boldsymbol{w}$ & 90LSD019 \\
\hline MBA4 & & $\boldsymbol{w}$ & 90LSD019 \\
\hline & & $\mathbf{w}$ & 90 LSD019 \\
\hline
\end{tabular}

$02 / 26 / 90$ $02 / 26 / 90$ $02 / 26 / 90$ $02 / 26 / 90$. $02 / 26 / 90$ $02 / 26 / 90$ $02 / 26 / 90$ $02 / 26 / 90$ $02 / 26 / 90$ $03 / 12 / 90$ $03 / 12 / 90$ $03 / 12 / 90$ $03 / 12 / 90$ $03 / 12 / 90$ $03 / 12 / 90$ $03 / 12 / 90$ $03 / 12 / 90$ 
Weston - SRP

CUSTOMER Mark T. Carkhuff

ATTENTION 208 Welsh POOl Rd.

ADORESS Lionville, $\mathrm{Pa} 19353$

aTr

$E-1588$

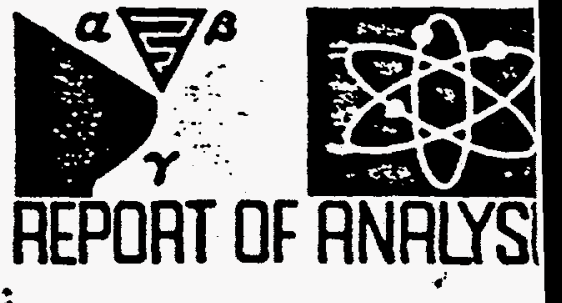

$03 / 09 / 90$
DATE

TIME

ANALY.

$$
\because-15-101
$$
$\because \therefore \because$ a

. TME OF ANALYeA

Customer

\section{L603002}

E1738

L603002

E1738

L603005

E1739

L603005

E1739

L603014

E1740

L603014

E1740

L606001

E1741

; 6001

141

L606002

E1742

L 606002

E1742

L606003

E1743

L606003

E1743

L606011

E1744

L 606011

E1744
021490

1245

021490

1245

021490

1130

021490

1130

021390

1400

021390

1400

022090

1120

022090

1120

022090

1230

022090

1230

022090

1430

022090

1430

041690

1510

041690

1510
Trpe of Analysis
UNTS ACCRCY INST/INI

$23.00 \quad 7.00 \quad \mathrm{pC} 1 / \mathrm{g} \quad 1.22 \quad 39 \mathrm{CA}$

$4.00 \quad 4.00 \quad \mathrm{pC} 1 / \mathrm{g} \quad 1.13 \quad 39 \mathrm{CA}$

$20.00 \quad 8.00 \quad \mathrm{pCl} / \mathrm{g} \quad 1.22 \quad 40 \mathrm{CA}$

$4.00 \quad 4.00 \quad \mathrm{pC} 1 / \mathrm{g} \quad 4.13 \quad 40 \mathrm{CA}$

$18.00 \quad 7.00 \quad \mathrm{pCi} / \mathrm{g} \quad 1.22 \quad 41 \mathrm{CA}$

$4.00 \quad 3.00 \quad \mathrm{pC1} / \mathrm{g} \quad 1.13 \quad 41 \mathrm{CA}$

02/13-21 BETA

02/13-21 ALPHA

02/13-21 BETA

02/13-21 ALPHA

02/13-21 BETA

02/13-21 ALPHA

02/13-21 BETA

$02 / 13-21$ ALPHA

02/13-21 BETA
14.00

0.00

21.00

8.00

30.00

9.00

22.00

10.00
$7.00 \mathrm{pCs} / \mathrm{g}$

1.22

3.00

$\mathrm{pC1/g}$

7.00

$\mathrm{pC} 1 / \mathrm{g}$

3.00

pC1/

8.00

pC1/

4.00

pCi/g

8.00

$\mathrm{pC1} / \mathrm{g}$

4.00

$\mathrm{pC1/g}$

1.13
$42 \mathrm{CA}$

$-$

1510


Weston - SRP

Mark T. Carkhuff 208 Welsh Pool Rd.

Lionville, $\mathrm{Pa} 19353$

E-1589

Lab Code : BE
DATE

TIME

Customer ANALY.

Identification
I 606014

E1745

L606014

E1745
ANALY. Date Collected

Type of Arialysis

032790

1045

032790 1045
$02 / 21 / 90$

ALPHA

$02 / 21 / 90$

BETA
ACTIVITY/ERROR

UNTS ACCRCY

INST/INI]
2.00

pC1/1

1.22

46 DDP

0.00

3.00

$\mathrm{pC} 1 / 1 \quad 1.13$

46 DDP 
CLIENT: WSRC GUNSITE 720

RFW : $9002 L 604$

W.0. \# : 0630-28-10

BAMPLES RECEIVED: $02-16-90$

\section{METAL8 MARRATIVE}

The following is a summary of the quality control results and a description of any problems encountered during the analysis of this batch of samples:

1. All sample holding times as required by 40 CFR136 were met for water samples. Note: Holding times for soil samples have not been promulgated by the USEPA.

2. All calibration verification checks were within the required control limits of 90-100\% (85-115\% for $-\mathrm{Hg})$. Calibration verification is performed using independent standards from Inorganic Ventures, Inc.

3. All preparation blanks were analyzed below the required detection limit.

4. Laboratory control standards were within the control limits of 80-120\% with the exception of silver (59\%) for site ID\# 90L0226-LCl. The blank spike reproducibility was outside the $20 \%$ window for silver at $58 \%$.

Note: The USEPA-CLP has dropped control limits for silver and antimony due to documented difficulties in obtaining reliable results. WESTON Analytics has adopted the same policy.

5. The analytical methods applied by the laboratory for the determination of metals are:
As: EPA 206.2
Hg:
EPA 245.1
Se: EPA 270.2
ICP Scan: EPA 200.7
$\mathrm{Pb}:$ EPA 239.2
All Others: EPA 200.7
T1: EPA 279.2
EP Leachates (except Hg) : 200.7

NOTE: For solid samples, all results are reported on a dry weight basis. 


\section{ROY $F$. WESTON, INC. \\ GLOSSARY OF TERMS - INORGANIC REPORTS}

DATA OUALIEIERS

$U$ - Indicates that the parameter was not detected at or above the reported ilmit. The associated numerical value is the sample detection 1 imit.

* - Indicates that the original sample result is greater than $4 x$ the spike amount added. The USEPA-CLP has determined that spike results on samples where this occurs may be unreliable and, therefore, the control limits are not applicable.

\section{ABBREVIATIONS}

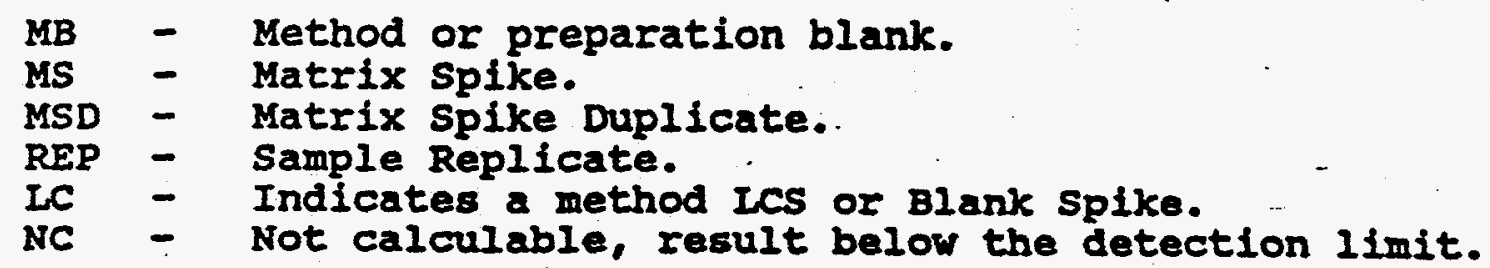

\section{LABORATORY CHRONOLOGY AND HOTDTIME REPORT}

The test code listed indicates the specific analysis or preparation procedure employed. The codes may be interpreted as follows:

MAAW - Metals prep test for AA digestion, water matrix. MAAS - Metals prep test for AA digestion, soil matrix. MICW - Metals prep test for ICP dígestion, water matrix. MICS - Metals prep test for ICP digestion, soll matrix.

$M * * T O-$ This type of code indicates a total metal analysis (eg. MAGTO indicates an analysis for total silver).

$M * * S O-\quad T h i s$ type of code indicates a soluble metal analysis. (eg. MAGSO indicates an analysis for soluble silver).

$M * \star E P-\quad T h i s$ type of code indicates an EProxICITY metals analysis (eg. MAGEP indicates an analysis for eptox eliver).

I**TO- This type of code indicates non-metallic total analysis. There 18 also a complimentary soluble analysis for each of these codes (eg. ICNTO indicates an analysis for total cyanide).

$A$ suffix of $-R$ or $-S$ following these codes indicates a replicate or spike analysis respectively. 
ROT F. WESTOR IRC.

INORGANICS DATA SUMARRX REPORT 04/09/90

CLIENT: WSRC GUNSIT: 720

WORK ORDER: 0630-28-13-0000

SAYPL.

cominam

$-001$

SITS ID

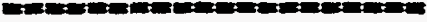

687200102

\section{Matry4.}

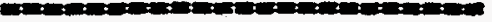

BIIVA, IOHAT.

ARSENIC, gOANI

BARIOL, IOMAT.

BERTIIUL, TOLAT

CADKIUK, FOTAT

CozarT, romar.

CEROyIUx, romar

COPEER, TONAL

MERCURY, TOUnI

MICUI, TOIAT

ITAD, TOLAT

ANIIMONY, 20 rer

SETERIOL, IOLAY

TIX, TOIXI

TEAIIIUK, TOTAY

VANADIUR, TOTAT

EIRC, TOMAT
WESTON BATCA * 9002L604

\begin{tabular}{|c|c|c|c|}
\hline RESULT & & $\begin{array}{l}\text { DRITS } \\
\text { = }\end{array}$ & $\begin{array}{l}\text { REPORTIR } \\
\text { LINII. . }\end{array}$ \\
\hline 1.7 & $\mathbf{u}^{-}$ & $210 / 20$ & 1.7 \\
\hline 1.7 & $\mathbf{u}$ & xe/xe & 1.7 \\
\hline 34.8 & $\mathbf{u}$ & Me/se & 34.8 \\
\hline 0.87 & $\mathbf{u}$ & Me/xo & 0.87 \\
\hline 0.87 & $\mathbf{u}$ & Me/Ke & 0.87 \\
\hline 8.7 & $\mathbf{u}$ & $20 / 20$ & 8.7 \\
\hline 3.2 & & $\mathrm{Me} / \mathrm{x}$ & 1.7 \\
\hline 4.4 & $\mathbf{u}$ & $210 / 250$ & 4.4 \\
\hline 0.12 & & $2 x / 20$ & 0.11 \\
\hline 7.0 & $\mathbf{u}$ & $26 / 250$ & 7.0 \\
\hline 5.6 & & $20 / 210$ & 0.52 \\
\hline 10.4 & $\mathbf{u}$ & $M \sigma / 20$ & 10.4 \\
\hline 0.87 & $\mathbf{x}$ & $150 / 20$ & 0.87 \\
\hline 25.7 & & ye/xo & $17 \cdot 4$ \\
\hline 1.7 & $\mathbf{u}$ & $36 / 26$ & 1.7 \\
\hline $\begin{array}{r}8.7 \\
88.7\end{array}$ & $\mathbf{u}$ & $\begin{array}{l}\text { MG/To } \\
\text { MG/xo }\end{array}$ & $\begin{array}{l}8.7 \\
3.5\end{array}$ \\
\hline & & & \\
\hline
\end{tabular}


ROY $\mathrm{F}$. WESTON IKC.

INORGANICS MEYHOO BLANK DATA SUARARY PAGE 04/09/90

CLIENT: WSRC GUNSITE 720

WORK ORDER\& 0630-28-13-0000
ARITYS

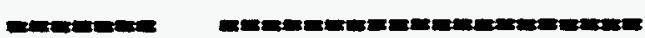

BLANR1 90L0226-MB1

BIANK1 90L0225-MBI

BLANKI $90 C 040 B-M B I$

BLAMK2 90CO4OB-MB2

BLANK3 90CO4OB-MB3

BLANKA 90CO4OB-MB4

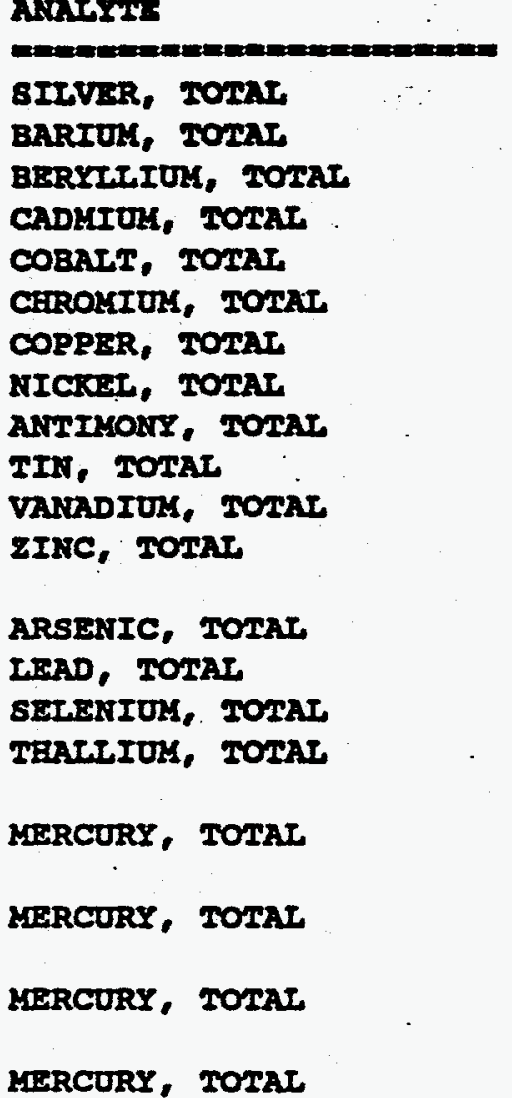

Mrstor BATCa ts 90025604

\begin{tabular}{|c|c|c|c|}
\hline RESULT & & ORIT8 & $\begin{array}{l}\text { REPORTINO } \\
\text { IIATE }\end{array}$ \\
\hline $\begin{array}{r}2.0 \\
40.0\end{array}$ & $\begin{array}{l}\mathbf{u} \\
\mathbf{u}\end{array}$ & $\begin{array}{l}x e / x e \\
40 / x e\end{array}$ & $\begin{array}{r}2.0 \\
40.0\end{array}$ \\
\hline 1.0 & $\mathbf{u}$ & עe/20 & 1.0 \\
\hline 1.0 & $\mathbf{u}$ & $20 / 150$ & 1.0 \\
\hline 10.0 & $\mathbf{u}$ & $\mathrm{xO} / \mathrm{x}$ & 10.0 \\
\hline 2.0 & $\mathbf{u}$ & MG/LG & 2.0 \\
\hline 5.0 & $\mathbf{u}$ & $x \theta / x 6$ & 5.0 \\
\hline 8.0 & $\mathbf{u}$ & $M G / 1 K 0$ & 8.0 \\
\hline 12.0 & $\mathbf{u}$ & MG/156 & 12.0 \\
\hline 20.0 & $\mathbf{u}$ & $30 / 20$ & 20.0 \\
\hline 10.0 & $\mathbf{u}$ & Me/Ko & 10.0 \\
\hline 4.0 & $\mathbf{u}$ & Me/Re & 4.0 \\
\hline $\begin{array}{l}2.0 \\
0.60\end{array}$ & $\begin{array}{l}\mathbf{u} \\
\mathbf{u}\end{array}$ & $\begin{array}{l}M G / \mathrm{KO} \\
\mathrm{MG} / \mathrm{KC}\end{array}$ & 0 \\
\hline 1.0 & $\mathbf{u}$ & MG/KG & 1.0 \\
\hline 2.0 & $\mathbf{u}$ & MG/xG & 26 \\
\hline
\end{tabular}

0.10 u MG/KG $\therefore \quad \therefore 0.10$

0.10 บ MG/KG, 0.10

0.10 u MG/KG 0.10

0.10 y $\mathrm{MG} / \mathrm{KG}$

0.10 
ROY P. WESTON IRC.

INORGANICS DUPLICATE SPIKE REPORT 04/09/90

CLIENT: WSRC GUNSITE 720

WORX ORDERs 0630-28-13-0000

SAMPL:

LCs2

SITE ID

-

90I0226-IC2

90L0225-LC2

$\operatorname{LCS} 2$

90CO4OB-LC2

ARRIXY:

SIIVER, ICS

BARIOH, ICS

BERYILIUK, ICS

CADKIUX, ICS

COBALT, ICS

CHROMIUY, ICS

COPPER, LCS

NICKCLI, ICS

ANIIMONY, LCS

TIN, ICS

VAMRDIOK, LCS

EINC, ICS

ARSEIIC, LCS

LEAD, ICS

SELENIOR, LCS

THALIIOK, LCS

LERCURY, LCS
MESTON BATCH \& 9002L604

\begin{tabular}{|c|c|c|}
\hline ERINEF & $\begin{array}{l}\text { 8PILEF } \\
\text { SRSCOV }\end{array}$ & IDISP \\
\hline 59.0 & 107 & 57.6 \\
\hline 102 & 101 & 0.74 \\
\hline 107 & 108 & 1.3 \\
\hline 106 & 106 & 0.30 \\
\hline 104 & $104^{\circ}$ & 0.029 \\
\hline 112 & 111 & 0.50 \\
\hline 109 & 110 & 0.95 \\
\hline 104 & 105 & 0.48. \\
\hline 93.1 & 93.7 & 0.64 \\
\hline 92.6 & 93.0 & 0.41 \\
\hline 116 & 118 & 1.7 \\
\hline 103 & 103 & 0.058 \\
\hline 94.0 & 97.7 & 3.8 \\
\hline 113 & 112 & 0.89 \\
\hline 111 & 113 & 1.5 \\
\hline 107 & 109 & 1.2 \\
\hline 106 & 103 & 3.4 \\
\hline
\end{tabular}

$=-$ 
ROY F. WESTON INC.

INORGANICS LABORATORY CONTROL STAMDARDS REPORT 04/09/90

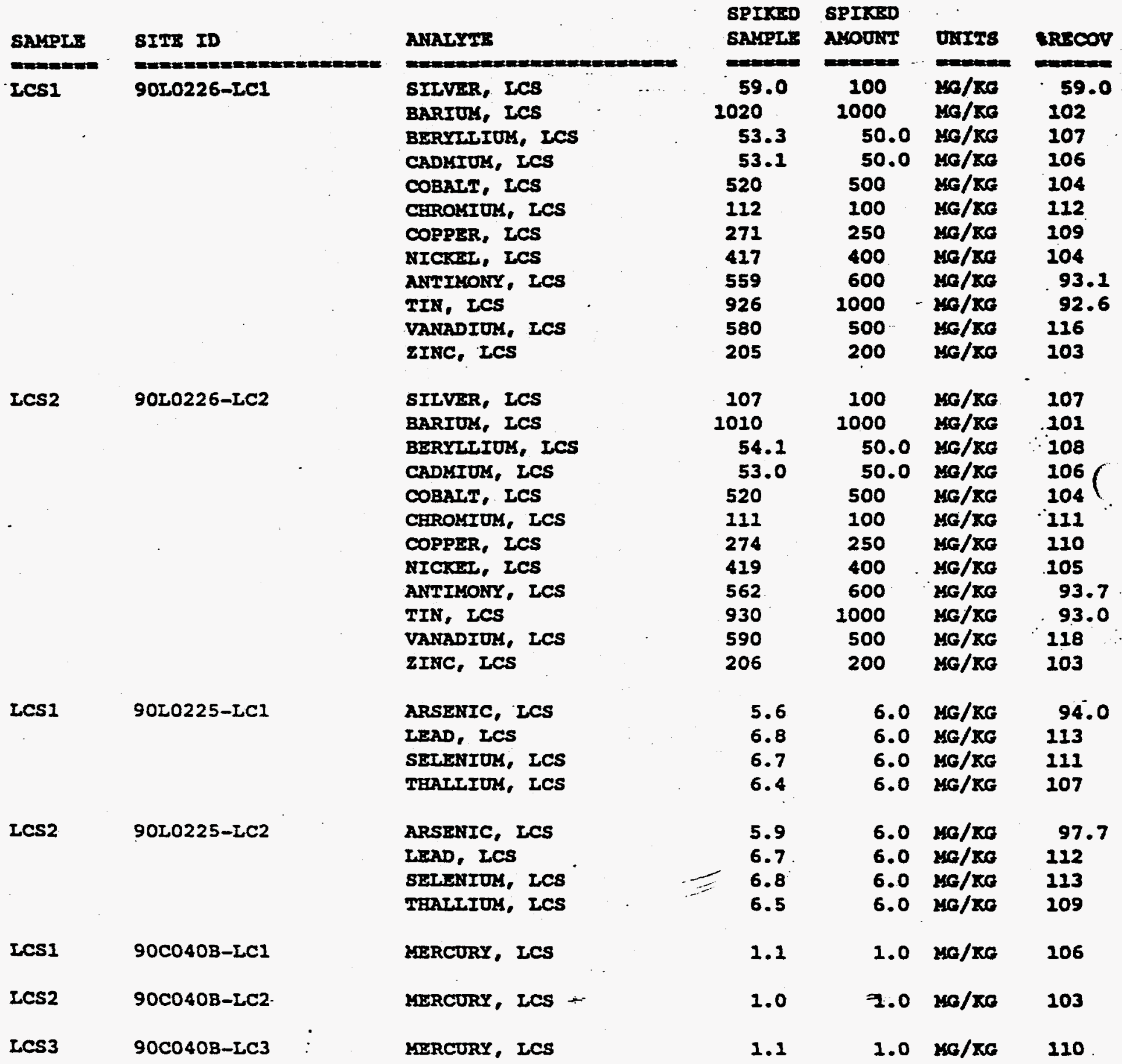


ROY F. WESTON INC.

IKORGANICS IABORATORY CONIROL STANDARDS REPORT 04/09/90

\begin{tabular}{|c|c|c|c|c|c|c|}
\hline $\begin{array}{l}\text { SAMPLR: } \\
\text { =mE=: }\end{array}$ & SITS ID & 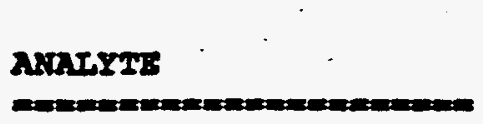 & 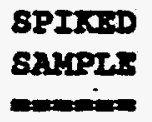 & 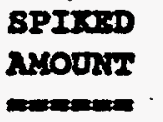 & 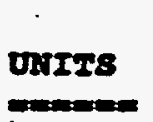 & SRecor \\
\hline $\operatorname{Lcs} 4$ & 90C040B-IC4 & IERCURY, ICS & 1.1 & 1.0 & $210 / 20$ & 114 \\
\hline
\end{tabular}


Roy F. Weston, Inc. - Ilonv1110 Laboratory

INORGANIC ANALYTICAL DATA PACKAGE FOR WSRC GUNSITE 720

DATE RECEIVED: 02/16/90

RFW LOT $: 90022604$

\begin{tabular}{|c|c|c|c|c|c|c|}
\hline CLIENT ID /ANALY & $\mathbf{R F}$ & $252 x$ & PREP & cotrescrios & EXTR/PREP & AnITYSIS \\
\hline \multicolumn{7}{|l|}{ GS720 0102} \\
\hline SILVER, TOTAL & 001 & $\mathbf{s}$ & 9020226 & $02 / 13 / 90$ & $03 / 09 / 90$ & 03/23/90 \\
\hline ARSENIC, TOTAL & 001 & $\mathbf{s}$ & 90L0225 & $02 / 13 / 90$ & $\begin{array}{l}03 / 09 / 90 \\
03 / 09 / 90\end{array}$ & $\begin{array}{l}03 / 30 / 90 \\
03 / 23 / 90\end{array}$ \\
\hline $\begin{array}{l}\text { BARIUM, TOTAL } \\
\text { BERYLLIUM, TOTAL }\end{array}$ & $\begin{array}{l}001 \\
001\end{array}$ & $\begin{array}{l}\mathbf{s} \\
\mathbf{s}\end{array}$ & $\begin{array}{l}9020226 \\
9020226\end{array}$ & $\begin{array}{l}02 / 13 / 90 \\
02 / 13 / 90\end{array}$ & $\begin{array}{l}03 / 09 / 90 \\
03 / 09 / 90\end{array}$ & $03 / 23 / 90$ \\
\hline CADMIUK, TOTAL & 002 & $\mathbf{s}$ & 9020226 & $02 / 13 / 90$ & $03 / 09 / 90$ & $03 / 23 / 90$ \\
\hline COBAIT, TOTAL & 001 & $\mathbf{s}$ & 9020226 & $02 / 13 / 90$ & $03 / 09 / 90$ & $03 / 23 / 90$ \\
\hline CHROMIUM, TOTAL & 001 & $\mathbf{s}$ & 9020226 & $02 / 13 / 90$ & $03 / 09 / 90$ & $03 / 23 / 90$ \\
\hline COPPER, TOTAI & 001 & $\mathbf{s}$ & 9010226 & $02 / 13 / 90$ & $03 / 09 / 90$ & $03 / 23 / 90$ \\
\hline IERCURY, TOTAL & 001 & 8 & $90 \mathrm{CO} 40 \mathrm{~B}$ & $02 / 13 / 90$ & $03 / 22 / 90$ & $03 / 13 / 90$ \\
\hline NICKCEL, TOTAL & 001 & $\mathbf{s}$ & 9020226 & $02 / 13 / 90$ & $03 / 09 / 90$ & $03 / 23 / 90$ \\
\hline IEAD, TOTAL & 001 & $\mathbf{s}$ & 90L0225 & 02/13/90 & $03 / 09 / 90$ & $04 / 05 / 90$ \\
\hline ANTIMONY, TOTAL & 001 & $\mathbf{s}$ & 9020226 & $02 / 13 / 90$ & $03 / 09 / 90$ & $03 / 23 / 90$ \\
\hline SELENIUK, TOTAL & 001 & $\mathbf{s}$ & 9020225 & $02 / 13 / 90$ & $03 / 09 / 90$ & $04 / 01 / 90$ \\
\hline TIN, TOTAL & 001 & $\mathbf{s}$ & 90L0226 & $02 / 13 / 90$ & $03 / 09 / 90$ & $03 / 23 / 90$ \\
\hline TEALLIOM, TOTAI & 001 & $\mathbf{s}$ & 9020225 & $02 / 13 / 90$ & $03 / 09 / 90$ & $04 / 04 / 90$ \\
\hline VANADIUM, TOTAL & 001 & $\mathbf{s}$ & 90L0226 & $02 / 13 / 90$ & $03 / 09 / 90$ & $03 / 23 / 90$ \\
\hline zINC, TOTAL & 001 & $\mathbf{s}$ & 9020226 & 02/13/90 & $03 / 09 / 90$ & $03 / 23 / 90$ \\
\hline
\end{tabular}

IAB QC:

$\begin{array}{ll}\text { SILVER LABORATORY } & \text { LC1 BS } \\ \text { BARIUM LABORATORY } & \text { LC1 BS } \\ \text { BERYLIIUM LABORATORY } & \text { LC1 BS } \\ \text { CADMIUM LABORATORY } & \text { LC1 BS } \\ \text { COBALT LABORATORY } & \text { LC1 BS } \\ \text { CHROMIUM LABORATORY } & \text { LC1 BS } \\ \text { CORPER LABORATORY } & \text { LC1 BS } \\ \text { NICKEL LABORATORY } & \text { LC1 BS } \\ \text { ANTIMONY LABORATORY } & \text { LC1 BS } \\ \text { TIN LABORATORY } & \text { LC1 BS } \\ \text { VANADIUM LABORATORY } & \text { LC1 BS } \\ \text { IINC LABORATORY } & \text { LC1 BS } \\ \text { SILVER LABORATORY : } & \text { LC2 BS } \\ \text { BARIUM LABORATORY } & \text { LC2 BS } \\ \text { BERYLIIUM LABORATORY } & \text { LC2 BS } \\ \text { CADMIUM LABORATORY } & \text { LC2 BS } \\ \text { COBALT LABORATORY } & \text { LC2 BS }\end{array}$

$\begin{array}{ll}\text { s } & 90 L 0226 \\ \text { s } & 90 L 0226 \\ \text { s } & 90 L 0226 \\ \text { s } & 90 L 0226 \\ \text { s } & 90 L 0226 \\ \text { s } & 90 L 0226 \\ \text { 8 } & 90 L 0226 \\ \text { s } & 90 L 0226 \\ \text { s } & 90 L 0226 \\ \text { s } & 90 L 0226 \\ \text { s } & 90 L 0226 \\ \text { s } & 90 L 0226 \\ \text { s } & 90 L 0226 \\ \text { s } & 90 L 0226 \\ \text { s } & 90 L 0226 \\ \text { s } & 90 L 0226 \\ \text { s } & 90 L 0226\end{array}$

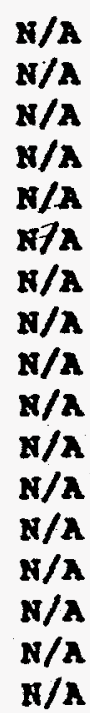

$03 / 09 / 90$

$03 / 09 / 90$

$03 / 09 / 90$

$03 / 09 / 90$

$03 / 09 / 90$

$03 / 09 / 90$

$03 / 09 / 90$

$03 / 09 / 90$

$03 / 09 / 90$

$03 / 09 / 90$

$03 / 09 / 90$

$03 / 09 / 90$

$03 / 09 / 90$

$03 / 09 / 90$

$03 / 09 / 90$

$03 / 09 / 90$

$03 / 09 / 90$
$03 / 23 / 90$

$03 / 23 / 90$

$03 / 23 / 90$

$03 / 23 / 90$

$03 / 23 / 90$

$03 / 23 / 90$

$03 / 23 / 90$

$03 / 23 / 90$

$03 / 23 / 90$

$03 / 23 / 90$

$03 / 23 / 90$

$03 / 23 / 90$

$03 / 23 / 90$

$03 / 23 / 90$

$03 / 23 / 90$

$03 / 23 / 90$

$03 / 23 / 90$ 
Roy F. Weston, Inc. - Ilonville Laboratory

INORGANIC ANALYTICAL DATA PACKAGE FOR

WSRC GUNSIIY 720

DATE RECEIUED: $02 / 16 / 90$

RFW LOT $: 9002 L 604$

\begin{tabular}{|c|c|c|c|c|c|c|c|}
\hline CLIENT ID / ANALYSIB & RUW & $\#$ & IFIX & PREP & COLTECTION & EXTR/PREP & MNALYSIS \\
\hline CEROKIUK IABORATORY & LC2 & $\mathbf{8 8}$ & 8 & 9020226 & $n / \mathbf{A}^{-}$ & $03 / 09 / 90$ & 03/23/90 \\
\hline COPPER IABORATORI & LC2 & 88 & $\mathbf{8}$ & 9020226 & $\mathbf{x} / \mathbf{A}$ & $03 / 09 / 90$ & $03 / 23 / 90$ \\
\hline NICKELI LABORATORY & LC2 & Bs & 8 & 9020226 & $\mathbf{n} / \mathbf{A}$ & $03 / 09 / 90$ & $03 / 23 / 90$ \\
\hline ANTIMONY IABORATORY & LC2 & Bs & $\boldsymbol{8}$ & 9020226 & $\mathbf{n} / \mathbf{a}$ & $03 / 09 / 90$ & $03 / 23 / 90$ \\
\hline TIN IABORATORY & LC2 & Bs & $\mathbf{s}$ & 9020226 & $x / \mathbf{A}$ & $03 / 09 / 90$ & $03 / 23 / 90$ \\
\hline VAMADIUN IABORATORY & IC2 & BS & $\mathbf{s}$ & 9020226 & $x / A$ & $03 / 09 / 90$ & $03 / 23 / 90$ \\
\hline ZINC IABORATORY & IC2 & Bs & $\mathbf{8}$ & 90L.0226 & $x / 2$ & $03 / 09 / 90$ & $03 / 23 / 90$ \\
\hline SILVER, TOTAL & MBI & & $\mathbf{8}$ & 9020226 & $x / 2$ & $03 / 09 / 90$ & $03 / 23 / 90$ \\
\hline BARIOK, TOTAL & MBI & & $\mathbf{s}$ & 90L0226 & $x / \mathbf{A}$ & $03 / 09 / 90$ & $03 / 23 / 90$ \\
\hline BERYLIIUS, TOTAL & 2081 & & 8 & 902.0226 & $x / \lambda$ & $03 / 09 / 90$ & $03 / 23 / 90$ \\
\hline CADMIOM, TOTAL & MB1 & & $\mathbf{8}$ & 9020226 & $n / \mathbf{x}$ & $03 / 09 / 90$ & $03 / 23 / 90$ \\
\hline COBALI, TOTAL & MB1 & & $\mathbf{s}$ & 9020226 & $\pi / A$ & $03 / 09 / 90$ & $03 / 23 / 90$ \\
\hline CEROMIOM, TOTAL & MBI & & $\boldsymbol{s}$ & 9020226 & $8 / \lambda$ & $03 / 09 / 90$ & 03/23/90 \\
\hline COPPER, TOTAL & 20B1 & & $\mathbf{s}$ & 9020226 & $x / n$ & $03 / 09 / 90$ & $03 / 23 / 90$ \\
\hline MICKEL, TOTAI & LEB1 & & $\mathbf{s}$ & 9020226 & $\pi / A$ & $03 / 09 / 90$ & $03 / 23 / 90$ \\
\hline ANTIMONY, TOTAL & MBI & & $\mathbf{s}$ & 9020226 & $\pi / \lambda$ & $03 / 09 / 90$ & $03 / 23 / 90$ \\
\hline TIN, TOTAI & MBI & & $\mathbf{s}$ & 9020226 & $B / \lambda$ & $03 / 09 / 90$ & $03 / 23 / 90$ \\
\hline VANADIUM, TOTAL & MBI & & s & 9020226 & $x / \lambda$ & $03 / 09 / 90$ & $03 / 23 / 90$ \\
\hline zINC, TOTAL & MBI & & s & 9020226 & $n / A$ & $03 / 09 / 90$ & $03 / 23 / 90$ \\
\hline ARSENIC LABORATORY & LCI & BS & $\mathbf{s}$ & 90L0225 & $H / A$ & $03 / 09 / 90$ & $03 / 30 / 90$ \\
\hline IEAD IABORATORY & LCI & Bs & 8 & $90 r 0225$ & $x / 2$ & $03 / 09 / 90$ & $04 / 05 / 90$ \\
\hline SELENIUM IABORATORY & ICI & Bs & $\mathbf{8}$ & 9020225 & $x / A$ & $03 / 09 / 90$ & $04 / 01 / 90$ \\
\hline THACLIUY IABORATORY & IC1 & Bs & $\mathbf{s}$ & 9020225 & $N / A$ & $03 / 09 / 90$ & $04 / 04 / 90$ \\
\hline ARSENIC LABORATORY & IC2 & Bs & $\mathbf{s}$ & 9020225 & $w / \lambda$ & $03 / 09 / 90$ & $03 / 30 / 90$ \\
\hline LEAD IAABORATORY & LC2 & BS & $\mathbf{s}$ & $90 L 0225$ & $N / A$ & $03 / 09 / 90$ & $04 / 05 / 90$ \\
\hline SELENIUM IABORATORY & LC2 & BS & $\mathbf{s}$ & 9020225 & $N / A$ & $03 / 09 / 90$ & $04 / 01 / 90$ \\
\hline TEALIIUM IABORAIORY. & LC2 & Bs & $\dot{\mathbf{s}}$ & 9020225 & $N / \mathbf{A}$ & 03/09/90 & $04 / 04 / 90$ \\
\hline ARSENIC, TOTAI & MB1 & & $\mathbf{8}$ & $90 \tau 0225$ & $x / \lambda$ & 03/09/90 & $03 / 30 / 90$ \\
\hline LEAD, TOTAL & MBI & & $\mathbf{s}$ & 9020225 & $N / A$ & 03/09/90 & $04 / 05 / 90$ \\
\hline SELENIOM, TOTAL & MB1 & & $\mathbf{s}$ & 9020225 & $\pi / A$ & $03 / 09 / 90$ & $04 / 01 / 90$ \\
\hline THAILIUM, TOTAL & MBI & & 8 & 9020225 & $M / A$ & $03 / 09 / 90$ & $04 / 04 / 90$ \\
\hline MERCURY LABORATORY & LCI & Bs & $\boldsymbol{x}$ & $90 \mathrm{CO} 40 \mathrm{~B}$ & $N / A$ & $03 / 12 / 90$ & $03 / 13 / 90$ \\
\hline MERCURY IABORATORY & LC2 & Bs & $\boldsymbol{\omega}$ & $90 \mathrm{CO} 40 \mathrm{~B}$ & $x / 2$ & $03 / 12 / 90$ & $03 / 13 / 90$ \\
\hline MERCURY LABORATORY & LC3 & Bs & $\pi$ & $90 \mathrm{CO4OB}$ & $\pi / \lambda$ & $03 / 12 / 90$ & $03 / 13 / 90$ \\
\hline MERCURY LABORATORY & LCA & Bs & $\boldsymbol{H}$ & $90 \mathrm{CO} 40 \mathrm{~B}$ & $x / x$ & $03 / 12 / 90$ & $03 / 13 / 90$ \\
\hline KERCURY, TOTAL & LB1 & & $\boldsymbol{H}$ & 9000408 & $N / A$ & $03 / 12 / 90$ & $03 / 13 / 90$ \\
\hline MERCURY, TOTA工 & MB2 & & $\mathbf{H}$ & $90 \mathrm{CO} 40 \mathrm{~B}$ & $\mathbf{8} / \mathbf{A}$ & $03 / 12 / 90$ & $03 / 13 / 90$ \\
\hline MERCURY, TOTAI & $\mathbf{M B 3}$ & & $\boldsymbol{W}$ & $90 \mathrm{C040B}$ & $\boldsymbol{x} / \mathbf{A}$ & $03 / 12 / 90$ & $03 / 13 / 90$ \\
\hline MERCURY, TOTAI & MB4 & & $\boldsymbol{n}$ & $90 \mathrm{CO} 40 \mathrm{~B}$ & $N / A$ & $03 / 12 / 90$ & $03 / 13 / 90$ \\
\hline
\end{tabular}


Roy F. Weston, Inc. - Ilonville Laboratory VOA ANALYTICAL DATA PACKAGE IOR WSRC GONSITX 720

DATE RECEIVID\& $\quad 02 / 16 / 90$

RFW IOT $\$ 9002 L 603$

CLIENT ID

\begin{tabular}{l} 
RIN \\
\hline 001 \\
002 \\
003 \\
004 \\
005 \\
006 \\
007 \\
008 \\
009 \\
010 \\
011 \\
012 \\
013 \\
014
\end{tabular}

MTX PREP

COLIECTIOU EXIR/PREP

MUATYSIS

GS720 10-015

GS720 14-02

G5720 04-01

GS720 02-01

ES720 03-01

GS720 02-01A

GS720 11-01E

G5720 06-01

GS720 05-01

GS720 12-01B

$68720 \quad 01-02$

G5720 $08-01$

G5720 07-01

G5720 01-01

LAB QC:

\section{VBLK}

VBLK

VBLK

vBLK

vacx
MBI

MBI

LBI

2181

YB1

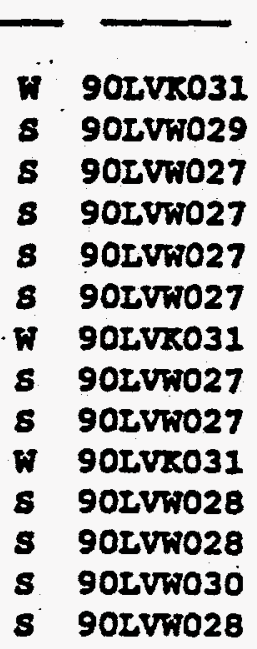

$02 / 14 / 90$
$02 / 14 / 90$
$02 / 14 / 90$
$02 / 14 / 90$
$02 / 14 / 90$
$02 / 14 / 90$
$02 / 14 / 90$
$02 / 14 / 90$
$02 / 14 / 90$
$02 / 14 / 90$
$02 / 13 / 90$
$02 / 13 / 90$
$02 / 13 / 90$
$02 / 13 / 90$

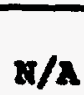

$x / 2$

$x / \lambda$

$\pi / \boldsymbol{A}$

$x / \lambda$

$n / A$

$M / A$

$x / 2$

$n / \lambda$

$n / x$

$n / x$

$n / A$

$x / a$

$N / A$

$02 / 26 / 90$

$02 / 26 / 90$

$02 / 23 / 90$

$02 / 23 / 90$

$02 / 23 / 90$

$02 / 23 / 90$

$02 / 26 / 90$

$02 / 23 / 90$

$02 / 23 / 90$

$02 / 26 / 90$

$02 / 24 / 90$

$02 / 24 / 90$

$02 / 27 / 90$

$02 / 24 / 90$

90LVRo31 90LVW029 90 LVพ027 90 LVw028

902 Vw0 30
$N / A$

$n / A$

$N / A$

$N / A \quad N / A$

$N / A \quad N / A$
$02 / 26 / 90$

$02 / 26 / 90$

$02 / 23 / 90$

$02 / 24 / 90$

$02 / 27 / 90$ 
$0.028 \% 9$

W

ROY F. HESTON, INC.

Ifonvilie Laboratory

CLIENT: WSRC-GUNSITE 720

BAMPIES RECEIVED: 02-16-90

RET $\$$ : $9002 L 603$, GC/MS VOLATILE

RoO. : $0630-28-13$

NARRATIVE

The set of samples consisted of three water samples and eleven soil samples collected on 02-13,14-90.

The samples were analyzed according to criteria set forth in SW 846 Method 8240 for TCL Volatile target compounds on $02-23,24,26,27-90$.

The following is a summary of the QC results accompanying these sample results and a description of any problems encountered during their analysis:

1. Non-target compounds were not detected in these samples.

2. All surrogate recoveries are within EPA QC limits.

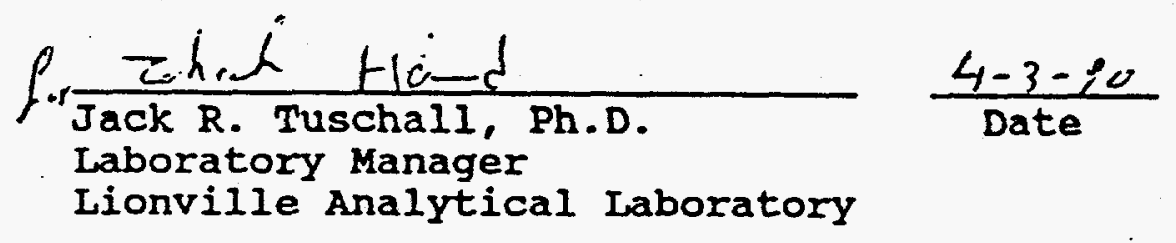

B-53 


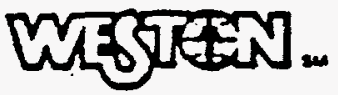

\section{DATA COATITIOBS}

$U$ - Compoind was analyzed for but not detected. Tha associated numerical valu is the estivated sample quantitation limit which is included and corrected for dilution and percent motstare.

$J$ - Indlates an ctimated valve. Inte $\mathrm{lag}$ is uned aither when estimating a cancentration for tentatively idantified

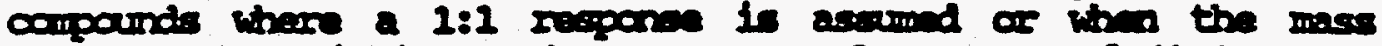
spectral data indicate the presence of a compourd that meets the idestification criterla but the reselt is 100 than the epeciffed detection limit but greatex then zeros for excomple, if the limit of detection is $10 \mathrm{ug} / \mathrm{L}$ and a cancentration of 3 ug $/ \mathrm{L}$ is calculated, it is reported as $3 \mathrm{~J}$.

B = Inis fleg is used when the analyte is ford in the associated blank as wll as in the somple. It indicates posetble/pocbable blank contaminatian. This elag is atsp used for a IIC as well as for a posttively identefled IC coipolind.

$E$ = Indicates that the capound wa detected beyold the . calibration rarge and was aboequntly analyzed at a dilution.

$I$ = Interference.

$X$ - Aditional qualifies used an required are explained in the case narrative.

NR = Recult qualitatively confiand but not able to quantify.

\section{ABEREVTATTONS}

BS = Indicate blank pike in wich ragant grod water is spiked with the CP materix epliking colution and carried through all the stepe in the method. Spike reovirien are rported.

BSD = Indtates blank epibe dpliata.

MS - Indtate matalx ailo.

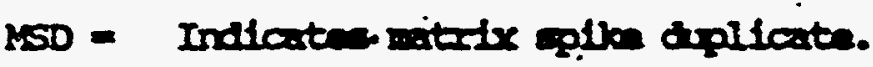

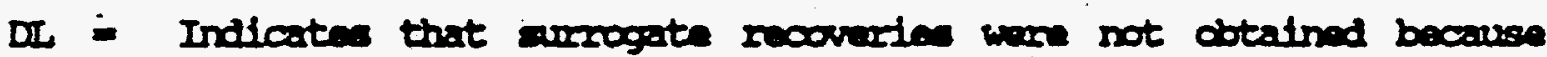
the extract had to be difluted for analysis.

Na = Not applicable.

DF - Dflution factor.

NR - Not requird. 
Cunt ID G8720 10-01R G8720 14-01" G8720 04-01 G8720 02-01 G8720 03-01 05720 02-01A

8 ample

Intormation

Rrwt: $001 \quad 002 \cdots 03$

003

atrixi

WATER

D.T.8

1.00

soIr

ug/L

$\mathbf{u g} / \mathrm{Kg}$

1.00

004

SOIL

Onit:8

$\mathrm{ug} / \mathrm{kg}$

1.00

005

006

$\mathbf{u g} / \mathbf{R g}$

1.00

soIs

Toluene-d8

surrogate

Bromofluorobenzene

Recovery

1,2-Dlchloroethane-d4

110
99
99

99
97
91

103
101
94

Chloromethane

Bromomethane

VInyl Chloride

Chloroethane

Methylene Chloride

Acetone

Carbon Disulfide

1,1-D1Chloroethen

1,1-Dichloroethane

1,2-Dichloroethene (total)

Chloroform

1,2-Dichloroethane

2-Butanone

1,1,1-Tr1ehloroethane

Carbon Tetrachlorlde

Vinyl Acetate

Bromodichloromethane

1, 2-Dichloropropane

c18-1,3-D1chloropropene

Trlchloroethene

Dibromochloromethane

1,1,2-Tr1chloroethane

Benzene

Trans-1,3-Dlchloropropeno

Bromotorm

4-Methy1-2-pentanone

2-Hexanone

Tetrachloroethene

1,1,2,2-Tetrachloroethane

$\begin{array}{rlrl}10 & \mathrm{U} & 11 & \mathrm{U} \\ 10 & \mathrm{U} & 11 & \mathrm{U} \\ 5 & \mathrm{~J} & 11 & \mathrm{U} \\ 10 & \mathrm{U} & 11 & \mathrm{U} \\ 3 & \mathrm{JB} & 11 & \mathrm{~B} \\ 10 & \mathrm{U} & 17 & \mathrm{~B} \\ 5 & \mathrm{U} & 5 & \mathrm{U} \\ 5 & \mathrm{U} & 5 & \mathrm{U} \\ 5 & \mathrm{U} & 5 & \mathrm{U} \\ 20 & & 5 & \mathrm{U} \\ 5 & \mathrm{U} & 5 & \mathrm{U} \\ 5 & \mathrm{U} & 5 & \mathrm{U} \\ 10 & \mathrm{U} & 11 & \mathrm{U} \\ 5 & \mathrm{U} & 5 & \mathrm{U} \\ 5 & \mathrm{U} & 5 & \mathrm{U} \\ 10 & \mathrm{U} & 11 & \mathrm{U} \\ 5 & \mathrm{U} & 5 & \mathrm{U} \\ 5 & \mathrm{U} & 5 & \mathrm{U} \\ 5 & \mathrm{U} & 5 & \mathrm{U} \\ 6 & & 5 & \mathrm{U} \\ 5 & \mathrm{U} & 5 & \mathrm{U} \\ 5 & \mathrm{U} & 5 & \mathrm{U} \\ 5 & \mathrm{U} & 5 & \mathrm{U} \\ 5 & \mathrm{U} & 5 & \mathrm{U} \\ 5 & \mathrm{U} & 5 & \mathrm{U} \\ 10 & \mathrm{U} & 11 & \mathrm{U} \\ 10 & \mathrm{U} & 11 & \mathrm{U} \\ 5 & & 5 & \mathrm{U} \\ 5 & \mathrm{~V} & 5 & \mathrm{U}\end{array}$

" = Outalde of EPA CLP OC IIm1ta.

$\begin{array}{rrr}106 & 104 & 102 \\ 104 & 102 & 105 \\ 93 & 96 & 100\end{array}$

$11 \mathrm{~V} 11 \mathrm{U} \quad 10 \mathrm{0}$

110

$10 \cdot 4$

110 ! 1100

$\begin{array}{llllll}11 & B & 8 & B & 8 & B\end{array}$

50

5 D

53

50

5 0

110

50

50

110

5 U

$13 \mathrm{~B}$

i


Cllent, WSRC GUNSITB " "0

Work order: $0630-28-13-0000$ ef 16 Cunt ID, 68720 10-01E CS720 14 G5720 04-01 G8720 02-01 63720 03-01 $68720 \quad 02-01 A$

Rart:

001

$002 \quad-003$

$004^{\circ}$

005

006

Toluene.

Chlorobenzene

50

50

50

50

$\begin{array}{ll}5 & 0 \\ 5 & 0\end{array}$

Bthylbenzene

50

styrene

5, 0

50

5 0

50

xylene (total)

* outolde of BPA CLP gC Iindto.

$\begin{array}{ll}5 & 0 \\ 5 & 0\end{array}$

50

50

50

50

$\begin{array}{ll}5 & 0 \\ 5 & 0\end{array}$

$\begin{array}{ll}5 & 0 \\ 5 & 0 \\ 5 & 0 \\ 5 & 0 \\ 5 & 0\end{array}$

50


Roy F. Heston, 1c. - LLonv111e Laboratory

Volatiles by GC/MS, Hsi Ilet

Report Date? 03/26/90 15849

Cust ID: GS720 11-01B Gs720 06-01

GS720 05-01

GS720 12-01B

$68720 \quad 01-02$

Q8720 08-02

Sample

Information

$\begin{array}{rccc}\text { RFH: } & 007 & 008 & 009 \\ \text { Matrix: } & \text { WATER } & \text { SOIL } & \text { soIL } \\ \text { D.F.: } & 1.00 & 1.00 & 1.00 \\ \text { Unlts: } & \text { ug/L } & \text { ug/Rg } & \text { ug/kg }\end{array}$

010
TATER
1.00
ug/t

011
soI1
1.00
ag/ $\mathrm{Kg}$

012

BOIL

$\operatorname{lig} / \mathrm{Rg}$

$\begin{array}{rr}\text { Toluene-d } & \text { Trogrofluorobenzene }\end{array}$

Bromofluorobenzene
Recovery' 1,2-D Lchloroethane-d4

$113 * 104$
101

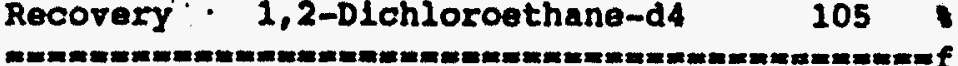

Chloromethane

Bromomethane

Vinyl Chloride

Chloroethane

Methylene chloride

Acetone

Carbon Dlsulelda

104

101

$10 \mathrm{U}$

96

101

$114 *$
101
101

95 .

101
101

$\begin{array}{ll}12 & \mathrm{U} \\ 12 & \mathrm{U}\end{array}$

$10 \mathrm{v}$

1,1-Dlchloroethene

1,1-D1Chloroethan

1,2-DLchlorodthene (total)

Chloroform

1,2-Dlchloroethane

2-Butanone

1,1,1-Tr1chloroethane

Carbon Tetrachlorlde

VIny I Acetate

Bromodlchloromethane

1,2-Dichloropropane

c18-1,3-D1chloropropene

Trlahloroethene

Dlbromochloromethane

1,1,2-Tr1chldtoethane

Benzene

Trane-1, 3-D1chloropropene

Bromoform

4-Methy 1-2-pentanone

2-Bexanone.

Tetrachloroethene

1,1,2,2-Tetrachloroethane

- Outslde of IPR ChP QC ILmite.

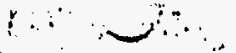

$2 J$

$10 \mathrm{v}$

4 JB

$4 J$

$12 \mathrm{v}$

120

8 B

$17 \mathrm{~B}$

6 U

6 v

60

$6 \mathrm{U}$

2 JB

$6 \mathrm{v}$

12 บ

6 v

60

12 U

60

$6 \mathrm{U}$

$6 \mathrm{v}$

60

6 U

60

6 v

6 U

$6 \mathrm{v}$

12 v

120

60

25

5

60
110

110

11 v

110

8 B

$12 \mathrm{~B}$

50

5 U

5 U

5 t

$1 \mathrm{JB}$

50

110

50

50

11 U

50

5 U

50

50

5 v

$5 \mathrm{U}$

5 v

50

50

$11 \mathrm{v}$

110

50

50
10

100

100

100

68

$10 \mathrm{D}$

50

50

50

15

5 ט

5 ' 0

10 t

5 v

50

100

5 บ

50

50

50

50

50

$5 \cdot 0$

50

50

$10 \mathrm{v}$

100

50

50

$\begin{array}{rr}106 & 100 \\ 100 & 99\end{array}$

97

$\begin{array}{rl}11 \mathrm{~V} & 12 \mathrm{~V}\end{array}$

110012

1100120

1100120

$9 \mathrm{~B} \quad 10 \mathrm{~B}$

24 B $\quad 16$ B

$5 \mathrm{~V} \quad 60$

50

$5 \mathbf{0}$

50

50

50

110

50

50

110

50

5 U

50

50

50

50

50

5 v

50

110

110

$\begin{array}{ll}5 & 0 \\ 5 & 0\end{array}$ 
Cust ID: G8720 11-018 G8720 06-01

GS720 05-01 G5720 12-018 65720 01-02 G5720 08-02

RFW

007

008 009

010

011

012

Toluene

Chlorobenzene

Bthylbenzene

50

$\begin{array}{ll}5 & 0 \\ 5 & 0\end{array}$

$\begin{array}{ll}5 & 0 \\ 5 & 0\end{array}$

$\begin{array}{ll}5 & 0 \\ 5 & 0\end{array}$

Styrene

xylene (total)

60

5 v

60

60

60

* = Outalde of EPA CLP QC IImita.

$\begin{array}{ll}5 & \mathbf{U} \\ 5 & \mathbf{U} \\ 5 & \mathbf{U} \\ 5 & \mathbf{U} \\ 5 & \mathbf{U}\end{array}$

$\begin{array}{ll}5 & \mathbf{U} \\ 5 & 0 \\ 5 & 0 \\ 5 & \mathrm{U} \\ 5 & 0\end{array}$

50

60

60

60

60

$6 \mathrm{v}$ 


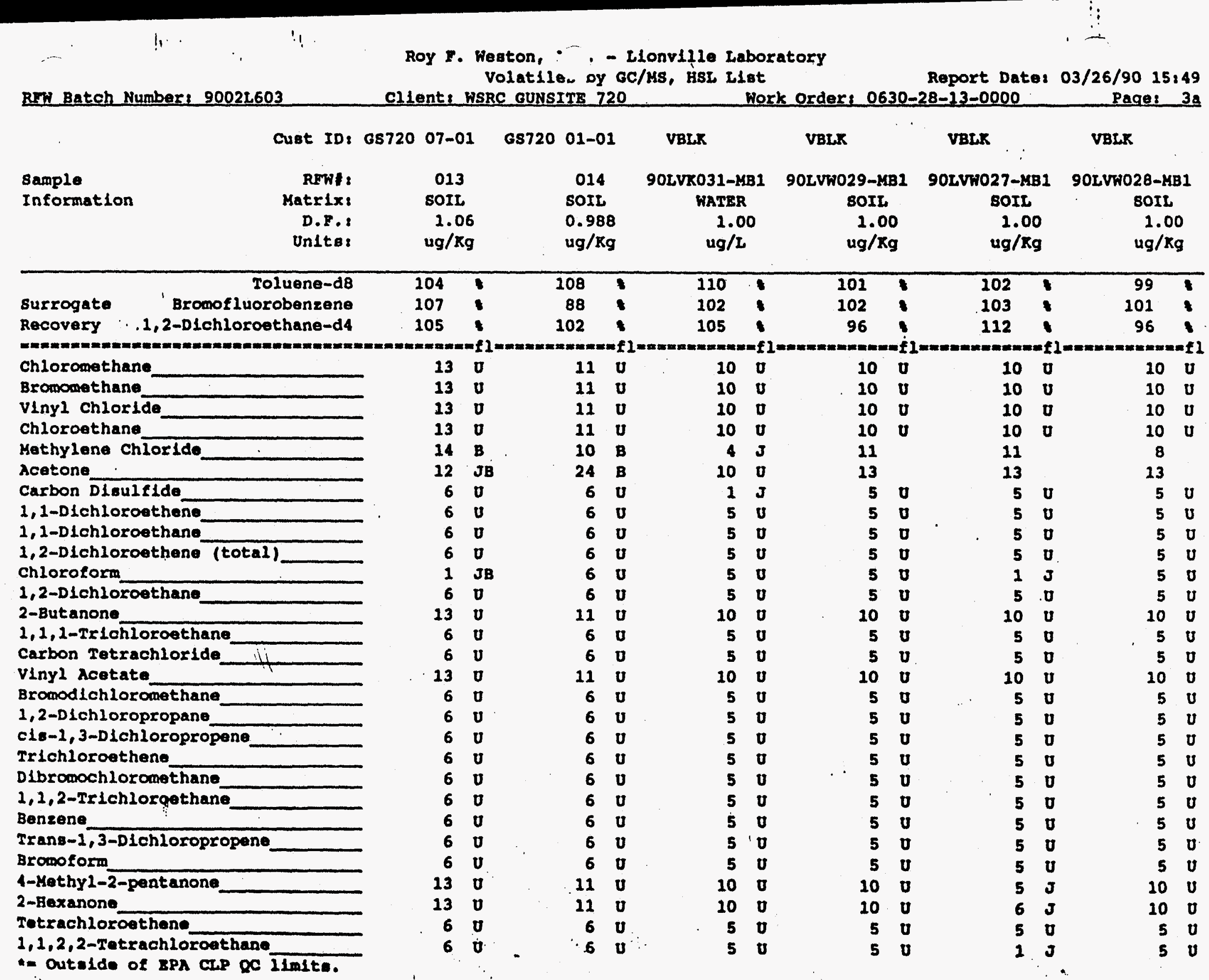


Rrw Batch Number: 9002L603

ClLent: WSRC GUNSITE 720 Cust ID: GS720 07-01 GS720 01-01 VBLX

Hork Order: 0630-28-13-0000 Page: 3b

RFWI :

013

014

90LVR031-MB1

VBLX

VBLX

VBLX

Toluene

$\begin{array}{ll}6 & 0 \\ 6 & 0\end{array}$

chlorobenzene

Bthylbenzene

60

60

60

60

Xylene (total)

6 U

6. $\mathrm{v}$

$6 \mathrm{v}$

60

$\begin{array}{ll}5 & \mathbf{U} \\ 5 & \mathbf{U} \\ 5 & \mathbf{U} \\ 5 & \mathbf{U} \\ 5 & \mathbf{U}\end{array}$

90LVพ029-KB1

90LVพ027-MB1 90LVW028-MB1

** Outside of EPA CLP QC IImits. 


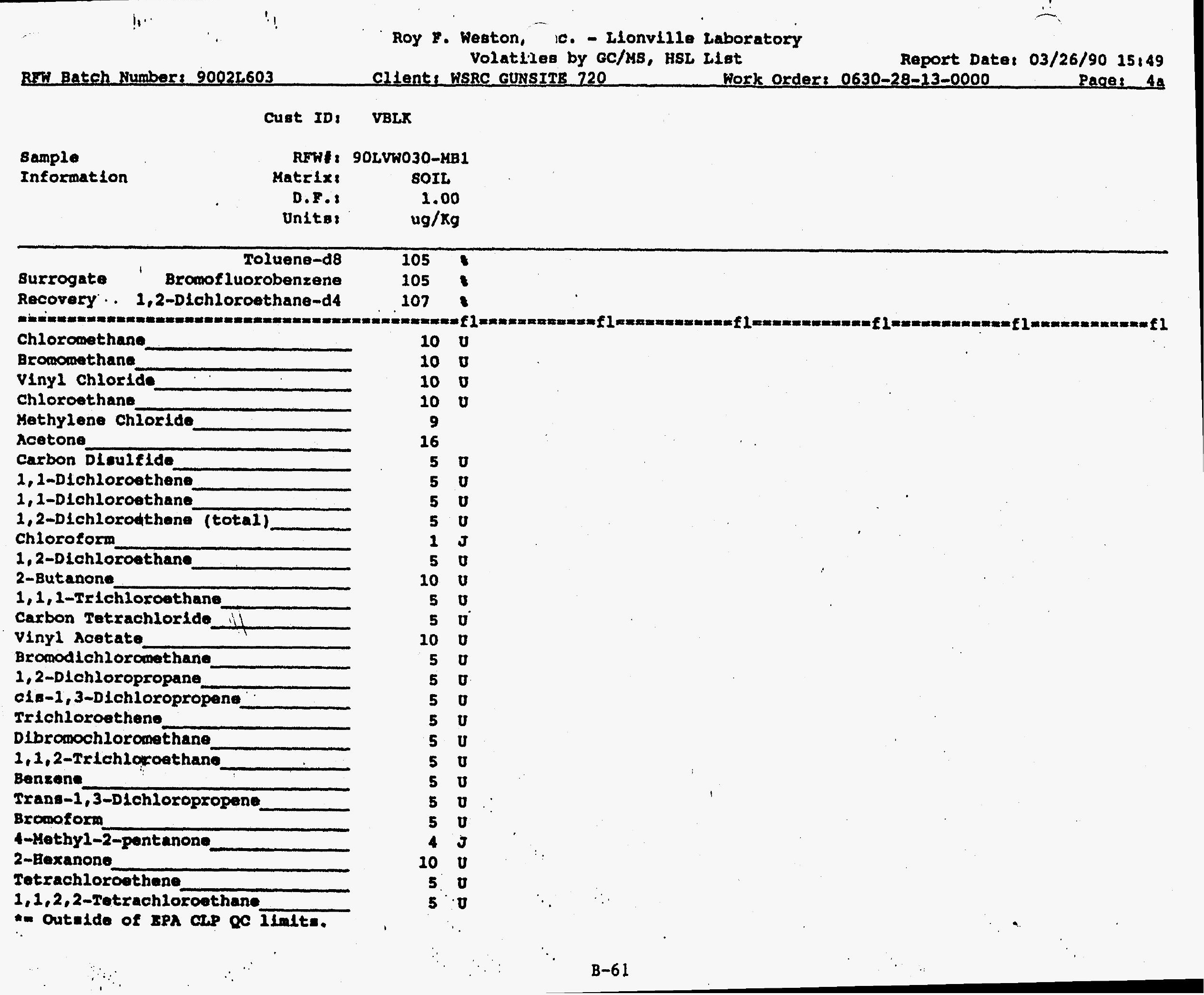


RFHE: 90LVW030-MBI

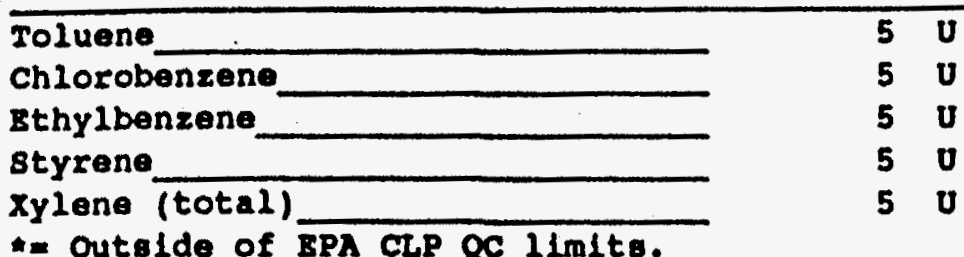


Q W

CLIENT: WSRC GUNSITE 720

RFW : $9002 L 603$

T.O. : $0630-28-13$
ROY E. WESTON, IXC.

Lionville Laboratory

\section{METAL8 NARRATIVE}

The following is a summary of the quality control results and a description of any problems encountered during the analysis of this batch of samples:

1. Al1 sample holding times as required by 4 OCFR136 were met for water samples. Note: Holding times for soil samples have not been promulgated by the USEPA.

2. All calibration verification checks were within the required control limits of 90-100\% (85-115\% for-Hg). Calibration verification is performed using independent standards from Inorganic Ventures, Inc.

3. All preparation blanks were analyzed below the required detection limit.

4. Laboratory control standards were within the control limits of 80-120\% with the exception of silver (59\%) for site ID\# 90L0226-LC1 and (127\%) for site ID\# 90L0219-LCI. The blank spike reproducibility was outside the 20 of window for silver at $58 \%$.

Note: The USEPA-CLP has dropped control limits for silver and antimony due to documented difficulties in obtaining reliable results. WESTON Analytics has adopted the same policy.

5. The analytical methods applied by the laboratory for the determination of metals are:

$\begin{array}{ll}\text { As: } & \text { EPA } 206.2 \\ \mathrm{Se} & \mathrm{EPA} 270.2 \\ \mathrm{~Pb} & \mathrm{EPA} 239.2 \\ \mathrm{Tl} & \text { EPA } 279.2\end{array}$

Hg: $\quad$ EPA 245.1

ICP Scan: EPA 200.7

All Others: EPA 200.7

EP Leachates (except $\mathrm{Hg}$ ) : 200.7

NOTE: For solid samples, all results are reported on a dry weight basis.

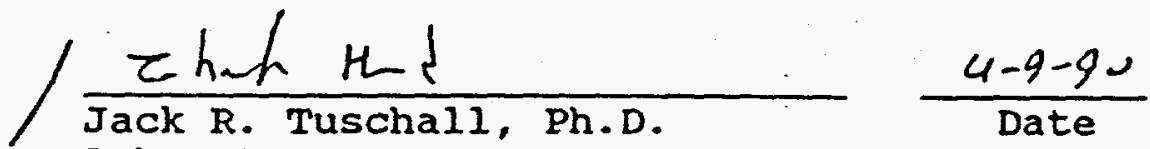

Laboratory Manager

Lionville Analytical Laboratory 


\section{ROY F. WESTON, INC. \\ GLOSSARY OF TERMS - INORGANIC REPORTS}

\section{DATA OUALIEIERS}

$U$ - Indicates that the parameter was not detected at or above the reported limit. The associated numerical value is the sample detection 1 imlt.

* - Indicates that the original sample result is greater than $4 x$ the spike amount added. The USEPA-CLP has determined that spike results on samples where this occurs may be unreliable and, therefore, the control limits are not applicable.

\section{ABBREVIATIONS}

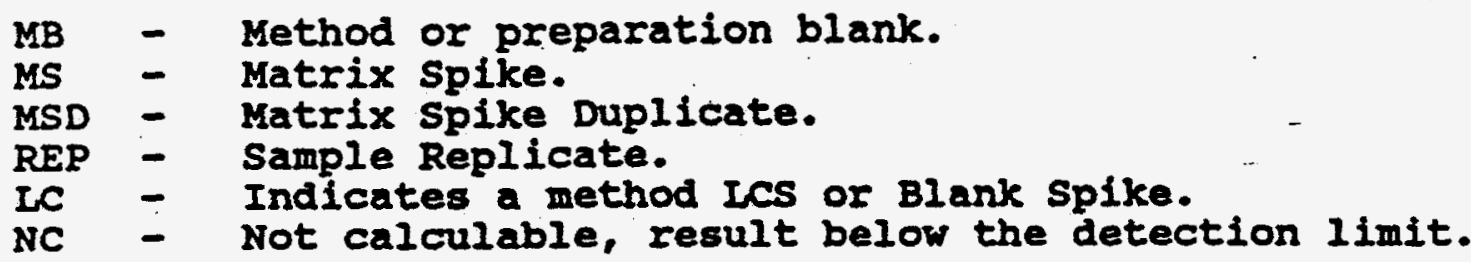

\section{IABORATORY CHRONOLOGY AND HOLDTIME REPORT}

The test code listed indicates the specific analysis or preparation procedure employed. The codes may be interpreted as follows:

\footnotetext{
MAAW - Metals prep test for AA digestion, water matrix. MAAS - Metals prep test for AA digestion, soil matrix. MICW - Metals prep test for ICP digestion, water matrix. MICS - Metals prep test for ICP digestion, soil matrix.

M**TO- This type of code indicates a total metal analysis (eg. KAGTO indicates an analysis for total silver).

M**SO- This type of code indicates a soluble metal analysis. (eg. MAGSO indicates an analysis for soluble silver).

$M * * E P-$ This type of code indicates an EPTOXICITY metals analysis (eg. MAGEP indicates an analysis for eptox eilvex).

I**To- This type of code indicates a non-metallic total analysis. There is also a complimentary soluble analysis for each of these codes (og. ICNTO indicates an analysis for total cyanidef.

$A$ suffix of $-R$ or -5 following these codes indicates a replicate or spike analysis respectively.
} 
ROY 2. WESTON IRC.

INORGANICS DATA SULAMRY REPORT D4/09/90

CLIENT: WSRC GUNSITE 720

WORK ORDER: 0630-28-13-0000

$\begin{array}{ll}\text { SAYPLE } & \text { SITS ID } \\ -001 & \text { GS720 10-018 }\end{array}$

$-002 \quad$ GS720 14-01

$-003$

$-004$

GS720 02-01

GS720 04-01

\section{ARTIXY.}

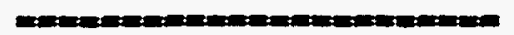

sItVia, romer

ARsENIC, TOTAT

BARTUK, TOTAL

CADMrUx, romer.

carourus, romar.

YIERCURY, TOIAT

IEAD, IOTAT

SELENIUX, IOTAT

SILVER, TOTAT

ARSEKIC, TOMAR

BARIUL, TOLN

CADKIOA, TOTAT

CEROKIUL, rOIAT.

IERCURY, TOTAT

IEAD, TOTAL

SEIMNIUK, TOMAT.

c5720 02-01

\section{MESTON BATCA $9002 L 603$}

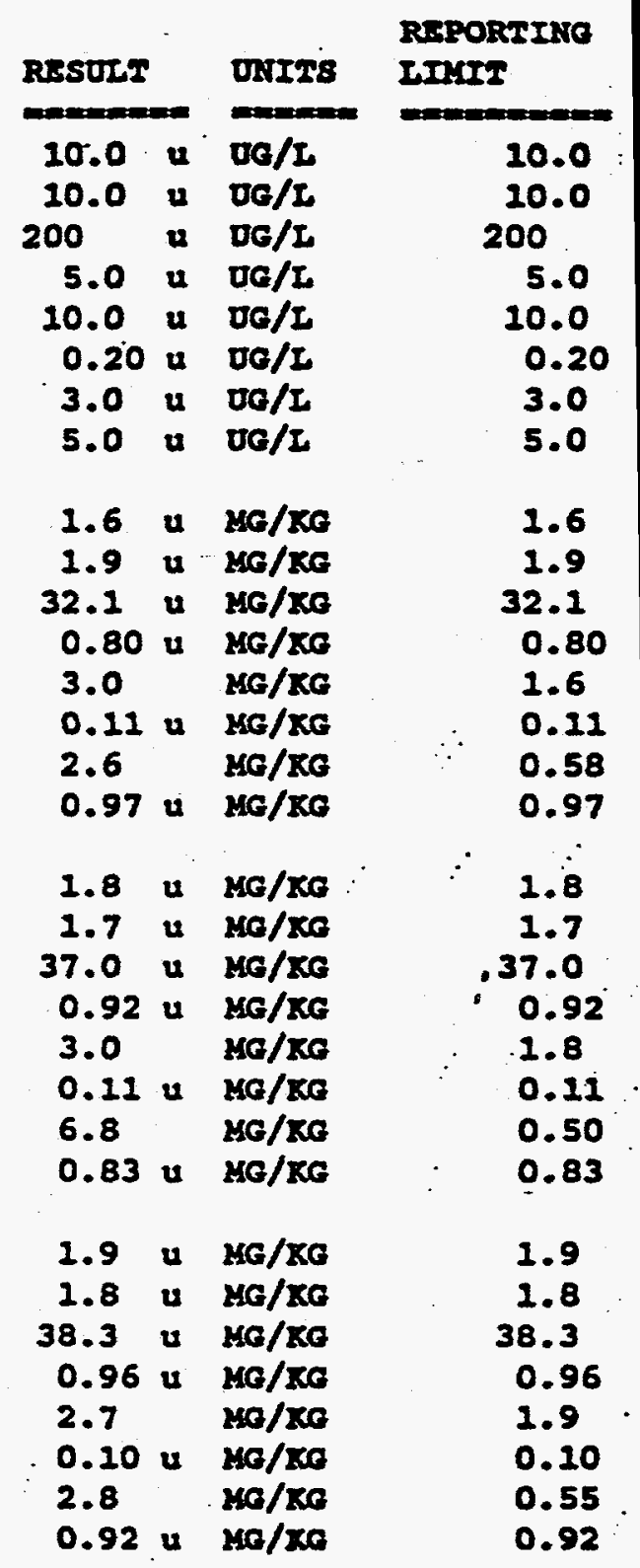


ROY F. KESTON INC.

INORGANICS DATA SUMRARY RRPORT 04/09/90

CLIENT: WSRC GUASITE 720

WORK ORDER: 0630-28-13-0000

\section{SAYPL:}

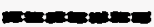

$-005$

SITE ID

c5720 03-01

$-011$

GS720 01-02

$-014$

G5720 01-01
WESTOR BATCE \& 90022603

\begin{tabular}{|c|c|c|c|}
\hline \multicolumn{2}{|c|}{ REsuLx } & OxITs & $\begin{array}{l}\text { REPORTINe } \\
\text { InTx }\end{array}$ \\
\hline $\begin{array}{l}2.1 \\
2.0\end{array}$ & a & $\begin{array}{l}\mathrm{HC} / \mathrm{KR} \\
\mathrm{He} / \mathrm{KO}\end{array}$ & 2.1 \\
\hline 41.8 & u & $\mathrm{kg} / \mathrm{KC}$ & 41.8 \\
\hline 1.0 & $\mathbf{u}$ & $\mathrm{MC} / \mathrm{KC}$ & 1.0 \\
\hline 2.9 & & $\mathrm{MC} / \mathrm{KC}$ & 2.1 \\
\hline 0.11 & $\mathbf{u}$ & $\mathrm{HE} / \mathrm{XC}$ & 0.21 \\
\hline 2.2 & & MG/RE & 0.60 \\
\hline 1.0 & $\mathbf{u}$ & $\mathrm{Me} / \mathrm{KG}$ & 1.0 \\
\hline 1.6 & $\mathbf{u}$ & $20 / 20$ & 1.6 \\
\hline 1.7 & $\mathbf{u}$ & $\mathrm{Me} / \mathrm{KO}$ & 1.7 \\
\hline 31.8 & $\mathbf{u}$ & $\mathrm{Me} / \mathrm{KCO}$ & 31.8 \\
\hline 0.80 & $\mathbf{u}$ & $\mathrm{MG} / \mathrm{KO}$ & 0.80 \\
\hline 6.1 & & MG/KG & 1.6 \\
\hline 0.22 & & $M G / x c$ & 0.11 \\
\hline 3.9 & & $\mathrm{MG} / \mathrm{Ko}$ & 0.52 \\
\hline 0.87 & $\mathbf{u}$ & $\mathrm{MG} / \mathrm{KG}$ & ${ }^{0}($ \\
\hline 2.0 & $\mathbf{u}$ & $\mathrm{MG} / \mathrm{KG}$ & 2.0 \\
\hline 2.2 & $\mathbf{u}$ & $\mathrm{MG} / \mathrm{KO}$ & 2.2 \\
\hline 53.9 & & $200 / 200$ & 39.6 \\
\hline 0.99 & $\mathbf{u}$ & $\mathrm{MG} / \mathrm{KG}$ & 0.99 \\
\hline 4.0 & & $\mathrm{MG} / \mathrm{KG}$ & 2.0 \\
\hline 0.21 & $\mathbf{u}$ & $\mathrm{MG} / \mathrm{KG}$ & 0.11 \\
\hline 4.4 & & $\mathrm{NG} / \mathrm{KG}$ & 0.65 \\
\hline 1.1 & $\mathbf{u}$ & $\mathrm{MC} / \mathrm{MC}$ & 1.1 \\
\hline
\end{tabular}


ROY F. KESTON IXC.

INORGANICS METHOD BLANK DATA SURRARY PAGE 04/09/90

CLIENT: WSRC GUNSITE 720

MORK ORDERs 0630-28-13-0000

SAMPL:

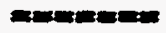

BLANK1

8ITE: ID

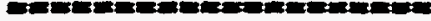

9020219-1KB1

BLANR1 90L0218-KB1

BLANRI 90CO4OA-MBI

BLANK2 90CO4OA-KB2

BLANR3 90CO4OA-KB3

BLANK4 90CO4OA-MB4

BLANRI 90LO226-MBI

BLANRI 90LO225-KB1

BLANRI 90CO40B-सBI

BLANK2 90CO4OB-2GB2
MALYYS:

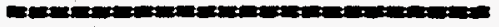

BILVER, TOTAL

BARIUK, TOTAL

CADMIUS, TOTAS

CHROMIDS, TOTAL

ARSERIC, TOTAL

LEAD, TOTAC

SELEAYIOS, TOTAL

MERCURY, TOTAI

MERCURY, TOTAI

MERCURY, TOTAL

RERCURY, TOTAL

SILVER, TOTAL

BARIUK, TOTAL

CADEIUS, TOTAL

CRROMIUX, TOTAI

ARSENIC, TOTAI

LEAD, TOTAL

SELENIUR, TOTAL

HERCURY, TOTAL

IERCORY, TOTAL
MESTON BATCA \& $9002 L 603$

\begin{tabular}{|c|c|c|c|}
\hline RESULT & & DAITs & $\begin{array}{l}\text { REPORIING } \\
\text { IIMIT }\end{array}$ \\
\hline $\begin{array}{c}10.0 \\
200 \\
5.0 \\
10.0\end{array}$ & $\begin{array}{l}\mathbf{u} \\
\mathbf{u} \\
\mathbf{u} \\
\mathbf{u}\end{array}$ & $\begin{array}{l}0 \sigma / L \\
0 G / L \\
0 G / L \\
0 G / L\end{array}$ & $\begin{array}{r}10.0 \\
200 \\
5.0 \\
10.0\end{array}$ \\
\hline $\begin{array}{r}10.0 \\
3.0 \\
5.0\end{array}$ & $\begin{array}{l}u \\
u \\
u\end{array}$ & $\begin{array}{l}0 G / L \\
0 G / L \\
0 G / L\end{array}$ & $\begin{array}{r}10.0 \\
3.0 \\
5.0\end{array}$ \\
\hline 0.20 & $\mathbf{u}$ & $\nabla \bar{G} / L$ & 0.20 \\
\hline 0.20 & u & $D G / L$ & 0.20 \\
\hline 0.20 & $u$ & $0 G / L$ & 0.20 \\
\hline 0.20 & u & $0 G / I$ & 0.20 \\
\hline 2.0 & $\mathbf{u}$ & $M G / K G$ & 2.0 \\
\hline 40.0 & $\mathbf{u}$ & $M G / K G$ & 40.0 \\
\hline 1.0 & $\mathbf{u}$ & $\mathrm{MG} / \mathrm{KG}$ & 1.0 \\
\hline 2.0 & $\mathbf{u}$ & $\mathrm{MG} / \mathrm{KC}$ & 2.0 \\
\hline $\begin{array}{l}2.0 \\
0.60 \\
1.0\end{array}$ & $\begin{array}{l}u \\
u \\
u\end{array}$ & $\begin{array}{l}\mathrm{MG} / \mathrm{KG} \\
\mathrm{MG} / \mathrm{KG} \\
\mathrm{MG} / \mathrm{KG}\end{array}$ & $\begin{array}{l}2.0 \\
0.60 \\
1.0\end{array}$ \\
\hline 0.20 & $\mathbf{u}$ & $M G / K G$ & 0.10 \\
\hline 0.20 & $\mathbf{u}$ & $\mathrm{MG} / \mathrm{KC}$ & 0.10 \\
\hline
\end{tabular}


ROY I. MESTON Inc.

\section{INORGANICS EETHOD BLANR DATA SDMARRY PAGE 04/09/90}

CLIENT: WSRC GUNSITE 720

WORK ORDER: 0630-28-13-0000

EAxpr:

amine-

Branks

SITE ID

900040B-2BB3

BEANK4. 900040B-4BB

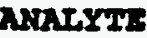

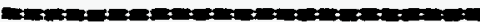

HESTO:

BrIC:

MERCURY, TOMAT

R.sULT

$\therefore=0=$

0.20

0.10

MBRCURY, TOTAI
RaPOREIKG

Trars

DNITS

$\cos$

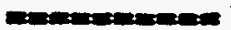

0.10 .

0.10 
ROY F. WESTON IRC.

INORGAKICS DUPLICATE SPIKE REPORT 04/09/90

CIIENT: WSRC GUNSITE 720

WESTOA BATCE is 90022603

WORK ORDER: 0630-28-13-0000

\begin{tabular}{ll} 
SAMPLE & SITR ID \\
\hline ICS2 & 90L0219-LC2
\end{tabular}

Nutares:

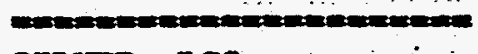

SIIVAR, ICS

BARIOK, LCS

CADLIUK, ICS

LCs2 90L0218-LC2

ICs2 90C040A-IC2

ICS2 90L0226-LC2

LCs2

90L0225-LC2

Lcs2
CHROAIUL, LCs

ARsEnIC, LCS

ITAD, ICS

sLturtux, ICS

IVERCURY, ICS

SIIVER, LCS

BARIUM, ICS

CADYITU, LCS

cerroytur, ics

ARSHITC, ICS

LEAD, ICS

SETENIUL, LCS

YERCURY, LCS
BPIxat2 spIxat2

SRBCOV SRTCOV SDIET

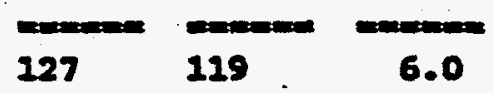

$102 \quad 102 \quad 1.2$

$115 \quad 121 \quad 3.4$

$120 \quad 116 \quad 3.3$

$87.0 \quad 90.7 \cdot 4.1$

$\begin{array}{lll}105 & 104 & 0.95\end{array}$

$110 \quad 113 \cdot 2.7$

$106 \quad 103 \quad 3.4$

$59.0 \quad 107 \quad 57.6$

$102 \quad 101 \quad 0.74$

$106 \quad 206 \quad 0.30$

$\begin{array}{lll}112 & 111 & 0.50\end{array}$

$\begin{array}{lll}94.0 & 97.7 & 3.8\end{array}$

$\begin{array}{lll}113 & 112 & 0.89\end{array}$

$111 \quad 123 \quad 1.5$

$106 \quad 203 \quad 3.4$ 
ROY I. WESTON INC.

INORGANICS LABORATORY CONTROL STANDARDS REPORT 04/09/90

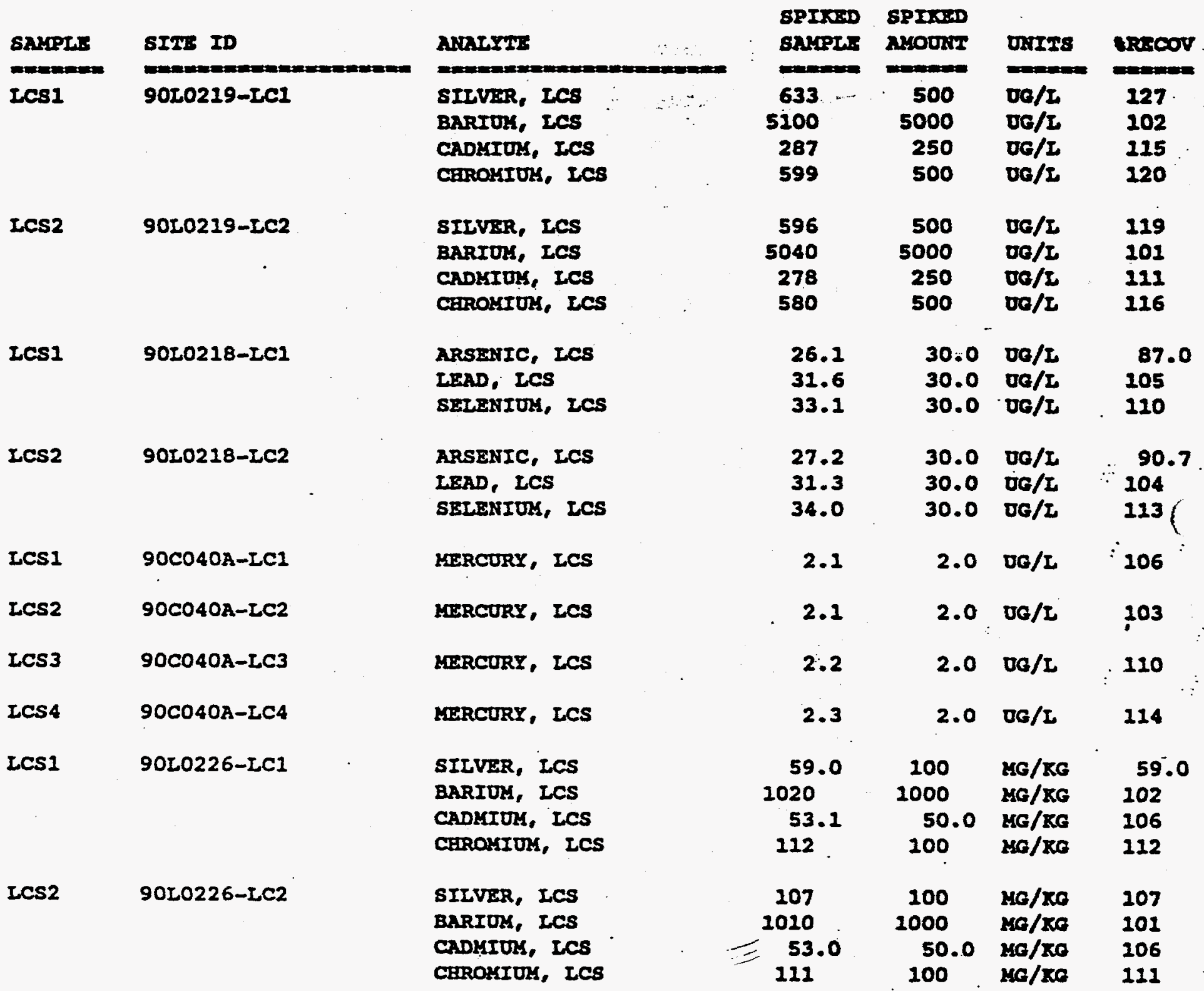


ROY Z. WESTON IMC.

INORGANICS IAABORATORY CONIROT STANDARDS REPORT 04/09/90

\begin{tabular}{|c|c|c|c|c|c|c|}
\hline 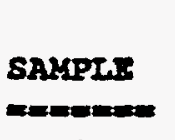 & 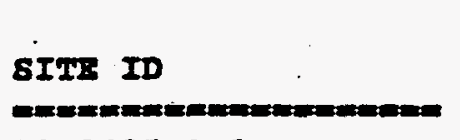 & ARALYHZ & 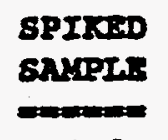 & 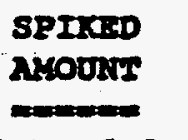 & 0nT28 & SRRCOV \\
\hline $\operatorname{Lcs} 1$ & 90L0225-LC1 & $\begin{array}{l}\text { ARSBAIC, ICS } \\
\text { LEAD, ICS } \\
\text { SELEIUK, LCS }\end{array}$ & $\begin{array}{l}5.6 \\
6.8 \\
6.7\end{array}$ & $\begin{array}{l}6.0 \\
6.0 \\
6.0\end{array}$ & 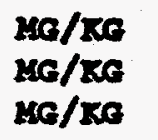 & $\begin{array}{l}94.0 \\
113 \\
111\end{array}$ \\
\hline $\operatorname{LCS} 2$ & 90I0225-LC2 & $\begin{array}{l}\text { ARSEUIC, LCS } \\
\text { LEAD, ICS } \\
\text { SWLENIUK, ICS }\end{array}$ & $\begin{array}{l}5.9 \\
6.7 \\
6.8\end{array}$ & $\begin{array}{l}6.0 \\
6.0 \\
6.0\end{array}$ & 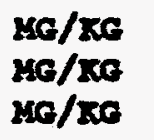 & $\begin{array}{l}97.7 \\
112 \\
113\end{array}$ \\
\hline $\operatorname{LCs} 1$ & $90 C 040 B-2 C 2$ & KERCORY, ICS & 1.1 & 1.0 & $140 / 20$ & 106 \\
\hline $\operatorname{LCs} 2$ & $90 \mathrm{CO} 40 \mathrm{~B}-\mathrm{LC2}$ & YERCURY, LCS & 1.0 & 1.0 & $10 / \pi 0$ & 103 \\
\hline $\operatorname{LCs} 3$ & $90 C 040 B-L C 3$ & MERCURY, ICS & 1.1 & 1.0 & $\mathrm{Me} / \mathrm{KO}$ & 110 \\
\hline $\operatorname{LCS} 4$ & $90 C 040 B-L C 4$ & MERCURY, ICS & 1.1 & 1.0 & 216/20 & .114 \\
\hline
\end{tabular}


Roy I. Weston, Inc. - Ilonil110 Laboratory IMORGANIC ANALYTICAI DATA PACKACE FOR WSRC CUNSITE 720

DATE RECEIVED: 02/16/90

RFW LOT 890022603

CLIENT ID /ANALYSIS RF' * MTX PREP COLTECTION EXTR/PREP

AMareIs

GS720 10-01E

SILVER, TOTAL 001

ARSENIC, TOTAL 001

BARIUK, TOTAL 001

CADKIUA, TOTAL 001

CEROMIUT, TOTAL 001

MERCURY, TOTAL 001

LEAD, TOTAL 001

SELENIUY, TOTAL 001

\begin{tabular}{|c|c|c|}
\hline & 90L0219 & $02 / 14$ \\
\hline & 9020218 & $02 / 14 / 90$ \\
\hline & 90L0219 & $02 / 14 / 90$ \\
\hline & 90L0219 & $02 / 14 / 90$ \\
\hline & 9020219 & $02 / 14 / 90$ \\
\hline & $90 \mathrm{CO} 40 \mathrm{~A}$ & $02 / 14$ \\
\hline & 9020218 & $02 / 24 /$ \\
\hline & 9020218 & \\
\hline
\end{tabular}

$03 / 08 / 90$

$03 / 08 / 90$

$03 / 23 / 90$

$03 / 08 / 90$

$03 / 30 / 90$

$03 / 08 / 90$

$03 / 08 / 90$

$03 / 12 / 90$

$03 / 08 / 90$

03/08/90

$03 / 23 / 90$

$03 / 23 / 90$

$03 / 23 / 90$

$03 / 23 / 90$

$04 / 05 / 90$

$04 / 02 / 90$

$\operatorname{cs720\quad 14-01}$

SILVER, TOTAL

ARSENIC, TOTAL

002

002

BARIUA, TOTAL

002

CADMIUM, TOTAL

CEROMIUM, TOTAI

002

MERCURY, TOTAI

002

LEAD, TOTAL

002

002

SELENIUM, TOTAL

002

$\begin{array}{ll}\text { s } & 90 L 0226 \\ \text { s } & 90 L 0225 \\ \text { s } & 90 L 0226 \\ \text { s } & 90 L 0226 \\ \text { s } & 90 L 0226 \\ \text { s } & 90 \mathrm{CO} 0408 \\ \text { s } & 90 L 0225 \\ \text { s } & 90 L 0225\end{array}$

G5720 04-01
$02 / 14 / 90$

$02 / 14 / 90$

$02 / 14 / 90$

$02 / 14 / 90$

$02 / 14 / 90$

$02 / 14 / 90$

$02 / 14 / 90$

$02 / 14 / 90$
$03 / 09 / 90$

$03 / 09 / 90$

$03 / 09 / 90$

$03 / 09 / 90$

$03 / 09 / 90$

$03 / 12 / 90$

$03 / 09 / 90$

$03 / 09 / 90$
$03 / 23 / 90$

$03 / 30 / 90$

$03 / 23 / 90$

$03 / 23 / 90$

$03 / 23 / 90$

$03 / 13 / 90$

04/05/90

$04 / 01 / 90$
SILVER, TOTAL

ARSENIC, TOTAL.

003

003

003

003

003

003

003

003

CADMIOM, TOTAL

CHROMIUT, TOTAL

MERCURY, TOTAI

SELENIUM, TOTAI

$\begin{array}{ll}\text { S } & 9020226 \\ \text { s } & 9020225 \\ \text { s } & 90 L 0226 \\ \text { s } & 90 L 0226 \\ \text { s } & 9020226 \\ \text { 8 } & 90 C 040 B \\ \text { 8 } & 9020225 \\ \text { s } & 9020225\end{array}$

G5720 02-01

SILVER, TOTAL

ARSENIC, TOTAL

BARIOR, TOTAL

CADMIUY, TOTAL
004

004

004

004 $\begin{array}{lr}\text { s } & 9020226 \\ \text { s } & 902 \overline{0225} \\ \text { s } & 9020226 \\ \text { s } & 9020226\end{array}$
$02 / 14 / 90$

$02 / 14 / 90$

$02 / 14 / 90$

$02 / 14 / 90$

$02 / 14 / 90$

$02 / 14 / 90$

$02 / 14 / 90$

$02 / 14 / 90$
03/09/90

$03 / 09 / 90$

$03 / 09 / 90$

$.03 / 09 / 90$

$03 / 09 / 90$

$03 / 12 / 90$

$03 / 09 / 90$

03/09/90
$03 / 23 / 90$

$03 / 30 / 90$

$03 / 23 / 90$

$03 / 23 / 90$

$03 / 23 / 90$

$03 / 13 / 90$

04/05/90

$04 / 01 / 90$

$\begin{array}{lll}= & & 004 \\ \text { ARSENIC, TOTAL } & 004 \\ \text { BARIOM, TOTAL } & : 004 \\ \text { CADMIUM, TOTAL } & : 004\end{array}$

$02 / 14 / 90$

$02 / 14 / 90$

$02 / 14 / 90$

$02 / 14 / 90$
$03 / 09 / 90$

$03 / 09 / 90$

$03 / 09 / 90$

$03 / 09 / 90$
$03 / 23 / 90$

$03 / 30 / 90$

$03 / 23 / 90$

$03 / 23 / 90$ 
Roy 7. Weston, Inc. - Ilonv1110 Laboratory. IXORGAMIC AMALYTICAL DATA PACKAGE EOR

WSRC consITE 720

DATE RECEIVED: 02/16/90

RFW LOT $\$ 2002 L 603$

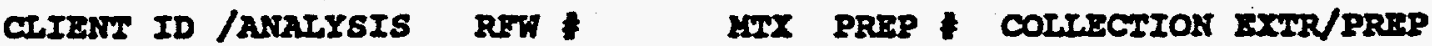

MRAYSIS

CAROAIUY, TOTAT
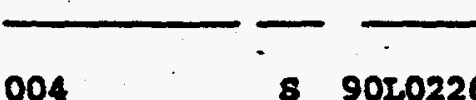

MERCURY, TOTAI

004

9020226

IEAD, TOTAS

004

8 90CO4OB

004

SELENIUS, TOTAL

004

89020225

89020225

$02 / 14 / 90$

$02 / 14 / 90$

$03 / 09 / 90$

$03 / 22 / 90$

$02 / 14 / 90$

$03 / 09 / 90$

$02 / 14 / 90$

$03 / 09 / 90$

$03 / 23 / 90$

$03 / 13 / 90$

$04 / 05 / 90$

$04 / 01 / 90$

G5720 03-01

SILVER, TOTAL

ARSENIC, TOTAL

005

005

BARIUI, TOTAL

005

CADMIUR, TOTAL

005

CHROMIUT, TOTAL

005

MERCURY, TOTAL

005

LEAD, TOTAL

SELENIUS, TOTAL

005

005

$02 / 14 / 90$

$03 / 09 / 90$

$03 / 09 / 90$

$03 / 09 / 90$

$02 / 14 / 90$

$02 / 14 / 90$

$02 / 14 / 90$

$02 / 14 / 90$

$02 / 24 / 90$

$03 / 09 / 90$

$03 / 09 / 90$

$03 / 12 / 90$

$03 / 09 / 90$

$02 / 14 / 90$

$03 / 09 / 90$

$03 / 23 / 90$

$03 / 30 / 90$

$03 / 23 / 90$

$03 / 23 / 90$

$03 / 23 / 90$

$03 / 13 / 90$

$04 / 05 / 90$

04/01/90

G5720 01-02

SILVER, TOTAL

ARSENIC, TOTAI

011

011

BARIUM, TOTAL

011

CADKIOM, TOTAT

011

CEROKIUM, TOTAL

011

YERCURY, TOTAI

011

LEAD, TOTAL

011

SELENIUM, TOTAL

011

$02 / 13 / 90$

$02 / 13 / 90$

$02 / 13 / 90$

$02 / 13 / 90$

$02 / 13 / 90$

$02 / 13 / 90$

$02 / 13 / 90$

$02 / 13 / 90$

$03 / 09 / 90$

$03 / 09 / 90$

$03 / 09 / 90$

$03 / 09 / 90$

$03 / 09 / 90$

$03 / 12 / 90$

$03 / 09 / 90$

$03 / 09 / 90$

$03 / 23 / 90$

$03 / 30 / 90$

$03 / 23 / 90$

$03 / 23 / 90$

$03 / 23 / 90$

$03 / 13 / 90$

$04 / 05 / 90$

$04 / 01 / 90$

GS720 01-01

SILVER, TOTAL

ARSENIC, TOTAL

014

014

$02 / 13 / 90$

$03 / 09 / 90$

$03 / 23 / 90$

014

$02 / 13 / 90$

$03 / 09 / 90$

$02 / 13 / 90$

014

CADMIUN, TOTAL

014

CEROMIUM, TOTAI

$02 / 23 / 90$

$03 / 09 / 90$

$03 / 09 / 90$

$03 / 30 / 90$

$03 / 23 / 90$

$03 / 23 / 90$

014

MERCURY, TOTAL

LEAD, TOTAL

SELENIUM, TOTAL

014

014

$02 / 13 / 90$

$02 / 13 / 90$

$03 / 09 / 90$

$03 / 23 / 90$

$03 / 12 / 90$

$03 / 13 / 90$

$02 / 13 / 90$

$03 / 09 / 90$

$04 / 05 / 90$

$03 / 09 / 90$

$04 / 01 / 90$

LAB QC:

SILVER IABORATORY

LC1 BS

พ 9020219

$\mathbf{x} / \mathbf{A}$

$03 / 08 / 90$

$03 / 23 / 90$ 
Roy F. Heston, Inc. - ILonfllle Laboratory INORGANIC ANALYTICAL DATA PACKAGE FOR WSRC CONSITE 720

DATE RECEIVED: $02 / 16 / 90$

RFW LOT $\div 9002 L 603$

\begin{tabular}{|c|c|c|c|c|c|c|c|}
\hline CLIENT ID /ANALYSIS & RFW & $\neq$ & $\operatorname{lngx}$ & PREP & COHEsction & EXIR/PREP & ANarysIs \\
\hline BARIUA LAABORAIORY & ICI & Bs & $\boldsymbol{n}$ & 9020219 & $\boldsymbol{n} / \mathbf{A}$ & $03 / 08 / 90$ & $03 / 23 / 90$ \\
\hline CADMIOM LABORAIORY & LCI & Bs & $\mathbf{n}$ & 9020219 & $\mathbf{x} / \mathbf{a}$ & $03 / 08 / 90$ & $03 / 23 / 90$ \\
\hline CEROMIOM LABORATORY & LC1 & Bs & $\boldsymbol{H}$ & 9020219 & $\pi / \lambda$ & $03 / 08 / 90$ & $03 / 23 / 90$ \\
\hline SIIVER IABORAIORY & IC2 & BS & $\boldsymbol{w}$ & 9010219 & $\pi / \lambda$ & $03 / 08 / 90$ & $03 / 23 / 90$ \\
\hline BARIUY ILABORATORY & IC2 & $\mathbf{B s}$ & $\boldsymbol{w}$ & 9020219 & $n / \lambda$ & $03 / 08 / 90$ & $03 / 23 / 90$ \\
\hline CADMIOM LABORATORY & LC2 & Bs & $\boldsymbol{w}$ & 9020219 & $\boldsymbol{x} / \boldsymbol{A}$ & $03 / 08 / 90$ & $03 / 23 / 90$ \\
\hline CHROMIULA IABORATORY & LC2 & BS & $\boldsymbol{w}$ & 90工0219 & $\boldsymbol{n} / \mathbf{\lambda}$ & $03 / 08 / 90$ & $03 / 23 / 90$ \\
\hline SILVER, TOTAI & MBI & & $\boldsymbol{m}$ & 9010219 & $n / \lambda$ & $03 / 08 / 90$ & $03 / 23 / 90$ \\
\hline BARIOR, TOTAL & 2B21 & & $\mathbf{w}$ & 9020229 & $n / \lambda$ & $03 / 08 / 90$ & $03 / 23 / 90$ \\
\hline CADMIOU, TOIAI & MB2 & & พ & 9020219 & $n / \mathbf{A}$ & $03 / 08 / 90$ & $03 / 23 / 90$ \\
\hline CEROLIOM, TOTAI & MBI & & $n$ & 9020219 & n/a & $03 / 08 / 90$ & $03 / 23 / 90$ \\
\hline ARSENIC LABORATORY & ICI & Bs & 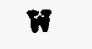 & 9020218 & $n / \lambda$ & $03 / 08 / 90$ & $03 / 30 / 90$ \\
\hline IEAD IAABORATORY & ICI & BS & $\boldsymbol{W}$ & 9020218 & $n / \lambda$ & $03 / 08 / 90$ & $04 / 05 / 90$ \\
\hline SELENIOM LABORATORY & LC1 & Bs & 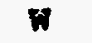 & 9020218 & $8 / \lambda$ & 03/08/90 & 04/02/90 \\
\hline ARSENIC IABORATORY & LC2 & BS & $\boldsymbol{n}$ & 9020218 & $N / A$ & 03/08/90 & $03 / 30 / 90$ \\
\hline IFAD LABORATORY & LC2 & BS & $H$ & 9020218 & $x / \lambda$ & $03 / 08 / 90$ & $04 / 05 / 90$ \\
\hline SELENIUY LABORATORY & LC2 & BS & $\boldsymbol{w}$ & 9020218 & $n / x$ & $03 / 08 / 90$ & $04 / 02 / 90$ \\
\hline ARSENIC, TOTAL & ZABI & & $H$ & 9020218 & $N / A$ & $03 / 08 / 90$ & $03 / 30 / 90$ \\
\hline LEAD, TOTAL & 2AB1 & & $\boldsymbol{n}$ & 9020218 & $x / A$ & 03/08/90 & $04 / 05 / 90$ \\
\hline SELENIUM, TOTAL & MBI & & $\mathbf{H}$ & 9020218 & $N / A$ & 03/08/90 & $04 / 02 / 90$ \\
\hline MERCURY LABORATORY & ICI & BS & $m$ & $90 C 040 A$ & $N / A$ & $03 / 12 / 90$ & $03 / 13 / 90$ \\
\hline MERCURY LABORATORY & LC2 & Bs & $\omega$ & $900040 A$ & $x / \lambda$ & $03 / 12 / 90$ & $03 / 13 / 90$ \\
\hline MERCURY LABORATORY & IC3 & Bs & $\omega$ & $900040 \mathrm{~A}$ & $\mathbf{N} / \mathbf{A}$ & $03 / 12 / 90$ & $03 / 23 / 90$ \\
\hline MERCURY IAABORATORY & LC4 & BS & W & $90 C 040 \mathrm{~A}$ & $n / x$ & $03 / 12 / 90$ & $03 / 13 / 90$ \\
\hline MERCURY, TOTAL & MB1 & & $n$ & $90 \mathrm{C040A}$ & $x / A$ & $03 / 12 / 90$ & $03 / 13 / 90$ \\
\hline MERCURY, TOTAL & MB2 & & $\boldsymbol{H}$ & $90 \mathrm{C040A}$ & $N / A$ & $03 / 12 / 90$ & $03 / 13 / 90$ \\
\hline MERCURY, TOTAL & MB3 & & $n$ & $90 \mathrm{CO40A}$ & $M / A$ & $03 / 12 / 90$ & $03 / 13 / 90$ \\
\hline MERCURY, TOTAL & MB4 & & $\boldsymbol{n}$ & $90 C 040 A$ & $N / A$ & $03 / 12 / 90$ & $03 / 13 / 90$ \\
\hline SILVER LABORATORY & LC1. & BS & 8 & 90L0226 & $N / A$ & $03 / 09 / 90$ & $03 / 23 / 90$ \\
\hline BARIUM LABORATORY & LC1 & BS & $\mathbf{8}$ & 90L0226 & $\mathbf{x} / \mathbf{A}$ & $03 / 09 / 90$ & $03 / 23 / 90$ \\
\hline BERYLLIOM LABORATORY & LC1 & Bs & 6 & 9020226 & $x / A$ & $03 / 09 / 90$ & $03 / 23 / 90$ \\
\hline CADMIUM IABORATORY & LC1 & BS & $\mathbf{s}$ & 90L0226 & $N / A$ & 03/09/90 & $03 / 23 / 90$ \\
\hline COBAIT LABORATORY & ICI & Bs & 8 & 9020226 & $N / A$ & $03 / 09 / 90$ & $03 / 23 / 90$ \\
\hline CEROMIUM LABORATORY & LC1 & Bs & 8 & 9020226 & $N / \mathbf{A}$ & $03 / 09 / 90$ & $03 / 23 / 90$ \\
\hline COPPER LABORATORY & LC1 & Bs & 8 & 90L0226 & $\pi / A$ & $03 / 09 / 90$ & $03 / 23 / 90$ \\
\hline IICKEL IABORATORY & LC1 & Bs & 8 & 9020226 & $\boldsymbol{\theta} / \mathrm{A}$ & $03 / 09 / 90$ & $03 / 23 / 90$ \\
\hline ANTIMONY IABORATORY & LC1 & Bs & $\mathbf{8}$ & 9020226 & $\boldsymbol{N} / \mathbf{A}$ & $03 / 09 / 90$ & $03 / 23 / 90$ \\
\hline TIN LABORATORY & ICI & BS & 8 & 90L0226 & $\pi / \lambda$ & 03/09/90 & $03 / 23 / 90$ \\
\hline VANADIUM IABORATORY & LC1 & BS & $\mathbf{s}$ & 9020226 & $x / \lambda$ & 03/09/90 & $03 / 23 / 90$ \\
\hline IINC LABORATORY & LC1 & BS & 8 & 9020226 & $N / \mathbf{A}$ & $03 / 09 / 90$ & $03 / 23 / 90$ \\
\hline
\end{tabular}


Roy F. Neuton, Inc. - Ilonv111 Laboratory

INORGAIIC ANALYTICAL DATA PACRAGE FOR HSRC GUISITE 720

DATE RECEIVED: 02/16/90

RFA LOT $\$ 8002 L 603$

\begin{tabular}{|c|c|c|c|c|c|c|c|}
\hline CLIENTI ID / ANALYSIS & RET & 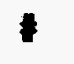 & Inx & PREP & corrserion & EXYN/PRTAP & Murrsis \\
\hline SILVER LABORATORY & $\mathbf{L C 2}$ & Bs & $\mathbf{8}$ & 9020226 & $\mathbf{n} / \mathbf{a}$ & $03 / 09 / 90$ & $03 / 23 / 90$ \\
\hline BARIUY LABORATORY & IC2 & $\mathbf{B s}$ & 8 & 9020226 & $\mathbf{x} / \mathbf{A}$ & $03 / 09 / 90$ & $03 / 23 / 90$ \\
\hline BERYIIIUM LABORATORY & LC2 & Bs & 8 & 9020226 & $\mathbf{x} / \mathbf{A}$ & $03 / 09 / 90$ & $03 / 23 / 90$ \\
\hline CADKIUY IABORATORY & LC2 & BS & $\mathbf{s}$ & 9020226 & $\pi / \lambda$ & $03 / 09 / 90$ & $03 / 23 / 90$ \\
\hline COBAIT LABORATORY & LC2 & Bs & 8 & 9020226 & $\pi / \lambda$ & $03 / 09 / 90$ & $03 / 23 / 90$ \\
\hline CEROMIUM LABORATORY & LC2 & Bs & 8 & 90г0226 & $\mathbf{n} / \boldsymbol{\lambda}$ & $03 / 09 / 90$ & $03 / 23 / 90$ \\
\hline COPPER LABORATORY & LC2 & BS & $\mathbf{8}$ & 90г0226 & $\mathbf{n} / \mathbf{A}$ & $03 / 09 / 90$ & $03 / 23 / 90$ \\
\hline NICKRI LABORATORY & LC2 & BS & $\mathbf{s}$ & 9020226 & $x / \pi$ & $03 / 09 / 90$ & $03 / 23 / 90$ \\
\hline ANTIMONY LABORATORY & LC2 & BS & $\mathbf{s}$ & 90L0226 & $\mathbf{n} / \mathbf{A}$ & $03 / 09 / 90$ & $03 / 23 / 90$ \\
\hline TIN LABORATORY & LC2 & BS & $\mathbf{s}$ & 9020226 & $\mathbf{n} / \mathbf{A}$ & $03 / 09 / 90$ & $03 / 23 / 90$ \\
\hline VANADIUM LABORATORY & LC2 & BS & $\mathbf{s}$ & 9020226 & $n / \boldsymbol{A}$ & $03 / 09 / 90$ & $03 / 23 / 90$ \\
\hline ZINC LABORATORY & LC2 & BS & $\mathbf{s}$ & $90 \check{0226}$ & $x / \mathbf{x}$ & $03 / 09 / 90$ & $03 / 23 / 90$ \\
\hline SILVER, TOTAI & MB1 & & 8 & 9020226 & $\boldsymbol{x} / \mathbf{\pi}$ & $03 / 09 / 90$ & $03 / 23 / 90$ \\
\hline BARIUS, TOTAI & 2081 & & 8 & 9020226 & $x / \lambda$ & $03 / 09 / 90$ & $03 / 23 / 90$ \\
\hline BERYLLIUK, TOTAL & MBI & & $\mathbf{s}$ & 9020226 & $\mathbf{n} / \mathbf{A}$ & $03 / 09 / 90$ & $03 / 23 / 90$ \\
\hline CADMIUK, TOTAI & MBI & & $\mathbf{8}$ & 9020226 & $x / x$ & $03 / 09 / 90$ & $03 / 23 / 90$ \\
\hline COBALT, TOTAL & MBI & & 8 & 9010226 & $n / \boldsymbol{n}$ & $03 / 09 / 90$ & $03 / 23 / 90$ \\
\hline CEROMIUM, TOTAL & $\mathbf{2 8 1}$ & & $\boldsymbol{s}$ & 9020226 & $x / \pi$ & $03 / 09 / 90$ & $03 / 23 / 90$ \\
\hline COPPER, TOTAL & MBI & & $\mathbf{s}$ & 9020226 & $N / A$ & $03 / 09 / 90$ & $03 / 23 / 90^{\circ}$ \\
\hline NICKEL, TOTAL & MBI & & $\mathbf{s}$ & 9020226 & $\pi / A$ & $03 / 09 / 90$ & $03 / 23 / 90$ \\
\hline ANTIHONY, TOTAL & MBI & & $\mathbf{s}$ & 9010226 & $\mathbf{x} / \mathbf{A}$ & $03 / 09 / 90$ & $03 / 23 / 90$ \\
\hline TIN, TOTAL & MBI & & $\boldsymbol{s}$ & 9020226 & $x / A$ & $03 / 09 / 90$ & $03 / 23 / 90$ \\
\hline VANADIUM, TOTAL & KBI & & $\mathbf{s}$ & 9020226 & $N / A$ & $03 / 09 / 90$ & $03 / 23 / 90$ \\
\hline ZINC, TOTAI & KB1 & & $\mathbf{s}$ & 9020226 & $x / \lambda$ & $03 / 09 / 90$ & $03 / 23 / 90$ \\
\hline ARSENIC LABORATORY & LCI & BS & $\mathbf{s}$ & 90L0225 & $N / \lambda$ & $03 / 09 / 90$ & $03 / 30 / 90$ \\
\hline LEAD LABORATORY & ICI & Bs & $\mathbf{s}$ & 9020225 & $N / A$ & $03 / 09 / 90$ & $04 / 05 / 90$ \\
\hline SEILENIUM LABORATORY & LCI & $\mathbf{B S}$ & $\mathbf{s}$ & 90L0225 & $\mathbf{N} / \mathrm{A}$ & $03 / 09 / 90$ & $04 / 01 / 90$ \\
\hline TEALIIUM LABORATORY & LCI & BS & $\mathbf{s}$ & 90L0225 & $N / A$ & $03 / 09 / 90$ & $04 / 04 / 90$ \\
\hline ARSENIC LABORATORY & LC2 & Bs & $\mathbf{s}$ & $90 \tau 0225$ & $x / x$ & $03 / 09 / 90$ & $03 / 30 / 90$ \\
\hline LEAD LABORATORY & LC2 & BS & $\mathbf{s}$ & $90 L 0225$ & $N / A$ & $03 / 09 / 90$ & $04 / 05 / 90$ \\
\hline SELENIUM LABORATORY & LC2 & Bs & $\mathbf{8}$ & 9050225 & $N / \mathrm{A}$ & $03 / 09 / 90$ & $04 / 01 / 90$ \\
\hline TEAIIIIUM LABORATORY & LC2 & Bs & $\mathbf{8}$ & 90L0225 & $x / \lambda$ & $03 / 09 / 90$ & $04 / 04 / 90$ \\
\hline ARSENIC, TOTAL & $\mathbf{2 0 B 1}$ & & 8 & 9020225 & $\mathbf{x} / \mathbf{a}$ & $03 / 09 / 90$ & $03 / 30 / 90$ \\
\hline LEAD, TOTAL & LBB1 & & $\mathbf{8}$ & $90 r 0225$ & $x / a$ & $03 / 09 / 90$ & $04 / 05 / 90$ \\
\hline SELENIUM, TOTAL & MBI & & 8 & 90L0225 & $a / x$ & $03 / 09 / 90$ & $04 / 01 / 90$ \\
\hline THAIIIUM, TOTAL & LB1 & & 8 & 9020225 & $x / \pi$ & $03 / 09 / 90$ & $04 / 04 / 90$ \\
\hline MERCURY IABORATORY & LC1 & Bs & $w$ & $90 \mathrm{CO} 408$ & $x / x$ & $03 / 12 / 90$ & $03 / 23 / 90$ \\
\hline WERCURY LABORATORY & LC2 & Bs & $\boldsymbol{w}$ & $90 \mathrm{CO} 40 \mathrm{~B}$ & $x / x$ & $03 / 12 / 90$ & $03 / 13 / 90$ \\
\hline MERCURY LABORATORY & LC3 & Bs & พ & $90 \mathrm{CO} 40 \mathrm{~B}$ & $\mathrm{n} / \mathrm{A}$ & $03 / 12 / 20$ & $03 / 13 / 90$ \\
\hline MERCORY LABORATORY & $\mathbf{2 C 4}$ & BS & $\omega$ & $90 \mathrm{CO} 40 \mathrm{~B}$ & $a / x$ & $03 / 12 / 90$ & $03 / 13 / 90$ \\
\hline
\end{tabular}


Roy F. Weeton, Inc. - Llonv111e Laboratory INORGANIC ANAIYTICAI DATA PACKAGS FOR

ASRC GUNSITH 720

DATE RECEIVED: 02/16/90

CLIENT ID / ANALYSIS

MERCURY, TOMRT

ILRCURY, TOTRT

MERCURY, TOTAT

MERCURY, TOMAT
RFW

281

LCB2

IBB3

YBB4
REA LOT * 890021603

MTX PREP * COLLECTIOA EXTR/PREP ARAYSIS

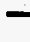

1) 9000408

II 90C040B

i. 9000408

i 90C040B

$n / 4$
$n / 4$
$n / 4$
$n / 4$

$03 / 13 / 90$

$03 / 13 / 90$

$03 / 13 / 90$

$03 / 13 / 90$ 
Roy F. Weston, Inc. - Llonville Laboratory BRA ANALYTICAI DATA PACKAGE YOR WSRC COASITE 720

DATE RECEIVED: $02 / 16 / 90$

RVH LOT 890022603

CLIENT ID

RPW

IHX PREP * COLLECTION EXTR/PREP

Aurysis

GS720 14-01

G5720 02-02

G5720 02-01A

GS720 06-01

G5720 05-01

GS720 01-02

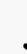

G5720 08-01

G5720 07-01

G5720 01-01

002

004

006

008

009

011

012

013

014

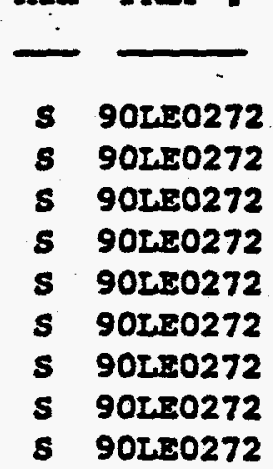

.

\section{$02 / 14 / 90$}

$02 / 14 / 90$

$02 / 14 / 90$

$02 / 14 / 90$

$02 / 14 / 90$

$02 / 13 / 90$

$02 / 13 / 90$

$02 / 13 / 90$

$02 / 13 / 90$

$02 / 26 / 90$

$02 / 26 / 90$

$02 / 26 / 90$

$02 / 26 / 90$

$02 / 26 / 90$

$02 / 26 / 90$

$02 / 26 / 90$

02/26/90

02/26/90

$03 / 08 / 90$

$03 / 08 / 90$

$03 / 08 / 90$

03/08/90

$03 / 08 / 90$

$03 / 09 / 90$

03/09/90

$03 / 09 / 90$

$03 / 09 / 90$

LAB OC:

SBLK

YB1

MB1 BS

s 90580272

$\mathbf{n} / \mathrm{A}$

$02 / 26 / 90$

$03 / 07 / 90$

SBLX

s 90 rE0272

N/A

$02 / 26 / 90$

03/07/90 
W

ROY F. FESTON, INC.

Lionville Laboratory

CLIENT: WSRC-GUNSITE 720

RFI : $9002 L 603$, SEMTVOLATILE

SAMPLEB RECEIVED: 02-16-90

W.0. : : 0630-28-13

NARRATIVE

The set of samples consisted of nine soil samples collected on $02-13,14-90$.

The samples were extracted on 02-26-90 and analyzed according to criteria set forth in SW 846 Method 8270 for TCL Semivolatile target compounds on 03-07,08,09-90.

The following is a summary of the QC results accompanying these sample results and a description of any problems encountered during their analysis:

1. Non-target compounds were detected in these samples.

2. One of sixty-six surrogate recoveries is outside the EPA QC limits. However, EPA QC surrogate recovery criteria are met $[i . e .$, no more than one outlier per fraction (acid and base neutral) and no recoveries less than 108].

3. The matrix spike and replicate requirement are fulfilled by sample GS720-01-02 (9002L604-001) also extracted in batch 90 LE0272.

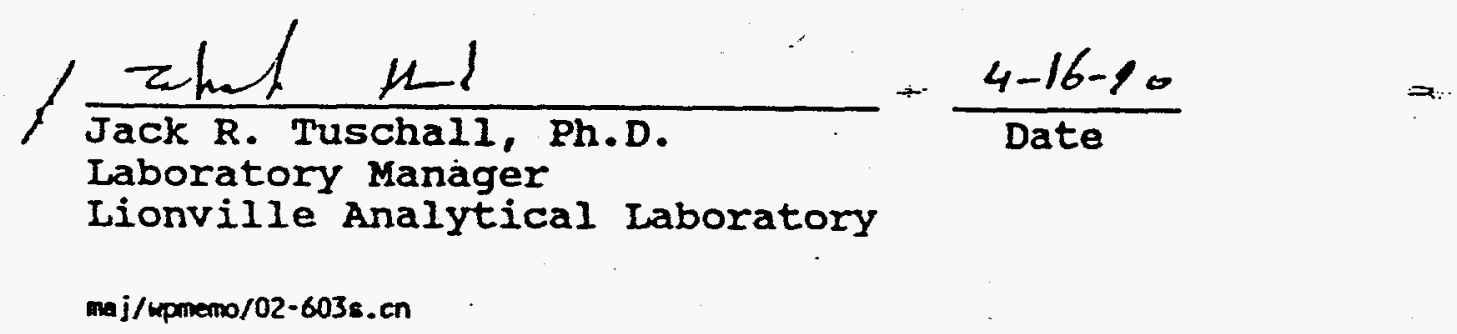




\section{WISTEN}

\section{DATA OUATIETERS}

$U$. compound was analyzed for but not detected. The associated numerical value is the estimated sample quantitation limit which is included and corrected for dilution and percent moisture.

$J$ = Indicates an estimated value. This Ilag is used either when estimating a concentration for tentatively identified caupounds where a $1: 1$ response is assumed or when the mass spectral data indicate the presence of a campound that meets the identification criteria but the result is less than the specified detection limit but greater than zero; for example, if the limit of detection is $10 \mathrm{ug} / \mathrm{L}$ and a concentration of 3 $u g / I$ is calculated, it is reported as $3 \mathrm{~J}$.

$B=$ This flag is used when the analyte is found in the associated blank as well as in the sample. It - indicates possible/probable blank contamination. This llag is also used for a TIC as well as for a positively identified TCL canpound.

$E=$ Indicates that the compound was detected beyond the calibration range and was subsequently analyzed at a dilution.

$I=$ Interference.

A = Aldol condensation Product.

$x=$ Additional qualifiers used as required are explained in the case narrative.

NQ = Result qualitatively confinmed but not able to quantify.

\section{ABEREVIATIONS}

BS = Indicates blank spike in which reagent grade water is spiked with the CIP matrix spiking solutions and carried through all the steps in the method. Spike recoveries are reported.

ESD = Indicates blank spike diplicate.

MS = Indicates iratrix spike.

MSD = Indicates matrix spike diplicate.

$\mathrm{DL}=$ Indicates that surrogate recoveries were not cbtained because the extract had to be diluted for analysis.

NA = Not applicable.

$D F=$ Dilution factor.

$\mathrm{NR}=$ Not required. 
noy 5. weaton, Inc. - ILonv1119 Laboratory

semivolatiles GC/MS, HSL Llet

Report Dates 04/04ind 17831

Bri Bi Number? 90022603 Cllent, N8RC OUNSITB I20 Work Order, 0630-28-13-0000

Pager 18

Cunt ID, 68720 14-01

68720 02-01 $\because 08720$ 02-01A 68720 06-01

08720 05-01

$68720 \quad 01-02$

8 ample

Intormation

$\begin{array}{rr}\text { Rrit: } & 002 \\ \text { Yatrix: } & 80 I I \\ \text { D.E.: } & 1.00 \\ \text { Unite: } & \text { ug/ } / \mathrm{g}\end{array}$

\begin{tabular}{|c|c|c|}
\hline 004 & 006 & 008 \\
\hline soIL & 60IL & 8OIL \\
\hline & & \\
\hline
\end{tabular}

$\begin{array}{cc}009 & 011 \\ \text { soIL } & \text { soIl } \\ 1.00 & 1.00 \\ \mathrm{ug} / \mathrm{kg} & \mathrm{ug} / \mathrm{Kg}\end{array}$

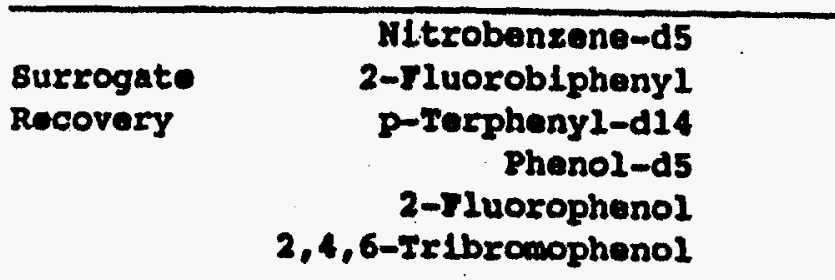

Phanol

ble (2-Chloroothyl)ethor.

2-chlorophenol

1,3-D1chlorobenxene

1, 4-DLchlorobenzene

Benzyl alcohol.

1,2-Dichlorobenzene

2-Yethylphenol

b10 (2-ch1orolsopropy 1) ether

4-Methylphenol.

H-N1trono-D1-n-propylamine

Hexachloroethane

Nitrobenzene

Imophorone

2-N1trophenol

56
68
69
62
64

$\begin{array}{llll}59 & 46 & \\ 68 & 53 & 63 \\ 79 & 52 & 45 \\ 71 & 39 & \end{array}$

2, 4-D Imethylphenol

Benzolc acld

bls (2-Chloroethoxy) mathane

2,4-DLChlorophenol

$1,2,4-$ Irlchlorobenzene

Naphthalene

4-Chloroani11ne

Hexachlorobutadiene

4-Chloro-3-methylphenol

2-Kethylnaphthalene

Hexachlorocyclopentadlene

$\begin{array}{lll}350 & 350\end{array}$

350 v 350 v

350 v

$350 \quad 0$

350, 0

350 U

350 v

$350 \mathrm{~d}$

$350 \mathrm{v}$

3500

$350 \mathrm{v}$

350 u

3500

350 v

$350 \mathrm{v}$

$350 \mathrm{v}$

$1800 \mathrm{U}$

$350 \mathrm{U}$

350 U

350 U

$350 \mathrm{U}$

$350 \mathrm{U}$

$350 \quad v$

$350 \mathrm{v}$

3500

$\begin{array}{ll}350 & \text { v } \\ 350 & 0\end{array}$

$350 \quad 0$

$350 \mathrm{U}$

350 U

$350 \quad 0$

350 v

350 v

$350 \quad v$

350 U

350 U

350 U

350 U

$350 \mathrm{U}$

$350 \mathrm{U}$

$1700 \mathrm{v}$

350 U

350 U

$350 \mathrm{U}$

$350 \mathrm{U}$

$350 \mathrm{U}$

$350 \mathrm{U}$

$350 \mathrm{U}$

$350 \mathrm{U}$

3500

$350 \quad U$

ug/

$\begin{array}{lll}60 & \\ 72 & & \\ 91 & & \\ 79 & & \end{array}$

$\begin{array}{rrr}65 & 83 & \\ 79 & 77 & 116 \\ 94 & 114 & \\ 79 & 91 & \\ 64 & 57 & \end{array}$

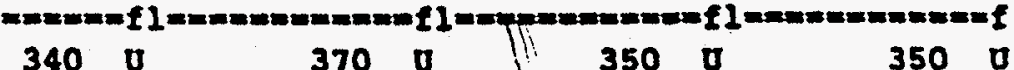

$\begin{array}{ll}340 & \text { v } \\ 340 & \mathrm{v}\end{array}$

$340 \mathrm{~V}$

340 U

$340 \mathrm{D}$

340 O

340 U

340 U

$340 \mathrm{~V}$

340 v

$340 \mathrm{~V}$

$340 \mathrm{U}$

$340 \mathrm{v}$

$340 \mathrm{~V}$

$340 \mathrm{U}$

$340 \mathrm{U}$

$1700 \mathrm{v}$

340 U

$340 \mathrm{U}$

$340 \mathrm{~V}$

340 U

340 U

340 v

340 U

$340 \mathrm{~V}$

- Outnide of ERA ChP gC IImits.

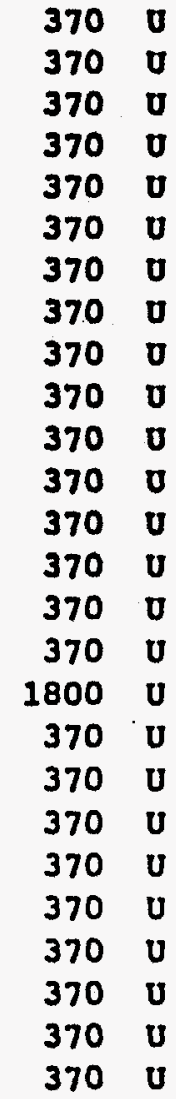

$\begin{array}{ll}350 & \mathbf{U} \\ 350 & \mathbf{U}\end{array}$

350 0

$\begin{array}{ll}350 & 0 \\ 350 & 0\end{array}$

$350 \quad 0$

350 d

$350 \quad 0$

$350 \quad 0$

$350 \mathrm{v}$

$350 \quad 0$

$350 \quad 0$

350 U

$350 \quad 0$

$350 \mathrm{v}$

$350 \mathrm{U}$

3500

$1800 \mathrm{U}$

$350 \mathrm{~d}$

350 U

$350 \mathrm{U}$

350 v

$350 \mathrm{U}$

$350 \quad 0$

3500

350.0

$350 \quad 0$

3500

350

3500

3500

350 v

3500

$350 \quad 0$

$350 \mathrm{v}$

3500

3500

3500

$350 \mathrm{U}$

350.0

$350 \mathrm{U}$

$350 \mathrm{~V}$

$1800 \mathrm{U}$

$350 \mathrm{U}$

$350 \quad \mathrm{v}$

$350 \mathrm{U}$

$350 \mathrm{U}$

$350 \mathrm{U}$

$350 \mathrm{~V}$

$350 \mathrm{U}$

$350 \mathrm{U}$

$350 \mathrm{U}$ 


\section{RPWE:}

$$
002
$$

004

. 006

008

009

011

2,4,6-Tr1chlorophenol

2,4,5-Tr lohlorophenol

2-Chloronaphthaleno.

2-N1troaniline

Dimethylphthalate

Acenaphthylene

2,6-Dinitrotoluene

3-Nitroaniline

Acenaphtheno

2,4-Dinitrophenol

4-N1trophenol

Dibenzofuran

2,4-Dinitrotoluene

Diethylphthalate.

4-Chlorophenyl-phenylethor

\section{Fluorene}

\section{4-N1troaniline}

4,6-DInitro-2-mathylphonol

N-Nitronodiphenylamine (1)

4-Bromophenyl-phenylether

Hexachlorobenzene

Pentachlorophenol

Phenanthrene

Anthracene

D1-n-Butylphthalate

Fluoranthene

Pyrene

Butylbenzylphthalate

3,3'-Dlchlorobenzidine

Benzo (a) anthracene

Chryeene

b1s (2-Ethylhexy1) phthalate

D1-n-octyl phthalate

Benzo(b) fluoranthene

Benzo(k) fluoranthene

Benzo (a) pyrene

Indeno $12,2,3$-cd) pyrene

DLbenzo $(a, h)$ anthracene

Benzo $(g, h, 1)$ perylene

(1) - Cannot be separated from Diphenylamine.

\begin{tabular}{|c|c|c|c|c|c|}
\hline 350 & $\mathbf{0}$ & 350 & 0 & 340 & 0 \\
\hline 1800 & $\mathbf{0}$ & 1700 & $\mathbf{u}$ & 1700 & $\mathbf{0}$ \\
\hline $\mathbf{3 5 0}$ & $\mathbf{v}$ & 350 & $\mathbf{0}$ & 340 & $\mathbf{0}$ \\
\hline 1800 & v & 1700 & v & 1700 & 0 \\
\hline 350 & 0 & 350 & $\mathbf{v}$ & 340 & $\boldsymbol{v}$ \\
\hline 350 & $\mathbf{v}$ & 350 & 0 & 340 & $\boldsymbol{0}$ \\
\hline 350 & $\mathbf{v}$ & 350 & $\mathbf{v}$ & 340 & 0 \\
\hline 1800 & $\mathbf{0}$ & 1700 & $\mathbf{v}$ & 1700 & U \\
\hline
\end{tabular}

$350 \quad 0$

$1800 \mathrm{~V}$

$1800 \mathrm{U}$

$350 \mathrm{U}$

$350 \quad 0$

$350 \mathrm{U}$

$350 \mathrm{O}$

350 0

$1800 \mathrm{U}$

$1800 \quad 0$

$350 \mathrm{v}$

$350 \mathrm{U}$

$350 \mathrm{U}$

$1800 \mathrm{v}$

350 v

350 . 0

$350 \mathrm{v}$

350 U

350 U

$350 \mathrm{U}$

$700 \mathrm{U}$

$350 \mathrm{U}$

$350 \mathrm{U}$

410

$350 \mathrm{U}$

$350 \mathrm{U}$

$350 \mathrm{U}$

$350 \quad 0$

$350 \mathrm{U}$

3500

$350 \mathrm{O}$
50 v

$1700 \mathrm{v}$

$1700 \mathrm{v}$

$.350 \mathrm{v}$

350 v

$350 \quad 0$

350 v

$350 \mathrm{v}$

$1700 \mathrm{v}$

$1700 \mathrm{v}$

$350 \quad 0$

$350 \quad 0$

$350 \mathrm{v}$

$1700 \mathrm{v}$

3500

350 0

$41 J$

$350 \quad 0$

350 v

350 v

$690 \mathrm{v}$

350 v

$350 \mathrm{U}$

$300 \mathrm{~J}$

$350 \mathrm{v}$

350 U

$350 \mathrm{v}$

350 U

350 v

350 U

$350 \mathrm{U}$

$\begin{array}{rl}370 & 0 \\ 1800 & 0 \\ 370 & 0\end{array}$

3700

$1800 \mathrm{t}$

$370 \mathrm{v}$

370 v

3700

18000

370 ס

$1800 \mathrm{0}$

$1800 \mathrm{~J}$

$370 \mathrm{v}$

370 d

$370 \mathrm{v}$

370 v

$370 \quad 0$

$1800 \mathrm{~V}$

$1800 \mathrm{~V}$

$370 \quad 0$

$370 \mathrm{v}$

$370 \mathrm{v}$

$1800 \mathrm{~V}$

$370 \mathrm{v}$

$370 \mathrm{v}$

$370 \mathrm{v}$

$370 \quad 0$

3700

$370 \quad 0$

$740 \mathrm{U}$

$370 \mathrm{v}$

$370 \cdot \mathrm{v}$

$190 \mathrm{~J}$

$370 \mathrm{v}$

$370 \mathrm{v}$

$370 \mathrm{U}$

$370 \mathrm{v}$

$370 \mathrm{U}$

370 U

* Outside of EPA CLP QC IImite.

\begin{tabular}{|c|c|c|c|}
\hline 350 & $\mathbf{0}$ & 350 & 0 \\
\hline 1800 & 0 & 1800 & 0 \\
\hline 350 & 0 & $\mathbf{3 5 0}$ & 0 \\
\hline 1800 & $\boldsymbol{0}$ & 1800 & 0 \\
\hline 350 & $\mathbf{u}$ & 350 & 0 \\
\hline 350 & $\boldsymbol{0}$ & 350 & 0 \\
\hline 350 & 6 & 350 & 0 \\
\hline 1800 & ठ & 1800 & 0 \\
\hline 350 & ठ & 350 & 0 \\
\hline 1800 & $\boldsymbol{\sigma}$ & 1800 & 0 \\
\hline 1800 & $\boldsymbol{\sigma}$ & 1800 & 0 \\
\hline 350 & 0 & 350 & 0 \\
\hline 350 & $\mathbf{0}$ & 350 & $\mathrm{U}$ \\
\hline 350 & $\boldsymbol{0}$ & 350 & 0 \\
\hline 350 & 0 & 350 & 0 \\
\hline 350 & ర & 350 & 0 \\
\hline 1800 & 0 & 1800 & U \\
\hline 1800 & ס & 1800 & o \\
\hline 350 & 0 & 350 & 0 \\
\hline 350 & $\mathbf{0}$ & 350 & 0 \\
\hline 350 & 0 & 350 & 0 \\
\hline 1800 & U & 1800 & U \\
\hline 350 & ס & 350 & v \\
\hline 350 & ס & 350 & 0 \\
\hline 350 & ठ & 40 & $\mathrm{~J}$ \\
\hline 350 & ర & 350 & 0 \\
\hline 350 & 0 & 350 & 0 \\
\hline 350 & $\mathbf{v}$ & 350 & 0 \\
\hline 710 & 0 & 700 & 0 \\
\hline 350 & U & 350 & 0 \\
\hline 350 & $\mathbf{v}$ & 350 & 0 \\
\hline 330 & $\mathbf{J}$ & 39 & 5 \\
\hline 350 & $\mathbf{0}$ & 350 & 0 \\
\hline 350 & $\mathbf{0}$ & 350 & 0 \\
\hline 350 & $\mathbf{U}$ & 350 & 0 \\
\hline 350 & $\mathbf{U}$ & 350 & U \\
\hline 350 & 0 & 350 & 0 \\
\hline 350 & $\mathbf{U}$ & 350 & $t$ \\
\hline 350 & 0 & 350 & 0 \\
\hline
\end{tabular}


wy, wescon, Inc. - LIonv111e Iaboratory

Bemivolat1le

GC/MS, HSL LLet

Report Date: 04/04,- $017: 31$

REN B $\quad$ Number: 90024603 Cllent: WSRC GUNSITE 20 Work order: 0630-28-13-0000 Pager 20

Cuet ID: 68720 08-01 68720 07-01 68720 01-01 GBLK

8 amplo

Informat $10 n$

\begin{tabular}{|c|c|c|c|c|c|}
\hline RWNE: & 012 & 013 & 014 & 90LB0272-MB1 & 90LB0272-MBI \\
\hline $\begin{array}{r}\text { MatrLX: } \\
\text { D. P. } \\
\text { Unites }\end{array}$ & $\begin{array}{l}\text { 80IL } \\
1.00 \\
\text { ug/xg }\end{array}$ & $\begin{array}{l}\text { 80IL } \\
1.00 \\
\text { ng/xg }\end{array}$ & $\begin{array}{l}\text { 80IL } \\
1.00 \\
\text { ug/Kg }\end{array}$ & $\begin{array}{l}\text { soII } \\
1.11 \\
\mathrm{ug} / \mathrm{Kg}\end{array}$ & $\begin{array}{c}\text { soIL } \\
1.11 \\
\text { ug/Kg }\end{array}$ \\
\hline
\end{tabular}

surrogate

Recovery
N1trobenzene-d5 2-Fluoroblphenyl p-xoxphonyl-d14 Phonol-d5

\section{2-Fluorophonol} 2,4,6-2xibromophenol

Phonol

b1e (2-Chloroathyl) other.

2-Chlorophenol.

1,3-Dlohlorobanzene

1,4-DLchlorobenzene

Benzyl alcohol.

1,2-DLchlorobenzene

2-Methy lphenol

ble (2-Chlorol oppropyl) other

4-Hethylphenol.

d-Hitroso-D1-n-propylamine

Hexachloroathane

Nitrobenzene

Isophorone

2-Nitrophenol

2, 4-Dimethylphenol.

Bonzolc acld

ble (2-Chloroethoxy) methane

2,4-Dlchlorophenol

1,2,4-2x1chlorobenzene

Naphthalene.

4-Chloroaniline

Hexachlorobutadlene

4-Chloro-3-methyl phenol

2-Kethy Inaphthalene

Bexachlorocyclopentadlene

- Outside of BPA CLP gC IImite.

$380 \quad 0$

$\begin{array}{ll}380 & \mathbf{U} \\ 380 & \mathbf{v}\end{array}$

$380 \quad \mathbf{0}$

3800

$380 \mathrm{v}$

$380 \mathrm{U}$

3800

$380 \quad 0$

$380 \mathrm{U}$

$380 \quad 0$

$380 \quad 0$

$380 \mathrm{U}$

$380 \mathrm{v}$

$1900 \mathrm{U}$

$380 \mathrm{U}$

$380 \mathrm{U}$

$380 \mathrm{v}$

$380 \mathrm{U}$

$380 \mathrm{U}$

$380 \mathrm{U}$

380 U

$380 \mathrm{U}$

$380 \mathrm{U}$

$\begin{array}{l:l}70 & \\ 66 & \\ 99 & \end{array}$

$\begin{array}{ll}48 & 8 \\ 47 & 8 \\ 86 & 8 \\ 64 & \\ 48 & 8 \\ 43 & 8 \\ 370 & 0\end{array}$

$\begin{array}{llll}380 & \mathbf{v} & 370 & \mathrm{~d} \\ 380 & \mathrm{v} & 370 & \mathrm{v} \\ 380 & \mathrm{v} & 370 & \mathrm{v}\end{array}$

370 U

$\begin{array}{ll}370 & 0 \\ 370 & 0\end{array}$

$370 \mathrm{v}$

$370 \quad 0$

3700

370 0

370 v

370 v

3700

3700

$370 \mathrm{U}$

$1800 \mathrm{v}$

370 U

$370 \quad 0$

370 v

$370 \mathrm{v}$

$370 \mathrm{U}$

370 v

370 v

$370 \mathrm{v}$
3700

$370 \mathrm{v}$

$370 \mathrm{v}$

75
69
93
99
71
43
350

$\begin{array}{lll}68 & 68 & 75 \\ 76 & 87 \\ 91 & 78 \\ 71 . & 64 \\ 55 & 59 \\ 42 & & \end{array}$

$360 \mathrm{v}$

$360 \mathrm{v}$

$360 \mathrm{v}$

360 U

360 U

3600

$360 \mathrm{U}$

$360 \mathrm{v}$

$360 \mathrm{U}$

$360 \mathrm{v}$

$360 \mathrm{v}$

360 U

$360 \mathrm{U}$

$360 \mathrm{v}$

360 U

$360 \mathrm{v}$

$1800 \mathrm{U}$

$360 \mathrm{U}$

360 v

$360 \mathrm{v}$

$360 \mathrm{U}$

$360 \mathrm{U}$

$360 \mathrm{U}$

$360 \mathrm{U}$

$360 \mathrm{U}$

$360 \mathrm{v}$

$\begin{array}{lll}68 & 68 \\ 76 & 75 \\ 91 & 87 \\ 71 . & 78 \\ 55 & 64 \\ 42 & 59\end{array}$

$370 \mathrm{v}$

$\begin{array}{ll}370 & \boldsymbol{v} \\ 370 & \mathbf{v}\end{array}$

$370 \mathrm{v}$

370 D

$370 \mathrm{D}$

3700

370 v

$370 \quad \mathbf{0}$

370 0

$370 \mathrm{D}$

370 ป

3700

3700

370 v

370 v

$1800 \mathrm{v}$

$370 \cdot 0$

$370 \mathrm{v}$

$370 \mathrm{v}$

$370 \mathrm{v}$

$370 \mathrm{v}$

$370 \mathrm{U}$

$370 \mathrm{U}$

$370 \mathrm{v}$

$\mathbf{3 7 0}$ v

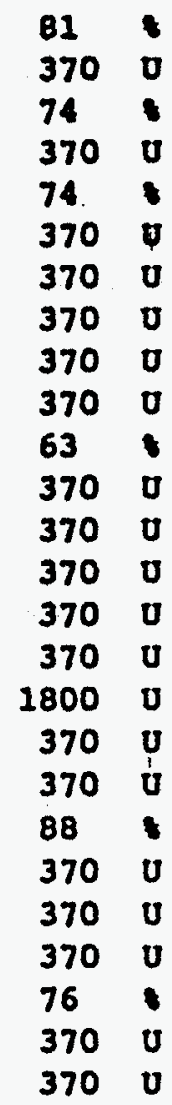




\section{RFW:}

012

\section{90LE0272-HBI 90LE0272-KB1}

\begin{tabular}{|c|c|c|c|c|c|c|c|c|c|c|}
\hline 2,4,6-Trlchlorophenol & 380 & $\mathbf{U}$ & 370 & $\mathbf{0}$ & 360 & $\mathbf{0}$ & 370 & $\mathbf{0}$ & 370 & $\mathbf{0}$ \\
\hline $2,4,5$-Trichlorophenol & 1900 & $\mathbf{v}$ & 1800 & $\mathbf{0} \ldots$ & 1800 & $\mathbf{v}$ & 1800 & $\mathbf{0}$ & 1800 & $\mathbf{0}$ \\
\hline 2-Chloronaphthalene & 380 & $\mathbf{u}$ & 370 & $\mathbf{0}$ & 360 & $\mathbf{0}$ & 370 & $\mathbf{0}$ & 370 & 0 \\
\hline 2-N1troan111ne & 1900, & $\mathbf{u}$ & 1800 & $\mathbf{0}$ & 1800 & $\mathbf{U}$ & 1800 & $\mathbf{v}$ & 1800 & $\mathbf{0}$ \\
\hline Dimethylphthalate & 380 & $\mathbf{\varphi}$ & 370 & $\mathbf{U}$ & 360 & $\mathbf{U}$ & 370 & $\mathbf{0}$ & 370 & $\mathbf{0}$ \\
\hline Acenaphthy lene & 380 & $\mathbf{U}$ & 370 & $\mathbf{0}$ & 360 & $\mathbf{0}$ & 370 & $\mathbf{0}$ & 370 & $\mathbf{v}$ \\
\hline 2,6-Dinitrotoluene & 380 & $\mathbf{v}$ & 370 & $\mathbf{u}$ & 360 & $\mathbf{u}$ & 370 & $\mathbf{u}$ & 370 & $d$ \\
\hline 3-N1troan $11 \ln \theta$ & 1900 & $\mathbf{v}$ & 1800 & $\mathbf{u}$ & 1800 & $\mathbf{U}$ & 1800 & $\mathbf{0}$ & 1800 & $\mathbf{0}$ \\
\hline Acenaphthene & 380 & $\mathbf{v}$ & 370 & $\mathbf{U}$ & 360 & $\mathbf{v}$ & 370 & $\mathbf{0}$ & 94 & $\mathbf{3}$ \\
\hline 2,4-Din1trophenol & 1900 & $\mathbf{v}$ & 1800 & $\mathbf{U}$ & 1800 & $\mathbf{u}$ & 1800 & $\mathbf{U}$ & 1800 & 0 \\
\hline 4-Nitrophenol & 1900 & $\mathbf{u}$ & 1800 & $\mathbf{0}$ & 1800 & $\mathbf{0}$ & 1800 & $\mathbf{v}$ & 106 & 1 \\
\hline DIbenzofuran & $\mathbf{3 8 0}$ & $\mathbf{v}$ & 370 & $\mathbf{v}$ & 360 & $\mathbf{U}$ & 370 & $\mathbf{v}$ & 370 & 0 \\
\hline 2,4-Dinitrotoluene & 380 & $\mathbf{0}$ & 370 & $\mathbf{u}$ & 360 & $\mathbf{U}$ & 370 & $\mathbf{U}$ & 78 & 1 \\
\hline Dlethylphthalate & 380 & $\mathbf{0}$ & 370 & $\mathbf{0}$ & 360 & $\mathbf{U}$ & 370 & $\mathbf{U}$ & 370 & 0 \\
\hline 4-Chlorophenyl-phenylether. & 380 & $\mathbf{v}$ & 370 & $\mathbf{U}$ & 360 & $\mathbf{0}$ & 370 & $\mathbf{u}$ & 370 & $\mathbf{0}$ \\
\hline Fluorene & 380 & $\mathbf{v}$ & 370 & $\mathbf{u}$ & 360 & $\mathbf{u}$ & 370 & $\mathbf{U}$ & 370 & $\mathbf{0}$ \\
\hline 4-Nitroaniline & 1900 & $\mathbf{v}$ & 1800 & $\mathbf{u}$ & 1800 & $\mathbf{U}$ & 1800 & $\mathbf{U}$ & 1800 & $\mathbf{v}$ \\
\hline 4,6-Dinitro-2-methylphenol & 1900 & $\mathbf{0}$ & 1800 & $\mathbf{v}$ & 1800 & $\mathbf{u}$ & 1800 & $\mathbf{U}$ & 1800 & $\mathbf{0}$ \\
\hline N-N1trosodiphenytamine (1) & 380 & $\mathbf{u}$ & 370 & $\mathbf{v}$ & 360 & $\mathbf{u}$ & 370 & $\mathbf{0}$ & 370 & $\dot{u}$ \\
\hline 4-Bromophenyl-phenylether & 380 & $\mathbf{u}$ & 370 & $\mathbf{u}$ & 360 & $\mathbf{0}$ & 370 & $\mathbf{U}$ & 370 & $\mathbf{v}$ \\
\hline Hexachlorobenzene & 380 & $\mathbf{u}$ & 370 & $\mathbf{v}$ & 360 & $\mathbf{u}$ & 370 & $\mathbf{v}$ & 370 & $\mathbf{0}$ \\
\hline Pentachlorophenol- & 1900 & $\mathbf{u}$ & 1800 & $\mathbf{v}$ & 1800 & $\mathbf{U}$ & 1800 & $\mathbf{u}$ & 95 & 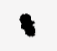 \\
\hline Phenanthrene & 380 & $\mathbf{U}$ & 370 & $\mathbf{u}$ & 360 & $\mathbf{u}$ & 370 & $\mathbf{U}$ & 370 & $\mathbf{0}$ \\
\hline Anthracene & 380 & $\mathbf{u}$ & 370 & $\boldsymbol{u}$ & 360 & $\mathbf{u}$ & 370 & $\mathbf{U}$ & 370 & $\mathbf{U}$ \\
\hline D1-n-Butyl phthalate & 380 & $\mathbf{u}$ & 370 & $\mathbf{u}$ & 360 & $\mathbf{u}$ & 370 & $\mathbf{v}$ & 370 & $\mathbf{0}$ \\
\hline Fluoranthene & 380 & $\mathbf{0}$ & 370 & $\mathbf{u}$ & 360 & $\mathbf{0}$ & 370 & $\mathbf{U}$ & 370 & $\mathbf{0}$ \\
\hline Pyrene & 380 & $\mathbf{u}$ & 370 & $\mathbf{u}$ & 360 & $\mathbf{u}$ & 370 & $\mathbf{U}$ & 113 & $\checkmark$ \\
\hline Butylbenzylphthalate & 380 & $\mathbf{u}$ & 370 & $\mathbf{u}$ & 360 & $\mathbf{U}$ & 370 & $\mathbf{U}$ & 370 & $\mathbf{0}$ \\
\hline $3,3^{\circ}$-DLchlorobenzldine & 750 & $\mathbf{u}$ & 730 & $\mathbf{U}$ & 720 & $\mathbf{U}$ & 740 & $\mathbf{U}$ & 740 & $\mathbf{0}$ \\
\hline Benzo (a) anthracene & 380 & $\mathbf{u}$ & 370 & v & 360 & $\mathbf{U}$ & 370 & $\mathbf{U}$ & 370 & $\mathbf{0}$ \\
\hline Chrysene & 380 & $\mathbf{u}$ & 370 & $\mathbf{u}$ & 360 & $\mathbf{u}$ & 370 & $\mathbf{U}$ & 370 & $\mathbf{U}$ \\
\hline b18(2-Ethylhexyl)phthalate & 55 & $\mathbf{J}$ & 67 & $\boldsymbol{J}$ & 360 & $\mathbf{u}$ & 370 & $\mathbf{u}$ & 370 & $\mathbf{v}$ \\
\hline D1-n-Octyl phthalate & 380 & $\mathbf{u}$ & 370 & $\mathbf{u}$ & 360 & $\mathbf{U}$ & 370 & $\mathbf{U}$ & 370 & U \\
\hline Benzo(b) f luoranthene & 380 & $\mathbf{U}$ & 370 & $\mathbf{U}$ & 360 & U & 370 & $\mathbf{U}$ & 370 & U \\
\hline Benzo (k) fluoranthene & 380 & $\mathbf{u}$ & 370 & $\mathbf{v}$ & 360 & $\mathbf{u}$ & 370 & $\mathbf{u}$ & 370 & $\mathbf{U}$ \\
\hline Benzo (a)pyrene & 380 & $\mathbf{u}$ & 370 & $\mathbf{u}$ & 360 & $\mathbf{u}$ & 370 & $\mathbf{u}$ & 370 & $\mathbf{U}$ \\
\hline Indeno $(1,2,3-c \mathrm{~d})$ pyrene & 380 & $\mathbf{u}$ & 370 & $\boldsymbol{v}$ & 360 & $\mathbf{U}$ & 370 & $\mathbf{u}$ & 370 & U \\
\hline DLbenzo $(a, h)$ anthracene & 380 & $\mathbf{u}$ & 370 & $\boldsymbol{U}$ & 360 & $\mathbf{U}$ & 370 & $\mathbf{U}$ & 370 & U \\
\hline Benzo $(g, h, 1)$ perylene & 380 & $\mathbf{U}$ & 370 & $\mathbf{U}$ & 360 & $\mathbf{U}$ & 370 & $\mathbf{u}$ & 370 & U \\
\hline
\end{tabular}

(1) - Cannot be separated from Diphenylamine. *m Outaide of EPA CLP QC 1 imita. 
SKMTVOTATILE ORGANICS ANAIYSIS SEBEY TENTATIVELY IDENTIEIED COAPOURDS

Lab Name: Roy F. Webton. Inc. Fork Order: 0630-28-13-0000

Client: FSRC GUISITE 720

Matrlx:

SOII.

Sample wt/vol: $30.9(\mathrm{~g} / \mathrm{mr}) \mathrm{G}$

Level: (low/med) Lof

3 Moleture: not dec. Extraction: (Sepr/Cont/Sonc) sonc GPC Cleanup: (Y/N) $\underline{Y}$ PE: 7.0
Iab Sample ID: 9002L603-002

Iab F110 ID: M030806

Date Recelveds $02 / 16 / 90$

Date ixtracteds 02/26/90

Date Analyzed: 03/08/90

Dilution Factors 1.00

Number TICs found: 5

CONCEATRATION UNITS: $(\mathrm{ug} / \mathrm{L}$ or $\mathrm{ug} / \mathrm{Kg}) \mathrm{ug} / \mathrm{Kg}$.

\begin{tabular}{|c|c|c|c|c|}
\hline CAS NURBER & COAPOULD MAYE & $\mathrm{RT}$ & EST. COHC. & $\mathbf{Q}$ \\
\hline , & 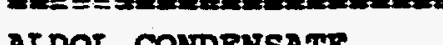 & 57 & Ionn & $\ln 20$ \\
\hline 1. & ATDOL CONDENSATE & 5.77 & $\begin{array}{l}900 \\
300\end{array}$ & TAB \\
\hline $\begin{array}{l}2 . \\
3 .\end{array}$ & $\begin{array}{l}\text { ALDOL CONDELSAIL } \\
\text { ONTENOWN }\end{array}$ & $\begin{array}{r}6.48 \\
19.18\end{array}$ & $\begin{array}{l}1300 \\
1300\end{array}$ & $\begin{array}{l}\mathbf{J A B} \\
\mathbf{J}\end{array}$ \\
\hline 4. & ADIPAME & 22.25 & 1100 & $\mathbf{J B}$ \\
\hline 5. & ENDROCARBON & 22.87 & 200 & $\boldsymbol{J}$ \\
\hline
\end{tabular}


Lab Name: Roy. Feston, Inc. Work Order: 0630-28-13-0000

Client: WSRC GUNSITE 720

Matrlx:

SOII

Sample wt/rol:

$30.9(\mathrm{~g} / \mathrm{mr}) \mathrm{G}$

Level: (Low/med) ION

1 dec.

- Noletures not dec.

(Sepr/cont/sone)

sore

GPC Cleanup:

(I/N) $\mathbf{I}$

pa:

7.0
Lab sample ID: 9002น603-004

Lab I11e ID: M030807

Date Recelved: $02 / 16 / 90$

Date Bxtracteds 02/26/90

Date Analyzed: 03/08/90

DLlution Eactor: 1.00

Number TICs found: 5

CONCENTRATION UAITS:

$(\mathrm{ug} / \mathrm{L}$ or $\mathrm{ug} / \mathrm{Kg}) \mathrm{ug} / \mathrm{Kg}$

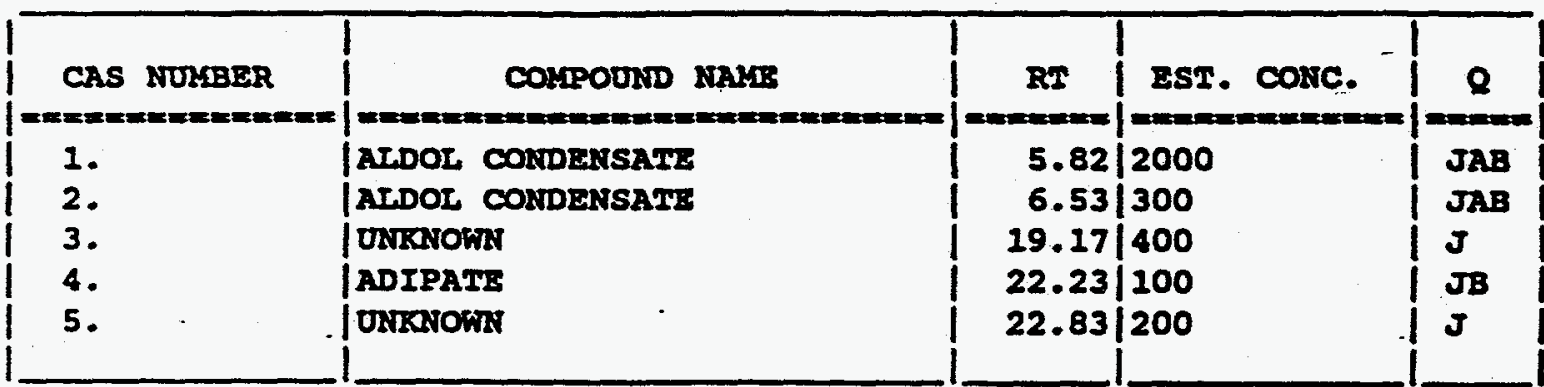



TENTATIVELY IDENTIEIED COMPOUNDS

Lab Xames Bor F. Weston. Inc. Work Order: 0630-28-13-0000 GS720 02-01R Cllent: WSRC GUNSITE 720

Mate1x:

sort.

Sample wt/rols $31.0(g / \mathrm{mL}) \mathrm{G}$

Lavel. (Low/med) IOW 5 dec.

t Moletures not dec.

Extraction: (Sepr/cont/sonc) sonc GPC Cleanup: $(X / N) \underline{X}$ pas $\quad 7.0$
Iab Sample ID: 9002L603-006

Iab F110 ID: y030808

Date Received: $02 / 16 / 90$

Date Ixtracted: 02/26/90

Date Analyzeds 03/08/90

Dilution Eactor: 1.00

Number TICE found: 5

CONCENTRATION URITS: (ug/t or ug/ $\mathrm{kg}$ ) ug/ $\mathrm{kg}$

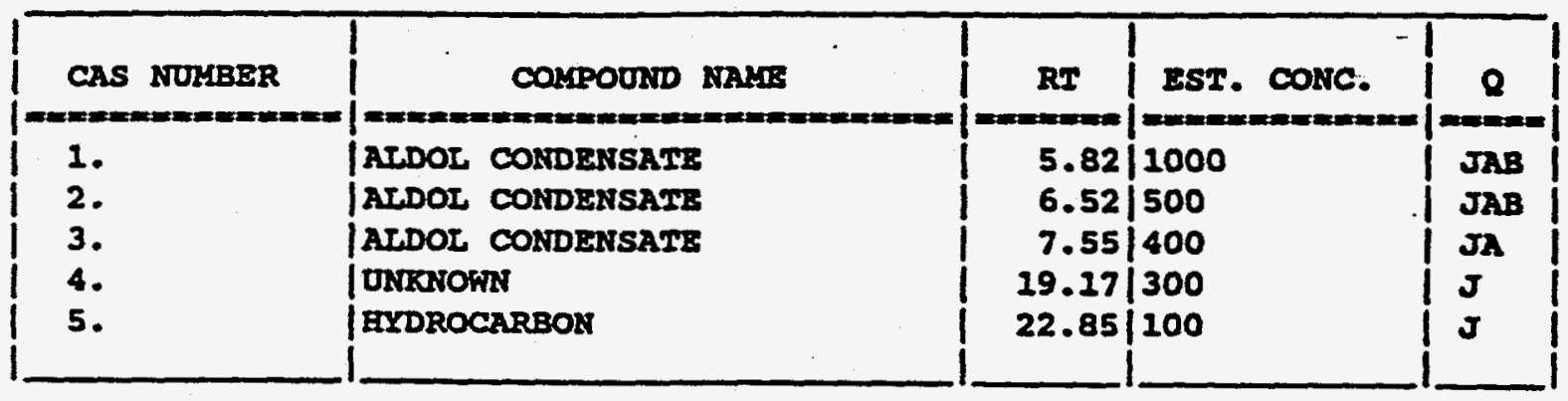


Lab Namer Roy F. Weaton. Inc. Work Order: 0630-28-13-0000

Client: WSRC GUNSITE 720

Matrix:

soIr

sample wt/vols $30.5(\mathrm{~g} / \mathrm{mL}) \mathrm{G}$

Lerel: (low/med) LOW

- Molstures not dec. 11 dec.

Extraction:

(SepF/cont/sonc)

sonc

GPC Cleanup: (Y/N) $\underline{\underline{Y}}$

pE: 7.0
Lab Sample ID: 9002L603-008

Lab E110 ID: N030809

Date Recelved: $.02 / 16 / 90$

Date Extracteds $02 / 26 / 90$

Date Analyzed $03 / 08 / 90$

Dilution Factor: 1.00

Number TICs found: 5

CONCEHTRATIOA ORITS: (ug/l or ug/ $\mathrm{kg}$ ) ug/kg

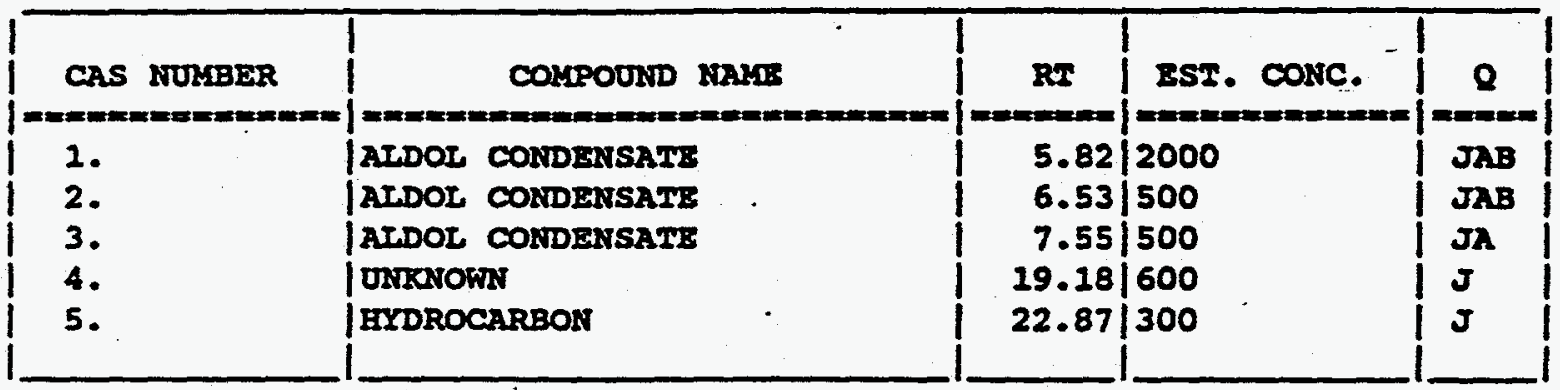


Lab Names Roy $F$. Weaton, Inc. Work Order: 0630-28-13-0000

Client: WSRC GUNSITE 720

MatrLx:

SOII

Sample wt/vol:
Lab Sample ID: 9002L603-009

Iab F110 ID:

Date Recelveds 02/16/90

Level: (low/med) IOW

Date Bxtracted: $02 / 26 / 90$

* Molsture: not dec. 1 dec.

sonc

Date Analyzedz $03 / 08 / 90$

GPC Cleanup: $\quad(Y / N) \underline{Y}$

pat 7.0

DLIution Factor: 1.00

CONCENHRATION UNITS:

Number TICs found: 5

(ug/t or ug/ $\mathrm{kg}$ ) ug/ $\mathrm{kg}$

\begin{tabular}{|c|c|c|c|c|}
\hline 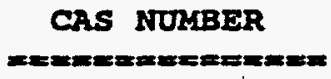 & 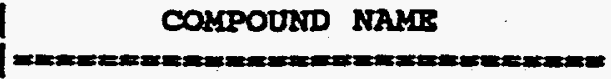 & $\operatorname{RT}_{2=\infty}$ & IST. CoNC. - & $\mathbf{Q}$ \\
\hline 1. & AIDOL CONDENSATE & 5.82 & 2000 & $\mathbf{J A B}$ \\
\hline 2. & | ATDOL CONDENSATB & 6.53 & 1400 & JAB \\
\hline 3. & 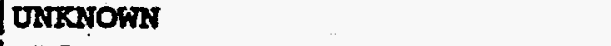 & 19.18 & 500 & $\mathbf{J}$ \\
\hline 4. & ADIPATE & 22.25 & 200 & $\mathbf{J B}$ \\
\hline 5. & EXDROCARBON & 22.87 & 200 & $\mathbf{J}$ \\
\hline
\end{tabular}


Lab Name: Roy $F$. Weston, Inc, Work Order: 0630-28-13-0000

Client: WSRC GUNSITE 720

Matrix: SoIr

Lab Sample IDz 9002L603-011

Sample wt/rol:

$30.8(\mathrm{~g} / \mathrm{mr}) \mathrm{C}$

Lab File IDs M030903

Level: (low/med) LOR

Date Recelvedz $\underline{02 / 16 / 90}$

- Moletures not dec.

dec.

Date ixtracted: 02/26/90

Extraction: (SepF/cont/sonc) sowe

Date Analyzeds $03 / 09 / 90$

GPC Cleanup: $(Y / W) \Psi$

pE: 7.0

Dilution Factor: 1.00

Number IICs found: 5

COXCENIRATIOA UIITS:

(ug/L or ug/Rg) ua/Ko

\begin{tabular}{|c|c|c|c|c|}
\hline CAS NUMBER & COMPOUND KAME & RT & EST. COAC. & $\mathbf{Q}$ \\
\hline 1. & ardor corpransatys & 585 & 3000 & $\mathrm{TAB}$ \\
\hline 2. & AIDOL CONDENSATE & 6.55 & 600 & JAB \\
\hline 3. & |ATDOL CORDENSATI & 7.57 & 400 & JA \\
\hline 4. & | OnKarown & 19.18 & 500 & $\mathbf{J}$ \\
\hline 5. & HYDROCARBON & 22.85 & 500 & $\boldsymbol{J}$ \\
\hline
\end{tabular}


15

SEMIVOTATILE ORGANICS ANATYSIS SERBP TEATATIVEIY IDENTIFIED COMPOUNDS

Iab Names Roy F. Feston. Inc. Fork Order: 0630-28-13-0000
CIIENT SAMPLE No.

$$
\text { GS720 08-01 }
$$

client: WSRC GONSITE 720

Matrixs

soIf

Sample wt/rols

$30.5(\mathrm{~g} / \mathrm{mr}) \mathrm{G}$

Levels (low/med) ION

* Molgture: not dec. 13 dec.

Extraction:

(Sepr/cont/sonc)

$(X / N) \underline{X}$

pR: -7.0
Lab Sample ID: 9002L603-012

Lab File ID:

M030904

Date Recelved: $02 / 16 / 90$

Date Extracted: 02/26/90

Date Analyzed: 03/09/90

Dilution Eactor: 1.00

CONCEHIRATION UNITS:

Number TICa found: 5 (ug/L or $\mathrm{ug} / \mathrm{xg}$ ) ua/ $\mathrm{kg}$

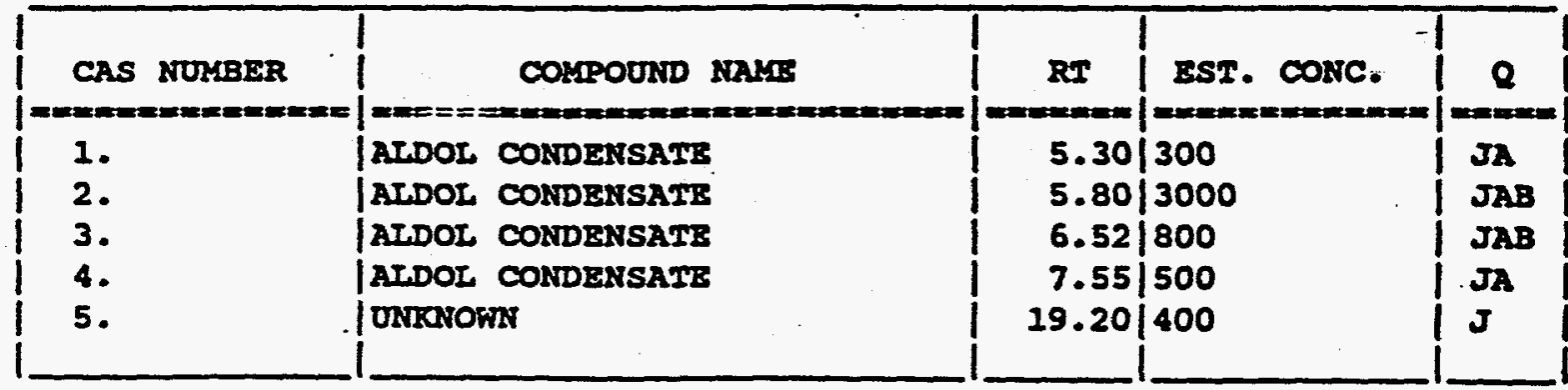


Lab Namer Roy $z$. Weaton, Inc. Work Order: 0630-28-13-0000

Cllent: WSRC GUNSIME 720

Matr $1 \times 8$

Sample wt/vol:

SOIL

$30.5(g / m r) G$

Level: (low/med) IOW

- Molstures not dec. 11 dec.

Extract Lon:

(Sepr/cont/Sonc)

sore

GPC Cleanup:

$(X / N) x$

pat

7.0
Lab Sample ID:

$90021603-013$

Lab File ID: M030905

Date Recelved: 02/16/90

Date Bxtracted: $02 / 26 / 90$

Date Analyzed: 03/09/90

DLlution Factor: 1.00

Number TICs founds 5

CORCENTRATION UNITS:

(ug/L or ug/trg) ug/xg

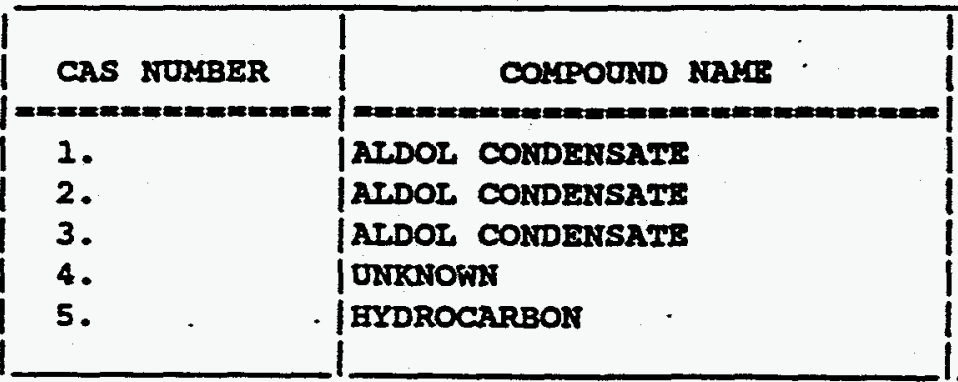

\begin{tabular}{|c|c|c|}
\hline$R T$ & IST. CONC. & $Q$ \\
\hline 5.82 & 2000 & \\
6.53 & 600 & $\mathrm{JAB}$ \\
7.55 & 600 & $\mathrm{JAB}$ \\
19.17 & 300 & $\mathrm{JA}$ \\
22.83 & 300 & $\mathrm{~J}$ \\
\hline
\end{tabular}


Lab namer Roy E. Wegton. Inc. Work Order: 0630-28-13-0000

Client: HSRC GUNSITE 720

Matrixs

Sample wt/vol:

SOIL

$30.1(g / m) G$

Level: (low/med) IOF

\& Molatures not dec. _ 8 dec.

Extractions (SepF/Cont/Sonc) sonc

GPC Cleanup: $\quad(Y / N) I$

pA: $\quad 7.0$
Lab sample ID: 9002L603-014

Lab File ID: M030906

Date Received: $02 / 16 / 90$

Date Extracteds $02 / 26 / 90$

Date Analyzed: 03/09/90

DLlution Pactor: 1.00

Number TICs found: $\underline{5}$

CONCENTRATION UNITS:

(ug/L or ug/Lg) ug/Rg.

\begin{tabular}{|c|c|c|c|c|}
\hline $\begin{array}{l}\text { CAS NUMGER } \\
\text { CAS }\end{array}$ & COMPOUND MAYS & $\mathbf{R I}$ & RST. Coxc. & $\mathbf{Q}$ \\
\hline 1. & ALDOL CONDENSATE & 5.82 & 3000 & $\mathbf{M A} \mathbf{B}$ \\
\hline 2. & ALDOI CONDENSATE & 6.53 & 1000 & JAB \\
\hline 3. & ATDOI CONDENSATE & 7.57 & 100 & JA \\
\hline 4. & ONRNOWN & 19.18 & 1000 & $\mathbf{J}$ \\
\hline 5. & EYDROCARBON & 22.82 & 1000 & $\boldsymbol{J}$ \\
\hline
\end{tabular}


SEMIVOLATIIE ORGANICS AKATYSIS SEEET TENTATIVELY IDENTIFIED COAPOUNDS

Lab Name: Roy E. Weston, Inc. Mork Order: 0630-28-13-0000

Cl1ent: WSRC GUNSTTE 720

Matrix:

Sample wt/rol:

SOII

$30.0(\mathrm{~g} / \mathrm{mc}) \subseteq$

Level: (low/med) LON

o dec.

Yolatures not dec.

Extraction: (SepF/cont/sone) sore

GPC Cleanup: $(Y / N) I$

pH: 7.0
Lab Sample IDI - 90LE0272-KBI

Iab File ID: M030713

Date Rocelved: 02/26/90

Date Ixtractads 02/26/90

Date Analyzed: 03/07/90

Dilution Factors 1.11

Number TICs found: 5

CONCENIRATION UNITS:

(ug/L or ug/Rg) ug/Kg

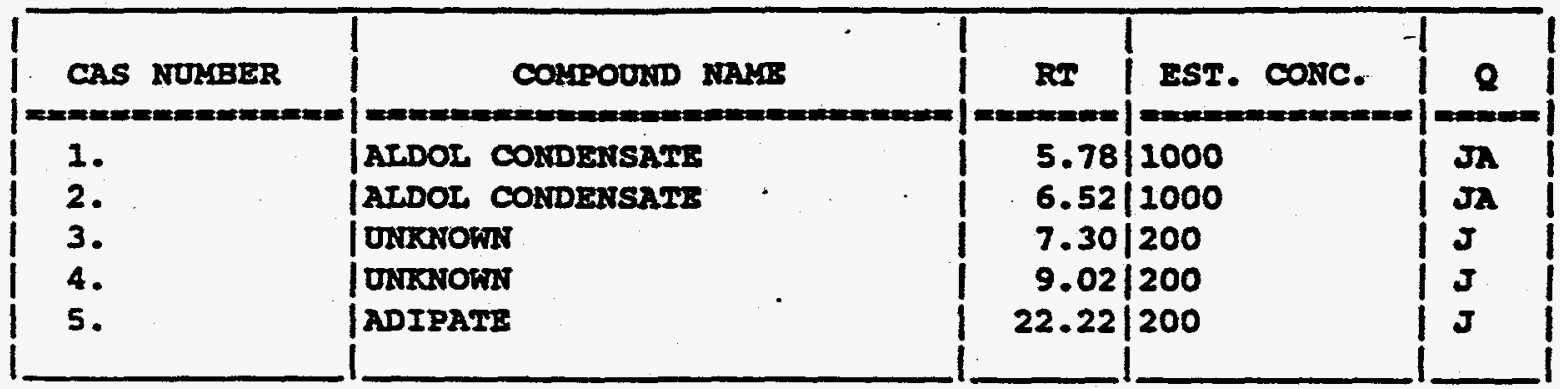




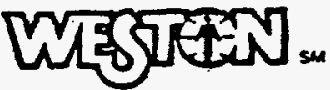

CLIENT: WSRC GUNSITE 720

RFW : $9002 \mathrm{~L} 603$

พ.0. * : 0630-28-13
ROY F. HESTOK, INC. Lionville Laboratory

BAXPLES RECEIVED: $02-26-90$

\section{INORGANIC NARRATIVE}

The following is a summary of the quality control results and a description of any problems encountered during the analysis of this batch of samples:

1. All preparation blanks were analyzed below the required detection limit.

2. All calibration verification checks were within the required control limits of 90-100\%. Calibration verification is performed using independent standards.

3. The analytical methods applied by the laboratory, unless otherwise requested, for all inorganic analyses are derived from the USEPA Method for Chemical Analysis of Water and Wastes (USEPA 600/4-79-020), and standard Methods for the Examination of Water and Wastewater 16 ed. Methods for the analysis of solid samples are derived from Test Methods for Evaluating Solid Waste (USEPA SW846).

NOTE: For solid samples, all results are reported on a dry weight basis. 


\author{
ROY F. WESTON, INC. \\ GLOSSARY OF TERMS - INORGANIC REPORTS
}

DATA QUALIFIERS

U - Indicates that the parameter was not detected at or above the reported limit. The associated numerical value is the sample detection limit.

* - Indicates that the original sample result is greater than $4 x$ the spike amount added. The USERA-CLP has determined that spike results on samples where this occurs may be unreliable and, therefore, the control limits are not applicable.

\title{
ABBREVIATIONS
}

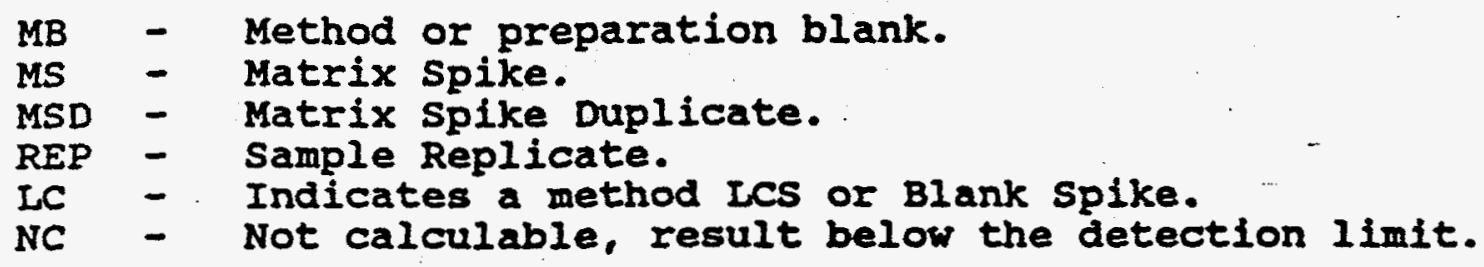

\section{LABORATORY CHRONOLOGY AND HOLDTIME REPORT}

The test code listed indicates the specific analysis or preparation procedure employed. The codes may be interpreted as follows:

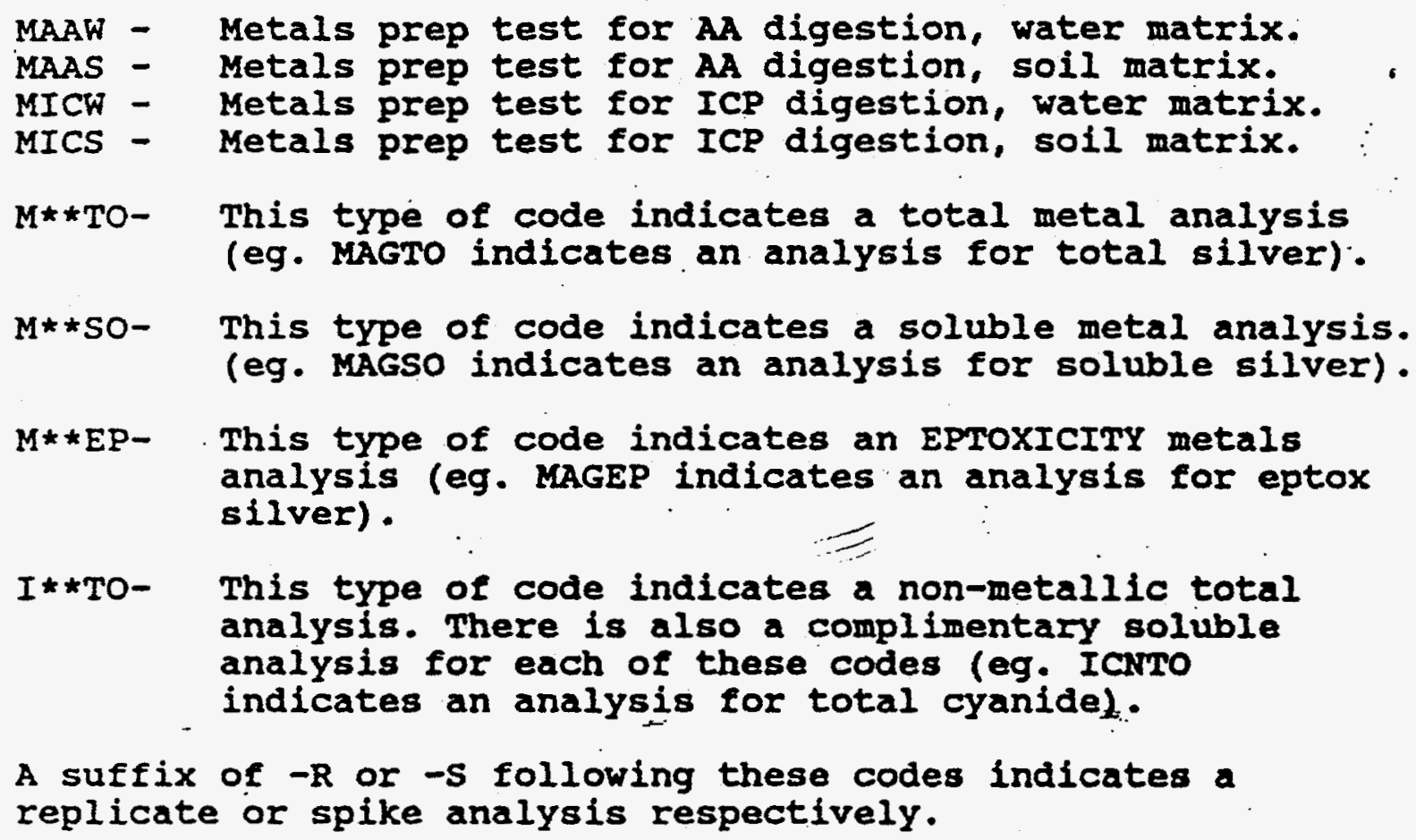

I**TO- This type of code indicates a non-metallic total analysis. There is also a complimentary soluble analysis for each of these codes (eg. ICNTO indicates an analysis for total cyanidel.

$A$ suffix of $-R$ or $-S$ following these codes indicates a replicate or spike analysis respectively. 
ROY $₹$. WESTOY IMC.

INORGANICS DATA SUMRARY REPORT 03/14/90

CLIEAT: WSRC GUNSITE 720

WORK ORDRR: 0630-28-23-0000

\section{SAYPL:}

an:man

$-002$

SITE ID

G5720 14-01

$-003$

GS720 04-01

$-004 \quad 65720 \quad 02-01$

$-005 \quad 65720 \quad 03-01$

$-011 \quad \operatorname{GS720} 01-02$

$-014$

GS720 01-01
ANALYTS

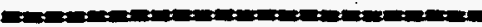

- sorIDs tomar orcanic carbor PE

\section{- SOLIDS}

total organIC carboN

PH

* solidas

- sorIDs

SOIIDS

- SOLIDS

TOTAL ORGANIC CaRBON

PE
RESTON BATCH \& 90022603

\begin{tabular}{|c|c|c|}
\hline RESULT & UNITS & $\begin{array}{l}\text { REPORTING } \\
\text { IIYIT }\end{array}$ \\
\hline $\begin{array}{l}92.2 \\
274\end{array}$ & MG/Ke & $\begin{array}{c}0.10 \\
28.0\end{array}$ \\
\hline & pR URITS & 0.10 \\
\hline
\end{tabular}

$\begin{array}{clc}93.4 & \text { MG/KG } & 0.10 \\ 2700 & 50.0 \\ 5.2 & \text { PH UNITS } & 0.10\end{array}$
94.8
$+$
0.10

94.7

$z^{-}$

0.20

93.0

8

0.10

89.9
5180

5.0

MG/Ke
pH UNITS

0.10 $\therefore 104$

0.10 
ROY F. MESTOR IXC.

INORGANICS METHOD BLANK DATA SUMARAY PAGE 03/14/90

CLIENTE WSRC GURSITE 720

HORK ORDER? 0630-28-13-0000

SAMPL:

SITR ID

Brantio

90LTZ001-LB1

BLANR20
AMATYTS

TOMAL ORGANIC CARBOA

TOTAL ORGAMIC CARBOA
WESTON BATCH \& $9002 L 603$

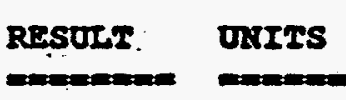

20.0 a $256 / 20$

$20.0 \mathrm{ne} / \mathrm{KO}$
REPORTING

IINIT

20.0

20.0 
ROY F. WRSTON INC.

IMORGANICS ACCURACI REPORT 03/14/90

CLIENTE WSRC GUNSITE 720

WORK ORDER: 0630-28-13-0000

SAMPLE

carmanem

BLANK10

SITE ID

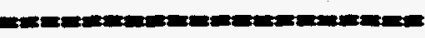

90LTZ001-LB1

BLANK20 90LTZ001-LB2

\section{ARACYTS}

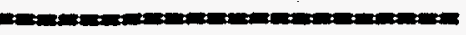

TOTAL ORGAITIC CARBOI

TOMAI ORGANIC CARBON

TOTAL ORGANIC CARBON
WESTON BATCA *8 9002L603

\begin{tabular}{|c|c|c|c|}
\hline $\begin{array}{l}\text { SPIKCED } \\
\text { SAYPLE: }\end{array}$ & $\begin{array}{l}\text { INITIAT } \\
\text { RESULT }\end{array}$ & $\begin{array}{l}\text { SPIXIND } \\
\text { AMOUnY }\end{array}$ & SRRCOV \\
\hline & & & \\
\hline $\begin{array}{l}410 \\
412\end{array}$ & $\begin{array}{l}20.0 \\
20.0\end{array}$ & $\begin{array}{l}400 \\
400\end{array}$ & $\begin{array}{l}102 \\
103\end{array}$ \\
\hline 395 & 20.0 & 400 & 98.8 \\
\hline
\end{tabular}


ROY F. FESTOR IRC.

IMORGAMICS DUPLICATE SPIKE REPORT 03/14/90

CLIENT: WSRC GONSITE 720

WESTON BATCH \&: 9002 Ĺ603

WORK ORDER: 0630-28-13-0000

SAMPLE

an-

BLANKIO
SITE ID

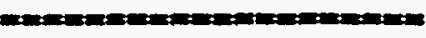

90LTZ001-LB1
ALALY2S

TOTAL ORCAIIC CARBOA
SPIKCEF1 SRIXEH2

IRECOV SRECOV SDIFE

$102=\frac{0.50}{103}$


Roy P. Weston, Inc. - Llonville Laboratory

INORGANIC ANALYTICAL DATA PACKAGE FOR

WSRC GUNSITE 720

DATE RECEIVED: 02/16/90

RUT IOT * :9002L603

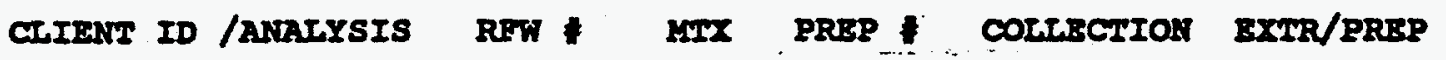

ANALYSIS
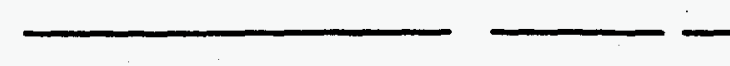

G5720 14-01

SOLIDS
GROSS ALTEA
GROSS BETA
TOIAL ORGANIC CARBON
PA

002

002

002

002

002

G5720 04-01

- SOLIDS TOTAL ORGANIC CARBON PE

003

003

003

G5720 02-01

- SOLIDS

G5720 03-01

\& solids

GROSS ALPEA

GROSS BETA

G\$720 01-02

- solidas

GS720 01-01

\section{- SOLIDS}

GROSS ALPEA

GROSS BETA

TOTAL ORGANIC CARBON PH

004

005

005

005

011

s 90Lะ5040

$02 / 13 / 90$

$03 / 03 / 90$

$03 / 04 / 90$

$02 / 14 / 90$

$02 / 14 / 90$

$02 / 14 / 90$

$02 / 14 / 90$

902TZ001 02/14/90

$02 / 14 / 90$ $\begin{array}{ll}03 / 03 / 90 & 03 / 04 / 90 \\ & \\ 03 / 01 / 90 & 03 / 01 / 90 \\ 03 / 08 / 90-03 / 08 / 90\end{array}$

$\begin{array}{ll}03 / 03 / 90 & 03 / 04 / 90 \\ & \\ 03 / 01 / 90 & 03 / 01 / 90 \\ 03 / 08 / 90-03 / 08 / 90\end{array}$

$\begin{array}{ll}03 / 03 / 90 & 03 / 04 / 90 \\ & \\ 03 / 01 / 90 & 03 / 01 / 90 \\ 03 / 08 / 90-03 / 08 / 90\end{array}$

$03 / 03 / 90$

$03 / 04 / 90$ $03 / 01 / 90$

$03 / 08 / 90$ $03 / 01 / 90$
$03 / 08 / 90$
03/08/90.

$03 / 04 / 90$

$03 / 03 / 90$

$03 / 04 / 90$

$03 / 03 / 90$

\section{0}

$\begin{array}{lll}s & 90 L \& 5040 & 02 / 14 / 90 \\ s & 90 L T Z 001 & 02 / 14 / 90\end{array}$

$03 / 03 / 90$

$03 / 04 / 90$

(

(

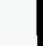


Roy F. Weston, Inc. - Llonville Laboratory IMORGANIC ANALYTICAL DATR PACRACE IOR

WSRC GUNSITE 720

DATE RECEIVED: $02 / 16 / 90$

REW LOT $\$ 90022603$

CLIENT ID /ANALYSIS

REN * $\quad$ MIXX

PREP

Cortriction

EXIR/PREP

ARATYSIS

TOTAL ORGAIIC CARBOA

TOTAL ORGAMIC CARBOA

TOTAL ORCANIC CARBOA

LB1 BS

LBI BSD

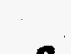

$2 B 2$

90212001

901rz001

$\begin{array}{ll}8 & \text { goLTzo01 } \\ 8 & \text { 90LTzo0i }\end{array}$

total organic carbor

LCB2 BS

$\mathbf{n} / \mathbf{x}$
$\mathbf{n} / \mathbf{x}$
$\mathbf{n} / \mathbf{x}$
$\mathbf{n} / \mathbf{x}$

$03 / 01 / 90$
$03 / 01 / 90$
$03 / 01 / 90$
$03 / 01 / 90$

03/01/90

$03 / 01 / 90$

$03 / 01 / 90$

$03 / 01 / 90$

$=$

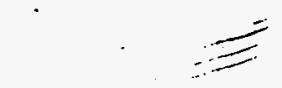

$=$ 
ROY $F$. FESTON, INC.

Lionville Laboratory.

Client: WSRC GUNSITE 720

RFW \# : $9002 L 603$

พ.0. \#: 0630-28-13-0000

$U=$ Indicates that the compound was analyzed for but not detected. The detection limit for the sample (not the method detection limit) is reported with $U$ (e.g.; 10u).

$J=$ Indicates an estimated value. This flag is used in cases where a target analyte is detected at a level less than the lower guantification level. If the limit of quantification is $\mathrm{lomg} / \mathrm{I}$ and a concentration of $3 \mathrm{mg} / \mathrm{L}$ is calculated, it is reported as $3 \mathrm{~J}$.

NA = Not Applicable. $\cdot$ NR = Not Required.

NC = Not calculable, results below detection limit.

The method uses. for the analysis of petroleum hydrocarbons is EPA Method 418.1 (USEPA 600/4-79-020). Solid samples are extracted using Method 9071 (USEPA SW846) then analyzed by EPA Method 418.1 .

The following is a summary of the QC results accompanying these sample results and a description of any problems encountered. during their analysis:

- Blank spike recoveries were acceptable.

- Blanks were free of contamination.

Samples Received : 02/16/90

Date of Extraction: $02 / 28 / 90$

Date of Analys1s:03/02/90

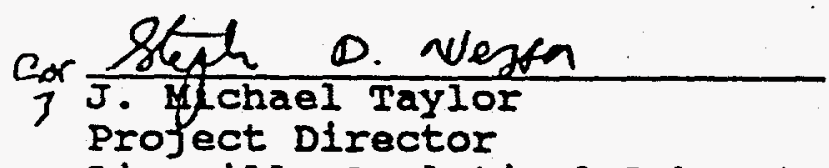

Lionville Analytical Laboratory

$\frac{3-13-90}{\text { DATE }}$




\section{RFH Batch Number: 90021603}

Petroleum Hydrocarbons by IR Report Date: $03 / 13 / 90$ 10:12 Client: HSRC GUNSIIE 720

Cust ID: 65720 06-01

GS720 08-01

65़720 07-01 65़720 07-01

$1-0000$

Page: 1

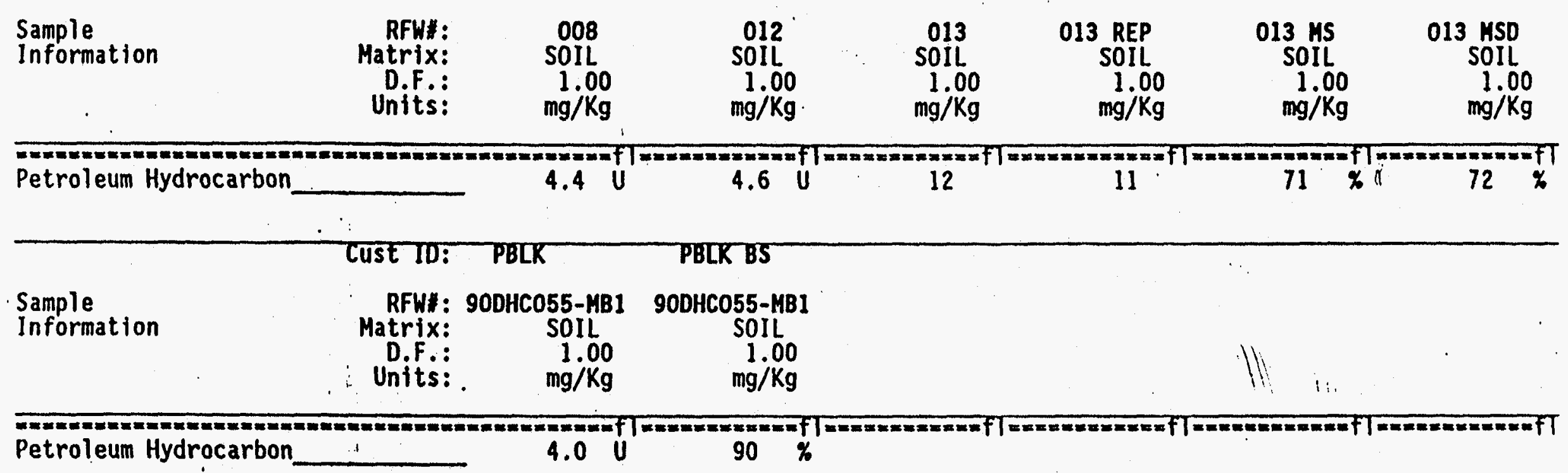

$U=$ Analyzed, not detected. $J=$ Present below detection limit. B= Present in blank. NR= Not reguested. NS= Not. spiked.

$\%=$ Percent recovery, $D=D$ iluted out. I= Interference. NA= Not Applicable. * $\star_{z}$ Outside of EPA CLP QC 
Client: WSRC GUNSITE 720

RFW \#: 9002L603

พ.0. *: 0630-28-13-0000

$U$ - Indicates that the compound was analyzed for but not detected. The detection limit for the sample (not the method detection Iimit) is reported with $U$ (e.g., 10u).

$J=$ Indicates an estimated value. This flag is used in cases where a target analyte is detected at a level less than the lower quantification level. If the limit of quantification is $10 \mathrm{mg} / \mathrm{L}$ and a concentration of $3 \mathrm{mg} / \mathrm{L}$ is calculated, it is reported as $3 \mathrm{~J}$.

NA = Not Applicable. $\quad N R=$ Not Required.

NC = Not calculable, results below detection limit. -

The method used for the analysis of petroleum hydrocarbons is EPA Method 418.1 (USEPA 600/4-79-020). Solld samples are extracted using Method 9071 (USEPA SW846) then analyzed by EPA Method 418.1 .

The following is a summary of the QC results accompanying these sample results and a description of any problems encountered during their analysis:

- Blank spike recoveries were acceptable.

- Blanks were free of contamination.

Samples Received : 02/16/90

Date of Extraction: 02/28/90

Date of Analysis : 03/02/90

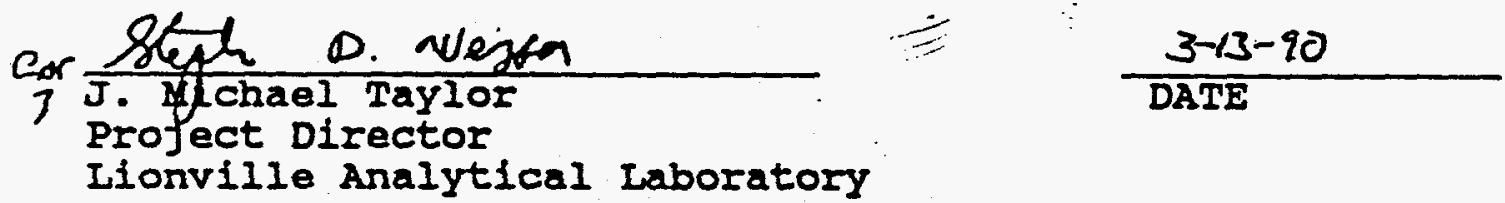

$=$ 


\section{REK Batch Number: 90021603}

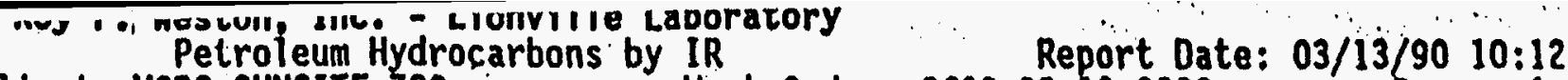

"Petroleum Hydrocarbons' by IR $\quad$ Report Date: 03/13/90 10:12 Client: USRC GUNSITE 120

Work Order: 0630-28-13-0000

Page: ?

Cust ID: GS720 06-01 GS720 08-01 GS720 07-01 GS720 07-01 GS720 07-01 GS720 07-01

Sample

Information

\begin{tabular}{|c|c|c|c|c|c|c|}
\hline $\begin{array}{r}\text { RFWH: } \\
\text { Matrix: } \\
\text { D.F.: } \\
\text { Units: }\end{array}$ & $\begin{array}{c}008 \\
\text { SOIL } \\
1.00 \\
\mathrm{mg} / \mathrm{Kg}\end{array}$ & $\begin{array}{l}012 \\
\text { SOIL } \\
1.00 \\
\mathrm{mg} / \mathrm{Kg}\end{array}$ & $\begin{array}{c}013 \\
\mathrm{SOIL} \\
1.00 \\
\mathrm{mg} / \mathrm{Kg}\end{array}$ & $\begin{array}{l}013 \text { REP } \\
\text { SOIL } \\
1.00 \\
\mathrm{mg} / \mathrm{Kg}\end{array}$ & $\begin{array}{r}013 \mathrm{KS} \\
\text { S0IL } \\
1.00 \\
\mathrm{mg} / \mathrm{Kg}\end{array}$ & $\begin{array}{r}013 \mathrm{HSD} \\
\text { sOIL } \\
1.00 \\
\mathrm{mg} / \mathrm{Kg}\end{array}$ \\
\hline
\end{tabular}

Petroleum Hydrocarbon

$4.4 U$

$4.6 \mathrm{U}$

12

11

$71 \quad x_{i}$

CUSE ID: PBLK PBLK BS

Sample

Information

RFWF: 90DHCO55-MB1 90DHCO55-MB1

$\begin{array}{rrr}\text { Matrix: } & \text { SOIL } & \text { SOIL } \\ \text { D.F.: } & 1.00 & 1.00 \\ \text { Units: } & \mathrm{mg} / \mathrm{Kg} & \mathrm{mg} / \mathrm{Kg}\end{array}$

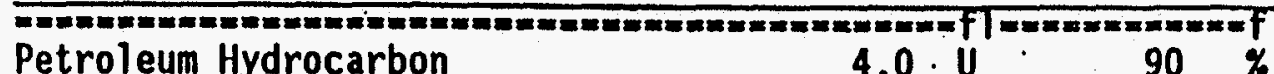

$U=$ Analyzed, not detected. $J=$ Present below detection 1 imit. B= Present in blank. NR= Not requested. NS= Not spiked.

$\%$. Percent recovery. $D=$ Diluted out. I = Interference. NA $=$ Not Applicable. $*=0 u t s i d e$ of EPA CLP $Q C$ 
WTSEREN

ROY F. REBTON, INC.

Lionville Laboratory

CLIENT: WSRC

RFI * : 9002L604, PCDD/PCDF

SAMPLES RECEIVED: $02 / 16 / 90$

W.0. : 0630-28-13

MARRATIVE

The set of samples consisted of 1 soil sample collected on $02 / 13 / 90$.

The samples were extrcted on $03 / 01 / 90$ and analyzed according to criteria set forth in Method $\mathbf{8 2 8 0}$ for Tetra through Hexa PCDD/PCDF target compound on $03 / 12 / 90$.

All surrogate and blank spike recoveries are within EPA QC limits.

\footnotetext{
$\int \frac{\text { Zhat } \bar{H} !}{\text { Jack R. Tuschall, Ph.D. }} \frac{3-28-90}{\text { Date }}$

Lionville Analytical Laboratory
} 


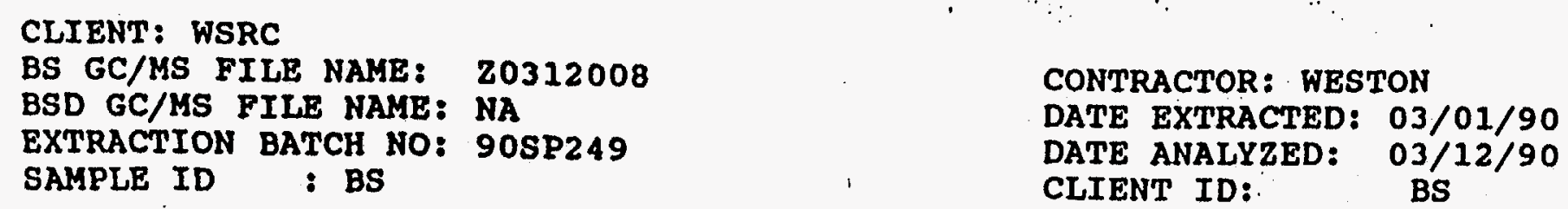

\begin{tabular}{|c|c|c|c|c|c|c|}
\hline 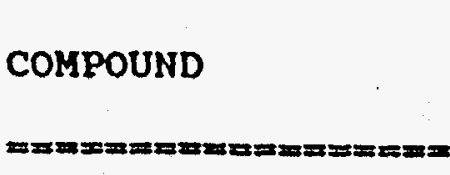 & $\begin{array}{r}\text { AMOUNT } \\
\text { SPIKED } \\
\text { ng } \\
=======\end{array}$ & $\begin{array}{l}\text { SAMPLE } \\
\text { WT./VOL. } \\
\end{array}$ & $\begin{array}{c}\text { SPIKE } \\
\text { CONC. } \\
\mathrm{Ng} / \mathrm{g} \\
======\end{array}$ & $\begin{array}{l}\text { CONC. } \\
\text { FOUND } \\
\text { Ng/g }\end{array}$ & $\begin{array}{l}\text { BLANK } \\
\text { CONC. } \\
=== \pm=0 \times x=\end{array}$ & REC \\
\hline $2,3,7,8-T C D D$ & 50 & 5.0 & 10 & 10.0 & ND & 100 \\
\hline $1,2,3,6,7,8-\mathrm{HXCDD}$ & 50 & 5.0 & 10 & 9.2 & ND & 92 \\
\hline OCDD & NA & NA & NA & NA & NA & NA \\
\hline $2,3,7,8-T C D F$ & 50 & 5.0 & 10 & 5.0 & ND & 50 \\
\hline $1,2,3,6,7,8-\mathrm{HXCDF}$ & 50 & 5.0 & 10 & 9.6 & ND & 96 \\
\hline OCDF & NA & NA & NA & NA & NA & NA \\
\hline
\end{tabular}


WESTON ANALYTIL

DIOXINS/FURANS DATA SUMMARY

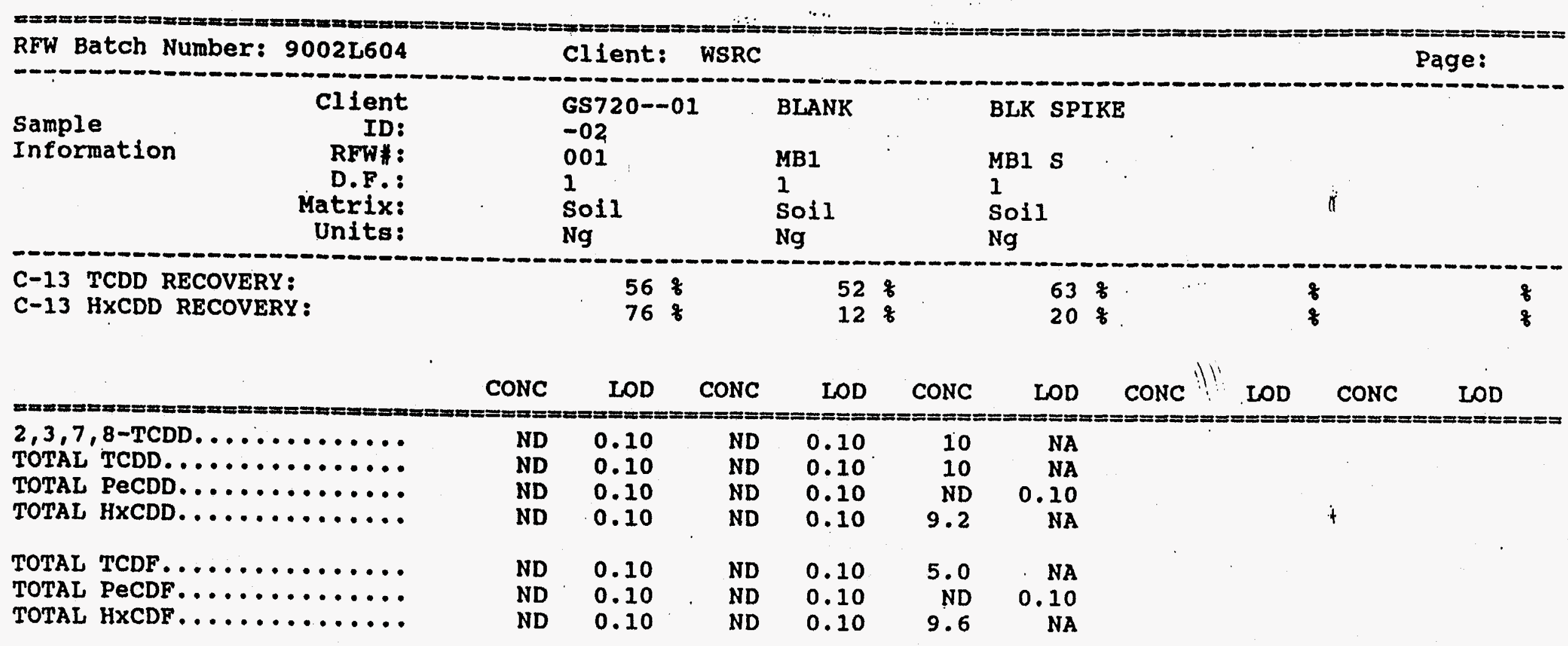

CONC CONCENTRATION

ND NONE DETECTED

NA NOT APPLICABLE

LOD LIMIT OF DETECTION 
Roy F. Weston, Inc. - ILonville Laboratory

HB ANALYTICNL DATA PACKAGE FOR

WSRC GUUSITE 720

DATE RECEIVED: $02 / 16 / 90$

RFW LOT $\$ 9002 L 604$

\begin{tabular}{|c|c|c|c|c|c|c|}
\hline CLIENTI ID & REW & $\operatorname{ser} x$ & PREP * & COLLECTION & EXTR/PREP & ARACYSIS \\
\hline $\begin{array}{lll}65720 & 01 & 02\end{array}$ & 001 & $\mathbf{s}$ & 90LE0282 & $02 / 13 / 90$ & $02 / 27 / 90$ & $03 / 14 / 90$ \\
\hline
\end{tabular}

IAB QC:

PBLX

LB1

MB1 BS

S $90 \mathrm{LE0282}$

N/A

$02 / 27 / 90$

$03 / 14 / 90$

PBIK

S 90IN50282 N/A

$02 / 27 / 90$

$03 / 14 / 90$

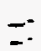

$=$ 
WISGRE Roy $F$. Weston, Inc. Lionville Laboratory

Client: WSRC Gunsite 720

RFW\#: $9002 L 604$, Herbicides

Date Received: $02 / 16 / 90$

พ.०.\#: 0630-28-13

The set of samples consisted of $I$ soil sample collected on 02/13/90.

The sample was extracted on $02 / 27 / 90$ and analyzed according to criteria set forth in Method 8150 for Chlorinated Phenoxy Acid Herbicide target compounds on $03 / 14 / 90$.

The following is a summary of the $Q C$ results accompanying these sample results and a description of any problem encountered during their analysis.

1. The blank spike recoveries are within laboratory control chart warning limits.

2. No problems were encountered during these analyses.

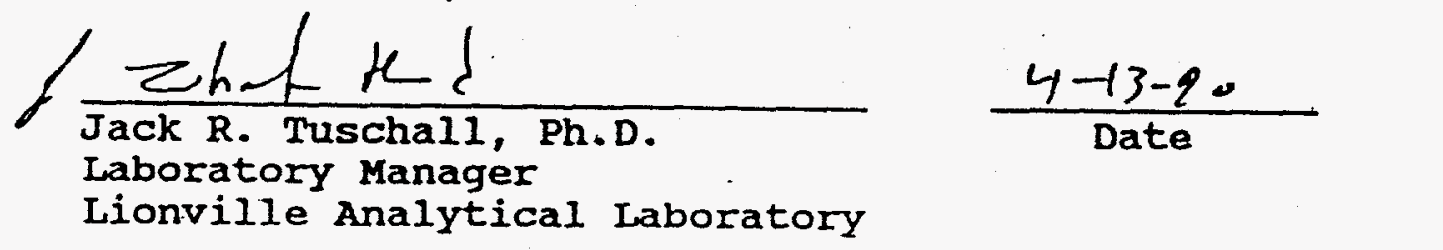




\section{Cust ID\& 68720 $0102 \quad$ PBLK $\because \cdots \quad \because \cdot$ PBLX B8}

\begin{tabular}{|c|c|c|c|c|}
\hline $\begin{array}{l}\text { Bample } \\
\text { Information }\end{array}$ & $\begin{array}{r}\text { RWW: } \\
\text { Ratx1x: } \\
\text { D.F.8 } \\
\text { Onlta: }\end{array}$ & $\begin{array}{c}001 \\
80 I 2 \\
1.00 \\
00 / \mathrm{KO}\end{array}$ & $\begin{array}{c}\text { 90LR0282-MBI } \\
\text { SOIL } \\
1.00 \\
\text { UG/KC }\end{array}$ & $\begin{array}{c}\text { 90LE0282-KB1 } \\
\text { 80IL } \\
1.00 \\
\text { UG/KO }\end{array}$ \\
\hline
\end{tabular}

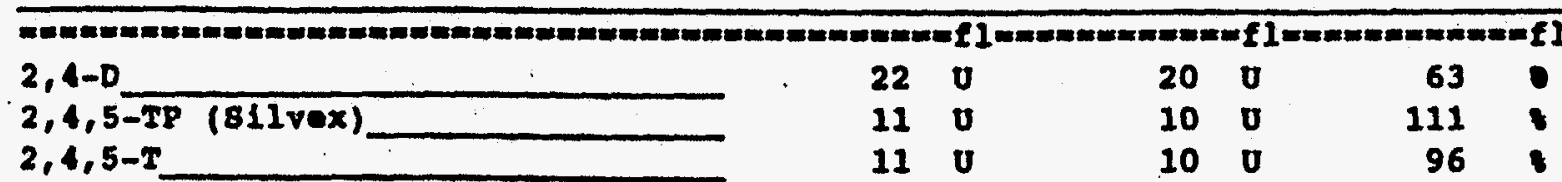

$2,4,5-T$

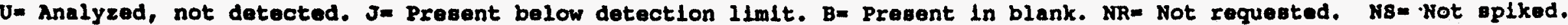

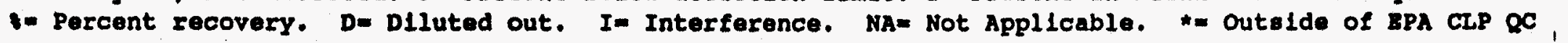


Roy F. Weston, Inc. - Ilonville Laboratory BNA ANALYTICAL DATA PACRAGE FOR WSRC GONSITI 720

DATE RECEIVED: 02/16/90

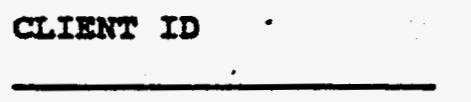

GS720 0102

G5720 0102

GS720 0102

\section{LAB QC:}

\section{$\operatorname{sBrx}$ \\ sBLK}

LBI
REM *

001

001 REP

001 us

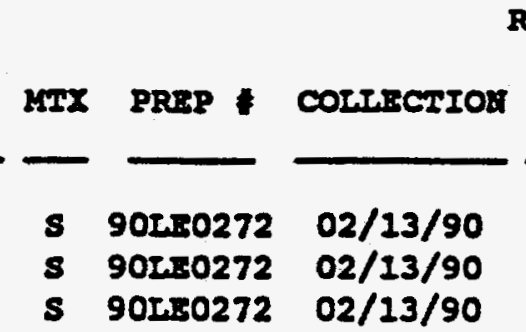

MIs
RTW LOT

390021604

EXIR/PREP

$02 / 26 / 90$

$02 / 26 / 90$

$02 / 26 / 90$
ARAIYSIS

$03 / 07 / 90$

$03 / 07 / 90$

03/07/90

MBI BS

\begin{abstract}
$\boldsymbol{x} / \mathbf{\lambda}$
\end{abstract}
$\mathbf{H} / \mathbf{A}$
$02 / 26 / 90$

$02 / 26 / 90$.
$03 / 07 / 90$

$03 / 07 / 90$ 
CLIENT: WSRC - GUNSITE 720

BAMPLES RBCEIVED: $02-16-90$

RFT *: 9002L604, GC/MS SEMIVOLATILE

พ.0. : $0630-28-13$

\section{NARRATIVE}

The set of samples consisted of one soil sample collected on 0213-90.

The sample wa extracted on $02-26-90$ and analyzed according to criteria set forth in Method 8270 for Appendix IX Semivolatile target compounds on 03-07-90.

The following is a summary of the QC results accompanying these sample results and a description of any problems encountered during their analysis:

1. Non-target compounds. were detected in these samples.

2. All surrogate, matrix and blank spike recoveries are within EPA QC limits.

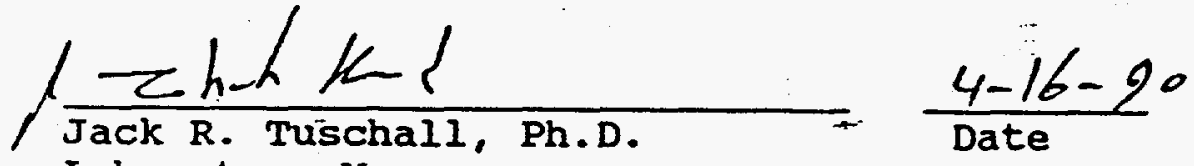

Laboratory Manager

Lionville Analytical Laboratory

sma/cn/02-604bicn 


\section{DATA QUATIFIERS}

$U$ = campound was analyzed for but not detected. The associated - rumerical value is the estimated sample quantitation limit which is included and corrected for dilution and percent moisture.

$J_{.}=$Indicates an estimated value. This $\mathfrak{l}$ ag is used either when estimating a concentration for tentatively identified coupounds where a $1: 1$ response is assumed or when the mass spectral data indicate the presence of a compound that meets the identification criteria but the result is less than the specified detection limit but greater than zero; for example, if the limit of detection is $10 \mathrm{ug} / \mathrm{L}$ and a concentration of 3 $u g / I$ is calculated, it is reported as $3 J$.

$B=$ This flag is used when the analyte is farnd in the associated blank as well as in the sample. It indicates possible/probable blank contamination. This flag is also used for a TIC as well as for a positively identified TCL cámpound.

$E$ = Indica=is that: the compound was detected beyond the calibration range and was subsequently analyzed at a dilution.

$I=$ Interference.

$A=$ Aldol Condensation Procuct.

$\mathrm{X}=$ Additional qualifiers used as required are explained in the case narative.

$\mathrm{NQ}=$ Result qualitatively confinmed but not able to quantify.

\section{ABEREVIATIONS}

BS = Indicates blank spike in which reagent grade water is spiked with the CIP matrix splking solutions and carried through all the steps in the method. Spike reooveries are reported.

BSD = Indicates blank spike duplicate.

MS = Indicates matrix spike.

MSD = Indicates matrix spike deplicate.

$D L=$ Indicates that surmogate recoveries were not obtained because the extract had to be diluted for analysis.

NA = Not applicable.

$D F=$ Dilution factor.

$\mathrm{NR}=$ Not required. 
"ux s. muscon, Inc. - LLonv111e Laboratory

semivolat Llea by GC/MB. Appendix" IX LIat

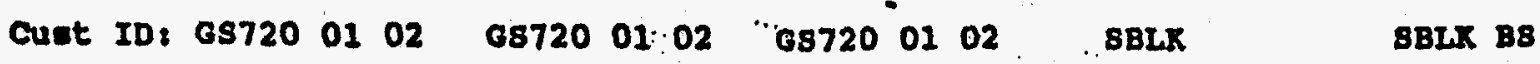

Bample

Information

\begin{tabular}{|c|c|c|}
\hline RET: & 001 & $001 \mathrm{RBP}$ \\
\hline Matr1x: & soIL & SOIL \\
\hline $\begin{array}{r}\text { D.P. } \\
\text { Unite: }\end{array}$ & $\begin{array}{r}1.11 \\
\mathrm{ug} / \mathrm{Kg}\end{array}$ & $\begin{array}{r}1.11 \\
\mathrm{ug} / \mathrm{xg}\end{array}$ \\
\hline
\end{tabular}

$\begin{array}{ccc}001 \mathrm{KS} & 90 \mathrm{LBO} 272-\mathrm{MB1} & \text { 90LE0272-KB1 } \\ \text { BOIL } & \text { SOIL } & \text { 8OIL } \\ .1 .11 & 1.11 & 1.11 \\ \mathrm{ug} / \mathrm{Kg} & \mathrm{ug} / \mathrm{Kg} & \mathrm{ug} / \mathrm{Kg}\end{array}$

\begin{tabular}{lr}
\hline H1trobenzene-d5 & 56 \\
Rurrogate & 2-Fluoroblphenyl \\
p-Tecovery & Phenol-d5 \\
& 2-FIuorophenol \\
& $2,4,6-$ Tribromophenol
\end{tabular}

Phenol

b I (2-Chloroethyl) ether

2-chlorophenol

1, 3-plchlorobenzene

1, 4-DLChlorobenzene

Benzyl alcohol

1,2-D1chlorobenzene

2-Methylphenol

b1e(2-Chlorol oopropy 1) ether

4-Kethylphenol

N-N1troso-D1-n-propylamine

Hexachloroethane

NLtrobenzene

I sophorone

2-N1trophenol

2, 4-D Imethylphenol

Benzolc acid

ble (2-Chloroethoxy) methane

2, 4-D1chlorophenol

1,2,4-Tx1chlorobenzene.

Raphthalene

4-Chloroan1IIne

Hexachlorobutadiene

4-Chloro-3-methyl phenol

2-Kethylnaphthalene

Hexachlorocyclopentadlene

$\begin{array}{ll}56 & : \\ 63 & \\ 73 & \\ 68 & \\ 60 & \end{array}$

47 :

* Outside of EPA CLP QC IImLts.

\begin{tabular}{|c|c|c|c|}
\hline 390 & $\boldsymbol{v}$ & 400 & $\mathbf{U}$ \\
\hline 390 & $\mathbf{u}$ & 400 & $\mathbf{U}$ \\
\hline 390 & $\mathbf{0}$ & 400 & $\mathbf{U}$ \\
\hline 390 & $\mathbf{0}$ & 400 & $\mathbf{U}$ \\
\hline 390 & $\mathbf{v}$ & 400 & $\mathbf{U}$ \\
\hline 390 & $\mathbf{v}$ & 400 & $\mathbf{U}$ \\
\hline 390 & $\mathbf{v}$ & 400 & $\mathbf{U}$ \\
\hline 390 & $\mathbf{0}$ & 400 & $\mathbf{U}$ \\
\hline 390 & $\mathbf{v}$ & 400 & $\mathbf{U}$ \\
\hline 390 & $\mathbf{v}$ & 400 & $\mathbf{v}$ \\
\hline 390 & $\mathbf{u}$ & 400 & $\mathbf{U}$ \\
\hline 390 & $\mathbf{0}$ & 400 & $\mathbf{U}$ \\
\hline 390 & $\mathbf{v}$ & 400 & $\mathbf{U}$ \\
\hline 390 & $\mathbf{U}$ & 400 & $\mathbf{U}$ \\
\hline 390 & $\mathbf{v}$ & 400 & $\mathbf{U}$ \\
\hline 390 & $\mathbf{v}$ & 400 & $\mathbf{u}$ \\
\hline 2000 & $\mathbf{v}$ & 2000 & $\mathbf{U}$ \\
\hline 390 & $\mathbf{U}$ & 400 & $\mathbf{v}$ \\
\hline 390 & $\mathbf{U}$ & 400 & $\mathbf{v}$ \\
\hline 390 & $\mathbf{U}$ & 400 & $\mathbf{v}$ \\
\hline 390 & $\mathbf{u}$ & 400 & $\mathbf{u}$ \\
\hline 390 & $\mathbf{U}$ & 400 & $\mathbf{u}$ \\
\hline 390 & $\mathbf{U}$ & 400 & $\mathbf{u}$ \\
\hline 390 & $\mathbf{U}$ & 400 & $\mathbf{u}$ \\
\hline 390 & $\mathbf{U}$ & 400 & $\mathbf{u}$ \\
\hline 390 & $\mathbf{U}$ & 400 & $\mathbf{U}$ \\
\hline
\end{tabular}

\begin{tabular}{|c|c|c|c|c|c|}
\hline 48 & 5 & 68 & ह & 68 & 81 \\
\hline 57 & 1 & 76 & 1 & 75 & 1 \\
\hline 70 & 1 & 91 & 1 & 87 & 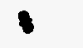 \\
\hline 61 & 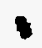 & 71 & 8 & 78 & 8 \\
\hline 51. & 1 & 55 & 1 & 64 & 1 \\
\hline 56 & 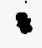 & 42 & 1 & 59 & 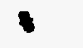 \\
\hline
\end{tabular}

$\begin{array}{lllllll}63 & 370 & 0 & 81 & \\ 380 & U & 370 & u & & 370 & u\end{array}$

$57 \quad 370$ 0 14.

$\begin{array}{lllll}380 & 0 & 370 & 0 & 370\end{array}$

$50 \quad 370$ U 34.

$\begin{array}{llllll}380 & U & 370 & v & 370 & U\end{array}$

$\begin{array}{llllll}380 & U & 370 & 0 & 370 & U\end{array}$

$\begin{array}{llllll}380 & 0 & 370 & 0 & 370 & 0\end{array}$

$\begin{array}{lllll}380 & U & 370 & U & 370 \\ 380 & 0 & 370 & 0 & \end{array}$

$\begin{array}{llllll}380 & U & 370 & 0 & 370 & 0\end{array}$

$46 \quad 370 \mathrm{U} \cdot 63$

$\begin{array}{llllll}380 & U & 370 & v & 370 & U\end{array}$

$\begin{array}{llllll}380 & v & 370 & 0 & 370 & U\end{array}$

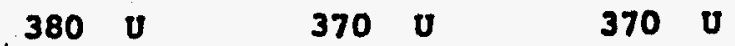

$\begin{array}{llllll}380 & v & 370 & v & 370 & U\end{array}$

$\begin{array}{llllll}380 & \mathbf{3} & 370 & \mathrm{U} & 370 & \mathrm{U}\end{array}$

$\begin{array}{llllll}1900 & U & 1800 & U & 1800 & U\end{array}$

$\begin{array}{llllll}380 & 0 & 370 & 0 & 370 & 0\end{array}$

$\begin{array}{lllll}380 & U & 370 & 0 & 370 \\ 6 & & 0\end{array}$

$60 \leqslant 370 \mathrm{U} \quad 88$.

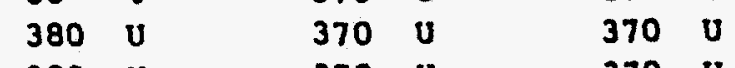

$\begin{array}{lllll}380 & U & 370 & U & 370 \\ 380\end{array}$

$\begin{array}{lllll}380 & U & 370 & U & 370 \\ 61\end{array}$

$61 \quad 370 \mathrm{U} \quad 76$.

$\begin{array}{lllll}380 & U & 370 & U & 370 \\ 380 & U & 370 & U & \end{array}$

$\begin{array}{lllll}380 & U & 370 & U & 370\end{array}$ 
C11ent:1 HSRC GUNSITSS $72 n$

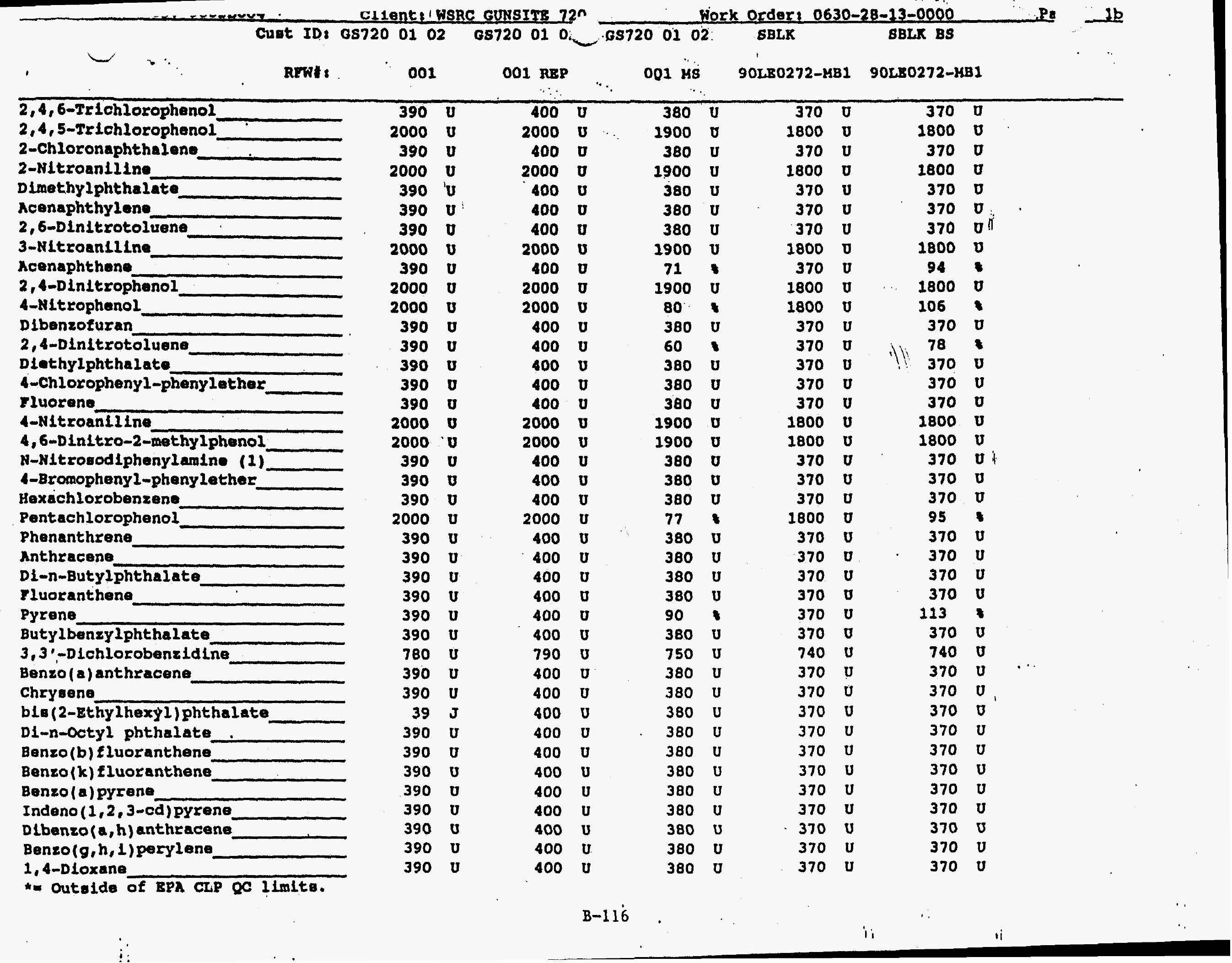


001

001 RBP

$001 \mathrm{Ms}$

90LE0272-KB1 90LE0272-KB1

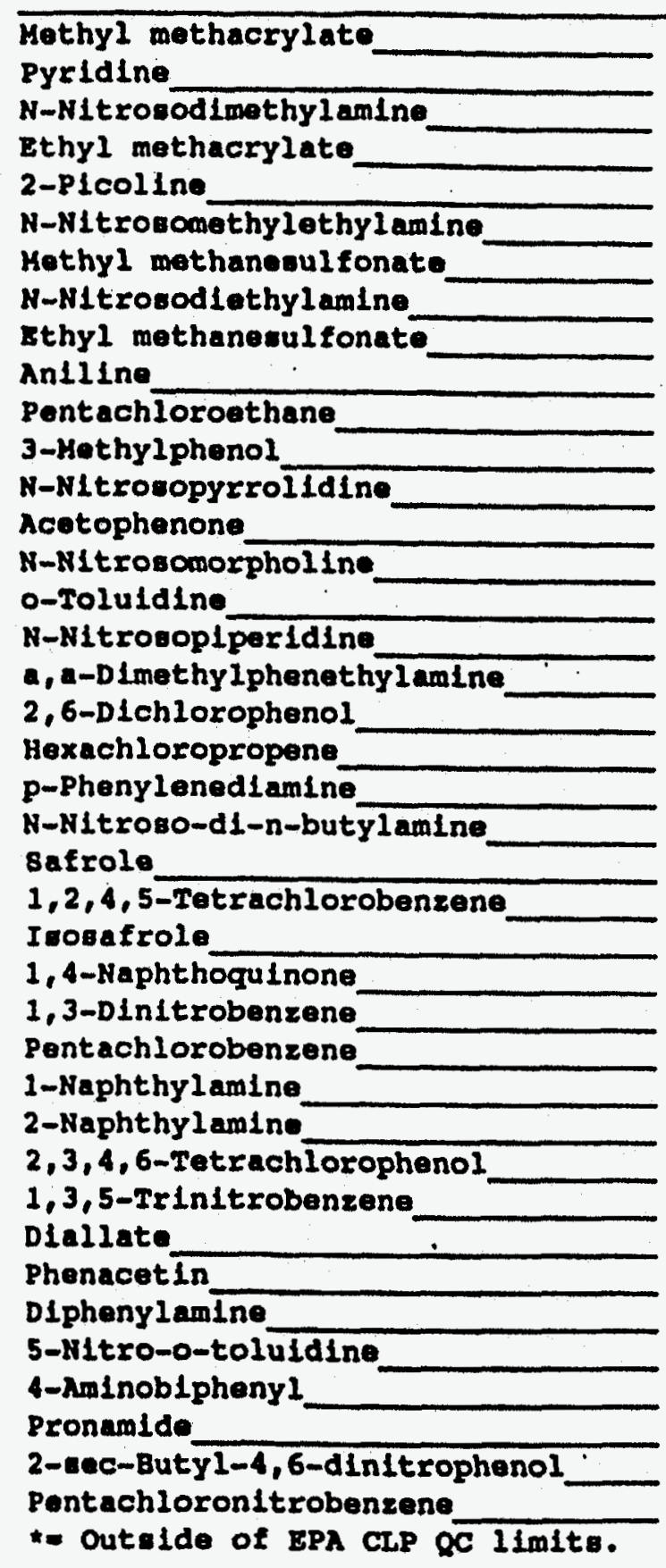

$390 \mathrm{U}$

$\begin{array}{ll}390 & \mathbf{U} \\ 390 & \mathbf{U}\end{array}$

$390 \mathrm{v}$

$390 \quad \mathbf{v}$

$390 \quad \mathrm{U}$

$390 \mathrm{v}:$

3900

$390 \mathrm{v}$

3900

$390 \mathrm{v}$

$390 \mathrm{v}$

$390 \mathrm{v}$

$390 \mathrm{v}$

$390 \mathrm{v}$

$390 \mathrm{v}$

390.0

$2000 \mathrm{v}$

$390 \cdot \mathrm{U}$

$390 \mathrm{U}$

$390 \mathrm{v}$

390 v

$390 \mathrm{U}$

390 U

$390 \mathrm{U}$

390 U

$390 \mathrm{v}$

$390 \mathrm{v}$

$390 \mathrm{U}$

390 v

$390 \mathrm{U}$

390 v

$390 \mathrm{U}$

$390 \mathrm{U}$

$390 \mathrm{u}$

390 v

$390 \mathrm{U}$

390 v

$390 \mathrm{v}$

$2000 \mathrm{v}$

$2000 \mathrm{U}$

\begin{tabular}{rl}
\hline 400 & $U$ \\
400 & $U$ \\
400 & $U$ \\
400 & $U$ \\
400 & $U$ \\
400 & $U$ \\
400 & $U$ \\
400 & $U$ \\
400 & $U$ \\
400 & $U$ \\
400 & $U$ \\
400 & $U$ \\
400 & $U$ \\
400 & $U$ \\
400 & $U$ \\
400 & $U$ \\
2000 & $U$ \\
400 & $U$ \\
400 & $U$ \\
400 & $U$ \\
400 & $U$ \\
400 & $U$ \\
400 & $U$ \\
400 & $U$ \\
400 & $U$ \\
400 & $U$ \\
400 & $U$ \\
400 & $U$ \\
400 & $U$ \\
400 & $U$ \\
400 & $U$ \\
400 & $U$ \\
400 & $U$ \\
400 & $U$ \\
400 & $U$ \\
400 & $U$ \\
400 & $U$ \\
400 & $U$ \\
2000 & $U$ \\
& $U$ \\
\hline
\end{tabular}

$380 \mathrm{U}$

$\begin{array}{ll}380 & U \\ 380 & U\end{array}$

380 U

380 U

3800

380 U

380 v

380 U

380 U

380 U

380 U

$380 \mathrm{U}$

380 U

$380 \mathrm{U}$

380 v

$380 \cdot 0$

$1900 \mathrm{v}$

380 U

$380 \mathrm{U}$

$380 \mathrm{U}$

380 v

380 U

380 v

380 U

380 U

380 U

380 U

380 U

$380 \mathrm{U}$

380 U

380 v

380 U

$380 U$

380 U

$380 \mathrm{U}$

$380 \quad U$

380 U

$380 \mathrm{U}$

$1900 \mathrm{U}$

$1900 \mathrm{U}$

\begin{tabular}{|c|c|c|c|}
\hline 370 & 0 & 370 & 0 \\
\hline 370 & $\mathbf{0}$ & 370 & $\mathbf{v}$ \\
\hline 370 & $\mathbf{0}$ & 370 & 0 \\
\hline 370 & $\mathbf{U}$ & 370 & $\mathbf{v}$ \\
\hline 370 & 0 & 370 & $\mathbf{v}$ \\
\hline 370 & $\mathbf{v}$ & 370 & $\mathbf{0}$ \\
\hline 370 & $\mathbf{0}$ & 370 & o \\
\hline 370 & $\mathbf{0}$ & 370 & $\mathbf{0}$ \\
\hline 370 & $\mathbf{0}$ & 370 & $\mathbf{0}$ \\
\hline 370 & 0 & 370 & $\mathbf{0}$ \\
\hline 370 & $\mathbf{v}$ & 370 & $\mathbf{v}$ \\
\hline 370 & $\mathbf{0}$ & 370 & 0 \\
\hline 370 & $\mathbf{v}$ & 370 & $\mathbf{0}$ \\
\hline 370 & $\mathbf{0}$ & 370 & $\mathbf{u}$ \\
\hline 370 & $\mathbf{v}$ & 370 & $\boldsymbol{0}$ \\
\hline 370 & $\mathbf{v}$ & 370 & $\mathbf{0}$ \\
\hline 1800 & $\mathbf{U}$ & 1800 & $\boldsymbol{v}$ \\
\hline 370 & t. & 370 & $\mathbf{v}$ \\
\hline 370 & $\mathbf{U}$ & 370 & $\mathbf{0}$ \\
\hline 370 & $\mathbf{U}$ & 370 & $\mathbf{v}$ \\
\hline 370 & $\mathbf{U}$ & 370 & $\mathbf{U}$ \\
\hline 370 & $\mathbf{U}$ & 370 & $\mathbf{0}$ \\
\hline 370 & $\mathbf{v}$ & 370 & $\mathbf{U}$ \\
\hline 370 & $\mathbf{U}$ & 370 & $\mathbf{U}$ \\
\hline 370 & $\mathbf{U}$ & 370 & $\mathbf{v}$ \\
\hline 370 & $\mathbf{u}$ & 370 & $\mathbf{v}$ \\
\hline 370 & $\mathbf{U}$ & 370 & $\mathbf{U}$ \\
\hline 370 & $\mathbf{U}$ & 370 & 0 \\
\hline 370 & $\mathbf{U}$ & 370 & $\mathbf{v}$ \\
\hline 370 & $\mathbf{U}$ & 370 & $\mathbf{0}$ \\
\hline 370 & $\mathbf{D}$ & 370 & $\mathbf{u}$ \\
\hline 370 & $\mathbf{U}$ & 370 & $\mathbf{v}$ \\
\hline 370 & $\mathbf{U}$ & 370 & $\mathbf{u}$ \\
\hline 370 & $\mathbf{U}$ & 370 & $\mathbf{U}$ \\
\hline 370 & $\mathbf{U}$ & 370 & $\mathbf{v}$ \\
\hline 370 & $\mathbf{U}$ & 370 & $\mathbf{U}$ \\
\hline 370 & $\mathbf{u}$ & 370 & $\mathbf{u}$ \\
\hline 370 & $\mathbf{U}$ & 370 & $\mathbf{v}$ \\
\hline 1800 & 0 & 1800 & $\mathbf{0}$ \\
\hline 1800 & $\mathbf{v}$ & 1800 & 0 \\
\hline
\end{tabular}


aten utuery u.03U-28-13-0000

Par-s 19

Cunt ID: Gs720 01 b2 68720010 ? $687200102 \quad$ SBLK 8BLK B8 001 HS 90LE0272-KB1 90LB0272-MB1

\begin{tabular}{|c|c|c|c|c|c|c|c|c|c|c|}
\hline 4-H1trogulnoline-1-oxide & 780 & $\mathbf{0}$ & 790 & $\mathbf{U}$ & 750 & $\mathbf{v}$ & 740 & $\mathbf{0}$ & 740 & $\mathbf{U}$ \\
\hline Methapyx 11ene & 390 & $\mathbf{U}$ & 400 & $\mathbf{u}$ & 380 & $\mathbf{0}$ & 370 & $\mathbf{U}$ & 370 & $\mathbf{0}$ \\
\hline Aramite & 780 & $\mathbf{0}$ & 790 & $\mathbf{v}$ & 750 & $\mathbf{0}$ & 740 & $\mathbf{v}$ & 740 & $\mathbf{U}$ \\
\hline Chlopobenellate & 390 & $\mathbf{u}$ & 400 & $\mathbf{U}$ & 380 & $\mathbf{U}$ & 370 & $\mathbf{0}$ & 370 & $\mathbf{0}$ \\
\hline p-D Imethy laminoazobenzens & 390 & , & 400 & $\mathbf{v}$ & 380 & $\mathbf{v}$ & 370 & $\mathbf{U}$ & .370 & $\mathbf{0}$ \\
\hline $3,3^{\prime}-\mathrm{DL}$ lmethylbenzldLne & 390 & $\mathbf{v}$ & 400 & $\mathbf{U}$ & 380 & $\mathbf{0}$ & 370 & $\mathbf{0}$ & 370 & $\mathbf{v}$ \\
\hline 2-Acetylaminofluorene & 390 & $\mathbf{v}$ & 400 & $\mathbf{v}$ & 380 & $\mathbf{u}$ & 370 & $\mathbf{U}$ & 370 & $\mathbf{U}$ \\
\hline 7, 12-Dimothylbens (a) anthrecens & 390 & $\mathbf{v}$ & 400 & $\mathbf{u}$ & 380 & $\mathbf{0}$ & 370 & $\mathbf{0}$ & $\mathbf{3 7 0}$ & $\mathbf{0}$ \\
\hline Hexachlorophene & 3500 & $\mathbf{v}$ & 3600 & $\mathbf{U}$ & 3400 & $\mathbf{0}$ & 3300 & $\mathbf{0}$ & 3300 & $\mathbf{U}$ \\
\hline 3-Hethyloholanthrene & 390 & $\mathbf{v}$ & 400 & $\mathbf{0}$ & 380 & $\mathbf{U}$ & 370 & $\mathbf{v}$ & 370 & $\mathbf{U}$ \\
\hline
\end{tabular}

(1) - Cannot be separated Exom Dlphenylamine. "- outside of EPA CLP QC $11 \mathrm{mits.}$ 
Lab vamer Roy F. Weston, Inc, Nork Order: 0630-28-13-0000

Client: HSRC GONSITE 720

Hatrixs

SOII.

Sample wt/rols

$30.8(g / m r)$

Levelt (1ow/mad) Ion

- Molsturer not dec. 8 dec.

Bxtraction: (Sepe/Cont/sonc) sonc

GPC Cleanup: $(Y / K) I$

par 7.0
Iab Sample ID: 9002L604-001

Iab F110 ID:

Date Recelved: $02 / 16 / 90$

Date ixtracted: 02/26/90

Date Inalyzeds 03/07/90

DilutLon Factor: 1.11

Number TICa found: 5

CONCENTRATION UNITS:

(ug/L or ug/ $\mathrm{kg}) \mathrm{ug} / \mathrm{Kg}$

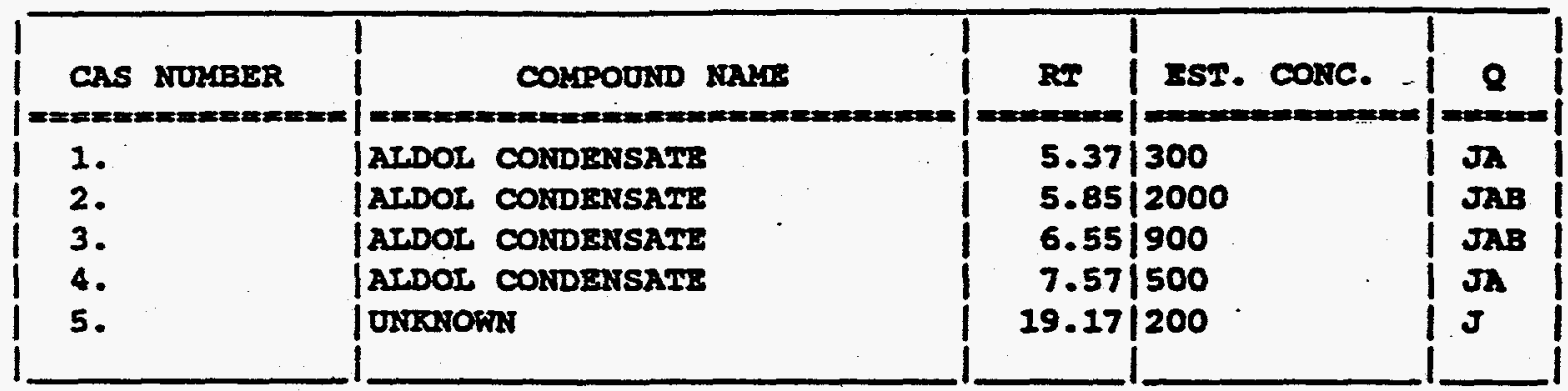


Lab Name: Boy F. Wegtor, Inc. Work Ordert 0630-28-13-0000

Cllent: WSRC GUTSIIE 720

Matrixz

SOIL

Sample wt/rol: $30.2(\mathrm{~g} / \mathrm{mL}) \mathrm{G}$

Levels (low/med) LON

8 Noletures not dec. 8 dec.

Extraction:

(SepE/Cont/Sone)

sorre

GPC Cleanup: (Y/N) $\underline{Y}$ pH: $\quad 7.0$
Iab Sample ID: 9002L604-001 REP

Lab F11e ID: M030709

Date Received: 02/16/90

Date Ixtracteds $02 / 26 / 90$

Date analyzeds 03/07/90

DLlution Factor: 1.11

CONCEHTRATION UNITS:

Number TICs found: 5 (ug/L or ug/ $\mathrm{kg}$ ) ua/ $\mathrm{kg}$

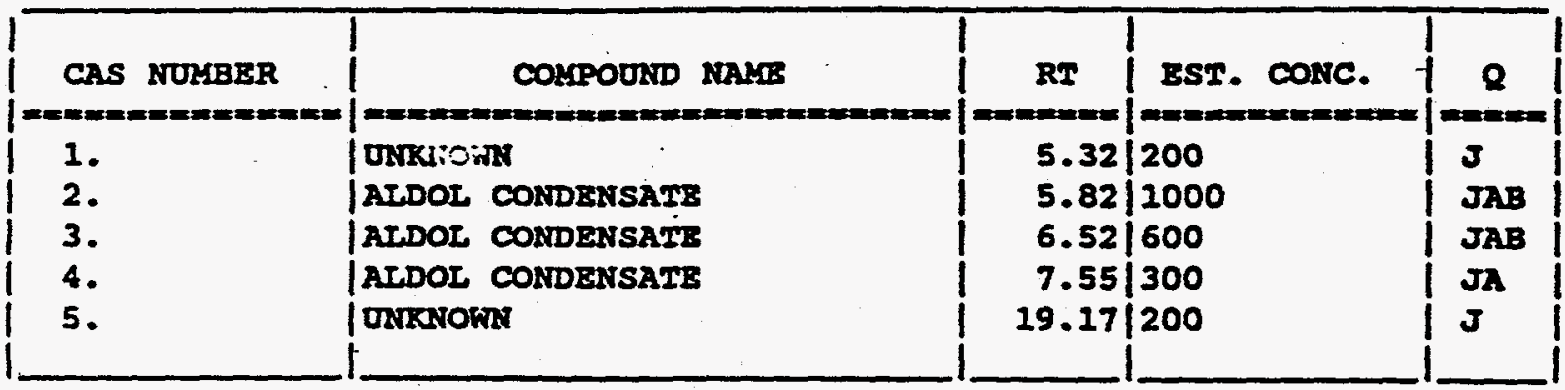


Lab Name: Roy F. Weston, Inc, Work Order: 0630-28-13-0000

Client: WSRC GONSITE 720

Latrix:

sample wt/vols

Level: (low/med) LOR

3olature: not dec. o dec.

Extraction:

(Sepr/conț/Sonc)

sore

GPC Cleanup: (Y/X) $\underline{I}$.

pBs 7.0
Iab Sample ID: 90TE0272-MB1

Lab F11e ID: M030713

Date Recelved: $\underline{02 / 26 / 90}$

Date Ixtracteds 02/26/90

Date Analyzeds 03/07/90

Dilution Factors 1.11

Number TICB found: 5

CONCENTRATION ONITS:

(ug/I or ug/ $\mathrm{ug}$ ) ug/rg

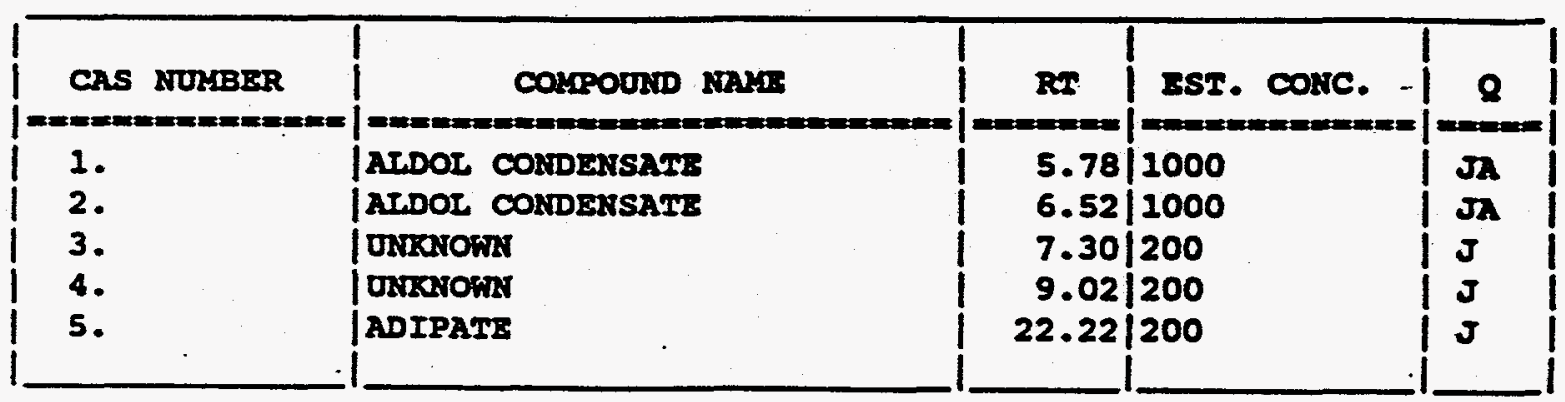


Whater.

GLOBgARY OF PF8T/PCB DATH

\section{DATA OUALIEIERS}

0 - Indicates that the compounds was analyzed for but not detected. The minimum detection limit for the sample (not the method detection 1 imit) is reported with the $U$ (e.g., 100).

$J$ - Indicates an estimated value. This flag is used in cases where a target analyte is detected at a level less than the lower quantification level. If the limit of quantification is $10 \mathrm{ug} / \mathrm{L}$ and a concentration of 3 $\mathrm{ug} / \mathrm{L}$ is calculated, it is reported as $3 \mathrm{~J}$.

B - This flag is used when the analyte is found in the associated blank as well as in the sample. It indicates possible/probable blank contamination. This flag is also used for a TIC as well as for a positively identified TCL compound.

E - Indicates that the compound was detected beyond the calibration range and was subsequentiy analyzed at a dilution.

I - Interference.

ABBREVIRTIONB

88 - Indicates blank spike in which reagent grade water is spiked with the CLP matrix spiking solutions and carried through all the steps in the method. spike recoveries are reported.

B8D - Indicates blank spike duplicate.

MB - Indicates matrix spike.

MSD - Indicates matrix spike duplicate.

DI - Indicates that recoveries were not obtained because the extract had to be diluted for analysis.

MA - Not applicable.

DF - Dilution factor.

NR - Not required. + - $=$ 
li.

$! 1$

Roy F. Weston, In - Llonv11le Laboratory

Pesticide/PCBa. wy GC, Appendix IX Llet

RF Batch Number! 90022604 Cllent: KSRC GUNSITE 720

Hork Order: 0630-28-13-0000

Report Date: 04/24/90 12:00

Cust ID, es720 0102

087200102

GS720 $01 \quad 02$

PBLT

PBLR Bs.

Sample

Information

\begin{tabular}{|c|c|c|c|c|c|}
\hline 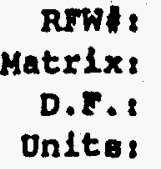 & $\begin{array}{r}001 \\
801 \mathrm{~L} \\
1.00 \\
\mathrm{ug} / \mathrm{kg}\end{array}$ & $\begin{array}{r}001 \mathrm{REP} \\
\text { sOIL } \\
1.00 \\
\mathrm{ug} / \mathrm{Kg}\end{array}$ & $\begin{array}{r}001 \mathrm{Ms} \\
\text { sotL } \\
1.00 \\
\mathrm{ug} / \mathrm{Kg}\end{array}$ & $\begin{array}{c}\text { 90LB0272-4B2 } \\
\text { sOIL } \\
1.00 \\
\text { ug } / \mathrm{kg}\end{array}$ & $\begin{array}{c}90 \mathrm{LB} 0272-\mathrm{HB} 2 \\
80 \mathrm{IL} \\
1.00 \\
\mathrm{ug} / \mathrm{Kg}\end{array}$ \\
\hline
\end{tabular}

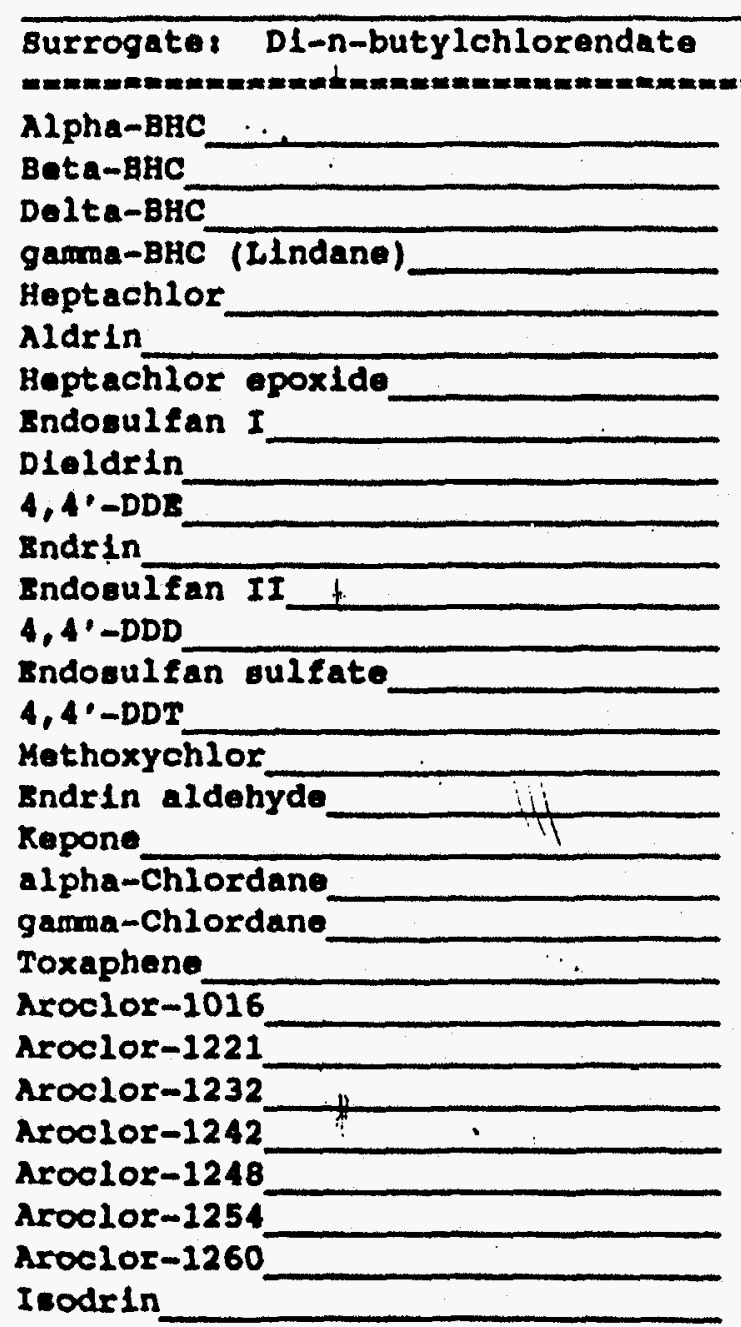

$175 \star$

$128 \quad$

$162 *$

$158 *$ :

$184 *$

$\begin{array}{cccccc}8.4 \mathrm{~V} & 8.6 \mathrm{~V} & 8.1 \mathrm{U} & 8.0 \mathrm{U} & 8.0 \mathrm{~J}\end{array}$

8.40

8.6 u

$8.1 \mathrm{U}$

8.40

$8.4 \mathrm{v}$

$8.6 \mathrm{U}$

8.40

8.40

8.6 v

$8.6 \mathrm{u}$

8.40

8.40

$8.6 \mathrm{U}$

$8.6 \mathrm{U}$

$8.6 \mathrm{v}$

$17 \mathrm{v}$

170

$17 v$

$17 \mathrm{U}$

$17 \mathrm{v}$

170

$17 \mathrm{U}$

84 v

$17 \mathrm{v}$

$17 \mathrm{v}$

$84 \mathrm{v}$

$84 v$

$170 \mathrm{U}$

$84 v$

$84 \mathrm{~V}$

$84 \mathrm{U}$

$84 v$

$84 \mathrm{U}$

$170 \mathrm{U}$

1700

170

170

170

$17 \cdot 0$

$17 \mathrm{v}$

$17 \mathrm{U}$

$4.3 \mathrm{~J}$

$86 \mathrm{U}$

170

170

$86 \mathrm{v}$

$86 \mathrm{U}$

$170 \mathrm{U}$

860

$86 \mathrm{U}$

$86 \mathrm{U}$

860

$86 \mathrm{v}$

$170 \mathrm{v}$

$170 \mathrm{v}$

$17 \mathrm{U} \quad 17 \mathrm{v}$

8.1 U

62

75

60
8.1

8.10

66

$16 \mathrm{~V}$

76

160

160

$16 \mathrm{~V}$

95

$81 \mathrm{v}$

160

$16 \mathrm{U}$

$\begin{array}{ll}81 & \mathrm{U} \\ 81 & \mathrm{U}\end{array}$

$160 \mathrm{U}$

$81 \mathrm{v}$

$\begin{array}{ll}81 & \mathrm{U} \\ 81 & \mathrm{U}\end{array}$

81; U

$160 \mathrm{U}$

$160 \mathrm{~V}$

$8.0 \mathrm{U} \quad 8.0 \mathrm{U}$

8.00

$8.0 \mathrm{U}$

$8.0 \mathrm{U}$

$8.0 \mathrm{U}$

$8.0 \mathrm{U}$

8.0 U

.160

160

$16 \mathrm{v}$

$16 \mathrm{v}$

$16 \mathrm{v}$

$16 \mathrm{v}$

$16 \mathrm{v}$

$80 \mathrm{~V}$

$16 \mathrm{v}$

160

$80 \mathrm{~V}$

$80 \mathrm{~V}$

$160 \mathrm{U}$

$80 \mathrm{U}$

$80 \mathrm{U}$

$.80 \mathrm{U}$

$80 \mathrm{U}$

$\begin{array}{rr}80 & 0 \\ 160 & v\end{array}$

1600

$16 \mathrm{~V}$

8.0 v

140 .

85

88

$8.0 \mathrm{U}$

$8.0 \mathrm{~V}$

92

$16 \mathrm{~V}$

114

$16 \mathrm{v}$

160

$16 \mathrm{v}$

$143 *$

$80 \mathrm{U}$

$16 \mathrm{v}$

16 U

80 D

800

$160 \mathrm{~V}$

$80 \mathrm{U}$

$80 \mathrm{~V}$

$80 \mathrm{v}$

$80 \mathrm{v}$

$80 \mathrm{v}$

$160 \mathrm{U}$

1600

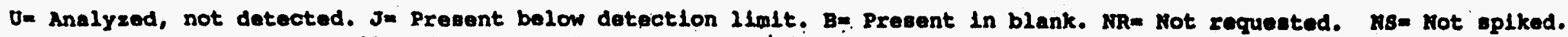

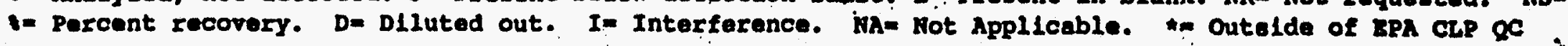




\section{WESTON Andytics Use Only \\ Lab Work Bequest}

$9002 L 604$ wsincloun 120

client WSPC Gunsite 20

Work order $0630-28-13000$

Date Roc'd. $2 / 16$ lan Date Dur $3 / 28190$

RFW Contact

Cllent Contacuphone

\begin{tabular}{|c|c|c|c|c|c|c|c|c|c|c|c|c|}
\hline $\begin{array}{l}\text { WA Use Only } \\
\text { Lab id }\end{array}$ & Client lovosectiption & Matrix & $\begin{array}{l}\text { Dalo } \\
\text { colloclod }\end{array}$ & $60^{2+4}$ & $d^{18^{80}}$ & $\alpha e^{2^{5 t}}$ & $0^{1068}$ & $0_{0} 0^{4}$ & ${ }_{08} \mathrm{p}$ & $5^{4^{0}}$ & $10^{\circ}$ & $\mathrm{jpp}^{p e 1}$ \\
\hline$\infty$ & $65720 \quad 01-01$ & 5 & 2113 & L & 2 & 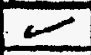 & $\nabla$ & 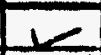 & $<$ & 2 & & L \\
\hline & & & & & & & & & & & & \\
\hline & & & & & & & & & & & & \\
\hline & & & & & & & & & & & & \\
\hline & & & & & & & & & & & & \\
\hline & & & & & & & & & & & & \\
\hline & & & & & & & & - & & & & \\
\hline & & & & & & & & & & & & \\
\hline & t: & & & $R$ & $\pi$ & & +1 & 21 & & 20 & & \\
\hline & & & & c & $2 n$ & 2 & ex & & & & & \\
\hline & & & & & SA & $2 C$ & ins & $n$ & & $\$$ & & \\
\hline & & & & & & & & & & & & \\
\hline & il & & & & & & - & & & & & \\
\hline & & & & & & & & & & & & \\
\hline & & & & & & & & & & & & \\
\hline 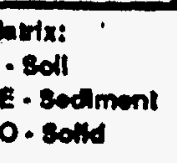 & $\begin{array}{l}\text { Ds. Drum Sollde } \\
\text { o. Drum Lquits } \\
\text { F. Filst } \\
\text { x. Other }\end{array}$ & & & & & & & & & & & \\
\hline
\end{tabular}

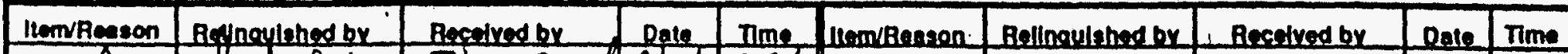

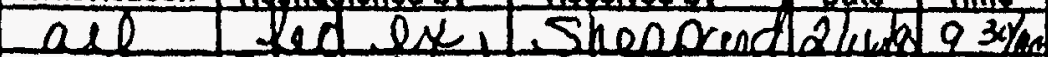

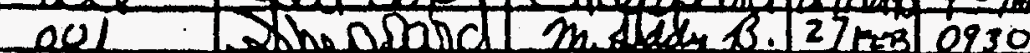

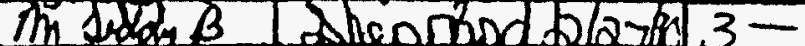
wet lah Shand 85 er 350 3/21 8110

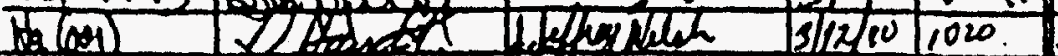

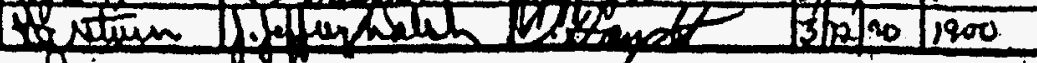
RFW $21.21 .001 / \mathrm{A} \cdot 7 / \mathrm{BB}$

Retrigeralort

iType Container

Volume

Preservative

ANALYSES

AEQUESTED

taml sand

- -

A A ORY

$-1+1 / 20$

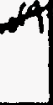

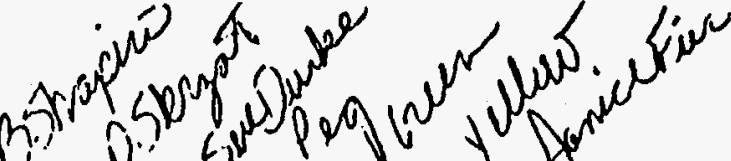


Roy F. Weston, Inc. - LLonville Laboratory OPP AMALYIICAL DAIA PACKACX zOR

WSRC GUISITE 720

DATE RECEIVED: $02 / 16 / 90$

CLIBATT ID

657200102
RWh

$$
001
$$

LAB QC:

PBLX

PBIX

IBBI

2BB1 BS
RTH LOT $\$ 9002 L 604$

ISTX PREP COLIRCTIOA EXIR/PREP

MRIISIS

s $90 \mathrm{LE0283} 02 / 13 / 90$

$02 / 27 / 90$

$03 / 23 / 90$
s 90450283
s 90250283
$\mathbf{n} / \mathbf{A}$
$\mathbf{N} / \mathbf{A}$

$02 / 27 / 90$

$03 / 23 / 90$

$03 / 23 / 90$ 


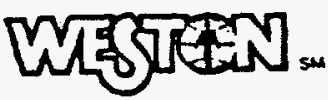

CLIENT: WSRC GUNSITE 720

RFW : 9002L604

W.O. : $0630-28-13$
ROY F. WEBTON, IHC.

Lionville Iaboratory

BALPLES RECEIVED: $02 / 16 / 90$

NARRATIVE

The set.of samples consisted of one soil sample collected on $02 / 13 / 90$.

The samples were extracted on $02 / 27 / 90$ and analyzed according to criteria set forth in Method 8140 for Appendix IX Organophosphorus Pesticide target compounds on $03 / 23 / 90$.

All surrogate and blank spike recoveries are within QC limits. No problems were encounterd during sample analysis.

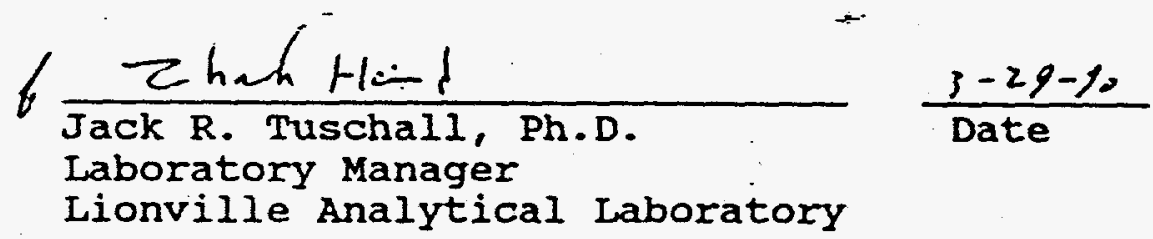


WISECEN

\author{
GTOB8ARY OF PFBT $\angle$ PCB DATA
}

\title{
DATR OUATIEIERB
}

0 - Indicates that the compounds was analyzed for but not detected. The minimum detection limit for the sample (not the method detection 1 imit) is-reported with the 0 (e.g., 100).

$J$ - Indicates an estimated value. This flag is used in cases where a target analyte is detected at a level less than the lower quantification level. If the limit of quantification is $10 \mathrm{ug} / \mathrm{L}$ and a concentration of 3 $\mathrm{ug} / \mathrm{L}$ is calculated, it is reported as $3 \mathrm{~J}$.

B - This flag is used when the analyte is found in the associated blank as well as in the sample. It indicates possible/probable blank contamiñation. This flag is also used for a TIC as well as for a positiveIy identified TCL compound.

B - Indicates that the compound was detected beyond the calibration range and was subsequently analyzed at a dilution.

I - Interference.

ABBREVTATIORS

B8 - Indicates blank spike in which reagent grade water is spiked with the cup matrix spiking solutions arid carried through all the steps in the method. Spike recoveries are reported.

B8D - Indicates blank spike duplicate.

48 - Indicates matrix spike.

M8D - Indicates matrix spike dupilcate.

DI - Indicates that recoveries were not obtained because the extract had to be diluted for analyais.

si - Not applicable.

Dr - Dilution Eactor.

MR - Not required. 
Roy . Weaton, Inc. - Lonv1lie Laboratory

ORTHOPHOSPL \& PESTICIDES

Cust IDi $687200102 \quad$ PBLX $\because \quad \cdots \quad$ PBLX Bs

\begin{tabular}{|c|c|c|c|c|}
\hline $\begin{array}{l}\text { 8ample } \\
\text { Information }\end{array}$ & $\begin{array}{r}\text { RuWl: } \\
\text { Matrix: } \\
\text { D.5.8 } \\
\text { Unlta: }\end{array}$ & $\begin{array}{l}001 \\
80 I L \\
0.500 \\
\text { ug/ Kg }\end{array}$ & $\begin{array}{c}\text { 90L:0283-KB1 } \\
\text { 80IL } \\
0.500 \\
\mathrm{ug} / \mathrm{kg}\end{array}$ & $\begin{array}{c}\text { 90LiE0283-MB1 } \\
\text { 80IL } \\
0.500 \\
\text { ug/Kg }\end{array}$ \\
\hline
\end{tabular}

\begin{tabular}{|c|c|c|c|c|c|c|c|}
\hline 8urrogate: $\quad$ Ethion & 69 & 1 & 62 & 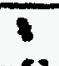 & 64 & 3 & - \\
\hline 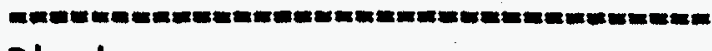 & & & & $=\mathbf{E l}$ & & $=\notin$ & 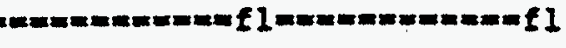 \\
\hline Dlazinon & 7.3 & $\mathbf{u}$ & 6.7 & $\mathbf{u}$ & 69 & - & . \\
\hline Methyl Parathion & 7.3 & $\mathbf{0}$ & 6.7 & $\mathbf{0}$ & 60 & * & $\cdots$ \\
\hline 0,0,0-Tr1ethy1 phomphorothloat. & 36 & $\mathbf{0}$ & 33 & v & 33 & v & \\
\hline Thionazin (zinophos) & 36 & $\mathbf{u}$ & 33 & $\mathbf{u}$ & 33 & $\mathbf{u}$ & \\
\hline Phorate & 7.3 & $\mathbf{v}$ & 6.7 & v & 6.7 & $\mathbf{0}$ & .11 \\
\hline 8ulfotepp & 36 & $\mathbf{v}$ & 33 & $\mathbf{v}$ & 33 & v. & 1. \\
\hline Dleulfoton & 7.3 & $\mathbf{U}$ & 6.7 & $\mathbf{u}$ & 6.7 & $\mathbf{u}$ & \\
\hline DLmethoate & 36 & $\mathbf{u}$ & 33 & $\mathbf{u}$ & 33 & $\mathbf{u}$ & \\
\hline Ethyl ParathLon & 7.3 & $\mathbf{u}$ & 6.7 & $\boldsymbol{U}$ & 6.7 & $\mathbf{0}$ & \\
\hline Famphur (Famophos) & 73 & $\mathbf{U}$ & 67 & $\mathbf{0}$ & 67 & $\mathbf{v}$ & \\
\hline
\end{tabular}

$U=$ Analyzed, not detected. J= Present below detection $11 \mathrm{mit}$. B= Present in blank. NR= Not requented. NB= Not splked. i= Percent recovery. D= Dlluted out. I= Interference. NA= Not Applicable. *= Outside of EPA CLP QC 
Weston - SRP

CUSTOMER

ATTENTION ADDRESS

CITY

W.O. No.

Mark T. Carkhuff

208 Welsh Pool Rd.

Lionville, Pa 19353

E-1588

$1028 \% 2$

Lab Code : BE

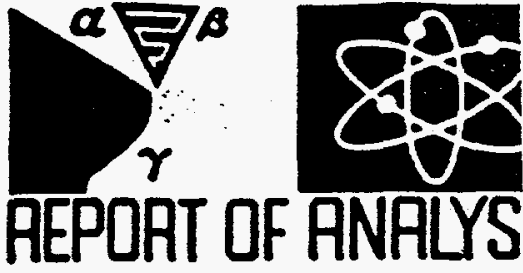

$03 / 09 / 90$
DATE

TIME

Customer ANALY.

Identification

L603002.

E1738

L 603002

E1738

L603005

E1739

L603005

E1739

L603014

E1740

L 603014

E1740

L606001

E1741

Lf 06001

i 41

36002

$\pm 1742$

L 606002

E1742

L606003

E1743

L606003

E1743

L606011

E1744

L606011

E1744
sMMPLS RECEIVED

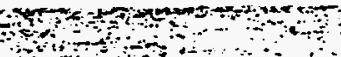

$15-101$

उe? 
weston - SRP

Mark T. Carkhuff

CUSTOMER

208 Welsh Pool Rd.

ADOHESS

CITY

Lionville, Pa i9353

$E-1589$

w.o. No.

Lab Code : BE

$$
\therefore \quad 15-101
$$

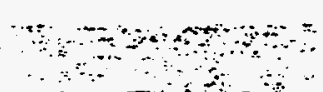

me of analvses

DATE

TIME

Customer

Identification

L606014

E1745

L606014

-E1745
ANALY.

Date

Collected

032790

1045

032790

1045 curromes onotin wamitis
$02 / 21 / 90$

$02 / 21 / 90 \quad$ BETA

Type of

ACTIVITY/ERROR

UNTS ACCRCY

INST/INI Analysis

ALPHA

0.00

2.00

pC1/1

1.22

0.00

3.00

$\mathrm{pC1} / 1$

1.13

46 DDP

$03 / 09 / 90$

SAMPLES RECEIVED

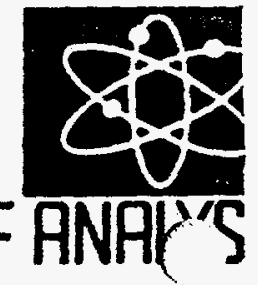


WESTER .

CLIENT: WSRC GUNSITE 720

RFW : 9002L604

W.0. \#: 0630-28-13
ROY F. MEBTON, INC.

Iionville Laboratory

SAMPLES RECEIVED: 02-16-90

\section{INORGANIC NARRATIVE}

The following is a summary of the quality control results and a description of any problems encountered during the analysis of this batch of samples:

1. All preparation blanks were analyzed below the required detection limit.

2. All calibration verification checks were within the required control limits of 90-100\%. Calibration verification is performed using independent standards.

3. All laboratory control standards (blank spikes) were within the control limits of 80-120\%.

4. The analytical methods applied by the laboratory, unless otherwise requested, for all inorganic analyses are derived from the USEPA Method for chemical Analysis of Water and wastes (USEPA 600/4-79-020), and Standard Methods for the Examination of Water and Wastewater $16 \mathrm{ed}$. Methods for the analysis of solid samples are derived from Test Methods for Evaluating Solid Waste (USEPA SW846).

5. USEPA-CLP SOW 787 was followed for the analysis of cyanide.

NOTE: For solid samples, all results are reported on a dry weight basis.

f) $\frac{2 h a h+1 a n d}{\text { Jack R. Tuschall, Ph.D. }} \frac{3-21-92}{\text { Date }}$

Laboratory Manager

Lionville Analytical Laboratory 
ROY F. FESTON, INC.

GLOSSARY OF TERMS - INORGANIC REPORTS

\section{DATA QUALIFIERS}

$\mathrm{U}$ - Indicates that the parameter was not detected at or above the reported limit. The associated numerical value is the sample detection limit.

* - Indicates that the original sample result is greater than $4 x$ the spike amount added. The USEPA-CLP has determined that spike results on samples where this occurs may be unreliable and, therefore, the control limits are not applicable.

\section{ABBREVIATIONS}

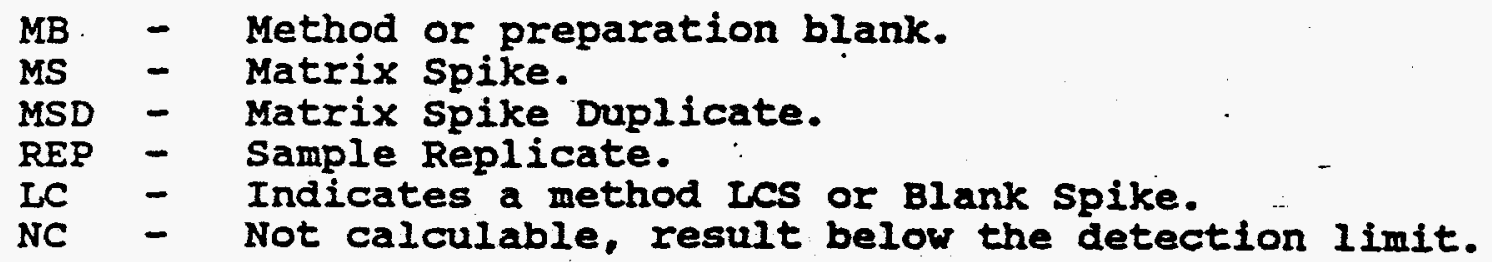

\section{IABORATORY CHRONOLOGY AND HOLDTIMTE REPORT}

The test code listed indicates the specific analysis or preparation procedure employed. The codes may be interpreted as follows:
MAAW - Metals prep test for AA digestion, water matrix. MAAS - Metals prep test for AA digestion, soil matrix. MICW - Metals prep test for ICP digestion, water matrix. MICS - Metals prep test for ICP digestion, soil matrix.
M**TO- This type of code indicates a total metal analysis (eg. MAGTO indicates an analysis for total silver).
$M \star \star S O-\quad T h i s$ type of code indicates a soluble metal analysis. (eg. MAGSo indicates an analysis for soluble silver).
$M \star \star E P-\quad T h i s$ type of code indicates an EPTOXICITY metals analysis (eg. MAGEP indicates an analysis for eptox silver).
$I * *$ TO- This type of code indicates a non-metallic total analysis. There is also a complimentary soluble analysis for each of these codes (eg. Icarro indicates an analysis for total cyanide).

A suffix of $-R$ or $-S$ following these codes indicates $a$ replicate or spike analysis respectively. 
ROY F. HESTOR INC.

IMORGAMICS DATA SURARAY RBPORT 03/14/90

CLIENT: HSRC GUNSI2Y 720

WORK ORDER: 0630-28-13-0000

SAMPTE:

$=$

$-001$
SIIS ID

687200102
AXACYYS

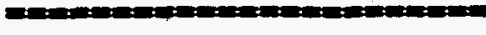

- SorIDs

CYATIDE, TONAI

8ULFIDE
MESTOA BATCR \&8 90025604

\begin{tabular}{|c|c|c|}
\hline RESULT. & DrIIS & $\begin{array}{l}\text { RUPORIIAG } \\
\text { LIXIT }\end{array}$ \\
\hline $\begin{array}{ll}92.1 & \\
1.1 & \text { u } \\
0.27 & \text { u }\end{array}$ & $\begin{array}{l}0 \\
y e / 210 \\
x \in / x e\end{array}$ & $\begin{array}{l}0.20 \\
1.1 \\
0.27\end{array}$ \\
\hline
\end{tabular}


ROY F. MESTOA Ixc.

INORGANICS METHOD BLAMK DATA SURARRY PAGE 03/14/90

CLIENT: HSRC GONSIT: 720

HORK OROER: 0630-28-13-0000

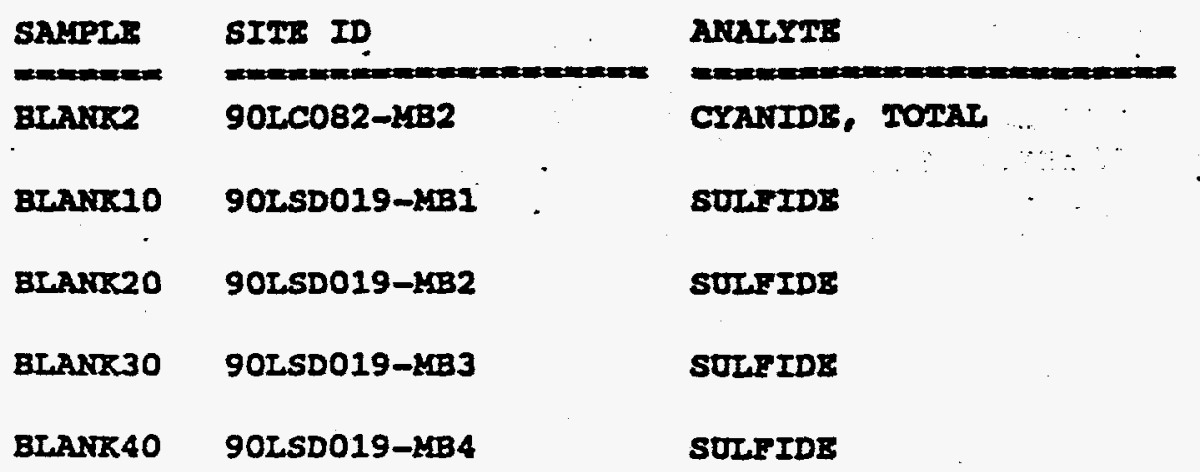

REsmot Baxat \& 9002260

\begin{tabular}{|c|c|c|c|}
\hline \multicolumn{2}{|c|}{ Risula . } & UIIIS & $\begin{array}{l}\text { RDORAIRO } \\
\text { ITER } \\
\end{array}$ \\
\hline 2.0 & $\mathbf{u}$ & Ne/15e & 1.0 \\
\hline 0.25 & $\mathbf{u}$ & ye/xo & 0.25 \\
\hline 0.25 & $\mathbf{u}$ & $4 \in / x e$ & 0.25 \\
\hline 0.25 & $\mathbf{u}$ & Me/Re & 0.25 \\
\hline 0.25 & $\mathbf{u}$ & $M G / 156$ & 0.25 \\
\hline
\end{tabular}


ROY P. WESTOR INC.

IKORGAKICS ACCURACT REPORT 03/14/90

CLIENT: WSRC GUTSIT: 720

WORK ORDER? 0630-28-13-0000

SAMPTI.

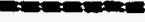

Brakrio

BLAMr20

BLarre30

BLANK 40
SITS In

9.m-

90LSD019-KB1

90LSD019-LB2

90L_SD019-LB3

90LSDO19-LB4
Anatyr:

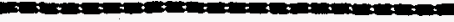

SULFID:

SULFIDS

SULFIDE

8ULFIDE
WESTOA BATCH \& 9002 í604

\begin{tabular}{|c|c|c|c|}
\hline $\begin{array}{l}\text { SPINED } \\
\text { SAYPLS }\end{array}$ & $\begin{array}{l}\text { INITIAI } \\
\text { Rustrar }\end{array}$ & $\begin{array}{l}\text { SPICLD } \\
\text { AYOOAr }\end{array}$ & Arseov \\
\hline $\begin{array}{l}1.0 \\
0.96\end{array}$ & $\begin{array}{l}0.25 u \\
0.25 u\end{array}$ & 1.0 & 102 \\
\hline 1.0 & $0.25 u$ & 1.0 & 102 \\
\hline 1.0 & $0.25 u$ & 1.0 & 102 \\
\hline
\end{tabular}


ROY F. WESTOA IRC.

IMORGANICS LABORATORY COATROL STAMDARDS REPORT 03/14/90

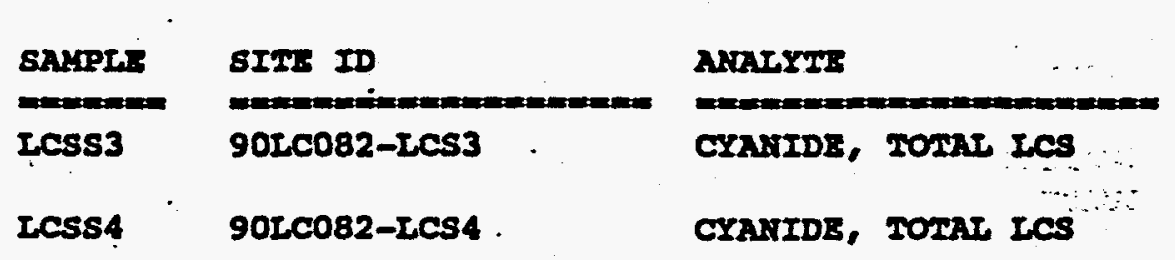

\begin{tabular}{|c|c|c|c|}
\hline SPIxto & SPT.MD & & \\
\hline ERyIPL: & Ayodxy & DiITS & ir.cov \\
\hline - & 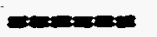 & 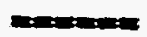 & $=$ \\
\hline 8.9 & 10.0 & $30 / 20$ & 89.3 \\
\hline 9.1 & 10.0 & $156 / x 6$ & 91.4 \\
\hline
\end{tabular}


Roy F. Weaton, Inc. - ILonville Laboratory

INORGNIIC ANALYTICAL DATA PACKACE FOR

WSRC CUNSITS 720

DATE RECEIVED: $02 / 16 / 90$

RW LOT * $\$ 9002 L 604$

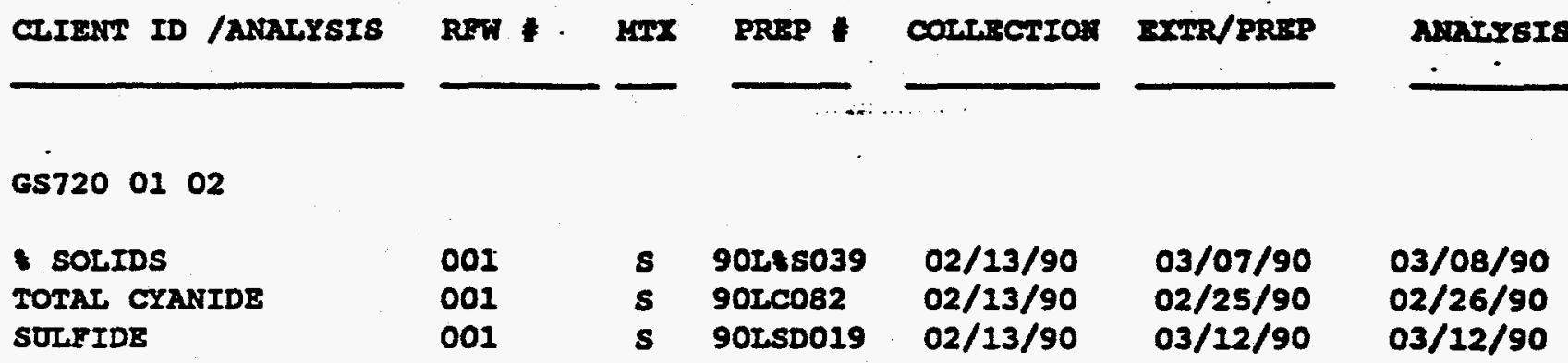

IAB QC:

TOTAL CYANIDE

TOTal CYanIDE

TOTAL CYANIDE

TOTAL CYANIDE

TOTAL CYANIDE

TOTAI CYANIDE

TOTAI CYANIDE

TOTAL CYANIDE

TOTAL CYANIDE

SULFIDE

SULFIDE

SULFIDE

SULFIDE

SULFIDE

SULPIDE

SULFIDE

SULFIDE

\begin{tabular}{|c|c|c|c|}
\hline $\mathrm{CCB}$ & & $\omega$ & $90 L C 082$ \\
\hline $\operatorname{ccs}$ & & $\boldsymbol{w}$ & 90LC082 \\
\hline $\operatorname{cov}$ & I & $n$ & $901 \mathrm{COB2}$ \\
\hline CCV & $\mathbf{L}$ & $\pi$ & 90rcos2 \\
\hline ICB & & n & 902C082 \\
\hline ICV & I & $n$ & 90LC082 \\
\hline LCS & $\mathbf{L}$ & $\omega$ & $902 \mathrm{Co82}$ \\
\hline ICs & I & $n$ & $902 c 082$ \\
\hline 2082 & & $\boldsymbol{n}$ & 90LC082 \\
\hline IBB & & $n$ & 90LSD019 \\
\hline LBI & Bs & $\boldsymbol{w}$ & 90LSDO19 \\
\hline MBZ2 & & 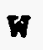 & 90LsD019 \\
\hline LBB2 & BS & $\boldsymbol{w}$ & 90LsD019 \\
\hline MBS3 & & $\boldsymbol{w}$ & 90LsD019 \\
\hline LB3 & BS & & 90LSD019 \\
\hline MB4 & & $\boldsymbol{W}$ & 90LsD019 \\
\hline MBA4 & BS & w. & 90LsD019 \\
\hline
\end{tabular}

$02 / 25 / 90$

$02 / 25 / 90$

$02 / 25 / 90$

$02 / 25 / 90$

$02 / 25 / 90$

$02 / 25 / 90$

$02 / 25 / 90$

$02 / 25 / 90$

$02 / 25 / 90$

$03 / 12 / 90$

$03 / 12 / 90$

$03 / 12 / 90$

$03 / 12 / 90$

$03 / 12 / 90$

$03 / 12 / 90$

$03 / 12 / 90$

$03 / 12 / 90$
$02 / 26 / 90$

$02 / 26 / 90^{\circ}$

$02 / 26 / 90$

$02 / 26 / 90$

$02 / 26 / 90$

$02 / 26 / 90$

$02 / 26 / 90$.

$02 / 26 / 90$

$02 / 26 / 90$

$03 / 12 / 90$

$03 / 12 / 90$

$03 / 12 / 90$

$03 / 12 / 90$

$03 / 12 / 90$

$03 / 12 / 90$

$03 / 12 / 90$

$03 / 12 / 90$ $x / A$

$n / x$ 
CLIENT: WSRC GUNSITE 720

SAKPLES RECEIVED: $02-16-90$

RFW : $9002 L 604$

W.0. : 0630-28-10

\section{METALS NARRATIVE}

The following is a summary of the quality control results and a description of any problems encountered during the analysis of this batch of samples:

1. All sample holding times as required by 40 CFR136 were met for water samples. Note: Holding times for soil samples have not been promulgated by the USEPA.

2. All calibration verification checks were within the required control limits of 90-100\% (85-115\% for $\mathrm{Hg}$ ) . calibration verification is performed using independent standards from Inorganic Ventures, Inc.

3. All preparation blanks were analyzed below the required detection limit.

4. Laboratory control standards were within the control limits of 80-120\% with the exception of silver (59\%) for site ID\# 90L0226-LC1. The blank spike reproducibility was outside the $20 \%$ window for silver at $58 \%$.

Note: The USEPA-CLP has dropped control limits for silver and antimony due to documented difficulties in obtaining reliable results. WESTON Analytics has adopted the same policy.

5. The analytical methods applied by the laboratory for the determination of metals are:

$\begin{array}{ll}\text { As: } & \text { EPA } 206.2 \\ \mathrm{Se}: & \mathrm{EPA} 270.2 \\ \mathrm{~Pb}: & \mathrm{EPA} 239.2 \\ \mathrm{TI} & \mathrm{EPA} 279.2\end{array}$
Hg:

ICP Scan: EPA 200.7

All Others: EPA 200.7

EP Leachates (except $\mathrm{Hg}$ ): 200.7 $=$

NOTE: For solid samples, all results are reported on a dry weight basis.

$\frac{\text { Zhh hl }}{\text { Jack R. Tuschali, Ph.D. }}$
Laboratory Manager
Lionville Analytical Laboratory 


\section{ROY F. WESTON, INC. \\ GLOSSARY OF TERMS - INORGANIC REPORTS}

\section{DATA OUAIIFIERS}

$U$ - Indicates that the parameter was not detected at or above the reported limit. The associated numerical value is the sample detection limit.

* - Indicates that the original sample result is greater than $4 x$ the splke amount added. The USEPA-CLP has determined that spike results on samples where this occurs may be unreliable and, therefore, the control limits are not applicable.

\section{ABBREVIATIONS}

MB - Method or preparation blank.
MS - Matrix Spike.
MSD - Matrix Spike Duplicate.
REP - Sample Replicate.
IC - Indicates a method ICs or Blank Spike.
NC - Not calculable, result below the detection limit.

\section{LABORATORY CHRONOLOGY AND HOLDTINE REPORT}

The test code listed indicates the specific analysis or preparation procedure employed. The codes may be interpreted as follows:

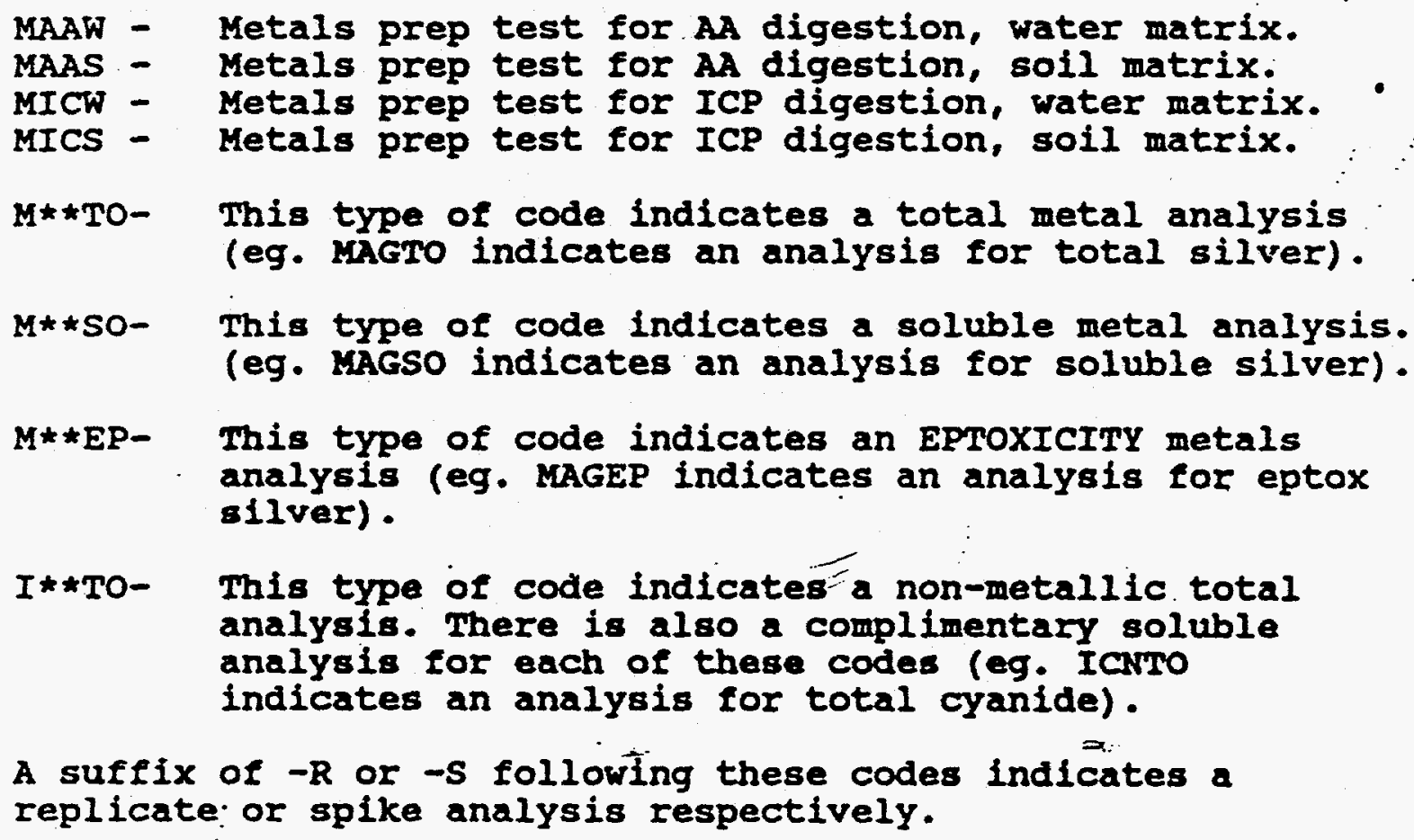


ROY F. WESTON INC.

INORGANICS DATA SURALRY REPORT 04/09/90

CLIENT: WSRC CUNSITE 720

WORK ORDER: 0630-28-13-0000

\begin{tabular}{|c|c|}
\hline SALPLE & $\begin{array}{l}\text { SITS ID } \\
\text { = }\end{array}$ \\
\hline-001 & $\begin{array}{lll}G 5720 & 01 & 02\end{array}$ \\
\hline
\end{tabular}

\section{ANaTYIB}

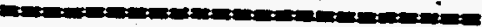

SIIVER, TOTAL

ARSEITIC, TOTAT

BARIUX, TOTAL

BERYLIIUI, TOTAL

CADKIOM, TOTAL

COBALT, TOTAL

CEROAIIUM, TOTAL

COPPER, TOTAL

MERCURY, TOTAL

NICTEL, TOTAL

IFAD, TOTAT

ANTIYORY, TOTAL SELENIUR, TOMAI

TIR, TOTAL.

THACLIU⿴, TOTAL

VANADIUM, TOTAI

zINC, TOTAL
WESTOR BATCH $\$ 2900226 b_{4}$

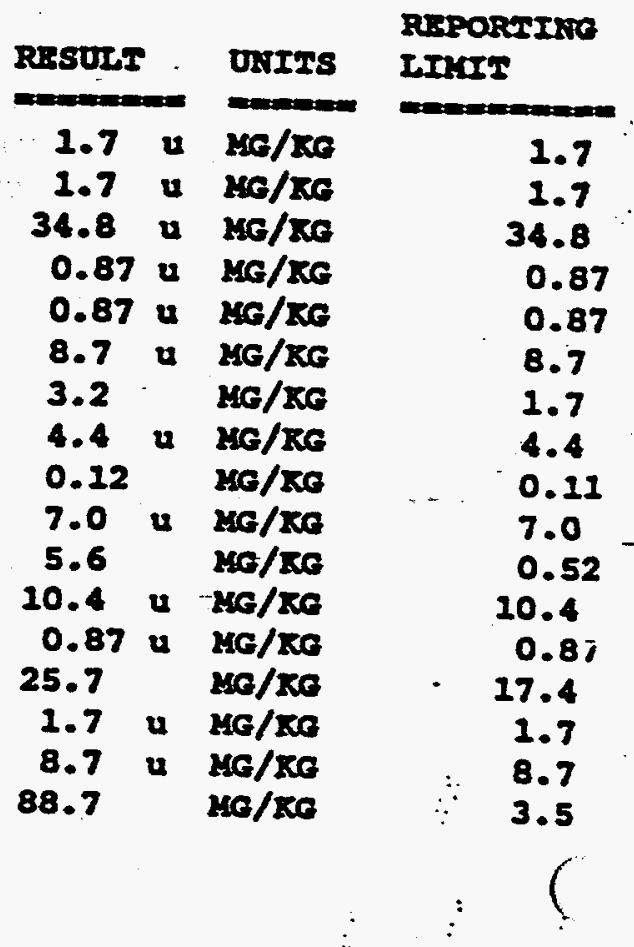


ROY F. FESTON IXC.

IMORGAKICS METHOD BLAKC DATA SUMARRY PAGE 04/09/90

CLIEAT: WSRC CONSITE 720

WORK ORDER: 0630-28-13-0000

\section{SARTLT}

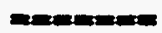

BLAMRI

SIIS ID

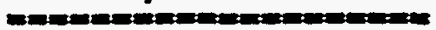

90L0226-LBBI

BLANK1 9050225-MB1

BLANK1 90C040B-MBI

BLANK2 90C040B-MB2

BLANK3 90C040B-MB3

BI.ANK4 90CO4OB-MB4
ARTrEx

SITVR, IONRT

BRRIU:, TOLXT

Batrartux, gorer.

CNDxIUX, TOLAI

cobary, TOIat

Carouctux, IOTAT.

COPPER, TOMA.

RICSEI, TOLAT

AxIIXONY, ToTAT

TIX, IOTAL

VAMADIU,, IOTAY

zIXC, TOIAT.

ARSENIC, TOTAL

IEAD, TOTAL

SELERITIM, TOTAL

THALIIUK, TOTAL

MERCURY, TOTAI

IERCURY, TOTAL

HERCURY, TOTAL

IERCURY, TOTAL heston BATCB $\$ 90022604$

\begin{tabular}{|c|c|c|c|c|}
\hline \multicolumn{2}{|c|}{ RESULT. } & \multirow{2}{*}{ 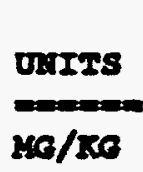 } & \multicolumn{2}{|c|}{$\begin{array}{l}\text { REPORTINE } \\
\text { IIMTY }\end{array}$} \\
\hline 2.0 & $u$ & & & 2.0 \\
\hline 40.0 & $\mathbf{u}$ & $150 / 20$ & & 40.0 \\
\hline 1.0 & $\mathbf{u}$ & $x \in / x e$ & & 1.0 \\
\hline 1.0 & $\mathbf{u}$ & $20 / 20$ & & 1.0 \\
\hline 10.0 & $\mathbf{u}$ & $M G / x G$ & & 10.0 \\
\hline 2.0 & u & $15 G / K G$ & & 2.0 \\
\hline 5.0 & $\mathbf{u}$ & $M G / K G$ & & 5.0 \\
\hline 8.0 & u & $K G / R G$ & & 8.0 \\
\hline 12.0 & $\mathbf{u}$ & $M C / R G$ & & 12.0 \\
\hline 20.0 & u & $250 / 20$ & - & 20.0 \\
\hline 10.0 & $\mathbf{u}$ & $\mathrm{MC} / \mathrm{xC}$ & & 10.0 \\
\hline 4.0 & $\mathbf{u}$ & MEg/xo & & 4.0 \\
\hline 2.0 & $\mathbf{u}$ & MG/KG & $\cdot$ & 2.0 \\
\hline 0.60 & $\mathbf{u}$ & MG/KO & & 0.60 \\
\hline 1.0 & $\mathbf{u}$ & $150 / 256$ & & 1.0 \\
\hline 2.0 & $\mathbf{u}$ & $M G / K G$ & $\because$ & 2.0 \\
\hline 0.10 & $\mathbf{u}$ & ME/ KG & & 0.10 \\
\hline 0.10 & $\mathbf{u}$ & $2 G / \mathrm{KG}$ & & 0.10 \\
\hline 0.10 & $\mathbf{u}$ & $L G / K_{G}$ & ? & 0.10 \\
\hline 0.10 & $\mathbf{u}$ & $\mathrm{BG} / \mathrm{KG}$ & $\therefore$ & 0.10 \\
\hline
\end{tabular}


ROY P. WESTON INC.

INORGANICS DUPLICATE SPIKS REPORT 04/09/90

CLIEATI: WSRC GONSITE 720

WORK ORDER: 0630-28-13-0000

SALPLS
LCS2

LCS2

90L0225-IC2

LCS2

90C040B-IC2

AKALYTX
SILVER, LCS
BARIUY, LCS
BERYIIUM, LCS
CADYIUY, LCS
COBALT, LCS
GEROMIUY, LCS
COPPER, LCS
RICKEI, LCS
ANTIMONY, LCS
TIN, LCS
VANADIUY, LCS
ZIKC, LCS

ARSEIIC, ICS

IFAD, LCS

SELENIOK, ICS

TEAIIIUM, LCS

KRRCURY, LCS
WESTON BATCE \&: $90021^{\prime} 604$

\begin{tabular}{|c|c|c|}
\hline IRECOV & RECOV & DIF \\
\hline 59.0 & 107 & 57.6 \\
\hline 102 & 101 & 0.74 \\
\hline 107 & 108 & 1.3 \\
\hline .06 & 106 & 0.30 \\
\hline 04 & 104 & 0.025 \\
\hline 12 & 111 & 0.50 \\
\hline 19 & 110 & 0.95 \\
\hline 104 & 105 & 0.48 \\
\hline 93.1 & 93.7 & 0.64 \\
\hline 92.6 & 93.0 & 0.41 \\
\hline 16 & 118 & -1.7 \\
\hline 103 & 103 & 0.058 \\
\hline 94.0 & 97.7 & 3.8 \\
\hline 13 & 112 & 0.89 \\
\hline & 113 & 1.5 \\
\hline & 109 & 1.2 \\
\hline & 103 & 3.4 \\
\hline
\end{tabular}


ROY F. hRSTOR IRC.

IKORGANICS LABORATORY CORTROL STAKDARDS REPORT 04/09/90

\begin{tabular}{|c|c|c|c|c|c|c|}
\hline SAMPLF & 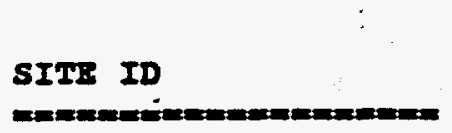 & 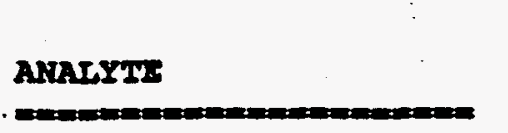 & 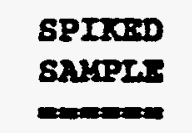 & 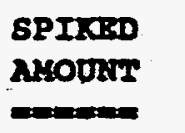 & Dirrs & RICON \\
\hline $\operatorname{Lcs} 1$ & 90L0226-LC1 & 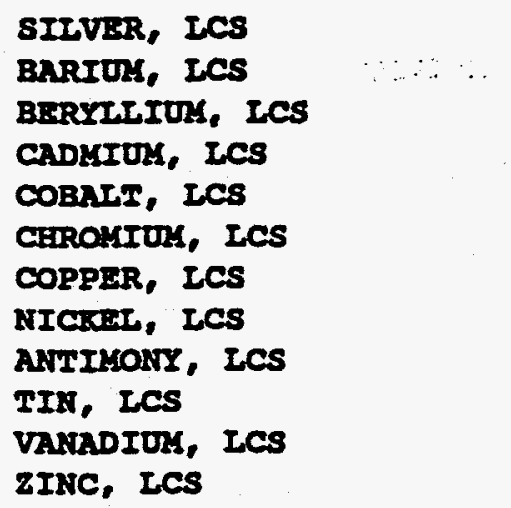 & $\begin{array}{l}59.0 \\
1020 \\
53.3 \\
53.1 \\
520 \\
112 \\
271 \\
417 \\
559 \\
926 \\
580 \\
205\end{array}$ & $\begin{array}{c}100 \\
1000 \\
50.0 \\
50.0 \\
500 \\
100 \\
250 \\
400 \\
600 \\
1000 \\
500 \\
200\end{array}$ & 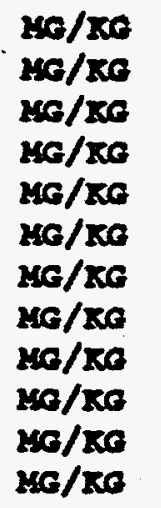 & $\begin{array}{l}59.0 \\
102 \\
107 \\
106 \\
104 \\
112 \\
109 \\
104 \\
93.1 \\
92.6 \\
116 \\
103\end{array}$ \\
\hline LCs2 & 90L0226-LC2 & 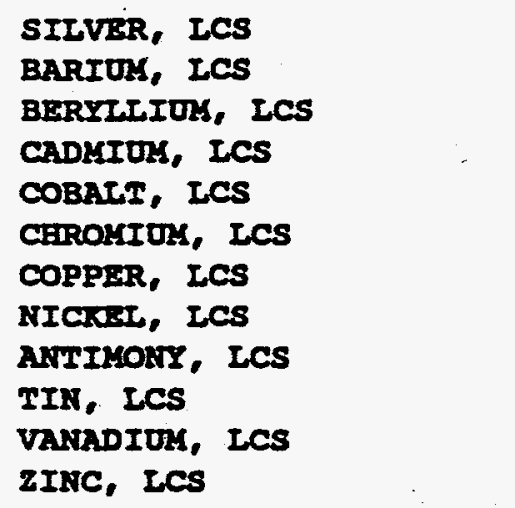 & $\begin{array}{l}107 \\
1010 \\
54.1 \\
53.0 \\
520 \\
111 \\
274 \\
419 \\
562 \\
930 \\
590 \\
206\end{array}$ & $\begin{array}{c}100 \\
1000 \\
50.0 \\
50.0 \\
500 \\
100 \\
250 \\
400 \\
600 \\
1000 \\
500 \\
200\end{array}$ & 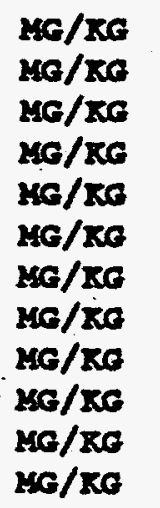 & $\begin{array}{c}107 \\
101 \\
108 \\
\because 106 \\
104 \\
111 \\
: 110 \\
105 \\
93.7 \\
93.0 \\
118 \\
103\end{array}$ \\
\hline LCSI & 90L0225-LC1 & $\begin{array}{l}\text { ARSENIC, LCS } \\
\text { IRAD, ICS } \\
\text { SETHNIOK, LCS } \\
\text { THALIIOK, LCS }\end{array}$ & $\begin{array}{l}5.6 \\
6.8 \\
6.7 \\
6.4\end{array}$ & $\begin{array}{l}6.0 \\
6.0 \\
6.0 \\
6.0\end{array}$ & $\begin{array}{l}\mathrm{MC} / \mathrm{KG} \\
\mathrm{MO} / \mathrm{KC} \\
\mathrm{MG} / \mathrm{KG} \\
\mathrm{MG} / \mathrm{KC}\end{array}$ & $\begin{array}{l}94.0 \\
113 \\
111 \\
107\end{array}$ \\
\hline LCS2 & 90L0225-LC2 & $\begin{array}{l}\text { ARSENIC, ICS } \\
\text { LEAD, ICS } \\
\text { SELENIUK, LCS } \\
\text { THATLIUK, LCS }\end{array}$ & $\begin{array}{l}5.9 \\
6.7 \\
6.8 \\
6.5\end{array}$ & $\begin{array}{l}6.0 \\
6.0 \\
6.0 \\
6.0\end{array}$ & 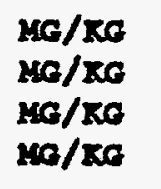 & $\begin{array}{l}97.7 \\
112 \\
113 \\
109\end{array}$ \\
\hline LCS1 & $90 \mathrm{CO} 40 \mathrm{~B}-\mathrm{LC1}$ & MERCURY, ICS & 1.1 & 1.0 & $2 x / x 0$ & 106 \\
\hline $\operatorname{LCS} 2$ & $\begin{array}{l}90 \mathrm{CO} 40 \mathrm{~B}-\mathrm{LC2} \\
90 \mathrm{CO} 40 \mathrm{~B}-\mathrm{LC} 3\end{array}$ & $\begin{array}{l}\text { KRRCURY, LCS } \\
\text { MRRCURY, LCS }\end{array}$ & $\begin{array}{l}1.0 \\
1.1\end{array}$ & $\begin{array}{l}1.0 \\
\approx \\
1.0\end{array}$ & $n e / x 0$ & 103 \\
\hline
\end{tabular}


ROY F. W'ESTON INC.

IMORGANICS IABORATORI CORYROL STMKTDARDS REPORI 04/09/90

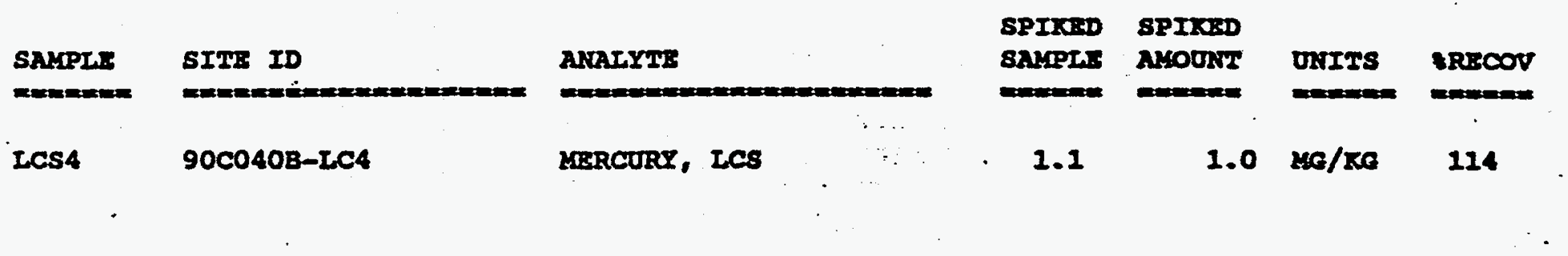



Roy P. Weaton, Inc. - Ifonville Laboratory INORGANIC ANALYTICAL DATA PACTOGS FOR WSRC GUNSITE 720

DATR RECEIVED: $02 / 16 / 90$

RFW IOT $\$ 90022604$

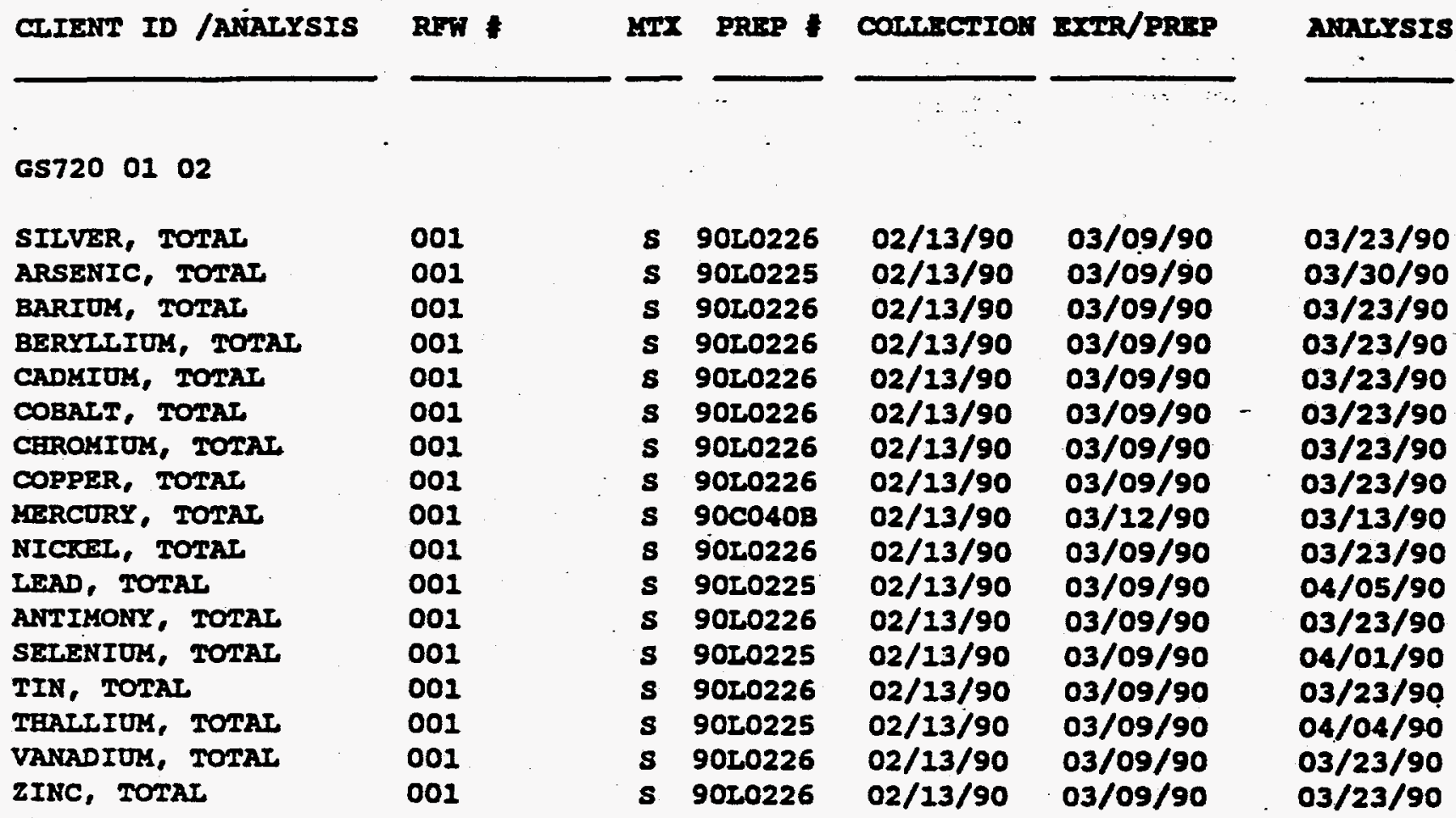

IAB QC:

\begin{tabular}{|c|c|}
\hline ILVER LABORATORY & LC \\
\hline ARIUM LABORATORY & LC] \\
\hline ERYLIIUY IAABORATORY & LCS \\
\hline ADKIOM LABORATORY & LCI \\
\hline JBALT LABORATORY & LCS \\
\hline IROEIUY IAAORATORY & LC] \\
\hline OPPER LABORATORY & LC] \\
\hline ICKCI LABORATORY & LCS \\
\hline NTIKONY LABORATORY & LCI \\
\hline IN LABORATORY & LCI \\
\hline ANADIUM LABORATORY & ICI \\
\hline INC LABORATORY & LCI \\
\hline ILVER LABORATORY & LC2 \\
\hline RIUY LABORATORY & LC2 \\
\hline ERYLLIOA LAB & LCS \\
\hline LABOR & LC2 \\
\hline OBA & LC \\
\hline
\end{tabular}

\begin{tabular}{|c|c|c|c|}
\hline & 90L0226 & $x / A$ & $03 / 09 / 90$ \\
\hline & 90L0226 & $N / A$ & $03 / 09 / 90$ \\
\hline & 9020226 & $x / \lambda$ & $03 / 09 / 90$ \\
\hline & 9020226 & $N / A$ & $03 / 09 / 90$ \\
\hline & 90L0226 & $R / A$ & $.03 / 09 / 90$ \\
\hline & 9020226 & $n / \lambda$ & $03 / 09 / 90$ \\
\hline & 90L0226 & $x / A$ & $03 / 09 / 90$ \\
\hline & 90L0226 & $8 / \lambda$ & $03 / 09 / 90$ \\
\hline & 9010226 & $g / \mathbf{A}$ & $03 / 09 / 90$ \\
\hline & 902.0226 & $x / \lambda$ & $03 / 09 / 90$ \\
\hline & 90L0226 & $n / \mathrm{A}$ & $03 / 09 / 90$ \\
\hline & 9020226 & $x / A$ & $03 / 09 / 90$ \\
\hline & 9020226 & $\pi / A$ & $03 / 09 / 90$ \\
\hline & $90 \mathrm{~L} 0226$ & $\pi / A$ & $03 /$ \\
\hline & 90L0226 & $8 / A$ & $03 / 0$ \\
\hline & $90 \mathrm{~L} 0226$ & $8 / \lambda$ & $03 /$ \\
\hline & 90L0226 & $\pi / \lambda$ & $03 /$ \\
\hline
\end{tabular}

$03 / 23 / 90$

$03 / 23 / 90$

$03 / 23 / 90$

$03 / 23 / 90$

$03 / 23 / 90$

$03 / 23 / 90$

$03 / 23 / 90$

$03 / 23 / 90$

$03 / 23 / 90$

$03 / 23 / 90$

$03 / 23 / 90$

$03 / 23 / 90$

$03 / 23 / 90$

$03 / 23 / 90$

$03 / 23 / 90$

$03 / 23 / 90$

$03 / 23 / 90$ 
Roy F. Weston, Inc. - Llonville Laboratory INORGANIC ANALYTICAI DATA PACKAGE IOR WSRC GUNSITE 720

DATE RECEIVED: $.02 / 16 / 90$

RFW LOT $89002 L 604$

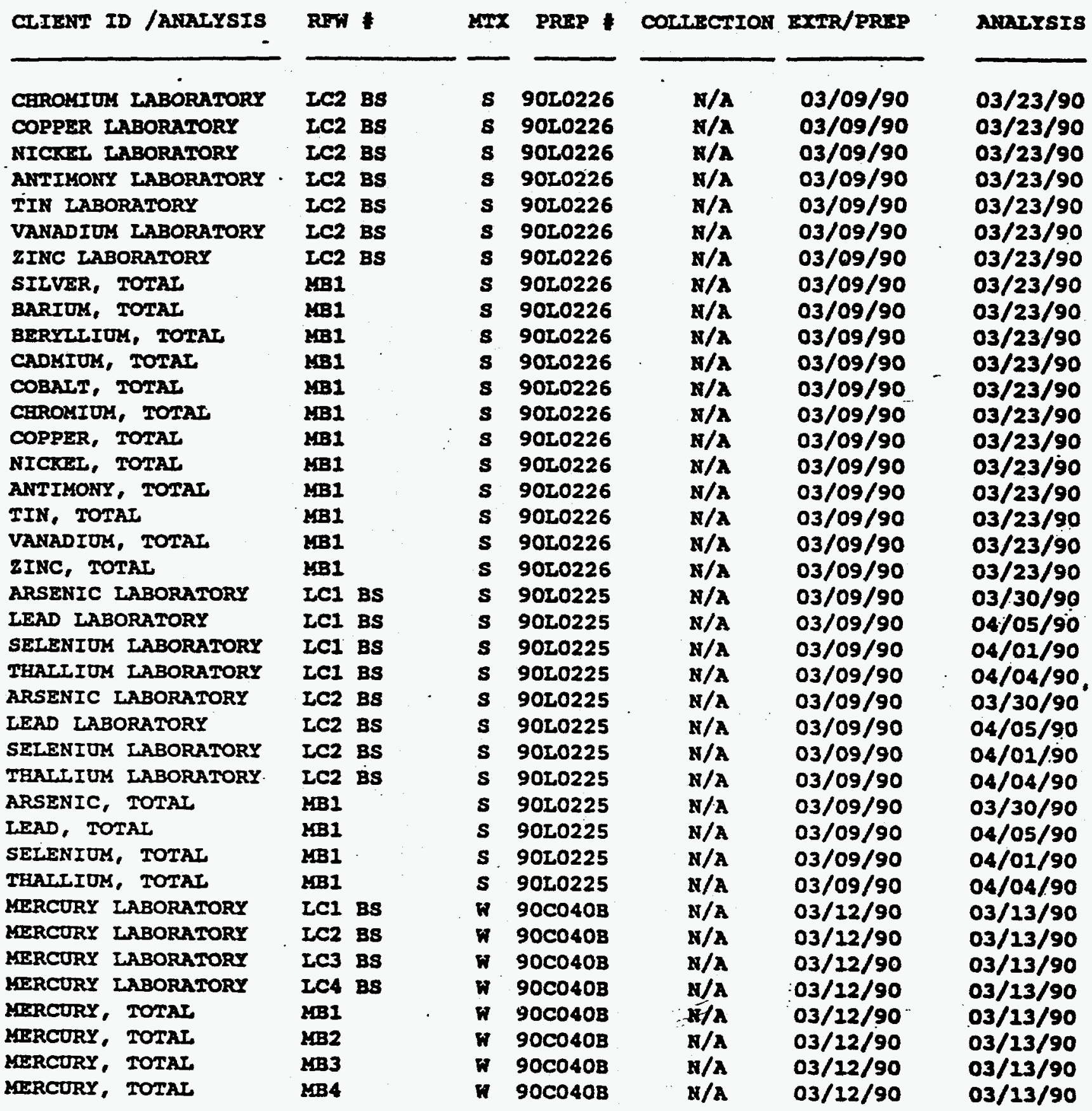


WTEREN.

CLIENT: WSRC GUNSITE 720

RFW : : 9002L603

W.0. : 0630-28-13
ROY F. WESTON, INC.

Lionville Laboratory

\section{METAL8 MARRATIVE}

The following is a summary of the quality control results and a description of any problems encountered during the analysis of this batch of samples:

1. All sample holding times as required by 40 CFRl36 were met for water samples. Note: Holding times for soil samples have not been promulgated by the USEPA.

2. All calibration verification checks were within the required control limits of 90-100\% (85-115\% for $\mathrm{Hg}$ ). Calibration verification is performed using independent standards from Inorganic Ventures, Inc.

3. All preparation blanks were analyzed below the required detection limit.

4. Iaboratory control standards were within the control limits of 80-120\% with the exception of silver (59\%) for site ID\# 90L0226-LCI and (127\%) for site ID\# 90L0219-LCI. The blank spike reproducibility was outside the $20 \%$ window for silver at $58 \%$.

Note: The USEPA-CLP has dropped control limits for silver and antimony due to documented difficulties in obtaining reliable results. WESTON Analytics has adopted the same policy.

5. The analytical methods applied by the laboratory for the determination of metals are:

$\begin{array}{ll}\text { As: } & \text { EPA } 206.2 \\ \text { Se: } & \text { EPA } 270.2 \\ \mathrm{~Pb}: & \text { EPA } 239.2 \\ \mathrm{~T} 1: & \text { EPA } 279.2\end{array}$

Hg: $\quad$ EPA 245.1

ICP Scan: EPA 200.7

All Others: : EPA 200.7

EP Leachates (except $\mathrm{Hg}$ ) : 200.7

NOTE: For solid samples, all results are reported on a dry weight basis.

$\int \frac{\text { chwhHll }}{\text { Jack R. Tuschall, Ph.D. }} \frac{4-9-9 \mathrm{~J}}{\text { Date }}$

Laboratory Manager

Lionville Analytical Laboratory

pas. 21/M2-603 
ROY F. WESTON, INC.

GLOSSARY OF TERMS - INORGANIC REPORTS

DATA QUALIEIERS

$U$ - Indicates that the parameter was not detected at or above the reported Iimit. The associated numerical value is the sample detection limit.

* - Indicates that the original sample result is greater than $4 x$ the spike amount added. The USEPA-CLP has determined that spike results on samples where this occurs may be unreliable and, therefore, the control limits are not applicable.

\section{ABBREVIATIONS}

MB - Method or preparation blank.

MS - Matrix Spike.

MSD - Matrix Spike Duplicate.

REP - Sample Replicate.

IC - Indicates a method ICS or Blank Spike.

NC - Not calculable, result below the detection 1 imit.

\section{IABORATORY CHRONOIOGY AND HOLDTINE RERORT}

The test code listed indicates the specific analysis or preparation procedure employed. The codes may be interpreted as follows:

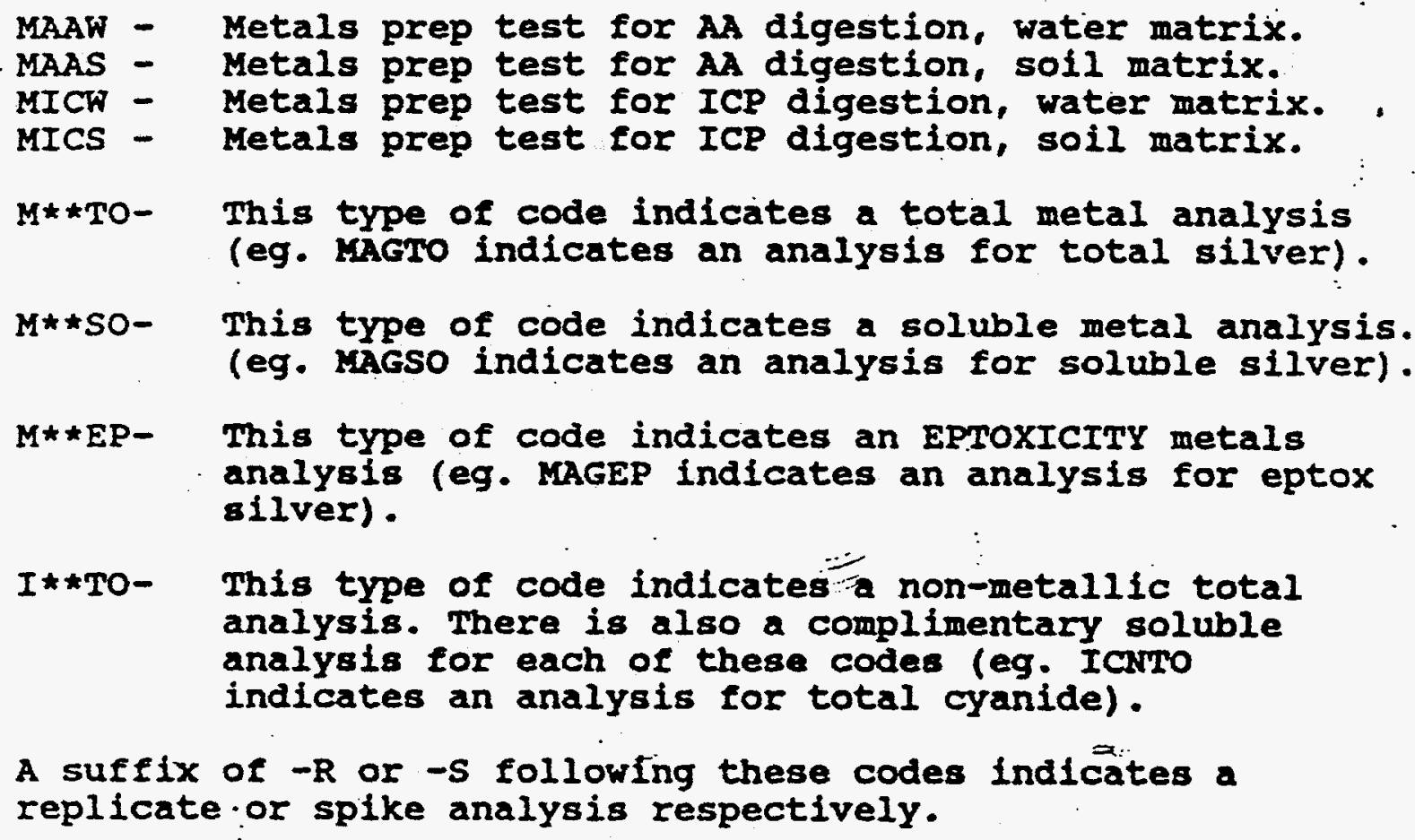


ROY F. HESTON IRC.

IMORGARICS DATA SUMARAY REPORT 04/09/90

CLIENT: WSRC GONSITI 720

FORK ORDER: 0630-28-13-0000

\section{SAYPT:}

antarim

$\cdot-001$

$-002$

GS720 14-01

$-003$
GS720 04-01

SITE ID

GS720 10-018

GS720 02-01
ARALYTS

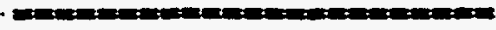

SIIVER, TOTAT.

ARSEITIC, TOTAL

BARIOL, TOTAI

CADKCOY, TOTAL

CEROMITU, TOTAx

MERCURY, TOTAL

IEAD, TOTAL

SELENIOM, TOTAL

SILVER, TOTAL ARSENIC, TOTAL BARIUX, TOTAL CADKIOU, TOTAL Carokrus, TOIAT ITRRCURY, TOTAL IEAD, TOTAL

SELENIUM, TOTAL

SIIVER, TOTAL ARSEIIC, TOTAL BARIUK, TOTAK CADKIU⿴, TOTAL CAROYIOS, TOMAI MERCURY, TOMNE IEAD, TOTAL SELENIOU, TOTAL

SILVER, TOTAL ARSENIC, TOTAL BARTUY, TOTAL CADKIUM, TOTAL CEROEIUY, TOTAL MERCURY, TOTAL ITHND, TOTAL BLIFIIUT, TOTAI.
WEston BATCH f: 9002L6́o3

\begin{tabular}{|c|c|c|c|}
\hline \multicolumn{2}{|l|}{ RTSULT. } & OnITS & $\begin{array}{l}\text { RSPORTINC } \\
\text { IIMIT }\end{array}$ \\
\hline 10.0 & $\mathbf{u}$ & $0 G / \mathrm{L}$. & 10.0 \\
\hline 10.0 & $\mathbf{u}$ & $\nabla G / L$ & 10.0 \\
\hline 200 & $\mathbf{u}$ & $0 G / \mathrm{L}$ & 200 \\
\hline 5.0 & $\mathbf{u}$ & $0 G / L$ & 5.0 \\
\hline 10.0 & $\mathbf{u}$ & $0 G / L$ & 10.0 \\
\hline 0.20 & $\mathbf{u}$ & UG/I & 0.20 \\
\hline 3.0 & $\mathbf{u}$ & $\mathrm{DG} / \mathrm{L}$ & 3.0 \\
\hline 5.0 & $\mathbf{u}$ & $U G / L$ & -5.0 \\
\hline 1.6 & $\mathbf{u}$ & $\mathrm{Me} / \mathrm{KO}$ & 1.6 \\
\hline 1.9 & $\mathbf{u}$ & $\mathrm{MC} / \mathrm{KO}$ & 1.9 \\
\hline 32.1 & $\mathbf{u}$ & $\mathrm{ng} / \mathrm{xc}$ & 32.1 \\
\hline 0.80 & $\mathbf{u}$ & $\mathrm{MG} / \mathrm{KO}$ & 0.80 \\
\hline 3.0 & & $\mathrm{BG} / \mathrm{KG}$ & 1.6 \\
\hline 0.11 & v & $\mathrm{MG} / \mathrm{KO}$ & 0.11 \\
\hline 2.6 & & $\mathrm{MG} / \mathrm{KG}$ & 0.58 \\
\hline 0.97 & $\mathbf{u}$ & $\mathrm{HG} / \mathrm{RG}$ & 0.97 \\
\hline 1.8 & $\mathbf{u}$ & $\mathrm{Ne} / \mathrm{KCO}$ & 1.8 \\
\hline 1.7 & $u$ & $M G / x \in$ & 1.7 \\
\hline 37.0 & $\mathbf{u}$ & $166 / 150$ & 37.0 \\
\hline 0.92 & $\mathbf{u}$ & KG/KG & 0.92 \\
\hline 3.0 & & $M G / x G$ & $1.8:$ \\
\hline 0.11 & $\mathbf{u}$ & $\mathrm{MO} / \mathrm{KO}$ & 0.11 \\
\hline 6.8 & & MG/KG & 0.50 \\
\hline 0.83 & $\mathbf{u}$ & $\mathrm{HG}_{\mathrm{K}} / \mathrm{KC}$ & 0.83 \\
\hline 1.9 & u & $\mathrm{KG} / \mathrm{KG}$ & 1.9 \\
\hline 1.8 & $\mathbf{u}$ & $M G / K G$ & 1.8 \\
\hline 38.3 & $\mathbf{u}$ & $\mathrm{MG} / \mathrm{KG}$ & 38.3 \\
\hline 0.96 & $\mathbf{u}$ & $\mathrm{MG} / \mathrm{KG}$ & 0.96 \\
\hline 2.7 & & $\mathrm{MC} / \mathrm{KO}$ & 1.9 \\
\hline 0.10 & $\mathbf{u}$ & $\mathrm{MG} / \mathrm{TO}$ & 0.10 \\
\hline 2.8 & & $\mathrm{Me} / \mathrm{xO}$ & 0.55 \\
\hline 0.92 & $\mathbf{u}$ & $150 / 200$ & 0.92 \\
\hline
\end{tabular}


ROY F. WESTOR IXC.

INORGANICS DATA SUMLSARY RAPORT 04/09/90

CLIENT: WSRC GONSITE 720

WORK ORDER: 0630-28-13-0000

GS720 01-02

$-014$

GS720 01-01

\section{ANATXI:}

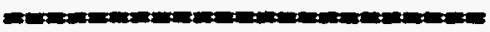

SIIVER, TOTAL

ARSEIIC, TOMAI

BARIOM, TOTAL

CADKIOK, TOTAL

CEROMIUM, TOTAL

MERCURY, TOTAL

IEAD, TOTAL

SELENIUM, TOTAL

SILVER, TOTAL.

ARSENIC, TOTAL

BarIUM, total

CADKIUY, TOTAL

CHROMIUI, TOTAL

LERRCURY, TOTAR

IEAD, TOTAI

SELENIUI, TOTAL

SILVER, TOTAL

ARSENIC, TOTAI

BARIDK, TOTAL

CADMIOM, TOTAL

CEROKSIOM, TOTAL

MERCURY, TOTAL

LEAD, TOTAI

SELENIUS, TOTAI
Weston Batc日 $\$ 2$ 90022603

\begin{tabular}{|c|c|c|c|}
\hline \multicolumn{2}{|c|}{ REsula } & UXITs & $\begin{array}{l}\text { REPORTING } \\
\text { LIEIT }\end{array}$ \\
\hline 2.1 & $\mathbf{u}$ & Me/xe & 2.1 \\
\hline 2.0 & $\mathbf{u}$ & $150 / 20$ & 2.0 \\
\hline 41.8 & u & Mo/xo & 41.8 \\
\hline 1.0 & $\mathbf{u}$ & Wo/ $/ \mathrm{KO}$ & 1.0 \\
\hline 2.9 & & $M G / x \sigma$ & 2.1 \\
\hline 0.11 & $\mathbf{u}$ & $M G / x G$ & 0.11 \\
\hline 2.2 & & $120 / \mathrm{Ka}$ & 0.60 \\
\hline 1.0 & $\mathbf{u}$ & $M G / \mathrm{KC}$ & 1.0 \\
\hline 1.6 & $\mathbf{u}$ & $26 / \pi 0$ & 1.6 \\
\hline 1.7 & $\mathbf{u}$ & $\mathrm{KC} / \mathrm{KC}$ & 1.7 \\
\hline 31.8 & $\mathbf{u}$ & $160 / \mathrm{Re}$ & 31.8 \\
\hline 0.80 & u & $M G / x O$ & 0.80 \\
\hline 6.1 & & He/XE & 1.6 \\
\hline 0.12 & & $x a / 20$ & 0.11 \\
\hline 3.9 & & $\mathrm{ke} / \mathrm{xe}$ & 0.52 \\
\hline 0.87 & $\mathbf{u}$ & $M G / x G$ & 0.87 \\
\hline 2.0 & $\mathbf{u}$ & $M G / K G$ & 2 \\
\hline 2.2 & $\mathbf{u}$ & $M G / K G$. & 2.2 \\
\hline 53.9 & & $\mathrm{MO} / \mathrm{KO}$ & 39.6 \\
\hline 0.99 & $\mathbf{u}$ & $\mathrm{KG} / \mathrm{KG}$ & 0.99 \\
\hline 4.0 & & MG/KG & 2.0 \\
\hline 0.11 & $\mathbf{u}$ & $M G / K G$ & 0.11 \\
\hline 4.4 & & MG/KG & 0.65 \\
\hline 1.1 & $\mathbf{u}$ & $M G / \pi G$ & 1.1 \\
\hline
\end{tabular}


ROY E. WESTON IKC.

INORGAKICS MEIEOD BLAKK DATA SUMARY PAGE 04/09/90

CLIBNT: HSRC GUASITS 720

MORK ORDER: 0630-28-13-0000

SARPL:

mancinim

Brantel

SIII: In

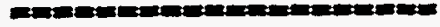

9020219-201

BTANKI 90L0218-2KB1

BLANK1 90C040A-LBI

BIANK2 90C040A-2BB2

BIANE3 9OCO4OA-MB3

BIANK4 90C040A-ZB4

BLANK1 90L0226-2BB1

BLANR1 90L0225-MBI

BLANKI 90C040B-MBI

BLANT2 90C040B-2BB2
ANRTYYS

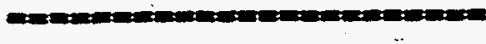

SIIVER, TOLIT.

BARIDK, TOYRI

CADMIUK, TOM2I

CBROMIOK, TOTAT

ARSENIC, TOMAT

LEAD, IOTAL

SELENIUK, TOIAT.

MERCURY, TOMAT

MERCURY, TOTAL

MERCURY, TOTAL

MERCURY, TOTAL

SITVBR, IOTAT

BARIUK, TOIAT

CADKIUA, TOTAT.

carrostur, rorns.

ARSENIC, TOTAL

IEAD, TOTAL

SETENIOK, TORA.

MERCURY, TOTAI

MERCURY, TOTAT
WESTOA BATCH \&8 $9002 L 603$

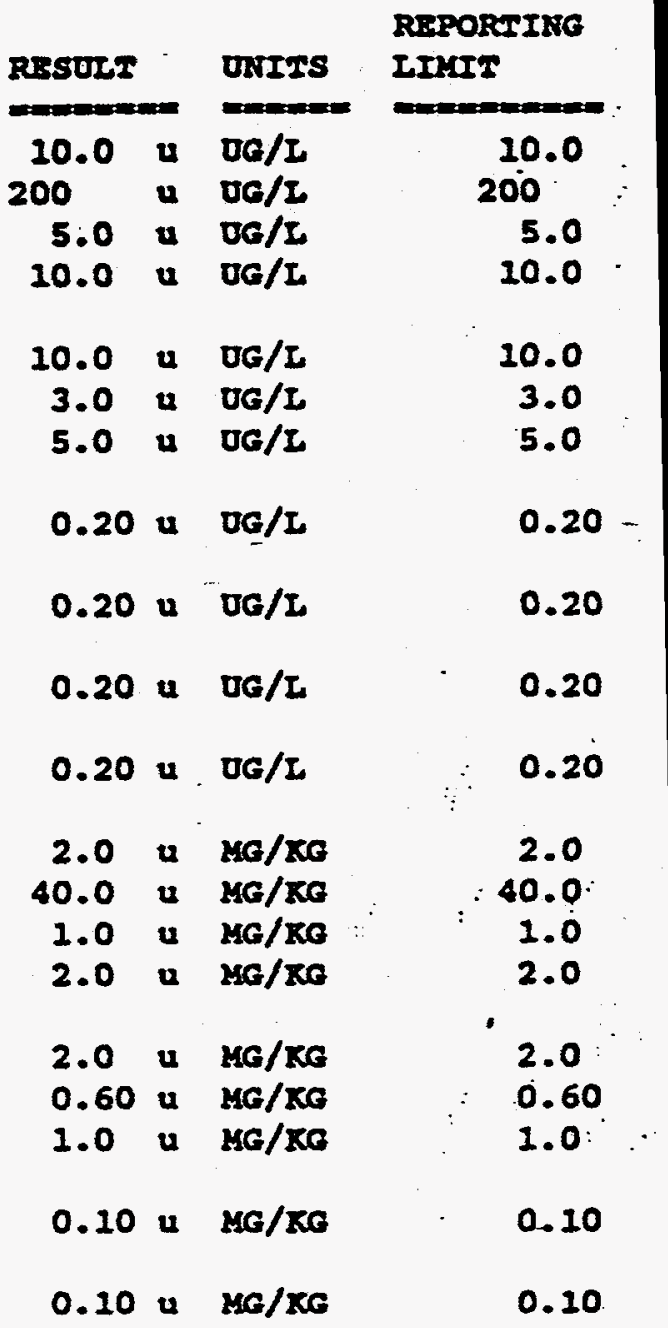


ROY F. WESTON IXC.

IMORGANICS METEOD BLANK DATA SUMARRY PAGE 04/09/90

CLIENT: WSRC GUNSITY 720

HORK ORDER: 0630-28-13-0000

SAMPTE SITS ID

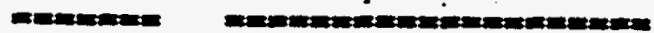

BLANR3

$900040 B-4 B 3$

BLARTK4

$900040 B-1 M B 4$
MNATYTS

ב

IIRTCRY, TOMAL

MERCURY, TOLAY
WESTOR BATCH is $9002 L 603$

\begin{tabular}{|c|c|c|}
\hline ResULT. & OxIT8 & $\begin{array}{l}\text { REPORTIKO } \\
\text { IIMTI }\end{array}$ \\
\hline $0.10 \mathrm{u}$ & $86 / x 0$ & 0.10 \\
\hline 0.10 & MG/Ke & 0.10 \\
\hline
\end{tabular}


ROY F. WBSTOR IXC:

IRORGANTCS DUPLICATE SFIKE REPORT 04/09/90

CLIENT: WSRC GUNSITE 720

WEsTOH BATCH \& 9002L603

WORK ORDER: 0630-28-13-0000

SAMPL: SITE ID
LCS2

ARATY2:

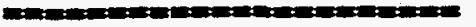

SIIVAR, LCS

BARIUK, ICS

CADurJy, ICS

cerroytus, zos

ARsENIC, LCS

IEAD, ICS

SELENIUK, ICS

ICs2 90C040A-LC2

IERCURY, ICS

LCS2 90L0226-LC2

SIIVER, LCS

BRRIOK, ICS

CADKIUK, LCS

chroyrux, LCS

ICs2 90L0225-IC2

ARSENIC, LCS

IRAD, ICS

SELENIUK, LCS

ICS2 90CO4OB-LC2

IRRCURY, LCS

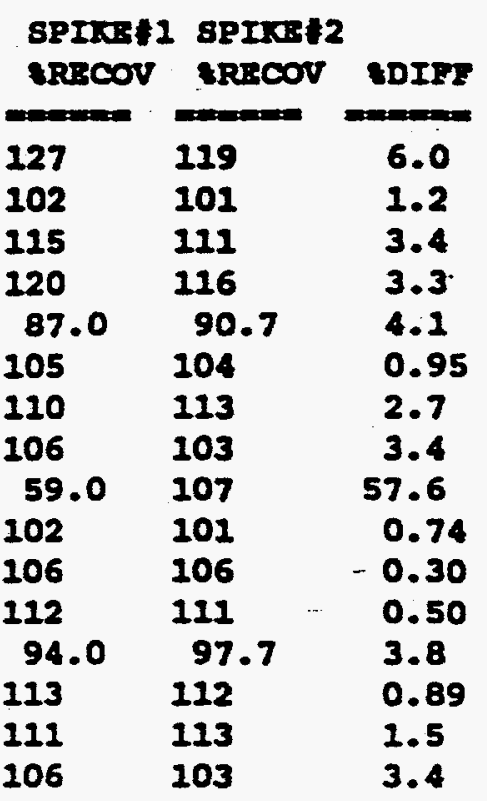


ROY F. WESTON INC.

INORGANICS LABORATORY CONTROT STAKDARDS RBPORT 04/09/90

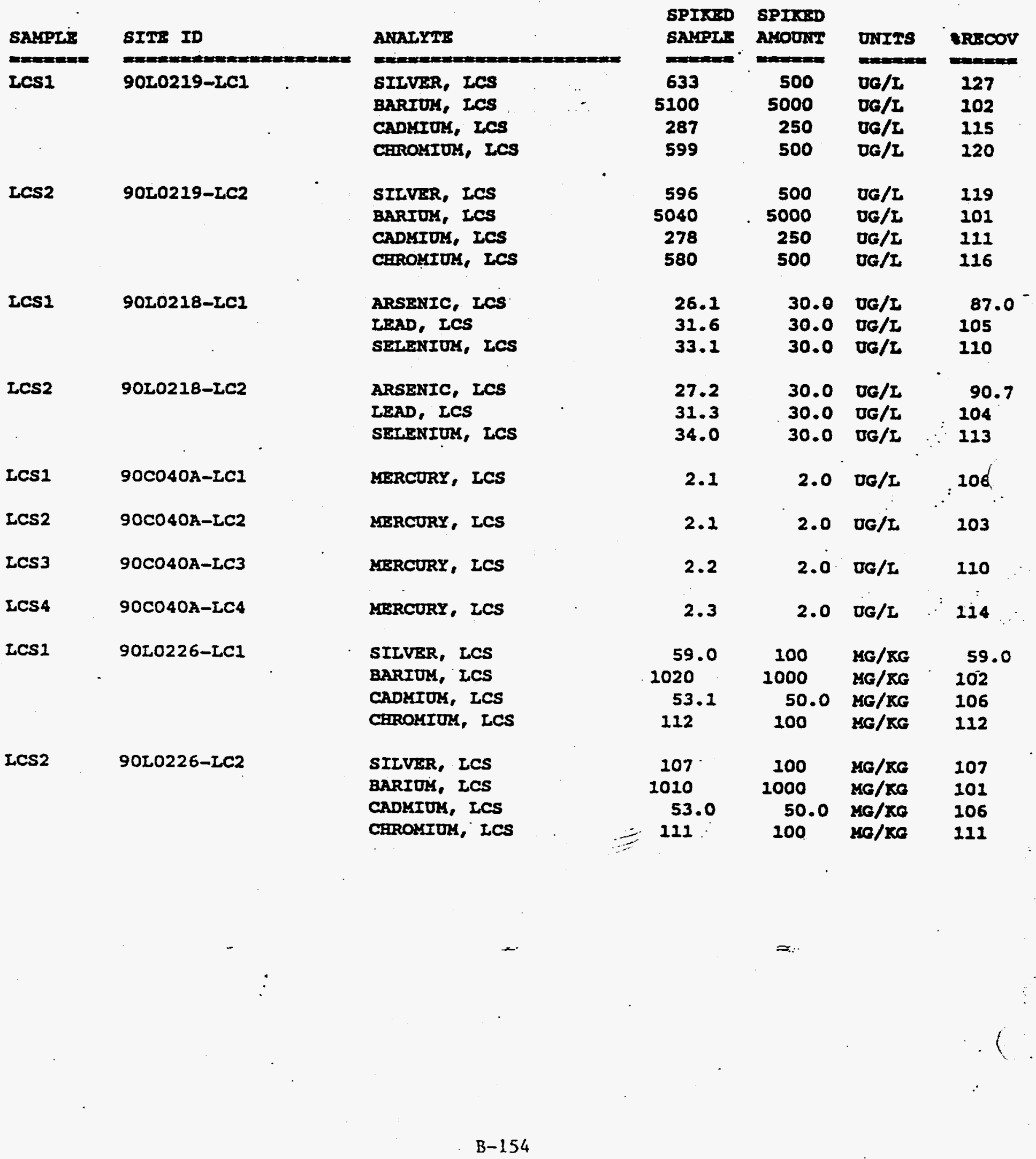


ROY F. WESTON IXC.

INORGANICS IABORATORY CONTROL STANDARDS REPORT 04/09/90

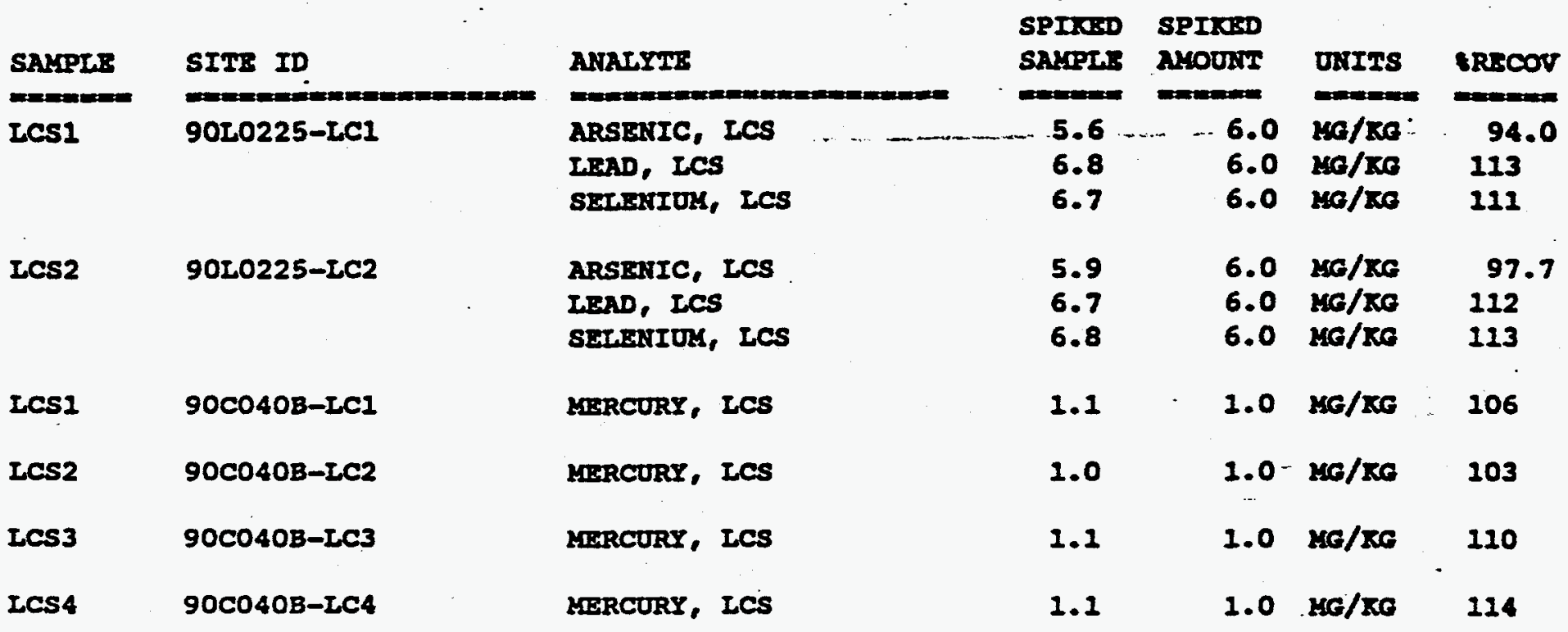


Roy 2. Heston, Inc. - Ilonville Laboratory INORGANIC ANALYTICAL DATA PACKAGR FOR

WSRC GUNSITS 720

DATE RECEIVED: 02/16/90

RFY LOT \& 290021603

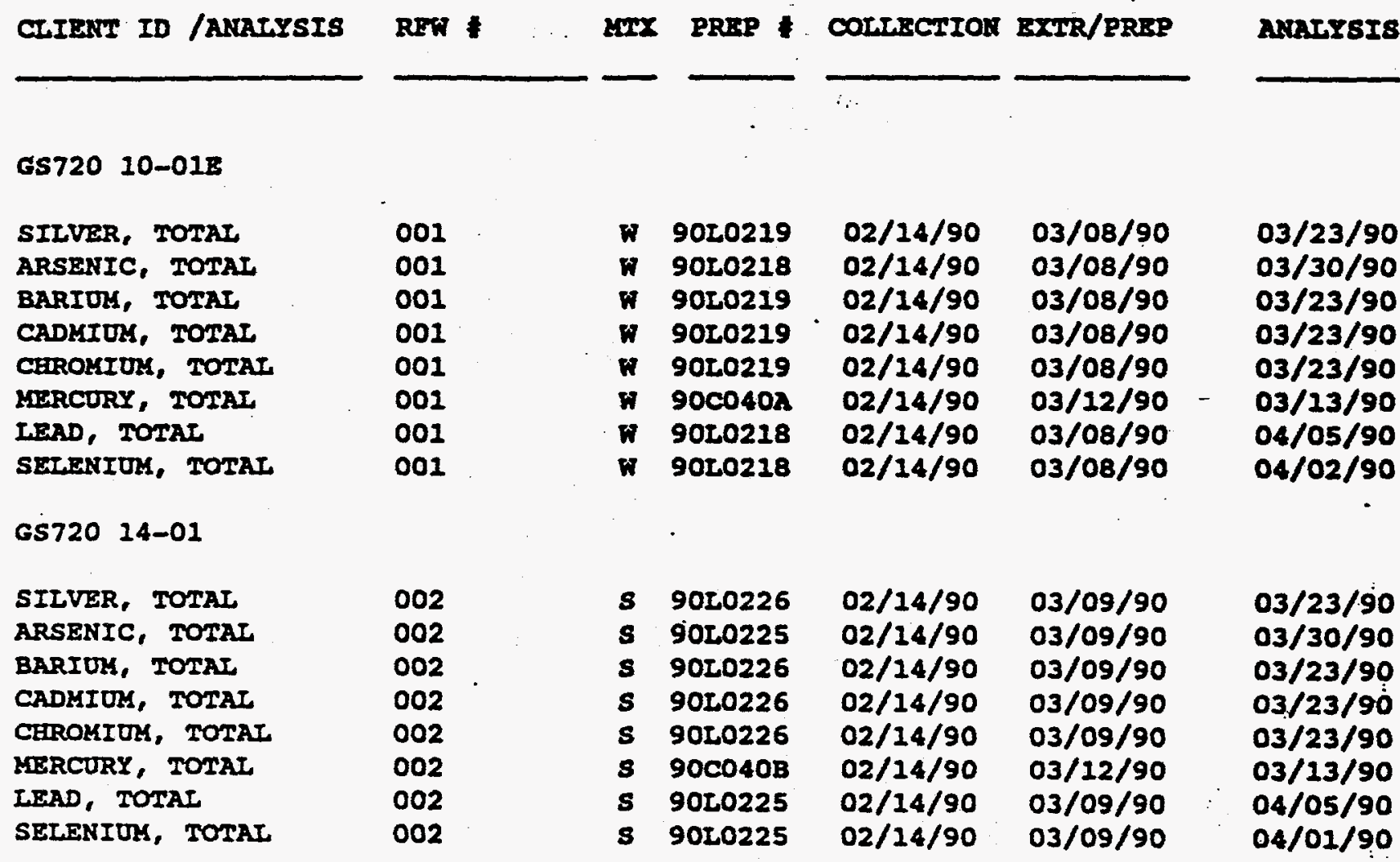

GS720 04-01

SILVER, TOTAL 003

ARSENIC, TOTAL 003

BARIUM, TOTAL 003

CADMIUM, TOTAL 003

CEROKIOK, TOTAL 003

MERCURY, TOTAL 003

LEAD, TOTAL 003

SELENIOM, TOTAI 003

$\begin{array}{llll}\text { s } & 9020226 & 02 / 14 / 90 & 03 / 09 / 90 \\ \text { s. } & 90 \mathrm{~L} 0225 & 02 / 14 / 90 & 03 / 09 / 90 \\ \text { s } & 90 \mathrm{OL226} & 02 / 14 / 90 & 03 / 09 / 90 \\ \text { s } & 90 \mathrm{~L} 0226 & 02 / 14 / 90 & 03 / 09 / 90 \\ \text { s } & 90 \mathrm{~L} 0226 & 02 / 14 / 90 & 03 / 09 / 90 \\ \text { s } & 90 \mathrm{C} 040 \mathrm{~B} & 02 / 14 / 90 & 03 / 12 / 90 \\ \text { s } & 90 \mathrm{~L} 0225 & 02 / 14 / 90 & 03 / 09 / 90 \\ \text { s } & 90 \mathrm{~L} 0225 & 02 / 14 / 90 & 03 / 09 / 90\end{array}$

$03 / 23 / 90$

$03 / 30 / 90$

$03 / 23 / 90$

$03 / 23 / 90$

$03 / 23 / 90$

$03 / 13 / 90$

$04 / 05 / 90$

$04 / 01 / 90$

GS720 02-01

SILVER, TOTAL 004

ARSENIC, TOTAL - 004

BARIUM, TOTAL - 004

CADMIUM, TOTAL $\vdots 004$

$\begin{array}{llll}\text { s } & 9020226 & 02 / 14 / 90 & 03 / 09 / 90 \\ \text { s } & 90 L 0225 & 02 / 14 / 90 & 03 / 09 / 90 \\ \text { s } & 9020226 & 02 / 14 / 90 & 03 / 09 / 90 \\ \text { s } & 90 L 0226 & 02 / 14 / 90 & 03 / 09 / 90\end{array}$

$03 / 23 / 90$

$03 / 30 / 90$

$03 / 23 / 90$

$03 / 23 / 90$ 
Roy F. Weston, Inc. - Llonville Laboratory INORGANIC ALAIYTICAL DATA PACNAGR FOR

WSRC GOUSITE 720

DATE RECEIVED: $02 / 16 / 90$

RFN IOT $\div 290022603$

CLIENT ID / ANALYSIS

RET :

YIX PREP

COTIRCIIOR EXTR/PREP

ARIISIS

CHROMIUK, TOTALL

004

ZIERCURY, TOTAI

004

IFAD, TOTAL

004

SELENIUS, TOTAL

004

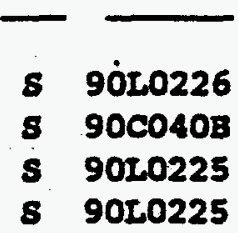

$02 / 14 / 90$
$02 / 14 / 90$
$02 / 14 / 90$
$02 / 14 / 90$

$03 / 09 / 90$

$03 / 12 / 90$

$03 / 09 / 90$

$03 / 09 / 90$

$03 / 23 / 90$

$03 / 13 / 90$

$04 / 05 / 90$

04/01/90

G5720 03-01

SILVER, TOTAL

ARSENIC, TOTAL

005

005

BARIUK, TOTAI

005

CADMIUM, TOTAL

005

CEROKIUY, TOTAL

005

MERCURY, TOTAI

005

IEAD, TOTAL

SELENIUR, TOTAL

005

005

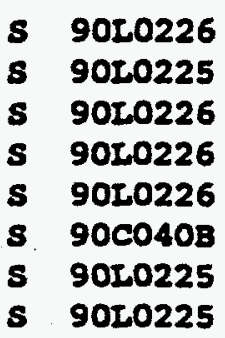

$02 / 14 / 90$

$02 / 14 / 90$

$02 / 14 / 90$

$02 / 14 / 90$

$02 / 14 / 90$

$02 / 14 / 90$

$02 / 14 / 90$

$02 / 14 / 90$

$03 / 09 / 90$

$03 / 09 / 90$

$03 / 09 / 90$

$03 / 09 / 90$

$03 / 09 / 90$

$03 / 12 / 90$

$03 / 09 / 90$

03/09/90

$03 / 23 / 90$

$03 / 30 / 90$

$03 / 23 / 90$

$03 / 23 / 90$

$03 / 23 / 90$

$03 / 13 / 90$

$04 / 05 / 90$

04/01/90

GS720 01-02

SILVER, TOTAI

ARSENIC, TOTAL

011

011

BARIUY, TOTAL

011

CADMIUM, TOTAL

011

CHROKIUY, TOTAL

011

MERCURY, TOTAI

011

LEAD, TOTAL

011

SELENIUT, TOTAL

011

$02 / 13 / 90$

$02 / 13 / 90$

$02 / 13 / 90$

$02 / 13 / 90$

$02 / 13 / 90$

$02 / 13 / 90$

$02 / 13 / 90$

$02 / 13 / 90$

$03 / 09 / 90$

$03 / 09 / 90$

$03 / 09 / 90$

$03 / 09 / 90$

$03 / 09 / 90$

$03 / 12 / 90$

$03 / 09 / 90$

$03 / 09 / 90$

$03 / 23 / 90$

$03 / 30 / 90$

$03 / 23 / 90$

$03 / 23 / 90$

$03 / 23 / 90$

$03 / 13 / 90$

$04 / 05 / 90$

$04 / 01 / 90$

GS720 01-01

SIIVER, TOTAL

ARSENIC, TOTAL

014

014

BARIOA, TOTAL

CADMIOM, TOTAL

014

014

CEROMIUN, TOTAI

014

MERCURY, TOTAL

014

LEAD, TOTAL

SELENIUM, TOTAL

014

014

$02 / 13 / 90$

$02 / 13 / 90$

$02 / 23 / 90$

$02 / 13 / 90$

$02 / 13 / 90$

$02 / 13 / 90$

$02 / 13 / 90$

$02 / 13 / 90$

$03 / 09 / 90$

$03 / 23 / 90$

$03 / 09 / 90$

$03 / 09 / 90$

$03 / 09 / 90$

$03 / 09 / 90$

$.03 / 12 / 90$

$03 / 09 / 90$

03/09/90

$03 / 30 / 90$

$03 / 23 / 90$

$03 / 23 / 90$

$03 / 23 / 90$

$03 / 13 / 90$

$04 / 05 / 90$

$04 / 01 / 90$

LAB QC:

SILVER ILABORATORY

LCI BS

พ 90L0219

$N / \boldsymbol{A}$

03/08/90

$03 / 23 / 90$ 
Roy F. Wanton, Inc. - Ilonville Laboratory

INORGANIC ANACYTICAI DATA PACKAGX FOR

WSRC GUNSITE 720

DATE RECEIVED; $02 / 16 / 90$

RWW LOT 290022603

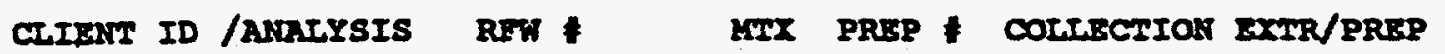

AnuYsIs

\begin{tabular}{|c|c|c|c|c|}
\hline BARIUY LABORATORY & LC1 & BS & $\boldsymbol{\omega}$ & 9020219 \\
\hline CADYIDE IABORATORY & LCI & BS & $\boldsymbol{B}$ & 9010219 \\
\hline CEROKIOI LABORATORY & ICI & BS & $n$ & 9020219 \\
\hline SILVER IABORATORY & $\mathbf{L C 2}$ & BS & พ & 9020229 \\
\hline BARIUY IABORATORY & LC2 & Bs & $\boldsymbol{\omega}$ & 9010219 \\
\hline CADMIUM IABORATORY & LC2 & BS & $\boldsymbol{พ}$ & 9010229 \\
\hline CRROMIOM IABORATORY & LC2 & Bs & $\boldsymbol{n}$ & 9010219 \\
\hline SILVER, TOTAL & KBBI & & $\boldsymbol{w}$ & 9020219 \\
\hline BARIOK, TOTAI & MBI & & $\boldsymbol{w}$ & 9010219 \\
\hline CADMIOK, TOTAI & XBB1 & & $\pi$ & 9020219 \\
\hline CEROMIOT, TOTAL & MBI & & $\boldsymbol{m}$ & 9010219 \\
\hline ARSENIC LABORATORY & LC1 & BS & ต & 9020218 \\
\hline IEAD LABORATORY & LCI & Bs & $\mathbf{n}$ & 901.0218 \\
\hline SELENIOUS LABORATORY & ICI & Bs & 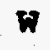 & 9020218 \\
\hline ARSENIC LABORATORY & LC2 & Bs & $\boldsymbol{n}$ & 902021 \\
\hline LEAD LABORATORY & LC2 & BS & $\boldsymbol{H}$ & 902021 \\
\hline SELENIOA LABORATORY & LC2 & Bs & $\mathbf{w}$ & 901022 \\
\hline ARSENIC, TOTAL & MBD1 & & $\omega$ & 902021 \\
\hline IEAD, TOTAL & KBBI & & $\boldsymbol{\varphi}$ & 902021 \\
\hline SELENIUK, TOTAI & 2MB1 & & $\mathbf{w}$ & 9020218 \\
\hline MERCURY LABORATORY & LCI & BS & $\omega$ & 9000402 \\
\hline MERCURY IABORATORY & LC2 & BS & ต & 9000402 \\
\hline MERCURY LABORATORY & IC3 & BS & $\omega$ & $900040 \Omega$ \\
\hline MERCURY IABORATORY & LC4 & BS & $\boldsymbol{\omega}$ & $900040 \Omega$ \\
\hline MBRCURY, TOTAL & MB1 & & i & $90 c 040 A$ \\
\hline MERCURY, TOTAL & $\mathbf{2 8 3 2}$ & & $\mathbf{T}$ & $90 c 0402$ \\
\hline MERCURY, TOTAL & 283 & & 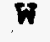 & 9000402 \\
\hline MERCURY, TOTAL & 2084 & & ผ & $90 \mathrm{CO40A}$ \\
\hline SILVER LABORATORY & LC1 & BS & $\mathbf{s}$ & 9020226 \\
\hline BARIOM LABORATORY & LC1 & BS & $\mathbf{s}$ & 90L0226 \\
\hline BERYLIIUM LABORATORY & LC1 & BS & $\mathbf{8}$ & 9020226 \\
\hline CADMIOXY LABORATORY & LC1 & BS & $\mathbf{8}$ & 9020226 \\
\hline COBALT LABORATORY. & LCI & Bs & $\mathbf{s}$ & 9020226 \\
\hline CHROMIOM LABORATORY & LCI & BS & 8 & 9010226 \\
\hline COPPER LABORATORY & LCI & Bs & $\mathbf{8}$ & $90 L 0226$ \\
\hline NICLEL IABORATORY & LCI & Bs & $\mathbf{8}$ & 90Z0226 \\
\hline ANTIMONY LABORATORY & LC1 & Bs & $\mathbf{s}$ & 9020226 \\
\hline TIR ILABORATORY & LCI & Bs & 8 & 9020226 \\
\hline VANADIUM LABORATORY & LCL & BS & 8 & 9020226 \\
\hline ZIRC LABORATORY & LCI & Bs & $\mathbf{8}$ & 9020226 \\
\hline
\end{tabular}

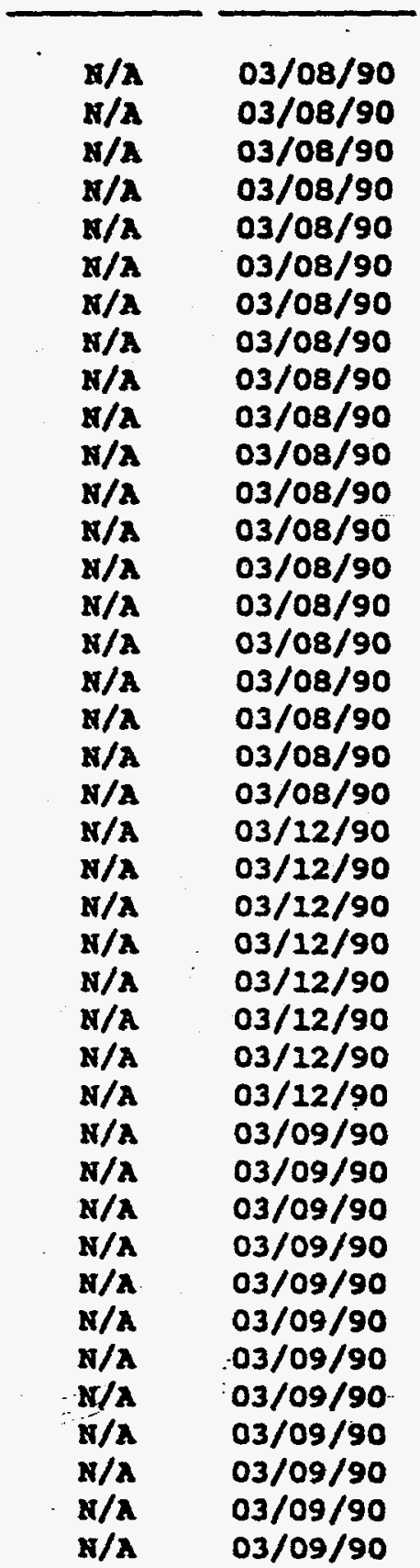

$03 / 23 / 90$

$03 / 23 / 90$

$03 / 23 / 90$

$03 / 23 / 90$

$03 / 23 / 90$

$03 / 23 / 90$

$03 / 23 / 90$

$03 / 23 / 90$

$03 / 23 / 90$

$03 / 23 / 90$

$03 / 23 / 90$

$03 / 30 / 90$

04/05/90

$04 / 02 / 90$

$03 / 30 / 90$

$04 / 05 / 90$

$04 / 02 / 90$

$03 / 30 / 90$

$04 / 05 / 90$

04/02/90

$03 / 13 / 90$

$03 / 13 / 90$

$03 / 13 / 90$

$03 / 13 / 9 \delta$

$03 / 13 / 90$

$03 / 13 / 90$

$03 / 13 / 90$

$03 / 13 / 90$

$03 / 23 / 90$

$03 / 23 / 90$

$03 / 23 / 90$

$03 / 23 / 90$

$03 / 23 / 90$

$03 / 23 / 90$

$03 / 23 / 90$

$03 / 23 / 90$

$03 / 23 / 90$

$03 / 23 / 90$

$03 / 23 / 90$

$03 / 23 / 90$ 
Roy F. Weston, Inc. - Ilonville Laboratory

INORGANIC ANALYTICAL DATA PACKAGE FOR WSRC GUNSITE 720

DATE RECRIVED: 02/16/90

RFW LOT $\$ 29002 L 603$

\begin{tabular}{|c|c|c|c|c|c|c|c|}
\hline $\begin{array}{l}\text { CLIENT ID /ANACYSIS } \\
:\end{array}$ & RPW & $\bullet$ & $\sin$ & PREP & cotrsction & EXTR/PREP & RARCYSIS \\
\hline SILVER LABORATORY & LC2 & BS & $\mathbf{s}$ & 9020226 & $\mathbf{n} / \mathbf{2}$ & 03/09/90 & $03 / 23 / 90$ \\
\hline BARIOA LABORATORY & LC2 & Bs & $\mathbf{8}$ & 90L0226 & $\mathbf{n} / \mathbf{x}$ & $03 / 09 / 90$ & $03 / 23 / 90$ \\
\hline BERYLLIUI LABORATORY & LC2 & Bs & $\boldsymbol{s}$ & 9020226 & $x / A$ & $03 / 09 / 90$ & $03 / 23 / 90$ \\
\hline CADKIUY LABORATORY & LC2 & Bs & $\mathbf{s}$ & 90L.0226 & $\mathbf{x} / \mathbf{a}$ & $03 / 09 / 90$ & $03 / 23 / 90$ \\
\hline COBALT IABORATORY & LC2 & Bs & $\mathbf{s}$ & 9020226 & $n / \lambda$ & $03 / 09 / 90$ & $03 / 23 / 90$ \\
\hline CHROMIUM IABORATORY & LC2 & Bs & $\mathbf{s}$ & 9010226 & $N / \lambda$ & $03 / 09 / 90$ & $03 / 23 / 90$ \\
\hline COPPER ILABORATORY & LC2 & BS & $\mathbf{s}$ & 9010226 & $\mathbf{R} / \mathbf{A}$ & $03 / 09 / 90$ & $03 / 23 / 90$ \\
\hline NICKEI IABORATORY & LC2 & BS & $\mathbf{s}$ & 9020226 & $\pi / A$ & $03 / 09 / 90$ & $03 / 23 / 90$ \\
\hline ANTIKONY LABORATORY & LC2 & Bs & $\mathbf{s}$ & 90L0226 & $N / \boldsymbol{A}$ & $03 / 09 / 90$ & $03 / 23 / 90$ \\
\hline TIN LABORATORY & LC2. & BS & $\mathbf{s}$ & 90L0226 & $\mathbf{N} / \mathbf{A}$ & $03 / 09 / 90$ & $03 / 23 / 90$ \\
\hline VANADIUM LABORATORY & LC2 & BS & $\mathbf{s}$ & 9020226 & $N / \pi$ & 03/09/90 & $03 / 23 / 90$ \\
\hline ZINC LABORATORY & LC2 & BS & $\mathbf{s}$ & 9020226 & $\pi / \lambda$ & $03 / 09 / 90$ & $03 / 23 / 90$ \\
\hline SILVER, TOTAI & MBI & & $\boldsymbol{s}$ & 90L0226 & $N / \boldsymbol{A}$ & $03 / 09 / 90$ & $03 / 23 / 90$ \\
\hline BARIUM, TOTAL : & $\because:=$ & & $\mathbf{s}$ & $90 \longleftarrow 0226$ & $r / \lambda$ & 03/09/90 & $03 / 23 / 90$ \\
\hline BERYLLIUM, TOTAI & MBI & & $\mathbf{s}$ & 9020226 & $N / \lambda$ & $03 / 09 / 90$ & $03 / 23 / 90$ \\
\hline CADMIUN, TOTAI & ABB1 & & $\mathbf{s}$ & $90 \check{0226}$ & $N / \lambda$ & $03 / 09 / 90$ & $03 / 23 / 90$ \\
\hline COBALT, TOTAL & MBI & & $\mathbf{s}$ & 9020226 & $N / A$ & $03 / 09 / 90$ & $03 / 23 / 90$ \\
\hline CHROMIUU, TOTAL & MBI & & $\mathbf{s}$ & 9020226 & $\pi / \lambda$ & $03 / 09 / 90$ & $03 / 23 / 90$ \\
\hline COPPER, TOTAL & MB1 & & $\mathbf{s}$ & 90L0226 & $\mathbf{N} / \mathbf{A}$ & $03 / 09 / 90$ & $03 / 23 / 90$ \\
\hline NICKEL, TOTAL & MBI & & $\mathbf{s}$ & 9020226 & $N / \lambda$ & $03 / 09 / 90$ & $03 / 23 / 90$ \\
\hline ANTIMONY, TOTAI & MBI & & $\mathbf{s}$ & 90L0226 & $N / \lambda$ & $03 / 09 / 90$ & $03 / 23 / 90$ \\
\hline TIN, TOTAL & MBI & & $s$ & 9020226 & $\mathrm{~N} / \mathrm{A}$ & $03 / 09 / 90$ & $03 / 23 / 90$ \\
\hline VANADIUM, TOTAL & MBB1 & & s & 9010226 . & $n / A$ & $03 / 09 / 90$ & $03 / 23 / 90$ \\
\hline ZINC, TOTAL & MB1 & & $\mathbf{s}$ & 9020226 & $\mathrm{~N} / \mathrm{A}$ & $03 / 09 / 90$ & $03 / 23 / 90$ \\
\hline ARSENIC LABORATORY & LC1 & BS & $\mathbf{s}$ & $90 \tau 0225$ & $x / A$ & $03 / 09 / 90$ & $03 / 30 / 90$ \\
\hline LEAD LABORATORY & LCI & BS & $\mathbf{s}$ & 9010225 & $N / \lambda$ & $03 / 09 / 90$ & $04 / 05 / 90$ \\
\hline SELENIUA LABORATORY & LCI & Bs & $\mathbf{s}$ & 9010225 & $N / A$ & $03 / 09 / 90$ & $04 / 02 / 90$ \\
\hline THALLIOM LABORATORY & LC1 & Bs & $\mathbf{s}$ & 9010225 & $N / \lambda$ & $03 / 09 / 90$ & $04 / 04 / 90$ \\
\hline ARSENIC IABORATORY & LC2 & Es & $\mathbf{s}$ & 9020225 & $\pi / \lambda$ & $03 / 09 / 90$ & $03 / 30 / 90$ \\
\hline LEAD LABORATORY & LC2 & Bs & $\mathbf{s}$ & 9010225 & $N / A$ & $03 / 09 / 90$ & $04 / 05 / 90$ \\
\hline SELENIOM LABORATORY & LC2 & Bs & $\mathbf{s}$ & 9020225 & $N / A$ & $03 / 09 / 90$ & $04 / 01 / 90$ \\
\hline TEALLIOM LABORATORY & LC2 & Bs & $\mathbf{s}$ & 9010225 & $N / A$ & $03 / 09 / 90$ & $04 / 04 / 90$ \\
\hline ARSENIC, TOTAL & MB1 & & $\mathbf{s}$ & 9020225 & $x / A$ & $03 / 09 / 90$ & $03 / 30 / 90$ \\
\hline LEAD, TOTAL & MB2 & & $\mathbf{s}$ & 9020225 & $x / \lambda$ & $03 / 09 / 90$ & $04 / 05 / 90$ \\
\hline SELENIUA, TOTAL & $\mathbf{M B 1}$ & & $\boldsymbol{s}$ & 90L0225 & $N / A$ & $03 / 09 / 90$ & $04 / 01 / 90$ \\
\hline TEACIIUK, TOTAL & MB1 & & $\boldsymbol{s}$ & $90 L 0225$ & $\mu / \lambda$ & $03 / 09 / 90$ & $04 / 04 / 90$ \\
\hline KERCURY LABORATORY & LC1 & Bs & w & $90 \mathrm{CO} 40 \mathrm{~B}$ & $\pi / \lambda$ & $03 / 12 / 90$ & $03 / 23 / 90$ \\
\hline MERCURY IABORATORY & LC2 & Bs & $\boldsymbol{w}$ & $90 \mathrm{CO} 40 \mathrm{~B}$ & $x / \lambda$ & $03 / 12 / 90$ & $03 / 13 / 90$ \\
\hline MERCURY IABORATORY & LC3 & Bs & $\omega$ & $90 \mathrm{CO} 40 \mathrm{~B}$ & $B / \lambda$ & $03 / 12 / 90$ & $03 / 13 / 90$ \\
\hline KERCURY IAAORATORY & LC4 & B8 & $\boldsymbol{\omega}$ & $90 \mathrm{CO} 40 \mathrm{~B}$ & $\mathbf{x} / \mathbf{A}$ & $03 / 12 / 90$ & $03 / 13 / 90$ \\
\hline
\end{tabular}


RoY Y. Weston, Inc. - Ilonv1110 Laboratory

IMORGANIC AMALYTICAL DATA PACKGGI FOR FSRC GONSITE 720

DATE RECEIYED: 02/16/90

REW IOT :9002L603

CLIENT ID / ARLATYSIS

IERRCURY, TOTAL

ERRCORY, TOTAL

LERCURY, TOTAL

IERRCURY, TOTAL
RUT



ICB2

IB3

LBS
MIX PREP \& COLTXCTION EXIT/PREP

$\mathbf{n} / \mathbf{A}$

$\mathbf{n} / \mathbf{A}$

$\mathbf{x / a}$

$\pi / 2$
$03 / 12 / 90$

$03 / 12 / 90$.

$03 / 12 / 90$

$03 / 12 / 90$
Antarys Is

$03 / 13 / 90$

$03 / 13 / 90$

$03 / 13 / 90$

$03 / 13 / 90$ 
Roy F. Weston, Inc. - Ilonville Laboratory

vOA ANRIYTICAI DATA PACKMGE FOR

WSRC GUNSITZ 720

DATE RECEIVED: $02 / 16 / 90$

RSW LOT $\$ 90022603$

CLIEAY ID

G5720 10-018

G5720 14-01

GS720 04-01

GS720 02-01

G5720 03-01

GS720 02-01A

GS720 11-018

Cs720 06-01

GS720 05-01

GS720 12-01B

GS720 01-02

GS720 08-01

G5720 07-01

GS720 01-01

IAB QC:

\begin{tabular}{l} 
RHA \\
\hline 001 \\
002 \\
003 \\
004 \\
005 \\
006 \\
007 \\
008 \\
009 \\
010 \\
011 \\
012 \\
013 \\
014
\end{tabular}

2xIX

PRRP

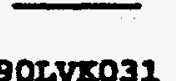

$\begin{array}{ll}\text { H } & 90 \text { Lvio31 } \\ 8 & 90 \text { Lvro29 }\end{array}$

s 90IVW027

$890 L \mathrm{LHO27}$

$890 L V$ L27

s 90LUพ027

90LVRo31

s 90Lvพ027

8 90LVพ027

พ 90LVรio31

s 902 VT028

s 90LvW028

s 90LVF030

s 90 LVW028

$02 / 14 / 90$

$02 / 14 / 90$

$02 / 14 / 90$

$02 / 14 / 90$

$02 / 14 / 90$

$02 / 14 / 90$

$02 / 14 / 90$

$02 / 14 / 90$

$02 / 14 / 90$

$02 / 14 / 90$

$02 / 13 / 90$

$02 / 13 / 90$

$02 / 13 / 90$

$02 / 13 / 90$
EXTR/PREP

ARAYSIS

$8 / 2$

$n / a$

$n / \pi$

$n / A$

$\boldsymbol{x} / \mathbf{A}$

$n / \mathbf{A}$

H/A

$x / a$

$n / \mathbf{A}$

$x / a$

$x / A$

$\pi / \lambda$

N/A

$N / A$
$02 / 26 / 90$

$02 / 26 / 90$

$02 / 23 / 90$

$02 / 23 / 90$.

$02 / 23 / 90$

$02 / 23 / 90$

$02 / 26 / 90$

$02 / 23 / 90$

$02 / 23 / 90$

$02 / 26 / 90$

$02 / 24 / 90$

$02 / 24 / 90$

$02 / 27 / 90$

$02 / 24 / 90$
VBLXX

VBIK

VBLX

VBIK

VBLX
LAB2

IBI

YBI

KBI

IAB1

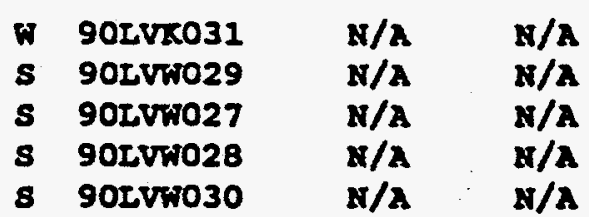

$02 / 26 / 90$

$02 / 26 / 90$

$02 / 23 / 90$

$02 / 24 / 90$

$02 / 27 / 90$ 


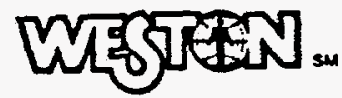

ROY F. MESTON, INC.

Lionville Laboratory

CLIENT: WSRC-GUNSITE 720

RFW : $\quad 9002 L 603$, GC/MS VOLATILE

BAMPLES RECEIVED: 02-16-90

W.O. : 0630-28-13

\section{NARRATIVE}

The set of samples consisted of three water samples and eleven soil samples collected on 02-13,14-90.

The samples were analyzed according to criteria set forth in SW 846 Method 8240 for TCL Volatile target compounds on $02-23,24,26,27-90$.

The following is a summary of the $Q \dot{C}$ results accompanying these sample results and a description of any problems encountered during their analysis:

1. Non-target compounds were not detected in these samples.

2. All surrogate recoveries are within EPA QC Iimits.

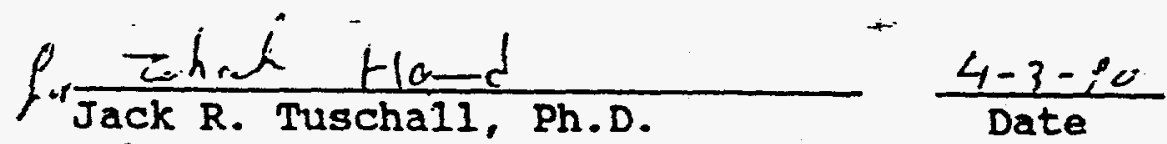




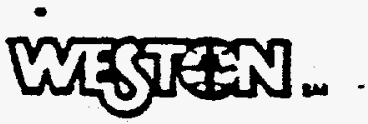

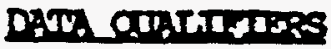

$\mathrm{v}=$ copound was analyzed for but not datected. Wh asaoclated

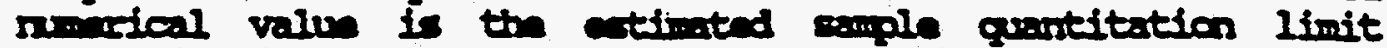

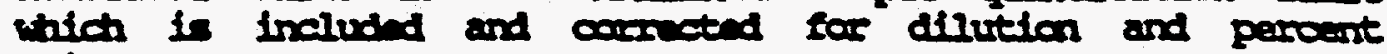
mot tare.

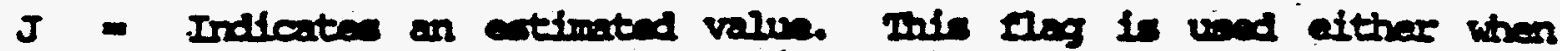

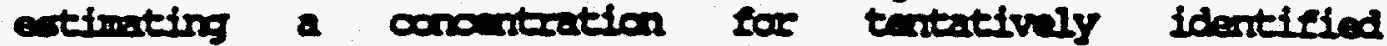

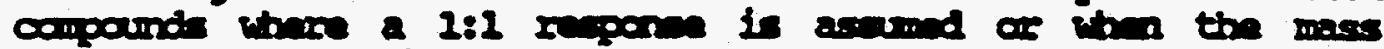

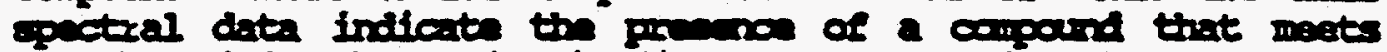

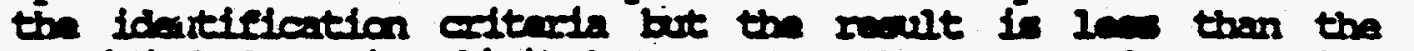

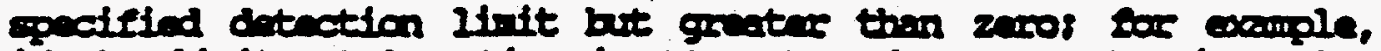
if the limit of detetion is $10 \mathrm{vg} / \mathrm{t}$ and a concuntration of 3 $u g / L$ is caloulated, it is reported as 35 .

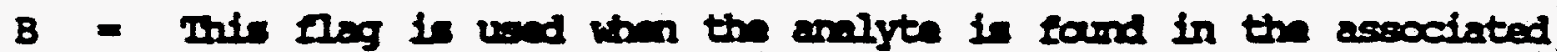
blank of il as in the rewple. It indlates

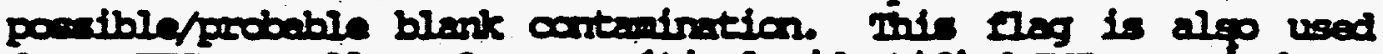

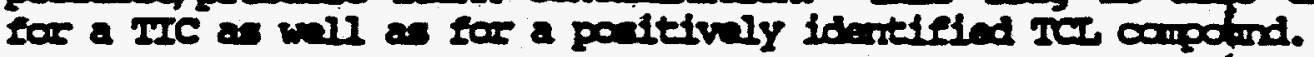

$E$ = Indicates that the compound was detected beychid the . calibration range and wes abequntly analyzed at a difution.

$I=$ Intenfereso.

$X$ - Adtitional gualifine und as rovired an coplained in the case narrative.

NQ = Roult galitatively confirma but not able to quantify.

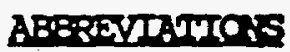

BS - Indicates blank give in ibich nogut grad wator is spilkad with the CIP nteix epilding colution and carried through all

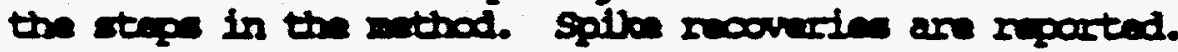

BSD - Indfoter blaris galle dupliate.

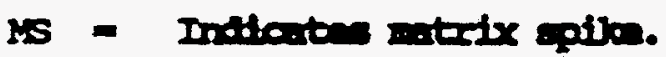

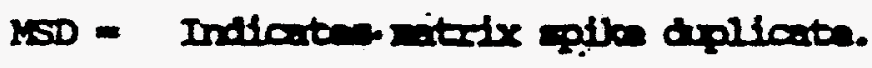

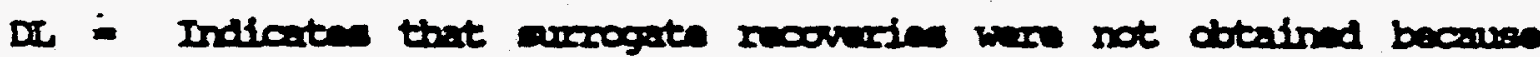
the extract had to be disluted for analyale.

N. - rot_appilable.

DF = Dilution factor.

NR - Not requirad. 
Roy 5 ! Houton, Inc. - Lonville Laboratory

Volatiles by /MS, HSL Llst CILent: FBRC GUNSITS 720 Nork Order: $0630-28-13-0000$

Report Dates 03/26/90 15849

G5720 02-01

C8720 03-01

68720 02-012

Sample

Information

Cust ID, 68720 10-015

08720 14-01 "68720 04-01

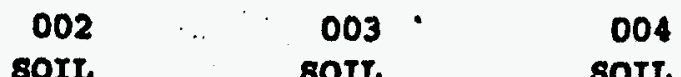

Matrix: MnTer

D.P.8 $\quad 1.00$

Unite:

ug/L

1.00

ug/Kg

1.00

1.00

ug/ $/ \mathbf{g g}$

$\mathrm{ug} / \mathrm{Kg}$

005
$801 L$
1.00
$u g / R g$

006

80IL

99

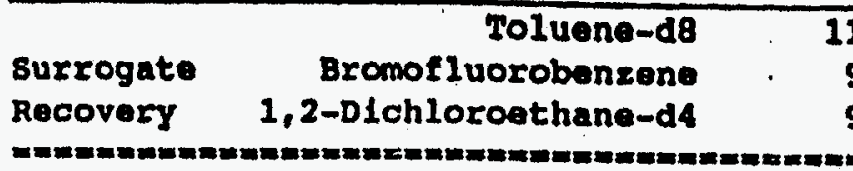

110
99
99
10

Chloromethane

Bromomethane

vinyl Chloride

Chloroethane

Methylene chioride

Acotone

Carbon DLeulfide

1,1-Dlchloroethene

1,1-Dlchloroethane

1,2-Dichloroethene (tótal)

Chloroform

$\begin{array}{l:c}99 & 103 \\ 97 & 101 \\ 91 & 94\end{array}$

1,2-Dlchloroethane

2-Butanone

1,1,1-Ixlchloroethane

Carbon Tetrachloride

vinyl Acetate

Bromodlchloromethane

1,2-Dichloropropane

cle-1,3-Dlchloropropene

Trlchloroethene

Dibromochloromethane

1,1,2-Trlehloroethane

Benzene.

Trane-1,3-D1Chloropropene

Bromoform

4-Methy 1-2-pentanona

2-Hexanone

Tetrachloroethene

1,1,2,2-Tetrechloroethane

\begin{tabular}{|c|c|c|}
\hline 10 & $\mathbf{0}$ & 11 \\
\hline 10 & 0 & 11 \\
\hline 5 & $\mathbf{J}$ & 11 \\
\hline 10 & & 11 \\
\hline 3 & JB & 11 \\
\hline 10 & v & 17 \\
\hline 5 & U & 5 \\
\hline 5 & v & 5 \\
\hline 5 & $\boldsymbol{0}$ & 5 \\
\hline 20 & & 5 \\
\hline 5 & v & 5 \\
\hline 5 & v & 5 \\
\hline 10 & v & 11 \\
\hline 5 & v & 5 \\
\hline 5 & $\mathbf{U}$ & 5 \\
\hline 10 & v & 11 \\
\hline 5 & 0 & 5 \\
\hline 5 & U & 5 \\
\hline 5 & U & 5 \\
\hline 6 & & 5 \\
\hline 5 & U & 5 \\
\hline 5 & 0 & 5 \\
\hline 5 & $\mathbf{U}$ & 5 \\
\hline 5 & U & 5 \\
\hline 5 & v & 5 \\
\hline 10 & v & 11 \\
\hline 10 & $\mathbf{U}$ & 11 \\
\hline 5 & & 5 \\
\hline 5 & $\mathbf{U}$ & 5 \\
\hline
\end{tabular}

103
101
94

\begin{tabular}{r|r|r|r|}
106 & 104 & 102 \\
104 & 102 & 105 \\
93 & 96 & 100
\end{tabular}

* = Outaide of BPA CLP QC IImits. 


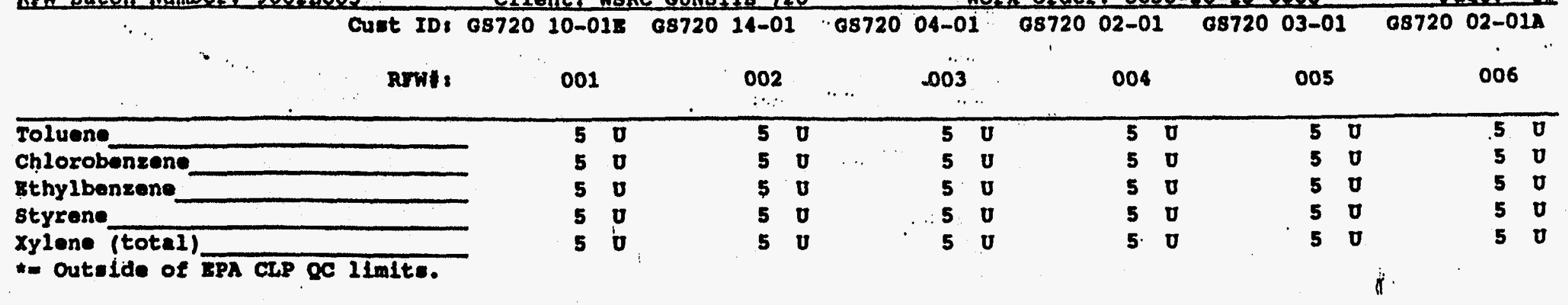


Roy I. Weston, Inc. - 'onville Laboratory

Volatiles by HS, BSL Llat

Report Dates 03/26/90-15:49

Cunt ID: 68720 11-018 68720 06-01

8 amplo

Information

$\begin{array}{rcr}\text { RFW: } & 007 & 008 \\ \text { Matrix: } & \text { WATER } & \text { SOIL } \\ \text { D.F.: } & 1.00 & 1.00\end{array}$

ø\$720 05-01 G8720 12-01B $68720 \quad 01-02$

$68720 \quad 08-01$

Unita:

$\mathrm{ug} / \mathrm{L}$

1.00

009

SOIL

$u g / \mathrm{Kg} u g / \mathrm{Kg}$

010
WATER
1.00
ug/L

011

012

:

\begin{tabular}{|c|c|c|}
\hline $\begin{array}{l}\text { Buxrogate } \\
\text { Recovery }\end{array}$ & $\begin{array}{r}\text { Toluene-d8 } \\
\text { Bromofluorobenzene } \\
\text { 1,2-Dichloroethane-d4 }\end{array}$ & $\begin{array}{l}113 \\
101 \\
105\end{array}$ \\
\hline
\end{tabular}

$\begin{array}{lll}104 & 101 \\ 107 & 104\end{array}$

\section{Chloromethane}

Bromomethane

vinyl Chloride

Chloroethane

Methylene Chlorlde

\section{Acetone}

Carbon DIsulfide

1,1-D1Chloroethene

1,1-D1chloroethane

1,2-D1chloroethene (total)

Chlorotorm

1,2-Dichloroethane

2-Butanone

1,1,1-Trlchloroethane

Carbon Tetrachloride

Vinyl Acetate

Bromodichloromethane

1,2-DIchloropropane

Cla-1, 3-DLChloropropene

Trichloroethene

Dlbromochloromethane

1,1,2-Trichloroethane

Benzene

Trans-1, 3-Dlchloropropena

Bromoform

4-Methy 1-2-pentanone

2-Hexanone

Tetrachloroethene

1,1,2,2-Tetrachloroethane

* - Outalde of BPA CLP QC IInits.

$\begin{array}{rlrl}10 & \mathrm{U} & 12 & \mathrm{U} \\ 10 & \mathrm{U} & 12 & \mathrm{U} \\ 2 & \mathrm{~J} & 12 & \mathrm{U} \\ 10 & \mathrm{U} & 12 & \mathrm{U} \\ 4 & \mathrm{JB} & 8 & \mathrm{~B} \\ 4 & \mathrm{~J} & 17 & \mathrm{~B} \\ 2 & \mathrm{JB} & 6 & \mathrm{U} \\ 5 & \mathrm{U} & 6 & \mathrm{U} \\ 5 & \mathrm{U} & 6 & \mathrm{U} \\ 8 & & 6 & \mathrm{U} \\ 5 & \mathrm{U} & 2 & \mathrm{JB} \\ 5 & \mathrm{U} & 6 & \mathrm{U} \\ 10 & \mathrm{U} & 12 & \mathrm{U} \\ 5 & \mathrm{U} & 6 & \mathrm{U} \\ 5 & \mathrm{U} & 6 & \mathrm{U} \\ 10 & \mathrm{U} & 12 & \mathrm{U} \\ 5 & \mathrm{U} & 6 & \mathrm{U} \\ 5 & \mathrm{U} & 6 & \mathrm{U} \\ 5 & \mathrm{U} & 6 & \mathrm{U} \\ 2 & \mathrm{~J} & 6 & \mathrm{U} \\ 5 & \mathrm{U} & 6 & \mathrm{U} \\ 5 & \mathrm{U} & 6 & \mathrm{U} \\ 5 & \mathrm{U} & 6 & \mathrm{U} \\ 5 & \mathrm{U} & 6 & \mathrm{U} \\ 5 & \mathrm{U} & 6 & \mathrm{U} \\ 10 & \mathrm{U} & 12 & \mathrm{U} \\ 10 & \mathrm{U} & 12 & \mathrm{U} \\ 2 & \mathrm{~J} & 6 & \mathrm{U} \\ 5 & \mathrm{U} & 6 & \mathrm{U}\end{array}$

$\begin{array}{rl}11 & U \\ 11 & U \\ 11 & U \\ 11 & U \\ 8 & B \\ 12 & B \\ 5 & 0 \\ 5 & U \\ 5 & U \\ 5 & U \\ 1 & J B \\ 5 & U \\ 11 & U \\ 5 & U \\ 5 & U \\ 11 & U \\ 5 & U \\ 5 & U \\ 5 & U \\ 5 & U \\ 5 & U \\ 5 & U \\ 5 & U \\ 5 & U \\ 5 & U \\ 11 & U \\ 11 & U \\ 5 & U \\ 5 & U\end{array}$

$114 * 101$

1.00

0.986

$u g / \mathrm{Kg} \quad \mathrm{ug} / \mathrm{Kg}$ 
$\therefore$ RWE : $007 \quad 008$

009

010

011

012

Toluene

Chlorobonzene

sthy lbenzene

Btyrene

xylono (total)

- $=$ Outalde of ERA CLP QC IImIta.

5060

$\begin{array}{ll}6 & 0 \\ 6 & 0\end{array}$

50

50

5. 0

50

50

510

60

3.0

50

50

50

$\begin{array}{ll}5 & 0 \\ 5 & 0\end{array}$

$\begin{array}{ll}5 & 0 \\ 5 & 0\end{array}$

50

60

60

60

$\begin{array}{ll}6 & 0 \\ 6 & 0\end{array}$ 
Roy F.' Weston, Inc. - - 'onv1110 Labóratory

Volat11ea by, M8, H8L L1eit

Report Dater 03/26/90 15,49 Cllent: W8RC GUNSITE 720

Nork Order, 0630-28-13-0000

Paget 39

Cuat ID: 68720 07-01 G8720 01-01 " vBLK $\cdots \cdot$ VBLK

Sample

Information

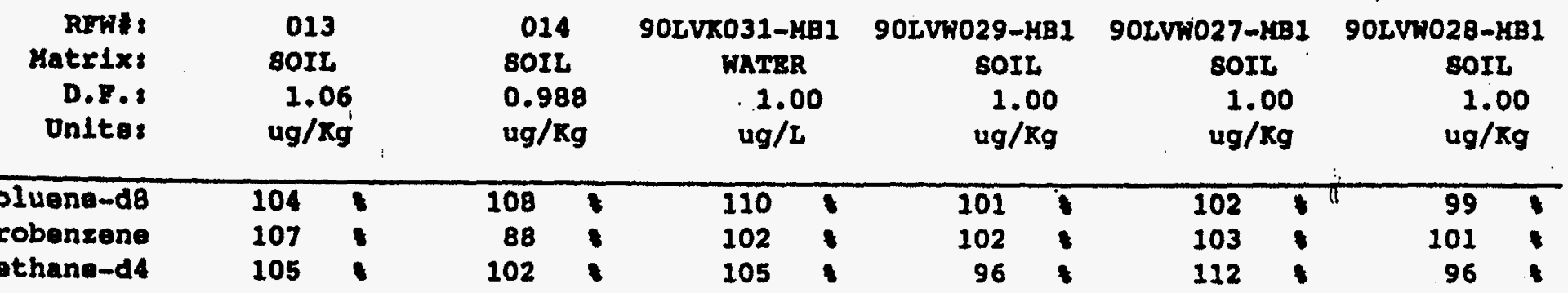

Burrogate
Recovery
1,2-Dlchlorocthane-d

105

102

105

112

Chloromethane

Bromomethane

Vinyl Chloride

Chloroethane

Methylene Chlorlde

Acetone

Carbon Dlsulfide.

1,1-Dichloroethene

1,1-DLchloroethane

1,2-D1chloroethene (total)

chloroform

1,2-DLchloroethane

2-Butanone

1,1,1-Tr10hloroethane

Carbon Tetrachlorlda

vinyl reetate

Bromodlchloromethane

1,2-DLehloropropane

c1E-1, 3-D1chloropropene

Trlchloroethene

Dibromochloromethane

1,1,2-Trlchloroethane

Benzene

Trane-1,3-DLehloropropene

Bromoform

4-Methy 1-2-pentanone

2-Hexanone

Tetrachloroethene

1,1,2,2-Tetrachloroethane

* w outulde of EPA CLP QC IImits.

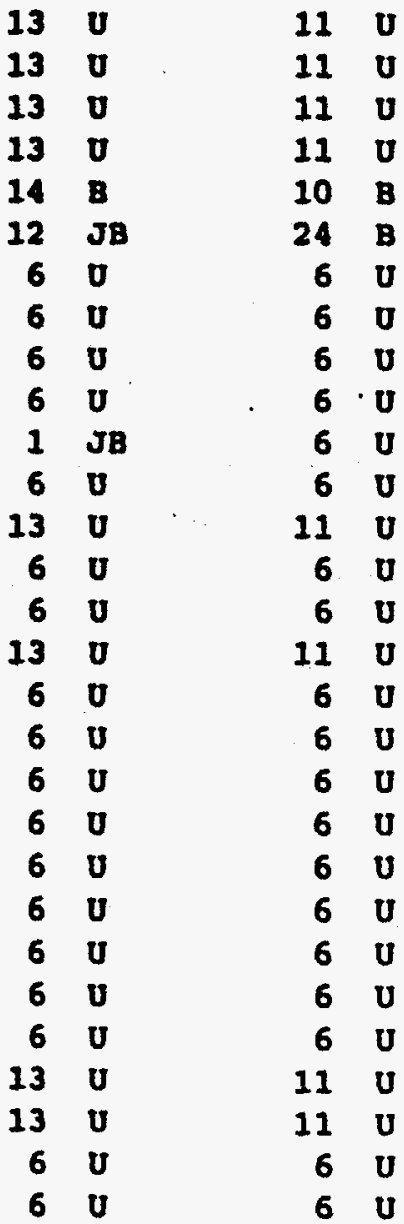

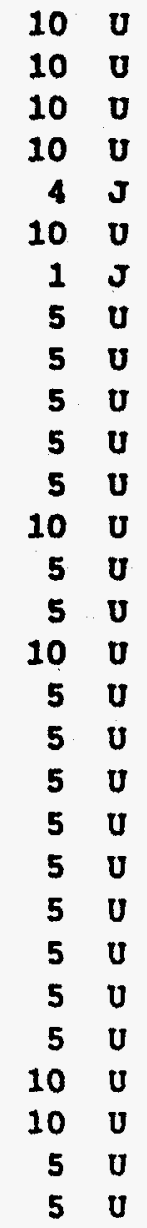

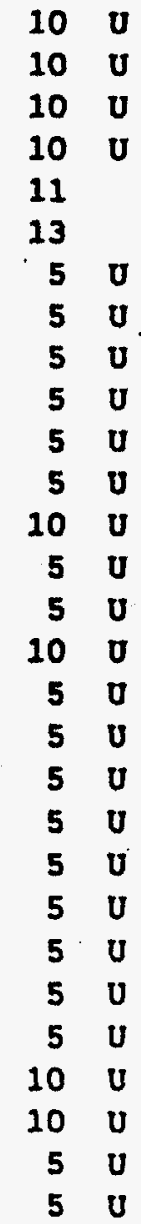

$10 \mathrm{v}$

100

100

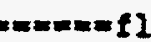


nore yeaer $1630-28-13-0000$

Curit ID: 68720 07-01 $6872001-01$

VBLX

Pear

YRr.

\begin{tabular}{|c|c|c|c|c|c|c|c|c|c|c|c|c|}
\hline - RWH: & 013 & & 014 & & 90LVR031-m & & 90LV*029-10 & & 90Lviv027-K & B1 & 90LViro28-K & $\mathbf{B}$ \\
\hline & 6 & $\mathbf{0}$ & 6 & $\mathbf{0}$ & 5 & 0 & 5 & $\mathbf{v}$ & 5 & $\mathbf{0}$ & 5 & U \\
\hline & & $\mathbf{0}$ & 6 & $\mathbf{0}$ & 5 & $\mathbf{0}$ & 5 & $\mathbf{v}$ & $\mathbf{5}$ & $\mathbf{0}$ & 5 & 0 \\
\hline & 6 & $\mathbf{0}$ & 6 & $\mathbf{0}$ & 5 & $\mathbf{u}$ & 5 & $\mathbf{0}$ & 5 & $\mathbf{0}$ & 5 & $\mathbf{0}$ \\
\hline & 6 & $\mathbf{0}$ & 6 & $\mathbf{0}$ & 5 & $\mathbf{u}$ & 5 & $\mathbf{0}$ & $\mathbf{5}$ & $\mathbf{0}$ & 5 & $\boldsymbol{U}$ \\
\hline & 6 & $\mathbf{0}$ & 6 & $\mathbf{0}$ & 5 & $\mathbf{0}$ & 5 & $\mathbf{0}$ & $\mathbf{5}$ & $\mathbf{0}$ & 5 & 0 \\
\hline
\end{tabular}

Toluene

Chlorobenzene

Ethylbensene

styrene

xylene (total)

* Outalde of IPA CLP QC IImita. 


\section{Cuet ID: VBLR}

sample

Information

REWI: 90LVW030-KB1

$\begin{array}{rc}\text { Hatrix: } & \text { 80IL } \\ \text { D.F.8 } & 1.00 \\ \text { Unitaz } & \text { ug/Xg }\end{array}$

$\begin{array}{rr}\text { D.F.8 } & 1.00 \\ \text { Unit:s } & u g / x g\end{array}$

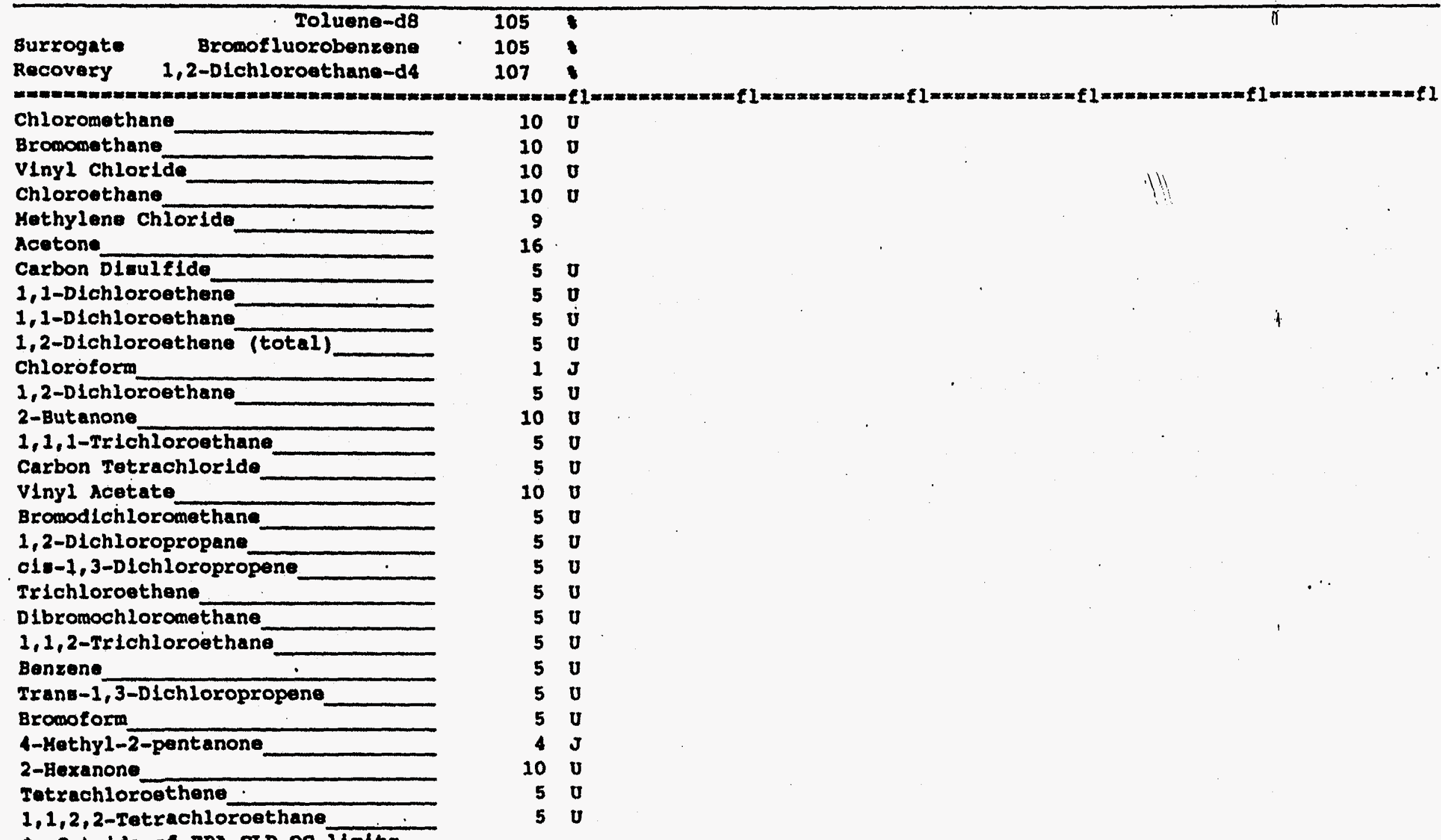




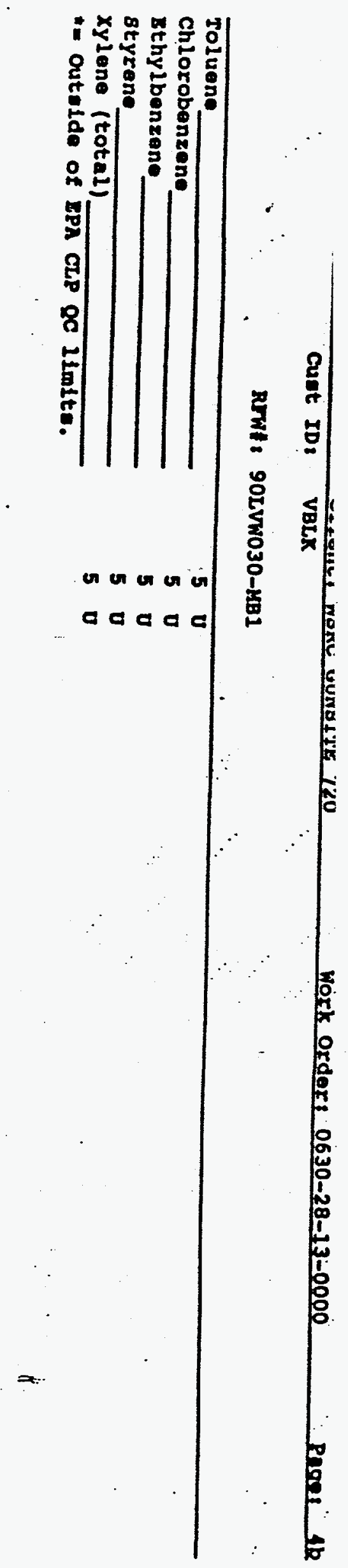


Roy F. Weston, Inc. - Ilonville Laboratory BNA ANALYTICAL DATA PACKAGE FOR HSRC GUNSITE 720

DATE RECEIVED: $02 / 16 / 90$

RPW LOT :9002L603

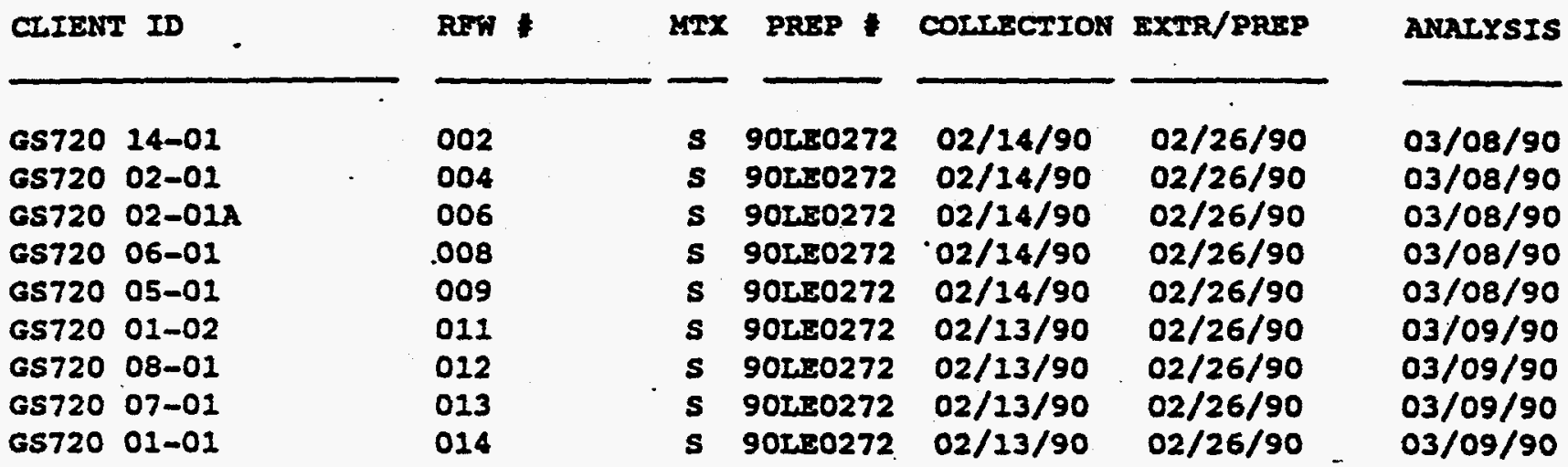

LAB QC:

SBLR

MBI

MBI BS

s 90LE0272

s 90450272

$N / A$

$02 / 26 / 90$

N/A

$02 / 26 / 90$

$03 / 07 / 90$

$03 / 07 / 90$

三:

$\exists$ 
WESTER .

ROY F. FESTON, INC.

Lionville Laboratory

CLIENT: WSRC-GUNSITE 720

BAYPLEB RECEIVED: 02-16-90

RFW $\$:$ 9002L603, SEMTVOLATILE

H.0. * : 0630-28-13

NARRATIVE

The set of samples consisted of nine soil samples collected on 02-13,14-90.

The samples were extracted on 02-26-90 and analyzed according to criteria set forth in SW 846 Method 8270 for TCL Semivolatile target compounds on 03-07,08,09-90.

The following is a summary of the QC results accompanying these sample results and a description of any problems encountered during their analysis:

1. Non-target compounds were detected in these samples.

2. One of sixty-six surrogate recoveries is outside the EPA QC limits. However, EPA QC surrogate recovery criteria are met [i.e., no more than one outlier per fraction (acid and base neutral) and no recoveries less than 108].

3. The matrix spike and replicate requirement are fulfilled by sample GS720-01-02 (9002L604-001) also extracted in batch 90LE0272.

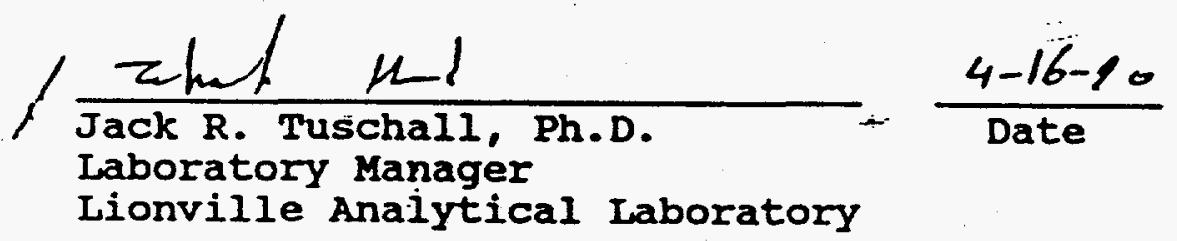

maj/upmeno/02-603s.cn 
DATA QUATIETERS

$$
\operatorname{lin} 28 \%
$$

$U=$ compound was analyzed for but not detected. The associated mumerical value is the estimated sample quantitation limit which is included and corrected for dilution and percent moisture.

$\mathrm{J} \doteq$ Indicates an estimated value. This flag is used either when estimating a concentration for tentatively identified compounds where a 1:1 respanse is assumed or when the mass spectral data indicate the presence of a coupound that meets the identification criteria but the result is less than the specified detection limit but greater than zexo; for example, if the limit of detection is $10 \mathrm{ug} / \mathrm{L}$ and a concentration of 3 $\mathrm{ug} / \mathrm{L}$ is calculated, it is regorted as $3 \mathrm{~J}$.

$B=$ This flag is used when the arialyte is found in the associated blank as well as in the sauple. It indicates possible/probable blank cortamiration. This flag is also used for a TIC as well as for a positively identified TCI campound.

$E=$ Indicates that the compound was detected beyand the calibration range and was subsequently analyzed at a dilution.

$I=$ Interference.

$A=$ Aldol condensation Product.

$X=$ Additional qualifiers used as required are explained in the case narrative.

NQ = Result qualitatively confinmed but not able to quantify.

\section{ABBREVIATIONS}

BS = Indicates blank spike in wich reagent grade water is spiked with the CIP matrix spiking solutions and carried through all the steps in the method. Spike recoveries are reported.

BSD = Indicates blank spike duplicate.

MS = Indicates matrix spike.

MSD = Indicates matrix spike diplicate.

$D L=$ Indicates that surrogate recoveries were not obtained because the extract had to be diluted for analysis.

NA $=$ Not applicable.

$D F=$ Dilution factor.

$\mathrm{NR}=$ Not required. 
Roy F. Weaton, Inc. - LLonv111e Laboratory

semLvolat1len by GC/Ms, HsL Llet

Report Dater 04/04/90 17:31 cllent, VSRC QUNSITE 720

Nork Order: 0630-28-13-0000

Pagei 18

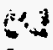

Cust ID 68720 14-01 G8720 02-01 "08720 02-01A G8720 06-01 G8720 05-01 G8720 01-02

14 8 ample

Eo Information

1

$\begin{array}{rr}\text { RIF:8 } & 002 \\ \text { Hatrix: } & \text { soIL }\end{array}$

D.F.8

1.00

$004 \quad 006$

006
8012

1.00

1.00

ug/ $\mathrm{kg}$

008

009

011

Unites

ug/Kg

$\mathrm{ug} / \mathrm{Kg}$

1.00

ug/xg

1.00

soIL

Nitrobenzene-d5

surrogate

2-Fluoroblphony 1

p-Terpheny 1-d14

Phonol-d5

2-Fluorophenol

2,4,6-Tx1bromophonol

Phonol

b1e (2-Chloroethy 1) ether

2-Chlorophenol

1,3-DLchlorobenzene

1,4-Dlchlorobenzene

Benzyl alcohol.

1,2-Dlchlorobenzene

2-Methylphenol

b1e(2-Chloroleopropy l)ether

4-Kethylphenol.

N-NLtromo-D1-n-propylamine

Hexachloroethane

NLtrobenzene

Imophorone

2-N1trophenol

56
68
80
69
62

59
68
79
71
59

$\begin{array}{ll}46 & \\ 53 & \\ 63 & \\ 52 & \\ 45 & \\ 39 & \end{array}$

$\begin{array}{ll}60 & \\ 72 & \\ 91 & \\ 79 & \\ 72 & \\ 81 & \end{array}$

$\mathbf{u g} / \mathrm{xg}$

1.00

$\begin{array}{rrr}65 & 83 \\ 79 & 77 \\ 94 & 116 \\ 79 & 114 \\ 64 & 91 \\ 54 & 57\end{array}$

350 U

3500

3500

$340 \mathrm{U}$

370 I

$\begin{array}{lll}350 & 0 & 350\end{array}$

3500

350,0

$350 \mathrm{U}$

350 U

350.0

350 i

350 U

350 U

$350 \quad 0$

350 u

350 v

350 d

3500

350 U

350 U

350 U

$350 \mathrm{U}$

$350 \mathrm{U}$

$1800 \mathrm{~V}$

350 U

350 U

$350 \mathrm{U}$

350 U

350 U

350 U

350 U

350 U

350 U

$350 \mathrm{U}$

350 U

$350 \quad 0$

$350 \quad 0$

350 U

$350 \quad \mathbf{U}$

$350 \mathrm{U}$

$350 \mathrm{U}$

$350 \mathrm{U}$

$350 \mathrm{U}$

350 U

$1700 \mathrm{U}$

$350 \mathrm{U}$

350 U

$350 \mathrm{U}$

350 U

$350 \mathrm{U}$

$350 \mathrm{U}$

350 U

350 U

2-Kothy Inaphthalene

Hexachlorocyclopentadiene

$350 \mathrm{U}$

3400

340 v

$340 \mathrm{v}$

3400

$340 \quad 0$

340 U

$340 \mathrm{U}$

340 U

$340 \mathrm{v}$

$340 \mathrm{U}$

$340 \mathrm{U}$

$340 \mathrm{U}$

$340 \mathrm{v}$

$340 \mathrm{~V}$

$340 \mathrm{v}$

$1700 \mathrm{v}$

$340 \mathrm{v}$

$340 \mathrm{v}$

$340 \mathrm{U}$

$340 \mathrm{U}$

$340 \mathrm{U}$

$340 \mathrm{U}$

$340 \mathrm{U}$

$340 \mathrm{U}$

$340 \mathrm{U}$

$370 \mathrm{v}$

370 o

$370 \mathrm{v}$

$370 \mathrm{v}$

370 v

$370 \mathrm{v}$

370 v

370 v

3700

3700

$370 \mathrm{U}$

3700

370 U

$370 \mathrm{U}$

3700

$1800 \mathrm{U}$

370 v

$370 \mathrm{U}$

$370 \mathrm{U}$

$370 \mathrm{U}$

$370 \mathrm{U}$

370 U

$370 \mathrm{U}$

$370 \mathrm{U}$

$370 \mathrm{U}$

350 v

$350 \quad 0$

$\begin{array}{llll}350 & 0 & 350 & 0 \\ 350 & 0 & 350\end{array}$

$\begin{array}{llll}350 & \mathbf{0} & \mathbf{3 5 0} & 0 \\ \mathbf{3 5 0} & \mathrm{U} & \mathbf{3 5 0} & \mathbf{0}\end{array}$

350 U t 350 u

$\begin{array}{llll}350 & 0 & 350 & 0\end{array}$

350 0 350 0

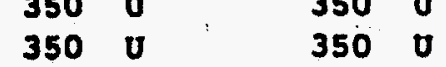

$\begin{array}{lll}350 & 0 & 350 \\ 3\end{array}$

350 U 350 U

$\begin{array}{llll}350 & 0 & 350 & 0\end{array}$

350 0 350 U

$350 \quad v \quad 350 \quad U$

$350 \mathrm{U} \quad 350 \mathrm{U}$

$3500 \quad 350 \quad 0$

$\begin{array}{lllll}1800 & \mathrm{U} & \cdots & 1800 & \mathrm{U}\end{array}$

$\begin{array}{llll}350 & 0 & 350 & 0\end{array}$

$3500^{\prime} \quad 350 \quad 0$

$350 \quad 0 \quad 350$ U

$350 \quad 0 \quad 350 \quad v$

$350 \mathrm{U} \quad 350$

$350 \mathrm{U} \quad 350 \mathrm{U}$

$350 \mathrm{U} \quad 350$

350 U 350 U

* Outside of EPA CLP QC IImite. 
client, wsRC GUN8ITE 720

Work Order: 0630-28-13-0000 (:8720 02-01 68720 02-011 68720 06-01 68720 05-01

Per

08720 L $\frac{1 b}{32}$

BNAt:

004

$.00 \ddot{6}$

008

009

011

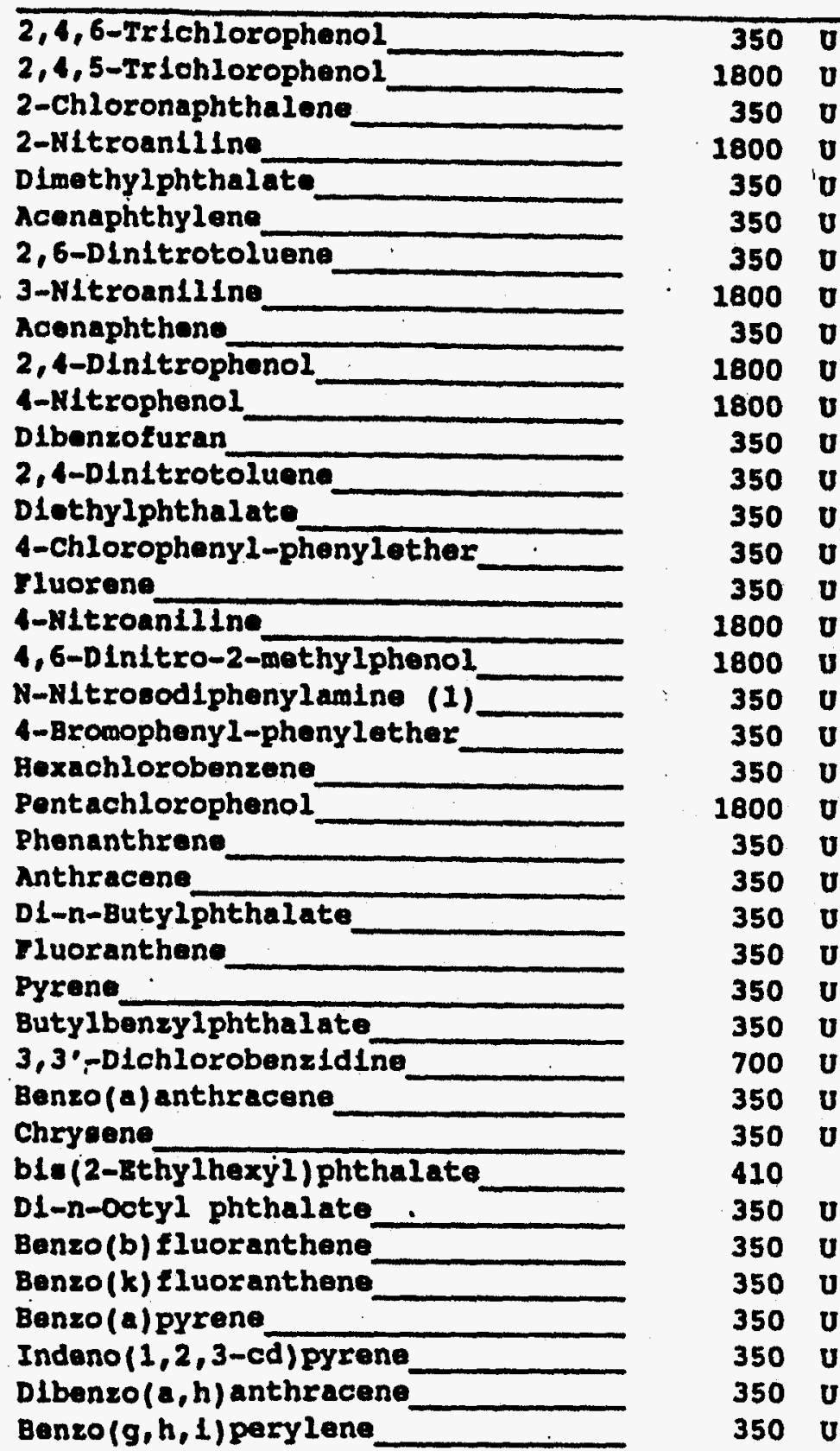

(1) - Cannot be separated from DIphenylamine.

* = outside of EPA CLP OC Iimits.

\begin{tabular}{|c|c|c|c|c|c|c|c|c|c|}
\hline 350 & 0 & 340 & $\mathbf{v}$ & $\mathbf{3 7 0}$ & 0 & 350 & ס & 350 & $\mathbf{0}$ \\
\hline 1700 & v & 1700 & 0 & 1800 & v & 1800 & 0 & 1800 & v \\
\hline $\mathbf{3 5 0}$ & $\mathbf{v}$ & 340 & 0 & 370 & v & 350 & 0 & 350 & D \\
\hline 1700 & v & 1700 & U & 1800 & U & 1800 & 0 & 1800 & D \\
\hline 350 & U & 340 & v & 370 & U & 350 & 0 & 350 & ర \\
\hline 350 & U & 340 & 0 & 370 & U & 350 & 0 & 350 & 0 \\
\hline 350 & $\mathbf{U}$ & 340 & 0 & 370 & ర & 350 & 0 & 350 & U \\
\hline 1700 & $\mathbf{v}$ & 1700 & $\mathbf{u}$ & 1800 & U & 1800 & 0 & 1800 & 0 \\
\hline 350 & v & 340 & ס & 370 & $\mathbf{u}$ & 350 & 0 & 350 & v \\
\hline 1700 & 0 & 1700 & $\mathbf{0}$ & 1800 & U & 1800 & ס & 1800 & 0 \\
\hline 1700 & v & 1700 & 0 & 1800 & U & 1800 & o & 1800 & $\boldsymbol{B}$ \\
\hline 350 & $\mathbf{U}$ & 340 & $\boldsymbol{0}$ & 370 & U & 350 & ర & 350 & 0 \\
\hline 350 & 0 & 340 & $\mathbf{v}$ & 370 & v & 350 & 0 & 350 & 0 \\
\hline 350 & 0 & 340 & $\mathbf{v}$ & 370 & 0 & 350 & 0 & 350 & v \\
\hline 350 & $\mathbf{0}$ & 340 & 0 & 370 & U & 350 & o & 350 & v \\
\hline 350 & $\mathbf{0}$ & 340 & 0 & 370 & 0 & 350 & 0 & 350 & v \\
\hline 1700 & U & 1700 & 0 & 1800 & $\mathbf{U}$ & 1800 & ס & 1800 & $\mathbf{v}$ \\
\hline 1700 & 0 & 1700 & $\mathbf{U}$ & 1800 & 0 & 1800 & $\boldsymbol{U}$ & 1800 & $\mathrm{D}$ \\
\hline 350 & $\mathbf{v}$ & 340 & 0 & 370 & U & 350 & $\mathbf{0}$ & 350 & $\mathbf{U}$ \\
\hline 350 & $\mathbf{v}$ & 340 & U & 370 & U & 350 & 0 & 350 & o \\
\hline 350 & U & 340 & U & 370 & U & 350 & 0 & 350 & D \\
\hline 1700 & $\mathbf{U}$ & 1700 & U & 1800 & $\mathbf{U}$ & 1800 & ס & 1800 & v \\
\hline 350 & v & 340 & v & 370 & v & 350 & U & 350 & U \\
\hline 350 & U & 340 & U & 370 & $\mathbf{U}$ & 350 & 0 & 350 & u \\
\hline 41 & $\mathbf{J}$ & 340 & 0 & 370 & $\mathbf{U}$ & 350 & 0 & 40 & $\mathbf{J}$ \\
\hline 350 & 0 & 340 & 0 & 370 & 0 & 350 & $\mathbf{u}$ & 350 & 0 \\
\hline 350 & $\mathbf{U}$ & 340 & $\mathbf{v}$ & 370 & $\mathbf{U}$ & 350 & 0 & 350 & $\mathbf{u}$ \\
\hline 350 & $\mathbf{v}$ & 340 & v & 370 & $\mathbf{u}$ & 350 & 0 & 350 & 0 \\
\hline 690 & U & 680 & 0 & 740 & U & 710 & U & 700 & 0 \\
\hline 350 & $\mathbf{u}$ & 340 & $\mathbf{U}$ & 370 & $\mathbf{U}$ & 350 & $\mathbf{U}$ & 350 & 0 \\
\hline 350 & $\mathbf{U}$ & 340 & U & 370 & $\mathbf{U}$ & 350 & $\mathbf{U}$ & 350 & 0 \\
\hline 300 & $\mathbf{J}$ & 660 & & 190 & $\mathrm{~J}$ & 330 & $J$ & 39 & $\mathbf{J}$ \\
\hline 350 & $\mathbf{U}$ & 340 & U & 370 & $\mathbf{U}$ & 350 & $\mathbf{u}$ & 350 & U \\
\hline 350 & U & 340 & U & 370 & u & 350 & $\mathbf{u}$ & 350 & $\mathbf{v}$ \\
\hline 350 & u & 340 & U & 370 & $\mathbf{U}$ & 350 & $\mathbf{U}$ & 350 & U \\
\hline 350 & $\mathbf{U}$ & 340 & $\boldsymbol{U}$ & 370 & $\mathbf{U}$ & 350 & u & 350 & U \\
\hline 350 & U & 340 & $v$ & 370 & $U$ & 350 & $\mathbf{U}$ & 350 & U \\
\hline 350 & U & 340 & U & 370 & U & 350 & $\mathbf{U}$ & 350 & U \\
\hline 350 & $\mathbf{U}$ & 340 & U & 370 & U & 350 & $\mathbf{U}$ & 350 & 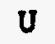 \\
\hline
\end{tabular}


moy $r$ : weaton, Inc. - ILonv111e Laboratory

semivolatiles by CC/MS, Hist Llet

Report Dates 04/01/90 17:31

Rew Batch Number? 90021603 Cllent: WSRC GUNSITE 720 Nork Order: $0630-28-13-0000$ Peges 2.

Cunt ID: 68720 08-01 $0872007-01 \quad 68720$ 01-01 $\because \quad$ sBLx $\quad$ 8BLx B8

8ample

Information

$\begin{array}{rrr}\text { Rwt: } & 012 & 013 \\ \text { Niatx1X: } & 80 I L & \text { s0IL } \\ \text { D.I.: } & 1.00 & 1.00 \\ \text { Unlts: } & \text { ug/Kg } & \text { ug/kg }\end{array}$

$\begin{array}{ccc}014 & 902 B 0272-\mathrm{KBI} & 90 \mathrm{HEO} 272-\mathrm{KBI} \\ 80 I I & 80 \mathrm{IL} & 80 \mathrm{IL} \\ 1.00 & 1.11 & 1.11 \\ \mathrm{ug} / \mathrm{Kg} & \mathrm{ug} / \mathrm{Kg} & \mathrm{ug} / \mathrm{Kg}\end{array}$

\begin{tabular}{lr}
\hline Altrobenzeno-d5 \\
2-Fluoroblphonyl \\
Recovery & p-Terphenyl-d14 \\
Phenol-d5 \\
2-Fluorophenol \\
\end{tabular}

Phenol

ble (2-Chloroothyl)ether.

2-Chlorophenol

1,3-Dichlorobenzene.

1, 4-DLchlorobenzene

Bonzyl alcohol

1,2-DLchlorobenzene

2-Hethylphenol

$\begin{array}{ll}70 & : \\ 66 & \\ 99 & \\ 93 & \\ 66 & \\ 44 & \\ 380 & 0\end{array}$

$48+2$

75

$68+2$

\begin{tabular}{|c|c|c|c|}
\hline 68 & 8 & 68 & 811 \\
\hline 76 & 1 & 75 & 8 \\
\hline 91 & $\$$ & 87 & 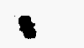 \\
\hline 71 & 8 & 78 & 8 \\
\hline 55 & 1 & 64 & 8 \\
\hline 42 & 1 & 59 & 8 \\
\hline
\end{tabular}

bie (2-Chloroleopropy 1 ) ether

4-Hethylphanol.

N-NLtromo-D1-n-propylamine

Hexachloroethane

N1trobenzene

Ixophorone

2-Nitrophenol

2, 4-Dimethylphenol.

Bensole acid

bIe (2-Chloroethoxy) methane

2,4-Dlchlorophenol

$1,2,4-$ Trichlorobenzena.

raphthalene

4-Chloroandilne

Hexachlorobutad Iene

4-Chloro-3-methyl phenol.

2-Kethylnaphthalene

Hexachlorocyclopentadlene

* Outilde of EPA CLP gC IImits.

48
47
86
64
48
43

75
69
93
99
71
43
3

\section{U}

$380 \mathrm{U}$

$380 \therefore \mathbf{U}$

$380 \mathrm{U}$

$380 \mathrm{U}$

380 U

380 U

380 U

$380 \mathrm{v}$

380 v

$.380 \quad \mathbf{0}$

$380 \mathrm{U}$

3800

$380 \mathrm{v}$

$380 \mathrm{v}$

$380 \mathrm{v}$

$1900 \mathrm{U}$

$380 \mathrm{v}$

380 v

380 U

$380 \mathrm{U}$

380 v

380 U

380 U

380 U

$380 \mathrm{U}$

$\begin{array}{ll}\mathbf{3 7 0} & \mathbf{U} \\ \mathbf{3 7 0} & \mathbf{U} \\ \mathbf{3 7 0} & \mathbf{U}\end{array}$

$360 \mathrm{U}$

$360 \mathrm{U}$

360 . V

$\begin{array}{llll}370 & 0 & 360 & \mathrm{U}\end{array}$

$\begin{array}{llll}370 & v & 360 & 0\end{array}$

$370 \mathrm{U} \quad 360 . \mathrm{U}$

$370 U$ U $360^{\circ} U$

$370 \mathrm{U} \quad 360 \mathrm{U}$

$370 \mathrm{U} \quad 360$ U

$\begin{array}{llll}370 & 0 & 360 & 0\end{array}$

$\begin{array}{llll}370 & v & 360 & 0\end{array}$

$370 v$

370 v

370 v

$370 \mathrm{U}$

$370 \mathrm{v}$

1800,0

$370 \mathrm{v}$

370 v

$370 \mathrm{U}$

3700

$370 \mathrm{U}$

$370 \mathrm{v}$

370 v

$370 \mathrm{v}$

370 v

3600

360 v

$360 \mathrm{U}$

360 v

$360 \mathrm{v}$

$1800 \mathrm{v}$

$360 \mathrm{U}$

360 U

$360 \mathrm{~V}$

360 v

360 U

$360 \mathrm{U}$

$360 \mathrm{U}$

$360 \mathrm{U}$

$360 \mathrm{U}$

$\begin{array}{lll}370 & 0\end{array}$

$370 \mathrm{U}: 370 \mathrm{U}$

370 v 74

$3700 \quad 370 \quad 0$

$370 \mathrm{0}$

$370 \mathrm{v}$

$370 \mathrm{U}$

$\begin{array}{ll}370 & \mathbf{U} \\ 370 & \mathrm{U}\end{array}$

$370 \mathrm{v}$

$370 \mathrm{v}$

370.0

$370 \mathrm{v}$

370 v

$370 \mathrm{v}$

$370 \mathrm{v}$

$1800 \mathrm{U}$

3700

$370 \mathrm{v}$

370 U

370 v

$370 \mathrm{U}$

$370 v$

$370 \mathrm{v}$

370 U

$370 \mathrm{v}$

$\begin{array}{ll}370 & 0 \\ 74 & \end{array}$

$370 \quad \mathbf{U}$

$370 \mathrm{v}$

$370 \mathrm{U}$

$370 \mathrm{U}$

$370 \quad 0$

63

3700

$370 \quad 0$

$370 \mathrm{U}$

370 v

3700

18000

$370 \mathrm{U}$

$370 \mathrm{v}$ '

88

$370 \mathrm{U}$

370 U

$370 \mathrm{U}$

- 76

$370 \mathrm{v}$

$370 \mathrm{U}$ 
Work Order: 0630-28-13-0000 Pag: BBLK BS 38720 01-01 6BLK 014 90LB0272-MB1 90LE0272-KB1

RFWI: 012 013

3600

2,4,6-Irlchlorophenol 2,4,5-Irlehlorophenol 2-Chloronaphthalene 2-N1troaniline Dimothylphthalate Acenaphthylene

2,6-Dinitrotoluene 3-Nitroaniline Acenaphthene

2,4-Din1trophenol 4-Ritrophenol Dibenzofuran

2,4-Dinitrotoluene

Diothylphthalate

4-Chloropheny 1-phenylether

Fluorene

1-Nitroaniline

4,6-Dinitro-2-methylphonol

N-N1trosodiphenylamine (1)

4-Bromophenyl-pheny lether

Hexachlorobenzene

Pentachlorophenol

Phonanthrene.

Anthracene

D1-n-Butylphthalate

Iluoranthene

Pyrene

Butylbenzylphthalate

3,3'-Dlchlorobenridine

Benzo (a) anthracene

Chrymene.

b1s(2-sthylhexyl) phthalate

D1-n-octyl phthalate.

Benzo(b) fluoranthene

Benzo (k) fluoranthene

Benzo (a) pyrene

Indeno $(1,2,3-c d)$ pyrene

D1benzo $(a, h)$ anthracene

Benzo ( $g, h, 1$ ) perylene

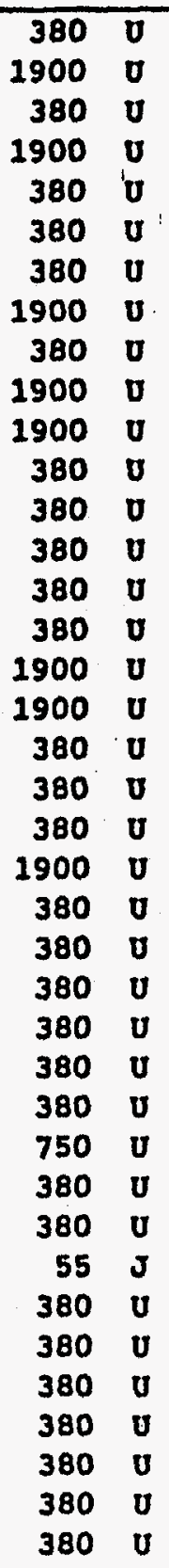

(1) - Cannot be separated from DIphenylamine.

\begin{tabular}{rr}
370 & $\mathbf{U}$ \\
1800 & $\mathbf{U}$ \\
370 & $\mathbf{U}$ \\
1800 & $\mathbf{U}$ \\
370 & $\mathbf{U}$ \\
370 & $\mathbf{U}$ \\
370 & $\mathbf{U}$ \\
1800 & $\mathbf{U}$ \\
370 & $\mathbf{U}$ \\
1800 & $\mathbf{U}$ \\
1800 & $\mathbf{U}$ \\
370 & $\mathbf{U}$ \\
370 & $\mathbf{U}$ \\
370 & $\mathbf{U}$ \\
370 & $\mathbf{U}$ \\
370 & $\mathbf{U}$ \\
1800 & $\mathbf{U}$ \\
1800 & $\mathbf{U}$ \\
370 & $\mathbf{U}$ \\
370 & $\mathbf{U}$ \\
370 & $\mathbf{U}$ \\
1800 & $\mathbf{U}$ \\
370 & $\mathbf{U}$ \\
370 & $\mathbf{U}$ \\
370 & $\mathbf{U}$ \\
370 & $\mathbf{U}$ \\
370 & $\mathbf{U}$ \\
370 & $\mathbf{U}$ \\
730 & $\mathbf{U}$ \\
370 & $\mathbf{U}$ \\
370 & $\mathbf{U}$ \\
67 & $\mathbf{J}$ \\
370 & $\mathbf{U}$ \\
370 & $\mathbf{U}$ \\
370 & $\mathbf{U}$ \\
370 & $\mathbf{U}$ \\
370 & $\mathbf{U}$ \\
370 & $\mathbf{U}$ \\
370 & $\mathbf{U}$ \\
\hline 100 & 0 \\
\hline
\end{tabular}

\begin{tabular}{|c|c|c|c|c|c|}
\hline 360 & 0 & 370 & U & 370 & v \\
\hline 1800 & v & 1800 & 0 & 1800 & ס \\
\hline 360 & v & 370 & 0 & 370 & 0 \\
\hline 1800 & v & 1800 & 0 & 2800 & 0 \\
\hline 360 & 0 & 370 & U & 370 & 0 \\
\hline 360 & $\mathbf{u}$ & 370 & $\mathbf{v}$ & 370 & 0 \\
\hline 360 & v & 370 & $\mathbf{u}$ & 370 & 0 \\
\hline 1800 & $v$ & 1800 & ס & 1800 & 0 \\
\hline 360 & v & 370 & U & 94 & 1 \\
\hline 1800 & v & 1800 & 0 & 1800 & v \\
\hline 1800 & $\mathbf{v}$ & 1800 & $\mathbf{U}$ & 106 & 1 \\
\hline 360 & v & 370 & v & 370 & ס \\
\hline 360 & 0 & 370 & $\mathbf{U}$ & 78 & $\checkmark$ \\
\hline 360 & v & 370 & $\mathbf{U}$ & 370 & $\boldsymbol{0}$ \\
\hline 360 & $\mathbf{v}$ & 370 & $\mathbf{U}$ & 370 & U \\
\hline 360 & $\mathbf{U}$ & 370 & 0 & 370 & 0 \\
\hline 1800 & $\mathbf{U}$ & 1800 & $\mathbf{U}$ & 1800 & ט \\
\hline 1800 & $\mathbf{u}$ & 1800 & 0 & 1800 & $\mathbf{U}$ \\
\hline 360 & U & 370 & 0 & 370 & 0 \\
\hline 360 & 0 & 370 & 0 & 370 & U \\
\hline 360 & U & 370 & $\mathbf{U}$ & 370 & 0 \\
\hline 1800 & $\mathbf{U}$ & 1800 & 0 & 95 & 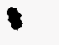 \\
\hline 360 & $\mathbf{U}$ & 370 & d & 370 & $\mathbf{U}$ \\
\hline 360 & $\mathbf{U}$ & 370 & U & 370 & U \\
\hline 360 & $\mathbf{U}$ & 370 & v & 370 & 0 \\
\hline 360 & U & 370 & $\mathbf{u}$ & 370 & 0 \\
\hline 360 & U & 370 & v & 113 & 1 \\
\hline 360 & v & 370 & v & 370 & 0 \\
\hline 720 & $\mathbf{U}$ & 740 & $\mathbf{U}$ & 740 & 0 \\
\hline 360 & U & 370 & $\mathbf{u}$ & 370 & v \\
\hline 360 & $\mathbf{U}$ & 370 & $\mathrm{u}$ & 370 & 0 \\
\hline 360 & U & 370 & $\mathbf{U}$ & 370 & U \\
\hline 360 & $\mathbf{U}$ & 370 & $\mathbf{u}$ & 370 & 0 \\
\hline 360 & v & 370 & U & 370 & $\mathbf{U}$ \\
\hline 360 & $\mathbf{U}$ & 370 & $\mathbf{U}$ & 370 & $\mathbf{v}$ \\
\hline 360 & v & 370 & $\mathbf{U}$ & 370 & v \\
\hline 360 & U & 370 & U & 370 & ర \\
\hline 360 & $\mathbf{U}$ & 370 & U & 370 & 0 \\
\hline 360 & U & 370 & U & 370 & v \\
\hline
\end{tabular}

\begin{tabular}{|c|c|c|c|c|c|}
\hline 360 & 0 & 370 & U & 370 & v \\
\hline 1800 & v & 1800 & 0 & 1800 & ס \\
\hline 360 & $\mathbf{v}$ & 370 & 0 & 370 & 0 \\
\hline 1800 & v & 1800 & 0 & 2800 & v \\
\hline 360 & 0 & 370 & U & 370 & 0 \\
\hline 360 & $\mathbf{u}$ & 370 & $\mathbf{v}$ & 370 & 0 \\
\hline 360 & v & 370 & $\mathbf{u}$ & 370 & 0 \\
\hline 1800 & $v$ & 1800 & ס & 1800 & 0 \\
\hline 360 & v & 370 & U & 94 & 1 \\
\hline 1800 & v & 1800 & 0 & 1800 & v \\
\hline 1800 & $\mathbf{v}$ & 1800 & $\mathbf{U}$ & 106 & 1 \\
\hline 360 & v & 370 & v & 370 & ס \\
\hline 360 & 0 & 370 & $\mathbf{U}$ & 78 & 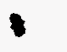 \\
\hline 360 & v & 370 & $\mathbf{U}$ & 370 & 0 \\
\hline 360 & $\mathbf{v}$ & 370 & $\mathbf{U}$ & 370 & U \\
\hline 360 & $\mathbf{U}$ & 370 & 0 & 370 & U \\
\hline 1800 & $\mathbf{U}$ & 1800 & $\mathbf{U}$ & 1800 & ర \\
\hline 1800 & $\mathbf{u}$ & 1800 & 0 & 1800 & $\mathbf{U}$ \\
\hline 360 & U & 370 & 0 & 370 & 0 \\
\hline 360 & 0 & 370 & 0 & 370 & U \\
\hline 360 & U & 370 & $\mathbf{U}$ & 370 & 0 \\
\hline 1800 & $\mathbf{U}$ & 1800 & 0 & 95 & 1 \\
\hline 360 & $\mathbf{U}$ & 370 & d & 370 & $\mathbf{U}$ \\
\hline 360 & $\mathbf{U}$ & 370 & $\mathbf{0}$ & 370 & v \\
\hline 360 & $\mathbf{U}$ & 370 & v & 370 & v \\
\hline 360 & U & 370 & $\mathbf{u}$ & 370 & U \\
\hline 360 & U & 370 & v & 113 & 1 \\
\hline 360 & v & 370 & v & 370 & 0 \\
\hline 720 & $\mathbf{U}$ & 740 & $\mathbf{U}$ & 740 & 0 \\
\hline 360 & U & 370 & $\mathbf{u}$ & 370 & 0 \\
\hline 360 & u & 370 & $\mathrm{u}$ & 370 & 0 \\
\hline 360 & U & 370 & $\mathbf{U}$ & 370 & v \\
\hline 360 & $\mathbf{U}$ & 370 & $\mathbf{u}$ & 370 & 0 \\
\hline 360 & v & 370 & U & 370 & $\mathbf{U}$ \\
\hline 360 & $\mathbf{U}$ & 370 & $\mathbf{U}$ & 370 & $\mathbf{v}$ \\
\hline 360 & U & 370 & $\mathbf{U}$ & 370 & 0 \\
\hline 360 & U & 370 & U & 370 & 0 \\
\hline 360 & $\mathbf{U}$ & 370 & U & 370 & 0 \\
\hline 360 & $\mathbf{U}$ & 370 & U & 370 & v \\
\hline
\end{tabular}

$\star=$ Outolde of EPA CLP QC IImita. 
Lab Names Roy $z$. Weston, Inc. Work Order: 0630-28-13-0000

Client: WSRC GONSITE 720

Matrix:

Sample wt/rol:

$30.9(\mathrm{~g} / \mathrm{mr}) \mathrm{G}$

Level. (low/med) Lon

* Molatures not dec. 8 dec.

Extraction: (SepF/Cont/Sonc) sore

GPC Cleanup: (Y/W) $Y$ pBs $\mathbf{7 . 0}$

CONCENTRATION URITS:

Number TICs found: 5 (ug/L or ug/Rg) ug/ $\mathrm{ug}$
Lab sample ID: 9002L603-002

Iab F110 ID: 1030806

Date Recelved: 02/16/90

Date Extracted: 02/26/90

Date Analyzed: 03/08/90

Dilution Factor: 1.00

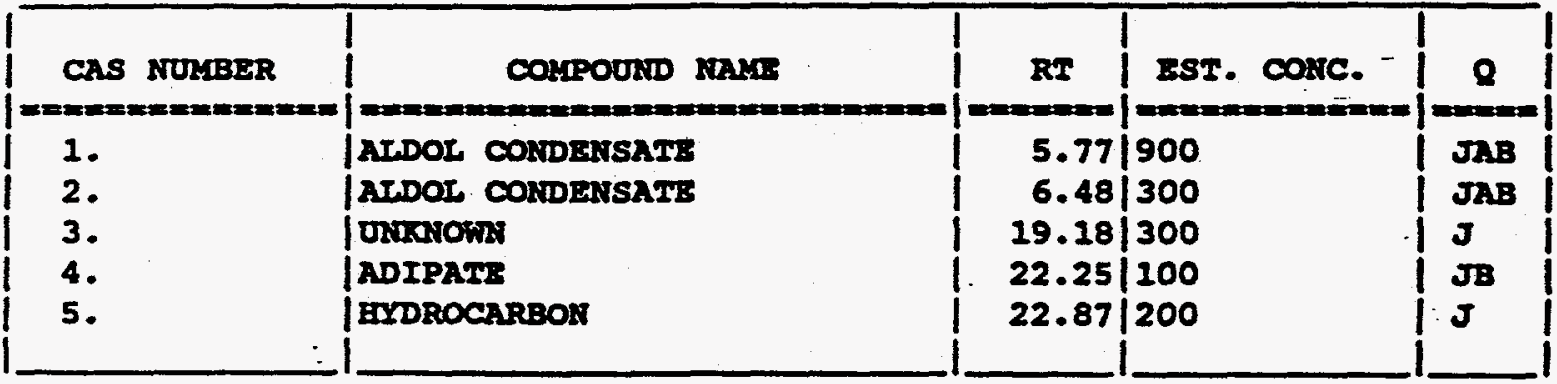


Lab Vames Roy F. Weston. Inc. Hork Order: 0630-28-13-0000

Client: HSRC GONSITB $\mathbf{7 2 0}$

Matrlxs

BOIL

Sample wt/rols $30.9(\mathrm{~g} / \mathrm{mr}) \mathrm{G}$

Leve1: (Low/med) ION

s Moletures not dec. 7 dec. Extraction: (Sepr/Cont/sone) sonc. GPC Cleanup: $(Y / N) I$ pAs 7.0

CONCENHRATION UNITS: Number TICs found: 5 (ug/L of ug/Kg) ug/ $\mathrm{kg}$
Lab sample ID: 9002L603-004

Lab PLIe ID:

Y030807

Date Recelved: $02 / 16 / 90$

Dat: Ixtracted: $02 / 26 / 90$

Date nnalyzed: $03 / 08 / 90$

DLlution Factor: 1.00

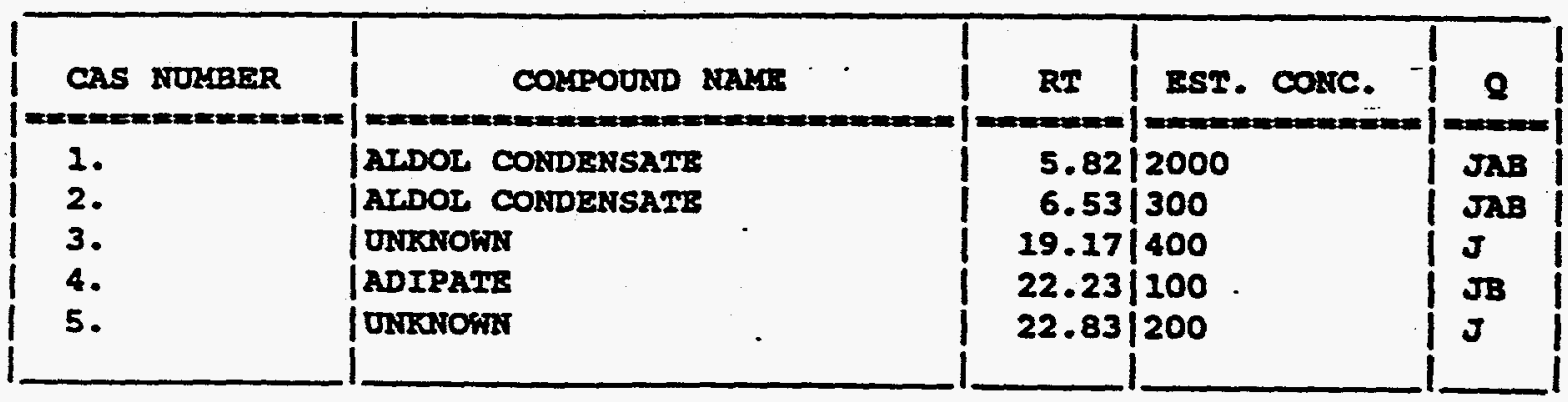


Lab Names Roy. Weston. Inc. Fork Orders 0630-28-13-0000

105720 02-014

Cllent: MSRC GUNSIL: 720

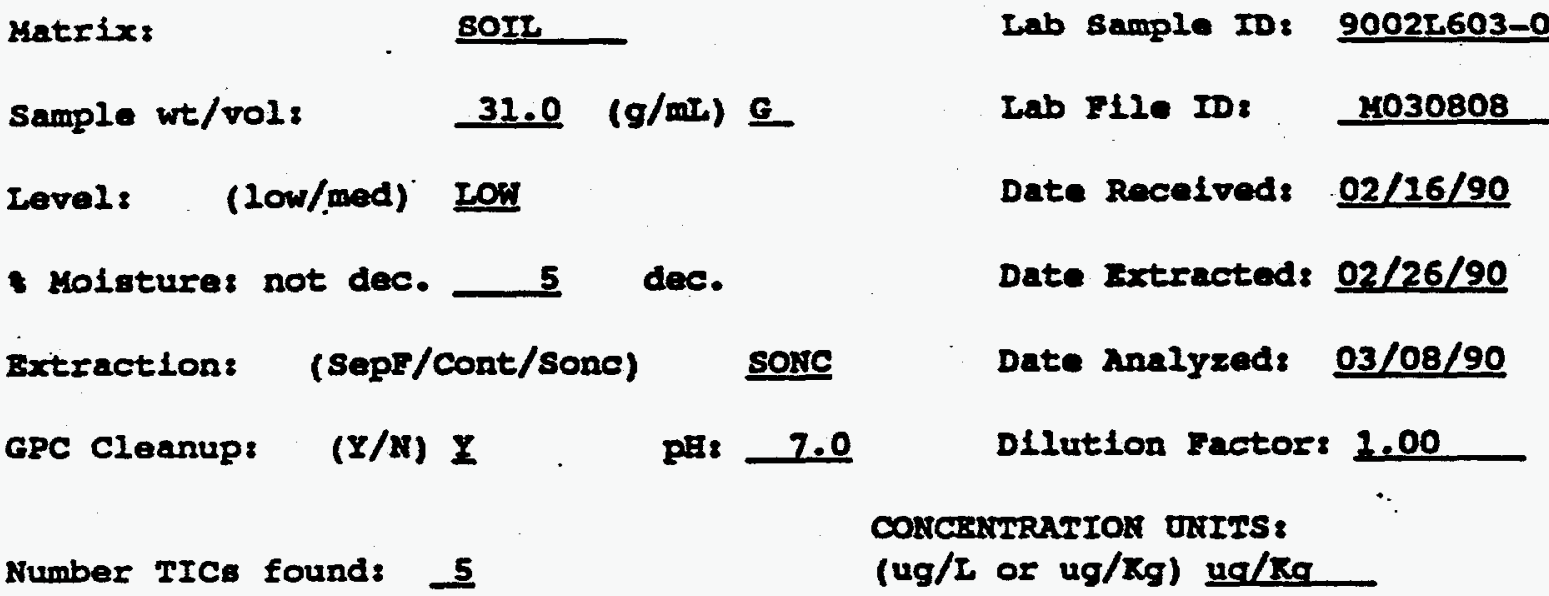

\begin{tabular}{|c|c|c|c|c|}
\hline CAS IUMBER & COKPODLD RAYS & RT & Est. Coric. & $\mathbf{Q}$ \\
\hline 1. & ArDOR COMDENSATU: & 5.82 & 11000 & $\mathbf{T R}$ \\
\hline 2. & ATDOL CONDENSATE & 6.52 & 500 & JAB \\
\hline 3. & ALDOT CORDERSATE & 7.55 & 1400 & JA \\
\hline 4. & | unkaroms & 19.17 & 1300 & $\mathbf{J}$ \\
\hline 5. & EYDROCARBON & 22.85 & 100 & $\mathbf{J}$ \\
\hline
\end{tabular}


Lab Names Roy F. Meaton, Inc. Work Order: 0630-28-13-0000

client: WSRC GUNSIIE 720

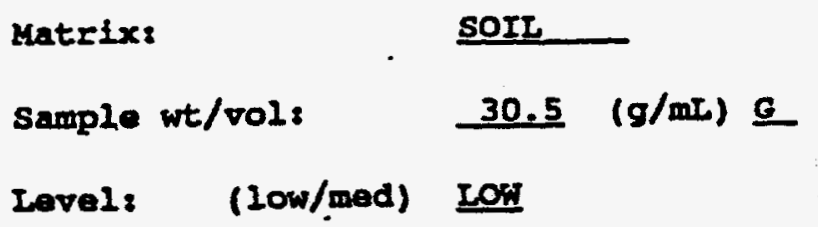

Moleturer not dec. 12 dec.

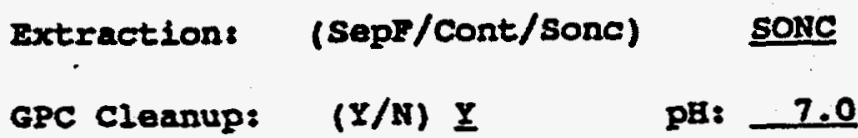
Number TICs found: 5
Lab Sample ID: 9002L603-008

Lab File ID:

$\underline{2030809}$

Date Recelveds $02 / 16 / 90$

Date sxtracted: 02/26/90

Date Analyzed: 03/08/90

Dllution Factor: 1.00

CONCBNTRATION UNITS:

(ug/L or ug/Kg) ug/Rg

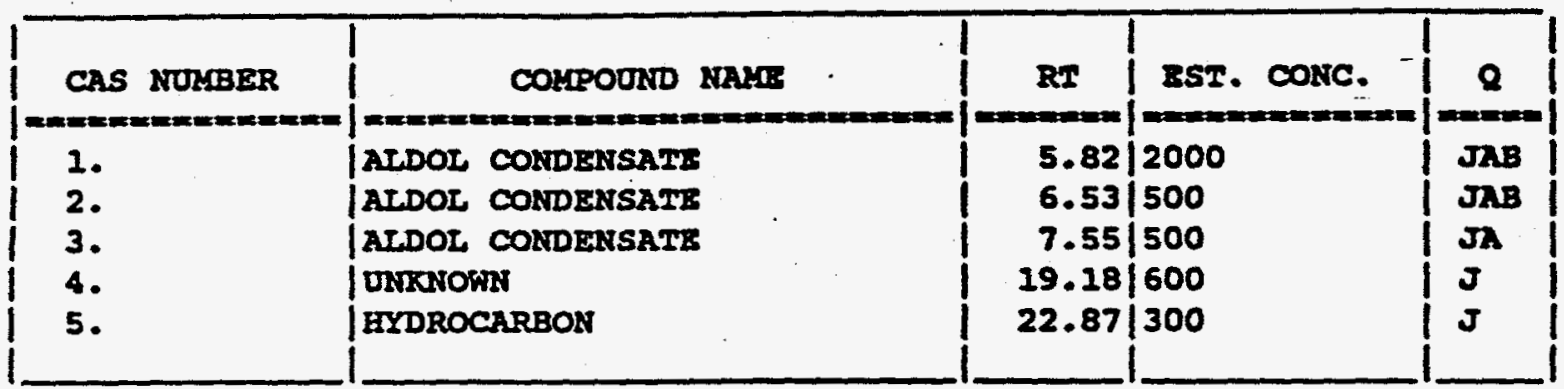


Lab Names Roy F. Wenton, Inc. Work Orders 0630-28-13-0000

ClLent: WSRC GUNSITB 720

Hatrix:

SoIL

Sample wt/rol: $30.6(\mathrm{~g} / \mathrm{mL}) \mathrm{G}$

Levels (low/med) IOH

s Nolsturer not dec. 7 dec.

Extraction: (sepr/Cont/sone) sosc

GPC Cleanup: $(Y / x) \underline{Y}$

Number TICs found: 5
Lab Sample ID: 9002L603-009

Lab File IDE M030810

Date Recelved: 02/16/90

Date Extractedr 02/26/90

Date Analyzeds $03 / 08 / 90$

Dilution Factor: 1.00

CONCENTIRATION UNITS:

(ug/L or ug/ $\mathrm{Kg}$ ) ug/Rg

\begin{tabular}{|c|c|c|c|c|}
\hline CAS NUIBER & COAPOUID ILAXE & RT & Est. CoNe. - & $\mathbf{Q}$ \\
\hline 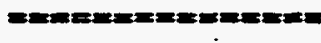 & 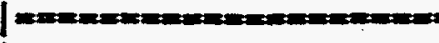 & & 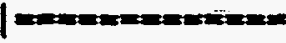 & \\
\hline 1. & |AIDO- CONDERSATE & 5.82 & 2000 & JAB \\
\hline 3. & $\begin{array}{l}\text { ALDOL CONDERSATE } \\
\text { UIERTOWN }\end{array}$ & $\begin{array}{r}6.53 \\
19.18\end{array}$ & $\begin{array}{l}1400 \\
1500\end{array}$ & 2 \\
\hline 4. & |ADIPATE & 22.25 & 200 & JB \\
\hline 5 . & EYDROCARBON & 22.87 & 200 & $\boldsymbol{J}$ \\
\hline
\end{tabular}


Iab Namer Ror $F$. Hestón, Inc, Work Orders 0630-28-13-0000

Cl1ent: HSRC GUISIME 720

Mateixs

sort.

Sample $w$ trol:

$30.8(g / \mathrm{mr}) \mathrm{G}$

Level: (low/med) LOA

+1 dec.

* Wolaturas not dec.

Extraction:

(Sept/Cont/sone)

solic

GPC Cleanup:

(I/N) $\mathbf{I}$

pE: 7.0
Iab sample ID: 90021603-011

Iab I11 ID: M030903

Date Recelreds $02 / 16 / 90$

Date Inxtracted: 02/26/90

Date Analyzed: 03/09/90

Dilution Factor: 1.00

Number TICs found: 5

CONCENTRATION UNITS:

(ug/L or ug/ $\mathrm{ug}$ ) ua/ $\mathrm{xa}$

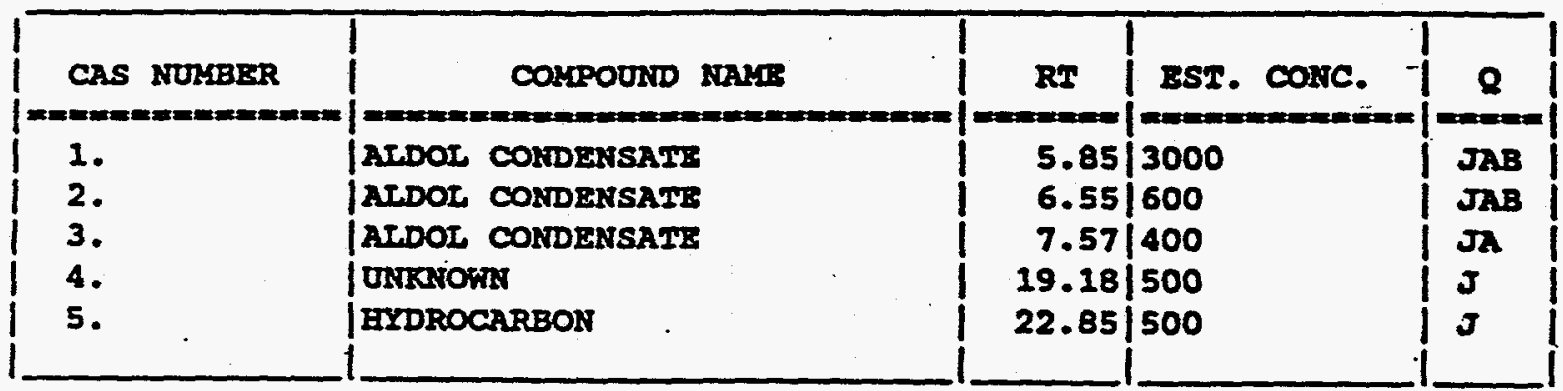


Lab Names Roy F. Westori. Inc. Work Order: 0630-28-13-0000

Cllent: ASRC GONSITE 720

Matrixs

sample wt/rols

sorI.

$30.5(\mathrm{~g} / \mathrm{mr}) \mathrm{G}$

Leve1: (low/med) LON

* Moleture: not dec. 13 dec. Extractions (SepI/Cont/sone) sone GPC Cleanup: (Y/X) $I \quad$ pAs 7.0 Number TICs found: 5
Iab Sample ID: 9002L603-012

Lab Flle ID: M030904

Date Recelveds 02/16/90

Date Ixtracted: 02/26/90

Date Analyzeds $03 / 09 / 90$

DLlution Factors 1.00

CONCENTRATION UAITS: (ug/L or ug/ $\mathrm{ug}$ ) ug/ $\mathrm{Kg}$

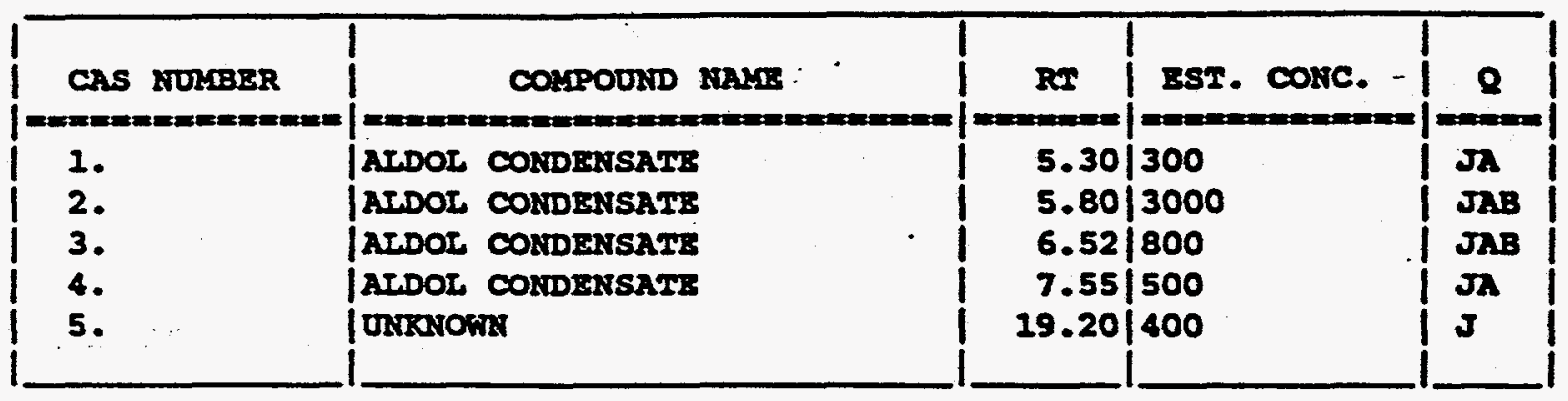


Lab Namer Roy F. Weston, Inc. Fork Orders 0630-28-13-0000

Client: WSRC GUNSITE 720

Lat Ix:

SOIL.

Sample wt/rols $30.5(g / m L)$

Levels (low/med) Ion

v Holetures not dec.

11 dec.

Extraction: (SepF/Cont/sonc) sonc

GPC Cleanup: $(Y / N) I$

prs: 7.0
Lab sample ID: 90025603-013

Iab File IDs. M030905

Date Recelreds 02/16/90

Date Extracteds 02/26/90

Date Analyreds $03 / 09 / 90$

Dllution Factors 1.00

Number IICa found: 5

CONCEArTRATIOA URITS:

(ug/L of ug/ $\mathrm{Kg}$ ) ug/Rg

\begin{tabular}{|c|c|c|c|c|}
\hline CAS MTLEER & COMPOUND NAME: & RT & 25x. corc. - & $\mathbf{a}$ \\
\hline 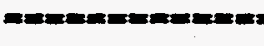 & 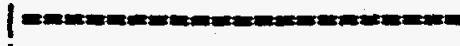 & 至 & | & $=$ \\
\hline 1. & |ATDOT CONDENSATS & 5.82 & 2000 & $\mathbf{J A B}$ \\
\hline 2. & | AtDOL CONDENSATI & 6.53 & 600 & $\mathbf{M A B}$ \\
\hline 3. & |ATDOL CONDENSATE & 7.55 & 600 & $\sqrt{\lambda}$ \\
\hline 4. & | ouxaromis & 19.17 & 300 & $\mathbf{J}$ \\
\hline 5. & EYDROCARBON & 22.83 & 1300 & $\boldsymbol{J}$ \\
\hline
\end{tabular}


SEMIVOLATILE ÖRGANICS ANACYSIS SBEWT

TERTATIVELY IDERTIFIED COKPOUNDS

Lab Name: Roy F. Weston. Inc. Work Order: 0630-28-13-0000
MIENT SAMPLE NO.

165720 01-01

Cllents HSRC GOASITE 720

Mateles

SOIL.

Sample wt/vol: $30.1(\mathrm{~g} / \mathrm{mL}) \mathrm{G}$

Level: (low/med) ION

8 dec.

Noletures not dec. dec.

Extractions (sepl/cont/sonc) soic

GPC Cleanup: $\quad(Y / K) I$ pHs 7.0
Lab sample ID: 9002L603-014

Iab F11 ID: $\quad 2030906$

Date Recelved: $02 / 16 / 90$

Date Extractod: 02/26/90

Date Anslyzed: $03 / 09 / 90$

DLlution Factor: 1.00

Number TICs found: $\underline{5}$

COKCENIRATION UNITS:

(ug/L or ug/ $\mathrm{ug}$ ) ug/ $\mathrm{kg}$

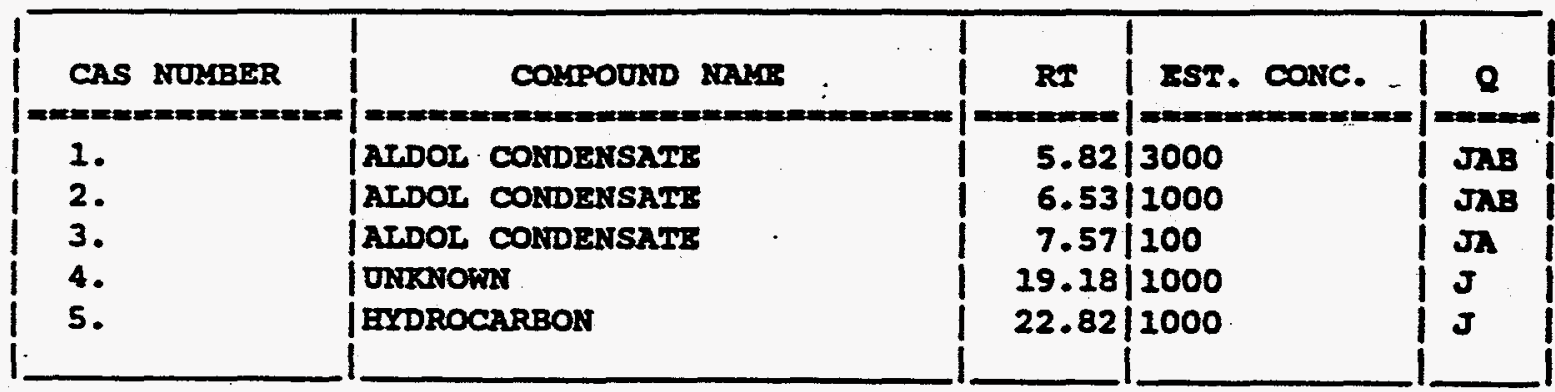


Iab Names Roy F. Weston. Inc. Wark Order: 0630-28-13-0000

Cllent: ASRC GUNSITE 720

Latrixs

SOIL

sample wt/rols $30.0(\mathrm{~g} / \mathrm{mL}) \mathrm{G}$

Level. (Low/med) LOW

- Molatures not dec. o dec.

Bxtraction:

$$
\text { (SepF/Cont/Sonc) }
$$

sone

GPC Cleanup: $\quad(Y / N) Y$ pat 7.0
SBTK
Lab sample ID: 90450272-191

Iab File ID: M030713

Date Recelvad: 02/26/90

Date Extracted $02 / 26 / 90$

Date Analyzeds "03/07/90

Dilution Factor: 1.11

Number TICs found: 5

CONCENTRATION ONITS:

(ug/L or ug/kg) ug/Ka

\begin{tabular}{|c|c|c|c|c|}
\hline CAS NUMBER & COLPOUND NAME & RT & EST. CONC. - & 2 \\
\hline 1. & ALDOL CONDENSAIE & 5.78 & 1000 & $\mathbf{J}$ \\
\hline 2. & ACDOL CONDENSATE & 6.52 & 1000 & $\mathbf{J A}$ \\
\hline 3. & 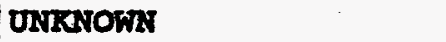 & 7.30 & 200 & $\boldsymbol{J}$ \\
\hline 4. & | unrenown & 9.02 & 200 & $\mathbf{J}$ \\
\hline 5 . & ADIPATE & 22.22 & 200 & $\mathbf{J}$ \\
\hline
\end{tabular}




\section{IKORGANIC MARRATIVE}

The following is a summary of the quality control results and a description of any problems encountered during the analysis of this batch of samples:

1. All preparation blanks were analyzed below the required detection limit.

2. All calibration verification checks were within the required control limits of 90-100\%. Calibration verification is performed using independent standards.

3. The analytical methods applied by the laboratory, unless otherwise requested, for all inorganic analyses are derived from the USEPA Method for Chemical Analysis of Water and $h=$ ites (USEPA 600/4-79-020), and stendard Methods for the Examination of Water and Wastewater 16 ed: Methods for the analysis of solid samples are derived from Test Methods for Evaluating Solid Waste (USEPA SW846).

NOTE: For solid samples, all results are reported on a dry weight basis.

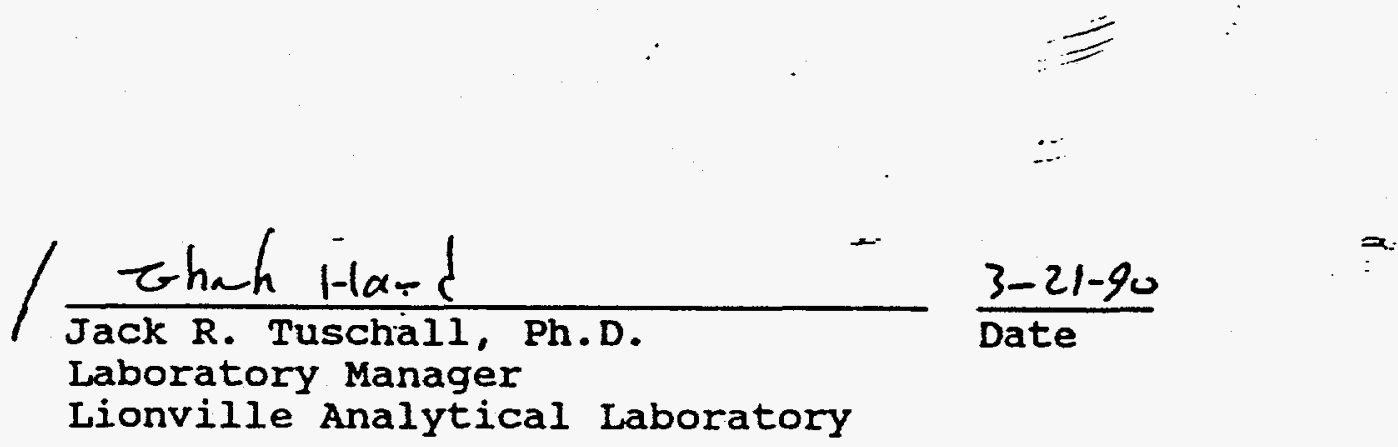


ROY F. WESTON, INC.

GLOSSARY OF TERMS - INORGANIC REPORTS

\section{DATA OUALIEIERS}

$\mathrm{U}$ - Indicates that the parameter was not detected at or above the reported limit. The associated numerical value is the sample detection limit.

* - Indicates that the original sample result is greater than $4 x$ the spike amount added. The USEPA-CL.P has determined that spike results on samples where this occurs may be unreliable and, therefore, the control limits are not applicable.

\section{ABBREVIATIONS}

MB - Method or preparation blank.

MS - Matrix Spike.

MSD - Matrix spike Duplicate.

REP - Sample Replicate.

LC - Indicates a method ICS or Blank spike.

NC - Not calculable, result below the detection limit.

LABORATORY CHRONOLOGY AND HOLDTIME REPORT

The test code listed indicates the specific analysis or preparation procedure employed. The codes may be interpreted as follows:

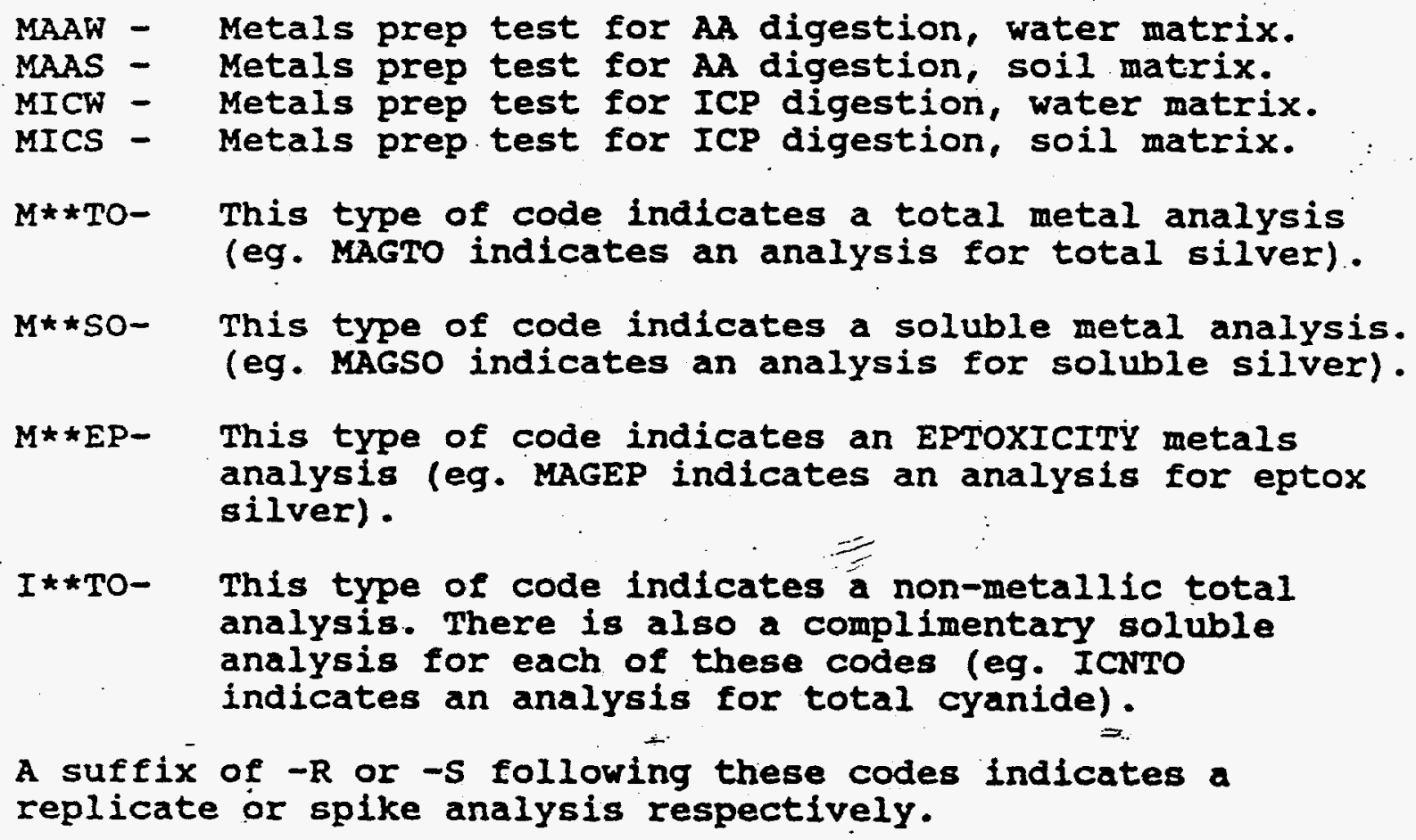


ROY F. HESTOA INC.

IMORGANICS DATA SURARRY REPORT 03/14/90

CLIENT: WSRC GONSITE 720

WORX ORDER: 0630-28-13-0000

\section{SAMPL:}

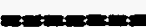

$-002$

$-003$

$-004$

$-005 \quad$ GS720 03-01

$-011 \quad$ GS720 01-02

$-014$
GS720 04-01

GS720 02-01

SITR ID

GS720 14-01

GS720 01-01
AMALYTE

sotids

tomal orcaric carbon

PE

- sorIDs

TOTAL OREAKIC CARBON

PH

- sorIDs

- soridDs

sorIDs

- solids

TOTAL ORGAMIC CARBOA

PE
WESTOA BATCE \& 900216063

REPORTIRG

RESULT ONITS IIITT

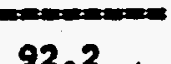

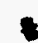

274

4.9

$150 / 156$

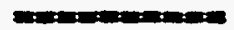

$\therefore \quad 0.10$

pe Uirss

28.0

0.10

93.4

2700 . ME/KC

5.2 pH ovITs

0.10

50.0

0.10

94.8

$\checkmark$

0.10

94.7

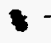

0.10

93.0

$\checkmark$

0.10

89.9

5180

$$
3
$$

5.0
Me/Ko

0.10 104

pH oxITs

0.10 
ROY Y. HISTOO IAC.

IMORGANICS METHOD BLANK DATA SURARYY PAGK 03/14/90

CIIENT: WSRC CURISITE 720

WORX ORDER: 0630-28-13-0000

SARTIE SITS ID

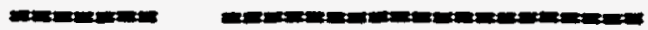

Branio

90LI2001-2B2

BrAN20
AMTIXIE

201010

TOMAL ORCANIC CRRBOA

TOTAT ORCaric cirbon
WESTON BATCB \& 90022603

$$
\begin{array}{ccc}
\text { RESULI } & \text { UNITS } \\
20.0 \text { u } & \text { Me/Ko } \\
20.0 \text { u } & \text { Me/Ke }
\end{array}
$$

RAPOREInG rIMIX 20.0 20.0 
ROY $P$. MESTON IRC.

INORGANICS ACCURACT REPORT 03/14/90

CLIEIT: WSRC GUISITE 720

WORX ORDER: 0630-28-13-0000

SAYPLE SITE ID

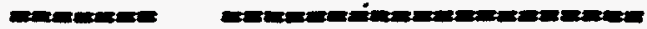

BLANR10 90LTr001-LB1

BLAKR20 90LTZ001-LB2
ANATYMS

-

TOTRI ORCAIIC CARBOA

TOMAL ORCAHIC CARBOA

TOMnI ORCAMIC CARBOA
WRSTOA BATCA is 90025603

\begin{tabular}{|c|c|c|c|}
\hline 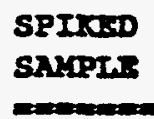 & $\begin{array}{l}\text { IRITIAI } \\
\text { RESULT }\end{array}$ & $\begin{array}{l}\text { SPIXSD } \\
\text { AMOONTS }\end{array}$ & SRECOV \\
\hline 410 & 20.0 & 400 & 102 \\
\hline $\begin{array}{l}412 \\
395\end{array}$ & $\begin{array}{l}20.0 \\
20.0\end{array}$ & $\begin{array}{l}400 \\
400\end{array}$ & $\begin{array}{c}103 \\
98.8\end{array}$ \\
\hline
\end{tabular}


ROY E. WESTON INC.

INORGANICS DUPLICATE SPIKS REPORT 03/14/90

CTIENT: WSRC GUVISITE 720

WESTON BATCA \& 90022603

WORK ORDER? 0630-28-13-0000

SAMPUS

mancarm

BLANRIO
SITE ID

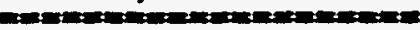

902TZ001-KB1
MWATYTSE

-

TOMAT ORGAMIC CARBOA

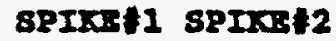

ERECOV SRECOV SDIFE

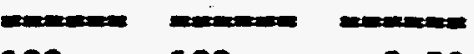


Roy F. Weston, Inc. - Lionville Laboratory

INORGANIC ANAIYTICAL DATA PACKAGE FOR

WSRC GOASITE 720

DATE RECEIVED: $02 / 16 / 90$

RFW LOT $\$ 89002 L 603$

CLIENT ID / ARIALYSIS REW * MITX PREP * COTIECTIOA EXIR/PREP

Aracrsis

GS720 14-01

$\begin{array}{lllllll}\text { SOLIDS } & 002 & \text { S } & 902 \& 5040 & 02 / 14 / 90 & 03 / 03 / 90 & 03 / 04 / 90 \\ \text { GROSS ALPEA } & 002 & \text { S } & & 02 / 14 / 90 & : & \\ \text { GROSS BETA } & 002 & \text { S } & & 02 / 14 / 90 & & \\ \text { TOTAL ORGANIC CARBON } & 002 & \text { S } & 90 L T Z 001 & 02 / 14 / 90 & 03 / 01 / 90 & 03 / 01 / 90 \\ \text { PB } & 002 & \text { S } & 90 \text { LPBO42 } & 02 / 14 / 90 & 03 / 08 / 90 & 03 / 08 / 90\end{array}$

G5720 04-01

sorios

003 TOTAL ORGAKIC CARBOH 003 $\mathrm{PB}$

003
s 90L:5040
s. 90LT2001
S 9OLPEO42
$02 / 14 / 90$
$02 / 14 / 90$
$02 / 14 / 90$

$03 / 03 / 90$

$03 / 01 / 90$

$03 / 08 / 90$

$03 / 04 / 90$

$03 / 01 / 90$

$03 / 08 / 90$

GS720 02-01

s sorIDs

004

s 90L:5040

$02 / 14 / 90$

$03 / 03 / 90$

$03 / 04 / 90^{\circ}$

G5720 03-01

\begin{abstract}
- solids
GROSS ALPEA

GROSS BETA
\end{abstract}

$\begin{array}{lllll}005 & & s & 90 L: 5040 & 02 / 14 / 90 \\ 005 & & s & & 02 / 14 / 90 \\ 005 & \text { s } & & 02 / 14 / 90\end{array}$

65720 01-02

- soridas

011

s 902ะ5040

$02 / 13 / 90$

$03 / 03 / 90$

$03 / 04 / 90$

GS720 01-01

\section{- SOLIDS}

GROSS ATREA

GROSS BETA

TOTAL ORCAHIC CARBOA PH

014
014
014
014
014

90Zะs040

$02 / 13 / 90$

$02 / 13 / 90$

$02 / 13 / 90$

902TZ001

$02 / 13 / 90$

$02 / 13 / 90$

$03 / 03 / 90$

$03 / 04 / 90$

$03 / 02 / 90$

$03 / 08 / 90$

$03 / 01 / 90$

$03 / 08 / 90$

Ins gC:

TOTAL ORGANIC CARBON LEL

$8 \quad 902 T 2001$

N/A

$03 / 01 / 90$

$03 / 01 / 90$ 
Roy F. Weston, Inc. - Llonville Laboratory INORGANIC ANALYTICAL DATA PACKAGR FOR WSRC CURSITS 720

DATB RBCBIVED\& $02 / 16 / 90$

RFW LOT $\$ 9002 L 603$

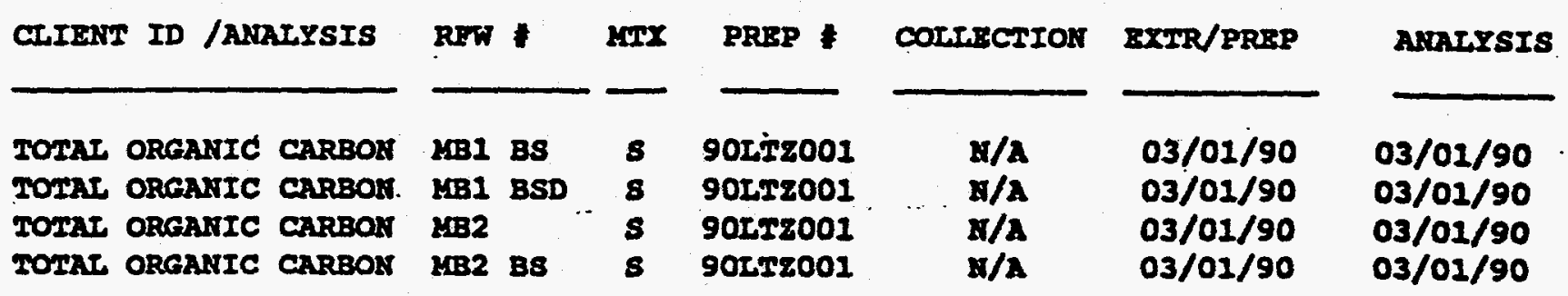




\section{May 1990}

Mr. Howard Hickey

Westinghouse Savannah River Company

Building 740-3A

Aiken, SC 29808

Re: Analytical results for samples collected at Gunsite 720 (RFW batches $9002 L 603$ and 604)

Dear Mr. Hickey:

Enclosed are the analytical results for WSRC release order 13, Gunsite 720 . These results consist of an electronic data deliverable, and a standard commerclal report which includes a case narrative summarizing $\mathrm{QA} / \mathrm{QC}$ results.

If we can provide any further information, please feel free to contact myself or Ben Shapiro.

Very truly yours,

ROY F. WESTON, INC.

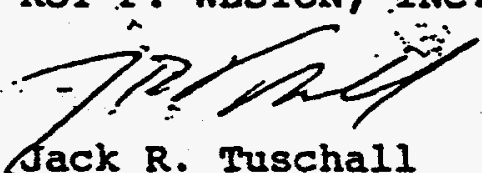

Laboratory Manager

Analytics Division

JRT/Clk

$\therefore$ Ençosure:

CC: " Michelle Wilson

David Oliphant

$=$
$=$

i: Ben Shapirg
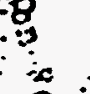

$=$ 
WESTON ANAIYTICS

LIONVIITE, PA

DATA TRAYSFER RECORD

SHEET 1 OF 1

DISK 1 OF $\frac{1}{1}$

IIMS

WATIS

INITIAL $\bar{x}$

CORRECTED

OTHER -

CLIENT: WSRC GUNSITE 720

PROJECT MANAGER: BEN SHAPIRO

ELECIRONIC $X$ HARD COPY

ก.O. *

ANALYSIS

VOA

BNA

INORGANICS

PHC

RAD

VOA

PEST/PCB

BNA

HERBICIDES

TDF

OP PEST

INORGANICS

METALS
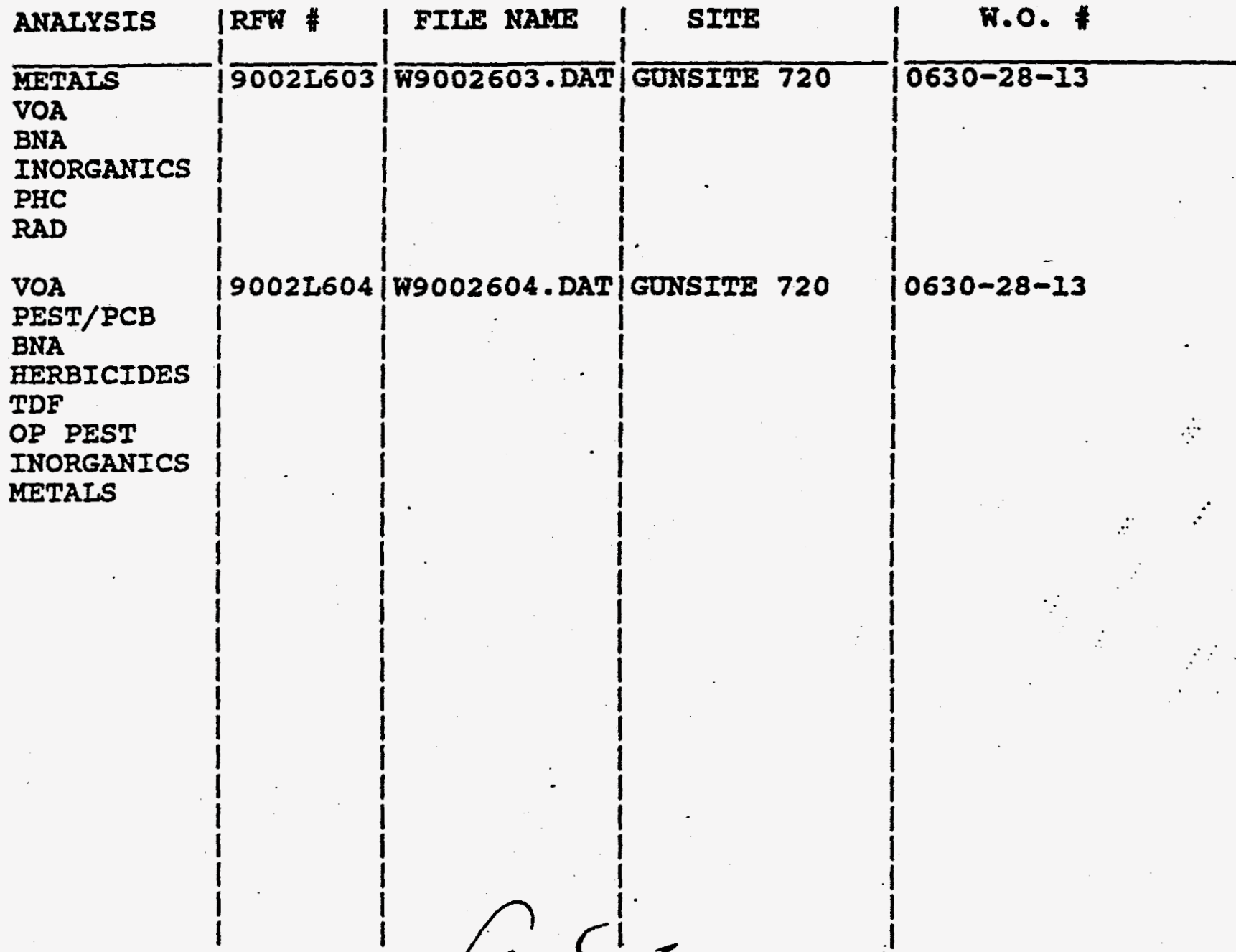

$9002 L 604$

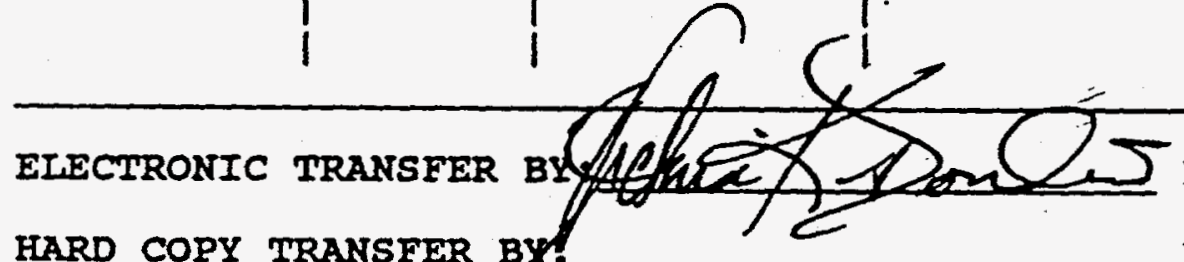

HARD COPY TRANSFER

By.

$\rightarrow$ DATE OF TRANSFER:

RECEIVED BY:

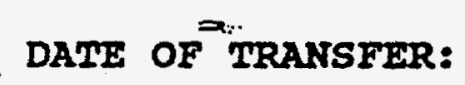


Roy F. Meston, Inc. - ILonville Laboratory VOA ANALYTICAL DATA PACKAGE rOR

WSRC GUNSITE 720

DATE RECEIVED: 02/26/90

CLIENT ID

$65720 \quad 0102$

IAB. QC:

RFW LOT :9002L604

MBI
RFW *

002 $\operatorname{sex}$

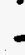

8 90Lvro28
$02 / 24 / 90$
MRALYSIS

-

$02 / 13 / 90 \quad x / A$

EXXR/PREP

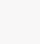

$02 / 24 / 90-$

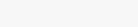

VBLK

MBI
S $90 \mathrm{LVw028}$

$\mathbf{N} / \mathbf{A}$

$\mathbf{x} / \mathbf{a}$

$02 / 24 / 90$ 
Wistret.

ROY F. MESTON, INC.

Lionville Laboratory

CLIENT: WSRC GUNSITE 720

RFT : 9002L604, GC/MS VOLATILE

BAMPLES RECEIVED: 02-16-90

7.0. * : 0630-28-13

\section{MARRATIVE:}

The set of samples consisted of one soil sample collected on $02-13-90$.

The sample was analyzed according to criteria set forth in

SW 846 Method 8240 for Appendix IX Volatile target compounds on $02-24-90$.

The following is a summary of the $Q C$ results accompanying these sample results and a description of any problems encountered during their analysis:

1. Non-target compounds were not detected in this sample.

2. All surrogate recoveries are within EPA QC limits.

3. The blank contains Methylene chloride and Acetone at levels less than $5 x$ the CRQL.

$\int \frac{\text { Zhuh Hc- }}{\text { Jack R. Tuschall, Ph.D. }}+\frac{4-4-40}{\text { Date }}$

Laboratory Manager

Lionville Analytical Laboratory 
Roy F. Weston, Inc, - LLonvilie Laboratory Volat1lea by GC/Hs, Append1x. IX Liet

RFW Batch Numbers 90024604 cllent, MBRC QUNBITE 720 - Nork Order: 0630-28-13-0000

Cust ID: G\$720 0102 VBLR

Sample

Information

$\begin{array}{rcc}\text { RFWH: } & 001 & \text { 90LVW028-MBI } \\ \text { Matrix: } & \text { SOIL } & \text { SOIL } \\ \text { D.F.8 } & 0.986 & 1.00 \\ \text { Unit: } & \text { UO/KG } & \text { UO/KG }\end{array}$

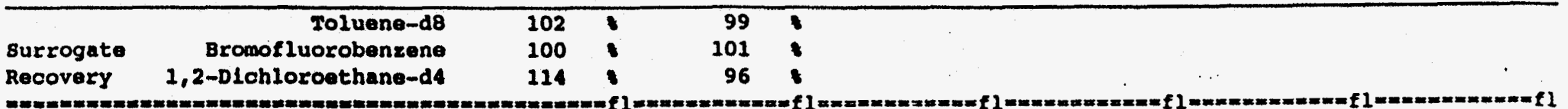

Chloromethane

Bromomethane

Vinyl chloride

Chloroethane

Mathylene chloride

Acetone

Carbon Dlsulflde

1,1-Dichloroethene

1,1-Dichloroethane

1,2-Dichloroethene (total)

Chloroform

1,2-Dichloroethane

2-Butanone

1,1,1-Trichloroethane

Carbon Tetrachloride

vinyl Acetate

Bromodlchloromethane

1,2-Dlchloropropane

C1s-1, 3-Dichloropropene

Trichloroethene

Dibromochloromethane

1,1,2-Trichloroethane

Benzene

Trans-1,3-D1Chloropropena

Bromoform

4-Hethy 1-2-pentanone

2-Hexanone

Tetrachloroethene

1,1,2,2-Tetrechloroethane

\begin{tabular}{|c|c|c|}
\hline 11 & $\mathbf{u}$ & 10 \\
\hline 11 & v & 10 \\
\hline 11 & $\mathbf{v}$ & 10 \\
\hline 11 & v & 10 \\
\hline 10 & B & 8 \\
\hline 26 & $\mathbf{B}$ & 13 \\
\hline 5 & $\mathbf{v}$ & 5 \\
\hline 5 & $\mathbf{U}$ & 5 \\
\hline 5 & v & 5 \\
\hline 5 & v & 5 \\
\hline 5 & v & 5 \\
\hline 5 & $\mathbf{U}$ & 5 \\
\hline 11 & $\mathbf{U}$ & 10 \\
\hline 5 & $\mathbf{v}$ & 5 \\
\hline 5 & $\mathbf{v}$ & 5 \\
\hline 11 & v & 10 \\
\hline 5 & $\mathbf{v}$ & 5 \\
\hline 5 & $\mathbf{U}$ & 5 \\
\hline 5 & $\mathbf{u}$ & 5 \\
\hline 5 & $\mathbf{v}$ & 5 \\
\hline 5 & $\mathbf{u}$ & 5 \\
\hline 5 & $\mathbf{U}$ & 5 \\
\hline 5 & $\mathbf{u}$ & 5 \\
\hline 5 & $\mathbf{U}$ & 5 \\
\hline 5 & $\mathbf{u}$ & 5 \\
\hline 11 & u & 3 \\
\hline 11 & $\mathbf{u}$ & 5 \\
\hline 5 & $\mathbf{U}$ & 5 \\
\hline 5 & v & 5 \\
\hline
\end{tabular}

* $=$ outuide of EPA CLP oc IImits.

$\div$ 
RF ,tch Number: $9002 \mathrm{~L} 604$

Cllent, WSRC GUNSF:-

VBLK Cust ID: Gs720 0102

001 90LVW028-MB1

\begin{tabular}{|c|c|c|c|}
\hline Toluene & 5 & $\mathbf{U}$ & 5 \\
\hline Chlorobenzene & 5 & $\mathbf{U}$ & $\mathbf{5}$ \\
\hline Ethylbenzeno & 5 & $\mathbf{U}$ & 5 \\
\hline styrene & 5 & $\mathbf{U}$ & 5 \\
\hline Xylene (total). & 5 & $\mathbf{u}$ & 5 \\
\hline Aorolein & 11 & $\mathbf{U}$ & 10 \\
\hline Acrylonitrile & 11 & $\mathbf{U}$ & 10 \\
\hline Trlchlorof luoromethano & 2 & $\mathbf{J}$ & 5 \\
\hline Dlchlorodifluoromathane. & 11 & $\mathbf{U}$ & 10 \\
\hline Acetonitr11e & 21 & $\mathbf{U}$ & 20 \\
\hline Iodomethane & 11 & $\mathbf{0}$ & 10 \\
\hline Proplonitrile (sthyl Cyanide). & 54 & $\mathbf{U}$ & 50 \\
\hline 3-Chloropropene & 21 & $\mathbf{U}$ & 20 \\
\hline Methacryloniteile & 21 & $\mathbf{U}$ & 20 \\
\hline Dlbromomothane & 11 & $\mathbf{U}$ & 10 \\
\hline Icobutyl alcohol & 21 & $\mathbf{U}$ & 20 \\
\hline 1,2-D1bromoathane & 21 & $\mathbf{U}$ & 20 \\
\hline $1,1,1,2$-Tetrachloroethane & 11 & $\mathbf{U}$ & 10 \\
\hline 1,2,3-TrLlch1oropropane & 11 & $\mathbf{U}$ & 10 \\
\hline $\operatorname{tran} 8-1,4-D 1$ chloro-2-butene & 54 & $\mathbf{U}$ & 50 \\
\hline 1,2-Dibromo-3-chloropropane & 21 & $\mathbf{U}$ & 20 \\
\hline 2-Chloro-1,3-Butadiene & 110 & $\mathbf{U}$ & 100 \\
\hline
\end{tabular}

* outalde of EPA CLP QC IImite. 
Gunsite 720 Rubble Pit Unit

RFI/RI Report
WSRC-RP-95-360, Rev. 1

March 1996

\section{APPENDIX C}

\section{RISK ASSESSMENT METHODS}




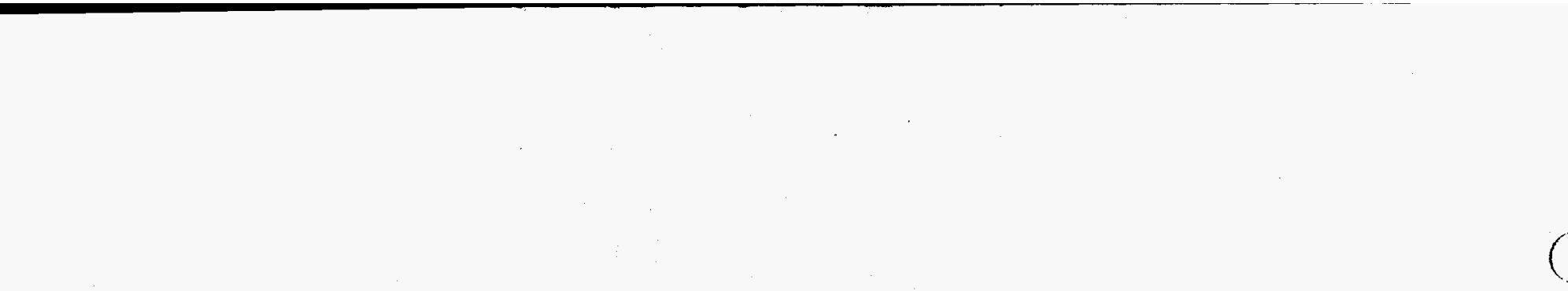

( 
Based upon the available evidence, there are no chemicals of potential concern. Because of this there are no chemicals remaining for evaluation by a CERCLA baseline risk assessment. Therefore, there is no determinable risk associated with Gunsite 720 Rubble Pit Unit. 